Prepared in cooperation with the Pike County Conservation District

\title{
Baseline Assessment of Groundwater Quality in Pike County, Pennsylvania, 2015
}

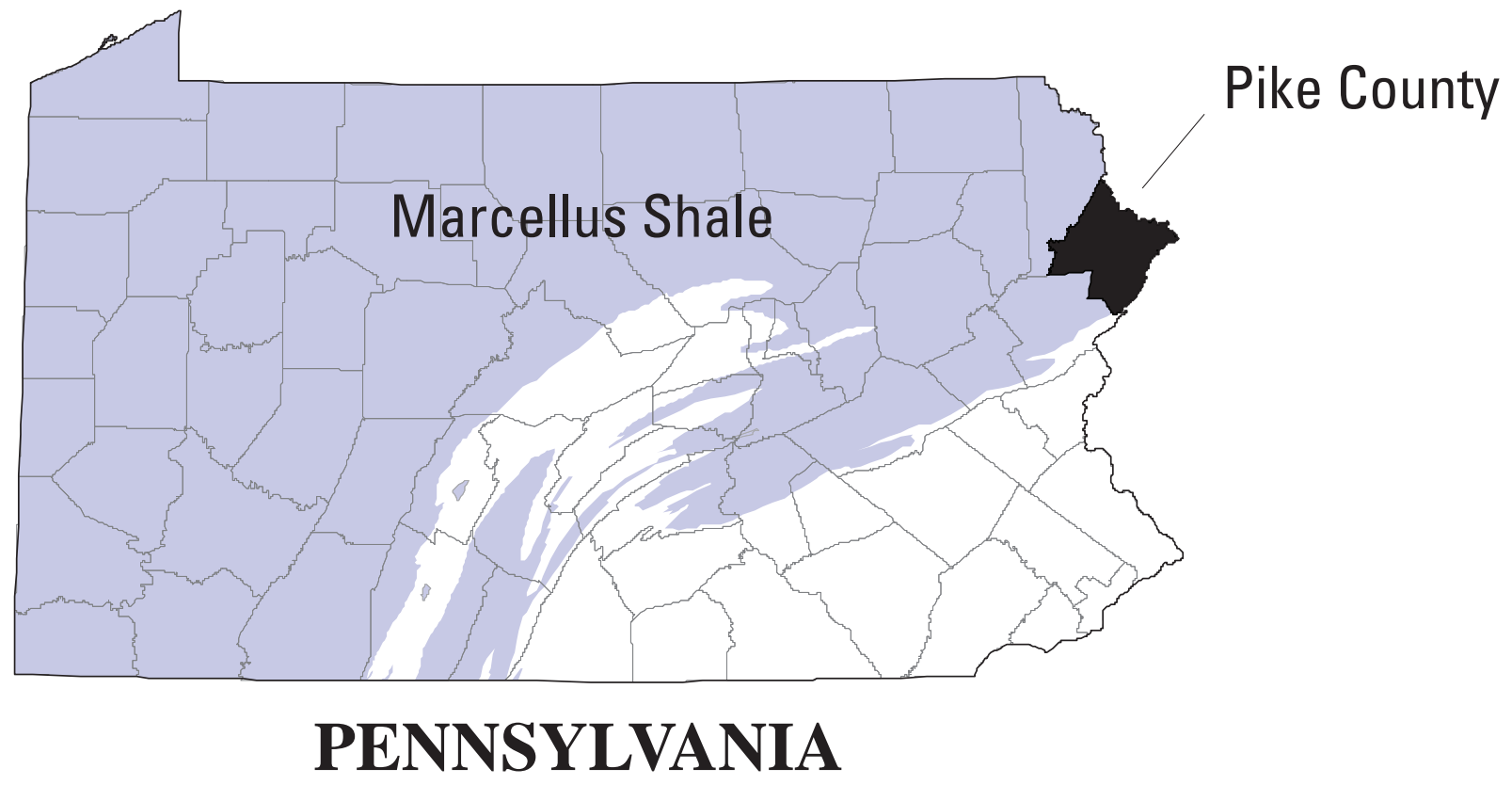

Scientific Investigations Report 2017-5110 



\section{Baseline Assessment of Groundwater Quality in Pike County, Pennsylvania, 2015}

By Lisa A. Senior and Charles A. Cravotta, III

Prepared in cooperation with the Pike County Conservation District

Scientific Investigations Report 2017-5110 


\title{
U.S. Department of the Interior \\ RYAN K. ZINKE, Secretary
}

\section{U.S. Geological Survey William H. Werkheiser, Deputy Director exercising the authority of the Director}

\author{
U.S. Geological Survey, Reston, Virginia: 2017
}

For more information on the USGS - the Federal source for science about the Earth, its natural and living resources, natural hazards, and the environment-visit https://www.usgs.gov or call 1-888-ASK-USGS.

For an overview of USGS information products, including maps, imagery, and publications, visit https://store.usgs.gov.

Any use of trade, firm, or product names is for descriptive purposes only and does not imply endorsement by the U.S. Government.

Although this information product, for the most part, is in the public domain, it also may contain copyrighted materials as noted in the text. Permission to reproduce copyrighted items must be secured from the copyright owner.

Suggested citation:

Senior, L.A., and Cravotta, C.A., III, 2017: Baseline assessment of groundwater quality in Pike County, Pennsylvania, 2015: U.S. Geological Survey Scientific Investigations Report 2017-5110, 181 p., https://doi.org/10.3133/ sir20175110.

ISSN 2328-0328 (online) 


\section{Acknowledgments}

The participation of individual well owners who made their wells accessible for the study is appreciated. The assistance and cooperation of Pike County Conservation District Board and staff members Sally Corrigan and Vincent Cordova in obtaining grant funding from the Pennsylvania Department of Community and Economic Development Baseline Water Quality Program, identifying and obtaining permission from well owners, and conducting field work is gratefully acknowledged. U.S. Geological Survey (USGS) personnel from the Pennsylvania Water Science Center who collected the groundwater samples include Dana Heston, Lee Eicholtz, Robert Meyer, Kyle Ohnstad, and Leif Olson, with assistance from summer interns Shane Fussel and Ben Davidson. Linda Zarr of USGS assisted in data processing. 



\section{Contents}

Acknowledgments …….................................................................................................................

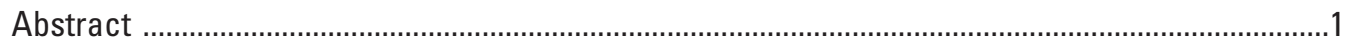

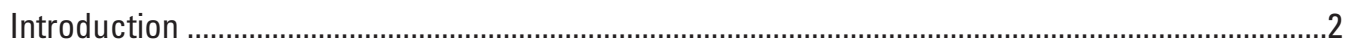

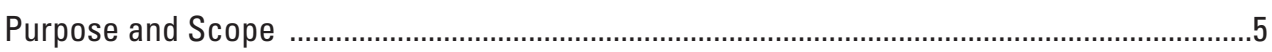

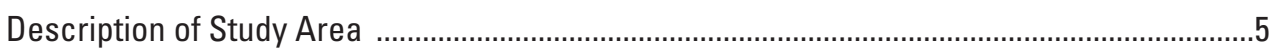

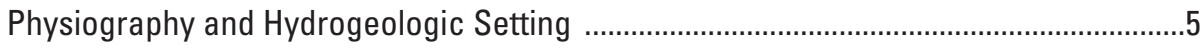

Hydrogeologic Setting ...........................................................................................

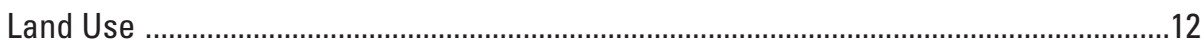

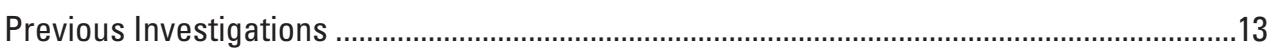

Methods of Sample Collection and Analysis ..........................................................................

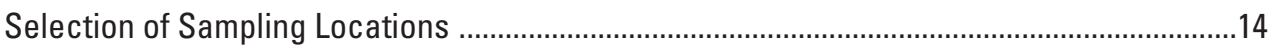

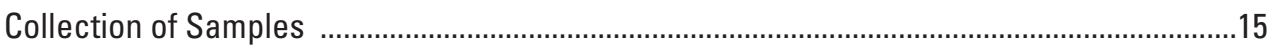

Analysis of Chemical, Physical, and other Characteristics and Reporting Units ...................16

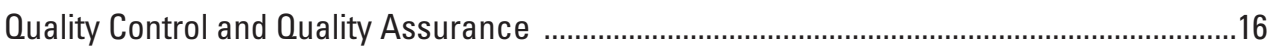

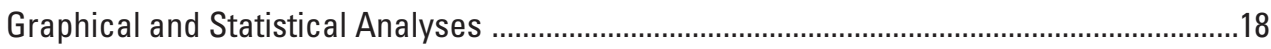

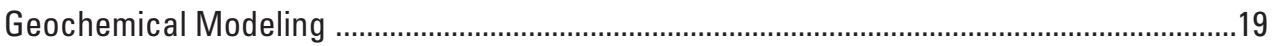

Baseline Groundwater Quality in Pike County .......................................................................19

Sources of and Geochemical Controls on Selected Constituents in Groundwater ..............19

Pike County Groundwater Quality and Its Relation to Drinking-Water Standards ................20

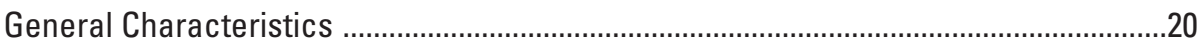

Field and laboratory measurements of $\mathrm{pH}$, Alkalinity, Specific

Conductance, and Dissolved Oxygen ..........................................................23

Total Dissolved Solids, Hardness, and Corrosivity ...............................................26

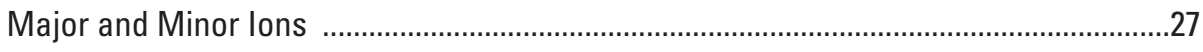

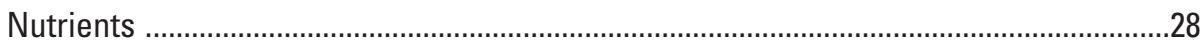

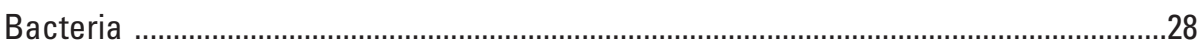

Trace Constituents ........................................................................................................31

Arsenic and Chemically Similar Trace Constituents .............................................31

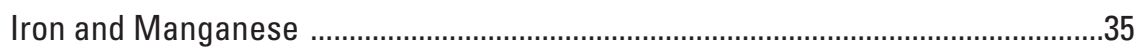

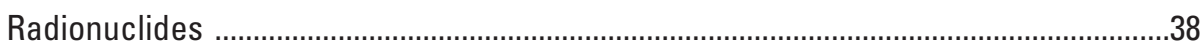

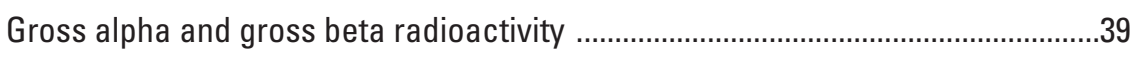

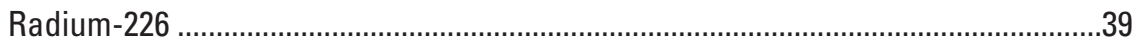

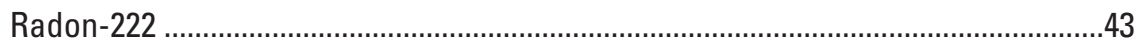

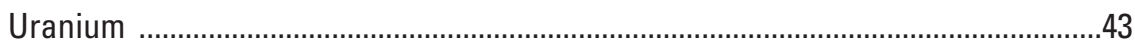

Total Organic Carbon and Man-Made Organic Compounds ..........................................45

Methane and Other Dissolved Hydrocarbon Gases ................................................................4

Methane Isotopic Composition and Origin of Methane Gas ……….....................................50

Relation of Water Quality to Geochemical and Hydrogeologic Setting .........................................54

Evolution of Chemical Composition and Conceptual Hydrogeochemical Model ...................57

Types of Groundwater as Characterized by Major lons ……............................................59

Geochemical Modeling of Mineral Saturation Indices .......................................................62

Ratios of Chloride, Bromide, Sodium, and Lithium in Groundwater .....................................64

Correlations Among Major and Trace Constituents in Groundwater ...................................67

Spatial Distribution of Groundwater Quality and Relation to Hydrogeologic Setting ............71 
Local Spatial and Temporal Variability in Groundwater Quality .............................................75

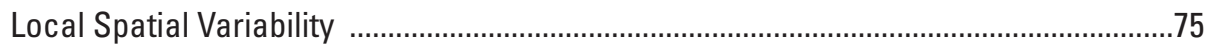

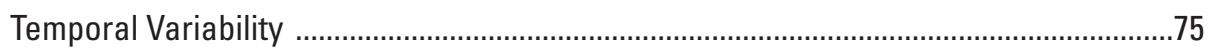

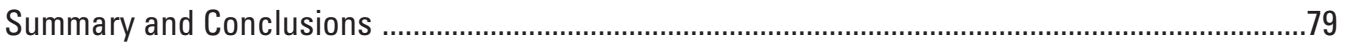

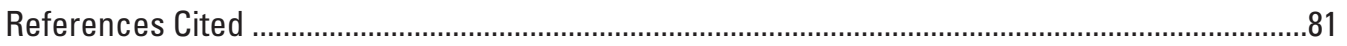

Appendixes

1. Analytical methods and reporting levels for constituents analyzed, by laboratory .....115

2. Quality assurance and quality control data ...............................................................115

3. Spearman rho correlations and boxplots showing sample compositions by groups (ranges of $\mathrm{pH}$, specific conductance, and redox values, principal components, and geologic units) for groundwater samples collected from 79 wells in Pike County, Pennsylvania, 2015

4. Field measurements and results of laboratory analyses for major and minor ions, nutrients, bacteria, trace metals, radioactivity, radon-222, and dissolved gases in groundwater samples collected from 7 pairs of closely spaced wells in Pike County, Pennsylvania, 2015

5. Field measurements and results of laboratory analyses for major and minor ions, nutrients, trace metals, radioactivity, radon-222 in groundwater samples collected from 18 wells in Pike County, Pennsylvania, 2007-15

\section{Figures}

1. Map showing location of Delaware River Basin boundary and gas wells drilled in Pike County, Pennsylvania, during 1959-71 and in nearby counties in Pennsylvania during 2007 through June 2016

2. Map and graph showing $A$, land-surface altitude, streams and major watersheds, and location of wells sampled in 2012 and 2015, in Pike County, Pennsylvania, and $B$, transects $A-A^{\prime}$ and $B-B^{\prime}$. Transects $A-A^{\prime}$ and $B-B^{\prime}$ terminate at the Delaware River, but transect $A-A^{\prime}$ originates near the highest altitudes in southwestern Pike County, and transect $B-B^{\prime}$ originates at Lake Wallenpaupack at western edge of Pike County

3. Map showing geology of the bedrock closest to land surface and location of wells sampled in Pike County, Pennsylvania, 2015

4. Stratigraphic columns showing summary of rock units penetrated by three gas exploration wells in Pike County, Pennsylvania

5. Hydrograph showing daily mean water levels measured during 2015 and longterm, 2001-16, median of daily mean water levels in observation well PI-522, Pike County, Pennsylvania

6. Map showing geological units and spatial distribution of $\mathrm{pH}$ in groundwater samples collected from 79 wells in Pike County, Pennsylvania, 2015

7. Graphs showing the relation of field measured $\mathrm{pH}$ to $A$, laboratory determined alkalinity, $B$, laboratory measured specific conductance, and $C$, field measured dissolved oxygen concentrations in groundwater samples collected from 79 wells in Pike County, Pennsylvania, 2015

8. Graph showing relation of laboratory measured specific conductance to concentrations of total dissolved solids in groundwater samples collected from 79 wells in Pike County, Pennsylvania, 2015

9. Graphs showing relation of field measured $\mathrm{pH}$ to $A$, hardness, and $B$, corrosivity, as measured by calcite saturation index, in groundwater samples collected from 79 wells in Pike County, Pennsylvania, 2015 
10. Map showing geologic units and spatial distribution of dissolved sodium concentrations in groundwater samples collected from 79 wells in Pike County, Pennsylvania, 2015

11. Map showing 2005 land use and spatial distribution of dissolved chloride concentrations in groundwater samples collected from 79 wells in Pike County, Pennsylvania, 2015

12. Graphs showing relation of field measured $\mathrm{pH}$ to dissolved concentrations of $A$, arsenic, $B$, molybdenum, and $C$, copper, lead, and zinc in groundwater samples collected from 79 wells in Pike County, Pennsylvania, 2015

13. Graph showing relation of dissolved to total arsenic concentrations in filtered and unfiltered groundwater samples, respectively, collected from 79 wells in Pike County, Pennsylvania, 2015

14. Graphs showing relation between concentrations of $A$, dissolved and total iron, and $B$, dissolved and total manganese in filtered and unfiltered groundwater samples, respectively, collected from 79 wells in Pike County, Pennsylvania, 2015

15. Map showing geologic units and spatial distribution of total iron and total manganese concentrations in groundwater samples collected from 79 wells in Pike County, Pennsylvania, 2015

16. Graphs showing relation of concentrations of nitrate to concentrations of $A$, dissolved iron and $B$, dissolved manganese and concentrations of dissolved oxygen to concentrations of $C$, dissolved iron and $D$, dissolved manganese in groundwater samples collected from 79 wells in Pike County, Pennsylvania, 2015

17. Graphs showing relation between $A, 72$-hour and 30-day gross alpha- and gross beta-particle activities, and $B$, gross alpha-particle activity and gross betaparticle activity at 72 hours and 30 days in groundwater samples collected from 78 wells in Pike County, Pennsylvania, 2015

18. Graphs showing rRelation of radium-226 activity to $A$, gross alpha-particle activity at 30 days, $B$, laboratory specific conductance, and $C$, radon-222 activity in groundwater samples collected from 12 wells in Pike County, Pennsylvania, 2015

19. Map showing geologic units and spatial distribution of radon-222 concentrations in groundwater samples collected from 79 wells in Pike County, Pennsylvania, 2015

20. Graph showing relation of concentrations of dissolved uranium to field measured $\mathrm{pH}$ in groundwater samples collected from 79 wells in Pike County, Pennsylvania, 2015

21. Map showing geologic units and spatial distribution of methane and lithium concentrations in water samples collected from 79 wells in Pike County, Pennsylvania, 2015

22. Methane concentrations in relation to lithium concentrations in water samples collected from 79 wells in Pike County, Pennsylvania, 2015

23. Relation of methane concentrations determined by Isotech Laboratories, Inc., to those determined by Seewald Laboratories, Inc., in groundwater samples collected from 79 wells in Pike County, Pennsylvania, J2015

24. A, Isotopic composition of methane in groundwater samples collected from 9 wells in Pike County, Pennsylvania, 2012-15, and in mud-gas logging samples collected from various geologic formations during drilling of gas wells in Marcellus Shale in Pennsylvania, and $B, C 1 / C 2$ ratios in relation to carbonisotopic composition for methane in the same samples 
25. Relation of methane concentrations to isotopic composition of methane $\left(\mathrm{CH}_{4}\right)$ as $A$, hydrogen/deuterium component ( $\delta \mathrm{D}$ ) and $B$, carbon-12/carbon-13 component $\left(\delta^{13} \mathrm{C}\right)$ in groundwater samples collected from 10 wells in Pike County, Pennsylvania, 2015

26. Relation of $\mathrm{pH}$ to concentrations of $A$, sodium, fluoride, and methane and $B$, lithium, boron, and bromide in groundwater samples collected from 79 wells in Pike County, Pennsylvania, 2015

27. Schematic diagram of generalized conceptual hydrogeochemical model for distribution of fresh and saline groundwater in fractured bedrock aquifer setting showing 1) evolution of groundwater composition from calcium-magnesiumbicarbonate-sulfate type with relatively low $\mathrm{pH}$ and high dissolved oxygen concentrations (DO) in recharge areas and local flow zones to predominantly sodium-bicarbonate-sulfate with higher $\mathrm{pH}$ and lower $\mathrm{DO}$ along intermediate flow paths and 2) presence of deeper or regional water that is relatively saline and possibly mixing with intermediate-flow waters, especially in discharge areas, such as stream valleys, where methane from microbial and (or) thermogenic sources appears to be present most frequently and at highest concentrations in northeastern Pennsylvania

28. Piper diagrams showing major ion composition for water samples collected from 79 wells in Pike County, Pennsylvania, 2015, for ranges of $A$, field $\mathrm{pH}$ and $B$, laboratory specific conductance

29. Relation of saturation indices for minerals and other solids to $\mathrm{pH}$ for groundwater samples from 79 wells in Pike County, Pennsylvania, 2015, computed using PHREEQC with WATEQ4F database

30. Relation of chloride concentrations to $A$, sodium concentrations, $B$, bromide concentrations, $C$, chloride/bromide mass ratios, and $D$, lithium/chloride mass ratios in groundwater samples with and without methane concentrations greater than 0.3 milligrams per liter collected from 79 wells in Pike County, Pennsylvania, 2015, plus median values for Salt Spring, flowback waters from Marcellus Shale gas wells, and oil- and gas-field brines from western Pennsylvania

31. Relation of $\mathrm{pH}$ to mass ratios of (Strontium + Barium)/Magnesium in groundwater samples collected from 79 wells in Pike County, Pennsylvania, 2015

32. Boxplots showing distribution by geologic formation of $A, \mathrm{pH}$ and dissolved concentrations of total dissolved solids, hardness, sodium, potassium, alkalinity, fluoride, boron, and lithium and $B$, dissolved concentrations of iron, manganese, dissolved oxygen, uranium, arsenic, methane, and radon-222, and land-surface altitude and temperature in water samples collected from 79 wells in Pike County, Pennsylvania, 2015

33. Piper diagrams showing composition of water for seven pairs of closely spaced wells sampled in Pike County, Pennsylvania, 2015

34. A, Chloride concentrations in water samples collected from wells at least twice during 2007-15 and $B$, chloride/bromide ratios in relation to chloride concentrations in water samples collected from wells during 2012-13 and 2015 in Pike County, Pennsylvania 


\section{Tables}

1. Maximum concentrations reported for selected inorganic constituents in oil and gas well brines or flowback waters in western Pennsylvania and in Salt Spring in Susquehanna County, Pennsylvania 4

2. Pre-drill basic list of constituents recommended by the Pennsylvania Department of Environmental Protection in 2014 for analysis in private water supply wells prior to gas drilling

3. Lithology and mineralogy of Devonian-age bedrock geologic units in Pike County, Pennsylvania

4. Minimum, median, and maximum of well characteristics, chemical and physical properties measured in the field, and concentrations of total dissolved solids, major ions, nutrients, total organic carbon, and bacteria determined in the laboratory for groundwater samples collected from 79 wells in Pike County, Pennsylvania, 2015

5. Minimum, median, and maximum concentrations of trace constituents determined in the laboratory for groundwater samples collected from 79 wells in Pike County, Pennsylvania, 2015

6. Minimum, median, and maximum concentrations of selected radioactive constituents determined in the laboratory for groundwater samples collected from 79 wells in Pike County, Pennsylvania, 2015

7. Reporting levels and drinking-water standards for man-made organic compounds analyzed in groundwater samples collected from 20 wells in Pike County, Pennsylvania, 2015

8. Minimum, median, and maximum concentrations of methane, ethane, and propane determined in the laboratory using method PA-DEP 3686 for groundwater samples collected from 79 wells in Pike County, Pennsylvania, 2015, and recommended action levels for methane in well water

9. Concentrations of methane and ethane determined by two laboratories for groundwater samples collected from 17 wells and isotopic composition of methane in 10 of the 17 wells in Pike County, Pennsylvania, 2015

10. Principal components analysis model of major factors controlling the chemistry of groundwater and statistically significant Spearman rank correlations of other variables with those factors determined from chemical properties of and dissolved concentrations of constituents in groundwater samples from 79 wells, Pike County, Pennsylvania, 2015

11. Minimum, median, and maximum of actual and percent differences in chemical and physical properties measured in the field, and concentrations of total dissolved solids, major ions, nutrients, selected minor ions and trace metals, radon-222, and methane determined in the laboratory for water samples collected from 16 wells sampled during 2011-12 and 2015 in Pike County, Pennsylvania .

12. Land-surface altitude, well depth, and geologic unit (aquifer) code for 79 wells sampled in 2015 in Pike County, Pennsylvania

13. Field measurements and results of laboratory analyses for major and minor ions, nutrients, bacteria, trace metals, volatile organic compounds radioactivity, radon-222, and dissolved gases for water samples collected from 79 wells in 2015 in Pike County, Pennsylvania

14. Results of dissolved gas analysis and isotopic characterization of methane by Isotech Laboratories, Inc. for water samples collected from 17 wells in Pike County, 2015 


\section{Conversion Factors}

Inch/Pound to International System of Units

\begin{tabular}{|c|c|c|}
\hline Multiply & By & To obtain \\
\hline \multicolumn{3}{|c|}{ Length } \\
\hline inch (in.) & 2.54 & centimeter $(\mathrm{cm})$ \\
\hline inch (in.) & 25.4 & millimeter (mm) \\
\hline foot $(\mathrm{ft})$ & 0.3048 & meter (m) \\
\hline mile (mi) & 1.609 & kilometer (km) \\
\hline \multicolumn{3}{|c|}{ Area } \\
\hline acre & 0.4047 & hectare (ha) \\
\hline acre & 0.004047 & square kilometer $\left(\mathrm{km}^{2}\right)$ \\
\hline square mile $\left(\mathrm{mi}^{2}\right)$ & 259.0 & hectare (ha) \\
\hline square mile $\left(\mathrm{mi}^{2}\right)$ & 2.590 & square kilometer $\left(\mathrm{km}^{2}\right)$ \\
\hline \multicolumn{3}{|c|}{ Volume } \\
\hline gallon (gal) & 3.785 & liter (L) \\
\hline gallon (gal) & 0.003785 & cubic meter $\left(\mathrm{m}^{3}\right)$ \\
\hline \multicolumn{3}{|c|}{ Flow rate } \\
\hline gallon per minute (gal/min) & 0.06309 & liter per second (L/s) \\
\hline inch per year (in/yr) & 25.4 & millimeter per year (mm/yr) \\
\hline \multicolumn{3}{|c|}{ Pressure } \\
\hline atmosphere, standard (atm) & 101.3 & kilopascal (kPa) \\
\hline bar & 100 & kilopascal (kPa) \\
\hline inch of mercury at $60^{\circ} \mathrm{F}$ (in $\mathrm{Hg}$ ) & 3.377 & kilopascal (kPa) \\
\hline \multicolumn{3}{|c|}{ Radioactivity } \\
\hline picocurie per liter (pCi/L) & 0.037 & becquerel per liter $(\mathrm{Bq} / \mathrm{L})$ \\
\hline \multicolumn{3}{|c|}{ Specific capacity } \\
\hline $\begin{array}{l}\text { gallon per minute per foot } \\
[\text { [(gal/min }) / \mathrm{ft})]\end{array}$ & 0.2070 & $\begin{array}{l}\text { liter per second per meter } \\
{[(\mathrm{L} / \mathrm{s}) / \mathrm{m}]}\end{array}$ \\
\hline \multicolumn{3}{|c|}{ Hydraulic gradient } \\
\hline foot per mile ( $\mathrm{ft} / \mathrm{mi})$ & 0.1894 & meter per kilometer $(\mathrm{m} / \mathrm{km})$ \\
\hline
\end{tabular}

Temperature in degrees Celsius $\left({ }^{\circ} \mathrm{C}\right)$ may be converted to degrees Fahrenheit $\left({ }^{\circ} \mathrm{F}\right)$ as ${ }^{\circ} \mathrm{F}=(1.8 \times$ $\left.{ }^{\circ} \mathrm{C}\right)+32$.

Temperature in degrees Fahrenheit $\left({ }^{\circ} \mathrm{F}\right)$ may be converted to degrees Celsius $\left({ }^{\circ} \mathrm{C}\right)$ as ${ }^{\circ} \mathrm{C}=\left({ }^{\circ} \mathrm{F}-\right.$ 32) / 1.8 . 


\section{Datum}

Vertical coordinate information is referenced to the North American Vertical Datum of 1988 (NAVD 88)].

Horizontal coordinate information is referenced to the North American Datum of 1983 (NAD 83).

Altitude, as used in this report, refers to distance above the vertical datum.

\section{Supplemental Information}

Specific conductance is given in microsiemens per centimeter at 25 degrees Celsius $(\mu \mathrm{S} / \mathrm{cm}$ at $\left.25^{\circ} \mathrm{C}\right)$.

Concentrations of chemical constituents in water are given in either milligrams per liter (mg/L) or micrograms per liter $(\mu \mathrm{g} / \mathrm{L})$.

Activities for radioactive constituents in water are given in picocuries per liter ( $\mathrm{pCi} / \mathrm{L}$ ).

Results for measurements of stable isotopes of an element in water, solids, and dissolved constituents commonly are expressed as the relative difference in the ratio of the number of the less abundant isotope to the number of the more abundant isotope of a sample with respect to a measurement standard. 


\section{Abbreviations}

$\begin{array}{ll}\text { AMCL } & \text { alternate maximum contaminant levels } \\ \text { DO } & \text { dissolved oxygen } \\ \text { EPA } & \text { U.S. Environmental Protection Agency } \\ \text { HA } & \text { Health Advisory } \\ \text { MCL } & \text { maximum contaminant level } \\ \text { PADEP } & \text { Pennsylvania Department of Environmental Protection } \\ \text { ROE } & \text { residue on evaporation } \\ \text { SC } & \text { specific conductance } \\ \text { SI } & \text { saturation index } \\ \text { SMCL } & \text { secondary maximum contaminant level } \\ \text { TDS } & \text { total dissolved solids } \\ \text { USGS } & \text { U.S. Geological Survey } \\ \text { VOC } & \text { volatile organic compound } \\ \mu \mathrm{g} / \mathrm{L} & \text { micrograms per liter } \\ \mathrm{mg} / \mathrm{L} & \text { milligrams per liter } \\ \mu \mathrm{S} / \mathrm{cm} \text { at } 25{ }^{\circ} \mathrm{C} & \text { microsiemens per centimeter at } 25 \text { degrees Celsius } \\ \mathrm{pCi} / \mathrm{L} & \text { picocuries per liter } \\ 0 / 00 & \text { per mil }\end{array}$




\title{
Baseline Assessment of Groundwater Quality in Pike County, Pennsylvania, 2015
}

\author{
By Lisa A. Senior and Charles A. Cravotta, III
}

\section{Abstract}

The Devonian-age Marcellus Shale and the Ordovicianage Utica Shale, which have the potential for natural gas development, underlie Pike County and neighboring counties in northeastern Pennsylvania. In 2015, the U.S. Geological Survey, in cooperation with the Pike County Conservation District, conducted a study that expanded on a previous more limited 2012 study to assess baseline shallow groundwater quality in bedrock aquifers in Pike County prior to possible extensive shale-gas development. Seventy-nine water wells ranging in depths from 80 to 610 feet were sampled during June through September 2015 to provide data on the presence of methane and other aspects of existing groundwater quality in the various bedrock geologic units throughout the county, including concentrations of inorganic constituents commonly present at low values in shallow, fresh groundwater but elevated in brines associated with fluids extracted from geologic formations during shale-gas development. All groundwater samples collected in 2015 were analyzed for bacteria, dissolved and total major ions, nutrients, selected dissolved and total inorganic trace constituents (including metals and other elements), radon-222, gross alpha- and gross beta-particle activity, dissolved gases (methane, ethane, and propane), and, if sufficient methane was present, the isotopic composition of methane. Additionally, samples from 20 wells distributed throughout the county were analyzed for selected man-made volatile organic compounds, and samples from 13 wells where waters had detectable gross alpha activity were analyzed for radium-226 on the basis of relatively elevated gross alpha-particle activity.

Results of the 2015 study show that groundwater quality generally met most drinking-water standards for constituents and properties included in analyses, but groundwater samples from some wells had one or more constituents or properties, including arsenic, iron, manganese, $\mathrm{pH}$, bacteria, sodium, chloride, sulfate, total dissolved solids, and radon-222, that did not meet (commonly termed failed or exceeded) primary or secondary maximum contaminant levels (MCLs) or Health Advisories (HA) for drinking water. Except for iron, dissolved and total concentrations of major ions and most trace constituents generally were similar. Only 1 of 79 well-water samples had any constituent that exceeded a
MCL, with an arsenic concentration of about 30 micrograms per liter $(\mu \mathrm{g} / \mathrm{L})$ that was higher than the MCL of $10 \mu \mathrm{g} / \mathrm{L}$. However, total arsenic concentrations were higher than the HA of $2 \mu \mathrm{g} / \mathrm{L}$ in samples from another 12 of 79 wells (about 15 percent). Secondary maximum contaminant levels (SMCLs) were exceeded most frequently by $\mathrm{pH}$ and concentrations of iron and manganese. The $\mathrm{pH}$ was outside of the SMCL range of 6.5-8.5 in samples from 24 of 79 wells (30 percent), ranging from 5.5 to 9.2; more samples had $\mathrm{pH}$ values less than 6.5 than had $\mathrm{pH}$ values greater than 8.5 . Total iron concentrations typically were much greater than dissolved iron concentrations, indicating substantial presence of iron in particulate phase, and exceeded the SMCL of $300 \mu \mathrm{g} / \mathrm{L}$ more often [35 of 79 samples (44 percent)] than dissolved iron concentrations [samples from 8 of 79 wells (10 percent)]. Total manganese concentrations exceeded the SMCL of $50 \mu \mathrm{g} / \mathrm{L}$ in samples from 31 of 79 wells (39 percent) and the HA of $300 \mu \mathrm{g} / \mathrm{L}$ in samples from 13 of 79 wells (about 16 percent). A few (1-2) samples had concentrations of sodium, chloride, sulfate, or TDS higher than the SMCLs of 60, 250, 250, and $500 \mathrm{mg} / \mathrm{L}$, respectively. However, dissolved sodium concentrations were higher than the HA of $20 \mathrm{mg} / \mathrm{L}$ in samples from 15 of 79 wells (nearly 20 percent). Total coliform bacteria were detected in samples from 25 of 79 wells (32 percent) but Escherichia coli were not detected in any sample. Radon-222 activities ranged from 11 to 5,100 picocuries per liter (pCi/L), with a median of $1,440 \mathrm{pCi} / \mathrm{L}$, and exceeded the proposed and the alternate proposed drinking-water standards of 300 and 4,000 pCi/L, respectively, in samples from 60 of 79 wells (75 percent) and in samples from 2 of 79 wells (3 percent), respectively.

Groundwater samples from all wells were analyzed for dissolved methane by one contract laboratory that determined water from 19 of the 79 wells (24 percent) had concentrations of methane greater than the reporting level of 0.010 milligrams per liter $(\mathrm{mg} / \mathrm{L})$ with a maximum methane concentration of $2.5 \mathrm{mg} / \mathrm{L}$. Methane concentrations in 18 replicate samples submitted to a second laboratory for dissolved gas and isotopic analysis generally were higher by as much as a factor of 2.7 from those determined by the first laboratory, indicating potential bias related to combined sampling and analytical methods, and therefore, caution needs to be used when comparing methane results determined by different methods. 
The isotopic composition of methane in 9 of 10 samples with sufficient dissolved methane (about $0.3 \mathrm{mg} / \mathrm{L}$ ) for isotopic analysis is consistent with values reported for methane of microbial origin produced through carbon dioxide reduction; an isotopic shift in 1 or 2 samples may indicate subsequent methane oxidation. The low concentrations of ethane relative to methane in these samples further indicate that the methane may be of microbial origin. Groundwater samples with relatively elevated methane concentrations (near or greater than $0.3 \mathrm{mg} / \mathrm{L}$ ) also had chemical compositions that differed in some respects from groundwater with relatively low methane concentrations (less than $0.3 \mathrm{mg} / \mathrm{L}$ ) by having higher $\mathrm{pH}$ (greater than 8) and higher concentrations of sodium, lithium, boron, fluoride, arsenic, and bromide and chloride/bromide ratios indicative of mixing with a small amount of brine of probable natural occurrence.

The spatial distribution of groundwater compositions differs by topographic setting and lithology and generally shows that (1) relatively dilute, slightly acidic, oxygenated, calcium-carbonate type waters tend to occur in the uplands underlain by the undivided Poplar Gap and Packerton members of the Catskill Formation in southwestern Pike County; (2) waters of near neutral $\mathrm{pH}$ with the highest amounts of hardness (calcium and magnesium) generally occur in areas of intermediate altitudes underlain by other members of the Catskill Formation; and (3) waters with $\mathrm{pH}$ values greater than 8 , low oxygen concentrations, and the highest arsenic, sodium, lithium, bromide, and methane concentrations can be present in deep wells in uplands but most frequently occur in stream valleys, especially at low altitudes (less than about 1,200 feet above North American Vertical Datum of 1988) where groundwater may be discharging regionally, such as to the Delaware River in northern and eastern Pike County. Thus, the baseline assessment of groundwater quality in Pike County prior to gas-well development shows that shallow (less than about 1,000 feet deep) groundwater generally meets primary drinking-water standards for inorganic constituents but varies spatially, with methane and some constituents present in high concentrations in brine (and connate waters from gas and oil reservoirs) present at low to moderate concentrations in some parts of Pike County.

\section{Introduction}

Pike County in northeastern Pennsylvania (fig. 1) is underlain by the Marcellus Shale and, at greater depths, the Utica Shale. These formations are being developed in western and northern Pennsylvania for natural gas, using unconventional methods that involve hydraulic fracturing. The Marcellus Shale is exposed at the land surface in southeastern
Pike County, cropping out along the Delaware River, and is present at increasing depths to the west. Test holes indicate depths to the formation are about 5,500 to 6,500 feet (ft) below land surface in north-central and western Pike County (Sevon and others, 1989). The Utica Shale is present thousands of feet (about 5,550 ft in western Pike County as indicated by a test hole described by Sevon and others, 1989) below the Marcellus Shale. Residents of largely rural Pike County rely on groundwater as the primary source of water supply. Drilling and hydraulic fracturing of horizontal natural gas wells used to develop the shale gas deposits have the potential to contaminate freshwater aquifers that provide drinking water and the base flow of streams (Kargbo and others, 2010; Kerr, 2010; U.S. Environmental Protection Agency, 2014, 2015, and 2016). Produced (flowback) fluids generated as a result of drilling and hydraulic-fracturing activities commonly contain concentrations elevated above background for chloride, bromide, sodium, calcium, and other constituents present in oil and gas well brines and naturally occurring Appalachian Basin brines in eastern United States (Llewellyn, 2014) (table 1).

Since 2006 when development of natural gas in shale formations using hydraulic fracturing began to increase in Pennsylvania, land was leased in northern and western Pike County for gas development (Pike County Marcellus Shale Task Force, written commun., 2011), but no permits for wells were issued. In neighboring Wayne County, permits have been issued for 33 Marcellus Shale gas wells (Pennsylvania Department of Environmental Protection, 2017). However, partly because of a drilling moratorium in the Deleware River Basin imposed by the Delaware River Basin Commission (DRBC) in 2010 (Delaware River Basin Commission, 2014), only nine vertical exploratory gas wells have been drilled in Wayne County (fig. 1) as of September 2016, and these wells were drilled during 2008-10 (Pennsylvania Department of Environmental Protection, 2016a). Three vertical exploratory natural gas test holes were drilled in Pike County between 1958 and 1971 (Sevon and others, 1989). No horizontal drilling has been conducted, and no well has been hydraulically fractured in either Pike or Wayne Counties. In contrast, in Susquehanna County on the western border of Wayne County and in the Susquehanna River Basin, where the DRBC moratorium is not applicable, a total of 1,218 gas wells (fig. 1) have been drilled from 2005 through June 2016 (Pennsylvania Department of Environmental Protection, 2016a).

Without baseline water-quality data, it is difficult to determine the effects of natural-gas production and related activities on the shallow groundwater chemistry. This study, conducted by the U.S. Geological Survey (USGS) in cooperation with Pike County Conservation District (PCCD), expands on a preliminary baseline assessment of groundwater quality done during $2012-13$ by USGS in cooperation with the PCCD. 


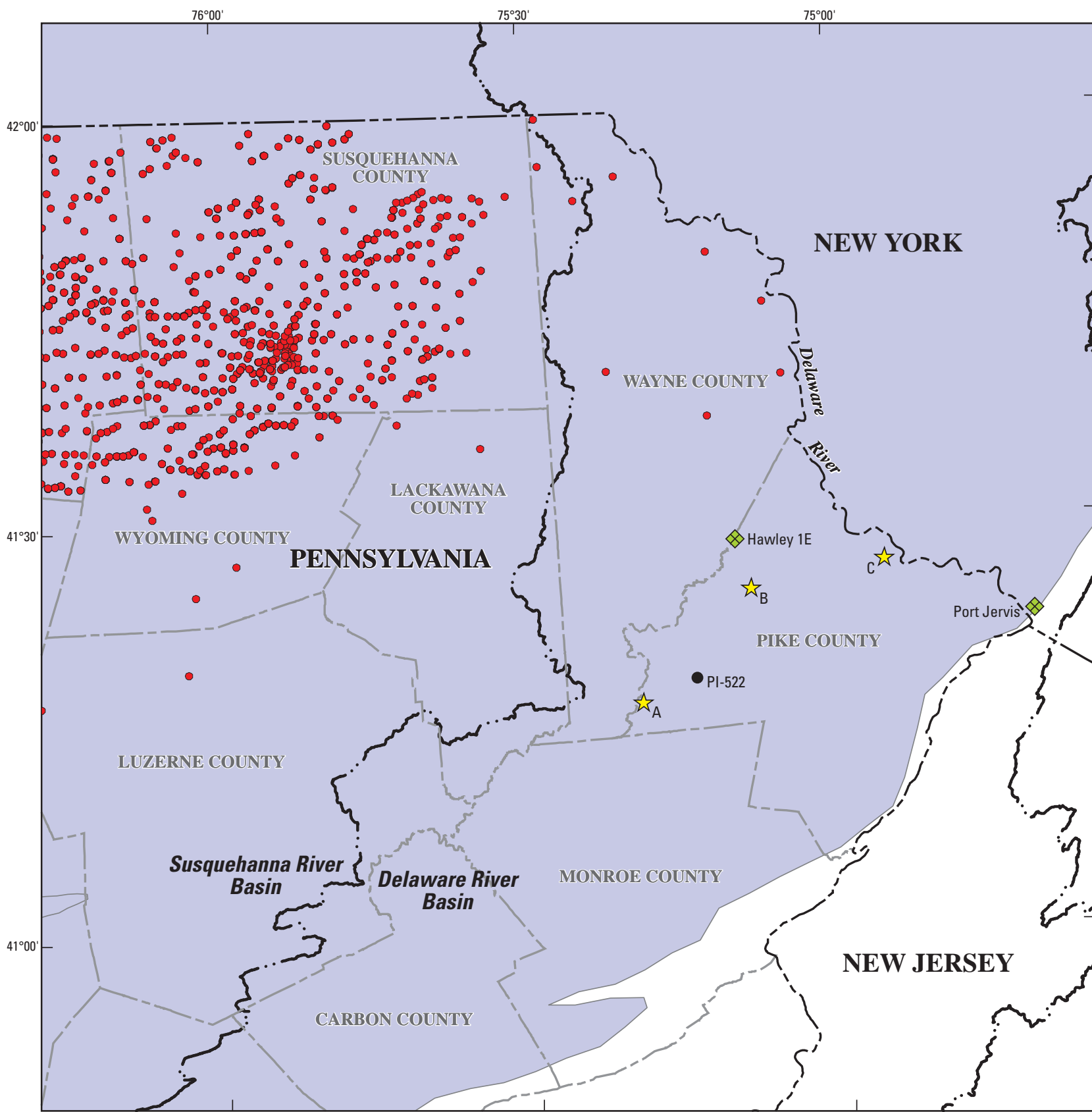

Base from U.S. Geological Survey digital data, 1972, Albers Equal-Area Conic Projection North American Datum, 1983 (NAD 83) and North American Vertical Datum, 1988 (NAVD 88) $\begin{array}{llcccc}0 & & 5 & 10 & 15 & 20 \\ 0 & 5 & 10 & 15 & 20 \text { KILOMETERS }\end{array}$

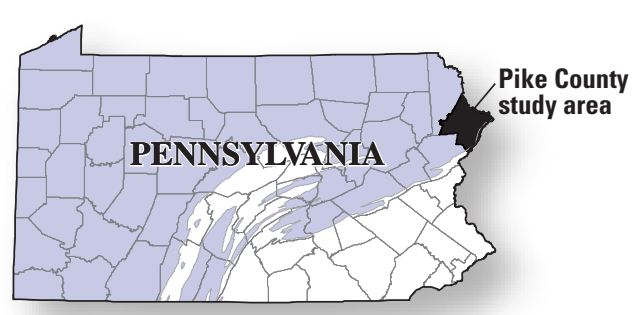

\section{EXPLANATION}

Area underlain by Marcellus Shale

- Delaware River Basin boundary

- PI-522 U.S. Geological Survey observation well and site name

A Gas exploration well drilled during 1959-71 and identifier Gas well drilled since 2007

Port Jervis $\otimes \quad$ Meteorological station and station name

Figure 1. Location of Delaware River Basin boundary and gas wells drilled in Pike County, Pennsylvania, during 1959-71 and in nearby counties in Pennsylvania during 2007 through June 2016. Gas well data for 2007-16 from Pennsylvania Department of Environmental Protection (2016b). 
Table 1. Maximum concentrations reported for selected inorganic constituents in oil and gas well brines or flowback waters in western Pennsylvania and in Salt Spring in Susquehanna County, Pennsylvania.

[PA, Pennsylvania; mg/L, milligrams per liter; $\mathrm{CaCO}_{3}$, calcium carbonate; TDS, total dissolved solids; pCi/L, picocuries per liter; --, no data; $\mathrm{Cl}$, chloride; Br, bromide; Li, lithium; Mg, magnesium; $\mathrm{Ba}$, barium; $\mathrm{Sr}$, strontium]

\begin{tabular}{|c|c|c|c|c|}
\hline \multirow[b]{2}{*}{ Constituent } & \multirow[b]{2}{*}{$\begin{array}{c}\text { Concen- } \\
\text { tration } \\
\text { unit }\end{array}$} & \multicolumn{3}{|c|}{ Reported maximum concentration } \\
\hline & & $\begin{array}{c}\text { Western } \\
\text { PA }^{1}\end{array}$ & $\begin{array}{l}\text { Marcellus } \\
\text { Shale } \\
\text { flowback } \\
\text { fluid }^{2}\end{array}$ & $\begin{array}{c}\text { Salt } \\
\text { Spring }^{3}\end{array}$ \\
\hline \multicolumn{5}{|c|}{ Major ions } \\
\hline Calcium & $\mathrm{mg} / \mathrm{L}$ & 41,600 & 17,900 & 370 \\
\hline Magnesium & $\mathrm{mg} / \mathrm{L}$ & 4,150 & -- & 61 \\
\hline Potassium & $\mathrm{mg} / \mathrm{L}$ & 4,860 & 5,240 & -- \\
\hline Sodium & $\mathrm{mg} / \mathrm{L}$ & 83,000 & 37,800 & 1,800 \\
\hline Chloride & $\mathrm{mg} / \mathrm{L}$ & 207,000 & 105,000 & 4,014 \\
\hline Sulfate & $\mathrm{mg} / \mathrm{L}$ & 850 & 420 & 0.65 \\
\hline Alkalinity & $\begin{array}{l}\mathrm{mg} / \mathrm{L} \text { as } \\
\mathrm{CaCO}_{3}\end{array}$ & 1,520 & 939 & 138 \\
\hline TDS & $\mathrm{mg} / \mathrm{L}$ & 354,000 & 197,000 & 6,418 \\
\hline \multicolumn{5}{|c|}{ Minor ions, trace elements, and metals } \\
\hline Barium & $\mathrm{mg} / \mathrm{L}$ & 4,370 & 6,270 & 84.4 \\
\hline Bromide & $\mathrm{mg} / \mathrm{L}$ & 2,240 & 613 & 37.9 \\
\hline Copper & $\mathrm{mg} / \mathrm{L}$ & 0.13 & -- & -- \\
\hline Iodide & $\mathrm{mg} / \mathrm{L}$ & 56 & -- & -- \\
\hline Iron & $\mathrm{mg} / \mathrm{L}$ & 494 & -- & -- \\
\hline Lithium & $\mathrm{mg} / \mathrm{L}$ & 315 & -- & 4.3 \\
\hline Lead & $\mathrm{mg} / \mathrm{L}$ & 0.04 & -- & -- \\
\hline Manganese & $\mathrm{mg} / \mathrm{L}$ & 96 & 29 & -- \\
\hline Strontium & $\mathrm{mg} / \mathrm{L}$ & 13,100 & 3,570 & 48.5 \\
\hline Zinc & $\mathrm{mg} / \mathrm{L}$ & 1.3 & -- & -- \\
\hline \multicolumn{5}{|c|}{ Radionuclides } \\
\hline Radium-226 & $\mathrm{pCi} / \mathrm{L}$ & 5,300 & 5,830 & 18.4 \\
\hline Radium-228 & $\mathrm{pCi} / \mathrm{L}$ & -- & 710 & 9.3 \\
\hline \multicolumn{5}{|c|}{ Ratios ${ }^{4}$} \\
\hline$(\mathrm{Cl} / \mathrm{Br})$ & mass ratio & 92 & ${ }^{\mathrm{a}} 129$ & 106 \\
\hline (Cl/Li) & mass ratio & 657 & -- & 933 \\
\hline$(\mathrm{Sr}+\mathrm{Ba}) / \mathrm{Mg}$ & mass ratio & 4.2 & -- & 2.2 \\
\hline
\end{tabular}

${ }^{1}$ Brines from oil and gas wells in Devonian- and Silurian-age rocks in western Pennsylvania (Dresel and Rose, 2010).

${ }^{2}$ Data from Pennsylvania Department of Environmental Protection Bureau of Oil and Gas Management reported in Haluszczak and others (2013).

${ }^{3}$ Data from Warner and others, 2012.

${ }^{4}$ Mass ratios calculated from concentrations listed in column above, unless otherwise noted.

${ }^{a}$ Median $\mathrm{Cl} / \mathrm{Br}$ mass ratio for 19 samples; data from Pennsylvania Department of Environmental Protection Bureau of Oil and Gas Management reported in Haluszczak and others (2013).
The 2015 groundwater-quality assessment is intended to provide current data on the presence, concentrations, and distribution of methane, inorganic constituents, and selected man-made organic compounds in shallow groundwater (less than about 1,000 feet deep) in bedrock aquifers prior to shale-gas production in Pike County. Groundwater samples were analyzed for constituents recommended in 2014 by the Pennsylvania Department of Environmental Protection (PADEP), which, in 2016, slightly revised the list of recommended constituents for testing of private wells in areas where gas drilling may occur in the future by adding some trace constituents and ethylene glycol (table 2) (Pennsylvania Department of Environmental Protection, 2014; 2016c). The 2015 study also included analyses for other constituents to provide a more comprehensive characterization of groundwater quality than the constituents on the basic predrill list. The data collected during the 2015 study described

Table 2. Pre-drill basic list of constituents recommended by the Pennsylvania Department of Environmental Protection in 2014 for analysis in private water supply wells prior to gas drilling.

[Data from Pennsylvania Department of Environmental Protection, 2014; TDS, total dissolved solids; TSS, total suspended solids]

\begin{tabular}{|c|c|c|c|}
\hline $\begin{array}{c}\text { Analyte } \\
\text { (inorganic) }\end{array}$ & $\begin{array}{c}\text { Analyte } \\
\text { (trace metal) }\end{array}$ & $\begin{array}{c}\text { Analyte } \\
\text { (organic) }^{2}\end{array}$ & $\begin{array}{c}\text { Analyte } \\
\text { (microbiologic) }\end{array}$ \\
\hline Alkalinity* & Barium* & Ethane $^{*}$ & $\begin{array}{l}\text { Total coliform } \\
\text { bacteria }\end{array}$ \\
\hline Chloride* & C alcium* & M ethane* & \\
\hline Conductivity & Iron $^{*}$ & Propane* & \\
\hline Hardness & Magnesium & $\begin{array}{l}\text { Total petroleum } \\
\text { hydrocarbons }\end{array}$ & \\
\hline Bromide & M anganese* & & \\
\hline $\mathrm{pH}^{*}$ & Potassium & & \\
\hline Sulfate $e^{* *}$ & Sodium* & & \\
\hline TDS* & Strontium & & \\
\hline Turbidity* $^{*}$ & Arsenic & & \\
\hline \multirow[t]{4}{*}{ TSS } & Zinc & & \\
\hline & Aluminum & & \\
\hline & Lithium & & \\
\hline & Selenium & & \\
\hline
\end{tabular}

${ }^{*}$ As a minimum, a homeowner wishing to have their private well tested should analyze for these constituents.

${ }^{* *}$ Consider where coal formations are present.

${ }^{* * *}$ Consider in western Pennsylvania’s oil-producing regions.

${ }^{1}$ Pre-drill basic list revised in 2016 included all constituents in 2014 list plus copper, vanadium, boron, and chromium (Pennsylvania Department of Environmental Protection, 2016c).

${ }^{2}$ Pre-drill basic list revised in 2016 included all constituents in 2014 list plus ethylene glycol and for western Pennsylvania, volatile organic compounds and benzene, toluene, ethylbenzene, and xylene(BTEX compounds) (Pennsylvania Department of Environmental Protection, 2016c). 
in this report and the previous 2012-13 study document groundwater quality in Pike County. In addition to serving as a baseline for future evaluations that might determine the effect of shale-gas development or other land-use changes on groundwater quality, the assessment also may be used to evaluate overall general groundwater quality in the county and identify constituents in local drinking water that may pose a health risk.

\section{Purpose and Scope}

This report presents analytical data for groundwater samples collected from 79 domestic wells in Pike County during summer 2015. The groundwater samples were analyzed for chemical and physical properties and a suite of constituents, including nutrients, major ions, trace elements and metals, radioactivity, bacteria, radon-222, and methane and other dissolved hydrocarbon gases. Samples from 20 of the 79 wells were also analyzed for selected man-made organic compounds, and samples from 13 of the 79 wells were analyzed for radium-226. The groundwater-quality data and summary statistics are presented to provide a pre-gaswell drilling baseline and for comparison to drinking-water standards to identify existing water-quality problems. The isotopic composition of methane in groundwater samples with sufficient methane to perform the analysis is compared to reported compositions of methane with thermogenic or biogenic origins.

Relations among constituents in the 2015 groundwater samples are described to provide insight into the presence of, and geochemical controls on, selected constituents, including those that pose health risks at elevated concentrations, such as arsenic, and others of concern, such as methane, which have been documented to be present in the county during previous studies (Eckhardt and Sloto, 2012; Senior, 2014). Statistical tests were used to identify groupings of constituents. Geochemical controls on the solubility of selected trace elements are shown in illustrations in relation to $\mathrm{pH}$ and oxidation-reduction conditions. Trilinear (Piper) diagrams are presented to show the types of groundwater in Pike County. Use of chloride/bromide $(\mathrm{Cl} / \mathrm{Br})$ ratios to identify sources of chloride is discussed. The spatial distribution of selected constituents is displayed on maps to illustrate the spatial patterns and to indicate the possible role of hydrogeologic setting on the presence of elevated concentrations of constituents of concern.

Additionally, the report includes analytical data for 1) 7 pairs of closely-spaced wells sampled in 2015 to provide data on local spatial variability in groundwater quality, and 2) 18 wells in Pike County that had been sampled by USGS at least once previously for more limited assessments in 2007, 2011, or 2012-13 (Senior, 2009; Eckhardt and Sloto, 2012; Senior, 2014) and that were resampled as part of the 2015 assessment to provide some information on variability of water quality through time. Differences and similarities in the compositions of water from the 7 pairs of closely-spaced sampled in 2015 and the 18 wells sampled in 2015 and at least once previously during 2007-13 are discussed.

\section{Description of Study Area}

Pike County covers 547 square miles $\left(\mathrm{mi}^{2}\right)$ in northeastern Pennsylvania and is flanked on the north and east by the Delaware River, which forms the boundary between Pennsylvania and the adjacent States of New York and New Jersey (fig. 1). In Pennsylvania, Pike County is bordered by Wayne County to the west and Monroe County to the south. The climate and general physical characteristics are described in more detail by Davis (1989).

\section{Physiography and Hydrogeologic Setting}

Most of Pike County is in the Glaciated Low Plateau Section of the Appalachian Plateaus Physiographic Province, but the southwestern corner of the county is in the Glaciated Pocono Plateau Section of the Appalachian Plateaus Physiographic Province (fig. 2). The Glaciated Low Plateau Section is characterized by low to moderately high rounded hills and broad to narrow valleys, all of which have been modified by glacial erosion and deposition. Swamps and peat bogs are common. The Glaciated Pocono Plateau Section is characterized by broad, undulatory upland surfaces with dissected margins (Sevon, 2000). Land-surface altitudes are highest [more than 2,000 ft above the North American Vertical Datum of 1988 (NAVD 88)] in the southwestern corner of the county (Glaciated Pocono Plateau Section) and lowest along the Delaware River (as low as about $320 \mathrm{ft}$ above NAVD 88) (fig. 2). 


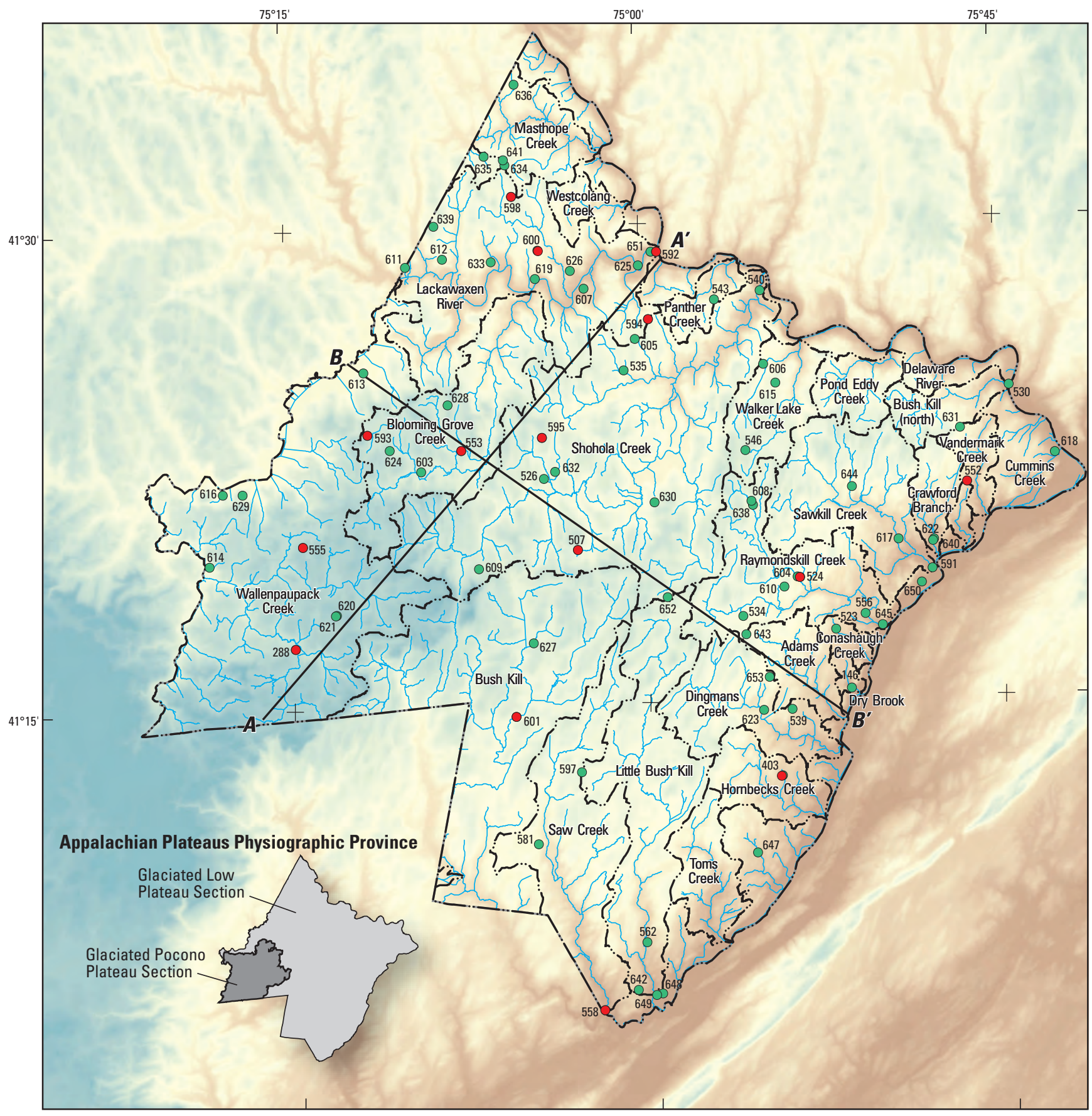

Base from U.S. Geological Survey digital data, 1972, 1:2,000,000 Base Pennsylvania Geological Survey PAMAP—Municipal Boundaries, 2007 Albers Equal-Area Conic Projection

North American Datum, 1983 (NAD 83) and

North American Vertical Datum, 1988 (NAVD 88)

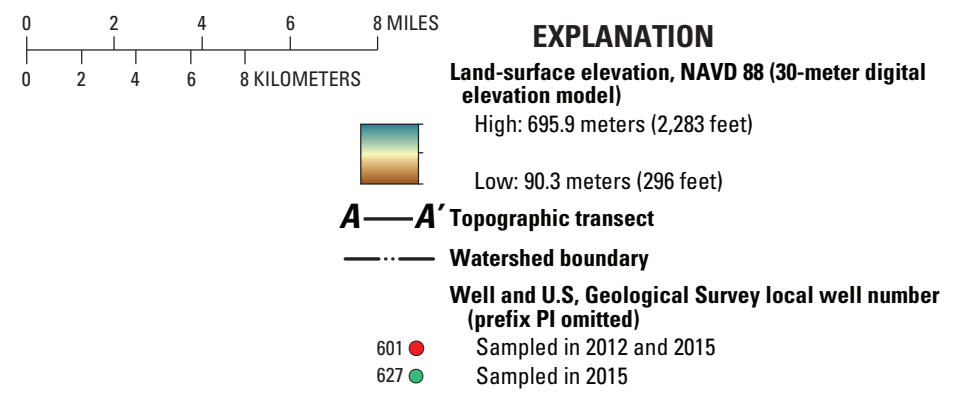

Figure 2. A, Land-surface altitude, streams and major watersheds, and location of wells sampled in 2012 and 2015, in Pike County, Pennsylvania, and $B$, transects $A-A^{\prime}$ and $B-B^{\prime}$. Transects $A-A^{\prime}$ and $B-B^{\prime}$ terminate at the Delaware River, but transect $A-A^{\prime}$ originates near the highest altitudes in southwestern Pike County, and transect $B-B^{\prime}$ originates at Lake Wallenpaupack at western edge of Pike County. 

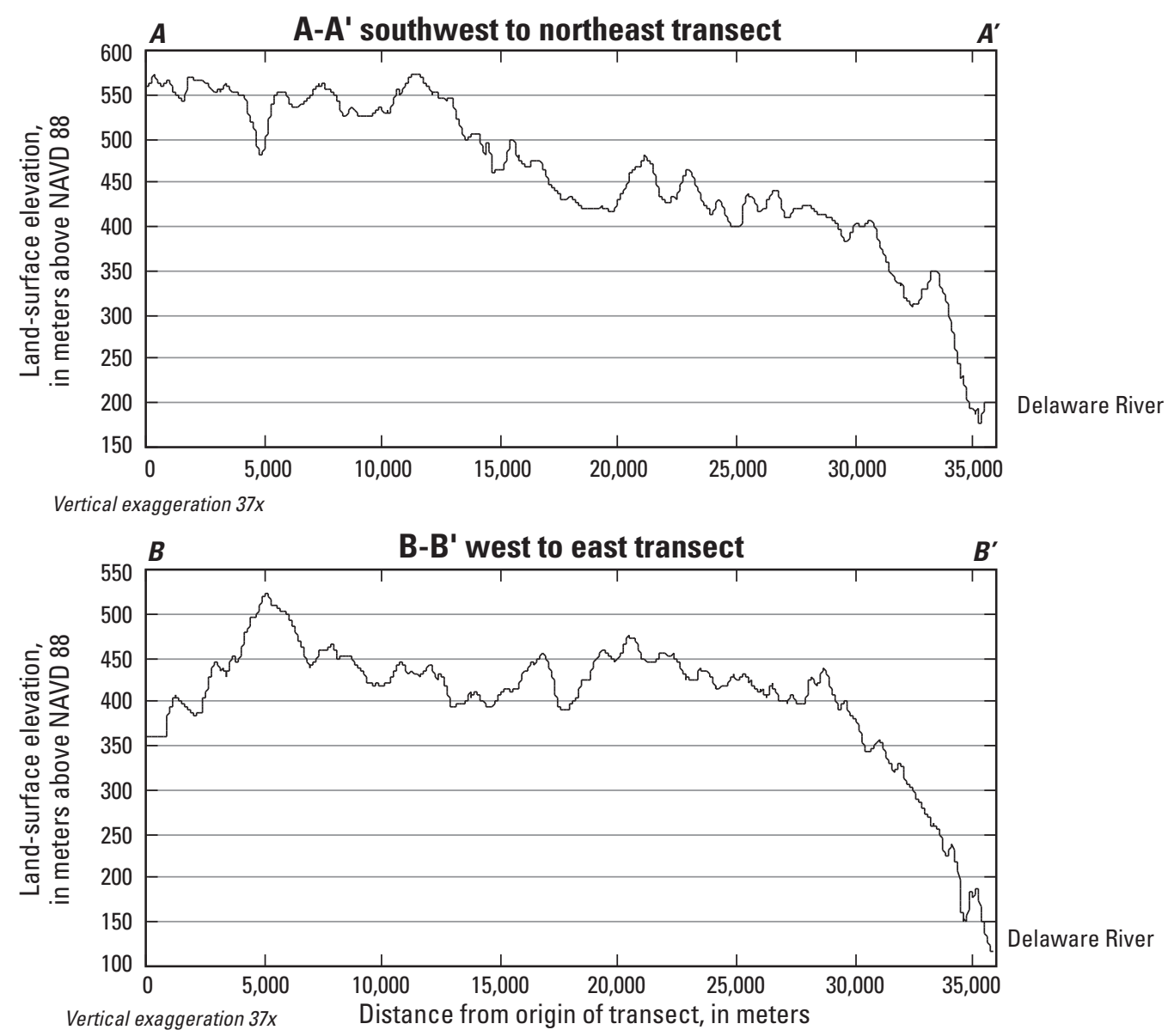

Figure 2. A, Land-surface altitude, streams and major watersheds, and location of wells sampled in 2012 and 2015, in Pike County, Pennsylvania, and $B$, transects $A-A^{\prime}$ and $B-B^{\prime}$. Transects $A-A^{\prime}$ and $B-B^{\prime}$ terminate at the Delaware River, but transect $A-A^{\prime}$ originates near the highest altitudes in southwestern Pike County, and transect $B-B^{\prime}$ originates at Lake Wallenpaupack at western edge of Pike County.-Continued

The bedrock geologic units that underlie and crop out in Pike County are Devonian-age sedimentary rocks that have been mapped (fig. 3) using the Pennsylvania Geological Survey (PAGS) nomenclature (Berg and others, 1980; Berg and Dodge, 1981), in order of decreasing age from east to west, as the Marcellus Formation (Marcellus Shale in USGS nomenclature), Mahantango Formation, Trimmers Rock Formation, Towamensing Member of the Catskill Formation, undivided Long Run and Walcksville Members of the Catskill Formation, and undivided Poplar Gap and Packerton Members of the Catskill Formation (fig. 3). In subsequent mapping (Sevon and others, 1989), the undivided Long Run and Walcksville Members of the Catskill Formation were differentiated and renamed as the Lackawaxen and Delaware River Members of the Catskill Formation; this mapping shows the Lackawaxen Member overlying the Delaware River Formation and present only in western Pike County. Mapping by Sevon and others (1989) also subdivided the siltstones and sandstones of the Trimmers Rock Formation into the Sloats Brook member (predominantly siltstone) overlain by the Millrift member (predominantly sandstone). However, the mineralogy of the two members was not differentiated (Sevon and others, 1989); therefore, these members are not differentiated for this report. The Devonian-age sedimentary rock formations in Pike County generally show a trend from finer-grained rocks (shales and siltstones) in the older units in the eastern part of the county to coarser-grained rocks (sandstones and conglomerates) in younger units in the western part of the county (fig. 3; table 3). The bedrock units generally dip to the west at moderate to low angles, with the steepest dips (as much as 20 degrees) in the eastern part of the county and shallowest dips (0 to 5 degrees) in the western part of the county (Sevon and others, 1989). 


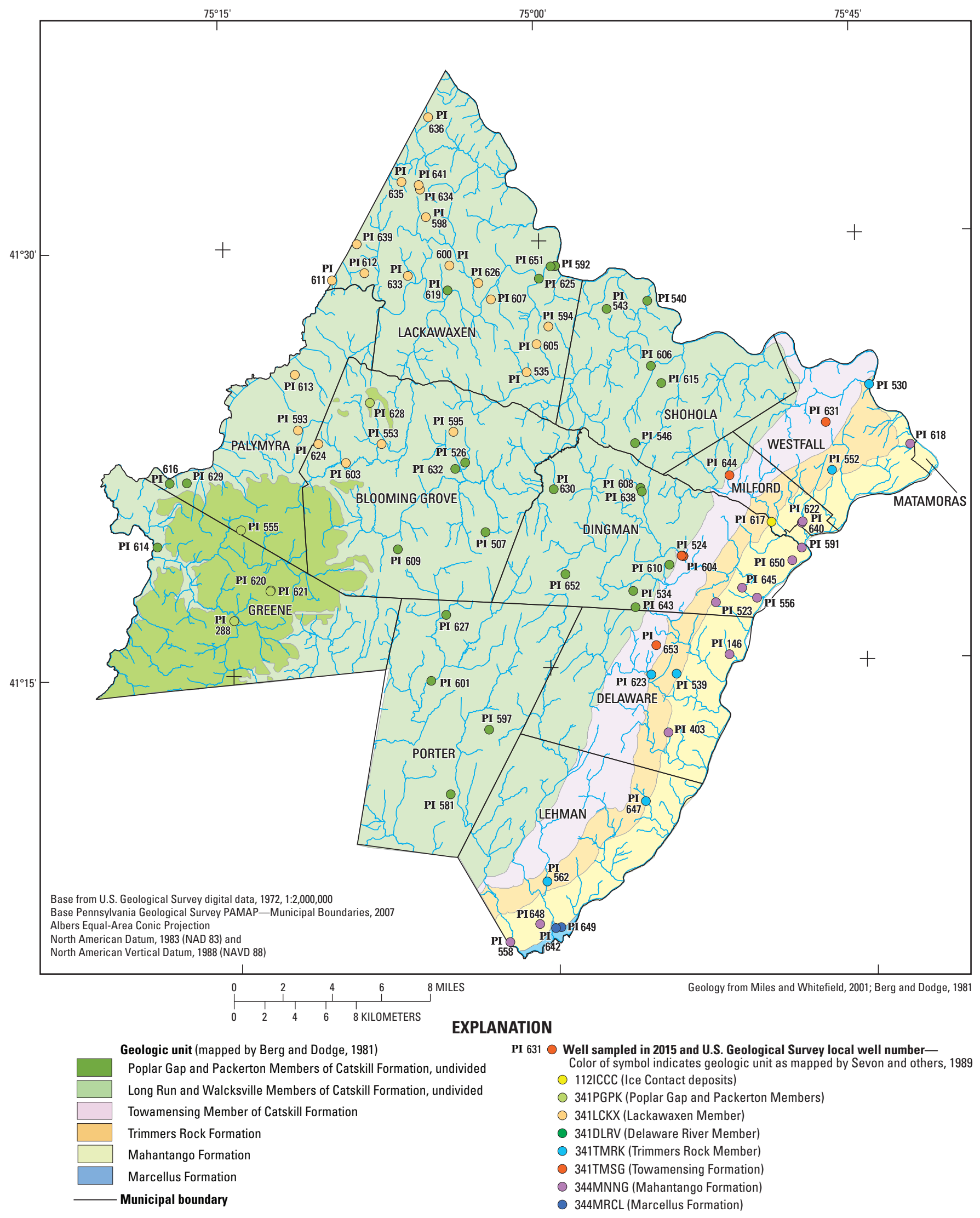

Figure 3. Geology of the bedrock closest to land surface and location of wells sampled in Pike County, Pennsylvania, 2015. 
Table 3. Lithology and mineralogy of Devonian-age bedrock geologic units in Pike County, Pennsylvania.

[Descriptions of predominant lithology (rock type) and mineralogy of geologic units from Sevon and others (1989), listed in order of decreasing age, with oldest unit at bottom; Al, aluminum; C, carbon; $\mathrm{Ca}$, calcium; Cl, chloride; $\mathrm{Cr}$, chromium; F, fluoride; Fe, iron; $\mathrm{H}$, hydrogen; $\mathrm{K}$, potassium; Li, lithium; Mg, magnesium; Mn, manganese; Na, sodium; Ni, nickel; O, oxygen; P, phosphorus; $\mathrm{S}$, sulfur; Si, silicon; Th, thorium; Ti, titanium; U, uranium; V, vanadium; Zn, zinc; Zr, zirconium]

\begin{tabular}{|c|c|c|c|}
\hline Formation name & Lithology & Mineralogy & Chemical formula for selected minerals \\
\hline \multicolumn{4}{|l|}{ Catskill Formation: } \\
\hline $\begin{array}{l}\text { Poplar Gap and } \\
\text { Packerton Members, } \\
\text { undivided }\end{array}$ & $\begin{array}{l}\text { Sandstone, conglomerate, siltstone, claystone, } \\
\text { calcareous intraformational coglomerate }\end{array}$ & $\begin{array}{l}\text { Quartz, muscovite, biotite, illite, chlorite, trace } \\
\text { calcite }\end{array}$ & Biotite $\mathrm{K}\left(\mathrm{Mg}, \mathrm{Fe}_{2}^{+3}\right)\left(\mathrm{Al}, \mathrm{Fe}^{3+}\right) \mathrm{Si}_{3} \mathrm{O}_{10}(\mathrm{OH}, \mathrm{F})_{2}$ \\
\hline Lackawaxen Member ${ }^{1}$ & $\begin{array}{l}\text { Sandstone, siltstone, claystone, intraformational } \\
\text { conglomerates with calcite cement }\end{array}$ & $\begin{array}{l}\text { Quartz, muscovite, biotite, feldspar (orthoclase, } \\
\text { plagioclase), illite, chlorite, calcite, garnet, } \\
\text { apatite, magnetite }\end{array}$ & $\begin{array}{l}\text { Orthoclase } \mathrm{KAlSi}_{3} \mathrm{O}_{8} \text { plagioclase }(\mathrm{Na}, \mathrm{Ca}) \mathrm{AlSi}_{3} \mathrm{O}_{8} \\
\text { apatite } \mathrm{Ca}_{5}(\mathrm{PO} 4)_{3}(\mathrm{~F}, \mathrm{Cl}, \mathrm{OH}) \text { garnet }\left(\mathrm{Ca}, \mathrm{Mg}, \mathrm{Fe}^{2+}\right)_{3} \\
\quad\left(\mathrm{Al}, \mathrm{Fe}^{3+}, \mathrm{Mn}^{3+}, \mathrm{V}^{3+}, \mathrm{Cr}^{3+}\right)\left(\mathrm{SiO}_{4}\right)_{3}\end{array}$ \\
\hline $\begin{array}{l}\text { Delaware River } \\
\text { Member }^{1}\end{array}$ & $\begin{array}{l}\text { Sandstone, interbedded siltstone and claystone, } \\
\text { intraformational conglomerates with calcite } \\
\text { cement }\end{array}$ & $\begin{array}{l}\text { Quartz, feldspar, limonite, illite, microcrystalline } \\
\text { silica, calcite, zircon, leucoxene }\end{array}$ & Leocoxene altered $\mathrm{TiO}_{2}$, zircon $\mathrm{ZrSiO}_{4}$ with $\mathrm{U}$ Th \\
\hline Towamensing Member & $\begin{array}{l}\text { Sandstone, interbedded siltstone and claystone, } \\
\text { intraformational conglomerates with calcite } \\
\text { cement }\end{array}$ & $\begin{array}{l}\text { Quartz, feldspar, limonite, illite, chlorite, } \\
\text { kaolinite, calcite, zircon, apatite, magnetite, } \\
\text { leucoxene }\end{array}$ & $\begin{array}{l}\text { Illite }\left(\mathrm{K}, \mathrm{H}_{3} \mathrm{O}\right)(\mathrm{Al}, \mathrm{Mg}, \mathrm{Fe})_{2}(\mathrm{Si}, \mathrm{Al})_{4} \mathrm{O}_{10}\left[(\mathrm{OH})_{2},\left(\mathrm{H}_{2} \mathrm{O}\right)\right] \\
\text { magnetite } \mathrm{Fe}^{2+}\left(\mathrm{Fe}^{3+}\right)_{2} \mathrm{O}_{4} \text { with Mn, Mg, } \mathrm{Zn}, \mathrm{Ni}, \mathrm{Al}, \mathrm{Cr}\end{array}$ \\
\hline $\begin{array}{l}\text { Trimmers Rock } \\
\text { Formation }\end{array}$ & Siltstone, silty shale, sandstone, and claystone & $\begin{array}{l}\text { Quartz, illite, chlorite, microcrystalline silica, } \\
\text { limonite, trace calcite and feldspar }\end{array}$ & Chlorite (Mg,Fe, $\mathrm{Li})_{6} \mathrm{AlSi}_{3} \mathrm{O}_{10}(\mathrm{OH})_{8}$ \\
\hline Mahantango Formation & Siltstone, silty shale, and claystone & $\begin{array}{l}\text { Quartz, illite, chlorite, microcrystalline silica, } \\
\text { limonite }\end{array}$ & Limonite $\mathrm{FeO}(\mathrm{OH}) \mathrm{nH}_{2} \mathrm{O}$ \\
\hline Marcellus Shale & Slightly siliceous clay shale and silty clay shale & $\begin{array}{l}\text { Quartz, chlorite, muscovite, pyrite, siderite, } \\
\text { marcasite, dolomite, calcite(?), feldspar } \\
\text { (albite?) }\end{array}$ & $\begin{array}{l}\text { Marcasite } \mathrm{FeS}_{2} \text { siderite } \mathrm{FeCO}_{3} \text { muscovite } \\
\qquad \mathrm{KAl}_{2}\left(\mathrm{Si}_{3} \mathrm{Al}\right) \mathrm{O}_{10}(\mathrm{OH}, \mathrm{F})_{2} \text { albite } \mathrm{NaAlSi}_{3} \mathrm{O}_{8}\end{array}$ \\
\hline
\end{tabular}

${ }^{1}$ Mapped as Long Run and Walcksville Members of the Catskill Formation, undivided, by Berg and others (1980). 
The Marcellus Shale (Marcellus Formation in PAGS nomenclature) underlies all of Pike County and crops out at the eastern edge of the county near the Delaware River (figs. 1 and 3). In Pike County, the thickness of the gas-producing organic-rich section of the Marcellus Shale increases from east to west and is estimated to be about 100-150 ft in western part of the county (Piotrowski and Harper, 1979). The Ordovicianage Utica Shale, another gas-producing formation, is older than, and occurs several thousand feet beneath, the Marcellus Shale and also underlies all of Pike County (Kirschbaum and others, 2012). Two of three deep wells drilled in central to western Pike County for natural gas exploration during 195871 penetrated the Marcellus Shale at depths of 5,500-7,500 ft below land surface, and the deepest of the three penetrated the Utica Formation at depth of about 13,000 ft below land surface (Sevon and others, 1989) (fig. 4). An exploratory 1,842-ft-deep oil and gas test hole drilled in eastern Pike County near Matamoras (fig. 3) penetrated bituminous black slate (Marcellus Shale) at a depth of about 1,040 ft, as reported by Lohman (1937).

Unconsolidated Wisconsin-age glacial deposits cover part of the bedrock units and vary in thickness and type, with the thickest deposits in valleys and thinnest deposits in upland areas, as described by Sevon and others (1989). Less than one-half of Pike County is overlain by glacial deposits, and most of these deposits are mapped as glacial till that typically is thin (less than $6 \mathrm{ft}$ thick). Bedrock is exposed at the land surface in many areas not overlain by glacial deposits. The thickest glacial deposits and younger alluvium are present in a narrow band along the eastern flank of Pike County adjacent to the Delaware River and along some of the larger streams in the county, as shown by Sevon and others (1989). Other more recent types of deposits with more limited areal extent include alluvium in valleys and swamp and peat deposits that commonly occur in poorly drained glacial depressions throughout the county.

\section{Hydrogeologic Setting}

Most of the county is underlain by Devonian-age fractured-rock aquifers (shales, siltstones, and sandstones) (fig. 3) with unconsolidated Quaternary-age glacial deposits that are high yielding in groundwater in a band parallel to the Delaware River on the eastern edge of the county and in some upland stream valleys (Sevon and others, 1989). Groundwater in bedrock units and overlying glacial deposits is the main source of water supply for Pike County. These aquifers are recharged locally by precipitation and subsequently discharge to streams. Depth to water tends to be greater in upland areas than in valleys. The sedimentary rocks underlying Pike County form a layered, fractured-rock aquifer system.

In Pike County, local, intermediate, and regional groundwater flow systems with complex flow paths are thought to be present. Local and intermediate systems likely discharge to streams and larger tributaries, respectively, and the deeper regional system discharges to the Delaware River (Davis, 1989) along northern and eastern borders of the county, and possibly to other large streams, such as the Lackawaxen River (fig. 2). Topography likely affects directions of local and intermediate groundwater flow, as described in studies of Pike County and nearby counties and in other areas of the Appalachian Plateau region (Carswell and Lloyd, 1979; Davis, 1989; Reese, 2014). Shallow- to intermediate-depth fresh groundwater flows from recharge areas at higher altitudes and discharges locally and regionally into streams at lower altitudes as base flow. Only a small part of recharge is thought to enter and flow through the deeper regional flow system (Davis, 1989). Depth to saline water, which can be present in low-permeability areas of the aquifer with restricted flow, has been estimated to be greater than or equal to $1,000 \mathrm{ft}$ in northeastern Pennsylvania in the vicinity of Pike County (Feth and others, 1965). For the surfacewater system, streams eventually drain toward the Delaware River, radiating from near the center of Pike County (fig. 2). The aquifer properties of the various geologic units and hydrogeology of the county are described in greater detail by Davis (1989).

Most domestic wells in Pike County currently are completed in fractured bedrock aquifers rather than the overlying unconsolidated glacial deposits, except in areas along the Delaware River where thick sequences of coarse to fine glacial sediment are present and, to a lesser extent, in stream valleys and lower slopes where sufficient thickness of glacial till is present and some wells completed are in the unconsolidated deposits. The wells completed in fractured rock typically are constructed as open holes below surface casing and intercept multiple water-bearing fractures at various depths. Wells for drinking-water supply typically are completed within the local, freshwater flow system (less than $1,000 \mathrm{ft}$ in depth). However, at depth in underlying rocks with restricted groundwater circulation, brines with elevated concentrations of sodium, chloride, bromide, barium, strontium, and other solutes may be present. The highly saline sodium chloride brines and overlying groundwaters of intermediate salinity generally are thought to be present at about $1,000 \mathrm{ft}$ or more below the land surface in eastern Pennsylvania (Feth and others, 1965; Heisig and Scott, 2013). 

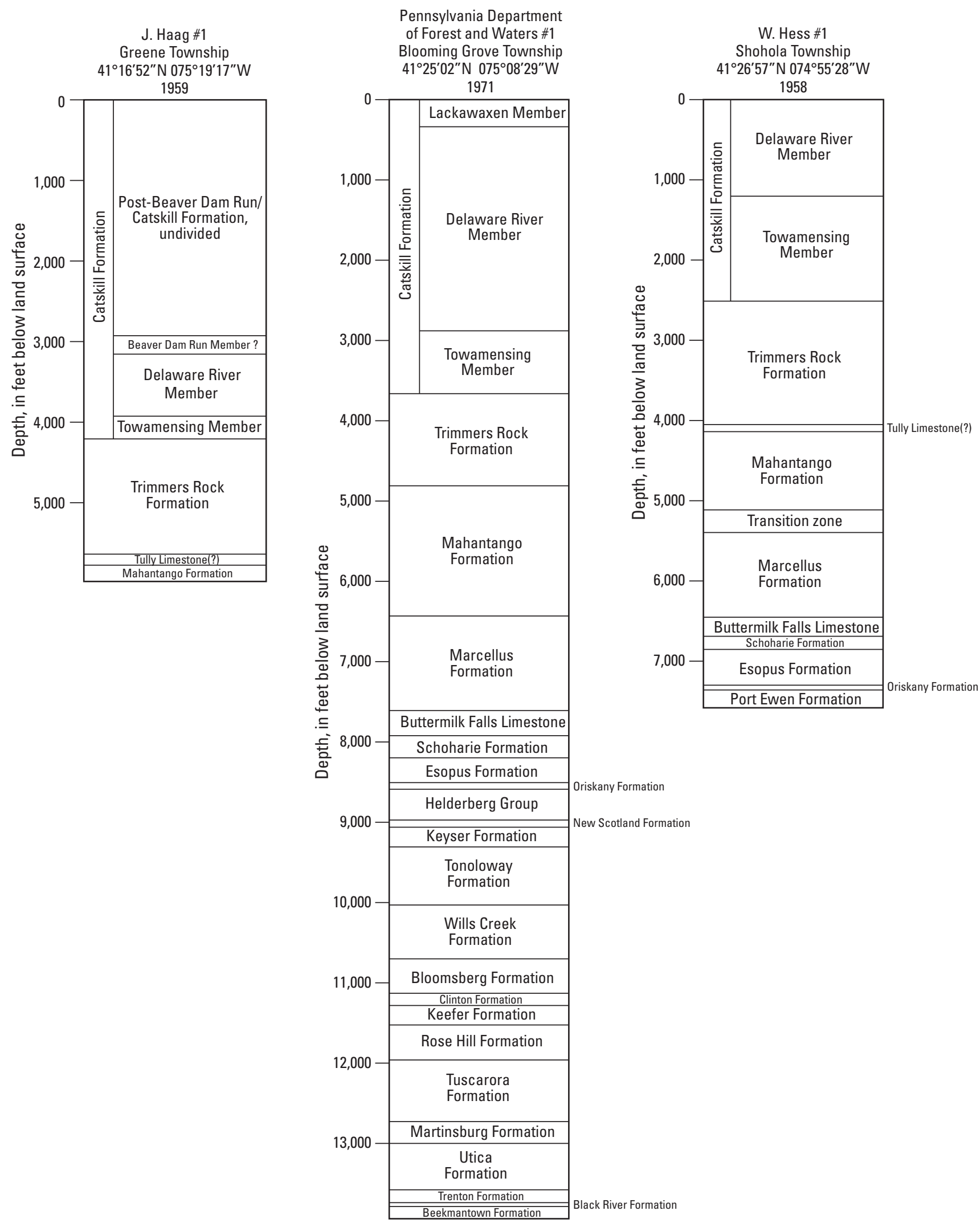

Figure 4. Stratigraphic columns showing summary of rock units penetrated by three gas exploration wells in Pike County, Pennsylvania. Well name, location, and date of drilling listed for each well are from Sevon and others, 1989, figure 2, p. 8. Location of wells shown in figure 1. 
Annual precipitation that recharges the aquifers varies spatially by a few inches throughout the county, as indicated by precipitation records. The long-term [30-year normal (average), 1981-2010] total annual precipitation is about 42.9 inches (in.) at the National Oceanic and Atmospheric Administration (NOAA) Hawley 1E meteorological station on the western border between Pike and Wayne Counties, and about 46.4 in. at Port Jervis, New York, meteorological station on the eastern border of Pike County with New York State (fig. 1) (National Oceanic and Atmospheric Administration, 2015). Precipitation falls approximately evenly throughout the year, although recharge rates differ seasonally because frozen ground can inhibit recharge during winter months, and evapotranspiration reduces recharge during the warm spring and summer months of the growing season. The seasonal pattern in net recharge rates is reflected in annual fluctuations in long-term (about 15 years, 2001-16) daily median groundwater levels in the USGS observation well PI-522 in Pike County (fig. 1), a 150-ft deep well completed in the undivided Poplar Gap and Packerton Members of the Catskill Formation. Each year, generally rising water levels occur during 2 periods (March to mid-May and October to midNovember), indicating net positive recharge, and generally flat to declining water levels occur during 2 periods (midNovember to March and mid-May through September), indicating reduced to negligible recharge (fig. 5).
The groundwater-level and precipitation data from the USGS National Water Information System (NWIS) and NOAA databases indicate that the hydrologic conditions during summer 2015 were similar to, but in late June and early July were slightly wetter than, the long-term average or median conditions. During this study, daily mean groundwater levels measured in long-term observation well PI-522 were greater than the long-term median of daily mean values in late June and early July 2015 but fell to levels close to the long-term median of daily mean values by August 2015 and remained at or near the long-term median of daily mean values through the sampling period that ended in late September 2015 (fig. 5). Reported precipitation was greater than the long-term (30-year) normal for June at both the Hawley and Port Jervis meteorological stations (about 2.7 to 3.9 in., respectively); it was greater than the 30-year normal at Port Jervis (3.8 in.) but similar to the 30-year normal at Hawley in July 2015, and similar to 30-year normal at both Hawley and Port Jervis in August and September 2015 (National Oceanic and Atmospheric Administration, 2015).

\section{Land Use}

As of 2005, the principal land uses in the county were public (33 percent), residential (24 percent), agricultural (23 percent), hunt club/private recreational (14 percent), roads

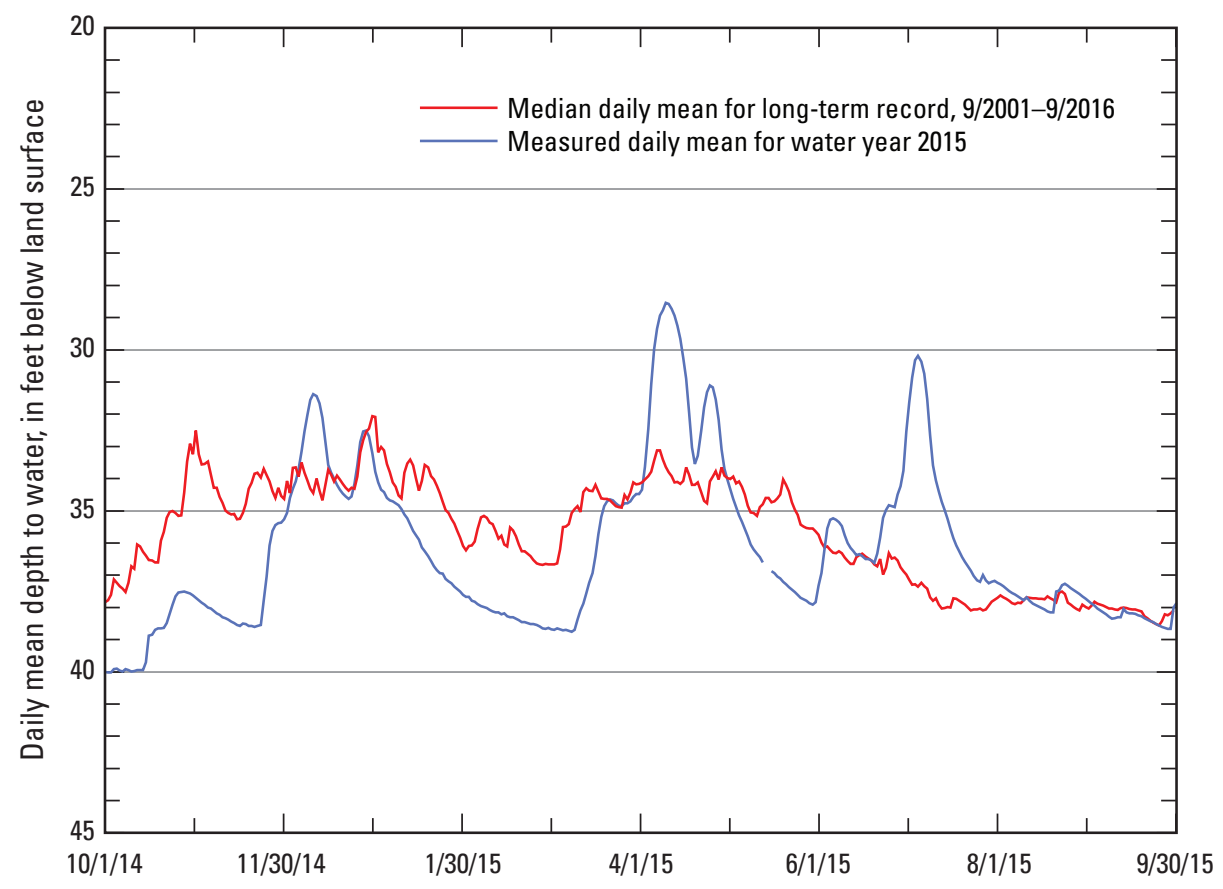

Figure 5. Hydrograph showing daily mean water levels measured during 2015 and long-term, 2001 16, median of daily mean water levels in observation well PI-522, Pike County, Pennsylvania. Data from the U.S. Geological Survey National Water Information System database. 
(2 percent), and commercial (2 percent) (Pike County Planning Commission, 2006). The public lands include state forest, state park, state game, state natural area, and U.S. National Park Service (NPS) parcels, much of which are forested as are hunt club parcels. Most of the land designated as agricultural use is forested, with little in actual cultivation or other agricultural operations (28,260 acres or about 8 percent of county area is active farms according to U.S. Department of Agriculture, 2012). Much of the developed land area (residential and commercial) is in the eastern third of the county, and some areas have relatively greater development in the northern half of the county and along the western boundary with Wayne County, as shown by Senior (2014).

Population has been growing in Pike County since 1940 (Davis, 1989). The 2010 population of 57,369 (U.S. Census Bureau, 2017) represents an increase of 23.9 percent (or 11,067 people) from the population in 2000 and is more than three times the population of 18,271 in 1980. However, the recent rate of population growth has slowed in Pike County, with estimates of population relatively stable from 2010 through 2012 but decreasing slightly thereafter to about 55,652 in 2016 (U.S. Census Bureau, 2017). Because much land is public or private forested land, the population growth occurs in limited areas, as indicated by the distribution of residential land in Pike County. The largest population centers are along or near the Route 209 corridor, including Milford and Matamoras Boroughs and numerous residential developments in the eastern part of the county. In addition to the census (permanent) population, use of land for recreation results in seasonal increases in population and potential stresses on the groundwater system and associated surface waters.

Groundwater is the main source of drinking water in the county. Individual on-site wells are common in many residential areas, although some developments are supplied by community or public supply wells. Milford and Matamoras Boroughs are served by public supplies whose sources are springs and wells, respectively. On-site wastewater disposal is common in residential areas; sand mounds are more commonly used than septic systems in recent developments (Pike County Conservation District, 2014). Some developments are sewered and have sewage treatment systems that discharge treated effluent to land areas or to surface water.

\section{Previous Investigations}

Lohman (1937) presents limited water-quality data for a few wells in Pike County, including a description of one deep well with saltwater at a depth of about $1,040 \mathrm{ft}$ in eastern Pike County near the Delaware River. A county-wide assessment of groundwater resources, including evaluation of general groundwater quality (major ions, nutrients, iron, and manganese) and, for some samples, selected trace metals, was done in the early 1980s (Davis, 1989). An investigation of nitrate and chloride in the glacial aquifer underlying Route 209 north of Milford in Pike County was done in 1991 (Senior, 1994). In 2001, groundwater from four domestic wells completed in the glacial aquifer near the Delaware River was sampled and analyzed for major ions, nutrients, trace metals, pesticides, volatile organic compounds, and radon-222 as part of the National Water-Quality Assessment (NAWQA) in the Delaware River Basin (Durlin and Schaffstall, 2002).

In 2007, the USGS, in cooperation with the PCCD, sampled 20 domestic wells throughout Pike County to provide a reconnaissance assessment of groundwater quality in the main land uses and geologic units (Senior, 2009) (17 wells were completed in bedrock aquifers, and 3 wells were completed in glacial aquifers). The laboratory analyses selected for the 2007 samples were intended to identify naturally occurring constituents in the aquifer or constituents introduced by human activities that pose a health risk or otherwise were of concern for groundwater in the county. Samples were analyzed for major ions, nutrients, selected trace metals, volatile organic compounds (VOCs), a suite of organic wastewater compounds, gross alpha- and gross beta-particle activity, and radon-222. Man-made organic compounds, including a few VOCs and wastewater compounds, were detected at low levels in groundwater from 10 of the 20 wells sampled in 2007, indicating human activities at the land surface have affected groundwater quality to some degree. Chloride and nitrite plus nitrate concentrations generally were greater in water from wells in the commercial and residential areas with on-site wastewater disposal than in undeveloped and sewered areas. Radon-222 levels ranged from 90 to 2,650 picocuries per liter $(\mathrm{pCi} / \mathrm{L})$ and were greater than or equal to the U.S. Environmental Protection Agency (EPA) proposed drinking-water standard of $300 \mathrm{pCi} / \mathrm{L}$ in water from 15 (75 percent) of the 20 wells.

In 2011, 6 National Park Service (NPS) wells in the Delaware Water Gap National Recreation Area (DEWA) and Upper Delaware Scenic and Recreational River (UPDE) national park units in northeastern Pennsylvania and 10 other wells or springs were sampled as part of a baseline groundwater-quality assessment of nine national park units in New York, Pennsylvania, and West Virginia that might be affected by shale-gas development (Eckhardt and Sloto, 2012). Two of the six DEWA and UPDE wells sampled in 2011 are in Pike County near the Delaware River, one in each of the two national park units (DEWA on eastern edge and UPDE on northern edge of Pike County). Water samples from these two wells contained methane in concentrations ranging from 2.52 to 4.77 milligrams per liter (mg/L), which were among the highest methane concentrations measured in the study.

Data were collected by USGS during 2012-13 for a reconnaissance assessment (with spatial and temporal components) of baseline groundwater quality in bedrock aquifers used for drinking-water supply in Pike County prior to potential shale-gas development (Senior, 2014). Results of the spatial component of the assessment, for which 20 wells were sampled in summer 2012 to provide baseline groundwater-quality data throughout the county but with emphasis on areas with relatively high potential for shale-gas development (mostly in the northern and western parts of the 
county), showed that water from 16 (80 percent) of 20 wells had detectable concentrations of methane, but concentrations were less than $0.1 \mathrm{mg} / \mathrm{L}$ in most well-water samples; only two well-water samples had concentrations greater than $1 \mathrm{mg} / \mathrm{L}$. The groundwater with relatively elevated methane (greater than about $0.5 \mathrm{mg} / \mathrm{L}$ ) also had a chemical composition that differed in some respects ( $\mathrm{pH}$, selected major ions, and inorganic trace constituents) from groundwater with lower methane concentrations. Results of the temporal component of the assessment, for which 4 of the 20 wells in the summer 2012 survey were sampled monthly for 1 year ending June 2013 to provide data on seasonal or other temporal variability in groundwater quality, showed that concentrations of major ions generally varied by less than 20 percent with most differences less than $4 \mathrm{mg} / \mathrm{L}$ and concentrations of methane varied by less than $1 \mu \mathrm{g} / \mathrm{L}(0.001 \mathrm{mg} / \mathrm{L})$ in samples from three wells with low methane and by as much as $1 \mathrm{mg} / \mathrm{L}$ $(1,000 \mu \mathrm{g} / \mathrm{L})$ in samples from one well with relatively high methane.

\section{Methods of Sample Collection and Analysis}

To provide current data on the occurrence and spatial distribution of methane and various inorganic and man-made organic constituents in groundwater used for drinking-water supply, 79 wells throughout Pike County were sampled during summer 2015. The laboratory analyses selected were intended to determine baseline groundwater concentrations of methane and inorganic constituents, including radionuclides, that are commonly present in elevated concentrations in brines that, when disturbed, contribute to produced (flowback) fluids generated as a result of drilling and hydraulic-fracturing activities (table 1). Water samples were collected once per site from 78 wells and twice from 1 well (for a total of 79 individual wells) from late June through September 2015 and analyzed to characterize their physical properties and chemical characteristics. Samples were analyzed for all constituents on the PADEP modified pre-drill list (table 2) as of 2014 (Pennsylvania Department of Environmental Protection, 2014) and all constituents except vanadium, chrome, and ethylene glycol on the 2016 revised expanded pre-drill list (Pennsylvania Department of Environmental Protection, 2016c) (table 2). Analyses also were conducted for additional major ions, trace constituents, and dissolved gases, including methane, ethane, and radon-222. Samples from 20 wells throughout the county were also analyzed for selected man-made compounds (VOCs). Samples from 13 wells with the highest elevated gross alpha-particle activities were analyzed for radium-226. The 2015 analyses were done on unfiltered water samples using drinking-water methods for all major and several trace ions and on filtered water samples for major and trace ions using USGS methods and for additional bromide analysis by EPA method 300.1 (Appendix 1). The
2015 data enhance the 2012 data on groundwater quality in Pike County by providing greater spatial and chemical characterization of constituents, including determination of both total and dissolved concentrations of major ions, selected metals and trace elements, and additional man-made organic compounds.

\section{Selection of Sampling Locations}

Well locations were selected to provide spatially distributed data on groundwater quality in bedrock aquifers throughout Pike County. Although the goal was to have an evenly spaced sample distribution, the availability of wells constrained the selection process. Most wells considered for inclusion in the study are domestic wells used to supply individual residences or other facilities in Pike County, but a few (4) were larger supply wells that served multiple residences or were institutional. Criteria for well selection included availability of information about well construction from drillers' records submitted to the Pennsylvania Geological Survey and from well owners or other sources. Additionally, the ability to obtain a raw-water sample from a well was a requirement. The Pike County Conservation District provided support in identifying wells and obtaining permission from well owners for study participation and sampling.

Seventy-nine wells were selected for sampling in 2015 (fig. 2), 19 of which had been previously sampled at least once by USGS during 2007-12 (Senior, 2017; Appendix 5). To provide information about variability in pre-drill baseline water quality through time, the 2015 study resampled 15 of the 20 wells sampled for the 2012 reconnaissance study (Senior, 2014) and 1 other well sampled in 2011 (Eckhardt and Sloto, 2012), but 5 of the 20 wells sampled in 2012 were not resampled in 2015 because of well conditions or unavailability. Eight of the 79 wells sampled in 2015 had been sampled in 2007 (Senior, 2009), and 6 of these 8 wells were also sampled in 2012 (Senior, 2014). Nine other wells had been inventoried by USGS as part of an arsenic study for which well owners collected the samples (Low and Galeone, 2007).

Depths and other characteristics of the 79 wells sampled in 2015 are listed in table 12 (at the back of the report). Seventy-five wells were domestic wells serving individual residences, three wells served multiple residences, and one well was institutional. Wells sampled in 2015 range in depth from 80 to $610 \mathrm{ft}$ with a median depth of $262 \mathrm{ft}$ (as determined by available data for 74 of 79 wells). For wells with known construction, most were completed as 6-inch-diameter open holes for which steel casing was extended into competent bedrock with the remainder of the borehole left open. One well (PI-617) is reported to be completed in unconsolidated glacial deposits, an aquifer type in which wells typically are constructed with casing along the entire depth, sometimes with screens or perforations in the casing at selected depths or just open at the bottom of casing. Other wells are reported 
or presumed to be completed in bedrock on the basis of well construction information. The number of wells sampled in each bedrock geologic unit is approximately proportional to the areal extent of that formation in the county. Of the 79 wells, 2 wells were completed in the Marcellus Shale, 12 in the Mahantango Formation, 6 in the Trimmers Rock Formation, 5 in the Towmensing Member of the Catskill Formation, 48 in the undivided Long Run and Walcksville Members of the Catskill Formation (differentiated into two units and renamed the Lackawaxen River and Delaware River Members of the Catskill Formation in mapping by Sevon,1989), 5 in the undivided Poplar Gap and Packerton Members of the Catskill Formation, and 1 in the unconsolidated glacial (ice contact) deposits (table 12). Using the Sevon (1989) mapping, the 48 wells in the undivided Long Run and Walcksville Members of the Catskill Formation are distributed as 27 wells in the Delaware River Member and 21 wells in the Lackawaxen River Member (fig. 3).

\section{Collection of Samples}

The USGS sampled the 79 wells using standard USGS field-sampling protocols. Samples were collected at an untreated tap, typically at a pressure tank or outside tap and before any filtration, water softening, or bacteriological treatment. Water samples were analyzed in the field for unstable physical and chemical properties (such as temperature) and dissolved oxygen (DO), then shipped overnight to laboratories for analysis for major ions, nutrients, metals, trace elements, gross alpha and beta radioactivity, bacteria, man-made organic compounds, and dissolved gases. All well-water samples were collected and processed for analysis by methods described in USGS manuals for the collection of water-quality data (U.S. Geological Survey, variously dated).

Sampling was conducted at each well using the following steps. The existing submersible well pump was turned on and allowed to run. A raw-water tap was opened, and the water was allowed to flush to minimize possible effects of plumbing and ensure that the water was representative of the aquifer. While the well was pumped, the water discharging from the tap was analyzed with a multi-parameter probe meter for temperature, specific conductance (SC), $\mathrm{pH}$, and $\mathrm{DO}$ concentration with the probe submerged in an overflowing bucket filled by the discharge line (hose). After the values of these properties and parameters stabilized, sample bottles were filled according to USGS protocols (U.S. Geological Survey, variously dated). Samples were collected through Teflon tubing attached to the raw-water tap, which avoided all watertreatment systems.

Unfiltered (whole-water) samples were collected for determination of physical properties and for analyses for radioactivity, dissolved gases, and the PADEP pre-drill constituents to obtain total concentrations (Appendix 1). Samples for analyses for concentrations of dissolved nutrients, major ions, metals, and trace elements were filtered through a field-rinsed 0.45-micrometer pore-size cellulose capsule filter. To prevent sample degradation, nitric acid was added to the major cation, metals, and trace-element samples. No preservative was added to samples for analysis of major anions and dissolved nutrients. Samples for VOC analysis were preserved with hydrochloric acid. Samples for radon analysis were obtained through an inline flexible (silicon) hose with a gas-tight syringe to avoid atmospheric contact. Samples for dissolved gases were obtained through 1) copper refrigeration grade tubing placed in sets of three $40 \mathrm{~mL}$ glass bottles that were filled and stoppered while submerged to avoid atmospheric contact for analysis by Seewald Laboratories, Inc., and(or) 2) direct flexible-tubing connection to an Isoflask for analysis by Isotech Laboratories, Inc.

The samples were stored on ice in coolers and shipped by overnight delivery to the following laboratories: (1) the USGS National Water Quality Laboratory (NWQL) in Denver, Colorado, for analysis for major ions, nutrients, total dissolved solids (TDS), metals, and trace elements in filtered water samples, and radon; (2) ALS Environmental, Fort Collins, Colorado, a USGS contract laboratory, for analysis of gross alpha- and gross beta-particle activity (also referred to as gross alpha and gross beta radioactivity) and, in selected samples, radium-226; and (3) Seewald Laboratories, Inc., in Williamsport, Pennsylvania, a laboratory accredited by PADEP Bureau of Laboratories, for analysis of unfiltered samples using approved drinking-water methods for (a) the 2014 PADEP pre-drill constituents (table 2), including major ions, iron, manganese, aluminum, arsenic, barium, bromide, lithium, selenium, strontium, zinc, TDS, total suspended solids (TSS), and total coliform and Escherichia coli (E. coli) bacteria; (b) dissolved methane, ethane, and propane gases; and for 20 samples (c) selected man-made organic compounds (VOCs). Filtered samples from most wells also were sent to Weck Laboratories, City of Industry, California for bromide analysis with a low reporting level (Appendix 1). Additionally, replicate samples from selected wells were sent to Isotech Laboratories, Inc., in Champaign, Illinois, for analysis of dissolved methane, other dissolved gases including hydrocarbons, and isotopes of hydrogen and carbon in methane.

Water samples from 10 wells containing a sufficient concentration of methane (as measured in replicate samples by Seewald Laboratories, Inc.), which generally is greater than about $0.3 \mathrm{mg} / \mathrm{L}$, were submitted to Isotech Laboratories, Inc., for determination of (1) the isotopic composition of methane with analysis for the stable carbon isotopes ${ }^{12} \mathrm{C}$ and ${ }^{13} \mathrm{C}$ and the stable hydrogen isotopes ${ }^{1} \mathrm{H}$ (protium) and ${ }^{2} \mathrm{H}$ (deuterium) and (2) dissolved gases (oxygen, nitrogen, carbon dioxide, carbon monoxide, hydrogen, and argon) and selected hydrocarbons (methane, ethane, propane, and higher-carbon alkanes). Water samples from nine other wells with methane concentrations less than $0.3 \mathrm{mg} / \mathrm{L}$ (as measured in replicate samples by Seewald Laboratories, Inc.) were submitted to Isotech Laboratories, Inc., for analysis of dissolved gases (oxygen, nitrogen, carbon dioxide, carbon monoxide, hydrogen, and 
argon) and selected hydrocarbons (methane, ethane, propane, and higher-carbon alkanes) as part of quality assurance for dissolved gas concentrations.

\section{Analysis of Chemical, Physical, and other Characteristics and Reporting Units}

Analytical methods and reporting levels for constituents analyzed by PADEP Bureau of Laboratories accredited laboratories and other laboratories are listed in Appendix 1 (table 1-3). Descriptions of analytical methods for constituents analyzed by the USGS NWQL are available from the U.S. Geological Survey (2014a). Reporting levels for constituents analyzed by NWQL are listed in Appendix 1 (tables 1-1 and $1-2)$. The analytical results are available online from the USGS National Water Information System (U.S. Geological Survey, 2014b) and as a companion data release (Senior, 2017).

Methane was the only hydrocarbon with sufficient mass in the Pike County groundwater samples for isotopic carbon and hydrogen determination by Isotech Laboratories, Inc., using a method that involved initial separation of hydrocarbons followed by conversion of methane $\left(\mathrm{CH}_{4}\right)$ into carbon dioxide (for carbon isotopic analysis) and water (for hydrogen isotopic analysis) for subsequent mass-spectrometric analysis and comparison to standards (Alan R. Langenfeld, Isotech Laboratories, Inc., written commun., 2012; Senior and Cravotta, 2016). Isotopic ratios for the sample are reported relative to the isotopic ratio of a standard, where the difference (delta or $\delta$ ) typically is given in parts per thousand (ppt; also denoted as \%o or per mill) with positive values indicating enrichment of the heavier isotope and negative values indicating depletion of the heavier isotope. Thus, for $\mathrm{R}=$ ratio of heavier to lighter isotope, $\delta$ (in \%o) $=\left[\mathrm{R}_{\text {sample }} /\left(\mathrm{R}_{\text {standard }}-1\right)\right]$ $\times(1,000)$. The ${ }^{13} \mathrm{C} /{ }^{12} \mathrm{C}$ carbon isotopic ratio value $\left(\delta^{13} \mathrm{C}\right)$ of methane in a sample is reported in terms of the \%o notation relative to the Vienna Pee Dee Belemnite (VPDB) standard. The ${ }^{2} \mathrm{H} /{ }^{1} \mathrm{H}$ hydrogen isotopic ratio value $(\delta \mathrm{D})$ of methane in a sample is reported in terms of the \%o notation relative to the Vienna Standard Mean Ocean Water (VSMOW) standard.

The other water-quality constituents have various reporting units. Specific conductance (SC) is reported in temperature-compensated units of microsiemens per centimeter at 25 degrees Celsius $\left(\mu \mathrm{S} / \mathrm{cm}\right.$ at $\left.25{ }^{\circ} \mathrm{C}\right)$. Reporting units for dissolved and total chemical concentrations are milligrams per liter (mg/L) or micrograms per liter ( $\mu \mathrm{g} / \mathrm{L})$; $1 \mathrm{mg} / \mathrm{L}$ is approximately equal to 1 part per million, and $1 \mathrm{mg} / \mathrm{L}$ is approximately equivalent to 1 part per billion. One $\mathrm{mg} / \mathrm{L}$ equals $1,000 \mathrm{mg} / \mathrm{L}$. Reporting units for bacteria are the most probable number of colonies per 100 milliliters of sample (MPN/100 mL). Reporting units for radioactivity are picocuries per liter (pCi/L), a commonly used unit for radioactivity in water. One picocurie (pCi) equals $10^{-12}$ Curie or $3.7 \times 10^{-2}$ atomic disintegrations per second. Activity refers to the number of particles emitted by a radionuclide. The rate of decay is proportional to the number of atoms present and inversely proportional to half-life, which is the amount of time it takes for a radioactive element to decay to one-half its original quantity. In gas samples analyzed by Isotech Laboratories, Inc., dissolved gas values were reported in terms of mole percent in headspace for the water sample, and methane was reported as a dissolved concentration in units of $\mathrm{mg} / \mathrm{L}$.

\section{Quality Control and Quality Assurance}

For quality control (QC), replicate, blank, and reference samples were submitted to various laboratories. A total of seven intra-laboratory replicate pairs were collected. Two replicate pairs were collected for major ions, minor constituents, radon-222, and gross alpha and beta activity analysis. Three replicate pairs were collected for dissolved gases and isotopic composition of methane. One replicate pair was collected for VOC analysis, and one replicate pair was collected for radium-226 analysis. Replicate samples collected from two wells (PI-524 and PI-592) were submitted to the NWQL, ALS Environmental, and Seewald Laboratories, Inc., for analysis of major ions, minor constituents, radon222, gross alpha and beta radioactivity, and bacteria. Replicate samples from three wells (PI-524, PI-592, and PI-647) for dissolved gas analysis were submitted to both the Seewald Laboratories, Inc., and Isotech Laboratories, Inc.; replicate samples for analysis of dissolved gases and isotopic composition of methane were submitted to Isotech Laboratories, Inc., only. Additionally, replicate samples from one well (PI-592) were submitted to Seewald Laboratories, Inc., for VOC analysis, and replicates from another well (PI524) were submitted to ALS Environmental for radium-226 analysis. The QC replicate results are listed in Appendix 2 (table 2-1).

The differences in concentrations between replicate paired samples varied on the basis of analyte group, and the relative magnitude of differences tended to be greatest when concentrations were lowest. The analytes with the largest relative differences in concentrations between the sample (c1) and its replicate (c2), where the relative difference, in percent, is calculated as $100 \times(\mathrm{c} 1-\mathrm{c} 2) /[(\mathrm{c} 1+\mathrm{c} 2) / 2)$, were in samples with low concentrations of these analytes near the laboratory reporting level. Typically, acceptable precision for many analyses is 5 percent. However, small absolute differences in reported concentrations between replicates can result in relative differences greater than 5 percent. For major ions, most relative differences were less than 5 percent. Only one major ion (potassium) replicate pair had a difference (6.76 percent) of more than plus or minus $( \pm) 5$ percent, which involved low (less than $0.8 \mathrm{mg} / \mathrm{L}$ ) potassium concentrations. The difference between concentrations in replicate samples for metals and trace elements generally was less than 5 percent, but relative differences greater than 5 percent (10-30 percent) were apparent for one each of total iron and total zinc concentrations. The larger differences in analytical results for total metals may be related to generally greater uncertainty 
associated with analysis of unfiltered samples, which is a more complicated process involving chemical digestion than analysis of filtered samples. Differences among replicates for gross alpha and gross beta radioactivity were commonly 10-20 percent, which reflects some intrinsic uncertainty in the analysis, particularly for results near the reporting level of $3 \mathrm{pCi} / \mathrm{L}$. Therefore, no corrective action to the analytical results was needed, but replicate results show that analytical uncertainty may be relatively greater for constituent concentrations near detection limits.

Results of replicate analyses for determination of bacteria show the maximum difference in the number of colonies between replicates was 19 for total coliform for one sample pair (which had results of $<1$ and $19 \mathrm{MPN} / 100 \mathrm{~mL}$ ), but other results of replicate analyses were consistent-no colonies detected. E. coli bacteria were not detected in any sample. All replicates had relatively low (<20 MPN/ $100 \mathrm{~mL}$ for total coliform bacteria) to undetectable numbers of bacteria (Appendix 2, table 2-1). Differences in replicate results may be partly related to inherent variability in analyses for bacteria, especially at very low levels. Additional uncertainty in results of analyses for bacteria may have been introduced because the holding times (elapsed time from sample collection to sample preparation in the laboratory) exceeded the 6-hour limit used for compliance monitoring (although holding times were usually within the 24-hour limit used for routine monitoring).

Additionally, 18 inter-laboratory replicate samples collected from 17 wells (one well sampled twice) were submitted for dissolved gas (methane, ethane, propane) to two different laboratories, Seewald Laboratories, Inc. and Isotech Laboratories, Inc. that had different reporting levels and specified sample collection in different types of containers. Methane concentrations in replicate samples determined by the two different laboratories differed by as much as a factor of 2.7, with concentrations determined by the Seewald Laboratories, Inc. laboratory generally lower than those determined by the Isotech Laboratories, Inc., suggesting bias related to combined sampling and analytical methods and therefore indicating caution when comparing methane concentrations in well-water samples determined by different methods.

One blank (autoclaved water) was submitted to Seewald Laboratories, Inc., for bacteria analysis, and one equipment blank was submitted to NWQL for analysis of major ions, trace constituents, nutrients, and total organic carbon. No bacteria were detected in the autoclaved water sample sent to Seewald Laboratories, Inc. The equipment blanks were collected at the USGS office in Exton, Pa., by running deionized water (DI) through the flexible tubing and brass hose splitter used in the field for sample purging and collection. The equipment blanks contained no detectable concentrations of any analyzed constituent.

Three standard reference samples were submitted to Seewald Laboratories, Inc., for analysis of major ions and trace constituents. Concentrations determined by Seewald Laboratories, Inc., generally were similar or slightly higher than the reference sample concentrations for most major ions and trace constituents. The differences in concentrations determined by Seewald, Laboratories, Inc., (Cs) relative to the reference sample concentration $(\mathrm{Cr})$ were less than 8 percent [calculated as $100 \times(\mathrm{Cs}-\mathrm{Cr} / \mathrm{Cr})$ ] for most analyzed constituents, less than 5 percent for many analyzed constituents, but greater than 15 percent for bromide and lithium. The relative larger percent differences for lithium and bromide indicate greater uncertainty in Seewald Laboratories, Inc., results for these constituents at concentrations near or less than that laboratory's reporting level of $0.1 \mathrm{mg} / \mathrm{L}$ for bromide and $10 \mu \mathrm{g} / \mathrm{L}$ for lithium.

Other QC checks on the accuracy of the data included computation of cation-anion balance, SC, and dissolved solids. These checks largely involve major ion concentrations. Differences in the sum of cation and anion milliequivalents [calculated as $100 \times(\mathrm{C}-\mathrm{A}) /(\mathrm{C}+\mathrm{A})$, in percent, where $\mathrm{C}$ is cation milliequivalents and $\mathrm{A}$ is anion milliequivalents] of 5 percent or less indicate accurate determination of major ion concentrations. The 2015 Pike County groundwater samples, using alkalinity determined in the laboratory, had cationanion balances that met this criterion, with the exception of samples from three wells (PI-650, PI-610, and PI-631), which had cation-anion balances of greater than 5 but less than +/- 8 percent $(-7.08,+6.68$, and +5.61 percent respectively). The sample with the largest cation-anion balance of -7.08 percent was from the well (PI-650) that had the highest TDS of all samples and had relatively high concentrations of lithium, strontium, and bromide that typically are not included in, but can affect, cation-anion balance calculations. On the basis of the cation-anion balance evaluation in a previous study in a similar hydrogeologic setting in nearby Wayne County (Senior and others, 2016), the laboratory alkalinities were determined to be generally more reliable than field alkalinities, and consequently, only laboratory alkalinity values were determined and used in data analysis for the Pike County study in 2015.

The field and laboratory measured values were in good agreement for $\mathrm{pH}$ and SC, with a few exceptions. Furthermore, the $\mathrm{SC}$, which is measured with a meter in the field or laboratory, and TDS, which is measured in the laboratory as residue on evaporation (ROE) or computed from measured ion concentrations, were linearly related with strong correlation coefficients. Differences between field SC and laboratory SC were less than 10 percent (calculated as $100 *($ field-lab)/[0.5 $\times($ field + lab) $]$ for all but three samples from wells PI-650, PI-640, and PI-615 for which differences were 17.9, 11.7, and 11.6 percent, respectively. For these three samples, the field SC was less than the laboratory value, which could result from gas bubbles accumulating on the conductivity electrode during sampling, especially as noted in the field for well PI-650 which had unstable and rising SC measured while purging. The laboratory measured SC values and most of the field SC values were equivalent to the computed SC on the basis of ionic conductivity contributions. Likewise, the measured TDS was equivalent to the computed TDS from the sum of ions (see 
figures in Appendix 2). These results indicate that field and laboratory measurements were consistent with one another and with the major ion analyses and therefore could be presumed to be accurate.

Reviews of data included comparison of dissolved and total concentrations determined by NWQL and Seewald Laboratories, Inc., respectively, using methods listed in Appendix 1. Except for iron, dissolved and total concentrations of major ions and most trace constituents generally were similar, indicating that these constituents mostly present in dissolved phase and that the two different laboratories provided consistent results. In about 10 percent of the analyses, total concentrations were less than the dissolved concentrations, with total concentrations ranging from 2 to 10 percent smaller than dissolved concentrations for most analyses and constituents and up to 20 to 30 percent smaller for a few cases. Total concentrations were less than dissolved concentrations most frequently for magnesium and lithium determinations. On the basis of other information, including cation-anion balances for dissolved concentrations of major ions, computed and measured sums of dissolved constituents, and reported precisions of analytical methods, the dissolved concentrations are considered more accurate than the total concentrations.

\section{Graphical and Statistical Analyses}

Various graphical and statistical techniques were used in this study to compare water-quality data among different sites, to estimate natural and man-made sources of dissolved constituents, and to identify possible factors affecting the presence, concentration, spatial distribution, or transport of solutes in the aquifers in the study area. Scatter plots were created to investigate potential relations among $\mathrm{pH}$, selected constituent concentrations, and the saturation index (SI) values for minerals that may be sources or controls of the constituents. Major ion data were plotted on Piper diagrams (Appelo and Postma, 2005; Back, 1966; Hem, 1985) to illustrate the range of water composition of the samples collected for this study and to investigate possible processes, such as calcite dissolution, cation exchange, and mixing with road deicing salt or brine, that could produce the observed variations in major ions. The Piper diagrams were generated using the Geochemist's Workbench (Bethke and Yeakel, 2010).

In general, nonparametric, rank-based statistical approaches were used to accommodate non-normally distributed and censored data typical of most environmental samples (Helsel and Hirsch, 2002). Data for individual continuous variables, such as chemical concentrations, were censored to a common level, and censored values were set to a common reporting limit of 0.99 times the highest censored value before ranks were computed for use in statistical tests. Values at the highest common reporting level were assigned the minimum rank. Relations between continuous variables were evaluated with scatter plots and correlation coefficients
(Spearman's rho); distributions of continuous variables were compared among different sample classifications using notched boxplots (Velleman and Hoaglin, 1981; Helsel and Hirsch, 2002). Statistically significant (p less than or equal to 0.001 ) Spearman's correlation coefficients are presented in Appendix 3, table 3-1.

Notched boxplots shown in Appendix 3 were constructed with P-STAT (P-STAT, Inc., 2008) to compare concentrations of major ions, trace elements, and other water-quality variables among different subsets of the 2015 data in relation to $\mathrm{pH}$, specific conductance, redox variables, or aquifer geology. The $\mathrm{pH}$ classes considered in this report are (1) acidic, $\mathrm{pH}$ 5.4 to 6.4; (2) neutral, $\mathrm{pH} 6.5$ to 7.4; (3) alkaline, $\mathrm{pH} 7.5$ to 7.9; and (4) very alkaline, $\mathrm{pH} 8.0$ to 9.4. The SC classes are (1) 40 to $130 \mu \mathrm{S} / \mathrm{cm}$ at $25^{\circ} \mathrm{C}$; (2) 130 to $210 \mu \mathrm{S} / \mathrm{cm}$ at $25^{\circ} \mathrm{C}$; (3) 210 to $400 \mu \mathrm{S} / \mathrm{cm}$ at $25^{\circ} \mathrm{C}$; and (4) 400 to $1,600 \mu \mathrm{S} / \mathrm{cm}$ at $25^{\circ} \mathrm{C}$. For the $\mathrm{pH}$ and $\mathrm{SC}$ classifications, the middle two groups represent approximately 60 and 75 percent of the data values, respectively. The redox classifications used in this report were based on concentration thresholds of McMahon and Chapelle (2008) but were simplified to consider only three major classes: (1) anoxic (DO $\leq 0.5 \mathrm{mg} / \mathrm{L}),(2) \operatorname{mixed}(\mathrm{DO}>$ $0.5 \mathrm{mg} / \mathrm{L}$ and either manganese $\geq 50 \mu \mathrm{g} / \mathrm{L}$ or iron $\geq 100 \mu \mathrm{g} / \mathrm{L})$, and (3) oxic (DO $>0.5 \mathrm{mg} / \mathrm{L}$, manganese $<50 \mu \mathrm{g} / \mathrm{L}$, and iron $<100 \mu \mathrm{g} / \mathrm{L}$ ). Where the median for a group is greater than the common reporting limit, it is displayed as a horizontal line within the box that is defined by the 25th and 75th percentiles for that group; otherwise, the median is displayed at the reporting limit. If the notched intervals around the medians for sample subsets in boxplots do not overlap, the medians are statistically different at the 95-percent confidence interval.

Principal components analysis (PCA), computed with SAS 9.2 (SAS Institute, Inc., 2012), was used to evaluate multivariate correlations among the dissolved concentrations of elements in the regional groundwater dataset without prior classification. The goal was to identify important hydrochemical processes or master variables that could explain element associations and distributions (Joreskog and others, 1976; Drever, 1997; Thyne and others, 2004). The Spearman-rank correlation coefficient matrix for the groundwater dataset provided the standardized input for the PCA. Because the PCA model would exclude the entire record for any sample with a missing value, those constituents that were missing or those that were censored in more than 40 percent of the samples were excluded, including dissolved fluoride and some trace constituents. The PCA model was optimized with varimax rotation to maximize the differences among the principal components; only principal components with eigenvalues greater than unity, equivalent to correlations with a probability greater than or equal to 0.999 , were retained (Joreskog and others, 1976; Thyne and others, 2004). Loadings for each constituent included in the PCA model are equivalent to the Spearman-rank correlation coefficient between that constituent and the principal component. To aid in interpretations, the scores for each principal component in the PCA model were evaluated by correlation or graphical 
analysis with additional variables that had been excluded from the PCA, including lithology, land use, well depth, and chemical constituents. For simplification of displayed results, the loading values and Spearman-rank correlation coefficient values were multiplied by 100 and rounded. Significant correlation coefficients for the additional variables are displayed beneath the main PCA model results; only correlation coefficients with a probability greater than or equal to 0.999 are considered significant.

\section{Geochemical Modeling}

Aqueous speciation computations were conducted using the computer program PHREEQC (Appelo and Postma, 2005; Parkhurst and Appelo, 2013) with the WATEQ4F thermodynamic database (Ball and Nordstrom, 1991). The molal concentrations of aqueous species were used to estimate the ionic contributions to specific conductance (McCleskey and others, 2012). The mineral SI values for various major and trace minerals were used to indicate the potential for mineral dissolution and precipitation. If a mineral phase is undersaturated in groundwater (SI less than 0), that mineral phase (if present) has the potential to be dissolved by the groundwater. In contrast, if a mineral is supersaturated in groundwater (SI greater than 0), that mineral phase will not dissolve (if present), feasibly could precipitate, and thus limit dissolved concentrations and mobility of the component constituent.

\section{Baseline Groundwater Quality in Pike County}

The 2015 groundwater-quality assessment is intended to provide current data on the occurrence and concentrations of methane and a suite of inorganic constituents in groundwater in bedrock aquifers prior to potential shale-gas development in Pike County. Many of the inorganic constituents selected for analysis may be present in elevated concentrations in naturally occurring brines and in flowback and produced waters associated with unconventional shale-gas development (table 1) and, therefore, are part of the PADEP pre-drill list of constituents recommended for assessment (table 2). However, these same constituents commonly also are present at low to moderate concentrations in shallow, fresh (non-saline) groundwater, as has been shown for previous studies in Pike County and other areas of northeastern Pennsylvania (Senior, 2014; Sloto, 2013; Sloto, 2014; Senior and others, 2016). Additionally, some of the inorganic constituents included in groundwater analyses for this study can be introduced by human activities not directly related to shale-gas production, such as use of road salt or onsite wastewater disposal. In this report, the term "brine-related" refers to inorganic constituents present at high concentrations in brines; these constituents also may be present in low concentrations in freshwater as a result of mineral dissolution or possible mixing with small amounts of naturally-occurring brine or connate waters in the aquifer.

\section{Sources of and Geochemical Controls on Selected Constituents in Groundwater}

Dissolved constituents in groundwater may be derived from atmospheric, geologic, biologic, and man-made sources because the recharge and groundwater interact with various materials along transport pathways. Solute concentrations can range widely depending on the presence of constituents in the source(s); the extent of contact between water and the source; the aqueous solubility and interactions among the dissolved constituents and geochemical conditions, such as $\mathrm{pH}$ and oxidation-reduction (redox) state, that affect constituent form, mobility, and transport in the aqueous environment.

Major ions typically are derived by the dissolution of common minerals, including carbonates, silicates, oxides, sulfates, and sulfides, and their concentrations can be affected by ion exchange, redox processes, and mixing of freshwater with residual brines that remain in the aquifer matrix or that could be mobilized from deep sources. The concentrations of major ions, TDS, salinity, and SC of groundwater are directly related and generally expected to increase with progressive evaporation or mineral weathering (Hem, 1985). The concentrations of trace elements in solution may increase with TDS or SC, not only because of the release of trace constituents with the major ions dissolved from minerals, but also because of the potential for increased displacement of adsorbed or exchangeable trace ions from mineral surfaces.

Major cations (positively charged ions such as calcium, magnesium, sodium, and potassium), major anions (negatively charged ions such as sulfate, chloride, fluoride, and bicarbonate), and nonionic solutes (uncharged solutes such as silica) typically are present in natural waters at concentrations greater than $1 \mathrm{mg} / \mathrm{L}$, whereas dissolved trace elements (such as iron, manganese, zinc, lead, copper, nickel, vanadium, molybdenum, arsenic, selenium, radium, uranium, lithium, bromide) typically are present at concentrations less than $1 \mathrm{mg} / \mathrm{L}$ (Hem, 1985). Concentrations of DO range from less than $1 \mathrm{mg} / \mathrm{L}$ in geochemical environments where oxygen has been consumed by oxidation of organic compounds or minerals to as high as $12 \mathrm{mg} / \mathrm{L}$ at $7.5^{\circ} \mathrm{C}$ (saturation concentration is $11.9 \mathrm{mg} / \mathrm{L}$ at 1 atmosphere of pressure and $7.7^{\circ} \mathrm{C}$, the minimum measured groundwater temperature during 2015 sampling in Pike County) in freshly recharged or organic-poor groundwater. Concentrations of nutrients (such as nitrogen and phosphorus compounds) typically range from less than $1 \mathrm{mg} / \mathrm{L}$ in most natural settings to greater than $1 \mathrm{mg} / \mathrm{L}$ because of man-made inputs. Although biological (biochemical) processes can affect the concentrations of nutrients and trace constituents in groundwater directly or indirectly because of changes to $\mathrm{pH}$ and redox, such processes generally have minor effects on major ion concentrations (except sulfate). 
Elevated concentrations of major and trace constituents in groundwater tend to be present locally or are associated with specific geochemical aquifer settings, particularly under (1) acidic (low $\mathrm{pH}$ ) or basic (high $\mathrm{pH}$ ) conditions where the solubilities and mobilities of many element species are increased (Langmuir, 1997), (2) reducing conditions where the dissolution of iron and manganese oxides can release adsorbed and coprecipitated metals (Langmuir, 1997; McMahon and Chapelle, 2008), or (3) conditions where residual brines may mix with freshwaters (Whittemore, 2007; Haluszczak and others, 2013). Although the release of both major ions and trace elements through mineral weathering is a natural process, accelerated mineral decomposition that accompanies the development of strongly acidic or reducing conditions could be a consequence of human activities, including the infiltration of organic wastes (septic systems), compounds related to industrial activities, fertilization, road salt for deicing purposes, or other land applications. Thus, to be able to determine constituent concentrations that may have been added to groundwater as a consequence of land-use or waste-disposal practices, natural background concentrations for specific geologic or environmental settings need to be established.

In order to identify geochemical environments where elevated concentrations of constituents may be present, waterquality conditions, such as $\mathrm{pH}$ and redox state, and major ion composition, need to be characterized. For example, some trace elements and metals may be more soluble in acidic waters (such as copper and lead), whereas others may be more soluble in basic waters (such as arsenic as arsenate, and phosphorus as phosphate). Relative solubilities and the tendency of selected trace elements and metals (as commonly occurring ions) to adsorb onto or desorb from iron oxides in relation to $\mathrm{pH}$ are shown in a similar report on baseline groundwater quality in nearby Wayne County (Senior and others, 2016), which can be used to explain the presence of these constituents in similar aquifer settings such as that in Pike County.

\section{Pike County Groundwater Quality and Its Relation to Drinking-Water Standards}

Because groundwater is the main source of drinking water in Pike County, assessment of groundwater quality relative to drinking-water standards is important. Naturally occurring constituents and constituents introduced by human activities may pose a risk to human health when present at certain concentrations in groundwater used for drinking-water supply. The U.S. Environmental Protections Agency (EPA) has established maximum contaminant levels (MCLs) for many constituents in drinking water to protect human health (U.S. Environmental Protection Agency, 2012). These MCLs, also known as primary drinking-water standards, may be used as a guideline for private well owners but are mandatory for public drinking-water supplies. Other EPA non-regulatory drinkingwater guidelines include Health Advisory (HA) and secondary maximum contaminant levels (SMCLs). The HAs are listed by EPA for selected constituents that have no MCL or, in some cases, in addition to the MCL. SMCLs are listed for selected constituents that pose no known health risk but may have adverse aesthetic effects, such as staining or undesirable taste or odor (U.S. Environmental Protection Agency, 2012).

The concentrations of chemical constituents in the 2015 Pike County well-water samples were compared to established criteria for protection of human health, including the EPA MCLs and HAs (U.S. Environmental Protection Agency, 2012), additional health-based screening levels (HBSLs) defined by USGS (Toccalino and others, 2007; 2014), and to the non-health based SMCLs. Because water quality at a given location will vary temporally owing to natural hydrologic processes and seasonality, the assessment of water quality relative to established standards on the basis of samples collected only once from each well is limited to conditions at that time.

Overall, the quality of the groundwater sampled in Pike County in 2015 was generally within EPA drinking-water standards established for selected constituents. However, in some samples, the concentrations of certain constituents exceeded drinking-water standards (primary or secondary) and HAs (U.S. Environmental Protection Agency, 2012) indicating the water may not be suitable for drinking without treatment. Complete results for the 79 water samples are given in a USGS data release (Senior, 2017), and results for inorganic analyses are listed in table 13 at the back of the report. Summary statistics for results are discussed in the following sections from "General Characteristics" through "Man-Made Organic Compounds" and "Methane and Other Dissolved Hydrocarbon Gases”. The median and range of values for the water-quality characteristics measured in the 79 groundwater samples collected in 2015 are very similar to those determined for the 20 samples collected in 2012 (Senior, 2014). Furthermore, differences in constituent values for samples collected in 2012 and 2015 at a given site (as discussed in the section “Temporal Variability;” table 11 at back of report) were small compared to differences among sites (spatial variability), which supports the 2015 approach that considered one sample per site as representative of that site.

\section{General Characteristics}

Water quality often is characterized in terms of general chemical characteristics, such as $\mathrm{pH}$, conductivity, or hardness, and physical characteristics, such as temperature. Additional characteristics that describe the water quality in relation to drinking water or other uses also may be reported. Some of these characteristics, such as $\mathrm{pH}$, DO, and temperature, change after sample collection and, being unstable, typically are measured in the field at the time of sample collection. Summary statistics for chemical and physical properties measured in the field, in addition to measures of general water quality, are listed in table 4. 
Table 4. Minimum, median, and maximum of well characteristics, chemical and physical properties measured in the field, and concentrations of total dissolved solids, major ions, nutrients, total organic carbon, and bacteria determined in the laboratory for groundwater samples collected from 79 wells in Pike County, Pennsylvania, J2015.

[MCL, maximum contaminant level; HA, Health Advisory; SMCL, secondary maximum contaminant level; ${ }^{\circ} \mathrm{C}$, degrees Celsius; $\mu \mathrm{S} / \mathrm{cm}, \mathrm{microSiemens}$ per centimeter at 25 degrees Celsius; $\mathrm{mg} / \mathrm{L}$ as $\mathrm{CaCO}$, milligrams per liter as calcium carbonate; mg/L, milligrams per liter; $\mu \mathrm{g} / \mathrm{L}$, micrograms per liter; $\mathrm{SiO}_{2}$, silica; mg/L as $\mathrm{N}$, milligrams per liter as nitrogen; mg/L as $\mathrm{P}$, milligrams per liter as phosphorus; MPN/100 mL, most probable number of colonies per 100 milliliters; --, no data or not applicable; <, less than; > greater than]

\begin{tabular}{|c|c|c|c|c|c|c|c|c|c|}
\hline \multirow[b]{2}{*}{$\begin{array}{l}\text { Well characteristics, sample } \\
\text { properties and constituents }\end{array}$} & \multirow[b]{2}{*}{ Unit } & \multirow{2}{*}{$\begin{array}{c}\text { Number } \\
\text { (percent) } \\
\text { greater than } \\
\text { reporting } \\
\text { level }\end{array}$} & \multirow[b]{2}{*}{ Minimim } & \multirow[b]{2}{*}{ Median } & \multirow[b]{2}{*}{ Maximum } & \multirow{2}{*}{$\begin{array}{c}\text { Number } \\
\text { (percent) } \\
\text { exceeding } \\
\text { standard }\end{array}$} & \multicolumn{3}{|c|}{ Drinking-water standard ${ }^{1}$} \\
\hline & & & & & & & MCL & HA & SMCL \\
\hline \multicolumn{10}{|l|}{ Well characteristics } \\
\hline Well depth & feet & ${ }^{*} 74$ & 80 & 262 & 610 & -- & -- & -- & -- \\
\hline \multicolumn{10}{|l|}{ Field properties } \\
\hline Water temperature & ${ }^{\circ} \mathrm{C}$ & 79 (100) & 7.7 & 11 & 13.9 & -- & -- & -- & -- \\
\hline Dissolved oxygen & $\mathrm{mg} / \mathrm{L}$ & 78 (99) & $<0.1$ & 1.09 & 10.4 & -- & -- & -- & -- \\
\hline Specific conductance, field & $\mu \mathrm{S} / \mathrm{cm}$ & 79 (100) & 47 & 195 & 1,323 & -- & -- & -- & -- \\
\hline $\mathrm{pH}$, field & $\mathrm{pH}$ units & $79(100)$ & 5.5 & 7.2 & 9.2 & a24 (31) & $6.5-8.5$ & -- & -- \\
\hline \multicolumn{10}{|l|}{ Laboratory analyses, } \\
\hline Specific conductance, laboratory & $\mu \mathrm{S} / \mathrm{cm}$ & $79(100)$ & 45 & 205 & 1,582 & -- & -- & -- & -- \\
\hline Total dissolved solids & $\mathrm{mg} / \mathrm{L}$ & 79 (100) & 28 & 121 & 939 & $2(3)$ & -- & -- & b500 \\
\hline Suspended solids & $\mathrm{mg} / \mathrm{L}$ & $27(34)$ & $<5$ & $<5$ & 161 & -- & -- & -- & -- \\
\hline Hardness, total & $\mathrm{mg} / \mathrm{L}$ as $\mathrm{CaCO}_{3}$ & $79(100)$ & 14 & 70.9 & 392 & -- & -- & -- & $c_{--}$ \\
\hline \multicolumn{10}{|l|}{ Major ions (dissolved and total) } \\
\hline Calcium, dissolved & $\mathrm{mg} / \mathrm{L}$ & 79 (100) & 3.67 & 17.4 & 103.1 & -- & -- & -- & -- \\
\hline Calcium, total & $\mathrm{mg} / \mathrm{L}$ & 79 (100) & 3.63 & 17.2 & 106.0 & & & & \\
\hline Magnesium, dissolved & $\mathrm{mg} / \mathrm{L}$ & 79 (100) & 0.81 & 5.31 & 32.17 & -- & -- & -- & -- \\
\hline Magnesium, total & $\mathrm{mg} / \mathrm{L}$ & 79 (100) & 0.83 & 5.23 & 33.5 & -- & -- & -- & -- \\
\hline Sodium, dissolved & $\mathrm{mg} / \mathrm{L}$ & 79 (100) & 1.37 & 9.69 & 283 & d15 (19) & -- & e20 & -- \\
\hline Sodium, total & $\mathrm{mg} / \mathrm{L}$ & 78 (99) & 1.3 & 9.5 & 284 & d14 (18) & -- & e20 & -- \\
\hline Potassium, dissolved & $\mathrm{mg} / \mathrm{L}$ & 79 (100) & 0.19 & 0.59 & 1.77 & -- & -- & -- & -- \\
\hline Potassium, total & $\mathrm{mg} / \mathrm{L}$ & 79 (100) & 0.25 & 0.62 & 1.79 & -- & -- & -- & -- \\
\hline Alkalinity (dissolved) & $\mathrm{mg} / \mathrm{L}$ as $\mathrm{CaCO}_{3}$ & 79 (100) & 9.79 & 72.2 & 139.7 & -- & -- & -- & -- \\
\hline Bromide, dissolved & $\mu \mathrm{g} / \mathrm{L}$ & 70 (89) & $<10$ & 19 & 2,100 & -- & -- & -- & -- \\
\hline Bromide, total & $\mathrm{mg} / \mathrm{L}$ & $5(6)$ & $<0.10$ & $<0.10$ & 1.55 & -- & -- & -- & -- \\
\hline Chloride, dissolved & $\mathrm{mg} / \mathrm{L}$ & 79 (100) & 0.47 & 8.17 & 246 & $0(0)$ & -- & -- & b250 \\
\hline Chloride, total & $\mathrm{mg} / \mathrm{L}$ & $66(84)$ & $<1$ & 8.7 & 252 & $1(1)$ & -- & -- & b250 \\
\hline Fluoride, dissolved & $\mathrm{mg} / \mathrm{L}$ & 79 (100) & 0.023 & 0.09 & 0.964 & $0(0)$ & 4 & -- & 2 \\
\hline
\end{tabular}


Table 4. Minimum, median, and maximum of well characteristics, chemical and physical properties measured in the field, and concentrations of total dissolved solids, major ions, nutrients, total organic carbon, and bacteria determined in the laboratory for groundwater samples collected from 79 wells in Pike County, Pennsylvania, 2015.-Continued

[MCL, maximum contaminant level; HA, Health Advisory; SMCL, secondary maximum contaminant level; ${ }^{\circ} \mathrm{C}$, degrees Celsius; $\mu \mathrm{S} / \mathrm{cm}$, microSiemens per centimeter at 25 degrees Celsius; $\mathrm{mg} / \mathrm{L}$ as CaCO , milligrams per liter as calcium carbonate; $\mathrm{mg} / \mathrm{L}$, milligrams per liter; $\mu \mathrm{g} / \mathrm{L}$, micrograms per liter; $\mathrm{SiO}_{2}$, silica; $\mathrm{mg} / \mathrm{L}$ as $\mathrm{N}$, milligrams per liter as nitrogen; $\mathrm{mg} / \mathrm{L}$ as $\mathrm{P}$, milligrams per liter as phosphorus; MPN/100 mL, most probable number of colonies per 100 milliliters; --, no data or not applicable; <, less than; > greater than]

\begin{tabular}{|c|c|c|c|c|c|c|c|c|c|}
\hline \multirow[b]{2}{*}{$\begin{array}{l}\text { Well characteristics, sample } \\
\text { properties and constituents }\end{array}$} & \multirow[b]{2}{*}{ Unit } & \multirow{2}{*}{$\begin{array}{l}\text { Number } \\
\text { (percent) } \\
\text { greater than } \\
\text { reporting } \\
\text { level }\end{array}$} & \multirow[b]{2}{*}{ Minimim } & \multirow[b]{2}{*}{ Median } & \multirow[b]{2}{*}{ Maximum } & \multirow{2}{*}{$\begin{array}{c}\text { Number } \\
\text { (percent) } \\
\text { exceeding } \\
\text { standard }\end{array}$} & \multicolumn{3}{|c|}{ Drinking-water standard ${ }^{1}$} \\
\hline & & & & & & & MCL & HA & SMCL \\
\hline Sulfate, dissolved & $\mathrm{mg} / \mathrm{L}$ & $79(100)$ & 0.39 & 8.43 & 362 & $1(1)$ & -- & 500 & 250 \\
\hline Sulfate, total & $\mathrm{mg} / \mathrm{L}$ & 75 (95) & $<1$ & 8.7 & 322 & $1(1)$ & -- & 500 & 250 \\
\hline Silica, dissolved & $\mathrm{mg} / \mathrm{L}$ as $\mathrm{SiO}_{2}$ & 79 (100) & 4.00 & 10.25 & 17.2 & -- & -- & -- & -- \\
\hline \multicolumn{10}{|l|}{ Nutrients (dissolved) } \\
\hline Ammonia, dissolved & $\mathrm{mg} / \mathrm{L}$ as $\mathrm{N}$ & $32(41)$ & $<0.01$ & $<0.01$ & 0.625 & $0(0)$ & -- & 30 & -- \\
\hline Nitrite, dissolved & $\mathrm{mg} / \mathrm{L}$ as $\mathrm{N}$ & $3(4)$ & $<0.001$ & $<0.001$ & 0.019 & $0(0)$ & 1 & -- & -- \\
\hline Nitrate + nitrite, dissolved ${ }^{4}$ & $\mathrm{mg} / \mathrm{L}$ as $\mathrm{N}$ & $38(48)$ & $<0.04$ & $<0.04$ & 1.91 & $0(0)$ & 10 & -- & -- \\
\hline Orthophosphate, dissolved & $\mathrm{mg} / \mathrm{L}$ as $\mathrm{P}$ & $76(96)$ & $<0.004$ & 0.018 & 0.174 & -- & -- & -- & -- \\
\hline Total organic carbon & $\mathrm{mg} / \mathrm{L}$ & $0(0)$ & $<0.7$ & $<0.7$ & $<0.7$ & -- & -- & -- & -- \\
\hline \multicolumn{10}{|l|}{ Bacteria (total) } \\
\hline Total coliform & MPN/100 mL & $25(32)$ & $<1$ & $<1$ & 1,990 & $25(32)$ & $<1$ & -- & -- \\
\hline Escheria coli & MPN/100 mL & $0(0)$ & $<1$ & $<1$ & $<1$ & $0(0)$ & 0 & -- & -- \\
\hline
\end{tabular}

${ }^{1}$ U.S.Environmental Protection Agency (2012).

${ }^{2}$ Laboratory analysis for dissolved concentrations in filtered samples done by U.S. Geological Survey National Water Quality Laboratory (NWQL).

${ }^{3}$ Laboratory analysis for total concentrations in unfiltered samples done by contract laboratories using drinking-water methods (see Appendix 2).

${ }^{4}$ Because nitrite concentrations are low, nitrate is nearly equivalent to nitrate plus nitrite.

${ }^{\mathrm{a}} \mathrm{pH}$ was less than 6.5 in 16 samples (20 percent) and greater than 8.5 in 8 samples (10 percent).

${ }^{\mathrm{b}}$ Same standard established by Pennsylvania Department of Environmental Protection in 2010 for flowback discharge to streams (Pennsylvania Department of Environmental Protection, 025 Pa. Code $\S$ 95.10).

'No drinking-watering standard but water characterized as: soft, 0-60 mg/L in 29 samples (37 percent); moderately hard, 61-120 mg/L in 43 samples (54 percent); hard, $121-180 \mathrm{mg} / \mathrm{L}$ in 4 samples (5 percent); and very hard, $>180 \mathrm{mg} / \mathrm{L}$ in 3 samples ( 4 percent).

${ }^{\mathrm{d}}$ Concentrations exceeded drinking water health-based advisory of $20 \mathrm{mg} / \mathrm{L}$ in $15 \mathrm{samples}$ for dissolved sodium and in 14 samples for total sodium, and upper threshold for the drinking water advisory range of 30-60 mg/L in 2 samples for both dissolved and total sodium.

${ }^{\mathrm{e} E P A}$ levels for sodium are a health-based drinking water advisory of $20 \mathrm{mg} / \mathrm{L}$ for individuals on a sodium-restricted diet and taste-based drinking water advisory of 30-60 mg/L.

*Data on depths available for 74 wells. 
Field and laboratory measurements of $\mathrm{pH}$, Alkalinity, Specific Conductance, and Dissolved Oxygen

Of the physical and chemical properties measured in the field ( $\mathrm{pH}, \mathrm{DO}, \mathrm{SC}$, temperature), drinking-water standards have been established only for $\mathrm{pH}$, and results show that some samples have $\mathrm{pH}$ values that do not meet the SMCL range of 6.5-8.5 (table 4). $\mathrm{pH}$ is a measurement of the activity of hydrogen ions in water and is expressed in logarithmic units with a $\mathrm{pH}$ of 7 considered neutral. Water with a $\mathrm{pH}$ less than 7 is acidic; water with a $\mathrm{pH}$ greater than 7 is basic (or alkaline). The $\mathrm{pH}$ of groundwater samples collected from 79 wells in Pike County ranged from 5.5 to 9.2; the median $\mathrm{pH}$ was 7.2 (table 4). The $\mathrm{pH}$ of 24 of 79 samples (30 percent) was outside the EPA SMCL range of 6.5-8.5 (U.S. Environmental Protection Agency, 2012). Sixteen of 79 samples (20 percent) had a $\mathrm{pH}$ less than 6.5 , and 8 of 79 samples (10 percent) had a $\mathrm{pH}$ greater than 8.5 (table 4). Water with $\mathrm{pH}$ less than 6.5 tends to be corrosive and has potential to leach metals, such as lead and copper, from plumbing. The spatial distribution of $\mathrm{pH}$ values in Pike County groundwater is shown in figure 6.

Alkalinity of a solution is a measure of the capacity for the solutes contained in the solution to react with and neutralize acid and typically consists largely of carbonate and bicarbonate ions (Hem, 1985, p. 106). Alkalinity is related to the $\mathrm{pH}$ of a water sample. In general, water samples with a higher $\mathrm{pH}$ have a higher alkalinity (fig. 7A). Alkalinity ranged from about 10 to $140 \mathrm{mg} / \mathrm{L}$ as calcium carbonate $\left(\mathrm{CaCO}_{3}\right)$; the median alkalinity was $72.2 \mathrm{mg} / \mathrm{L}$ as $\mathrm{CaCO}_{3}$ (table 4).

Specific conductance is a measurement of the ability of water to conduct an electric current. Specific conductance measured in the field ranged from 47 to $1,320 \mu \mathrm{S} / \mathrm{cm}$ at $25{ }^{\circ} \mathrm{C}$ with a median specific conductance of $195 \mu \mathrm{S} / \mathrm{cm}$ at $25^{\circ} \mathrm{C}$ (table 4). Evaluation of field and laboratory specific conductance indicates values generally agree within 10 percent but that the laboratory values are more accurate than field values and in better agreement with computed conductance on the basis of the ionic contributions (Appendix 1, fig. 1-1).
Field notes made during sampling of the well (PI-650) with the highest field SC $\left(1,320 \mu \mathrm{S} / \mathrm{cm}\right.$ at $\left.25^{\circ} \mathrm{C}\right)$ indicate $\mathrm{SC}$ was unstable and rising during purging. The maximum laboratory specific conductance value of $1,580 \mu \mathrm{S} / \mathrm{cm}$ at $25^{\circ} \mathrm{C}$ (table 4 ) was measured in the PI-650 well-water sample. Specific conductance measured in the 79 water samples is linearly related to the TDS concentration, a measure of dissolved ionic concentrations (about $\mathrm{r}^{2}=0.99$ ) (fig. 8). Specific conductance (and TDS) tended to increase as $\mathrm{pH}$ increased in the Pike County groundwater samples (fig. 7B), relations that indicate that $\mathrm{pH}$ increases as mineral dissolution (and other weathering) increases in groundwater.

Concentrations of DO ranged from less than 0.1 to $10.4 \mathrm{mg} / \mathrm{L}$; the median concentration was $1.09 \mathrm{mg} / \mathrm{L}$ (table 4). The DO concentration was low, less than $0.5 \mathrm{mg} / \mathrm{L}$, in groundwater samples from 33 of 79 wells (about 42 percent) (table 13; Senior, 2017), which indicates suboxic to anoxic redox conditions in the aquifer (McMahon and Chapelle, 2008). Low DO concentrations are related to chemical or biochemical reactions that consume oxygen and may result in reducing conditions that promote the release of some metals. The chemical reactions that consume oxygen can be naturally occurring in soil or aquifer materials and are commonly associated with microbial activity or oxidation of organic carbon (from natural or man-made sources) and certain minerals such as pyrite. In the groundwater samples collected in Pike County, DO concentrations tended to decrease with increasing $\mathrm{pH}$; DO concentrations generally were highest in acidic ( $\mathrm{pH}$ less than 6.5) water and lowest (less than $0.5 \mathrm{mg} / \mathrm{L}$ ) in alkaline water ( $\mathrm{pH}$ greater than 7.8 ) (fig. 7C). These relations indicate that consumption of oxygen progresses with mineral weathering along groundwater flow paths, which are out of contact with air (source of oxygen). High DO concentrations in well-water samples most likely are associated with recently recharged groundwater, unless affected by aeration during pumping or cascading water from shallow water-bearing zones in boreholes. 


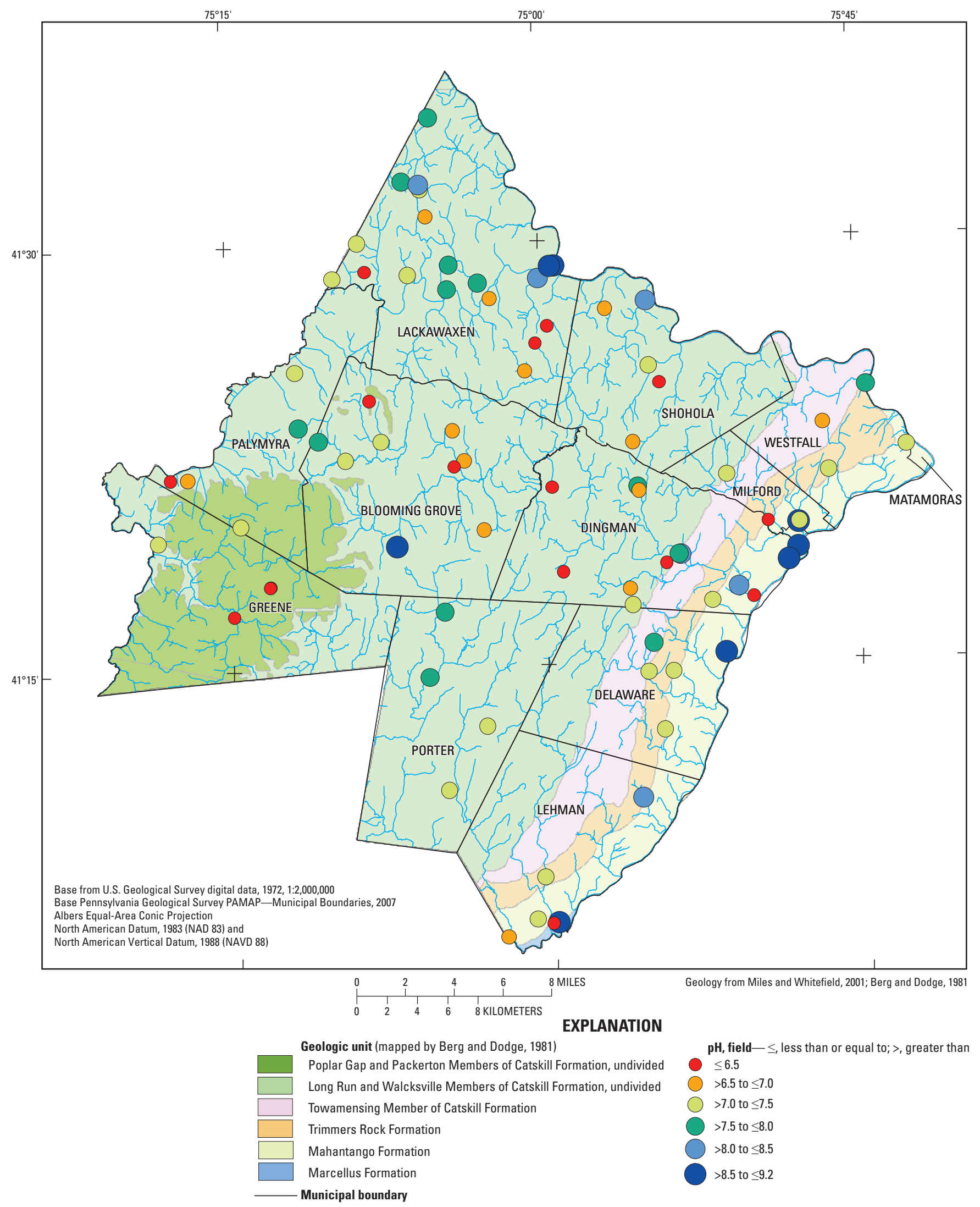

Figure 6. Geological units and spatial distribution of $\mathrm{pH}$ in groundwater samples collected from 79 wells in Pike County, Pennsylvania, 2015. 

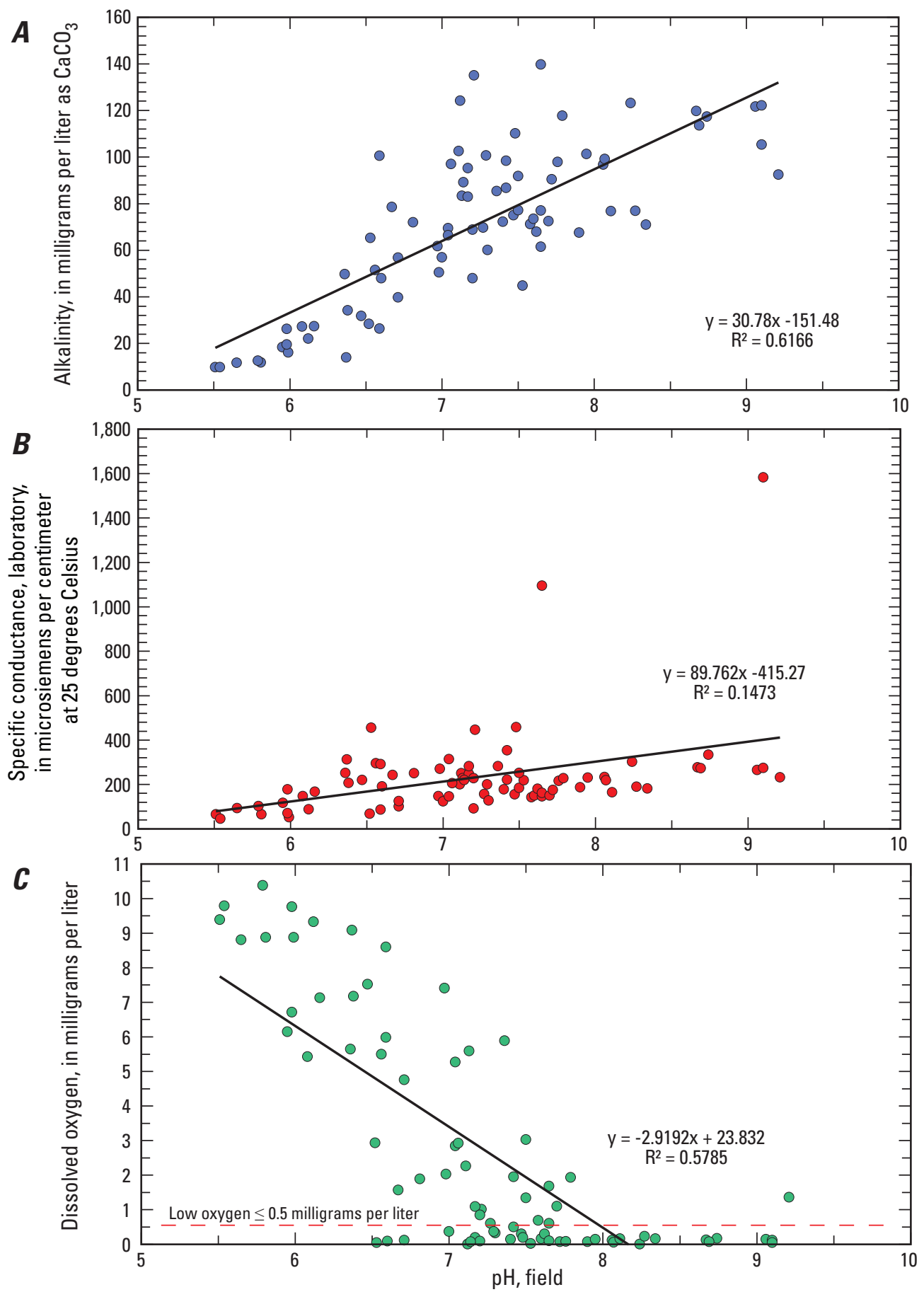

Figure 7. Relation of field measured pH to $A$, laboratory determined alkalinity, $B$, laboratory measured specific conductance, and $C$, field measured dissolved oxygen concentrations in groundwater samples collected from 79 wells in Pike County, Pennsylvania, 2015. $\left[\mathrm{CaCO}_{3^{\prime}}\right.$ calcium carbonate $]$ 


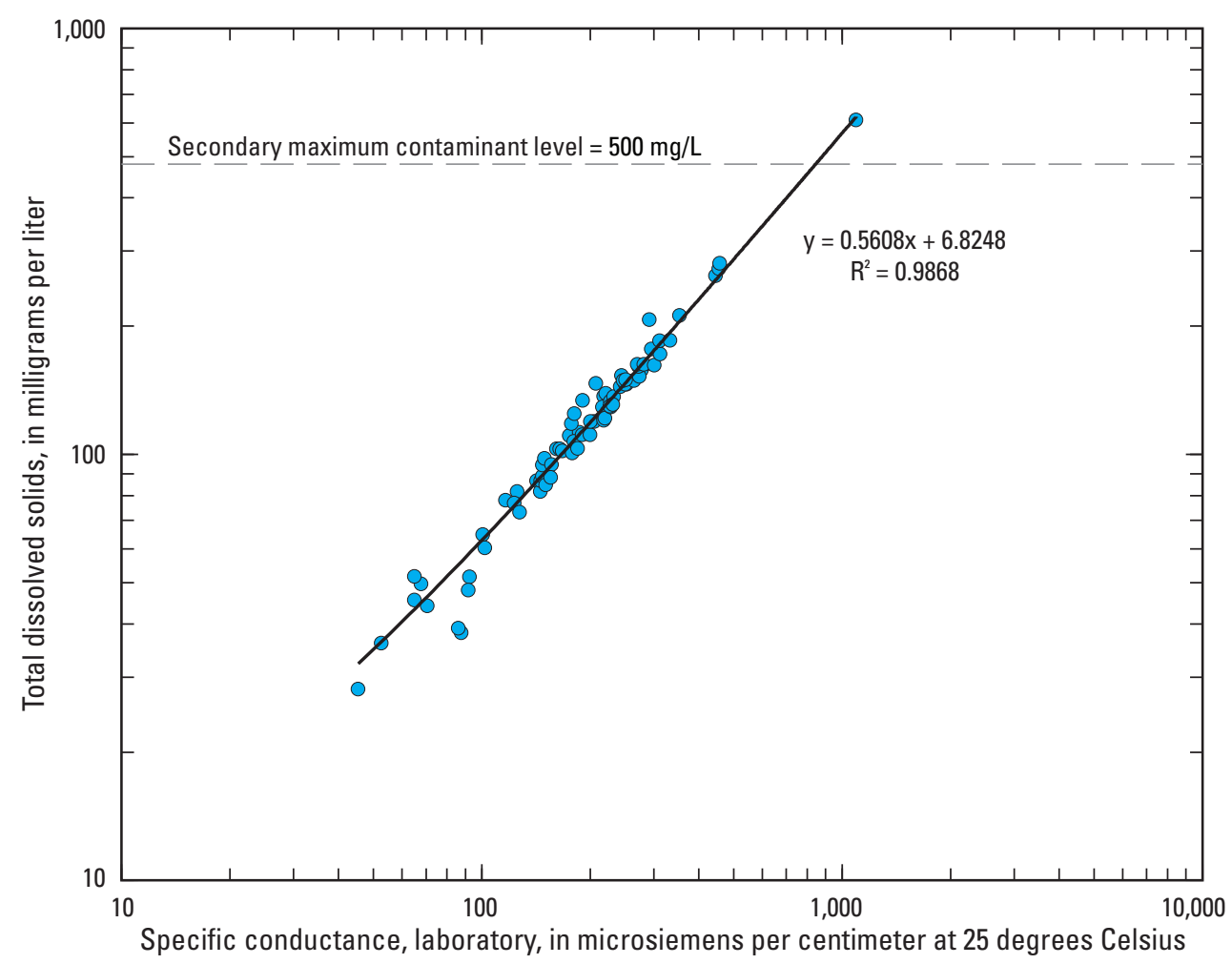

Figure 8. Relation of laboratory measured specific conductance to concentrations of total dissolved solids in groundwater samples collected from 79 wells in Pike County, Pennsylvania, 2015. [SMCL, secondary maximum contaminant level; $\mathrm{mg} / \mathrm{L}$, milligrams per liter]

\section{Total Dissolved Solids, Hardness, and Corrosivity}

Concentrations of TDS in the groundwater samples from 79 wells ranged from 28 to $939 \mathrm{mg} / \mathrm{L} ; 2$ samples had TDS concentrations greater than the SMCL of $500 \mathrm{mg} / \mathrm{L}$ (table 4). TDS concentrations often are used as a measure of salinity. Freshwater typically is defined as having TDS concentrations less than $1,000 \mathrm{mg} / \mathrm{L}$ and saline water as having TDS concentrations greater than 1,000 mg/L. In a regional study of the presence of saline water in the United States, depth to saline water (TDS greater than $1,000 \mathrm{mg} / \mathrm{L}$ ) was estimated to be greater than or equal to $1,000 \mathrm{ft}$ in northeastern Pennsylvania in the vicinity of Pike County (Feth and others, 1965). On the basis of geophysical logs in similar hydrogeologic settings in Pike, Wayne, and Monroe Counties, the depth of freshwater circulation was estimated to be greater than $800 \mathrm{ft}$ below land surface in Monroe County, which is south of, and adjacent to, Pike County (Carswell and Lloyd, 1979). Saltwater or brine was reported to be present at a depth of about $1,040 \mathrm{ft}$ in a 1,842 ft oil and gas test hole drilled in eastern Pike County near Matamoras (Lohman, 1937). Results from the 2015 sampling of the 79 wells with depths of as much as $610 \mathrm{ft}$ are consistent with these estimates of depth to saline water.
Hardness reflects the concentrations of calcium and magnesium ions, which are released into groundwater from the dissolution of calcium- and magnesium-bearing minerals. Hard water decreases lathering of soap and increases the potential for mineral deposits to accumulate and form scale in plumbing (pipes, sinks, showers) and on cooking utensils. Hardness of the water samples from 79 wells ranged from 14 to $392 \mathrm{mg} / \mathrm{L}$ as $\mathrm{CaCO}_{3}$ with a median value of $70.9 \mathrm{mg} / \mathrm{L}$ as $\mathrm{CaCO}_{3}$ (table 4) Using a common hardness classification (Dufor and Becker, 1964), the measured values (sum of dissolved calcium and magnesium concentrations) indicate that groundwater samples from 29 (37 percent) of the 79 wells were soft (less than $60 \mathrm{mg} / \mathrm{L}$ as $\mathrm{CaCO}_{3}$ ), 43 samples (54 percent) were moderately hard (61 to $120 \mathrm{mg} / \mathrm{L}$ as $\mathrm{CaCO}_{3}$ ), 4 samples (5 percent) were hard (121 to $180 \mathrm{mg} / \mathrm{L}$ as $\mathrm{CaCO}_{3}$ ), and 3 samples (4 percent were very hard (greater than $180 \mathrm{mg} / \mathrm{L}$ as $\mathrm{CaCO}_{3}$ ) (table 13; Senior, 2017). Hardness varied with $\mathrm{pH}$; hardness generally was greatest at intermediate $\mathrm{pH}$ values (6.5 to 7.8) (fig. 9A). Groundwater samples with low $\mathrm{pH}$ (less than 6.5) or high $\mathrm{pH}$ (greater than 7.8) typically had hardness less than $60 \mathrm{mg} / \mathrm{L}$ as $\mathrm{CaCO}_{3}$ and were soft. There are no health-related standards established specifically for hardness in drinking water. 

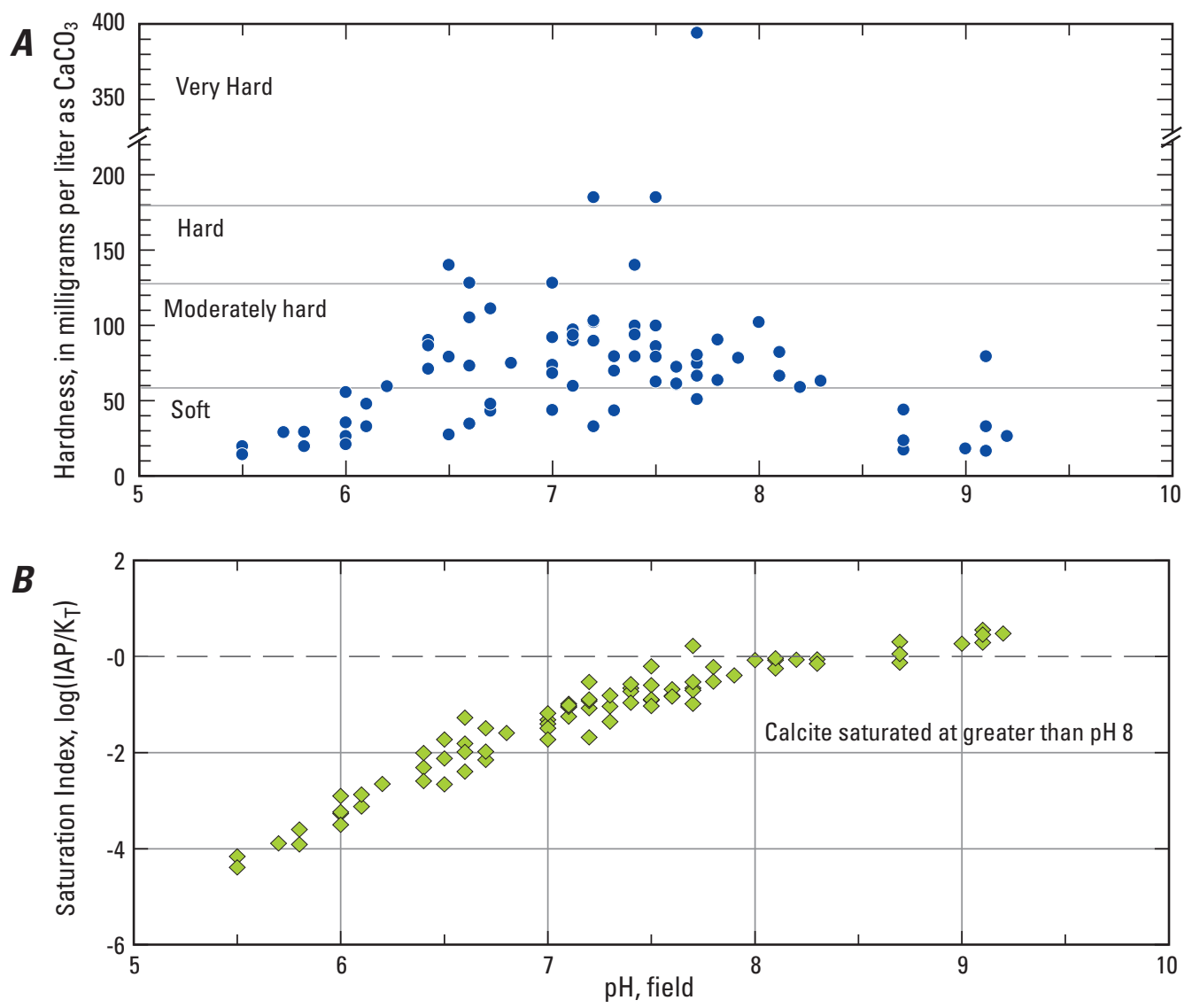

Figure 9. Relation of field measured $\mathrm{pH}$ to $A$, hardness, and $B$, corrosivity, as measured by calcite saturation index, in groundwater samples collected from 79 wells in Pike County, Pennsylvania, 2015. [IAP, ion activity product; KT, solubility product (thermodynamic equilibrium constant); $\mathrm{CaCO}_{3}$, calcium carbonate]

Water-resources engineers commonly identify the corrosion and encrustation potential of water on the basis of the Langelier Index (LI), which provides an indication of the potential for lead and copper to enter water supplies from pipes and plumbing (Snoeyink and Jenkins, 1981). The LI, which is the difference between the measured $\mathrm{pH}$ and the $\mathrm{pH}$ at equilibrium with calcite $\left(\mathrm{CaCO}_{3}\right)$, is equal in value to the calcite saturation index (SICAL), computed as the log of ion activity product divided by solubility product [log(IAP/ $\mathrm{K}_{\mathrm{T}}$ )] and discussed in more detail in section "Geochemical Modeling." If the LI or SICAL is positive, the $\mathrm{pH}$ is greater than that at equilibrium with $\mathrm{CaCO}_{3}$, and the water will tend to deposit a $\mathrm{CaCO}_{3}$ coating or scale that can insulate pipes, boilers, and other components of a system from contact with water; however, if the LI is negative, the water is undersaturated with $\mathrm{CaCO}_{3}$ and will tend to be corrosive in the distribution system, with decreasing negative values, indicating greater potential for corrosion. The optimum value for the LI or SICAL is close to zero, at which the water will be neither strongly corrosive nor scale forming. For the Pike County groundwater samples, SICAL ranged from -4.4 to
0.56 , generally increasing with $\mathrm{pH}$ to a $\mathrm{pH}$ of about 8 (fig. $9 B$ ). Of the water samples collected from 79 wells in 2015, 40 (51 percent) had LI values that were less than -1 , indicating potentially strongly corrosive characteristics with potential to leach lead, copper, and other metals from pipes and plumbing that may contain the metallic components. The most corrosive samples typically were acidic with $\mathrm{pH}$ less than 6.5 (and most were soft, fig. 9A). The remaining samples are considered neither strongly corrosive nor scale forming.

\section{Major and Minor lons}

Sources of major and minor ions include atmospheric precipitation, mineral dissolution, and compounds introduced or associated with land-use practices, such as use of deicing salts on roads, on-site wastewater disposal (septic systems), and agricultural application of lime or fertilizers on fields. The major ions consist of positively charged cations (calcium, magnesium, sodium, and potassium) balanced by negatively charged anions (bicarbonate, chloride, sulfate). Silica is a major constituent that commonly occurs as an uncharged 
ion. Nitrate, discussed in the section "Nutrients," is an anion that sometimes is present in large enough concentrations to be considered a major ion; nitrite rarely is present in concentrations greater than $1 \mathrm{mg} / \mathrm{L}$ in groundwater. Ammonia, a nitrogen compound that commonly occurs in groundwater as the cation ammonium, occasionally may be present in large enough concentrations to be considered a major ion.

Drinking-water standards have been established for only a few major ions and, except for two nitrogen compounds (nitrate and nitrite), are typically either a SMCL or HA, both of which are recommended rather than required standards. Drinking-water standards for the major ions include SMCLs for chloride and sulfate, and HAs for sodium and sulfate (table 4). Fluoride and bromide are minor anions typically present in concentrations of less than $1 \mathrm{mg} / \mathrm{L}$ in Pike County groundwater. Of these minor ions, only fluoride has an established MCL in drinking water.

The summary statistics for concentrations of major and minor ions listed in table 4 show that only sodium, chloride, and sulfate are present in concentrations greater than a HA or SMCL in a few of the 2015 Pike County groundwater samples. Dissolved sodium concentrations were greater than the HA level of $20 \mathrm{mg} / \mathrm{L}$ for individuals on a sodium-restricted diet in samples from 15 of 79 wells (19 percent) and were greater than the EPA (2012) upper drinking-water advisory limit of $60 \mathrm{mg} / \mathrm{L}$ in samples from 2 wells (PI-592, PI-650) (3 percent). These exceedances for sodium relative to the HA and SMCL were similar to those found in the 2012 study (Senior, 2014). The spatial distribution of dissolved sodium concentrations in Pike County groundwater in 2015 is shown in figure 10. In two of the wells that had sodium concentrations greater than the HA of $20 \mathrm{mg} / \mathrm{L}$, either the chloride or the sulfate concentration also exceeded the SMCLs for those constituents. Chloride concentrations were near (246 mg/L, dissolved) or greater than (252 mg/L, total) the SMCL of $250 \mathrm{mg} / \mathrm{L}$ in the water sample from one well (PI-653). Sulfate concentrations were greater than (362 and $322 \mathrm{mg} / \mathrm{L}$, dissolved and total, respectively) the SMCL of $250 \mathrm{mg} / \mathrm{L}$ in the water sample from well (PI-650), one of the two wells with elevated sodium concentrations. The highest chloride concentrations were in samples collected from wells in eastern Pike County (fig. 11).

Small (less than 5 percent) to no differences between dissolved and total concentrations of major and minor ions were apparent for most samples (tables 4 and 13; Senior, 2017), indicating these constituents predominantly are present in the dissolved phase in the groundwater samples. Additionally, the results of analyses for dissolved and total concentrations indicate that the quality of filtered and unfiltered water has a similar relation to drinking-water standards for these constituents.

\section{Nutrients}

The nutrients nitrogen $(\mathrm{N})$ and phosphorus $(\mathrm{P})$ most commonly are present in groundwater in the dissolved phase. Sources of nitrogen include atmospheric precipitation, decomposing organic matter (leaves and other vegetation), fertilizers, animal wastes, and septic systems; the latter three sources potentially contribute greater amounts to groundwater than precipitation, depending on land use in recharge area. Nitrogen may be present in various forms, depending on origin and geochemical environment. Ammonia and nitrite tend to be present in reducing or suboxic environments (oxygen concentrations typically less than $0.5 \mathrm{mg} / \mathrm{L}$ ), and nitrate tends to be present in oxidizing environments (oxygen concentrations typically greater than $0.5 \mathrm{mg} / \mathrm{L}$ ). Sources of phosphorus include mineral dissolution, fertilizers, animal wastes, and septic systems. Orthophosphate is a common sparingly soluble form of phosphorus, which is the predominant form in water, minerals (apatite), bones, and teeth.

Ammonia and nitrite were detected in about 41 percent and 4 percent of the samples, respectively, at relatively low concentrations that met respective drinking-water standards (table 4). Nitrate was detected in 48 percent of the samples at relatively low concentrations that ranged up to about $1.9 \mathrm{mg} / \mathrm{L}$ as $\mathrm{N}$ and was less than the MCL of $10 \mathrm{mg} / \mathrm{L}$ as $\mathrm{N}$ in all samples. Orthophosphate was detected in 96 percent of the samples, with concentrations ranging up to $0.174 \mathrm{mg} / \mathrm{L}$ as $\mathrm{P}$ and greater than or equal to $0.02 \mathrm{mg} / \mathrm{L}$ as $\mathrm{P}$ in 33 samples (about 42 percent). Concentrations of orthophosphate greater than 0.01 to $0.02 \mathrm{mg} / \mathrm{L}$ in streams in glaciated northeastern Pennsylvania may represent slight enrichment relative to reference conditions (U.S. Environmental Protection Agency, 2001) but not always. Denver and others (2010) report groundwater discharged to streams (as base flow) from forested settings that were underlain by crystalline bedrock aquifers contained orthophosphate concentrations greater than $0.02 \mathrm{mg} / \mathrm{L}$ as P. Sources of elevated orthophosphate in the Pike County groundwater samples have not been identified but could include dissolution of apatite or other phosphorusbearing minerals, such as impure feldspars (Denver and others, 2010), in addition to human-related phosphorus from wastewater disposal and fertilizers.

\section{Bacteria}

Total coliform bacteria were detected in groundwater samples from 25 of 79 (32 percent) wells (table 4) with concentrations ranging from less than $1 \mathrm{MPN} / 100 \mathrm{~mL}$ to 1,990 MPN/100 mL. The presence of total coliform does not necessarily indicate pathogenic bacteria, but does indicate potential pathways from the surface or near surface to groundwater. Guidelines for evaluation of health risks associated with bacteria state that analysis for bacteria of fecal origin, such as E. coli, should be done if total coliform bacteria are detected (U.S. Environmental Protection Agency, 2012). Of the 25 groundwater samples that had total coliform bacteria, no samples had detectable $E$. coli. Possible sources of $E$. coli include on-site wastewater disposal (septic system, sand mound) or other infiltration of surface waters containing fecal matter. 


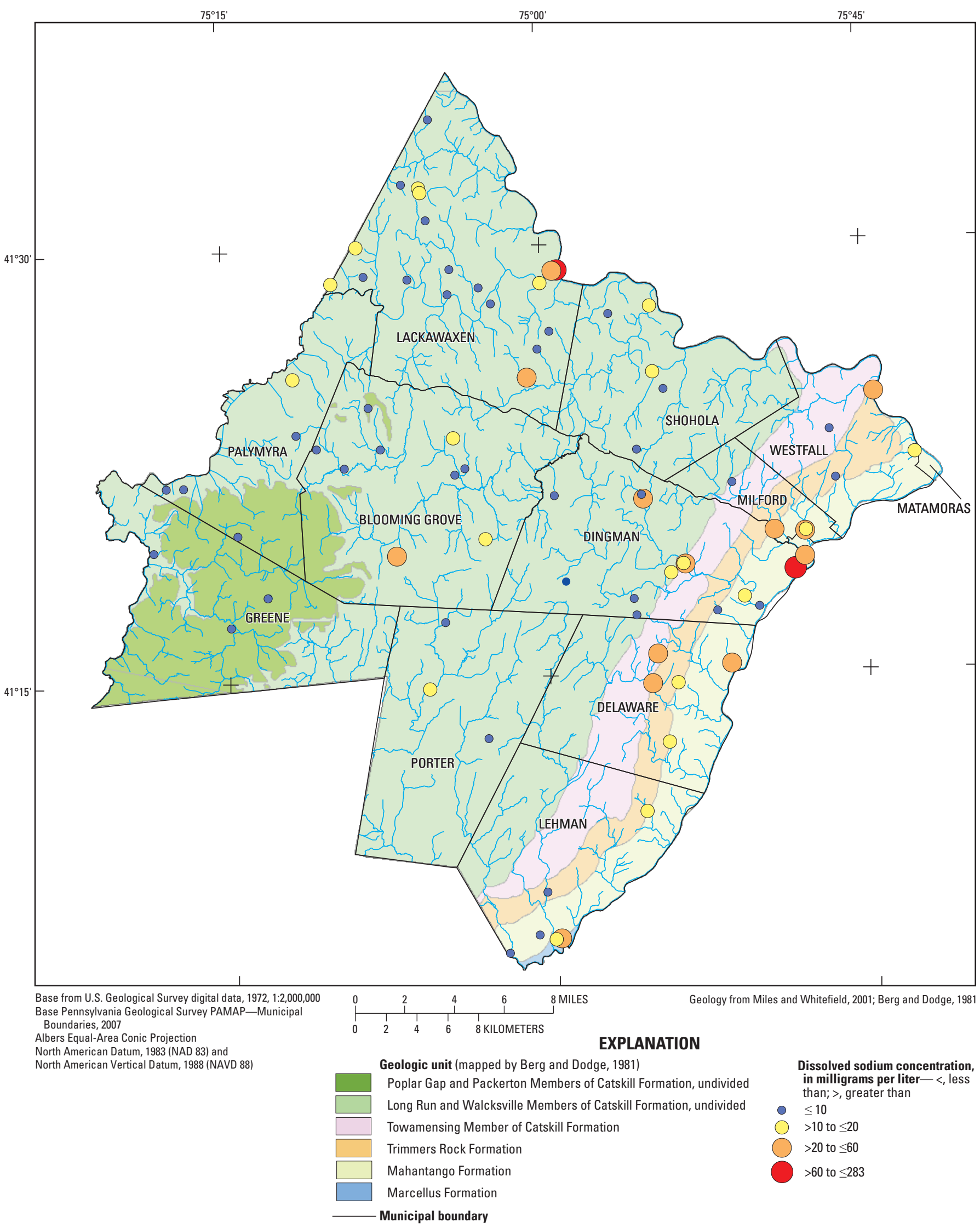

Figure 10. Geologic units and spatial distribution of dissolved sodium concentrations in groundwater samples collected from 79 wells in Pike County, Pennsylvania, 2015. 


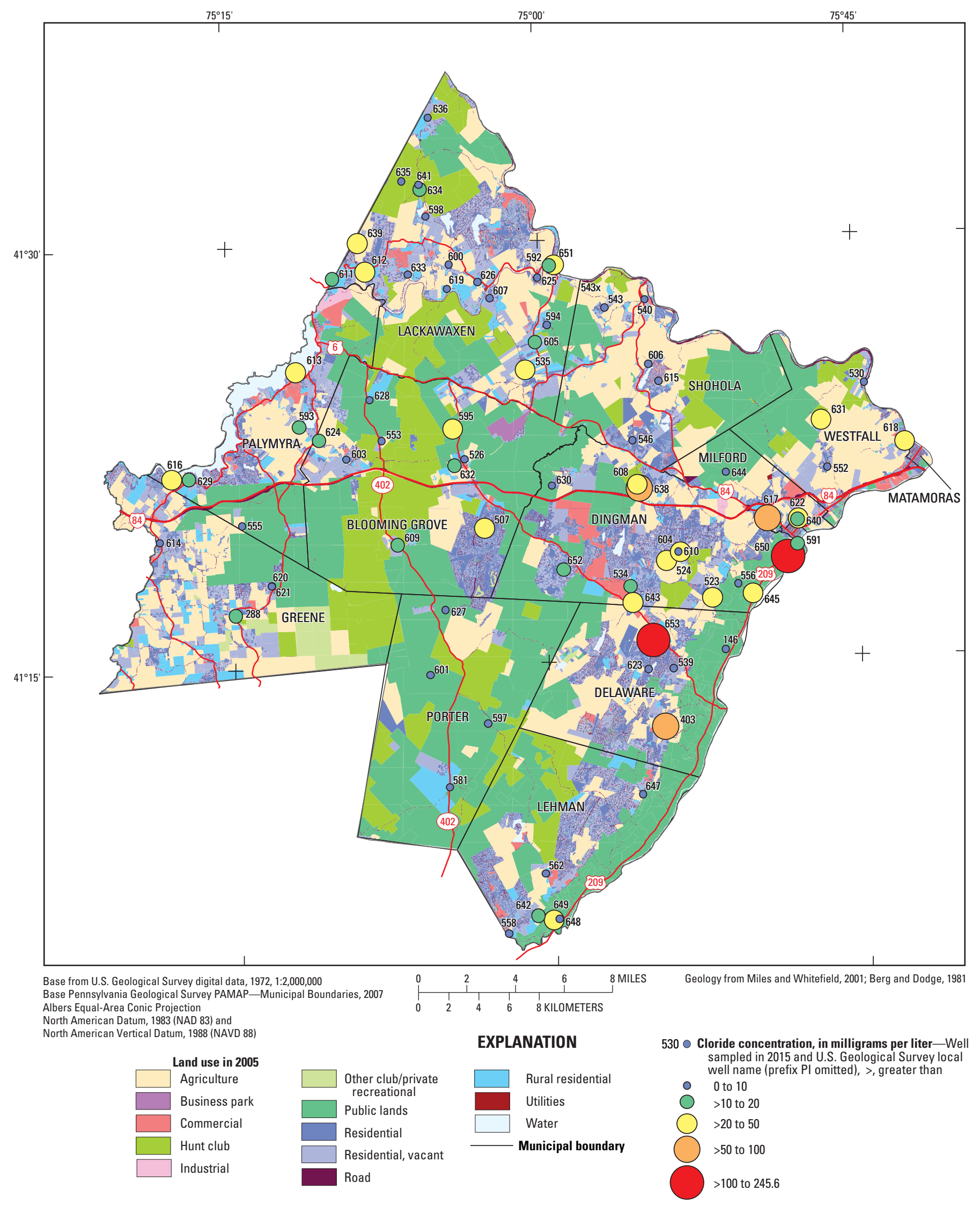

Figure 11. Map showing 2005 land use and spatial distribution of dissolved chloride concentrations in groundwater samples collected from 79 wells in Pike County, Pennsylvania, 2015. 


\section{Trace Constituents}

Most analyses for inorganic trace constituents (metals and other elements) were conducted on filtered samples (table 5) and represent dissolved concentrations. Analyses for selected constituents — aluminum, arsenic, barium, lithium, iron, manganese, selenium, strontium, and zinc-were conducted on both filtered and unfiltered samples (table 5) using USGS methods for filtered samples and drinkingwater methods for unfiltered samples. Small differences (less than 10 percent) between dissolved and total concentrations may be attributed to analytical uncertainty. However, total concentrations more than 10 percent greater than dissolved concentrations generally indicate that a solid, or particulate, phase of the constituent is present. Small to no differences between dissolved and total concentrations of barium, lithium, and strontium were apparent, indicating these constituents are mostly present in the dissolved form in the groundwater samples. Likewise, differences between dissolved and total concentrations of manganese and arsenic generally were small, with dissolved concentrations representing at least 70-80 percent of total concentrations in one-half of the samples. In contrast, substantial differences in dissolved and total concentrations of iron were measured for many samples with total concentrations exceeding dissolved concentrations by more than $100 \mu \mathrm{g} / \mathrm{L}$ and up to about 22,970 $\mu \mathrm{g} / \mathrm{L}$ in 41 of 79 samples (52 percent), indicating that large amounts of particulate iron are present in these samples. Differences in dissolved and total concentrations of trace constituents may occur and are sometimes caused by presence of, or adsorption of, trace metals on particulate iron or manganese oxides. Consequently, concentrations of some constituents (such as arsenic), in some cases, may exceed respective MCLs or SMCLs in unfiltered samples but not in filtered samples.

Of the 19 inorganic trace constituents (metals and other elements) included in 2015 analyses of filtered water samples, 18 were present in concentrations greater than the reporting level in at least one sample (table 5). Dissolved concentrations of the most frequently detected inorganic trace constituents (strontium, barium, lithium) generally were higher than dissolved concentrations of the less frequently detected constituents. Dissolved concentrations of barium, strontium, and lithium were measured at values greater than the reporting levels in all 79 samples. Arsenic, manganese, boron, lead, iron, and molybdenum were the next most frequently detected dissolved metals. Of the metals and trace constituents analyzed, only arsenic exceeded a primary drinking-water standard (MCL), but iron and manganese exceeded SMCLs. Arsenic and manganese exceeded HAs in some samples.

\section{Arsenic and Chemically Similar Trace Constituents}

Dissolved or total arsenic concentrations exceeded the MCL of $10 \mathrm{mg} / \mathrm{L}$ in only 1 of 79 samples (1 percent), with values of 27.8 and $30.1 \mu \mathrm{g} / \mathrm{L}$, respectively (table 5), and were higher than the HA level of $2 \mu \mathrm{g} / \mathrm{L}$ in 8 of 79 samples (10 percent). Elevated arsenic concentrations generally occur in water with elevated $\mathrm{pH}$. Arsenic concentrations in groundwater samples collected in Pike County in 2015 (fig. 12A) and 2012-13 (Senior, 2014) generally were greater than the MCL of $10 \mu \mathrm{g} / \mathrm{L}$ only when the $\mathrm{pH}$ was greater than 8.0 and greater than the $\mathrm{HA}$ of $2 \mu \mathrm{g} / \mathrm{L}$ when the $\mathrm{pH}$ was greater than 7.2. The relation between elevated $\mathrm{pH}$ and elevated arsenic concentrations in Pike County may be attributed to the increased mobility of arsenic under these geochemical conditions. Most arsenic is present in the dissolved phase, as shown by comparison of dissolved and total arsenic concentrations (fig. 13).

Increases in $\mathrm{pH}$ to levels greater than 7 may result in mobilization of some negatively charged ions (anions) that tend to be adsorbed on iron oxides or other mineral surfaces in aquifer materials at low $\mathrm{pH}$, as discussed for a similar hydrogeologic setting in Wayne County in Senior and others (2016). Arsenic commonly is present in groundwater as arsenate $\left(\mathrm{AsO}_{4}{ }^{3-}\right)$ or, in more reducing conditions, arsenite $\left(\mathrm{AsO}_{3}{ }^{3-}\right.$ ); both are oxyanions (Welch and others, 2000). Under acidic to near-neutral conditions, arsenate tends to remain mostly adsorbed on aquifer materials such as iron oxides, but at $\mathrm{pH}$ greater than about 7 , arsenate can be mobilized (desorbed) to a greater extent.

Other constituents that have some chemical characteristics similar to arsenic, forming oxyanions that are more mobile at higher $\mathrm{pH}$ values, include molybdenum, antimony, and selenium. Of these metals in the Pike County groundwater samples, the relation between increasing $\mathrm{pH}$ and dissolved concentrations was strongest for molybdenum (Appendix 3, fig. 3-1); generally higher concentrations molybdenum concentrations were measured in samples with pH greater than about 7.5 (fig. 12B), a value above which geochemical modeling indicates greater than 90 percent of the molybdenum ion molybdenate $\left(\mathrm{MoO}_{4}^{2-}\right)$ is likely to be dissolved rather than adsorbed (Senior and others, 2016). 
Table 5. Minimum, median, and maximum concentrations of trace constituents determined in the laboratory for groundwater samples collected from 79 wells in Pike County, Pennsylvania, 2015 .

[ $\mu \mathrm{g} / \mathrm{L}$, micrograms per liter; <, less than; --, no data or not applicable; MCL, maximum contaminant level; HA, Health Advisory; SMCL, secondary maximum level]

\begin{tabular}{|c|c|c|c|c|c|c|c|c|c|}
\hline \multirow[b]{2}{*}{ Constituent } & \multirow[b]{2}{*}{ Units } & \multirow{2}{*}{$\begin{array}{c}\text { Number } \\
\text { (percent) } \\
\text { above } \\
\text { reporting } \\
\text { level }\end{array}$} & \multicolumn{3}{|c|}{ Concentration range and median } & \multirow{2}{*}{$\begin{array}{l}\text { Number } \\
\text { (percent) } \\
\text { exceeding } \\
\text { standard }\end{array}$} & \multicolumn{3}{|c|}{ Drinking-water standard ${ }^{1}$} \\
\hline & & & Minimim & Median & Maximum & & MCL & HA & SMCL \\
\hline \multicolumn{10}{|c|}{ Dissolved trace constituent (filtered samples) ${ }^{2}$} \\
\hline Antimony & $\mu g / L$ & $43(54)$ & $<0.027$ & 0.0293 & 0.529 & $0(0)$ & 6 & -- & -- \\
\hline Beryllium & $\mu g / L$ & $11(14)$ & $<0.020$ & $<0.020$ & 0.1104 & $0(0)$ & 4 & -- & -- \\
\hline Boron & $\mu \mathrm{g} / \mathrm{L}$ & $66(84)$ & $<5$ & 10.87 & 651.4 & $0(0)$ & -- & 7,000 & -- \\
\hline Cadmium & $\mu g / L$ & $9(11)$ & $<0.030$ & $<0.030$ & 0.1453 & $0(0)$ & 5 & -- & -- \\
\hline Chromium & $\mu g / L$ & $0(0)$ & $<0.30$ & $<0.30$ & $<0.30$ & $0(0)$ & 100 & -- & -- \\
\hline Cobalt & $\mu \mathrm{g} / \mathrm{L}$ & $40(51)$ & $<0.050$ & 0.0509 & 2.757 & -- & -- & -- & -- \\
\hline Copper & $\mu \mathrm{g} / \mathrm{L}$ & $41(52)$ & $<0.80$ & 0.901 & 61.8 & $0(0)$ & 1,300 & 1,000 & -- \\
\hline Lead, dissolved & $\mu g / L$ & $59(75)$ & $<0.040$ & 0.11 & 3.688 & $0(0)$ & 15 & -- & -- \\
\hline Molybdenum & $\mu \mathrm{g} / \mathrm{L}$ & $54(68)$ & $<0.05$ & 0.0867 & 1.989 & $0(0)$ & -- & 40 & -- \\
\hline Nickel & $\mu \mathrm{g} / \mathrm{L}$ & $32(41)$ & $<0.20$ & $<0.20$ & 1.421 & $0(0)$ & -- & 100 & -- \\
\hline \multicolumn{10}{|c|}{ Dissolved and total trace constituents (filtered and unfiltered samples) } \\
\hline Aluminum, dissolved & $\mu g / L$ & 30 (38) & $<3$ & $<3$ & 401.6 & a5 (6) & -- & -- & 50-200 \\
\hline Aluminum, total & $\mu g / L$ & $60(76)$ & $<1,<2$ & 4.38 & 1,360 & a14 (18) & -- & -- & 50-200 \\
\hline Arsenic, dissolved & $\mu \mathrm{g} / \mathrm{L}$ & $68(86)$ & $<0.1$ & 0.43 & 27.8 & b1 (1) & 10 & 2 & -- \\
\hline Arsenic, total & $\mu g / L$ & $40(51)$ & $<0.5$ & 0.5 & 30.1 & ${ }^{\mathrm{b}} 1(1)$ & 10 & 2 & -- \\
\hline Barium, dissolved & $\mu g / L$ & 79 (100) & 0.54 & 28.2 & 382.9 & $0(0)$ & ${ }^{\prime}, \mathbf{0 0 0}$ & -- & -- \\
\hline Barium, total & $\mu g / L$ & $78(100)$ & $0.52,<5$ & 32.2 & 398 & $0(0)$ & ${ }^{\prime} \mathbf{2 , 0 0 0}$ & -- & -- \\
\hline Iron, dissolved & $\mu \mathrm{g} / \mathrm{L}$ & $54(68)$ & $<4.0$ & 10.5 & 4,010 & $8(10)$ & -- & -- & 300 \\
\hline Iron, total & $\mu \mathrm{g} / \mathrm{L}$ & 70 (89) & $<10$ & 147 & 23,000 & $35(44)$ & -- & -- & 300 \\
\hline Lithium, dissolved & $\mu \mathrm{g} / \mathrm{L}$ & 79 (100) & 1.625 & 10.49 & 1,077 & -- & -- & -- & -- \\
\hline Lithium, total & $\mu \mathrm{g} / \mathrm{L}$ & $58(100)$ & $<10$ & 11.5 & 1,140 & -- & -- & -- & -- \\
\hline Manganese, dissolved & $\mu g / L$ & $68(86)$ & $<0.40$ & 11.4 & 962.7 & d24 (30) & -- & 300 & 50 \\
\hline
\end{tabular}


Table 5. Minimum, median, and maximum concentrations of trace constituents determined in the laboratory for groundwater samples collected from 79 wells in Pike County, Pennsylvania, 2015.-Continued

[ug/L, micrograms per liter; <, less than; --, no data or not applicable; MCL, maximum contaminant level; HA, Health Advisory; SMCL, secondary maximum level]

\begin{tabular}{|c|c|c|c|c|c|c|c|c|c|}
\hline \multirow[b]{2}{*}{ Constituent } & \multirow[b]{2}{*}{ Units } & \multirow{2}{*}{$\begin{array}{c}\text { Number } \\
\text { (percent) } \\
\text { above } \\
\text { reporting } \\
\text { level }\end{array}$} & \multicolumn{3}{|c|}{ Concentration range and median } & \multirow{2}{*}{$\begin{array}{c}\text { Number } \\
\text { (percent) } \\
\text { exceeding } \\
\text { standard }\end{array}$} & \multicolumn{3}{|c|}{ Drinking-water standard ${ }^{1}$} \\
\hline & & & Minimim & Median & Maximum & & MCL & HA & SMCL \\
\hline Manganese, total & $\mu \mathrm{g} / \mathrm{L}$ & $73(92)$ & $<0.5,<10$ & 22 & 1,850 & d31 (39) & -- & 300 & 50 \\
\hline Selenium, dissolved & $\mu \mathrm{g} / \mathrm{L}$ & $36(46)$ & $<0.05$ & $<0.05$ & 0.972 & $0(0)$ & 50 & -- & -- \\
\hline Selenium, total & $\mu \mathrm{g} / \mathrm{L}$ & $4(5)$ & $<2.5$ & $<2.5$ & 33.3 & $0(0)$ & 50 & -- & -- \\
\hline Strontium, dissolved & $\mu \mathrm{g} / \mathrm{L}$ & $79(100)$ & 10.75 & 238.1 & 3,420 & $0(0)$ & -- & ${ }^{c} 4,000$ & -- \\
\hline Strontium, total & $\mu \mathrm{g} / \mathrm{L}$ & $79(100)$ & 11 & 245 & 2,700 & $0(0)$ & -- & ${ }^{c} 4,000$ & -- \\
\hline Zinc, dissolved & $\mu \mathrm{g} / \mathrm{L}$ & 42 (53) & $<2.0$ & 2.23 & 43.65 & $0(0)$ & -- & 2,000 & 5,000 \\
\hline Zinc, total & $\mu \mathrm{g} / \mathrm{L}$ & $71(90)$ & $<0.5,<5$ & 5.8 & 421 & $0(0)$ & -- & 2,000 & 5,000 \\
\hline
\end{tabular}

${ }^{1}$ U.S.Environmental Protection Agency (2012).

${ }^{2}$ Laboratory analysis for dissolved concentrations in filtered samples done by U.S. Geological Survey National Water Quality Laboratory (NWQL).

${ }^{3}$ Laboratory analysis for total concentrations in unfiltered samples done by contract laboratories using drinking-water methods (see Appendix 2).

${ }^{a}$ Dissolved aluminum concentrations exceeded the lower SMCL threshold of $50 \mu \mathrm{g} / \mathrm{L}$ in 5 samples (6 percent) and the upper SMCL threshold of $200 \mu \mathrm{g} / \mathrm{L}$ in 1 sample (1 percent); total aluminum concentrations exceeded the lower SMCL threshold of $50 \mu \mathrm{g} / \mathrm{L}$ in 14 samples (18 percent) and the upper SMCL threshold of $200 \mu \mathrm{g} / \mathrm{L}$ in $17 \mathrm{samples}$ (22 percent).

${ }^{b}$ Dissolved and total arsenic concentrations exceeded the MCL of $10 \mu \mathrm{g} / \mathrm{L}$ in 1 sample (1 percent); dissolved and total arsenic concentrations exceeded the HA of 2 ug/L and 8 samples (10 percent) and 14 samples (18 percent), respectively.

'Pennsylvania Department of Environmental Protection established standards in 2010 of $10 \mathrm{mg} / \mathrm{L}(10,000 \mu \mathrm{g} / \mathrm{L})$ for barium and $10 \mathrm{mg} / \mathrm{L}(10,000 \mu \mathrm{g} / \mathrm{L})$ for strontium in flowback discharge to streams (Pennsylvania Department of Environmental Protection, 025 Pa. Code $\S 95.10$ ).

${ }^{\mathrm{d}}$ Dissolved manganese concentrations exceeded the SMCL level of $50 \mathrm{ug} / \mathrm{L}$ in 24 of 79 samples (30 percent) and the HA of $300 \mu \mathrm{g} / \mathrm{L}$ in 10 of 79 samples (13 percent). Total manganese concentrations exceed the SMCL level of $50 \mu \mathrm{g} / \mathrm{L}$ in 31 of 79 samples (39 percent) and the HA of $300 \mu \mathrm{g} / \mathrm{L}$ in 13 of 79 samples (16.5 percent). 

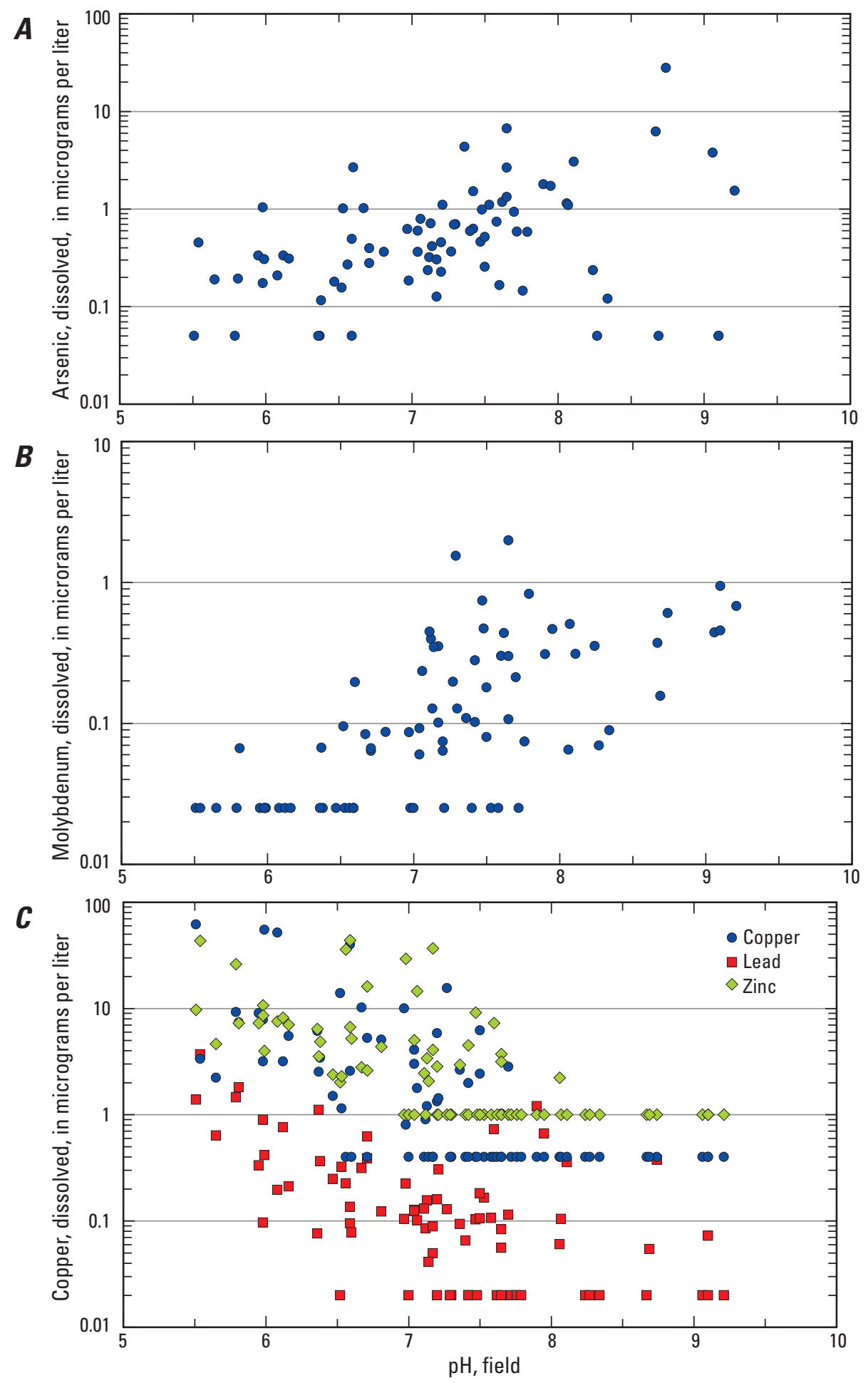

Figure 12. Relation of field measured $\mathrm{pH}$ to dissolved concentrations of $A$, arsenic, $B$, molybdenum, and $C$, copper, lead, and zinc in groundwater samples collected from 79 wells in Pike County, Pennsylvania, 2015. 


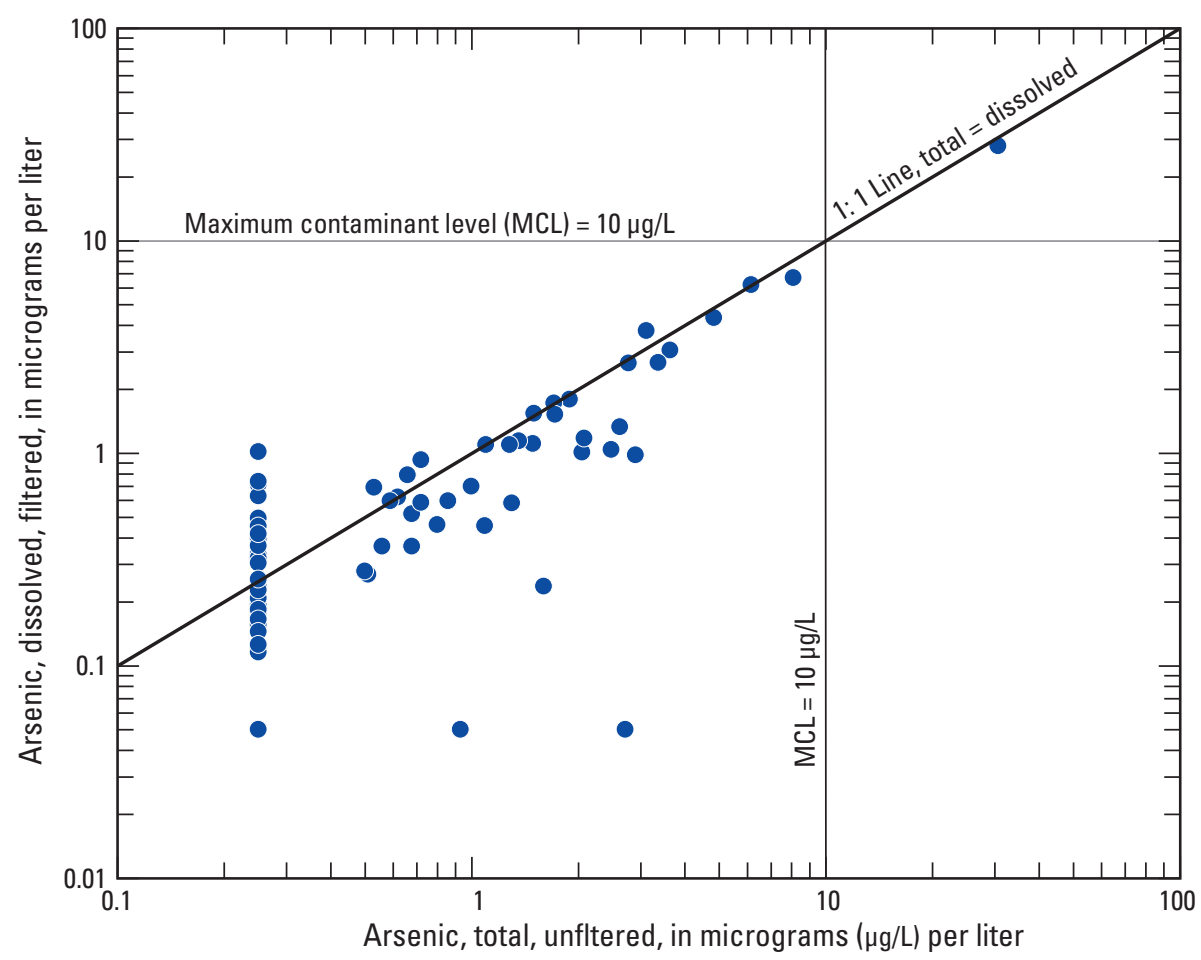

Figure 13. Relation of dissolved to total arsenic concentrations in filtered and unfiltered groundwater samples, respectively, collected from 79 wells in Pike County, Pennsylvania, 2015. [MCL, maximum contaminant level; $\mu \mathrm{g} / \mathrm{L}$, micrograms per liter]

\section{Iron and Manganese}

Total iron concentrations were greater than the SMCL of $300 \mu \mathrm{g} / \mathrm{L}$ in 35 of 79 samples (44 percent). Fewer dissolved iron concentrations (8 of 79 samples or 10 percent) exceeded this standard, indicating that the particulate phase of iron (as indicated by total concentrations greater than dissolved concentrations) is a more frequent water-quality concern (fig. 14A).

Concentrations of dissolved or total manganese exceeded the SMCL of $50 \mu \mathrm{g} / \mathrm{L}$ in 24 of 79 samples (30 percent) and in 31 of 79 samples (39 percent), respectively, indicating both dissolved and, to a lesser extent, particulate phases of manganese can be a waterquality concern (fig. 14B). Concentrations of dissolved and total manganese were nearly equal for about 20 percent of the samples and dissolved concentrations represented at least 70 percent of total manganese concentrations in one-half of the samples, showing that the dissolved phase of manganese is predominant for about 70 percent of the samples. Concentrations of dissolved or total manganese concentrations exceeded the HA of $300 \mu \mathrm{g} / \mathrm{L}$ in 10 of 79 samples (13 percent) and 13 of 79 samples (16 percent), respectively. The spatial distribution of total iron and manganese concentration in 2015 in Pike County groundwater samples is shown in figure 15 .
Dissolved iron and manganese concentrations greater than the SMCLs of 300 and $50 \mu \mathrm{g} / \mathrm{L}$, respectively, such as those in numerous groundwater samples in Pike County (fig. 14, table 4), generally are present in water that has low DO associated with reducing conditions favorable for iron and manganese mobilization. DO and nitrate concentrations were very low (less than $0.5 \mathrm{mg} / \mathrm{L}$ ) for most of the samples with elevated dissolved iron and manganese concentrations (fig. 16), indicating reducing (but not extremely reducing) conditions are present that can result in the reductive dissolution of iron and manganese oxides in aquifer materials.

Iron occurs in particulate form to a greater extent than does manganese in the Pike County groundwater samples, where the particulate concentration is the concentration of total minus dissolved metal. Total and particulate iron concentrations showed no clear relation to $\mathrm{pH}$, DO, nitrate, or sulfate concentrations, indicating that controls on the formation of particulate iron are complex and may involve additional factors (such as $\mathrm{pH}$ ) in combination with the redox conditions. Like iron, particulate manganese concentrations showed no strong relation to $\mathrm{pH}$ or $\mathrm{DO}$ concentration, but most of the highest total manganese concentrations were nearly equal to dissolved manganese concentrations and were associated with the lowest DO (and nitrate) concentrations, reflecting the predominant presence of manganese in the dissolved phase. 

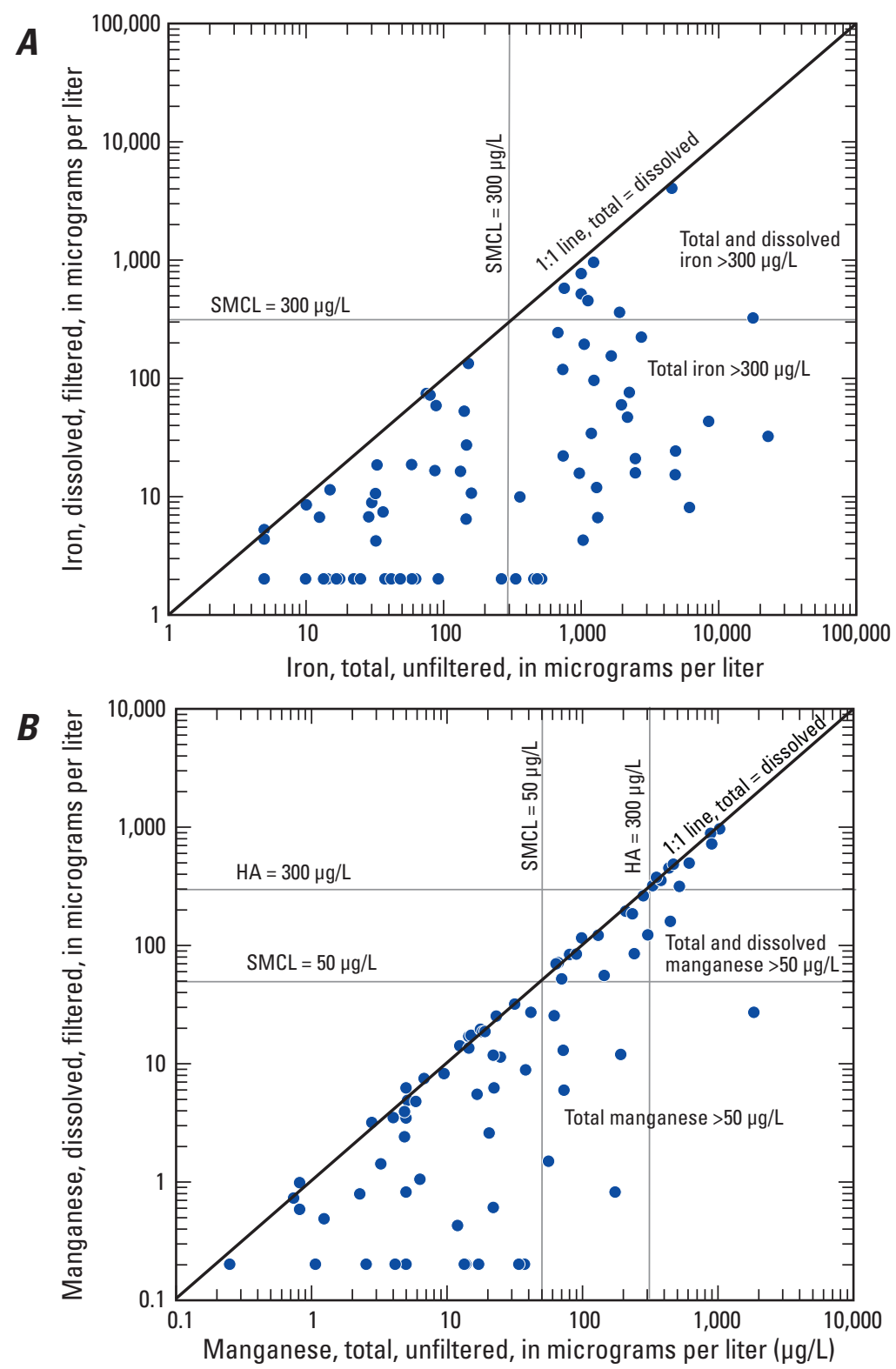

SMCL, Secondary maximum contaminant level HA, Health advisory

Figure 14. Relation between concentrations of $A$, dissolved and total iron, and $B$, dissolved and total manganese in filtered and unfiltered groundwater samples, respectively, collected from 79 wells in Pike County, Pennsylvania, 2015. [SMCL, secondary maximum contaminant level; HA, health advisory; $\mu \mathrm{g} / \mathrm{L}$, micrograms per liter] 


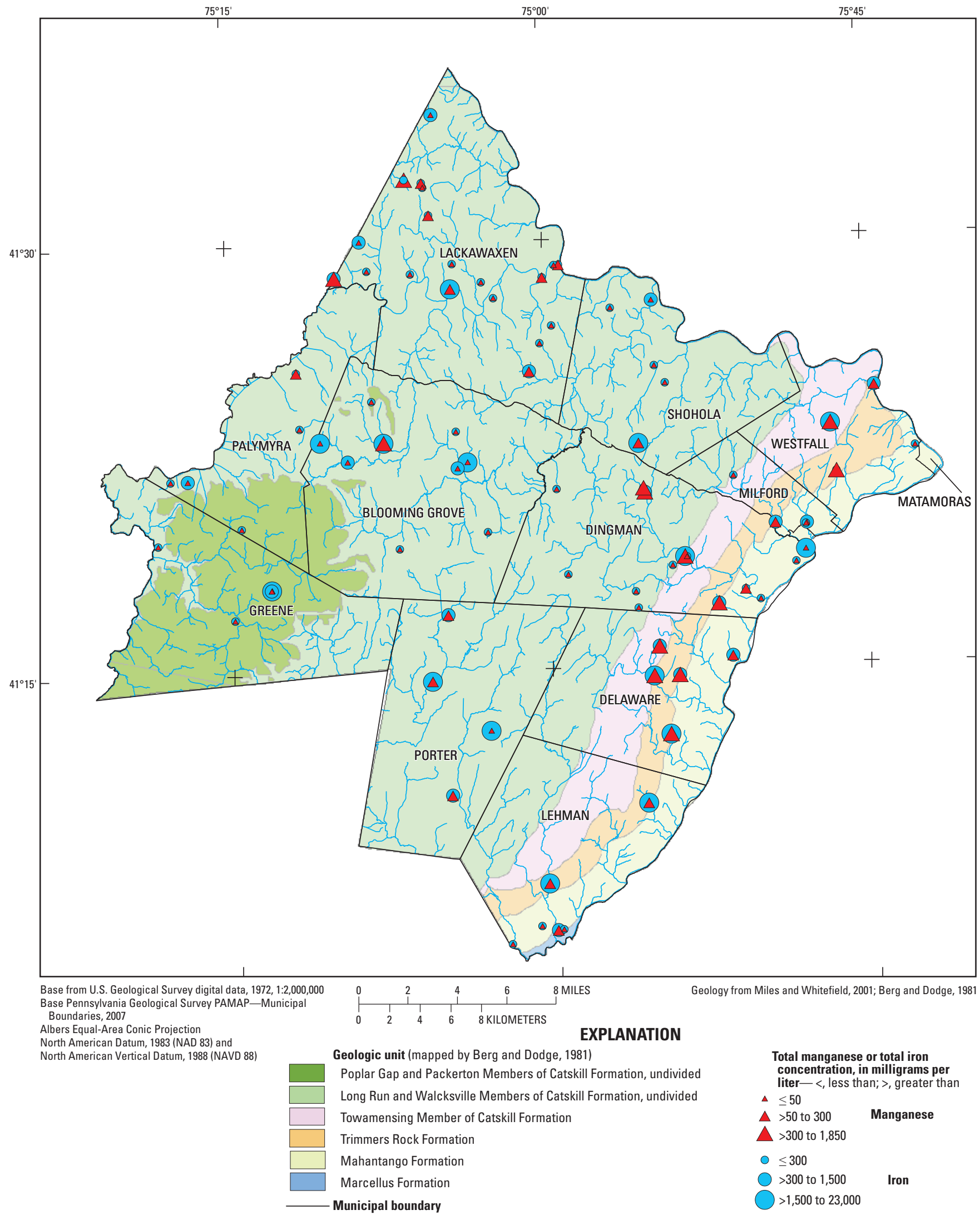

Figure 15. Geologic units and spatial distribution of total iron and total manganese concentrations in groundwater samples collected from 79 wells in Pike County, Pennsylvania, 2015. 

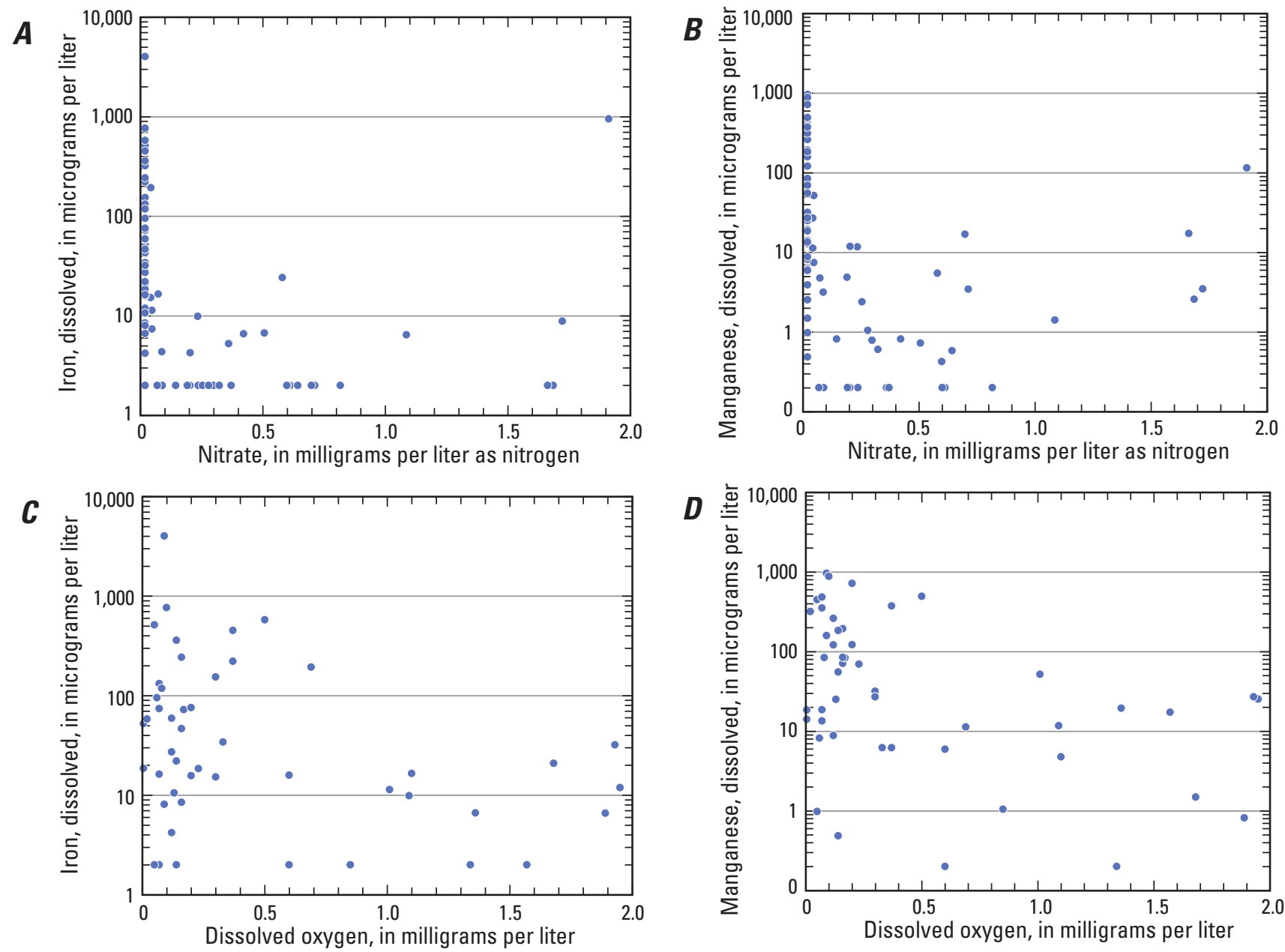

Figure 16. Relation of concentrations of nitrate to concentrations of $A$, dissolved iron and $B$, dissolved manganese and concentrations of dissolved oxygen to concentrations of $C$, dissolved iron and $D$, dissolved manganese in groundwater samples collected from 79 wells in Pike County, Pennsylvania, 2015. [SMCL, secondary maximum contaminant level; $\mu \mathrm{g} / \mathrm{L}$, micrograms per liter]

\section{Radionuclides}

Radionuclides naturally present in rocks and soils may enter or leach into groundwater through mineral dissolution, desorption from mineral surfaces, or in the case of radon (gas), diffusion. Elevated concentrations of some radionuclides, especially radium, are present in brines associated with Marcellus Shale and other formations with natural gas and oil (Rowan and others, 2011). Naturally occurring radioactivity in groundwater is produced primarily by the radioactive decay of uranium-238 and thorium-232. These isotopes of uranium and thorium disintegrate in steps emitting either alpha or beta particles and forming a series of radioactive nuclide “daughter" products, mostly short-lived, until a stable lead isotope is produced. Radioactivity is the release of energy and energetic particles (alpha or beta) by changes in the structure of certain unstable elements as they break down to form more stable arrangements, for which (1) alpha radiation consists of positively charged helium nuclei, (2) beta radiation consists of electrons or positrons, and (3) gamma radiation consists of electromagnetic waves. The uranium-238 decay series commonly produces the greatest amount of radioactivity in natural groundwater (Hem, 1985, p. 147), and includes the alpha-particle-emitting radionuclides radium-226 and its daughter product, radon-222. Radionuclides from the thorium-232 decay chain also can be present in groundwater in some geologic settings, including radium-228, a beta-particleemitting daughter product in the thorium-232 decay chain.

Analyses for radioactivity and radionuclides in the groundwater samples collected from 79 wells in Pike County in 2015 included gross alpha radioactivity, gross beta radioactivity, and dissolved radon-222 (radon gas). Uranium, a 
radioactive element (composed of uranium-238, uranium-235, and uranium-234 isotopes), also was analyzed in the dissolved form. Summary statistics for radioactive constituents are given in table 6, and analytical results are provided in Senior (2017) and table 13 (in back of report). Selected water samples with among the highest measured gross alpha radioactivity were analyzed for dissolved radium-226, a radionuclide that may be elevated (to a greater extent than radium-228) in brines associated with the Marcellus Shale (Rowan and others, 2011). The EPA drinking-water MCL is $5 \mathrm{pCi} / \mathrm{L}$ for combined radium-226 plus radium-228 activities. Previous limited results for radium in groundwater in Pike County show radium-226 values were less than $1 \mathrm{pCi} / \mathrm{L}$ (Senior, 2014).

\section{Gross Alpha and Gross Beta Radioactivity}

Various radioactive isotopes present in groundwater may contribute to the total or gross radioactivity measured in a sample, as measured in analyses for gross alpha and gross beta radioactivity. Differences between gross alpha and gross beta radioactivity measured soon after sample collection (within 72 hours) and after 30 days indicate whether short-lived radionuclides (such as radium-224, half-life of 3.6 days) are present in the sample. Because well owners typically are consuming water soon after it is pumped from a well, it is prudent to assess radioactivity measured as soon as possible (such as within 72 hours) relative to the established drinking-water standards. If gross alpha- or gross betaparticle activities are elevated, it is likely that a radionuclide (such as radium-226 for gross alpha-particle activities and potassium-40 for gross beta particle activities) that contributes to those radioactivities is also elevated. Thus, gross alpha- and gross beta-particle activities commonly are used to screen for possible presence of radionuclides in concentrations of concern.

The gross alpha-particle activity (72-hour count) in water from the 78 sampled wells ( 1 of 79 wells is missing gross alpha and beta analysis) ranged from non-detect (less than the detection limit) to $13.9 \mathrm{pCi} / \mathrm{L}$, and the median activity was $0.715 \mathrm{pCi} / \mathrm{L}$ (table 6). All water samples had gross alpha-particle activity less than the EPA MCL of $15 \mathrm{pCi} / \mathrm{L}$, although the maximum measured value of $13.9 \mathrm{pCi} / \mathrm{L}$ is near the MCL (table 6). Values considered "non-detects" are listed with an "R" preceding the value (Senior, 2017; table 13 at back of report). Most gross alpha radioactivity values were less than the method reporting level (MRL) of $3 \mathrm{pCi} / \mathrm{L}$ and, when reported without an " $R$ " qualifier, are considered to be estimated values that have larger uncertainty than those quantified at greater than the MRL. Seventeen of 78 samples (about 20 percent) had gross alpha radioactivity (72-hour count) greater than or equal to $3 \mathrm{pCi} / \mathrm{L}$. Gross alpha-particle activity in the 30-day count was similar to or slightly less than the activity in the 72-hour count (fig. 17A).

The gross beta-particle activity (72-hour count) ranged from non-detect (less than the detection limit) to $14 \mathrm{pCi} / \mathrm{L}$, and the median activity was $1.6 \mathrm{pCi} / \mathrm{L}$ (table 6 ). As with gross alpha-particle activity, uncertainty is relatively greater for values less than the MRL of $3 \mathrm{pCi} / \mathrm{L}$. Sixteen of 78 samples (20 percent) had gross beta-particle activity (72-hour count) greater than or equal to $3 \mathrm{pCi} / \mathrm{L}$. Gross beta-particle activity in the 30-day count was similar to, or either slightly higher or slightly lower than, the activity in the 72-hour count in most of the samples (fig. 17A). Gross alpha- and gross betaparticle activities generally were directly related but were more strongly related at 72 hours than at 30 days (fig. 17B). Relative changes in gross beta-particle activities differed from relative changes in gross alpha-particle activities when counts at 72 hours were compared to counts at 30 days, indicating that the relative abundance and composition of gross beta- and gross alpha-emitting radionuclides differ among the samples.

\section{Radium-226}

Radium-226 has a half-life of 1,620 years and emits alpha particles during radioactive decay. Samples from 12 wells with the highest gross alpha-particle activities were analyzed for radium-226.. The radium-226 activities ranged from 0.09 to $1.84 \mathrm{pCi} / \mathrm{L}$, with a median of $0.24 \mathrm{pCi} / \mathrm{L}$, less than the EPA MCL of $5 \mathrm{pCi} / \mathrm{L}$ on the basis of radium-226 alone in any sample. Radium-228 may also be present but was not included in the 2015 analyses. Radium-226 activities were related to gross alpha-particle activity at 30 days (fig. 18A) but not to gross alpha-particle activity at 72 hours, indicating that gross alpha-particle activity at 30 days appears to be a stronger indicator of radium-226 activity than gross alpha-particle activity at 72 hours in Pike County groundwater. Radium-226 likely contributes relatively more to the gross alpha-particle activity at 30 days than at 72 hours if other radionuclides with shorter half-lives are present. Radium-226 activities were related to specific conductance, with higher activities in samples with higher specific conductance (fig. 18B). 
Table 6. Minimum, median, and maximum concentrations of selected radioactive constituents determined in the laboratory for groundwater samples collected from 79 wells in

Pike County, Pennsylvania, 2015.

[pCi/L, picocuries per liter; mrem/yr, millirem per year; $\mu \mathrm{g} / \mathrm{L}$, micrograms per liter; <, less than; --, no data or not applicable; MCL, maximum contaminant level; HA, Health Advisory; SMCL, secondary maximum level; nd, non-detect]

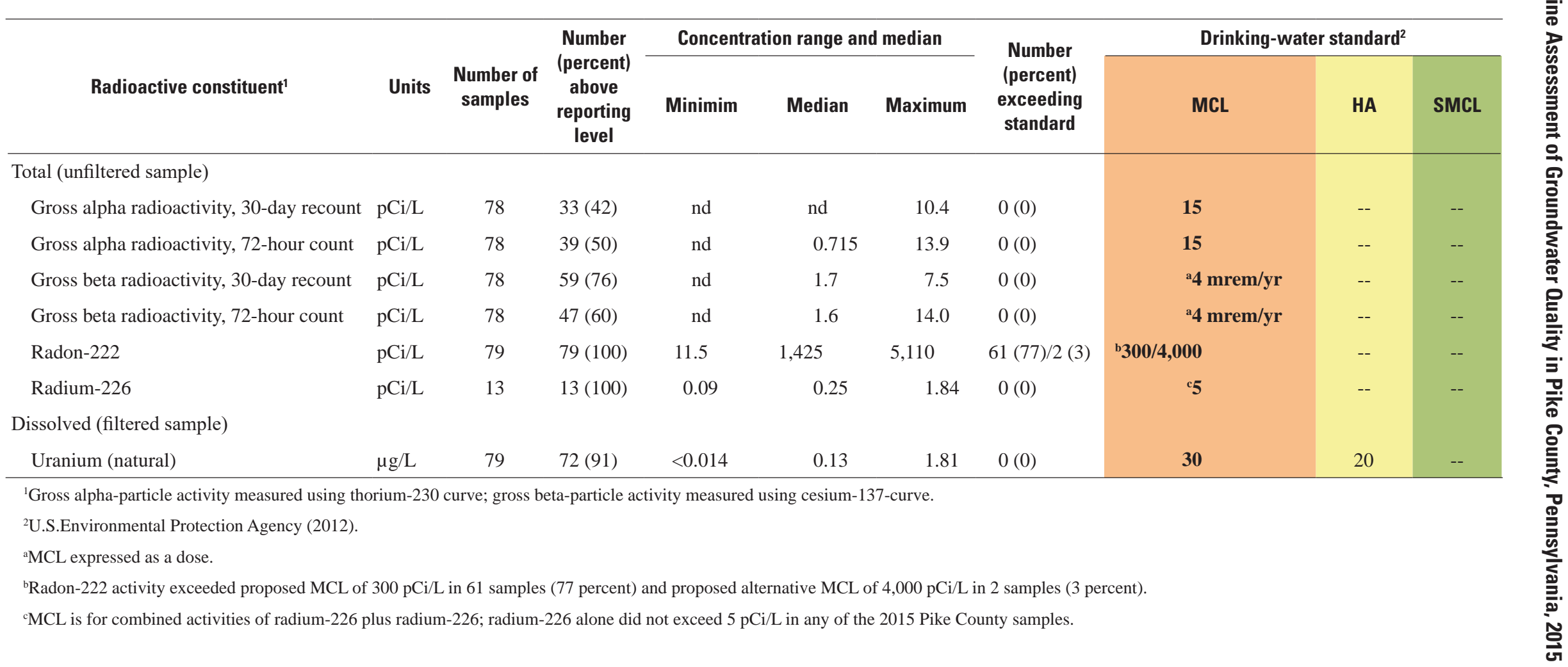



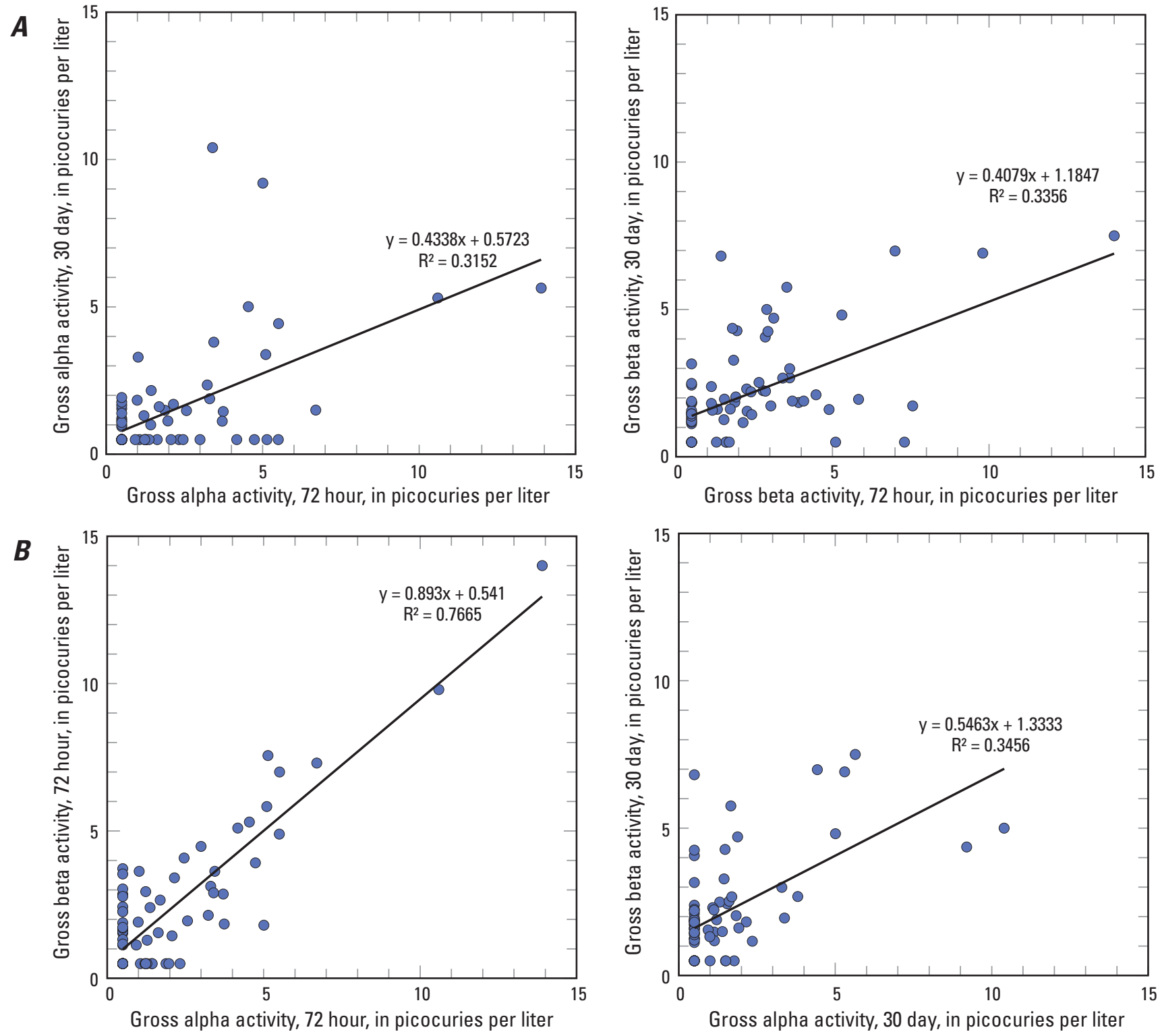

Figure 17. Relation between $A, 72$-hour and 30-day gross alpha- and gross beta-particle activities, and $B$, gross alpha-particle activity and gross beta-particle activity at 72 hours and 30 days in groundwater samples collected from 78 wells in Pike County, Pennsylvania, 2015. 

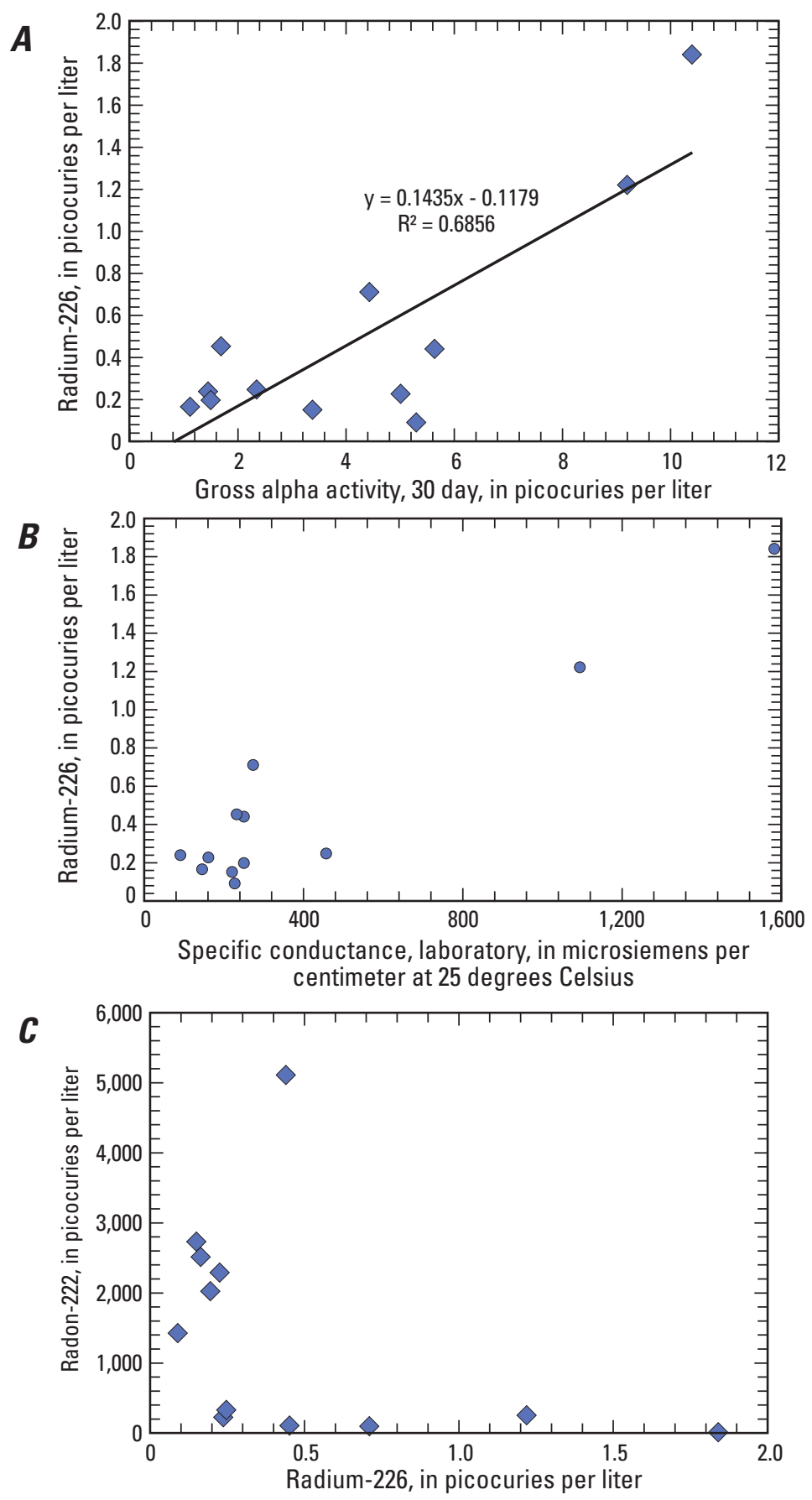

Figure 18. Relation of radium-226 activity to $A$, gross alpha-particle activity at 30 days, $B$, laboratory specific conductance, and $C$, radon-222 activity in groundwater samples collected from 12 wells in Pike County, Pennsylvania, 2015. 


\section{Radon-222}

Radon-222, a short-lived (half-life of 3.8 days) daughter product of radium-226 decay, is a colorless, odorless, chemically inert, alpha-particle-emitting gas that is soluble in water. The EPA has set a health-based standard for radon-222 in air $(4 \mathrm{pCi} / \mathrm{L})$ but currently does not regulate radon-222 in drinking water. However, under the framework specified by the 1999 Notice for the Proposed Radon in Drinking Water Rule (Federal Register, 1999), the EPA proposed an alternative maximum contaminant level (AMCL) of $4,000 \mathrm{pCi} / \mathrm{L}$ for radon-222 for community water systems that use groundwater for all or some of the supply in states with an enhanced indoor radon program. For states without an enhanced indoor air program, EPA proposed an MCL of $300 \mathrm{pCi} / \mathrm{L}$ for radon-222. Activities of radon-222 in water samples from the 79 wells ranged from 11.5 to $5,110 \mathrm{pCi} / \mathrm{L}$, with a median activity of $1,425 \mathrm{pCi} / \mathrm{L}$ (table 6 ). Water samples from 61 of the 79 wells (77 percent) exceeded the proposed EPA MCL of $300 \mathrm{pCi} / \mathrm{L}$, and samples from 2 of the 79 wells (3 percent) exceeded the proposed EPA AMCL of 4,000 pCi/L for radon222. Radon-222 activities in water samples from the 79 wells did not appear to be directly related to other measured sources of radioactivity (gross alpha- or gross beta-particle radioactivity, uranium, or radium-226). The limited available data (samples from 13 wells) indicate an inverse relation between radon-222 and its parent radium-226; relatively higher radon-222 activities were associated with relatively lower radium-226 activities (fig. 18C). The spatial distribution of radon-222 activities (concentrations) in Pike County groundwater is shown in figure 19.

\section{Uranium}

The concentration of uranium ranged from less than 0.014 to $1.81 \mu \mathrm{g} / \mathrm{L}$ with a median concentration of $0.13 \mu \mathrm{g} / \mathrm{L}$ (table 6). No water samples exceeded the EPA $\mathrm{MCL}$ of $30 \mu \mathrm{g} / \mathrm{L}$ or the HA of $20 \mu \mathrm{g} / \mathrm{L}$ for uranium. Uranium concentrations were only weakly related to gross alpha- and gross beta-particle activity measured at either 30 days or 72 hours, with a slightly stronger relation was observed for 30 -day gross alpha-particle activity $\left(\mathrm{r}^{2}=0.19\right)$ than for 30-day gross beta-particle activity $\left(\mathrm{r}^{2}=0.11\right)$. Thus, gross alphaparticle activity may be limited in strength, but more useful than gross beta-particle activity, to serve as a screen for potentially elevated concentrations of uranium in Pike County groundwater.

Although measured uranium concentrations in groundwater samples did not exceed drinking-water standards in Pike County, at least one sample had a concentration $(16.4 \mu \mathrm{g} / \mathrm{L})$ near the HA level of $20 \mu \mathrm{g} / \mathrm{L}$ in neighboring Wayne County, where uranium concentrations in groundwater generally are greater than in Pike County (Senior and others, 2016). Uranium has been reported to be present at enriched levels at some localities in the Catskill Formation in Pennsylvania (McCauley, 1961; Pirc and Rose, 1981), including central Wayne County (Kleimic, 1962). Where uranium is not present in enriched concentrations in aquifer materials, elevated concentrations in groundwater are less likely. Uranium ion solubility is affected by $\mathrm{pH}$, alkalinity, and redox conditions; uranium ions in +6 oxidation state $\left(\mathrm{UO}_{2}{ }^{+2}\right.$ under oxidizing conditions) can form soluble complexes with bicarbonate and carbonate, which commonly are abundant and can thus contribute to increased uranium mobility at neutral to alkaline $\mathrm{pH}$. The concentrations of uranium in groundwater in Pike County tended to be highest at or near neutral pH (fig. 20), which is similar to findings in neighboring Wayne County (Senior and others, 2016). 


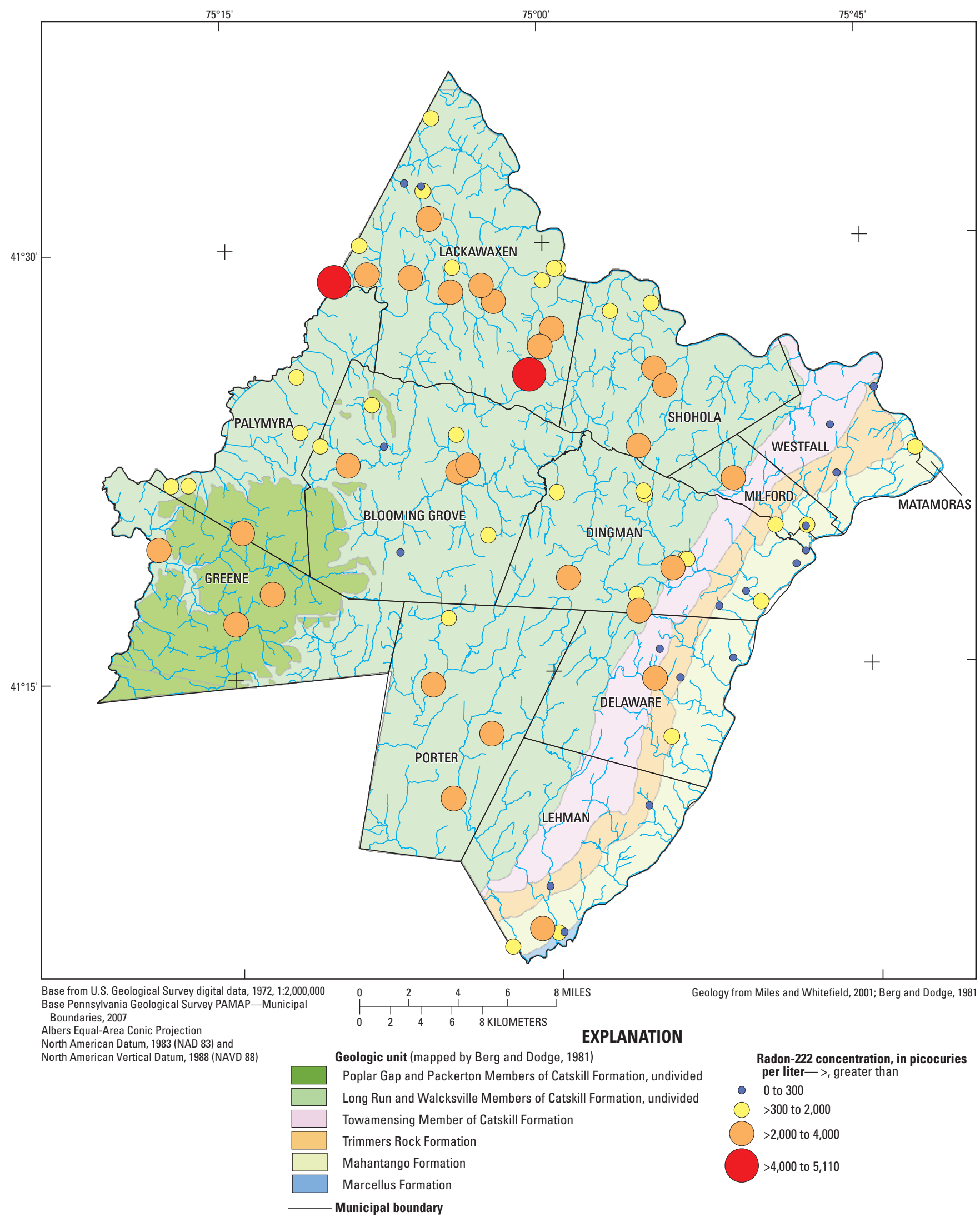

Figure 19. Geologic units and spatial distribution of radon-222 concentrations in groundwater samples collected from 79 wells in Pike County, Pennsylvania, 2015. 


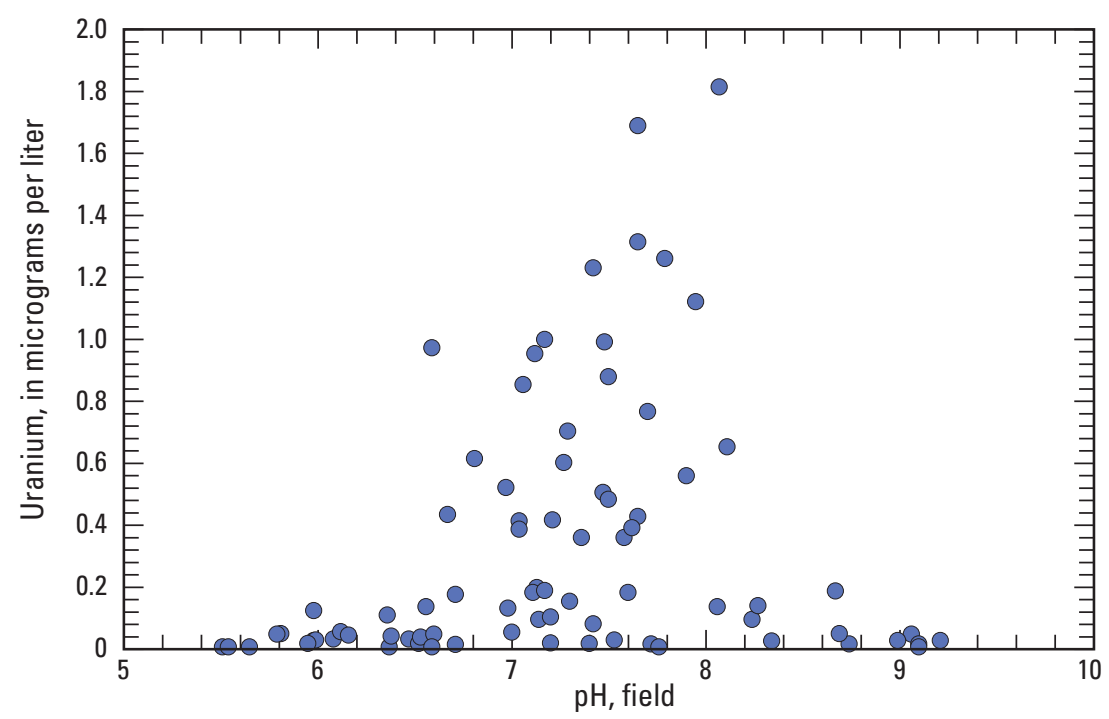

Figure 20. Relation of concentrations of dissolved uranium to field measured $\mathrm{pH}$ in groundwater samples collected from 79 wells in Pike County, Pennsylvania, 2015.

\section{Total Organic Carbon and Man-Made Organic Compounds}

Samples from all 79 wells were analyzed for total organic carbon to determine carbon concentrations in groundwater from both natural and man-made sources, if present. Natural organic carbon may be comprised of organic acids and other products formed by microbial decay of organic matter. No groundwater sample had detectable concentrations of total organic carbon greater than the reporting level of $0.7 \mathrm{mg} / \mathrm{L}$ (table 4).

Samples from 20 of 79 wells were analyzed for 68 man-made (synthetic) organic compounds (table 7). Three VOCs were detected in low concentrations in water samples from only two wells (PI-556, PI-617). The sources of, and explanation for, the presence of these VOCs in well-water samples in Pike County are unknown, although disposal of VOCs in septic or other on-lot systems may be a potential pathway for these compounds to enter groundwater. No detected VOC was present in concentrations that exceeded drinking-water MCLs. Toluene was measured at a concentration of $1.98 \mu \mathrm{g} / \mathrm{L}$ in the water sample from well PI-617. Toluene commonly is used as a solvent, such as in paint thinner. Trichlorofluoromethane, a chlorofluorocarbon (CFC), and styrene were measured at concentrations of $4.98 \mu \mathrm{g} / \mathrm{L}$ and $0.54 \mu \mathrm{g} / \mathrm{L}$, respectively, in the water sample from well PI-556, which when sampled previously in 2007 was also found to contain trichlorofluoromethane at $39 \mu \mathrm{g} / \mathrm{L}$ but no detectable styrene. Trichlorofluoromethane, also known as Freon-11 or CFC-11, was used as a refrigerant, degreaser, and solvent and as a component in aerosol products, fire extinguishing foam, and other applications from the 1950s until 1996 when CFC manufacture was banned in the United States because of CFC contribution to depletion of ozone in the atmosphere. Styrene can occur naturally at trace to low levels in some plants and foods (American sweetgum, cinnamon, beef, coffee beans, and strawberries, for example) but is also a man-made compound used in manufacture of polystyrene and other plastics.

The laboratory reporting level for VOCs was $0.5 \mu \mathrm{g} / \mathrm{L}$, which is lower than drinking-water MCLs established for most VOCs included in the analysis (table 7). However, drinking-water MCLs for two compounds-1,2-dibromo3-chloropropane (DBCP) and 1,2-dibromoethane (EDB)are less than the method reporting level, as performed by the laboratory, so for these compounds, a more sensitive method is needed to determine whether they are present in concentrations greater than the MCLs (although below the reporting level of $0.5 \mu \mathrm{g} / \mathrm{L}$ ). Therefore, with the exception of these two compounds, if VOCs are present in groundwater at concentrations less than the reporting level of $0.5 \mu \mathrm{g} / \mathrm{L}$, those concentrations would not exceed an established drinking-water standard. 
Table 7. Reporting levels and drinking-water standards for man-made organic compounds analyzed in groundwater samples collected from 20 wells in Pike County, Pennsylvania, 2015.

[USGS, U.S. Geological Survey; $\mu \mathrm{g} / \mathrm{L}$, micrograms per liter; \% Rec., percent recovery; MCL, maximum contaminant level; HA, health advisory; HBSL, healthbased screening level; --, no data or not available]

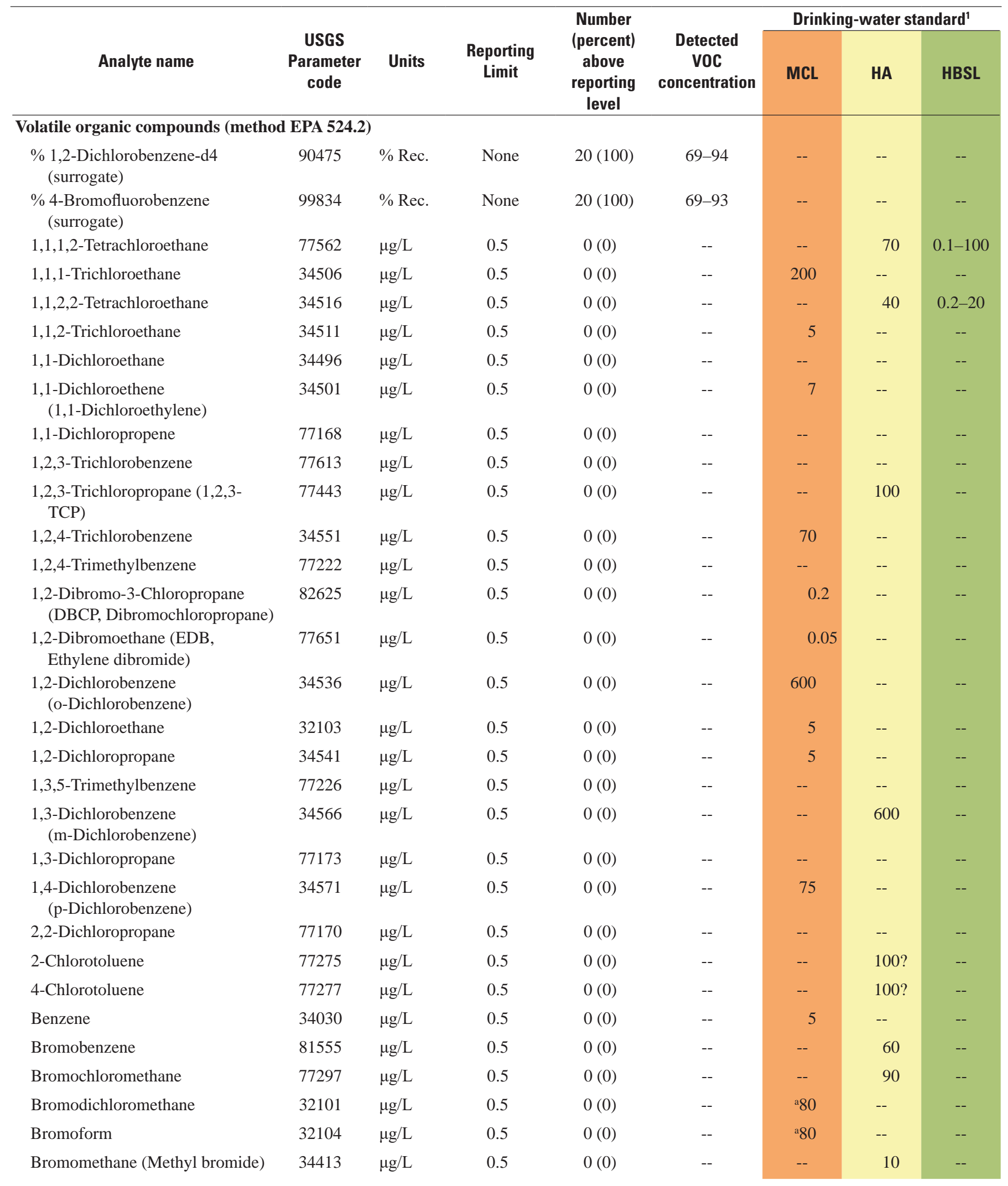


Table 7. Reporting levels and drinking-water standards for man-made organic compounds analyzed in groundwater samples collected from 20 wells in Pike County, Pennsylvania, 2015. - Continued

[USGS, U.S. Geological Survey; $\mu \mathrm{g} / \mathrm{L}$, micrograms per liter; \% Rec., percent recovery; MCL, maximum contaminant level; HA, health advisory; HBSL, healthbased screening level; --, no data or not available]

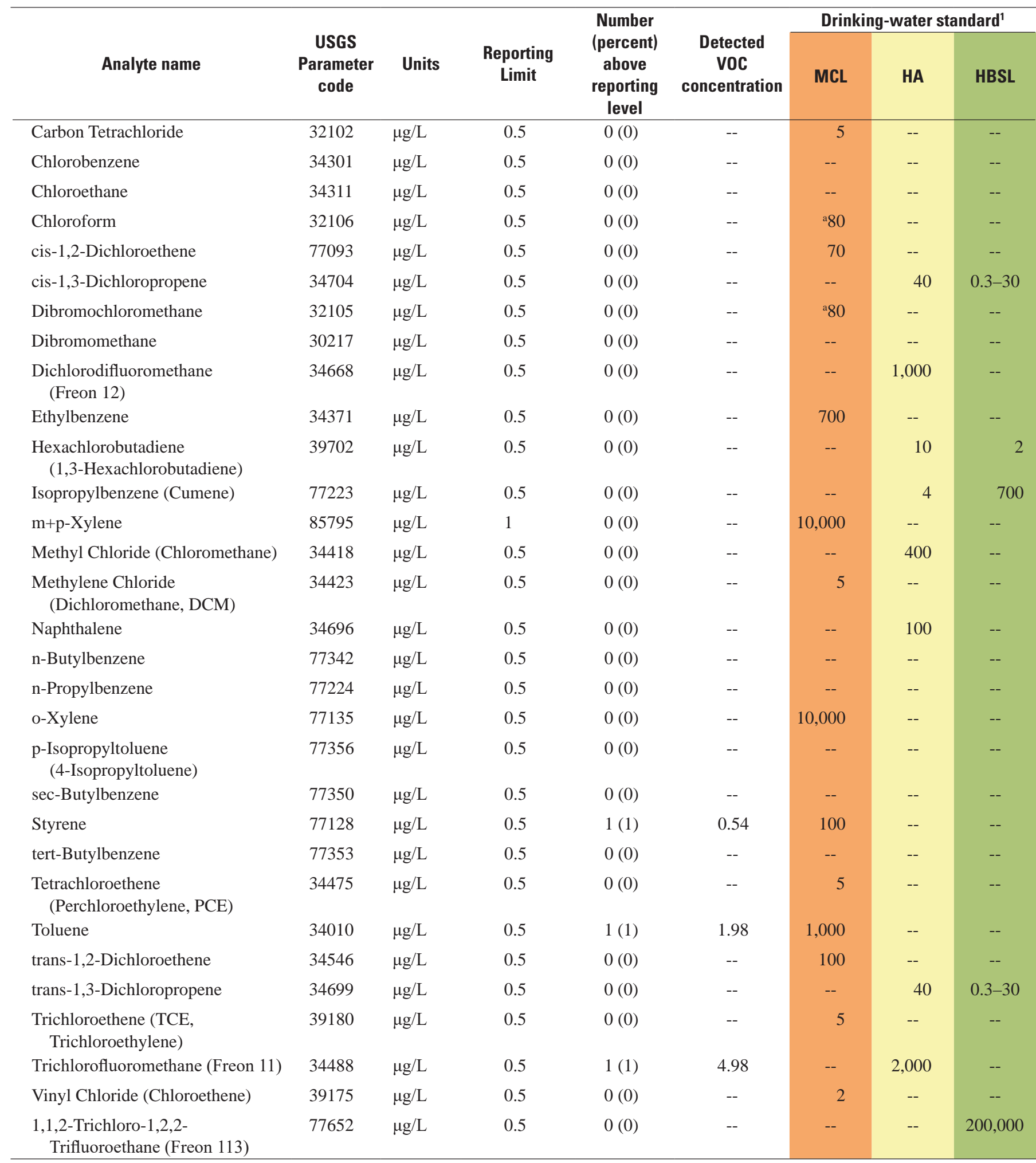

${ }^{1}$ U.S.Environmental Protection Agency (2012) for MCL and HA values and Toccalino (2007) for HBSLs that differ from MCL and HA values.

${ }^{a} \mathrm{MCL}$ for total trihalomethane concentrations is $80 \mu \mathrm{g} / \mathrm{L}$; trihalomethanes include bromodichloromethane, bromoform, dibromochloromethane, and chloroform. 


\section{Methane and Other Dissolved Hydrocarbon Gases}

Methane is a colorless, odorless, combustible gas that may occur naturally in groundwater. Methane may be derived from several sources, including but not limited to surficial sediments, organic-rich layers within rocks, and microbial activity involved in the breakdown of organic matter. Methane can be broadly classified as thermogenic or microbial (biogenic) in origin (Schoell, 1980). Thermogenic methane is formed from breakdown of organic material in sediments under high-temperature conditions caused by deep burial. In contrast, microbial methane is formed in shallow subsurface or near surface environments by microbial (bacterial) reduction of carbon dioxide or fermentation of organic debris (Breen and others, 2007). The methane present in the Marcellus Shale and Utica Shale being developed for natural gas in Pennsylvania is of thermogenic origin (Baldassare and others, 2014; Kirschbaum and others, 2012). Sources of methane may be inferred from the isotopic composition of the methane itself and from the presence of other gases on the basis of numerous studies described in Breen and others (2007).

Although the presence of methane in well water is not known to pose a health risk through ingestion, methane at sufficient concentrations in well water may increase the hazard of explosion when vented into a confined space (Eltschlager and others, 2001). Recommended action levels for methane concentrations in well water listed in table 8 are guidelines, but site-specific conditions need to be considered when evaluating potential risks (Eltschlager and others, 2001).
Water samples from 79 wells were analyzed for the hydrocarbon gases methane, ethane, and propane by a contract laboratory (Seewald Laboratories, Inc.) which used method PA-DEP 3686 for samples from 74 wells and subcontracted analyses for samples from 5 wells to a second laboratory that used a method (RSK-175) with lower reporting limits for these gases. In these analyses of water from 79 wells, only methane was detected. Methane was measured in concentrations greater than the laboratory reporting level of $0.010 \mathrm{mg} / \mathrm{L}$ for Seewald Laboratories, Inc. using method PA-DEP 3686 in samples from 19 of 79 wells (24 percent), ranging from less than 0.01 to $2.5 \mathrm{mg} / \mathrm{L}$, including results from the second laboratory (table 8). Methane was measured in concentrations greater than the second laboratory reporting level of $0.002 \mathrm{mg} / \mathrm{L}$ $(2 \mu \mathrm{g} / \mathrm{L})$ using method RSK-175 in 3 of 5 samples, ranging from 0.002 to $0.380 \mathrm{mg} / \mathrm{L}$ ( 2 to $380 \mu \mathrm{g} / \mathrm{L}$ ) with only 1 value greater than $0.010 \mathrm{mg} / \mathrm{L}$ (table 13; Senior, 2017). No sample had dissolved methane concentrations greater than the Pennsylvania action level of $7 \mathrm{mg} / \mathrm{L}$ set to minimize hazards related to explosion (Commonwealth of Pennsylvania, 2014). Ethane and propane, with laboratory reporting levels of 0.01 and $0.02 \mathrm{mg} / \mathrm{L}$, respectively, were not detected by the contract laboratory (Seewald Laboratories, Inc.) in any of the samples from the 79 wells.

The spatial distribution of relatively elevated methane concentrations (greater than $0.5 \mathrm{mg} / \mathrm{L}$ as determined by Seewald Laboratories, Inc.) in the 2015 Pike County groundwater samples is shown in figure 21, which also shows that relatively elevated methane tends to occur in samples with relatively elevated lithium concentrations. Methane

Table 8. Minimum, median, and maximum concentrations of methane, ethane, and propane determined in the laboratory using method PA-DEP 3686 for groundwater samples collected from 79 wells in Pike County, Pennsylvania, 2015, and recommended action levels for methane in well water.

[mg/L, milligrams per liter; <, less than; >, greater than; --, no data or not applicable; PA-DEP, Pennsylvania Department of Environmental Protection]

\begin{tabular}{|c|c|c|c|c|c|c|c|c|c|}
\hline & \multirow[b]{2}{*}{ Units } & \multirow{2}{*}{$\begin{array}{c}\text { Number } \\
\text { (percent) } \\
\text { above } \\
\text { reporting } \\
\text { level }\end{array}$} & \multicolumn{3}{|c|}{ Concentration range and median } & \multirow[b]{2}{*}{$\begin{array}{l}\text { Number } \\
\text { (percent) } \\
\text { exceeding } \\
\text { standard }\end{array}$} & \multicolumn{3}{|c|}{$\begin{array}{l}\text { Well-water action level' } \\
\text { (mg/L) }\end{array}$} \\
\hline & & & Minimim & Median & Maximum & & Immediate & $\begin{array}{l}\text { Warning - } \\
\text { investigate }\end{array}$ & $\begin{array}{c}\text { No } \\
\text { immediate } \\
\text { action - } \\
\text { periodic } \\
\text { monitoring }\end{array}$ \\
\hline Methane & $\mathrm{mg} / \mathrm{L}$ & a19 (24) & $<0.01,<0.0015$ & $<0.01$ & 2.5 & $0(0)$ & $>28$ & $>10$ but $<28$ & $<7$ \\
\hline Ethane & $\mathrm{mg} / \mathrm{L}$ & $0(0)$ & $<0.01,<0.0033$ & $<0.01$ & $<0.01$ & $0(0)$ & -- & -- & -- \\
\hline Propane & $\mathrm{mg} / \mathrm{L}$ & $0(0)$ & $<0.02,<0.0032$ & $<0.02$ & $<0.02$ & $0(0)$ & -- & -- & -- \\
\hline
\end{tabular}

${ }^{1}$ Recommended action level to minimize the hazard of explosion, with lowest action level of $10 \mathrm{mg} / \mathrm{L}$ (Eltschlager and others, 2001); alternate lowest action level for methane in well water is $7 \mathrm{mg} / \mathrm{L}$ (Commonwealth of Pennsylvania, 2014).

${ }^{2}$ Alternate RSK-175 method has lower reporting levels than PA-DEP 3686 method as listed in column for minimum concentrations.

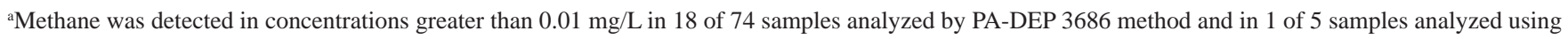
RSK-175 method, in addition to being measured in a concentration of $0.003 \mathrm{mg} / \mathrm{L}$ in another of the 5 water samples analyzed by RSK-175 method. 


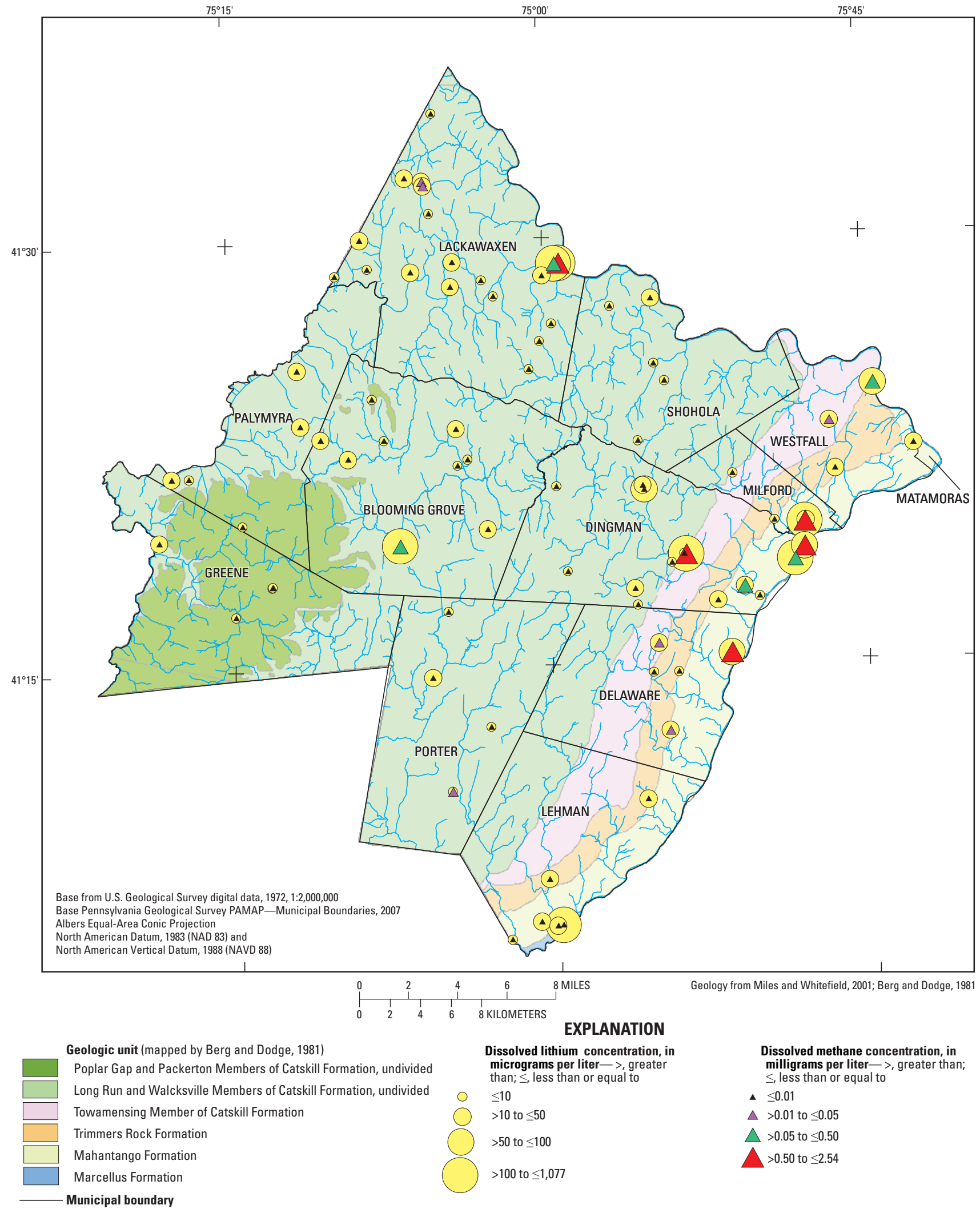

Figure 21. Map showing geologic units and spatial distribution of methane and lithium concentrations in water samples collected from 79 wells in Pike County, Pennsylvania, 2015. Methane concentrations shown were determined by Seewald Laboratories, Inc., for all 79 samples. [Methane concentrations determined by Seewald Laboratories, Inc., commonly were lower than (by as much as one-half) methane concentrations determined by Isotech Laboratories, Inc., in 18 replicates samples as shown in table 9.] 
concentrations (as determined by Seewald Laboratories, Inc.) generally were greater than $0.1 \mathrm{mg} / \mathrm{L}$ in groundwater samples that had lithium concentrations greater than $100 \mu \mathrm{g} / \mathrm{L}$ (fig. 22). Only one sample with a lithium concentration greater than $100 \mu \mathrm{g} / \mathrm{L}$ had a methane concentration less than $0.1 \mathrm{mg} / \mathrm{L}$; this sample (from well PI-648) had a dissolved lithium concentration of $115 \mu \mathrm{g} / \mathrm{L}$ and a dissolved methane concentration of less than $0.01 \mathrm{mg} / \mathrm{L}(0.002 \mathrm{mg} / \mathrm{L}$ as determined by Isotech Laboratories, Inc.). However, the methane gas concentration in the sample from this particular well (PI-648) could have been affected (lowered) by aeration during sampling because dissolved oxygen concentrations increased and bubbles were reported in purge water while the well was being pumped prior to sampling.

Eighteen inter-laboratory replicate samples from 17 wells (well PI-524 sampled twice) sampled in 2015 also were sent to Isotech Laboratories, Inc., for isotopic characterization of methane; for dissolved gas analysis that included methane, ethane, ethylene, propane, propylene, iso-butane, and N-butane; and for analysis for the hydrocarbon liquids isopentane, N-pentane, and hexane (table 14 at back of report; Senior, 2017). Replicate samples from 5 of 17 wells sent to Isotech Laboratories, Inc., for dissolved gas analysis had methane concentrations near or greater than $1 \mathrm{mg} / \mathrm{L}$, higher than but consistent with, the relatively elevated concentrations $(>0.5 \mathrm{mg} / \mathrm{L}$ ) determined by the other contract laboratory (Seewald Laboratories, Inc.) using method PA-DEP 3686. However, methane concentrations determined by Isotech Laboratories, Inc., generally were greater (commonly about 2 times greater and as much as 2.7 times greater) than those determined by Seewald Laboratories, Inc., using method PA-DEP 3686 (fig. 23, table 9). Differences in results between laboratories may be related to analytical techniques, calibrations, sample-collection methods, or sample containers.

Of the hydrocarbon gases analyzed by Isotech Laboratories, Inc., only methane and ethane were detected (table 14, at back of report). Methane concentrations were measured at greater than the reporting level of $0.0003 \mathrm{mg} / \mathrm{L}$ in all samples from the 17 wells; those concentrations ranged from 0.00036 to $5.9 \mathrm{mg} / \mathrm{L}$, with the highest level near the PADEP action level of $7 \mathrm{mg} / \mathrm{L}$ (table 9). Ethane was measured at greater than the reporting level of $0.0002 \mathrm{mg} / \mathrm{L}$ in samples from 6 of 17 wells; concentrations ranged from 0.00041 to $0.0019 \mathrm{mg} / \mathrm{L}$.

\section{Methane Isotopic Composition and Origin of Methane Gas}

The isotopic composition of methane was determined for groundwater samples from 10 wells that had methane concentrations ranging from 0.11 to $5.9 \mathrm{mg} / \mathrm{L}$, as determined by Isotech Laboratories, Inc., (or 0.084 to $4.12 \mathrm{mg} / \mathrm{L}$ as determined by Seewald Laboratories, Inc.) (table 9). The isotopic compositions of methane in Pike County groundwater samples when compared to methane of known origins plotted mostly in the range of compositions for methane gas of microbial origin (formed by carbon dioxide reduction processes). The sample from one well (see PI-622) plotted in the range of methane gas of thermogenic origin, and the

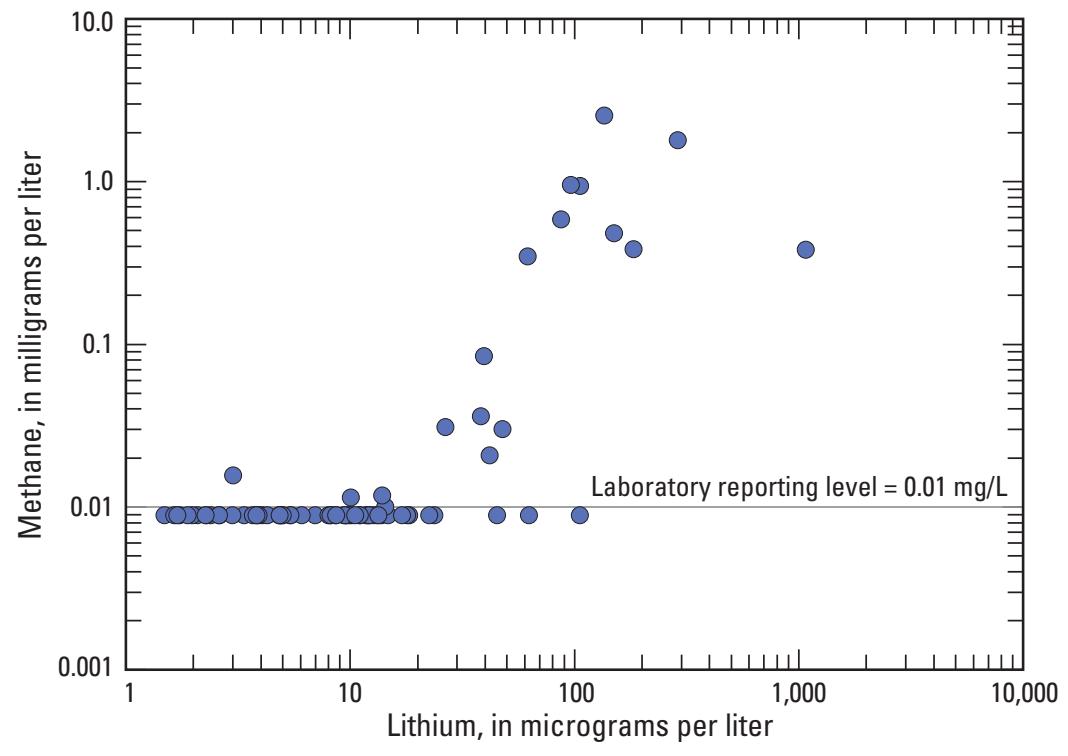

Figure 22. Methane concentrations in relation to lithium concentrations in water samples collected from 79 wells in Pike County, Pennsylvania, 2015. Methane concentrations shown were determined by Seewald Laboratories, Inc., for all 79 samples. [Methane concentrations determined by Seewald Laboratories, Inc., commonly were lower than (by as much as one-half of) methane concentrations determined by Isotech Laboratories, Inc., in 18 replicates samples as shown in table 9.] (mg/L, milligrams per liter) 


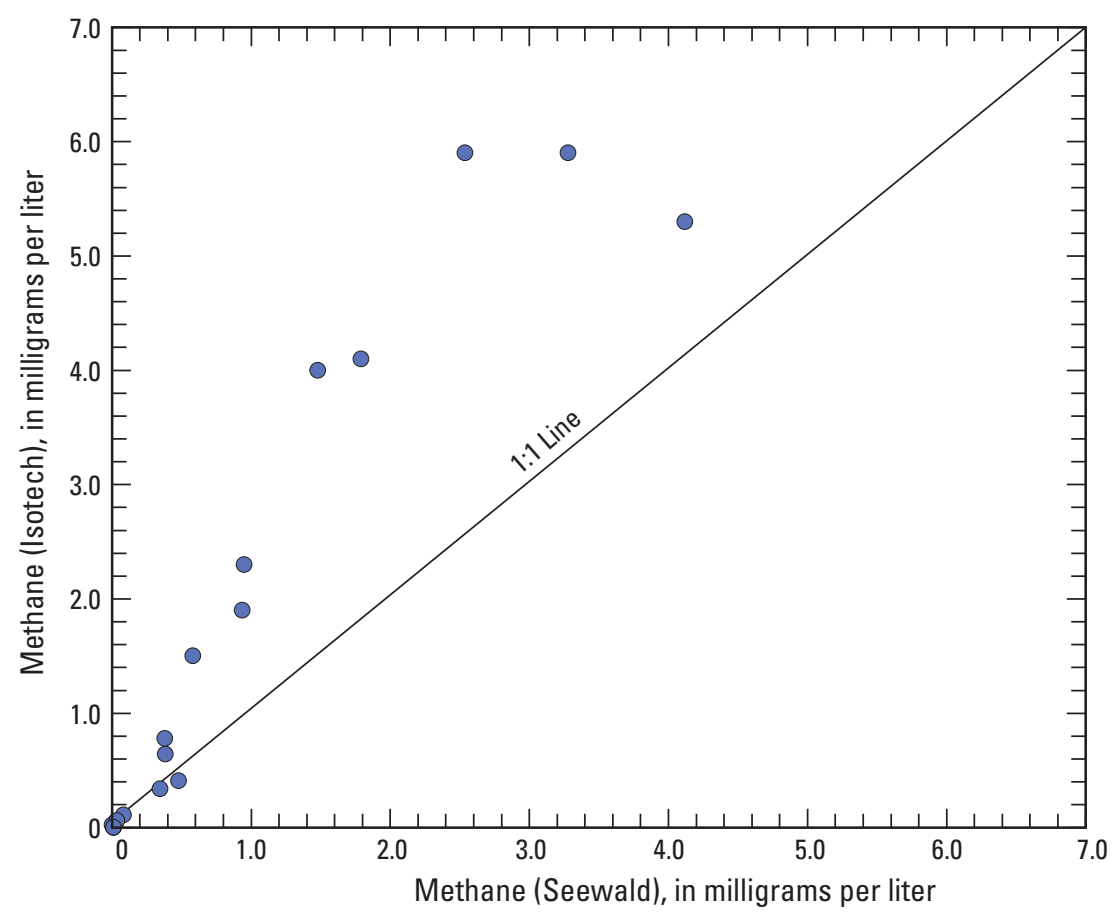

Figure 23. Relation of methane concentrations determined by Isotech Laboratories, Inc., to those determined by Seewald Laboratories, Inc., in groundwater samples collected from 78 wells in Pike County, Pennsylvania, 2015. Methane concentrations determined by Seewald Laboratories, Inc. (Seewald), typically were lower than (by as much as one-half) methane concentrations determined by Isotech Laboratories, Inc., (Isotech) in 18 replicates samples as shown in table 9.

samples from two wells (PI-530 and PI-651) plotted in an undefined field (fig. 24A). Microbial methane formed by carbon dioxide reduction is commonly associated with "drift gas" in glacial deposits. Microbial methane generated in nearsurface environments such as swamps and marshes is formed by a different chemical process (fermentation) involving acetate and has an isotopic composition that has lighter (more negative) $\delta \mathrm{D}_{\mathrm{CH} 4}$ and heavier (less negative) in $\delta^{13} \mathrm{C}_{\mathrm{CH} 4}$ values than the "drift-gas" methane (Coleman, 1995). The isotopic composition of methane from the PI-622 well water sample is in the range reported for methane gas derived from the geologic formations that underlie the study area (although gas samples are from elsewhere in Pennsylvania) (fig. 24A).

The isotopic composition of the methane in the water samples may not be conclusive, without other information, to identify sources of methane in these samples because the measured isotopic composition can result from more than one pathway or process, including gas maturation, oxidation, and (or) mixing of groundwater within the well or aquifer from different water-bearing zones. As gas matures or originates from greater depths, the isotopic composition of methane apparently becomes heavier (less negative), as shown by the composition of Marcellus gas samples in figure 24A (Baldassare and others, 2014). However, shifts in isotopic composition related to gas maturation and oxidation are similar. Oxidation of methane may result in a shift toward heavier composition (toward the upper right corner of figure 24A). Oxidation of microbial (“drift-gas” type) methane may account for the observed isotopic composition of samples (PI-530 and PI-651) that plot in the undefined field. Oxidation of microbial ("marsh" type) methane may result in an isotopic composition that is similar to that of thermogenic methane and could explain the isotopic composition of methane in water from well PI-622. Oxidation of the methane may not be occurring at locations in the aquifer where elevated methane concentrations were measured in the groundwater; all samples with methane concentrations greater than $0.5 \mathrm{mg} / \mathrm{L}$ had very low oxygen concentrations $(\leq 0.5 \mathrm{mg} / \mathrm{L})$. A previous study (Breen and others, 2007) indicates that the values for isotopic composition of dissolved inorganic carbon, $\delta^{13} \mathrm{C}_{\mathrm{DIC}}$, would be near $-25 \%$ if oxidation of methane were an active process in the groundwater. Limited data for $\delta^{13} \mathrm{C}_{\text {DIC }}$ (values ranged from -16 to $-10 \%$ in samples from three wells) from the 2012 Pike County groundwater study (Senior, 2014) do not provide sufficient evidence to definitively identify reactions involving methane. These $\delta^{13} \mathrm{C}_{\text {DIC }}$ values of -16 to $-10 \%$ likely reflect a mixture of isotopic compositions of DIC from various sources (dissolution of carbonate minerals, silicate mineral weathering reactions involving carbonic acid produced by dissolution of biogenic carbon dioxide entrained in recharge through soil zone, or possible oxidation of methane) and could indicate that oxidation of methane is not an active process where methane in groundwater was measured but could have occurred elsewhere in the aquifer. 
Table 9. Concentrations of methane and ethane determined by two laboratories for groundwater samples collected from 17 wells and isotopic composition of methane in 10 of the 17 wells in Pike County, Pennsylvania, 2015.

[Gas concentrations determined by Isotech Laboratories, Inc. (Isotech) and Seewald Labortories, Inc. (Seewald); USGS, U.S. Geological Survey; <, less than; nd, not detected; --, no data or not applicable; C1, methane (one carbon compound); C2, ethane (two carbon compound); C1/C2 ratio, ratio of methane (C1) to ethane (C2) concentration; shaded cells indicate replicate samples; values in italics determined by Seewald Laboratories, Inc.]

\begin{tabular}{|c|c|c|c|c|c|c|c|c|c|c|c|c|c|}
\hline \multirow{3}{*}{$\begin{array}{l}\text { USGS } \\
\text { local } \\
\text { well } \\
\text { number }\end{array}$} & \multirow{3}{*}{$\begin{array}{c}\text { Geologic } \\
\text { unit }\end{array}$} & \multirow{3}{*}{$\begin{array}{l}\text { Sample } \\
\text { date }\end{array}$} & \multirow{3}{*}{$\begin{array}{l}\text { Sample } \\
\text { time }\end{array}$} & \multirow{2}{*}{\multicolumn{3}{|c|}{$\begin{array}{l}\text { Dissolved carbon- } \\
\text { based gases }\end{array}$}} & \multirow{2}{*}{\multicolumn{2}{|c|}{$\begin{array}{c}\text { Methane } \\
\text { Isotopic composition }\end{array}$}} & \multicolumn{4}{|c|}{$\begin{array}{c}\text { Concentrations } \\
\text { (milligrams per liter) }\end{array}$} & \multirow{3}{*}{$\begin{array}{c}\text { Ratio of } \\
\text { Isotech to } \\
\text { Seewald } \\
\text { methane } \\
\text { concen- } \\
\text { tration }\end{array}$} \\
\hline & & & & & & & & & & & See & ald $^{2}$ & \\
\hline & & & & $\begin{array}{c}\text { C1 } \\
\text { (mole } \\
\text { percent) }\end{array}$ & $\begin{array}{c}\text { C2 } \\
\text { (mole } \\
\text { percent) }\end{array}$ & $\begin{array}{l}\mathrm{C} 1 / \mathrm{C} 2 \\
\text { ratio }\end{array}$ & $\begin{array}{c}\delta^{13} \mathbf{C}_{1} \\
\text { (per mil) }\end{array}$ & $\begin{array}{c}\delta D_{1} \\
\text { (per mil) }\end{array}$ & Methane & Ethane & Methane & Ethane & \\
\hline \multicolumn{14}{|c|}{ Water samples analyzed for dissolved gas and methane isotopic composition } \\
\hline PI 556 & 344MNNG & $8 / 6 / 2015$ & $10: 30$ & 0.614 & nd & -- & -48.04 & -- & 0.11 & $<0.0002$ & 0.084 & $<0.01$ & 1.31 \\
\hline PI 530 & $341 \mathrm{TMRK}$ & 8/5/2015 & $13: 30$ & 1.78 & nd & -- & -62.58 & -151.2 & 0.34 & $<0.0002$ & 0.346 & $<0.01$ & 0.98 \\
\hline PI 609 & 341LRBW & 7/8/2015 & $13: 00$ & 2.19 & nd & -- & -59.11 & -162.4 & 0.41 & $<0.0002$ & 0.479 & $<0.01$ & 0.86 \\
\hline PI 650 & 344MNNG & 9/23/2015 & $11: 00$ & 2.99 & 0.0023 & 1,300 & -57.74 & -193.9 & 0.78 & 0.0012 & 0.38 & $<0.01$ & 2.05 \\
\hline PI 651 & 341LRBW & 9/22/2015 & $11: 00$ & 3.23 & nd & -- & -54.41 & -121.7 & 0.64 & $<0.0002$ & 0.382 & $<0.01$ & 1.68 \\
\hline PI 146 & 344MNNG & 8/6/2015 & $14: 00$ & 7.17 & nd & -- & -58.89 & -175.3 & 1.5 & $<0.0002$ & 0.582 & $<0.01$ & 2.58 \\
\hline PI 622 & 344MNNG & 7/14/2015 & $16: 00$ & 7.38 & 0.0013 & 5,677 & -40.99 & -175.0 & 1.9 & 0.00067 & 0.936 & $<0.01$ & 2.03 \\
\hline PI 591 & 344MNNG & 8/5/2015 & $16: 00$ & 8.39 & 0.0007 & 11,986 & -58.97 & -203.2 & 2.3 & 0.00041 & 0.95 & $<0.01$ & 2.42 \\
\hline PI 592 & 341LRBW & 6/24/2015 & $11: 00$ & 16.17 & 0.0012 & 13,475 & -63.25 & -198.0 & 4.1 & 0.00059 & 1.79 & $<0.01$ & 2.29 \\
\hline PI 592 & 341LRBW & 6/24/2015 & 11:01 & 16.46 & 0.0014 & 11,757 & -63.32 & -199.7 & 4.0 & 0.00069 & 1.48 & $<0.05$ & 2.70 \\
\hline PI 524 & 341TMSG & 6/25/2015 & $15: 00$ & 20.18 & 0.0021 & 9,610 & -63.44 & -219.4 & 5.9 & 0.0013 & 2.54 & $<0.1$ & 2.32 \\
\hline PI 524 & 341TMSG & 9/22/2015 & $13: 30$ & 20.21 & 0.0029 & 6,969 & -63.28 & -221.2 & 5.3 & 0.0016 & 4.12 & $<0.01$ & 1.29 \\
\hline PI 524 & 341TMSG & 9/22/2015 & 13:31 & 21.89 & 0.0035 & 6,254 & -63.12 & -221.6 & 5.9 & 0.0019 & 3.28 & $<0.01$ & 1.80 \\
\hline \multicolumn{14}{|c|}{ Water samples analyzed for dissolved gas concentrations only } \\
\hline PI 642 & 344MNNG & 9/22/2015 & $14: 00$ & 0.0020 & nd & -- & -- & -- & 0.00036 & $<0.0002$ & $<0.01$ & $<0.01$ & -- \\
\hline PI 604 & 341TMSG & 9/21/2015 & $15: 00$ & 0.0052 & nd & -- & -- & -- & 0.00095 & $<0.0002$ & $<0.01$ & $<0.01$ & -- \\
\hline PI 625 & 341LRBW & 7/15/2015 & $10: 00$ & 0.0075 & nd & -- & -- & -- & 0.0013 & $<0.0002$ & $<0.01$ & $<0.01$ & -- \\
\hline PI 648 & 344MRCL & 9/24/2015 & $13: 00$ & 0.0102 & nd & -- & -- & -- & 0.0022 & $<0.0002$ & $<0.01$ & $<0.01$ & -- \\
\hline PI 647 & 341TMRK & 9/23/2015 & $15: 00$ & 0.125 & nd & -- & -- & -- & 0.023 & $<0.0002$ & 0.002 & $<0.01$ & 11.50 \\
\hline PI 647 & 341TMRK & $9 / 23 / 2015$ & $15: 01$ & 0.133 & nd & -- & -- & -- & 0.023 & $<0.0002$ & -- & -- & -- \\
\hline PI 641 & 341LRBW & 9/22/2015 & $10: 30$ & 0.287 & nd & -- & -- & -- & 0.055 & $<0.0002$ & 0.03 & $<0.01$ & 1.83 \\
\hline PI 653 & 341TMSG & 9/24/2015 & $11: 30$ & 0.317 & nd & -- & -- & -- & 0.058 & $<0.0002$ & 0.036 & $<0.01$ & 1.61 \\
\hline
\end{tabular}

${ }^{1}$ Isotech gas analytical results differentiated from Seewald results by 5 minute offset in time in USGS NWIS database.

${ }^{2}$ Gas concentrations determined using method PA-DEP 3686. 


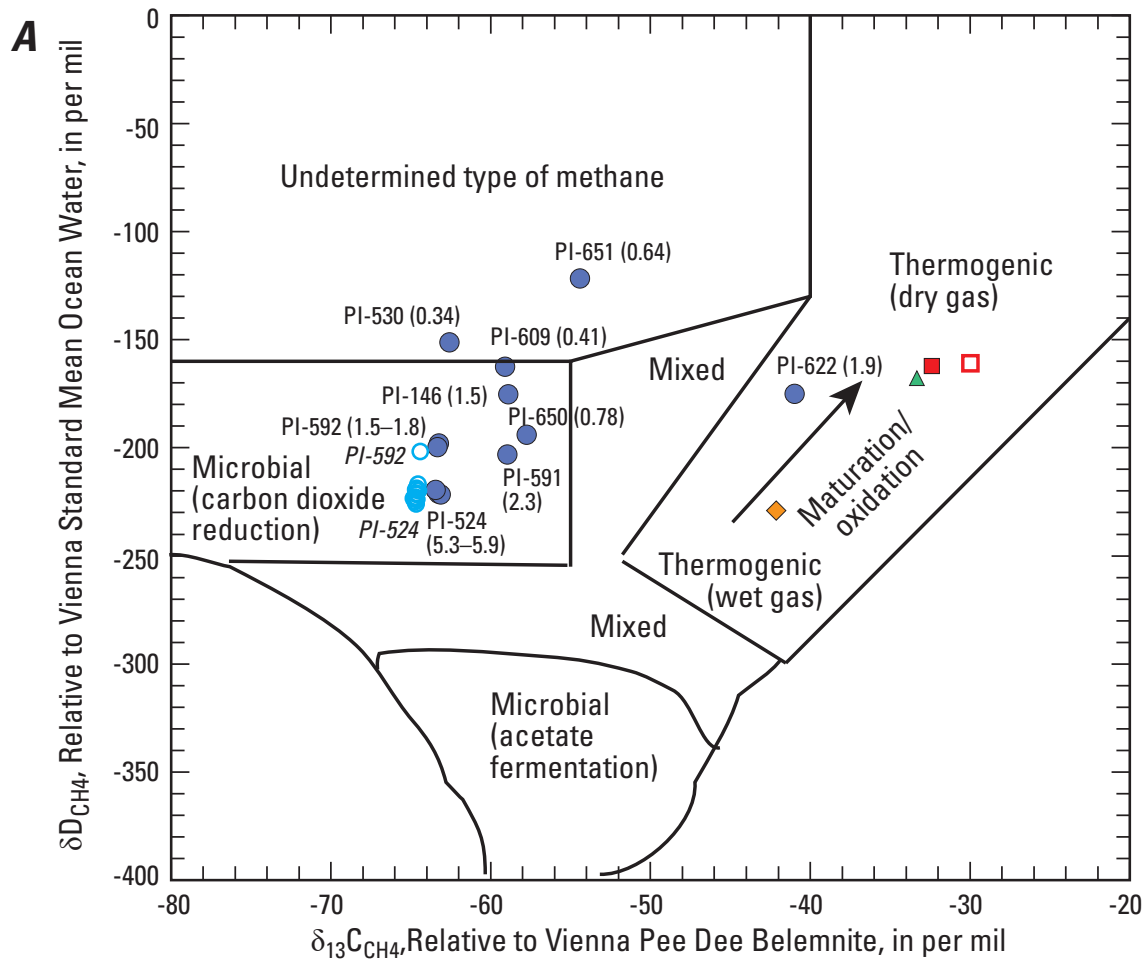

\section{EXPLANATION}

Isotopic composition of methane gas in groundwater in Pike County, identified by U.S. Geological Survey local well number, (2015 concentration of methane, in $\mathrm{mg} / \mathrm{L}$ ), and year of sampling

$$
\begin{aligned}
& \text { PI-622 (1.9) } 2015 \\
& \stackrel{P I-524}{\circ} 2012-13
\end{aligned}
$$

Mean isotopic composition of methane gas from mud-gas logging of shale-gas wells in Pennsylvania (Baldassare and others, 2014)

$\diamond$ Catskill/Lockhaven Formation

$\triangle$ Hamilton Group

Marcellus Formation

Methane gas composition, Susquehanna County Reese and others, 2014, fig. 30, p. 38

$\square$ Marcellus Formation

Compositional shift relates to gas maturation/oxidation<smiles>C1CCC2CCCC2C1</smiles>

Isotopic composition of carbon in methane gas and methane/ethane $(\mathrm{C} 1 / \mathrm{C} 2)$ ratio

- Pike County groundwater, 2015

O Pike County groundwater, 2012

$\square$ Marcellus Formation methane gas, Susquehanna County (Reese and others, 2014, fig. 30, p. 38)

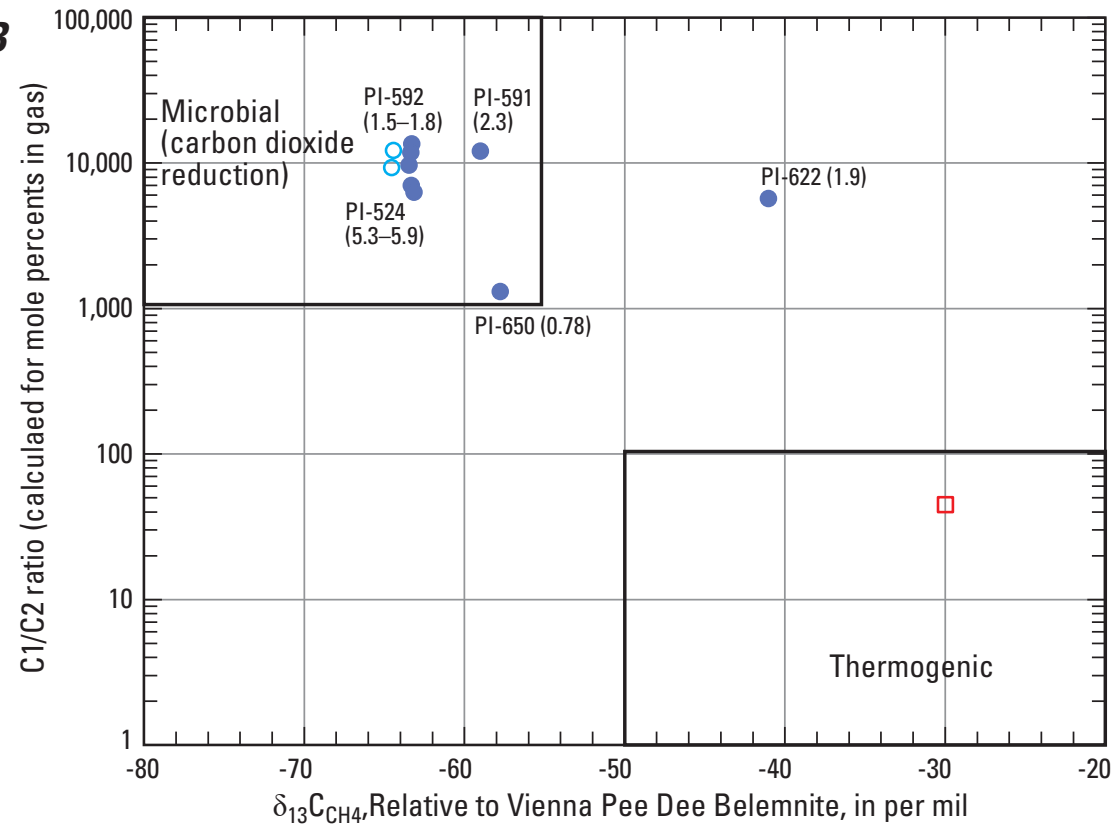

Figure 24. A, Isotopic composition of methane in groundwater samples collected from 9 wells in Pike County, Pennsylvania, 2012-15, and in mud-gas logging samples collected from various geologic formations during drilling of gas wells in Marcellus Shale in Pennsylvania, and $B, C 1 / C 2$ ratios in relation to carbon-isotopic composition for methane in the same samples. Boundaries of gas types from Reese and others (fig. 30, p. 38, 2014) and mud-gas logging data from Baldassare and others (2014). $\left(\partial^{13} \mathrm{C}_{\mathrm{CH} 4^{\prime}}\right.$ isotopic composition of carbon in methane; $\partial \mathrm{D}_{\mathrm{CH}}$, isotopic composition of hydrogen in methane; $\mathrm{C} 1 / \mathrm{C} 2$ ratio of methane to ethane) 
The isotopic composition of methane in the 2015 Pike County groundwater samples appeared to differ in relation to methane concentration (fig. 24A). Samples with relatively higher methane concentrations tended to have a lighter (more negative) isotopic composition for both $\delta \mathrm{D}$ and $\delta^{13} \mathrm{C}$ than samples with comparatively lower concentrations (figs. 24A; $25 A, B$ ). These relations indicate that processes, such as oxidation, may reduce the concentrations of methane and result in methane that has an isotopic composition relatively more enriched in heavier (less negative) isotopes in some water samples.

Microbial methane may be differentiated from thermogenic methane by evaluating the ratio of methane (C1) to ethane (C2) and higher chain carbon compounds. The ratio of methane to higher chain carbon compounds (commonly denoted as $\mathrm{C} 1 / \mathrm{C} 2$ for ratio of methane to ethane or $\mathrm{C} 1 / \mathrm{C} 2+$ for ratio of methane to sum of all higher chain carbon compounds) has been used to identify the origins of methane; the ratio also is a measure of gas "wetness," with larger amounts of $\mathrm{C} 2+$ compounds in wetter gas. Methane accompanied by low concentrations of ethane and higher chain carbon compounds commonly is called "dry gas." C1/C2+ ratios (calculated for gases reported in units of volume or molar percent) greater than 1,000 have been reported to indicate microbial origins and ratios less than 1,000 to indicate thermogenic origins (Taylor and others, 2000). The relatively small amounts of accompanying ethane and $\mathrm{C} 1 / \mathrm{C} 2$ ratios (computed from reported mole percent of gases) greater than 1,000 in the Pike County groundwater samples (fig. 24B) may be interpreted to support a microbial origin for the methane (Bernard and others, 1978; Schoell, 1980; Révész and others, 2012). The sample from well PI-622 could also have been derived from thermogenic natural gas that is depleted in ethane for other reasons, such as relative depletion of ethane as part of gas maturation or migration (Coleman and others, 1995).

The isotopic composition and C1/C2 ratios for gas dissolved in the Pike County groundwater samples do not definitively characterize the source of the methane gas. The available evidence indicates that the methane in groundwater appears to be predominantly of microbial origin and may have undergone various amounts of oxidation. Alternatively, methane in at least one of the samples (from well PI-622, fig. 24) may be thermogenic but from a source relatively depleted in ethane, such as been reported for a well in Bradford County, Pennsylvania (Risser and others, 2013). Organic material within the Catskill Formation and other Devonian-age deposits in northern Pennsylvania may be a source of "dry-gas" methane (Wilson, 2014). Use of both the isotopic composition of methane and C1/C2 ratios may be helpful in distinguishing existing baseline gas in groundwater from gas that might be introduced through shale-gas development. Additional data, such as analyses for carbon-14 (for age dating) of methane and for $\delta^{13} \mathrm{C}_{\mathrm{DIC}}$, discussed previously, might be useful to further characterize the origin and fate of methane in groundwater in Pike County and elsewhere.

\section{Relation of Water Quality to Geochemical and Hydrogeologic Setting}

Results from previous assessments of baseline groundwater quality in Pike County (Senior, 2014) and other counties in northeastern Pennsylvania with similar hydrogeology and little to no unconventional drilling for natural gas (Sloto, 2013; Senior and others, 2016) indicate some common associations among constituents and various types of groundwater that are associated with the presence or absence of detectable methane. Groundwater with relatively elevated methane concentrations (greater than about 0.3$0.5 \mathrm{mg} / \mathrm{L}$ ) differs in composition from that of groundwater with lower methane concentrations by having relatively higher $\mathrm{pH}$ (greater than 8) and higher concentrations of sodium, lithium, boron, fluoride, and bromide, as shown in figure 26 . Relatively elevated concentrations of some other constituents, such as barium, strontium, and chloride, commonly are present in, but not limited to, well-water samples with elevated methane concentrations in Pike County.

Identification of associations among constituents leads to improved understanding of processes controlling the existing water quality that may be useful in predicting where existing water-quality problems are likely to occur and in determining possible effects related to possible future shale-gas development or other changes in land use. Some associations among constituents likely are due to evolution of groundwater composition along flow paths in the aquifers that may differ in composition (mineralogy), but other associations likely are related to effects of current land-use activities that can contribute specific constituents (such as salts and nutrients from deicing roads and septic systems) to groundwater.

A general conceptual model to describe how groundwater quality evolves in the hydrogeologic setting in northeastern Pennsylvania, including Pike County, is useful to assist in understanding the main patterns of groundwater quality in Pike County. The 2015 water-quality data for Pike County are further analyzed in the following sections to characterize groundwater by use of (1) major ion composition or type through Piper diagrams, (2) geochemical modeling of mineral saturation indices to identify minerals that can affect groundwater composition through dissolution or precipitation, (3) ratios of chloride to bromide and sodium to provide insight on origins of chloride, (4) correlations among constituents to identify patterns in constituent associations and to infer geochemical processes that might affect groundwater composition, and (5) geologic units to identify differences in water quality related to aquifer lithology and mineralogy, and hydrogeologic setting. These additional analyses provide evidence to support the conceptual model of groundwater quality. Additionally, the spatial distribution of groundwater quality throughout Pike County is discussed. 

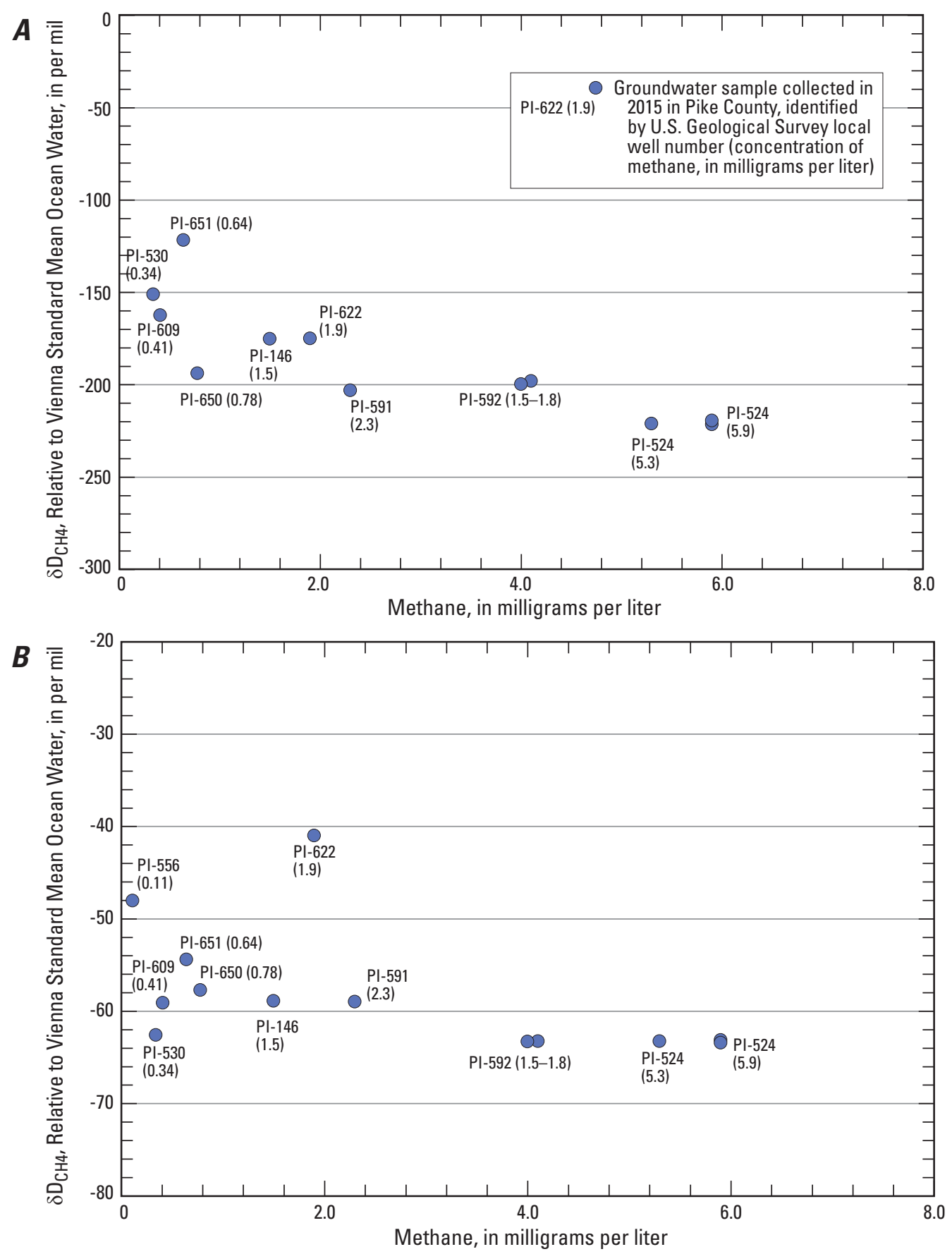

Figure 25. Relation of methane concentrations to isotopic composition of methane $\left(\mathrm{CH}_{4}\right)$ as $A$, hydrogen/deuterium component $(\delta \mathrm{D})$ and $B$, carbon-12/carbon-13 component $\left(\delta^{13} C\right)$ in groundwater samples collected from 10 wells in Pike County, Pennsylvania, 2015. The methane concentration was too low in the sample from one well (PI-556) to determine $\delta \mathrm{D}_{\text {СH4 }}$. 

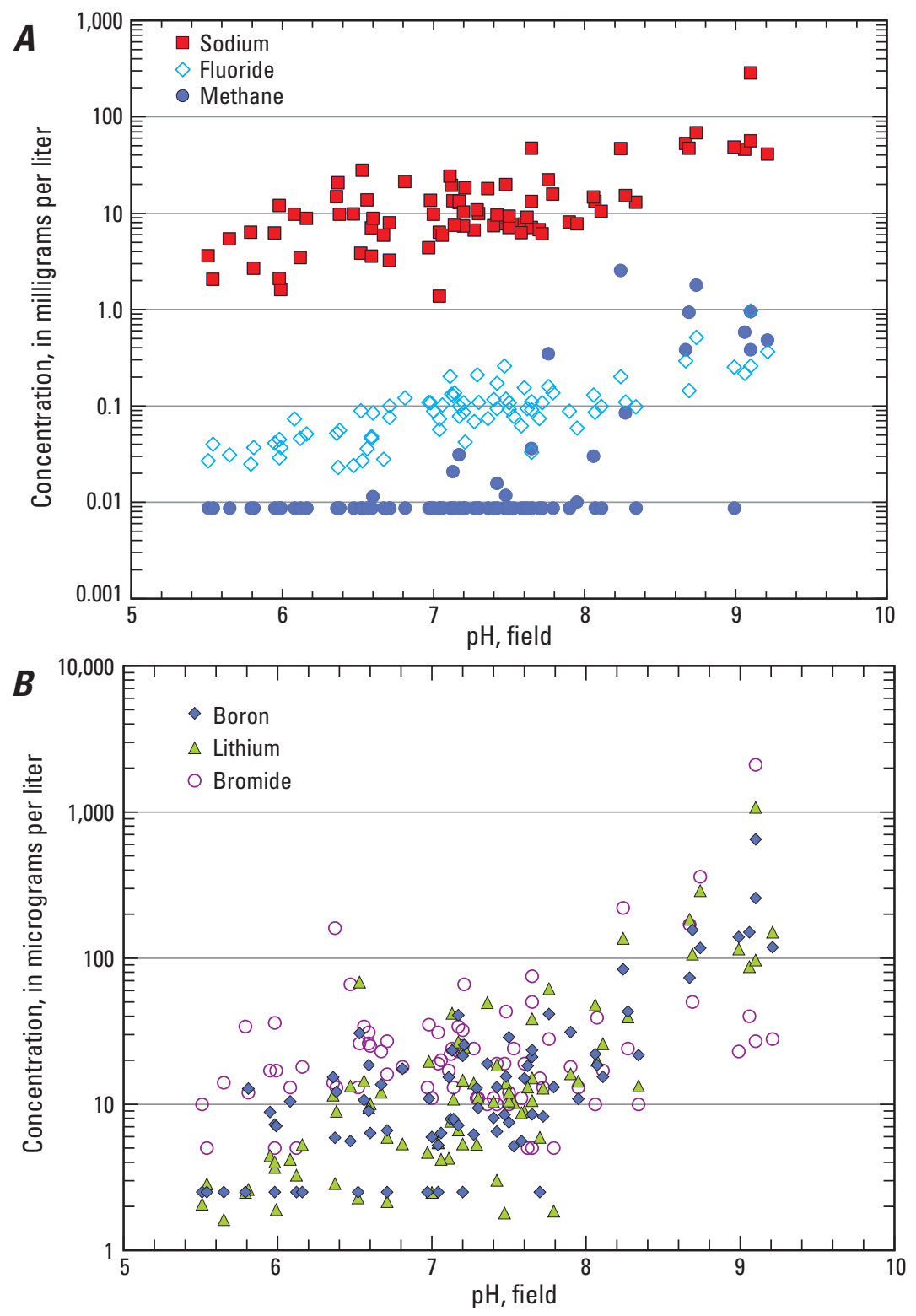

Figure 26. Relation of $\mathrm{pH}$ to concentrations of $A$, sodium, fluoride, and methane and $B$, lithium, boron, and bromide in groundwater samples collected from 79 wells in Pike County, Pennsylvania, 2015. 


\section{Evolution of Chemical Composition and Conceptual Hydrogeochemical Model}

The conceptual model for geochemical evolution of groundwater in hydrogeologic settings in northeastern Pennsylvania involves chemical reactions starting in the recharge areas and continuing along the groundwater flow paths. A schematic diagram illustrating the conceptual model of how water quality is thought to evolve along local and regional groundwater flow paths, based on the data analysis presented in this report and previous studies (for example, Senior and others, 2016), is shown in figure 27. The schematic diagram shows the general distribution of groundwater chemistry types but does not depict the complexity of groundwater flow paths in the hydrogeologic setting. The geologic units underlying Pike County form a layered (sedimentary) fractured-rock aquifer system, which has been described as having local, intermediate, and regional flow.

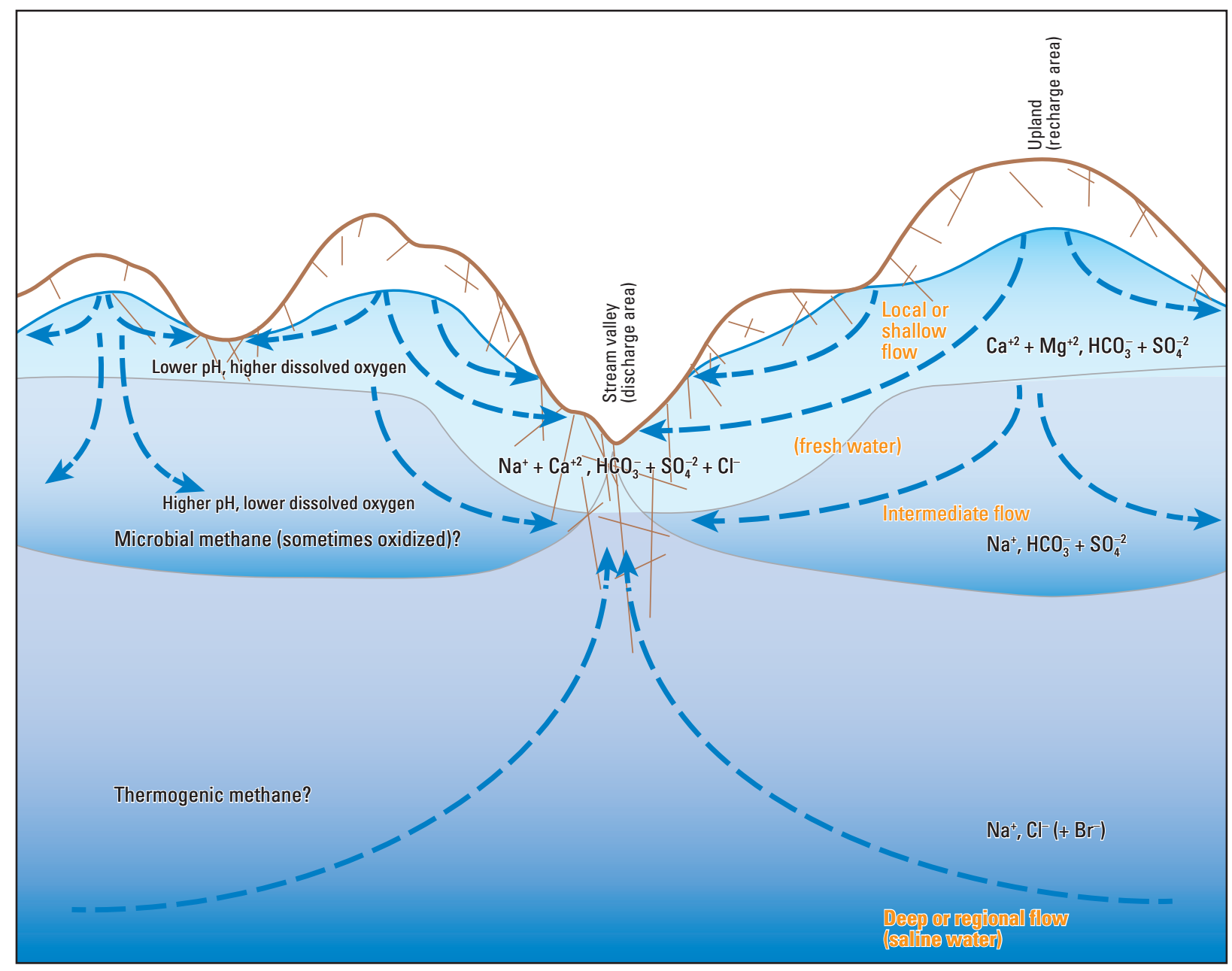

Not to scale

EXPLANATION

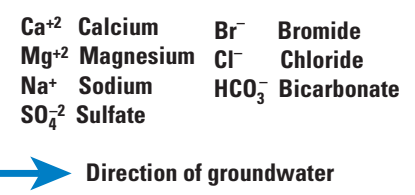

Figure 27. Schematic diagram of generalized conceptual hydrogeochemical model for distribution of fresh and saline groundwater in fractured bedrock aquifer setting showing 1) evolution of groundwater composition from calcium-magnesium-bicarbonate-sulfate type with relatively low $\mathrm{pH}$ and high dissolved oxygen concentrations (DO) in recharge areas and local flow zones to predominantly sodium-bicarbonate-sulfate with higher pH and lower DO along intermediate flow paths and 2) presence of deeper or regional water that is relatively saline and possibly mixing with intermediate-flow waters, especially in discharge areas, such as stream valleys, where methane from microbial and (or) thermogenic sources appears to be present most frequently and at highest concentrations in northeastern Pennsylvania. (Groundwater-flow directions shown in blue with local, intermediate, and regional flow paths indicated.) 
Groundwater in the uplands tends to be relatively dilute, acidic, oxygenated, and young, reflecting the quality of recharge water and degree of chemical weathering. This recently (less than a few years) recharged shallow groundwater in uplands likely has limited interaction with aquifer and soil materials and, consequently, has relatively low $\mathrm{pH}$, low TDS concentrations, and high DO concentrations. The precipitation that recharges aquifers in northeastern Pennsylvania is dilute and acidic, although currently (2015) less acidic than it was 30 years ago. The $\mathrm{pH}$ of precipitation has increased from about 4.2 in 1985 to about 5.0 in 2013 (National Atmospheric Deposition Program, 2016). In addition, rocks that underlie uplands tend to be more resistant to erosion and mineral weathering than rocks underlying lower elevations, and thus, groundwater in the uplands may also have smaller amounts of dissolved constituents than groundwater at lower elevations because of differences in mineralogy.

After recharge occurs in the shallow part of the aquifer, groundwater continues to interact with aquifer materials, and relatively soluble minerals, such as calcite, begin to dissolve. As calcite dissolves, $\mathrm{pH}$ rises to near neutral, and calcium, magnesium, and bicarbonate (alkalinity) concentrations increase. Hardness (a measure of calcium and magnesium) reaches a maximum near a $\mathrm{pH}$ of 7.5. Along the groundwater flow paths, oxygen is consumed by various biochemical reactions involving oxidation of organic material in soils or aquifer or by oxidation of some minerals, such as pyrite. Exchange of alkali metals (such as sodium and lithium) for alkaline earth metals (calcium, magnesium, and to a lesser extent barium and strontium) on mineral surfaces (such as illite, a mineral reported to be present in aquifer materials) is thought to occur on the basis of apparent relations between various constituents. Through ion exchange, concentrations of calcium and magnesium decrease, whereas sodium and other alkali metals, alkalinity, and $\mathrm{pH}$ continue to increase. This shift from calcium to sodium as the predominant cation generally is accompanied by increases in $\mathrm{pH}$, alkalinity, and TDS. The increases in $\mathrm{pH}$, alkalinity, and TDS result from the progressive dissolution of calcite (to maintain equilibrium) as calcium and magnesium are removed from solution by exchange processes. Formation of sodium-bicarbonate waters with elevated $\mathrm{pH}$ as a result of ion-exchange (sodium for calcium) has been reported for shallow shale aquifers elsewhere (Kresse and others, 2012). At $\mathrm{pH}$ values greater than 8, oxyanions, such as arsenate, are mobilized, resulting in increases in dissolved concentrations of arsenic and other trace elements with similar chemical properties.

Mixing of groundwater with naturally occurring Appalachian Basin brines or other saline waters from deep parts of the aquifer (fig. 27) or areas of restricted flow (low permeability) where flushing of the aquifer by freshwater may be limited and residual brines may be present contributes certain constituents, such as bromide and chloride. Wells that penetrate deep parts of the aquifer or are near areas of regional groundwater discharge appear to be the most likely to intercept groundwater with a saline component. Geochemical modeling indicates that the measured (observed) concentrations of chloride and bromide in nearby Wayne County groundwater samples with the highest concentrations of bromide could result from a mixture of freshwater and brine, with brine representing less than 0.02 percent of the solution (Senior and others, 2016). Other sources of chloride include road salt and septic effluent. Similar processes likely occur in Pike County.

Brines with elevated concentrations of sodium, chloride, bromide, barium, strontium, and other solutes occupy pore spaces in deep sedimentary rocks throughout Pennsylvania. The highly saline sodium/chloride brines and overlying groundwaters of intermediate salinity generally are present 1,000 feet or more below the surface (Feth and others, 1965; Heisig and Scott, 2013). Such brine-affected waters typically discharge from gas or oil wells (Dresel and Rose, 2010) and may be present locally at springs and some shallow water wells in northeastern Pennsylvania (Llewellyn, 2014), although shallow (less than 1,000 ft) brines have not been reported in Pike County.

The shallowest flow systems tend to be present in highly fractured aquifers where actively circulating freshwater over time has depleted sodium, chloride, and other vestiges of residual or connate brines (fluids trapped in rocks during and after formation). In the shallow groundwater zone (fig. 27), water types of predominantly calcium-magnesium/ bicarbonate and calcium-magnesium/bicarbonate-sulfate compositions are produced by the active weathering of moderately soluble carbonate minerals and, to a lesser extent sulfate, sulfide, and silicate minerals. In the intermediate zone, groundwater of sodium/bicarbonate type and moderate salinity typically is present between the shallow, actively circulating freshwater and the deeper, slower moving sodium/chloride type water. Poth (1963) explains the freshening process in the intermediate zone as follows: "[t]he chloride is readily removed by circulating groundwater, but the sodium is more difficult to remove because much of it is adsorbed on the clay in the rocks.” The sodium that occupies exchange sites on clay minerals, tends to be displaced by calcium and magnesium though cation exchange. Such processes lead to the formation of sodium/bicarbonate type waters, which are transitional between the sodium/chloride waters at great depth and the calcium-magnesium/bicarbonate waters in the overlying freshwater zone.

Most wells constructed for domestic use are completed within the local, freshwater flow system. Wells with known construction sampled for this study in Pike County were completed at depths ranging from 80 to $680 \mathrm{ft}$ below land surface; one-half of these were drilled to depths of about 180 to $360 \mathrm{ft}$. The observed water types and relations among selected constituents and pH in Pike County, nearby Wayne County (Senior, 2014; Sloto, 2014; Senior and others, 2016), and other areas in northeastern Pennsylvania (Sloto, 2013; Gross and Cravotta, 2017) indicate that dilute recharge waters likely interact with minerals in the near surface, gradually becoming less acidic and less oxygenated, while increasing in concentrations of dissolved constituents. 
Groundwater with lower $\mathrm{pH}(<6.4)$ tended to be the most dilute (TDS $<100 \mathrm{mg} / \mathrm{L}$ ) and have higher DO concentrations $(>3 \mathrm{mg} / \mathrm{L})$, whereas groundwater with higher $\mathrm{pH}(>7.8)$ tended to have higher concentrations of TDS $(>150 \mathrm{mg} / \mathrm{L})$ and lower concentrations of DO $(<1 \mathrm{mg} / \mathrm{L})$. Geochemical modeling showed that mineral dissolution, cation exchange (sodium for calcium), and mixing with small amounts of brine are processes that might explain the observed quality of groundwater associated with various ranges of methane concentrations in northeastern Pennsylvania, and Wayne and Lycoming Counties (Senior and others, 2016; Gross and Cravotta, 2017), and could be processes that help to explain the quality of groundwater with various methane concentrations in Pike County.

\section{Types of Groundwater as Characterized by Major Ions}

The relative proportions of major ions in water samples may be used to distinguish different types of water, as shown on Piper diagrams (fig. 28A, B). The types of water reflect natural processes of the interaction of recharge with minerals in the aquifer, geochemical reactions in the groundwater flow system, and (or) inputs from human activities, such as introduction of sodium chloride by roadsalt applications. Major cations are calcium, magnesium, and sodium (and potassium which usually is less than, but plotted with, the sodium component). Major anions are bicarbonate $\left(\mathrm{HCO}_{3}^{-}\right)$, sulfate, and chloride (and nitrate and fluoride, both of which are plotted with, but usually are less than, the chloride component). The types of waters are characterized by the predominant cation(s) and anion(s), calculated as a percentage of total cation or anion milliequivalents. For example, a calcium-bicarbonate type water has more than 50 percent calcium and bicarbonate as cations and anions, respectively, and in a mixed calcium-magnesium-bicarbonate water, the sum of calcium and magnesium ions is more than 50 percent of cations.

The major ion composition of water samples collected from 79 wells during 2015 in Pike County as plotted on Piper diagrams using different symbols to distinguish ranges of $\mathrm{pH}$ and SC (fig. 27A, B) shows differences in relation to those characteristics that may be helpful in distinguishing the origins of the groundwaters. Comparison of diagrams displaying water composition for ranges of $\mathrm{pH}$ and $\mathrm{SC}$ (fig. 28A, B) indicates the following general patterns: (1) the most acidic waters are of mixed ion composition with a wide range of SC values; (2) intermediate $\mathrm{pH}$ waters are predominantly calcium-bicarbonate type with intermediate SC; and (3) the highest $\mathrm{pH}$ waters are predominantly sodium-bicarbonate type with relatively higher SC. The SC is directly and linearly related to TDS in the Pike County groundwater samples (fig. 8), such that a $\mathrm{SC}$ of $130 \mu \mathrm{S} / \mathrm{cm}$ at $25^{\circ} \mathrm{C}$ is approximately equivalent to $80 \mathrm{mg} / \mathrm{L} \mathrm{TDS}$, and a SC of $435 \mu \mathrm{S} / \mathrm{cm}$ at $25^{\circ} \mathrm{C}$ is approximately equivalent to the SMCL of $250 \mathrm{mg} / \mathrm{L}$ for TDS. SC and TDS values in groundwater generally indicate the amount of dissolved constituents contributed by mineral weathering, although high SC and TDS values also may be related to road-salt or other salt contamination. The shift in groundwater composition from calcium (Ca) and magnesium $(\mathrm{Mg})$ as the predominant cations to sodium $(\mathrm{Na})$ as the predominant cation in Pike County groundwater accompanied by increases in $\mathrm{pH}$ and SC (and TDS), as shown on the Piper diagrams, likely reflects the processes of calcite dissolution followed by cation exchange, as described in the section "Evolution of Chemical Composition and Conceptual Hydrogeochemical Model."

The major ion composition of about two-thirds of the Pike County groundwater samples is predominantly calciumbicarbonate (about 38 percent of samples) or mixed calciummagnesium-bicarbonate (about 25 percent of samples). The $\mathrm{pH}$ of these predominantly calcium-bicarbonate type and mixed calcium-magnesium-bicarbonate type water samples was near neutral, ranging from 6.5 to 8.5 (fig. 28A). The SC of most of these samples ranged from relatively low (less than $130 \mu \mathrm{S} / \mathrm{cm}$ at $25^{\circ} \mathrm{C}$ ) to intermediate (up to $280 \mu \mathrm{S} / \mathrm{cm}$ at $25^{\circ} \mathrm{C}$ ); a few transitional (toward more chloride-type water) samples had higher SC of as much as $500 \mu \mathrm{S} / \mathrm{cm}$ at $25^{\circ} \mathrm{C}$ (fig. $28 B$ ). The calcium-bicarbonate type water samples with near neutral $\mathrm{pH}$ and a range of low to intermediate SC (and TDS concentrations) could have been produced by the dissolution of calcite with differing amounts of mineral dissolution (as indicated by TDS concentrations).

A few water samples ( 8 of 79 or about 10 percent) plot as much higher in sodium than the other samples, have bicarbonate as the predominant anion, and thus can be categorized as sodium-bicarbonate type water (more than 50 percent sodium and bicarbonate as cations and anions, respectively). In contrast to the calcium-carbonate type water samples, the $\mathrm{pH}$ of these predominantly sodium-bicarbonate type water samples is mostly alkaline (greater than 8.5) (fig. 28A) with somewhat higher SC, ranging from greater than 210 to $400 \mu \mathrm{S} / \mathrm{cm}$ (fig. 28B). Most water samples that are classified as sodium-bicarbonate types have intermediate to high SC, TDS, and $\mathrm{pH}$ values, indicating relatively greater amounts of mineral dissolution and sodium-for-calcium cation exchange. 


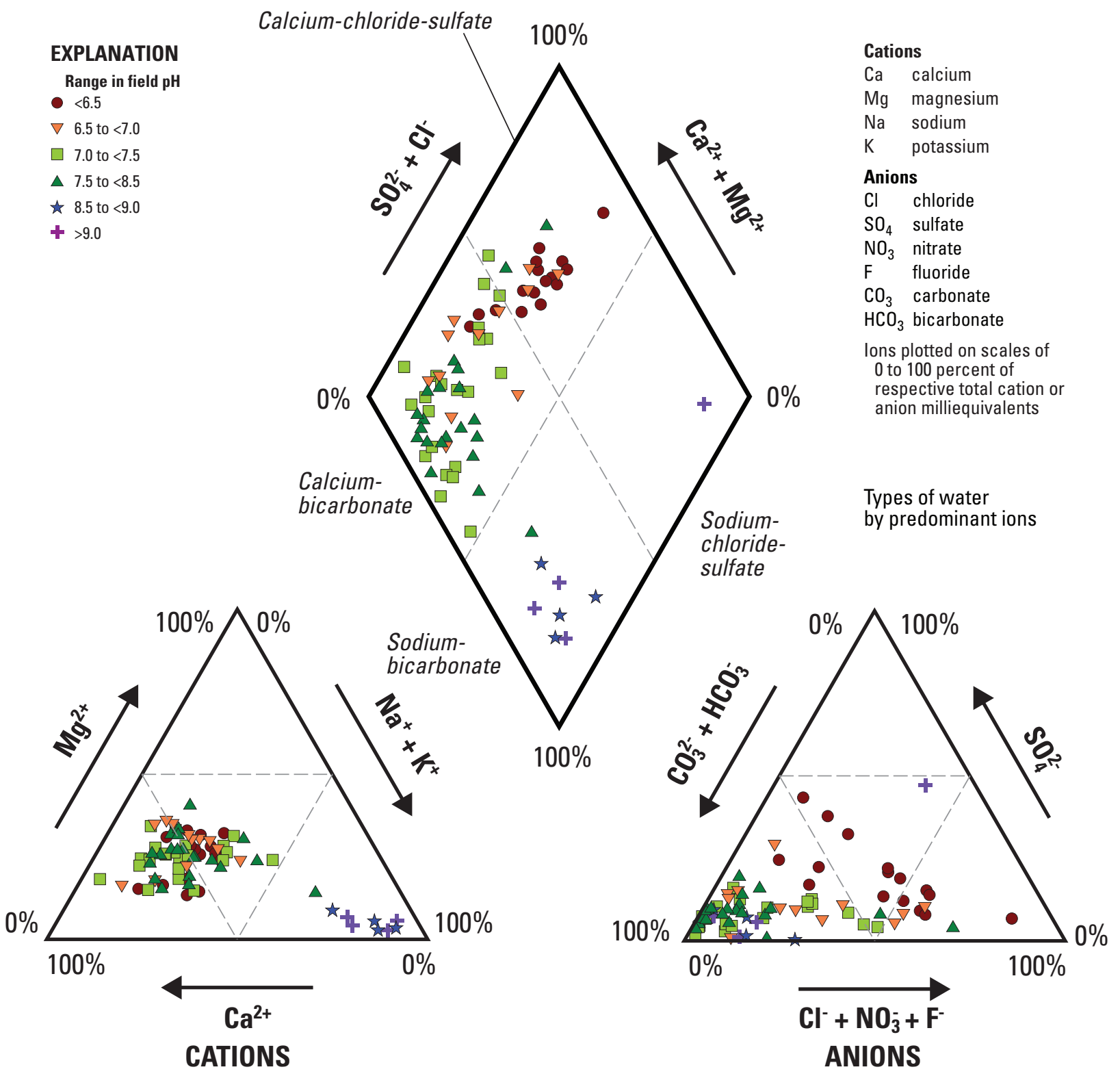

Figure 28. Piper diagrams showing major ion composition for water samples collected from 79 wells in Pike County, Pennsylvania, 2015 , for ranges of $A$, field $\mathrm{pH}$ and $B$, laboratory specific conductance.

Another sample (from well PI-650) with sodium as the predominant cation plotted as a sodium-sulfate-chloride type water with slightly greater percentages of sulfate than chloride, which exceeds bicarbonate, as anions (fig. 28A, B). This sample from well PI-650 had high pH (greater than 9) and the highest SC $(1,580 \mu \mathrm{S} / \mathrm{cm})$ (fig. $28 \mathrm{~A}, B)$ of the 79 well-water samples. Although the water sample from well PI-650 plotted in the area of the Piper diagram near the plotted location for Pennsylvania oil and gas-well brines and Marcellus flowback (sodium/chloride type) (Senior and others, 2016; fig. 25B, p. 46), it had a greater concentration of sulfate (362 mg/L) and much lower concentrations of chloride (223 mg/L) and sodium (283 mg/L) than typical brines (table 1). Geochemical modeling done in a study of similar groundwater in nearby Wayne County indicates that sodium-chloride type water with elevated $\mathrm{pH}$ can be formed by calcite dissolution followed by sodium-for-calcium cation exchange and mixing with residual brines in the aquifer (Senior and others, 2016). Likewise, a sodium-sulfate-bicarbonate type water could result where pyrite oxidation has occurred in addition to calcite dissolution and cation exchange. The geochemical modeling also describes an evolution pathway for mixing of groundwater plus road deicing salt that produces sodium/chloride water type (on the right corner of the Piper diagram). Sodiumchloride type waters resulting from contamination by road salt 


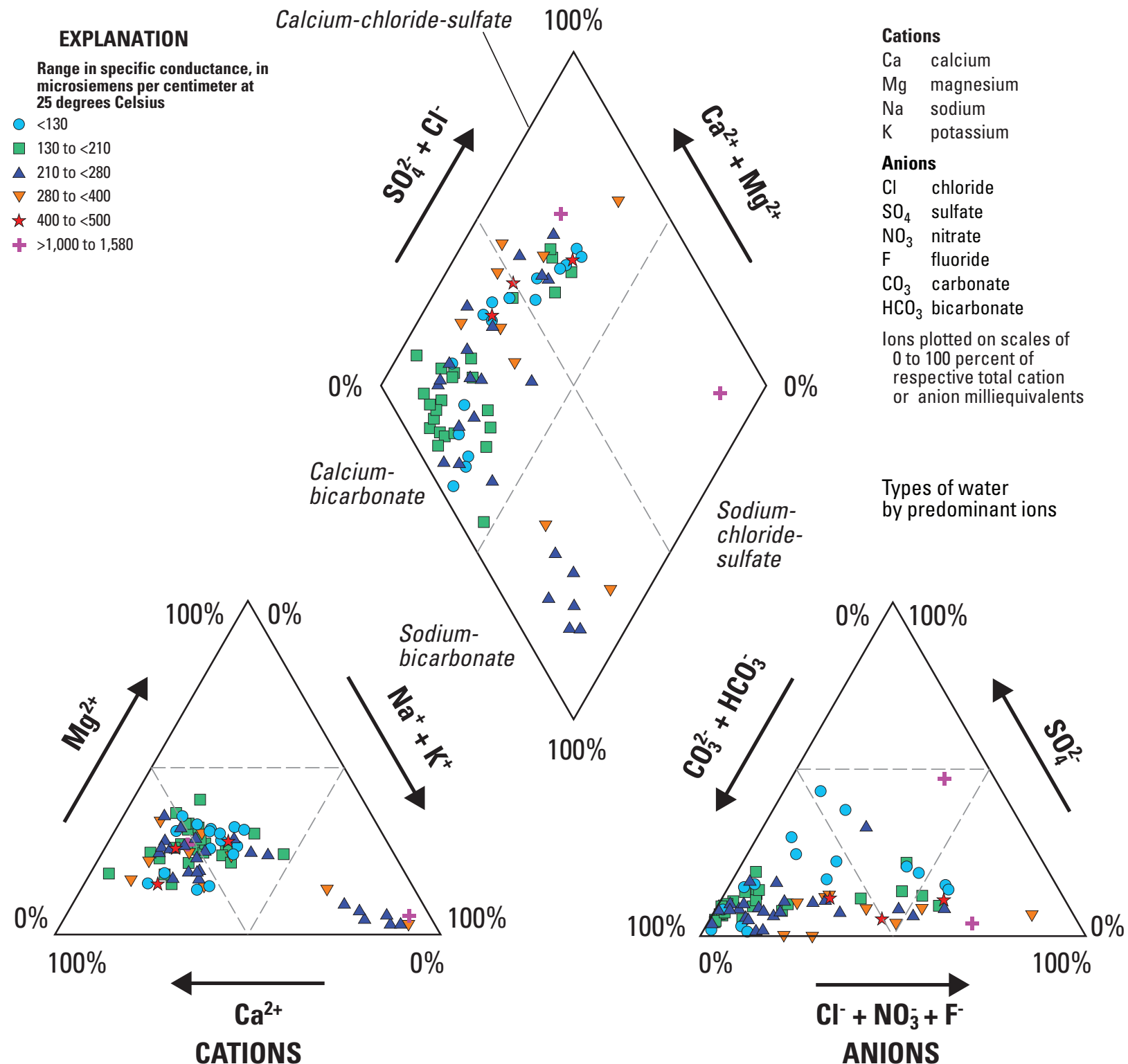

Figure 28. Piper diagrams showing major ion composition for water samples collected from 79 wells in Pike County, Pennsylvania, 2015 , for ranges of $A$, field $\mathrm{pH}$ and $B$, laboratory specific conductance.-Continued

have been described elsewhere in northeastern Pennsylvania (Reilly and others, 2015).

The remaining water samples can be characterized as mixed calcium-chloride-sulfate or mixed calcium-bicarbonatechloride-sulfate type waters with a wide range in $\mathrm{pH}$ $(<6.5-8.5)$ and SC (less than 130 to greater than 1,000 $\mu \mathrm{S} / \mathrm{cm}$ at $25^{\circ} \mathrm{C}$ ) (fig. $28 \mathrm{~A}, \mathrm{~B}$ ). All of the most acidic of the 79 wellwater samples (lowest $\mathrm{pH}$, less than 6.5) plotted as these mixed-type waters. These most acidic samples also tended to be the most dilute (SC less than $130 \mu \mathrm{S} / \mathrm{cm}$ at $25^{\circ} \mathrm{C}$ ). The characteristics of the dilute, acidic samples could have been formed by evaporation of rainwater (recharge) with minor additions of sulfate (from pyrite, gypsum, or other sources) and chloride (from road salt or other sources) and limited dissolution of calcite. Samples with $\mathrm{pH}$ in the range of 6.5-7.5 tended to have intermediate to relatively high SC $\left(210-500 \mu \mathrm{S} / \mathrm{cm}\right.$ at $\left.25^{\circ} \mathrm{C}\right)$ with generally more bicarbonate than the dilute samples, indicating greater amounts of mineral dissolution and the addition of chloride. One (well PI-653) of the two samples with $\mathrm{pH}$ in the range of 7.5-8.5 had very high SC $\left(>1,094 \mu \mathrm{S} / \mathrm{cm}\right.$ at $\left.25^{\circ} \mathrm{C}\right)$ and elevated calcium, magnesium, sodium, and chloride concentrations, possibly indicating the presence of calcium, magnesium, and sodium deicing salts. 


\section{Geochemical Modeling of Mineral Saturation Indices}

The potential for various minerals to be dissolved or precipitated can affect the composition of groundwater and can be evaluated by calculating the mineral SI, which takes into account such factors as $\mathrm{pH}$ and concentrations of all ions in solution. A negative value for SI indicates that the mineral is undersaturated, unstable, and can dissolve. A zero value for SI indicates that the mineral is at saturation (equilibrium between dissolution and precipitation), and a positive value for SI indicates that the mineral is oversaturated and can precipitate out of solution.

The bedrock units underlying Pike County consist of marine (Marcellus, Mahantango, and Trimmers Rock Formations) and non-marine (Catskill Formation) clastic sedimentary rocks, including shale, siltstones, and sandstones, that are mainly composed of silicate and aluminosilicate minerals, such as quartz, chlorite, muscovite, and illite (table 3), plus minor carbonate, sulfate, sulfide, and oxide minerals that occur as clasts, fracture filling, and cements. Feldspar is present in several members of the Catskill Formation but is not reported for the Poplar Gap and Packerton members of the Catskill Formation and is limited to trace amounts or no presence in the marine sedimentary rocks (Marcellus, Mahantango, and Trimmers Rock Formations; table 3) (Sevon and others, 1989). Although mineralogy is expected to vary locally, the carbonate (such as calcite, $\mathrm{CaCO}_{3}$ ), sulfate, and sulfide (such as pyrite, $\mathrm{FeS}_{2}$ ) minerals in particular are prone to weathering in nearsurface environments where they may be important sources of hardness (Ca and $\mathrm{Mg}$ ), acid neutralizing capacity (ANC) or alkalinity, sulfate $\left(\mathrm{SO}_{4}\right)$, and other solutes. Weathering of aluminosilicates, such as feldspars, can lead to release of cations, silica, and aluminum, and to formation of clays, which may undergo further dissolution. Additionally, various clay minerals, which are hydrated aluminosilicates having layered crystal structures that readily accommodate ionic substitutions, are widely recognized to be involved in cation-exchange and sorption processes (Hem, 1985; Appelo and Postma, 2005). In Pike County, for example, reactions involving common clay minerals in soils, shales, and siltstones, such as chlorite, muscovite, illite, and kaolinite, could affect solute concentrations in groundwater in the study area through both mineral dissolution/precipitation and ion-exchange processes.

To evaluate the potential for various minerals to be dissolved or precipitated by the groundwater, the SI values computed using PHREEQC (Parkhurst and Appelo, 2013) and WATEQ4F database (Ball and Nordstrom, 1991) are displayed as a function of $\mathrm{pH}$ for the 2015 Pike County well-water samples in figure 29. The SI for most carbonate minerals is negative at low $\mathrm{pH}$ (acidic water), indicating potential for dissolution, but increases with increasing $\mathrm{pH}$. Calcite $\left(\mathrm{CaCO}_{3}\right)$ is a carbonate mineral reported to be present in Pike County rocks and may be an important source of
Ca, alkalinity $\left(\mathrm{HCO}_{3}{ }^{-}, \mathrm{CO}_{3}{ }^{2-}\right)$, and acid neutralizing capacity (ANC). The samples that had $\mathrm{pH}$ less than or equal to 8 were undersaturated (SI less than 0 ) with respect to calcite and dolomite $\left[\mathrm{CaMg}\left(\mathrm{CO}_{3}\right)_{2}\right]$, indicating the groundwater could feasibly dissolve these carbonate minerals, if present. The SI for calcite increased linearly from $\mathrm{pH}$ of 5.5 (SI -4.2) to $\mathrm{pH}$ of 8 (SI -0.1), above which the SI value approximately equal to 0 was maintained. Despite the indicated equilibrium, dissolution of calcite could be anticipated to continue at $\mathrm{pH}$ values greater than 8 because of the removal of calcium in the exchange of sodium. As the concentrations of calcium are depleted, the groundwater could dissolve more calcite with progressive increases in concentrations of ANC and $\mathrm{pH}$ to values as high as 9.2 (fig. 29).

The major Ca and Mg carbonate minerals commonly contain traces of other cations, including iron (Fe), manganese (Mn), strontium (Sr), and barium (Ba) (Hanshaw and Back, 1979). These trace cations also could be present locally as pure carbonate phases. Understanding sources of, and geochemical controls on, barium and strontium in groundwater is important in baseline assessments because flowback and produced waters from gas-well development contain elevated concentrations of these constituents. Dissolution of calcite, dolomite, or other carbonates could release various trace cations to solution. Over the range of $\mathrm{pH}$, the SI values for siderite $\left(\mathrm{FeCO}_{3}\right)$ and witherite $\left(\mathrm{BaCO}_{3}\right)$ were negative (fig. 28), indicating these carbonate minerals, if present, could feasibly be dissolved by the groundwater. However, the SI values for other carbonate minerals_-rhodochrosite $\left(\mathrm{MnCO}_{3}\right)$ and strontianite $\left(\mathrm{SrCO}_{3}\right)$ — change from predominantly negative at low $\mathrm{pH}$ to mixed negative and positive with increasing $\mathrm{pH}$, indicating decreasing potential for dissolution at higher $\mathrm{pH}$ values and potential solubility controls on concentrations. The concentrations of trace elements may be further limited by the formation of other solid phases. For example, the accumulation of $\mathrm{SO}_{4}$ from rainfall, sulfide mineral oxidation, or gypsum $\left(\mathrm{CaSO}_{4} \cdot 2 \mathrm{H}_{2} \mathrm{O}\right)$ dissolution could promote the supersaturation and precipitation of barite $\left(\mathrm{BaSO}_{4}\right)$ and thus limit the concentrations of dissolved barium. The SI for barite in 2015 Pike County groundwater samples ranged from negative values at $\mathrm{pH}$ less than 6.5, indicating undersaturation, to mixed negative, near zero, and positive values at $\mathrm{pH}$ greater than 6.5 (fig. 29), indicating some potential for barite precipitation and limits to barium concentrations at $\mathrm{pH}$ greater than 6.5. In contrast, celestine $\left(\mathrm{Sr} \mathrm{SO}_{4}\right)$ was indicated to be undersaturated, and therefore an unlikely mineral to limit strontium concentrations, in all samples. However, strontium concentrations could possibly be limited by coprecipitation with barium in barite (Hanor, 1968), as well as by precipitation of strontianite $\left(\mathrm{SrCO}_{3}\right)$ at high $\mathrm{pH}$ (near $\mathrm{pH}$ of 9). Furthermore, strontium, barium, and other trace cations could participate in exchange reactions with clay minerals or adsorption processes, which may affect concentrations of those constituents in groundwater. 

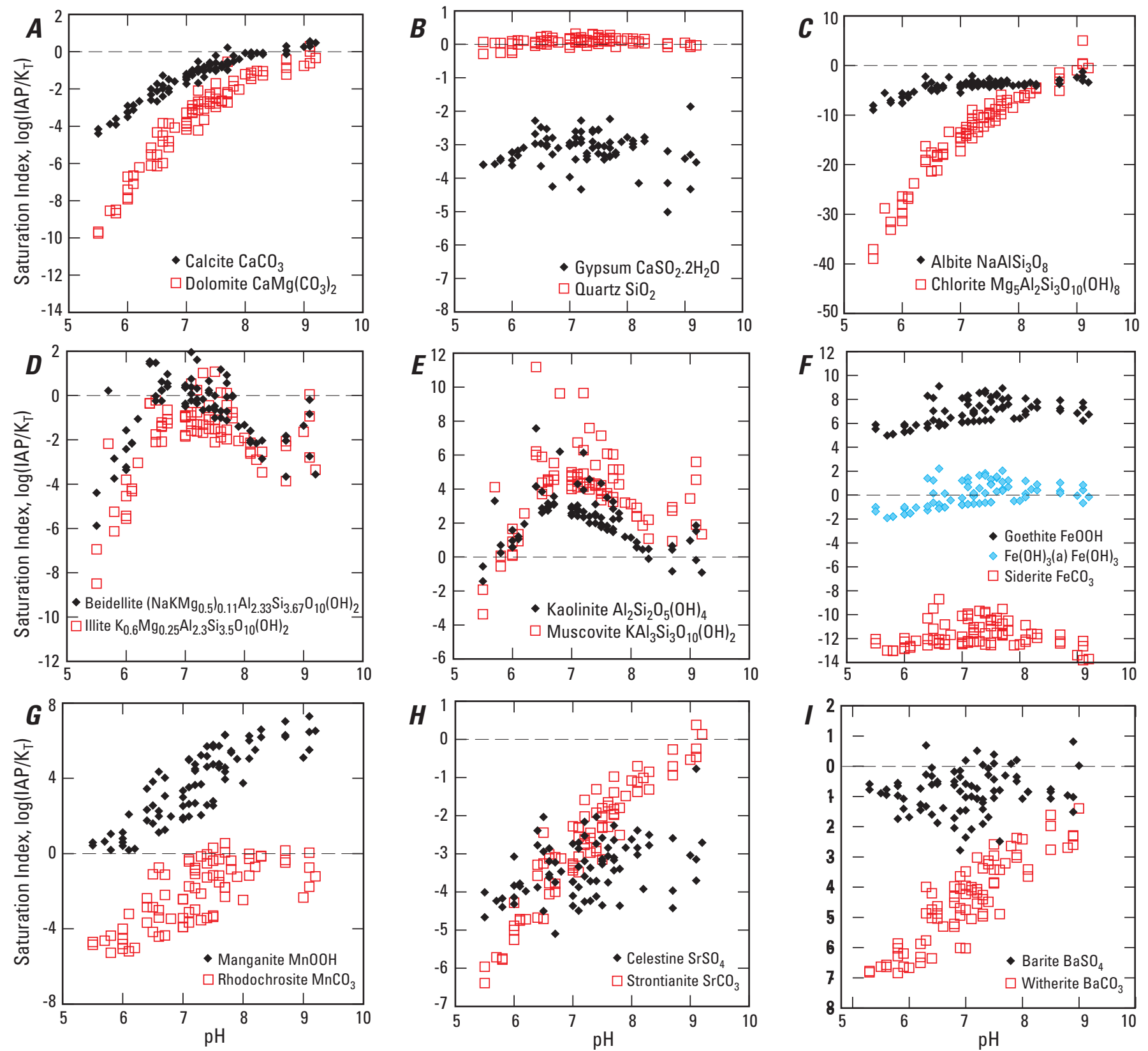

Figure 29. Relation of saturation indices for minerals and other solids to $\mathrm{pH}$ for groundwater samples from 79 wells in Pike County, Pennsylvania, 2015, computed using PHREEQC (Parkhurst and Appelo, 2013) with WATEQ4F database (Ball and Nordstrom, 1991). [IAP, ion activity product; KT, solubility product (thermodynamic equilibrium constant)] 
Over the range of $\mathrm{pH}$ for the samples in this study, the unstable aluminosilicates, such as feldspar, generally would be anticipated to dissolve incongruently, releasing cations to solution while silicon $(\mathrm{Si})$ and aluminum $(\mathrm{Al})$ are retained in secondary solid phases, such as quartz and kaolinite. On the basis of negative SI values, feldspar minerals represented by albite $\left(\mathrm{NaAlSi}_{3} \mathrm{O}_{8}\right)$ were undersaturated (fig. 29) and could feasibly dissolve in groundwater, albeit slowly. In addition to being sources of base cations [sodium, potassium (K), calcium], aluminum, and silica, the feldspars commonly contain traces of phosphate $\left(\mathrm{PO}_{4}\right)$ and, thus, could be a potential natural source of phosphate in the sampled groundwaters (Denver and others, 2010). The "clay" (phyllosilicate) mineral chlorite $\left.\left[\mathrm{Mg}_{5} \mathrm{Al}_{2} \mathrm{Si}_{3} \mathrm{O}_{10}(\mathrm{OH})_{8}\right)\right]$ was undersaturated at most $\mathrm{pH}$ values to about 9.1; at greater than 9.1, the SI value was positive or approximately equal to zero, indicating that chlorite would not continue to dissolve as a source of magnesium. In contrast, quartz $\left(\mathrm{SiO}_{2}\right)$ and kaolinite $\left[\mathrm{Al}_{2} \mathrm{Si}_{2} \mathrm{O}_{5}(\mathrm{OH})_{4}\right]$ were saturated or supersaturated and thus are stable. Other clay minerals, including illite $\left[\mathrm{K}_{0.6} \mathrm{Mg}_{0.25} \mathrm{Al}_{2.3} \mathrm{~S}\right.$ $\left.\left.\mathrm{i}_{3.5} \mathrm{O}_{10}(\mathrm{OH})_{2}\right)\right]$, muscovite $\left[\mathrm{KAl}_{3} \mathrm{Si}_{3} \mathrm{O}_{10}(\mathrm{OH})_{2}\right]$, and beidellite $\left.\left[\left(\mathrm{NaKMg}_{0.5}\right)_{0.11} \mathrm{Al}_{2.33} \mathrm{Si}_{3.67} \mathrm{O}_{10}(\mathrm{OH})_{2}\right)\right]$, had SI values that ranged from negative to positive (fig. 29), indicating these or similar phases could potentially dissolve where undersaturated, or such phases could participate in surface complexation or exchange reactions where saturated or supersaturated.

Hydrous oxides of iron [FeOOH, $\left.\mathrm{Fe}(\mathrm{OH})_{3}(\mathrm{a})\right]$ and manganese $(\mathrm{MnOOH})$ are common in soils and weathered bedrock. The groundwaters sampled for the study generally were indicated to be saturated or supersaturated with respect to some iron and manganese oxides, which indicates such phases could precipitate as stable secondary phases (although the redox state is uncertain) upon dissolution of carbonates or oxidation of sulfides containing iron and manganese. At low $\mathrm{pH}$, the iron oxide $\left[\mathrm{Fe}(\mathrm{OH})_{3}(\mathrm{a})\right]$ was slightly undersaturated (fig. 29), indicating possible dissolution of that iron-bearing mineral under acidic conditions (pH less than 6.5). The common occurrence of total iron concentrations that exceed dissolved iron concentrations in the 2015 Pike County groundwater samples indicates particulate iron is present, which is consistent with positive SI vales for hydrous iron oxides. The hydrous iron and manganese oxides are widely recognized as potential sorbents of trace anions such as arsenic, selenium, molybdenum, and boron (As, Se, Mo, $\mathrm{B})$ at acidic $\mathrm{pH}$ and cations such as copper, lead, and zinc $(\mathrm{Cu}, \mathrm{Pb}, \mathrm{Zn})$ at neutral to alkaline $\mathrm{pH}$ (Appelo and Postma, 2005; Dzombak and Morel, 1990; Hem 1985). Adsorption, or surface complexation, can maintain trace-element concentrations at low levels compared to the solubilities of corresponding trace-element minerals; however, as the $\mathrm{pH}$ or redox conditions change, the trace ions could be released into solution by the oxides (Chapman and others, 2013; Cravotta and Brady, 2015). In the Pike County groundwater samples, the pattern of higher concentrations of copper, lead, and zinc in acidic samples and higher concentrations of arsenic, selenium, molybdenum, and boron in alkaline samples may reflect differing adsorption characteristics of these ions on hydrous iron and manganese oxides.

\section{Ratios of Chloride, Bromide, Sodium, and Lithium in Groundwater}

Chloride/bromide ratios can be useful in distinguishing different sources of chloride (Davis and others, 1998; Mullaney and others, 2009; Whittemore, 2007). Bromide, like chloride, is a soluble anion that exhibits conservative transport properties and can be used as a tracer. Some sources of chloride introduced into the environment by human activities, such as salt (sodium chloride, $\mathrm{NaCl}$ ) used for road deicing or present in septic effluent, typically have relatively low amounts of bromide and, consequently, relatively high chloride/bromide mass ratios (Davis and others, 1998).

In Pike County, chloride concentrations greater than a few milligrams per liter in shallow groundwater likely represent the effects of local and distributed land-use activities or potential contributions from naturally occurring deeper, more saline groundwater of regional extent. The concentrations of chloride $(0.47-246 \mathrm{mg} / \mathrm{L})$ ranged widely for the groundwater samples collected in 2015 from 79 wells, as did concentrations of two constituents commonly associated with chloride — sodium (1.37-283 mg/L) and bromide $(<0.01-$ $2.1 \mathrm{mg} / \mathrm{L}$ ) (table 4). In some samples, the elevated chloride concentrations are associated with elevated concentrations of sodium (fig. 30A) and, in a few cases with relatively elevated nitrate, which indicates effects from human or animal waste. In other samples, elevated chloride concentrations are associated with relatively elevated bromide concentrations (fig. 30B), which could indicate effects from residual brine of geologic origin. Recent studies of groundwater quality in nearby Susquehanna County in northeastern Pennsylvania (Warner and others, 2012; Llewellyn, 2014) describe groundwater that has relatively elevated concentrations of chloride and chloride/ bromide ratios indicative of possible mixing of freshwater within the shallow aquifer with higher salinity or brine-type waters.

Plots of the mass ratio of chloride to bromide $(\mathrm{Cl} / \mathrm{Br})$ and the concentration of bromide or sodium compared to the concentration of chloride in groundwater samples show potentially different sources of salinity, including road-deicing salts and Appalachian Basin brines. Bromide concentrations determined by the laboratory (Weck Laboratories, Inc.) with the lowest reporting level of $0.010 \mathrm{mg} / \mathrm{L}(10 \mu \mathrm{g} / \mathrm{L})$ for bromide in summer 2015 were used to calculate chloride/bromide mass ratios. The chloride/bromide mass ratios for the 2015 water samples from 79 wells in Pike County are shown in relation to chloride concentrations in figure $30 \mathrm{C}$, which also shows curves (mixing lines) representing compositions resulting from mixing of different proportions of dilute groundwater with (1) low-bromide salt (such as sodium chloride used for road salt or in septic effluent) or (2) Appalachian Basin brine, including those of Marcellus Shale type oil and gas brines. 

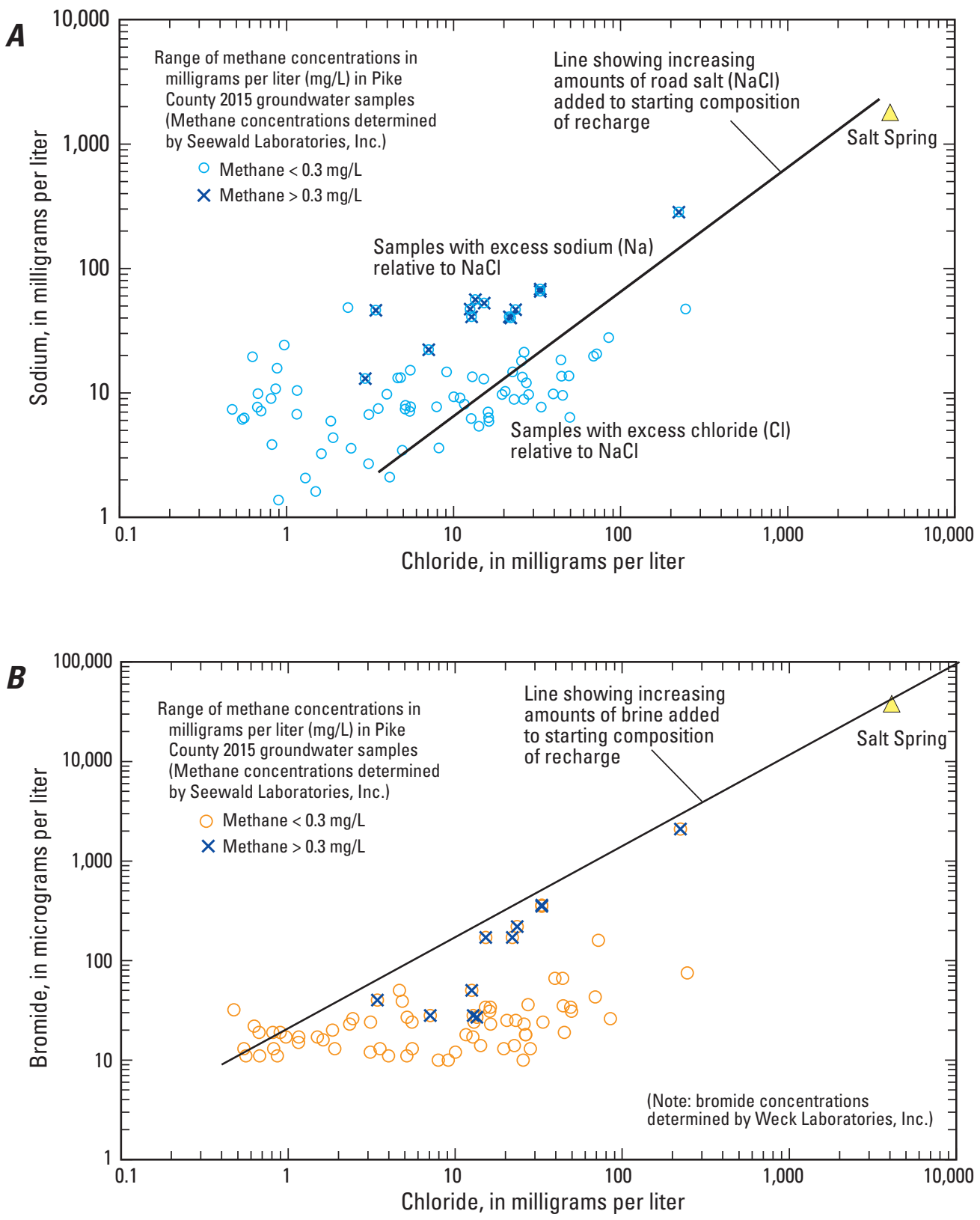

Figure 30. Relation of chloride concentrations to $A$, sodium concentrations, $B$, bromide concentrations, $C$, chloride/bromide mass ratios, and $D$, lithium/chloride mass ratios in groundwater samples with and without methane concentrations greater than 0.3 milligrams per liter collected from 79 wells in Pike County, Pennsylvania, 2015, plus median values for Salt Spring, flowback waters from Marcellus Shale gas wells, and oil- and gas-field brines from western Pennsylvania. Mixing lines were computed for initial freshwater with chloride concentration of $0.4 \mathrm{mg} / \mathrm{L}$ and bromide concentration of $0.01 \mathrm{mg} / \mathrm{L}$ mixed with road deicing salt having composition $\mathrm{NaCl}_{0.9996} \mathrm{Br}_{0.00004}$ or with median composition of oil- and gas-field brine. Salt Spring values from Llewellyn (2014) and Warner and others (2012). Flowback water values from Marcellus Shale gas wells from Hayes (2009). Oil- and gas-field brine values from Dresel and Rose (2010). Road salt composition from Llewellyn (2014). [CI/Li, chloride/lithium mass ratio] 


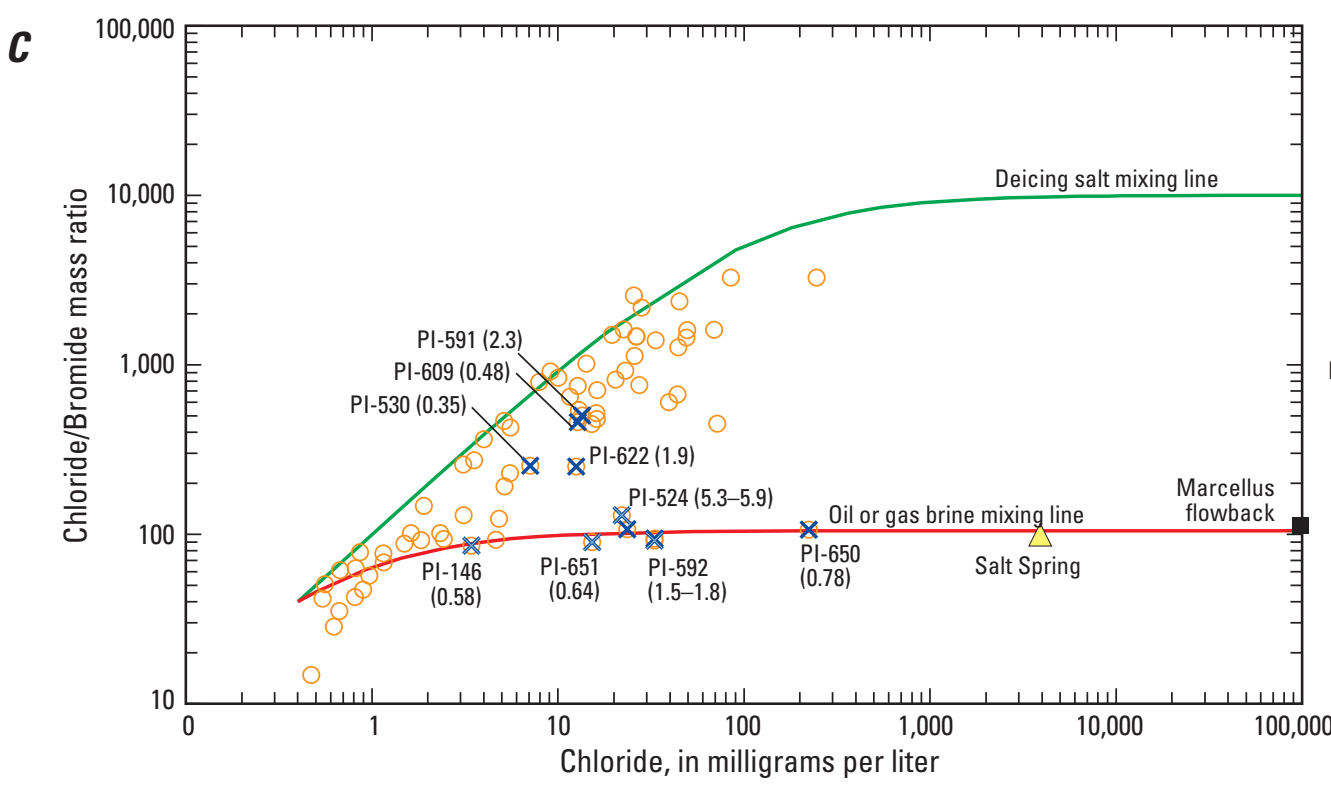

D

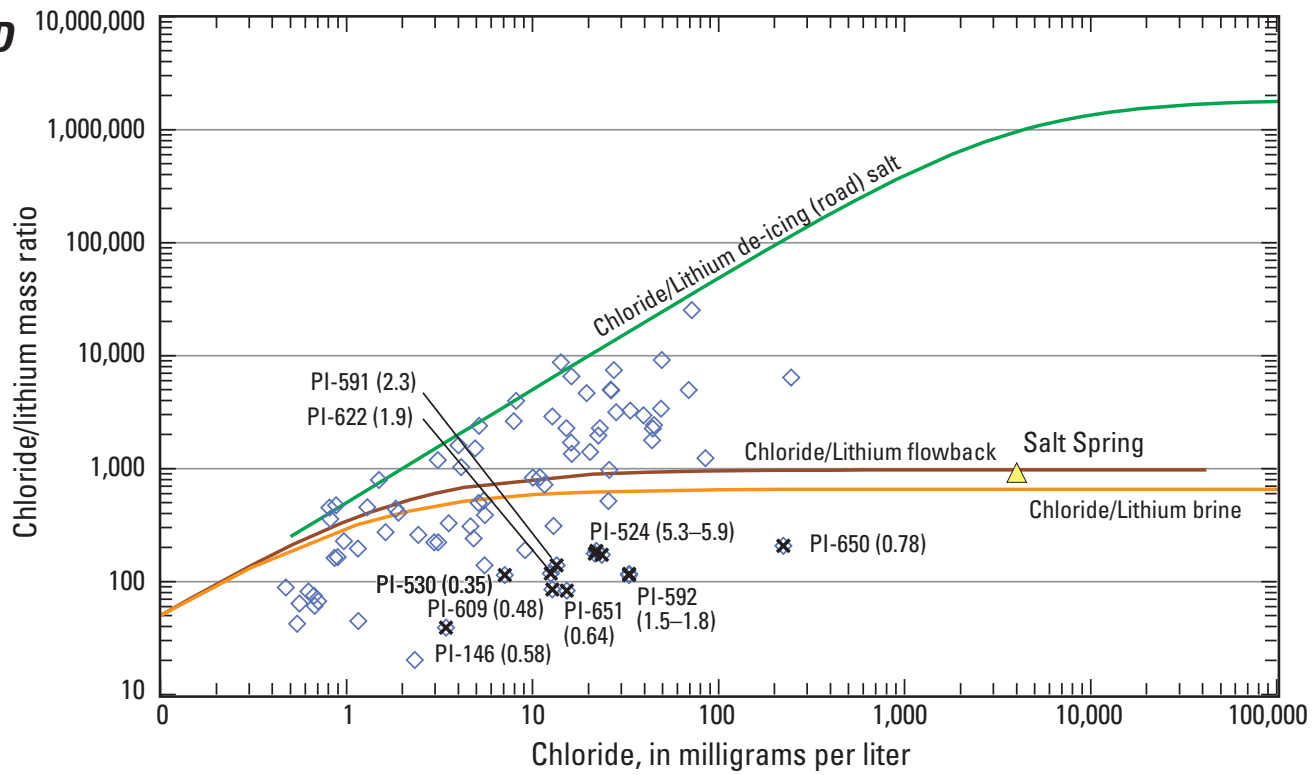

EXPLANATION

Range of methane concentrations in milligrams per liter $(\mathrm{mg} / \mathrm{L})$ in Pike County, 2015, groundwater samples; wells with greater than $(>) 0.3 \mathrm{mg} / \mathrm{L}$ methane identified by U.S.Geological Survey local well number and

(methane concentrations determined by Seewald Laboratories, Inc.)

$\bigcirc$ Methane $<0.3 \mathrm{mg} / \mathrm{L}$ $\mathrm{PI}-650 \times$ Methane $>0.3 \mathrm{mg} / \mathrm{L}$

(Note: bromide by Weck Laboratories, Inc.used to calculate chlorid/bromide ratio)

\section{EXPLANATION}

Range of methane concentrations in milligrams per liter $(\mathrm{mg} / \mathrm{L})$ in Pike County, 2015, groundwater samples; wells with greater than (>) $0.3 \mathrm{mg} / \mathrm{L}$ methane identified by U.S.Geological Survey local well number and

(methane concentrations determined by Seewald Laboratories, Inc.)

$\diamond$ Methane $<0.3 \mathrm{mg} / \mathrm{L}$ $\mathrm{Pl}-622 \times$ Methane $>0.3 \mathrm{mg} / \mathrm{L}$

Figure 30. Relation of chloride concentrations to $A$, sodium concentrations, $B$, bromide concentrations, $C$, chloride/bromide mass ratios, and $D$, lithium/chloride mass ratios in groundwater samples with and without methane concentrations greater than 0.3 milligrams per liter collected from 79 wells in Pike County, Pennsylvania, 2015, plus median values for Salt Spring, flowback waters from Marcellus Shale gas wells, and oil- and gas-field brines from western Pennsylvania. Mixing lines were computed for initial freshwater with chloride concentration of $0.4 \mathrm{mg} / \mathrm{L}$ and bromide concentration of $0.01 \mathrm{mg} / \mathrm{L}$ mixed with road deicing salt having composition $\mathrm{NaCl}_{0.9996} \mathrm{Br}_{0.00004}$ or with median composition of oil- and gas-field brine. Salt Spring values from Llewellyn (2014) and Warner and others (2012). Flowback water values from Marcellus Shale gas wells from Hayes (2009). Oil- and gas-field brine values from Dresel and Rose (2010). Road salt composition from Llewellyn (2014). [CI/Li, chloride/lithium mass ratio]—Continued 
The chloride/bromide mass ratio for saline water (Salt Spring) in Susquehanna County, Pa., is approximately 100 and is similar to the range of ratios reported for Salt Spring, which is a naturally occurring saline spring in Susquehanna County, and associated Appalachian Basin brine, as well as Marcellus Shale produced (flowback) waters and oil- and gas-field brines from Pennsylvania (table 1; fig. 30; Reilly and others, 2015).

Most of the Pike County well-water samples plot on or near the mixing-line curve representing chloride/bromide mass ratios that would result from addition of a low-bromide source of chloride, such as sodium chloride in deicing salt (road salt) or septic systems, to the groundwater (fig. 30C). However, several Pike County well-water samples (with bromide concentrations greater than $0.030 \mathrm{mg} / \mathrm{L}$ ) plot near or on the mixing-line curve for brines (including Salt Spring, a naturally occurring saline spring in Susquehanna County, and oil and gas field brines) (figs. $30 \mathrm{~A}$ and $\mathrm{C}$ ), indicating a possible small contribution of chloride and bromide from a brine-like source. As chloride concentrations increase, the chloride/ bromide mass ratios in these groundwater samples appear to stabilize on the brine mixing line at values of about 100 to 120 (fig. 30C). Pike County samples plotting on the brine mixing line with chloride concentrations as low as $3 \mathrm{mg} / \mathrm{L}$ have chloride/bromide mass ratios that are similar to those of the brines, indicating a source of chloride that is similarly enriched in bromide.

Six of the 10 water samples with methane concentrations greater than $0.3 \mathrm{mg} / \mathrm{L}$ (as determined by Seewald Laboratories, Inc.) are among those samples plotting on the brine mixing line (fig. 30C). The other four samples with relatively elevated methane plot between the road-deicing and brine mixing lines, which indicates that chloride from the two different sources is present in these samples. Also plotting on the brine mixing line is Salt Spring (fig. 30C). These methane and chloride/ bromide relations are similar to those for 20 groundwater samples collected in 2012 in Sullivan County (Sloto, 2013) and 117 groundwater samples collected during 2013-14 in Wayne County (Sloto, 2014; Senior and others, 2016), where relatively elevated methane concentrations (greater than $1 \mathrm{mg} / \mathrm{L}$ ) also were present in well-water samples that plot on the brine mixing line. The association of relatively elevated methane with chloride/bromide ratios on the brine mixing line confirms previous results for 20 groundwater samples collected in 2012 in Pike County (Senior, 2014). These findings indicate that groundwater with relatively elevated bromide and methane concentrations is present locally in northeastern Pennsylvania.

Although most of the Pike County well-water samples have chloride/bromide mass ratios that plot along the mixing curve for low-bromide salt $(\mathrm{NaCl})$ (fig. $30 C$ ), the concentrations of chloride are not balanced by equivalent amounts of sodium (fig. 30A). Many samples, including the 10 samples with relatively elevated methane $(>0.3 \mathrm{mg} / \mathrm{L})$, contain excess sodium relative to chloride, indicating sources for sodium other than salt. The most likely sources of this excess sodium, as explained previously in section "Evolution of Chemical Composition and Conceptual Hydrogeochemical Model," are residual sodium on cation exchange sites on clay minerals in the aquifer and, to a lesser extent, dissolution of sodium-bearing silicate minerals. Other samples have excess chloride relative to sodium, which may indicate the presence of calcium or magnesium chloride, compounds also used for deicing roads. Salt Spring, a naturally occurring saline water with brine characteristics, has only a slight excess of chloride relative to sodium compared to pure $\mathrm{NaCl}$ salt.

Lithium concentrations may be relatively elevated in brines (table 1) and are positively correlated with methane concentrations in groundwater samples in Pike County and nearby Wayne County (Senior and others, 2016). Like $\mathrm{Cl} / \mathrm{Br}$ mass ratios, the plot of chloride/lithium $(\mathrm{Cl} / \mathrm{Li})$ mass ratio in relation to chloride concentration (fig. 30D) shows that samples with relatively elevated methane have $\mathrm{Cl} / \mathrm{Li}$ mass ratios equal to about 100 . However, unlike the $\mathrm{Cl} / \mathrm{Br}$ mass ratios for these samples which are similar to those for brines (fig. 30C), the $\mathrm{Cl} / \mathrm{Li}$ mass ratios in the groundwater samples with relatively elevated methane are much lower than those for brines (table 1; fig. 30D; Macpherson, 2015), indicating that much of the lithium in these samples probably is from a source other than brines. Lithium, like sodium, may become enriched in groundwater through cation exchange. Shale and clay minerals may be a source of lithium (Macpherson, 2015). The association between lithium and methane may indicate that methane is present in relatively older water that has undergone extensive chemical reactions as indicated by elevated $\mathrm{pH}$ and concentrations of sodium and lithium.

\section{Correlations Among Major and Trace Constituents in Groundwater}

Correlations between individual constituents, as determined by the Spearman-rho rank correlation coefficient, assist in identifying chemical controls on and associations between constituents. Values of the Spearmanrho rank correlation coefficient greater than 0.42 (positive correlation) or less than -0.42 (negative correlation) generally indicate statistically significant correlations on the basis of corresponding p-values less than or equal to 0.0001 for the 79 groundwater samples (Appendix 3, table 3-1). Certain variables, such as $\mathrm{pH}, \mathrm{DO}$, and TDS, correlated with numerous other constituents, whereas others, such as barium, beryllium, cobalt, and gross alpha activity correlated with few other constituents. The relations between $\mathrm{pH}$ and $\mathrm{DO}$ and other constituents reflect geochemical controls of these variables. Constituents with few values greater than the reporting level, such as beryllium and other trace elements and gross alpha radioactivity, tend to be poorly or not correlated with other constituents. The sparsity of correlations between barium and other variables indicate processes other than, or in addition to, chemical controls affect barium distribution in groundwater. Boxplots included in Appendix 3 show the relations among selected individual constituents with $\mathrm{pH}, \mathrm{SC}$, and redox class intervals. 
Principal component analysis (PCA) is a statistical technique used to indicate intercorrelations among multiple chemical constituents and environmental variables that may provide further insight into hydrochemical processes affecting groundwater chemistry in the study area. Five principal components (PCs) explain about 81.3 percent of the variance in the groundwater dataset and consist of loadings (correlations of individual variables to PCs) for 22 commonly detected constituents (table 10). Associations of 15 additional chemical and physical variables excluded from the statistical (PCA) model because of few detections, redundancy, or other reasons are indicated by the Spearmanrho rank coefficient of correlation of these variables with the principal component scores, which are listed below the PCA model constituents with loading values in table 10. Positive correlations or loadings indicate that as the values of one constituent increases, the value of the correlated constituent also increases; negative correlations and loadings indicate that as the value of one constituent increases, the value of the correlated constituent decreases.

The first principal component, PC1, accounts for most of the variance of the data (35.2 percent) and is labeled " $\mathrm{pH}$ " (table 10) because many of the correlated constituents are interpreted to represent weathering and cation exchange processes as groundwater composition evolves, increasing in $\mathrm{pH}$ and becoming more reducing. PC1 has statistically significant positive loadings of $\mathrm{pH}$, fluoride, alkalinity, boron, sodium, lithium, and SC and negative loadings of DO and nitrate (table 10). Some of these relations can be seen in plots of constituents in relation to $\mathrm{pH}$ (fig. 26; Appendix 3). The negative associations of PC1 with DO and nitrate and positive associations with $\mathrm{pH}$ and alkalinity are consistent with the conceptual model of older, more evolved groundwater. As recharge passes through the soil zone into the underlying fractured rock aquifer, oxygen and nitrate are reduced by oxidation of organic matter, and $\mathrm{pH}$ and alkalinity increase as groundwater interacts with soil and aquifer materials. Groundwater becomes more mineralized, alkaline, and "softened" through cation exchange (lower in calcium and magnesium and higher in sodium) along flow paths from recharge areas in uplands to discharge areas in valleys. With the addition of sodium and the removal of calcium and magnesium from solution, the groundwater can become undersaturated with respect to calcite and dolomite, thus promoting additional dissolution of the carbonate minerals and progressive increases in $\mathrm{pH}$ and alkalinity. The resultant sodium-bicarbonate waters have alkaline (basic) $\mathrm{pH}$ values and high positive scores on PC1. Scores on PC1 are positively correlated with molybdenum, methane, and TDS and negatively correlated with zinc, copper, lead, and nickel (table 10). The positive scores for molybdenum and negative scores for zinc, copper, lead, and nickel reflect differences in mobilities of these metals under various $\mathrm{pH}$ conditions. Molybdenum tends to be mobile as an oxyanion in water with alkaline $\mathrm{pH}$ (values $>7$ ) and the other metals tend to be mobile as cations in water with acidic $\mathrm{pH}$ (values $<6$ ) but immobile owing to their adsorption by mineral surfaces at alkaline $\mathrm{pH}$ or by cation exchange. The higher concentrations of methane tend to be present in the higher $\mathrm{pH}$, apparently older groundwater. Of the constituents with loadings for PC1, methane correlates most strongly with lithium (Appendix 3, table 3-1). Lithium, a monovalent cation like sodium, may become progressively elevated in groundwater through cation exchange processes along the flow path. Boxplots in Appendix 3 indicate that PC1 scores increase progressively with $\mathrm{pH}$ class (fig. 3-1) and are highest for samples with $\mathrm{SC}$ greater than $400 \mu \mathrm{S} / \mathrm{cm}$ at $25^{\circ} \mathrm{C}$ but less than $1,600 \mu \mathrm{S} / \mathrm{cm}$ at $25^{\circ} \mathrm{C}$ and classified as anoxic (fig. 3-3).

PC2 is labeled "Redox" (table 10) because positive loadings and positively correlated constituents are interpreted to indicate reducing conditions, and negative loadings and negatively correlated constituents indicate oxidizing conditions. PC2, which explains 15.6 percent of the variance in the data, has positive loadings for dissolved iron and manganese and negative loadings for $\mathrm{DO}$, nitrate, and radon222 (table 10). Scores on PC2 are positively correlated with ammonia and negatively correlated with copper and selenium, which likely reflect that reducing conditions favor ammonia as reduced form of nitrogen and that copper and selenium are more soluble in oxic (and, for copper, the associated acidic) waters. Most samples that had positive scores for PC2 were classified as anoxic (DO less than or equal to $0.5 \mathrm{mg} / \mathrm{L}$ ) (Appendix 3, fig. 3-3). High positive scores on PC2 are interpreted to indicate isolation from the atmosphere and the development of reducing conditions through reactions that deplete oxygen and nitrate and increase dissolved iron and manganese concentrations in groundwater. The reductive dissolution of iron and manganese oxides typically is coupled with the oxidation of organic compounds after supplies of DO, nitrate $\left(\mathrm{NO}_{3}^{-}\right)$, and nitrite $\left(\mathrm{NO}_{2}^{-}\right)$have been depleted but before the development of sulfate-reducing conditions that can result in precipitation of sulfide minerals (Ehrlich, 1990; Stumm and Morgan, 1996; Drever, 1997; McMahon and Chapelle, 2008). Possible explanations for the negative loading of radon-222 on PC2 could include (1) the lack of potential iron or manganese oxide sorption sites for radium-226, parent (and source) of radon-222, under reducing conditions or (2) the possible tendency of concentrations of radon-222, a short-lived radionuclide, to be higher in groundwater that is younger and less isolated from the atmosphere than groundwater with high scores on PC2.

PC3 is labeled "Hardness" (table 10) because positive loadings and correlations are interpreted to indicate processes that increase hardness in groundwater. PC3, which explains 10.0 percent of the variance in the data, has positive loadings for magnesium, calcium, silica, sulfate, and specific conductance (table 10). Scores on PC3 are positively correlated with hardness, uranium, and dissolved solids [TDS and residue on evaporation (ROE)]. High positive scores on PC3 can be attributed to the dissolution of calcite, dolomite, gypsum, and possibly, calcium- and (or) magnesium-bearing aluminosilicates such as chlorite, and pyrite or other sulfide 
Table 10. Principal components analysis model of major factors controlling the chemistry of groundwater and statistically significant Spearman rank correlations of other variables with those factors determined from chemical properties of and dissolved concentrations of constituents in groundwater samples from 79 wells, Pike County, Pennsylvania, 2015.

[Varimax rotation factor pattern for rank-transformed data (SAS Institute, 2012); minimum eigenvalue >1; loading values multiplied by 100 and rounded; shading indicates significant loadings ( $\mathrm{p}<0.0001$ ); $\mathrm{Sr}-\mathrm{Li}$, strontium-lithium; $\mathrm{Cl}-\mathrm{Br}$, chloride-bromide; Ba-K, barium-potassium; PC, principal component; .., indicates Spearman correlation not significant at $\mathrm{P}<0.001]$

\begin{tabular}{|c|c|c|c|c|c|c|c|}
\hline Constituent loadings: & $\mathrm{pH}$ & Redox & Hardness & Sr-Li & $\mathrm{Cl}-\mathrm{Br}$ & \begin{tabular}{|l|} 
Ba-K \\
PC6
\end{tabular} & $\begin{array}{c}\text { Commu } \\
\text { nality }\end{array}$ \\
\hline & PC1 & PC2 & PC3 & PC4 & PC5 & reo & \\
\hline Fluoride (F) & 87 & 25 & -10 & -2 & -1 & -9 & 0.835 \\
\hline $\mathrm{pH}(\mathrm{pH})$ & 84 & 22 & 0 & 32 & 1 & 16 & 0.884 \\
\hline Alkalinity (ALK) & 83 & 13 & 28 & 12 & 20 & 9 & 0.856 \\
\hline Manganese (Mn) & 13 & 90 & 12 & 11 & 11 & 2 & 0.865 \\
\hline Iron $(\mathrm{Fe})$ & 16 & 89 & 4 & -8 & 9 & -8 & 0.841 \\
\hline Dissolved oxygen (DOX) & -53 & -60 & -19 & -22 & -7 & -20 & 0.771 \\
\hline Nitrate (NO3N) & -59 & -66 & 2 & -17 & 15 & -10 & 0.851 \\
\hline Magnesium (Mg) & 5 & 10 & 89 & -9 & 23 & 2 & 0.857 \\
\hline Calcium (Ca) & 5 & -4 & 87 & 6 & 17 & 19 & 0.827 \\
\hline Silica (SIO2) & 7 & 29 & 72 & 23 & -19 & 6 & 0.705 \\
\hline Strontium (Sr) & 32 & 4 & 25 & 70 & 24 & 39 & 0.856 \\
\hline Lithium (Li) & 50 & 2 & 9 & 69 & 35 & 25 & 0.913 \\
\hline Sulfate (SO4) & -17 & -24 & 55 & 63 & 9 & -17 & 0.819 \\
\hline Boron (B) & 59 & 1 & 1 & 60 & 36 & -6 & 0.846 \\
\hline Radon 222 (Rn222) & -20 & -39 & 5 & -75 & -17 & 6 & 0.781 \\
\hline Chloride (Cl) & -25 & -11 & 30 & 21 & 78 & 8 & 0.823 \\
\hline Bromide (Br) & 10 & 15 & -5 & 11 & 77 & 5 & 0.645 \\
\hline Specific conductance (SCL) & 39 & 2 & 47 & 24 & 69 & 9 & 0.92 \\
\hline Sodium $(\mathrm{Na})$ & 55 & 20 & 3 & 22 & 68 & -1 & 0.859 \\
\hline Barium (Ba) & 5 & 13 & -6 & 35 & 12 & 83 & 0.848 \\
\hline Potassium (K) & -9 & -21 & 7 & -20 & 21 & 70 & 0.638 \\
\hline Arsenic (As) & 24 & 13 & 29 & 1 & -22 & 66 & 0.641 \\
\hline Eigenvalue: & 7.735 & 3.428 & 2.21 & 1.794 & 1.432 & 1.281 & 17.881 \\
\hline Percent variance explained & 35.2 & 15.6 & 10.0 & 8.2 & 6.5 & 5.8 & \\
\hline Cumulative percent variance explained: & 35.2 & 50.7 & 60.8 & 68.9 & 75.5 & 81.3 & \\
\hline \multicolumn{8}{|c|}{ Significant Spearman Correlations ( $p<0.001)$ : } \\
\hline $\mathrm{pH}, \mathrm{Lab}(\mathrm{pHL})$ & 85 & .. & .. & .. & .. & .. & .. \\
\hline Molybdenum (Mo) & 78 & .. & .. & .. & .. & .. & .. \\
\hline Methane (Methane) & 49 & .. & .. & .. & .. & .. & .. \\
\hline Total dissolved solids (TDS) & 43 & .. & 48 & .. & 66 & .. & .. \\
\hline Nickel (Ni) & -48 & .. & .. & .. & .. & .. & .. \\
\hline Copper (Cu) & -53 & -58 & .. & .. & .. & .. & .. \\
\hline Lead $(\mathrm{Pb})$ & -54 & .. & .. & .. & .. & .. & .. \\
\hline Zinc (Zn) & -58 & .. & .. & .. & .. & .. & .. \\
\hline Ammonia (NH3N) & .. & 52 & .. & .. & .. & .. & .. \\
\hline Selenium (Se) & .. & -63 & .. & .. & .. & .. & .. \\
\hline Hardness (Hard) & .. & .. & 91 & .. & .. & .. & .. \\
\hline Uranium (U) & .. & .. & 53 & .. & .. & .. & .. \\
\hline Residue on Evaporation 180C (ROE180) & .. & .. & 51 & .. & 68 & .. & .. \\
\hline Specific conductance, field (SCF) & .. & .. & 49 & .. & 69 & .. & .. \\
\hline Land surface elevation (LSELEV) & .. & .. & .. & .. & .. & 46 & .. \\
\hline
\end{tabular}


minerals without the cation-exchange softening effects (alkaline $\mathrm{pH}$ ) indicated by high scores on PC1. Boxplots in Appendix 3 indicate that PC3 scores are highest for samples with $\mathrm{pH}$ greater than 7.4 but less than 7.9 (Appendix 3, fig. 3-1); PC3 scores increase progressively with SC (fig. 3-2) but are distributed among the redox classes (fig. 3-3). The positive correlation with uranium is consistent with its mobilization as the uranyl-carbonate complex, whereas positive association of sulfate implies intermediate redox conditions. Uranium mineralization at some locations in the Catskill Formation in northeastern Pennsylvania is associated with copper and iron sulfides (Klemic, 1962), potentially providing sources of sulfate where uranium is present.

PC4 is labeled "Sr-Li" for strontium-lithium (table 10) because positive loadings are for constituents strongly correlated with strontium and lithium. PC4, which explains 8.2 percent of the variance in the data, has negative loadings for radon-222, which is the most strongly associated constituent, and positive loadings for strontium, lithium, sulfate, and boron (table 10). Boxplots in Appendix 3 indicate that samples with the highest PC4 scores have $\mathrm{pH}$ greater than 7.4 (Appendix 3, fig. 3-1) and SC greater than $400 \mu \mathrm{S} / \mathrm{cm}$ at $25^{\circ} \mathrm{C}$, and are classified as anoxic (fig. 3-3). Additional boxplots for bedrock geology (fig. 3-4) indicate PC4 scores are generally higher for the water samples from wells completed in the Mahantango Formation (344MNNG) and Marcellus Shale (344MRCL) compared to those completed in other less shaley, sandstone-dominated units higher in the section (fig. 3-4; table 3). The younger sandstone-dominated units are exposed in the western, higher elevation areas of the county, whereas the shaley units are exposed in the eastern, lower elevations, corresponding to recharge and discharge areas, respectively, for regional groundwater (west to east flow paths). Thus, high scores on PC4 could be interpreted to indicate geochemically evolved water near the discharge area that contains strontium, lithium, and sulfate. Dissolution and ion exchange may enrich Sr and Li concentrations, resulting in progressively higher PC4 scores along the groundwater flow path. Low radon-222 activities may be related to sparsity (or limited surface availability) of radium-226 in aquifer materials. Such conditions may be associated with moderately reducing environments where sulfate remains stable but where iron (FeIII) and manganese (MnIII-IV) oxides are not available to sorb radium and where any previously released radon has disintegrated to low values.

PC5, which explains 6.5 percent of the variance in the data, is labeled "Cl-Br" for chloride-bromide (table 10) because it has positive loadings, in order of magnitude, for chloride, bromide, SC, and sodium. Scores on PC5 are positively correlated with TDS (and ROE) and tend to be greatest for the water samples collected from wells completed in the Mahantango Formation (344MNNG) and Marcellus Shale (344MRCL) (Appendix 3, fig. 3-4; table 3). Loadings and correlations for PC5 provide information about various possible sources of chloride and bromide. The strong positive association between chloride and bromide indicates a possible contribution of Appalachian Basin brine to the groundwater of associated well-water samples. However, few samples have elevated chloride and bromide, which produces statistically weak associations with the geology. Furthermore, the additional correlations with sodium indicate possible manmade sources of contamination, such as septic-system effluent or road-deicing salt, which could affect samples throughout the county, and the possible effect of cation exchange on the samples that have high scores on PC5. The relations between chloride and other constituents associated with PC5 indicate that chloride (and sodium) appears to be from multiple sources (high-bromide brine source and low-bromide man-made sources), as discussed in section "Ratios of Chloride, Bromide, Sodium, and Lithium in Groundwater" and shown on the sodium, bromide, chloride, and chloride/bromide ratio plots (fig. 30A-C).

PC6, which explains 5.8 percent of the variance in the data, is labeled "Ba-K" for barium-potassium (table 10) because it has positive loadings, in order of magnitude, by barium, potassium, arsenic, and strontium (table 10). Scores on PC6 are positively correlated with land-surface altitude and are highest for Catskill Formation bedrock geologic units that predominate in the western, higher elevation parts of the county [Appendix 3, fig. 3-4, Poplar Gap and Packerton Members (341PGPK); Lackawaxen Member (341LCKX); and Delaware River Member (341DLRV) of Catskill Formation]. The positive associations of these cations and land-surface altitude could indicate a common origin (source minerals within the aquifer in high-elevation parts of the county) or geochemical control. For example, barium, potassium, and strontium commonly substitute for calcium in carbonate (aragonite) minerals and one another in sulfate (barite-celestine) minerals, which could be possible sources or sinks of the cations (Hanor, 1968; Hanshaw and Back, 1979). Additionally, these cations generally will be more strongly retained than sodium and lithium, but less strongly than calcium and magnesium, by clay minerals involved in cation-exchange (Appelo and Postma, 2005) and, thus, may be released as the exchange sites become depleted in sodium and lithium and enriched in calcium and magnesium.

Barium and strontium also are present in high concentrations in brines (table 1), but the association of these constituents with PC6 rather than with PC5, the chloridebromide factor indicative of brines, indicates only a limited link between barium and strontium and brines in Pike County groundwater. The mass ratio of barium and strontium in relation to magnesium $[(\mathrm{Ba}+\mathrm{Sr}) / \mathrm{Mg}$ mass ratio] has been used to identify sources of regional brine and road salt in northern Susquehanna County and vicinity, with $(\mathrm{Ba}+\mathrm{Sr}) / \mathrm{Mg}$ mass ratio values greater than about 0.2 , indicating contributions of brine to groundwater and streams (Johnson and others, 2015). In the Pike County groundwater samples, the $(\mathrm{Ba}+\mathrm{Sr}) /$ $\mathrm{Mg}$ mass ratio generally increased with $\mathrm{pH}$ from values near $0.01-0.1$ at acidic $\mathrm{pH}$ (less than 6.5) to values near 0.1-1.2 at $\mathrm{pH}$ of 8 and greater (fig. 31), with some exceptions that may be related to local aquifer mineralogy, indicating possible 


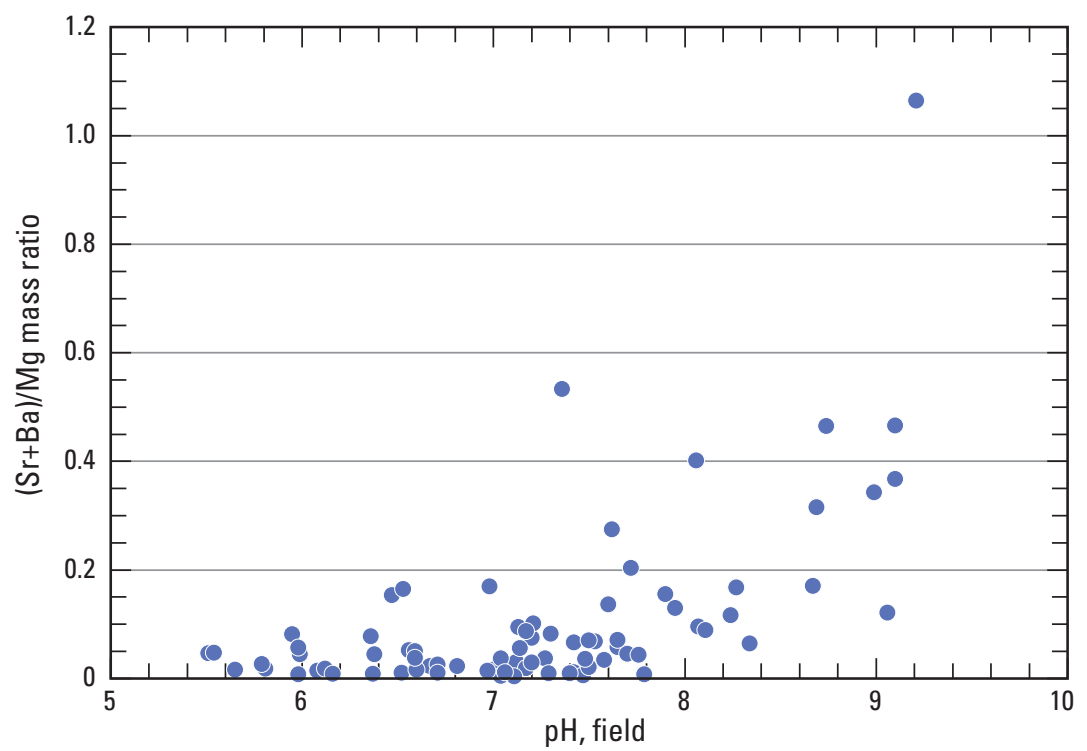

Figure 31. Relation of $\mathrm{pH}$ to mass ratios of (Strontium + Barium)/Magnesium in groundwater samples collected from 79 wells in Pike County, Pennsylvania, 2015. [Sr, strontium; Ba,barium; Mg, magnesium]

small contributions of barium and strontium in samples with pH 8 or greater. However, some of the increase in barium and strontium with $\mathrm{pH}$ may be related to dissolution of bariumand strontium-bearing minerals or cation exchange. Thus, barium and strontium may not be conservative tracers for the presence of brines in groundwater because these constituents may be removed from or added to solution through processes of ion exchange (like other alkaline earth metals such as calcium) or mineral dissolution and precipitation.

\section{Spatial Distribution of Groundwater Quality and Relation to Hydrogeologic Setting}

The observed distributions of water types, $\mathrm{pH}$, methane, and trace elements, such as lithium, vary spatially throughout Pike County and, in some cases, exhibit apparent relations to hydrogeologic setting. In the highlands along the southwestern areas of Pike County, groundwater tends to be relatively more dilute, with lower $\mathrm{pH}$, and higher $\mathrm{DO}$ concentrations than in other areas; the highlands areas correspond to the uplands recharge area on the generalized conceptual schematic diagram of groundwater flow (fig. 27). Sandstone is the predominant bedrock lithology at the land surface in the highlands, whereas shale is the predominant bedrock lithology at the land surface in the lowlands. At lower elevations in Pike County, groundwater has higher $\mathrm{pH}$, dissolved solids, alkalinity, and hardness; these areas correspond to the intermediate flow zone on the generalized conceptual schematic diagram (fig. 27). This schematic diagram is similar to that presented by Siegel and others (2015) for a generalized
Appalachian Plateau hydrogeologic setting, which would pertain to Pike County.

In selected stream valleys (Lackawaxen Creek) and (or) near the Delaware River in Pike County, some groundwater samples had high $\mathrm{pH}$ (greater than 8) and elevated concentrations of sodium, lithium, boron, bromide, fluoride, and methane; these areas correspond to the valley settings on the generalized conceptual schematic diagram in figure 27, where groundwaters from shallow local, intermediate, and deep regional flow zones mix. Similar occurrences of relatively elevated methane in groundwater associated with valley hydrogeologic settings have been reported for nearby areas in New York with similar geology. In a study of methane in groundwater in Upper Devonian shale bedrock in southcentral New York, methane concentrations were found to differ by hydrogeologic setting with the highest concentrations measured in water from wells in confined valley settings and the lowest concentrations in water from wells in upland unconfined settings (Heisig and Scott, 2013).

Statistically significant correlations indicated an inverse relation between the altitude of the well bottom (calculated by subtracting well depth from land-surface altitude) and pH, SC, TDS, sodium, lithium, boron, and water temperature (Appendix 3, table 3-1). These correlations support the conceptual model (fig. 27) by showing that the more chemically evolved waters, characterized by alkaline $\mathrm{pH}$, elevated SC, and reducing conditions, tend to be present at lower elevations that correspond to intermediate and regional groundwater discharge areas at the end of groundwater flow paths in the aquifer. The inverse relation between water temperature and well-bottom altitude may indicate the 
presence of deeper, warmer (geothermally affected), and likely older water at lower elevations than at higher elevations; differences in recharge temperature may also contribute to this inverse relation, with colder water being recharged at higher elevations than at lower elevations.

In Pike County, the topographic setting is related to underlying geologic unit lithology and structure and affects groundwater flow paths. Additionally, the chemical composition of water differs among the geologic units because of differences in lithology and position along groundwater flow paths. Differences in chemical composition among the geologic units are shown in boxplots (see Appendix 3, fig. 3-4); boxplots of selected constituents are shown in figure 32 in relation to geologic units. Data in boxplots are displayed in stratigraphic order, from youngest to oldest geologic units, which corresponds to the spatial distribution of youngest bedrock units in the west to oldest bedrock units in the east. The single sample from a well completed in youngest geologic formation (glacial deposits rather than bedrock) is plotted on the far right of the boxplots; this well was completed in glacial deposits overlying the Mahantango Formation in eastern Pike County. Concentrations of some constituents and properties appear to show trends by order of formation. From left to right on boxplots, corresponding to the sequence of youngest to oldest bedrock units (or west to east) and uplands to lowlands, values of $\mathrm{pH}$, SC, and water temperature, and concentrations of TDS, sodium, fluoride, sulfate, boron, and lithium generally increase, but land-surface and well-bottom altitudes and concentrations of dissolved oxygen, potassium, and radon-222 generally decrease (fig. 32; fig. A3-4 in Appendix 3).

The spatial distribution of $\mathrm{pH}$ values for samples collected from 79 wells in 2015 shows the lowest $\mathrm{pH}$ values ( $<6.5$, acidic water) in the highlands underlain by the Packerton and Poplar Gap Members, undivided, of the Catskill Formation in southwestern Pike County. The $\mathrm{pH}$ of groundwater in other geologic units generally is near neutral and tends to increase from west to east, and to a more limited extent, and from south to north coincident with decreasing altitude (figs. $2 \mathrm{~A}$ and 6 ). Groundwater with highest $\mathrm{pH}(>8.0$, alkaline water) tends to be present in stream valleys and (or) near the Delaware River. This observed distribution of $\mathrm{pH}$ is consistent (fig. 6) with a conceptual model that shows groundwater in upland areas is young, dilute, and acidic, whereas groundwater in lowland areas (at lower elevations) has higher $\mathrm{pH}$ and TDS acquired through mineral dissolution along flow paths. Groundwater samples with the highest $\mathrm{pH}$ $(>8)$ appear to represent waters that have undergone cation exchange, have mixed with a small amount of brine, and may be mixed with shallow groundwater of more recent origin.
Differences in $\mathrm{pH}$ in relation to altitude are indicated by boxplots showing the distribution in altitudes of well bottoms and land surfaces for four groups of $\mathrm{pH}$ ranges (Appendix 3 , fig. 3-1); the most acidic $(\mathrm{pH}<6.5)$ groundwater is associated with wells in uplands with the highest land-surface and wellbottom altitudes (where well-bottom altitude is calculated by subtracting well depth from land-surface altitude), and the most alkaline groundwater $(\mathrm{pH} \geq 8)$ is associated with wells in lowlands with the lowest land-surface and well-bottom altitudes. Little to no relation between $\mathrm{pH}$ and well depth is indicated by the data (Appendix 3, table 3-1).

Additionally, the spatial distribution of $\mathrm{pH}$ may reflect aquifer mineralogy. For example, the area of low $\mathrm{pH}(<6.5)$ in the uplands along the southwestern border of Pike County (fig. 6) is underlain by geologic units that are more resistant to erosion and, consequently, may contain a smaller amount of relatively soluble minerals (such as calcite in the humid climate of northeastern Pennsylvania) than those geologic units that underlie lowlands.

Other constituents also show upward trends in concentration from west to east, which is similar to the spatial trends in $\mathrm{pH}$. The samples with highest $\mathrm{pH}$ also generally have among the highest alkalinity and concentrations of dissolved methane, sodium, lithium, boron, bromide, and fluoride (fig. 26). Most of these constituents, as identified through statistical analysis, correlate with each other and generally group together (factor PC1). Of these constituents, methane concentrations are most strongly correlated with lithium concentrations (Appendix 3, table 3-1). Elevated lithium concentrations show a strong relation to elevated methane concentrations and are present in samples with the highest $\mathrm{pH}$, mostly in stream valley settings (figs. 6 and 21). Similar relations among constituents were apparent in studies of groundwater quality in nearby Wayne and Sullivan Counties (Senior and others, 2016; Sloto, 2013). The elevated sodium and lithium concentrations may be present as a result of cation exchange along flow paths. The presence of moderately elevated bromide may indicate a small amount of brine mixing with fresh groundwater, which has evolved in chemical composition along groundwater flow paths and discharges to stream valleys.

The spatial trends in radon-222 likely are partly related to differences in lithology and mineralogy (aquifer composition). In general, high concentrations of radon-222 are in western Pike County, and even higher concentrations are in the westward direction in Wayne County, where aquifer materials may be relatively enriched in uranium and daughter products. The presence of uranium associated with an old copper prospect in Waymart Township, west-central Wayne County, was described by Klemic (1962). 

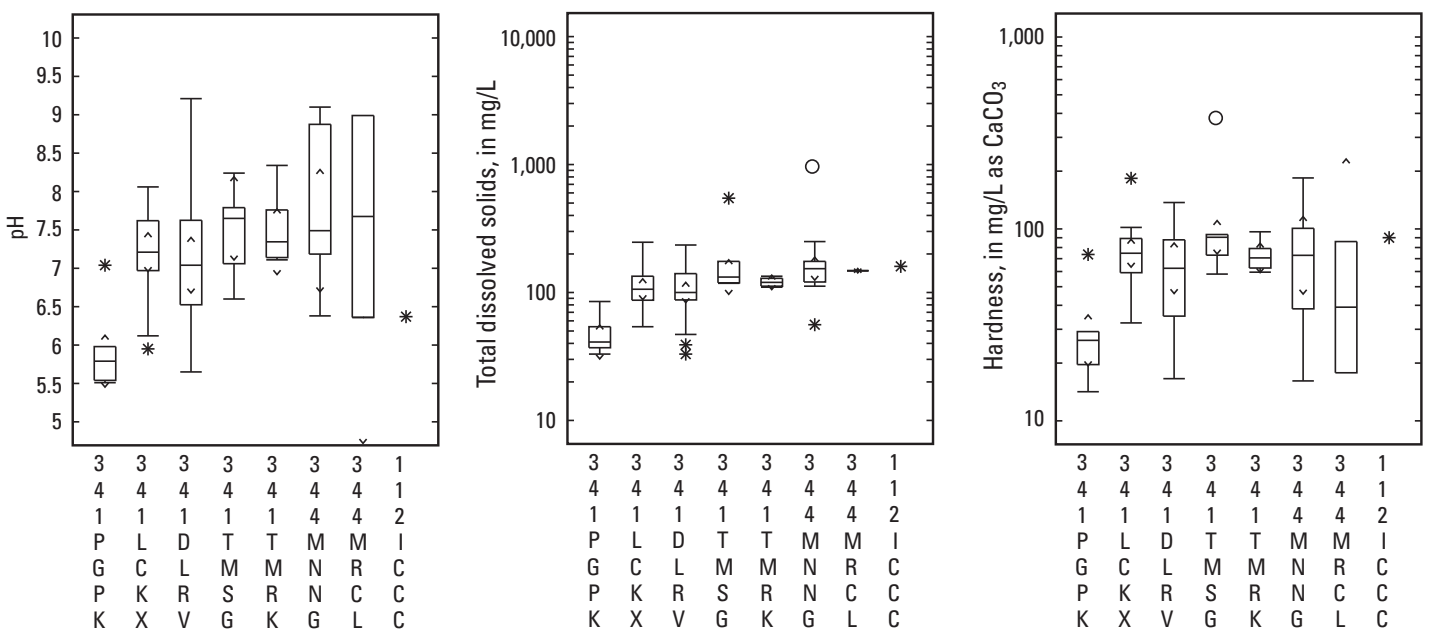

EXPLANATION

Outlier data value

greater than 3 times

the interquartile range

outside the quartile

* Outlier data value less grear or equal to 3 and

the interquartile range

outside the quartile

Data value less than

or equal to 1.5 times

outside the quartile
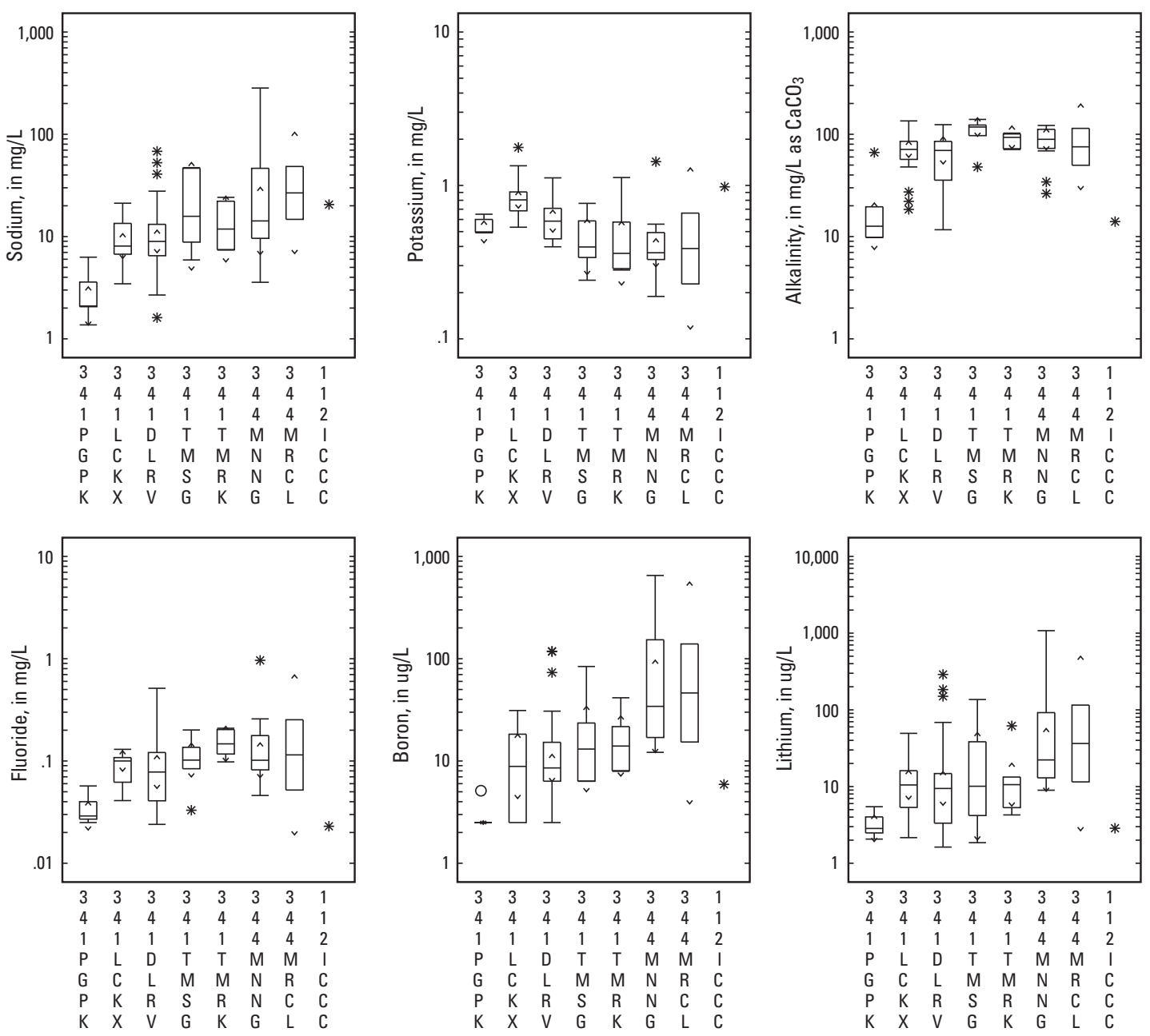

Figure 32. Boxplots showing distribution by geologic formation of $A$, $\mathrm{pH}$ and dissolved concentrations of total dissolved solids, hardness, sodium, potassium, alkalinity, fluoride, boron, and lithium and $B$, dissolved concentrations of iron, manganese, dissolved oxygen, uranium, arsenic, methane, and radon-222, and land-surface altitude and temperature in water samples collected from 79 wells in Pike County, Pennsylvania, 2015. [Altitudes are in feet above North American Vertical Datum 1988. $\mathrm{mg} / \mathrm{L}$, milligrams per liter; ug/L, micrograms per liter; $\mathrm{pCi} / \mathrm{L}$, picocuries per liter; $\mathrm{CaCO}_{3^{\prime}}$ calcium carbonate; Geologic units: 122ICC, Ice contact deposits; 341DLRV, Delaware River Member of the Catskill Formation; 341LCKX, Lackawaxen Member of the Catskill Formation; 341TMSG, Towamensing Member of the Catskill formation; 341TMRK, Trimmers Rock Formation; 344MRCL, Marcellus Shale] 

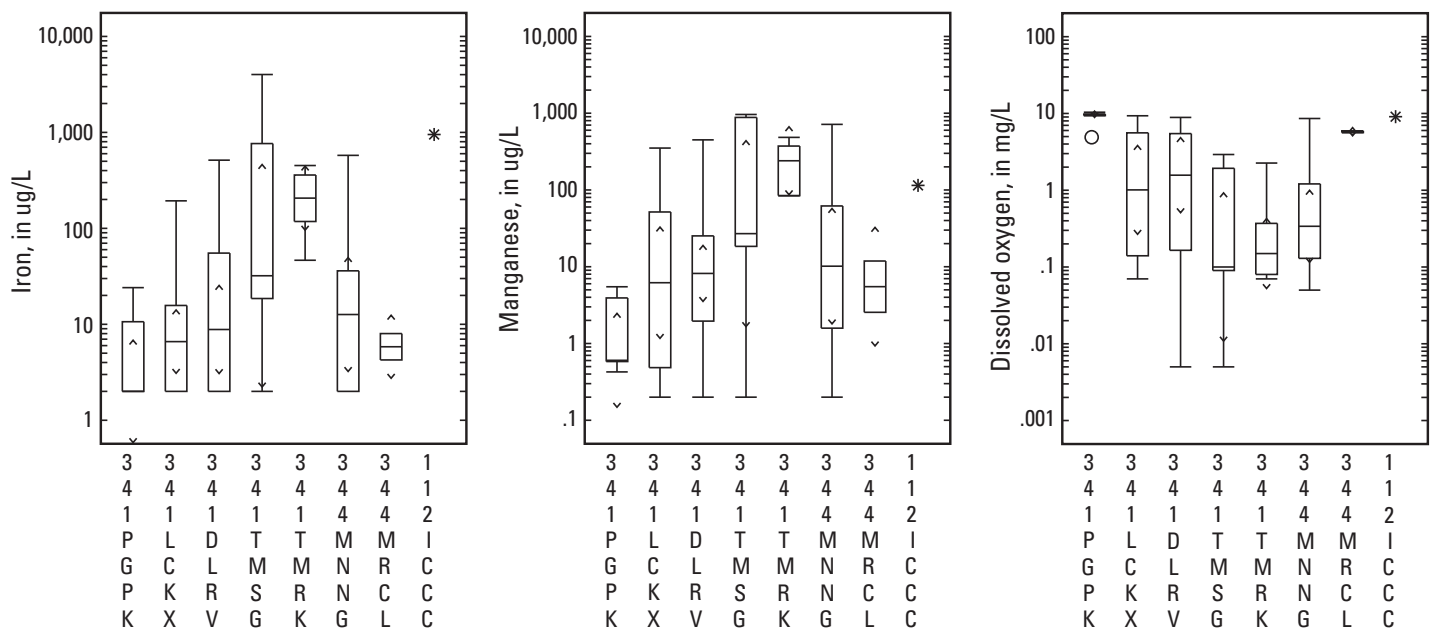

EXPLANATION

O Outlier data value greater than 3 times outside the quartile

* Outlier data value less than or equal to 3 and greater than 1.5 times the interquartile rang outside the quartile Data value less than or equal to 1.5 times

the interquartile range outside the quartile
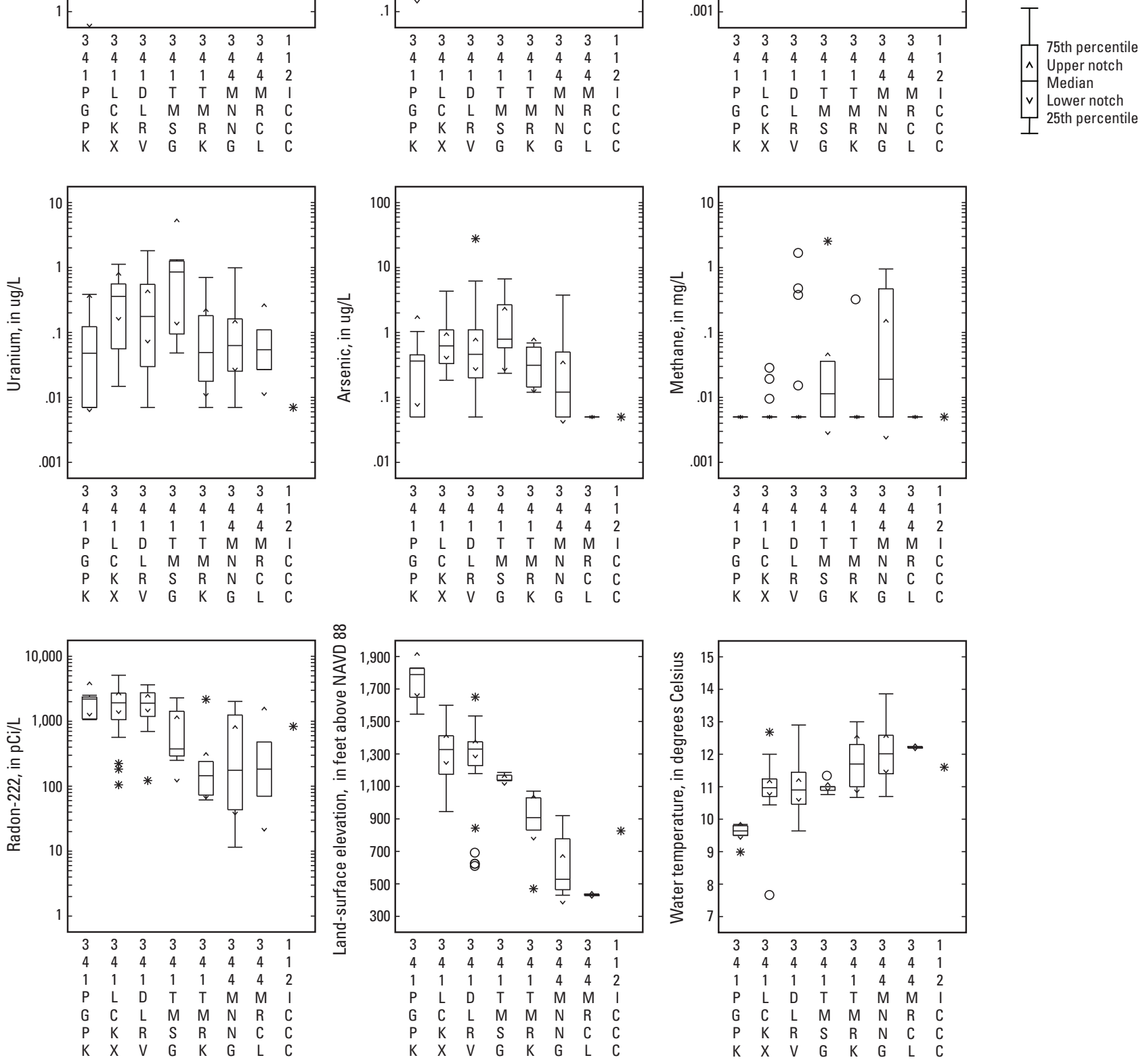

North American Vertical Datum, 1988 (NAVD 88)

Figure 32. Boxplots showing distribution by geologic formation of $A, \mathrm{pH}$ and dissolved concentrations of total dissolved solids, hardness, sodium, potassium, alkalinity, fluoride, boron, and lithium and $B$, dissolved concentrations of iron, manganese, dissolved oxygen, uranium, arsenic, methane, and radon-222, and land-surface altitude and temperature in water samples collected from 79 wells in Pike County, Pennsylvania, June-September 2015. [Altitudes are in feet above North American Vertical Datum 1988. mg/L, milligrams per liter; ug/L, micrograms per liter; $\mathrm{pCi} / \mathrm{L}$, picocuries per liter; $\mathrm{CaCO}_{3^{\prime}}$ calcium carbonate; Geologic units: 122ICC, Ice contact deposits; 341DLRV, Delaware River Member of the Catskill Formation; 341LCKX, Lackawaxen Member of the Catskill Formation; 341TMSG, Towamensing Member of the Catskill formation; 341TMRK, Trimmers Rock Formation; 344MRCL, Marcellus Shale]—Continued 
Other differences in groundwater composition among the various geologic units also may be at least partly related to aquifer composition. Potassium concentrations are highest in groundwater in the Lackawaxen member of the Catskill Formation (fig. 32A), the only geologic unit in Pike County reported to contain orthoclase, a potassium-bearing feldspar mineral. Groundwater in the western non-marine geologic units of the Catskill Formation tends to have higher concentrations of barium than groundwater in the eastern marine geologic units (Trimmers Rock, Mahantango, and Marcellus Formations), but the eastern units have higher sulfate concentrations (Appendix 3, fig. 3-4). The spatial trends in barium and sulfate probably are at least partly affected by differences in mineralogy among the geologic units. Barium was associated with potassium in the principal component analysis (PC6), indicating the possible presence of feldspars with barium substitution for potassium. Sulfate concentrations tend to be highest in the Marcellus Shale, a geologic unit reported to contain pyrite, an iron sulfide mineral that releases sulfate when oxidized.

Some differences in groundwater composition among the geologic units may be related to difference in chemical controls in addition to differences in aquifer mineralogy. Dissolved iron and manganese tend to be highest in the groundwater in the Trimmers Rock Formation (fig. 32B), which also has low dissolved oxygen concentrations that favors mobility of these metals. Concentrations of arsenic, molybdenum, uranium, and alkalinity tend to be highest in groundwater in the Towamensing Member of the Catskill Formation (fig. 32B; Appendix 3, table 3-4), which is reflective of similar chemical characteristics (arsenic and molybdenum) or favorable co-occurrence (uranium carbonate ion is most soluble at $\mathrm{pH}$ of about 7-8).

\section{Local Spatial and Temporal Variability in Groundwater Quality}

\section{Local Spatial Variability}

Samples were collected from seven pairs of closely spaced wells located throughout Pike County to provide data on local variability (Appendix 4, table 4-1). Comparison of water quality between the paired samples shows general similarity for many properties and constituent concentrations, but substantial differences were apparent for some properties and constituents in samples from some pairs. The general relative chemical composition depicted on Piper diagrams is similar for 5 of the 7 paired well samples, although with differences in concentrations, as indicated by differences in $\mathrm{SC}$ ranging from 6 to $238 \mu \mathrm{S} / \mathrm{cm}$ at $25^{\circ} \mathrm{C}$ (fig. 33). The largest apparent differences in general chemical composition were for samples from the well pairs PI-648 near PI-649 and PI-622 near PI-640 (fig. 33). Other differences were observed between the paired samples; for example, differences in $\mathrm{pH}$ ranged from 0 to 2.6, in barium from 1.6 to $208 \mu \mathrm{g} / \mathrm{L}$, in strontium from 13 to $1,496 \mu \mathrm{g} / \mathrm{L}$, in chloride from 4 to $51.4 \mathrm{mg} / \mathrm{L}$, in methane from $<0.01$ to $3 \mathrm{mg} / \mathrm{L}$, and in radon222 from 100 to $1,600 \mathrm{pCi} / \mathrm{L}$.

Some local variability may be related to differences in groundwater flow paths for specific fractures that contribute water to the wells. Factors that affect water quality of these fractures include local land use, aquifer mineralogy, and chemical reactions in the aquifer upgradient from the well. In fractured-rock settings, depths and water quality of waterbearing zones may differ in closely spaced wells, even wells of similar construction.

\section{Temporal Variability}

Samples were collected only once from 78 wells and twice from 1 well (for a total of 79 wells) in Pike County from June through September 2015, and the groundwater-quality data from those samples are assumed to be representative for the purpose of evaluating spatial distributions in water quality for this study. The proportion of well-water samples with various water-quality characteristics, including exceedances of drinking-water standards and detection of methane, would be expected to remain relatively constant for similarly distributed samples collected under relatively constant hydrologic conditions. For example, in an evaluation of groundwater quality in adjacent Wayne County, the overall distribution of groundwater quality for samples collected in the same season (summer) but 1 year apart and from different wells was similar (Senior and others, 2016).

However, groundwater quality may vary locally or regionally through time as a result of seasonal or annual differences in recharge, land use, or other factors. Some changes in water quality in a single well may be relatively rapid if there is good hydraulic connection to the land surface or near surface where contaminants, such as road salt, have been applied, but groundwater quality generally varied more spatially from well to well than temporally at a single well, as indicated during the 2-year study of 35 wells in Susquehanna County (Rhodes and Horton, 2015). In a 1-year study of temporal variability in groundwater quality with monthly sampling of four wells in Pike County during 2012-13, large increases in salt concentrations related to road-salt application near the well head were measured in samples from one well during winter months, and smaller differences in water quality were measured in samples from all wells during the study period (Senior, 2014).

To provide some assessment of possible differences in water quality in individual wells through time, 18 wells previously sampled by USGS during 2007-12 in Pike County were resampled in 2015; all wells were sampled in the same season (summer) of each year (Appendix 5). The resampled wells in 2015 included the following 16 wells from previous "pre-drill" baseline assessments in 2011 and 2012 (Eckhardt and Sloto, 2012; Senior, 2014): 1 well sampled in 2011 (PI591); 1 well sampled in both 2011 and 2012 (PI-592); and 14 wells sampled in 2012. Six wells previously sampled in 


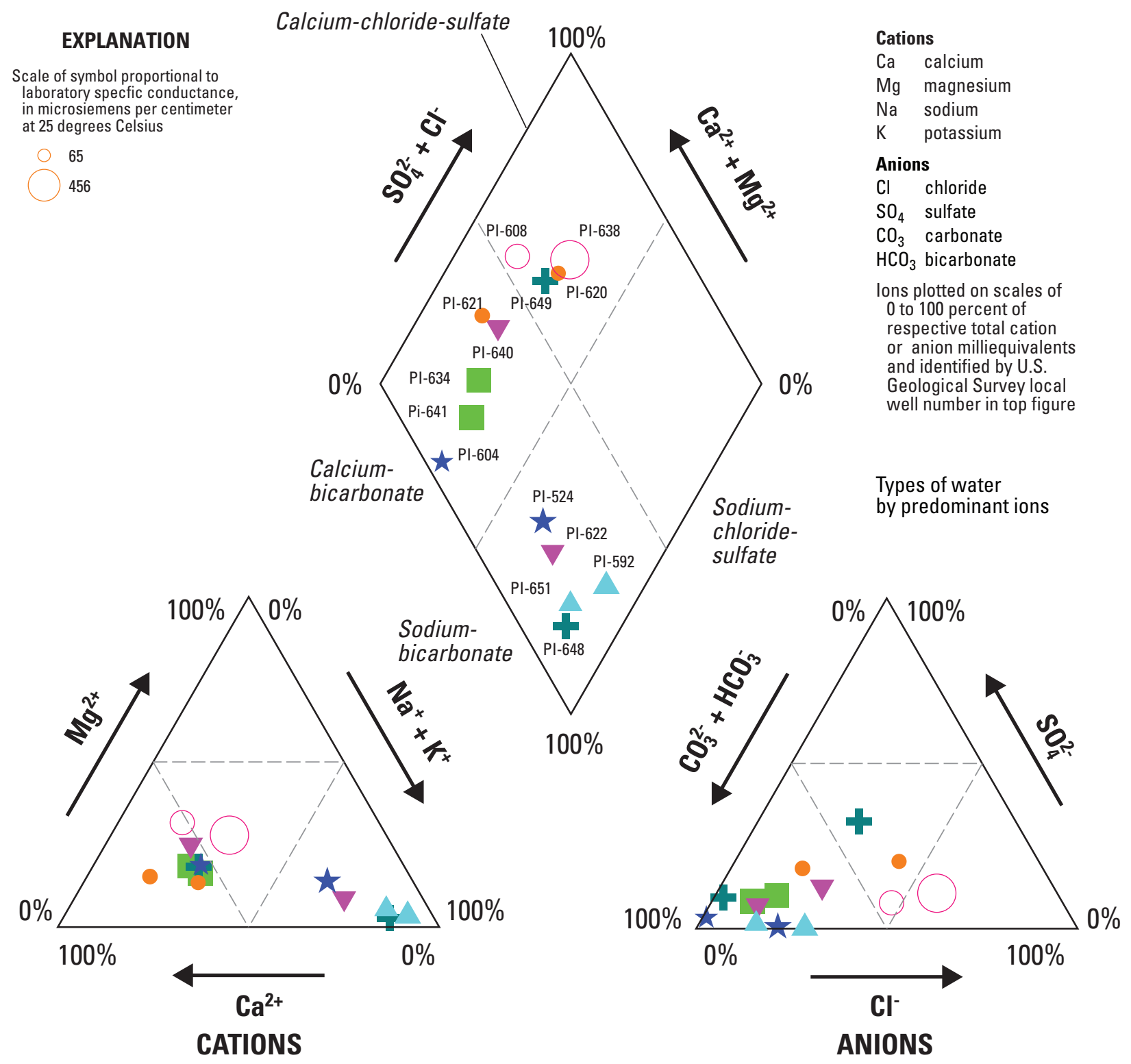

Figure 33. Piper diagrams showing composition of water for seven pairs of closely spaced wells sampled in Pike County, Pennsylvania, 2015. Each pair shown with the same symbol scaled to the specific conductance of the individual sample. 
summer 2012 also had been sampled in summer 2007 (Senior, 2009), and 2 other wells sampled in 2007, but not in 2012, were resampled in 2015. Additionally, 4 of the wells sampled in 2012 and resampled in 2015 had been sampled monthly from summer 2012 to summer 2013 (Senior, 2014). Results of the analyses for 16 wells sampled during 2011-12 and 2015 (table 11; Appendix 5) were compared; comparisons were limited to the constituents analyzed in the 2011-12 samples, which included dissolved major ions, nutrients, selected trace metals, gross alpha and gross beta radioactivity, radon-222, and methane. Available data also were compared for the two other wells sampled in 2007 and 2015 but not in 2012; comparisons were limited to the constituents analyzed in the 2007 samples, which included dissolved major ions, nutrients, selected trace metals, gross alpha and gross beta radioactivity, and radon-222. Minor differences may be expected owing to analytical uncertainty; however, differences greater than 20 percent for constituents occurring in concentrations substantially higher than the reporting level may represent real differences in water quality between samples collected at different times. At low concentrations, relatively small differences in concentrations can result in large percent differences in concentrations.

Differences in dissolved concentrations of major ions between most 2015 Pike County well-water samples and 2012 samples ranged from about -20 percent (2015 lower than 2012) to about +20 percent (2015 higher than 2012). For a few samples, differences between 2015 and 2012 concentrations were greater than $+/-20$ percent for some major ions and as large as about 36 percent for calcium (2 samples), 39 percent for magnesium (2 samples), 79 percent for sodium (2 samples), -25 to 199 percent for chloride (8 samples), and 220 percent for sulfate (2 samples) (table 11). These relatively large percent differences likely represent real, but sometimes relatively small, changes in concentrations of these ions. Samples collected from well PI-288 had the largest percent differences between 2015 and 2012 concentrations for calcium, magnesium, sodium, and chloride, although the differences between actual concentrations were not as large as those for other samples owing to the relatively dilute nature of water from well PI-288. Sulfate concentrations differed by only $0.26 \mathrm{mg} / \mathrm{L}$ in the samples with the largest percent difference of 220 between 2015 and 2012.

Changes in concentration greater than 20 percent were more common for chloride than for other major ions. Plots of chloride concentrations in samples collected during 2007-15 show that concentrations appear relatively constant in samples from one-half of the wells (such as PI-553, PI-555) but appeared to increase between 2012 and 2015 in samples from 7 of 16 wells (such as PI-288) (fig. 34A). Fluctuations in the same season from year to year may be smaller than fluctuations from month to month, as indicated by the chloride concentrations in samples collected monthly from four wells during 2012-13. Generally, the chloride/bromide ratios in water samples from wells collected during 2012-13 and again in 2015 were relatively similar, especially for samples that plot on the brine-mixing line (fig. 34B). Differences in chloride/ bromide ratios for some wells may be related to increases in chloride concentrations related to road salt, as indicated by ratios that plot along or parallel to the road salt mixing line (fig. 34B); such differences were described for samples from well PI-592, which had transient increases related to road salt contamination in winter 2012-13 (Senior, 2014).

The percent differences in dissolved concentrations of minor ions and trace metals in most 2015 Pike County well-water samples compared to 2012 samples generally were higher than percent differences in the major ions (table 11). Minor ions and trace metals commonly are present in relatively low concentrations, sometimes near or less than the laboratory reporting level, in Pike County groundwater, and small differences in actual concentrations can result in large percent differences for these constituents. Percent and actual differences in concentrations can be calculated precisely only for values greater than the reporting level. For most constituents that were reported as having concentrations less than the reporting level, such as nitrite and some trace metals (table 11; Appendix 5; Senior, 2017), the 2015 and 2012 results for samples collected from a given well were consistent. Concentrations of only a few trace constituentsbarium, strontium, and lithium—and radon-222 were measured at greater than the reporting level in all 2012 and 2015 samples, including barium, strontium, and lithium; for these constituents, differences in dissolved concentrations between 2015 and 2012 ranged from about -82 percent (2015 lower than 2012) to about 121 percent (2015 higher than 2012) (table 11). Decreases in concentrations of barium, lithium, and strontium in 2015 compared to 2012 in the samples from one well (PI-555) account for the relatively large negative percent differences for these constituents. Although the 2007 analyses did not include barium, lithium, and strontium, comparison of boron concentrations in 2007, 2012, and 2015 samples from well PI-555 show that 2007 and 2015 concentrations were similar and less than one-half of 2012 concentrations. The magnitudes of fluctuations of some trace constituent concentrations in samples from well PI-555 from 2007 to 2015 were larger than in samples from many other wells.

Evaluation of these limited results for 16 wells sampled twice about 3 years apart indicate that temporal variability in water quality may be a factor to consider when establishing baseline water quality. Additional monitoring through time beyond the one-time sampling conducted for this assessment would be needed to determine seasonal or other types of variability in water quality. 

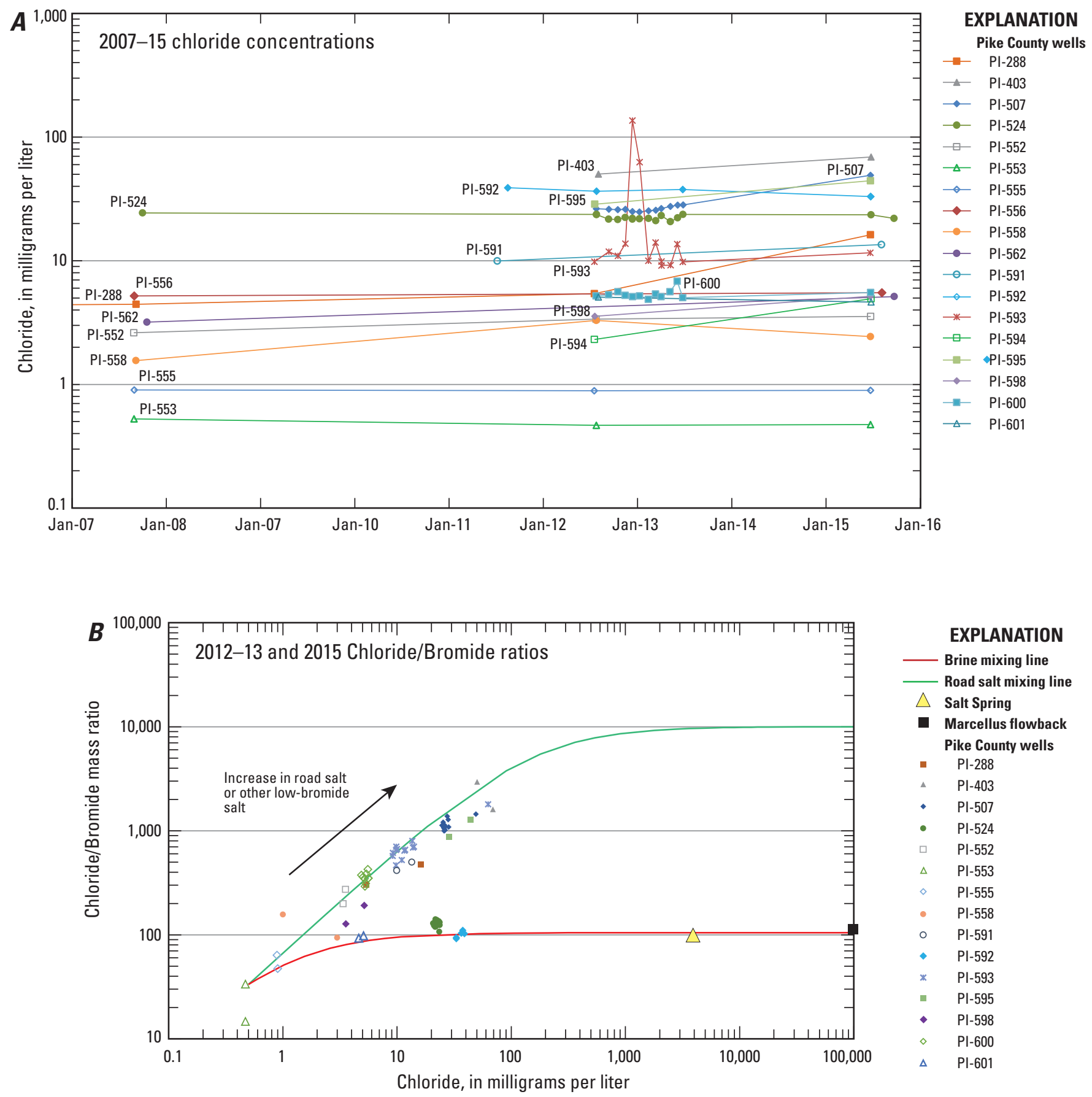

Figure 34. A, Chloride concentrations in water samples collected from wells at least twice during 2007-15 and $B$, chloride/ bromide ratios in relation to chloride concentrations in water samples collected from wells during 2012-13 and 2015 in Pike County, Pennsylvania. (Wells identified by U.S. Geological Survey local well number) 


\section{Summary and Conclusions}

In 2015, the U.S. Geological Survey (USGS), in cooperation with the Pike Conservation District, conducted a study to assess baseline shallow groundwater quality in bedrock aquifers prior to possible shale-gas development in Pike County. Pike County in northeastern Pennsylvania is underlain by Devonian-age and older sedimentary rocks, including the Devonian-age Marcellus Shale and Ordovicianage Utica Shale, formations that have potential for natural gas development and are being developed elsewhere in Pennsylvania as near as Susquehanna County, about 20 miles west of Pike County. The Marcellus Shale crops out at the eastern edge of Pike County, dips west, and is present at depths of about 7,500 feet (ft) below land surface in western Pike County. The Utica Shale is present thousands of feet below the Marcellus Shale. Bedrock units nearest the land surface in Pike County form fractured bedrock aquifers, which are recharged by precipitation and discharge locally to streams and regionally to rivers. Glacial deposits that partly cover the bedrock units are minor sources of groundwater. In rural Pike County, groundwater is the primary source of supply; most wells are completed in bedrock aquifers.

The 2015 study expanded on a previous study done in 2012, for which 20 wells were sampled in Pike County. Seventy-nine wells were sampled in summer 2015 to provide data on the presence of methane and other aspects of existing groundwater quality throughout the county, including concentrations of inorganic constituents typically present at low concentrations in shallow, fresh groundwater but elevated in brines present at depth in the region and also associated with fluids extracted from geologic formations during shale-gas development. Reported depths of sampled wells ranged from 80 to 610 feet (ft), with a median of $262 \mathrm{ft}$. All groundwater samples collected in Pike County in 2015 were analyzed for bacteria, major ions, nutrients, selected inorganic trace constituents (including metals and other elements), total organic carbon, radon-222, gross alpha- and gross beta-particle activity, dissolved hydrocarbon gases (methane, ethane, and propane), and if possible, the isotopic composition of methane. Analyses for total concentrations of major ions and selected trace constituents were done on unfiltered samples using U.S. Environmental Protection Agency drinking-water methods; analyses for dissolved concentrations were done on filtered samples using USGS National Water Quality Laboratory methods. Additionally, samples from 20 wells were analyzed for selected volatile organic compounds, and samples from 16 wells with relatively elevated gross alpha-particle activity were analyzed for radium-226.

Results of the 2015 sampling show that groundwater quality generally met most drinking-water standards, but some samples had one or more constituents or properties, including arsenic, $\mathrm{pH}$, iron, manganese, bacteria, sodium, total dissolved solids, sulfate, and radon-222, that exceeded primary or secondary maximum contaminant levels (MCLs) or a Health Advisory (HA). Arsenic concentrations were greater than the maximum contaminant level (MCL) of $10 \mu \mathrm{g} / \mathrm{L}$ in 1 of the 79 well-water samples (1 percent), as high as about $30 \mu \mathrm{g} / \mathrm{L}$. Arsenic concentrations were greater than the HA level of $2 \mu \mathrm{g} / \mathrm{L}$ in samples from 8 of 79 wells (10 percent). Only three VOCs were present in samples from two wells at low levels below MCLs.

Dissolved and total concentrations were similar in most samples for most constituents analyzed, indicating that these constituents predominantly are present in the dissolved phase. However, total concentrations commonly were higher than dissolved concentrations of iron, indicating particulate iron contributed substantially to the total iron concentrations. Total iron concentrations exceeded the secondary maximum contaminant level (SMCL) of 300 micrograms per liter $(\mu \mathrm{g} / \mathrm{L})$ in water samples from 35 of the 79 wells (44 percent), and dissolved iron concentrations exceeded the SMCL of $300 \mu \mathrm{g} / \mathrm{L}$ in only 8 of 79 well-water samples (10 percent). Dissolved and total manganese concentrations typically were similar; total manganese concentrations exceeded the SMCL of $50 \mu \mathrm{g} / \mathrm{L}$ in samples from 31 of 79 wells (39 percent).

The $\mathrm{pH}$ ranged from 5.5 to 9.2 and did not meet the SMCL range of 6.5-8.5 in groundwater samples from 24 of 79 wells (30 percent). Sixteen samples (20 percent) had $\mathrm{pH}$ less than 6.5 , and 8 samples (10 percent) had $\mathrm{pH}$ greater than 8.5. Total coliform bacteria were detected in samples from 25 of 79 wells (32 percent) but Escherichia coli (E. coli) was not detected in any sample. Radon-222 activities ranged from 11 to 5,110 picocuries per liter (pCi/L), with a median of $1,425 \mathrm{pCi} / \mathrm{L}$, and exceeded the proposed drinking-water standard of $300 \mathrm{pCi} / \mathrm{L}$ in samples from 61 of 79 wells (77 percent); radon-222 activities were higher than the alternative proposed standard of $4,000 \mathrm{pCi} / \mathrm{L}$ in samples from 2 of 79 wells (3 percent). A few (1-2) samples had concentrations of sodium, chloride, sulfate, or TDS that exceeded the SMCLs of 60, 250, 250, and $500 \mathrm{mg} / \mathrm{L}$, respectively. However, dissolved sodium concentrations exceeded the HA of $20 \mathrm{mg} / \mathrm{L}$ in samples from 15 of 79 wells (19 percent).

Water from 19 (24 percent) of 79 wells sampled in 2015 had concentrations of methane greater than the reporting level of 0.01 milligrams per liter (mg/L) with the maximum of 2.5-5.9 mg/L, depending on laboratory. Concentrations of methane in replicate samples from 16 wells analyzed by a second laboratory were correlated but were as much as about 2.7 times higher than the first laboratory. Low levels of ethane (as much as $0.0019 \mathrm{mg} / \mathrm{L}$ ) were measured by the second laboratory in the samples from five wells that had among the highest methane concentrations. Groundwater samples from nine wells had sufficient methane for isotopic analysis of both carbon and hydrogen components of methane, which yielded $\delta^{13} \mathrm{C}_{\mathrm{CH} 4}$ values ranging from -63.44 parts per thousand (\%) to $-40.99 \%$ and $\delta \mathrm{D}_{\mathrm{CH} 4}$ values ranging from $-221.6 \%$ to $-121.7 \%$. These results are consistent with isotopic compositions for a microbial methane (carbon dioxide reduction) source for most Pike County groundwater samples, a possibly oxidized microbial methane source for 2 samples, 
and a possible thermogenic methane source for 1 sample. However, the ratios of methane to ethane indicate that the methane in all samples is consistent with microbial origin. The sample that has methane with an isotopic composition within ranges reported for thermogenic methane may be a mixture of methane from a thermogenic source depleted in ethane and microbial source that underwent oxidation.

The groundwater with elevated methane concentrations had a chemical composition that differed in some respects $(\mathrm{pH}$, selected major ions, and inorganic trace constituents) from groundwater with low methane concentrations. The seven well-water samples with the highest methane concentrations (greater than $0.3 \mathrm{mg} / \mathrm{L}$ ) also had among the highest $\mathrm{pH}$ values (8.1-9.3, respectively) and highest concentrations of sodium, lithium, boron, fluoride, arsenic, ammonia, and bromide. Elevated concentrations of some other constituents, such as barium, strontium, and chloride, also were present but typically were not limited to well-water samples with elevated methane. Results of geochemical modeling of similar data from nearby Wayne County show that water in samples with elevated $\mathrm{pH}$, sodium, lithium, bromide, and alkalinity could have been formed by dissolution of calcite (calcium carbonate), followed by ion exchange, and mixing with a small amount (less than 0.02 percent) of brine. Brine contributions may originate from deep parts (greater than $1,000 \mathrm{ft}$ below land surface) of the aquifer system.

Characterization of water by major ion composition shows that most groundwaters are of a calcium-magnesiumbicarbonate-sulfate type; a few samples were mostly a sodium-bicarbonate type. The sodium-bicarbonate type waters generally have low dissolved oxygen and high $\mathrm{pH}$ values, and some of the highest concentrations of methane and arsenic. Elevated $\mathrm{pH}$ is an important geochemical control on arsenic concentrations because arsenic tends to be more soluble at $\mathrm{pH}$ values greater than 7.5. Relations among chemical constituents were investigated through statistical (principal component analysis; PCA) and graphical (Piper diagrams, scatter plots, and boxplots) methods, which aid in understanding how groundwaters develop different chemical compositions, especially those waters that have elevated concentrations of constituents of concern, such as arsenic and methane. The statistical grouping of constituents through PCA identified six main factors that reflect geochemical processes (including $\mathrm{pH}$, redox, ion exchange, mineral dissolution, mixing with brine) and man-made contributions (such as road salt).

Groundwater samples with elevated methane concentrations (near or greater than $0.3 \mathrm{mg} / \mathrm{L}$ as determined by one laboratory) have chloride/bromide ratios that indicate mixing with a small amount of Appalachian Basin brine similar in composition to that reported for shale-gas brines in Pennsylvania. Most other samples with low methane concentrations (less than about $0.3 \mathrm{mg} / \mathrm{L}$ ) have chloride/ bromide ratios that indicate predominantly man-made sources of chloride, such as road salt or septic systems.

The observed water types and relations among selected constituents and $\mathrm{pH}$ indicate that dilute recharge waters interact with minerals in the near surface, gradually becoming less acidic and less oxygenated while increasing in concentrations of dissolved constituents. The predominant processes that likely account for the observed chemical composition of groundwaters in Pike County are the progressive dissolution of calcite (calcium carbonate) to equilibrium, combined in some cases with cation exchange and mixing with saline or brine-like waters. In general, calcite is undersaturated (can dissolve) in waters with $\mathrm{pH}$ less than about 7.5 to 8 but nears saturation in waters with $\mathrm{pH}$ greater than about 8 . As calcite dissolves and other minerals undergo weathering, it is thought that the groundwater evolves from dilute acidic mixed-ion water that tends be soft (low hardness) to intermediate total dissolved solids, neutral $\mathrm{pH}$ calcium-bicarbonate water that tends to have moderate to high hardness. Further dissolution of calcite and sodiumfor-calcium ion exchange results in higher TDS sodium bicarbonate water with $\mathrm{pH}$ greater than 8 and low hardness. Mixing of these waters with road salt and (or) residual brine adds chloride and (or) bromide. These different types of waters were observed in Pike County.

Relatively elevated methane (greater than $0.3 \mathrm{mg} / \mathrm{L}$ as determined by Seewald Laboratories, Inc.) was measured most frequently in sodium-bicarbonate type groundwater samples with elevated $\mathrm{pH}$ (greater than 8), and chloride/bromide ratios indicative of brine contribution. These findings and chemical models indicate that the waters with the relatively elevated methane concentrations in Pike County and other areas in northeastern Pennsylvania appear to have been formed by a series of chemical reactions, including mineral dissolution, ion exchange, and some mixing with brine that could be residual, related to connate waters, or discharging from greater depths in the aquifer. Sodium-bicarbonate type water appears to be distinct from other groundwater types in Pike County, although data suggest this type of water may have formed gradually through a series of chemical reactions in the aquifer.

The composition of groundwater varies spatially in Pike County and differs by geologic unit, partly because of differences in aquifer mineralogy and different positions along groundwater flow paths. The spatial distribution of groundwater composition generally shows that relatively dilute, slightly acidic, oxygenated, calcium-carbonate type waters with relatively high radon-222 (>1,000 pCi/L) tend to be present in the uplands along the western border of Pike County; waters with near neutral $\mathrm{pH}$ and with the highest amounts of hardness (calcium and magnesium) generally were present in areas of intermediate elevations. Waters with $\mathrm{pH}$ values greater than 8 , low oxygen concentrations $(<1 \mathrm{mg} / \mathrm{L})$, and the highest arsenic, sodium, lithium, fluoride, boron, bromide, and methane concentrations but lowest radon-222 concentrations most frequently were present in lowland areas along stream valleys, especially at relatively lower elevations near areas of regional groundwater discharge, such as the Delaware River.

Thus, the baseline assessment of groundwater quality in Pike County prior to gas-well development shows that 
shallow (less than about 1,000 feet deep) groundwater is generally meets primary drinking-water standards for inorganic constituents but varies spatially. Methane and some constituents (sodium, lithium, bromide, boron, and others) that are present in high concentrations in residual or other naturally-occurring brines (and potentially associated with future shale-gas development in Pike County) and are present at low to moderate concentrations, and in some areas at relatively elevated concentrations, in groundwater in Pike County.

The flow and transport processes responsible for the presence of methane and the relatively elevated sodium and associated trace constituent concentrations in groundwater in Pike County are not known. Although isotopic characterization of methane may be used to help identify the naturally occurring methane in shallow bedrock aquifers as part of the baseline assessment, additional investigations may be needed to definitively determine the origin of this methane and explain its association with the high $\mathrm{pH}$, sodium-bicarbonate, bromide-enriched groundwater.

Results for 16 wells sampled twice about 3 years apart (15 wells in 2012 and 2015 and 1 well in 2011 and 2015) indicate that temporal variability in water quality may be a factor to consider when establishing baseline water quality. Although some differences may be related to analytical uncertainty, differences greater than 20 percent for constituents occurring in concentrations substantially higher than the reporting level may represent real differences in water quality between samples collected at different times. Additional monitoring through time beyond the one-time sampling conducted for this assessment would be needed to determine seasonal or other types of variability in water quality.

\section{References Cited}

Appelo, C.A.J., and Postma, D., 2005, Geochemistry, groundwater and pollution (2d ed.): Leiden, The Netherlands, A.A. Balkema Publishers, 649 p.

Back, William, 1966, Hydrochemical facies and ground-water flow patterns in northern part of Atlantic Coastal Plain: U.S. Geological Survey Professional Paper 498-A, p. A1-A42, $1 \mathrm{pl}$.

Ball, J.W., and Nordstrom, D.K., 1991, User's manual for WATEQ4F with revised database: U.S. Geological Survey Open-File Report 91-183, 189 p.

Baldassare, F.J., McCaffrey, M.A., and Harper, J.A., 2014, A geochemical context for stray gas investigations in the northern Appalachian Basin: Implications of analyses of natural gases from Neogene-through Devonian-age strata: American Association of Petroleum Geologists Bulletin, v. 98 , no. 2, p. 341-372.
Berg, T.M., Edmunds, W.E., Geyer, A.R., and others, compilers, 1980, Geologic map of Pennsylvania (2d ed.): Pennsylvania Geological Survey, 4th ser., Map 1, 3 sheets, scale 1:250,000.

Berg, T.M., and Dodge, C.M, eds., 1981, Atlas of preliminary geologic quadrangle maps of Pennsylvania: Pennsylvania Geological Survey, 4th Series, Map 61, scale 1:62,500.

Bernard, B.B., Brooks, J.J., and Sackett, W.M., 1978, Light hydrocarbons in recent Texas continental shelf and slope sediments: Journal of Geophysical Research, v. 83, p. $4053-4061$.

Bethke, C.M., and Yeakel, S., 2010, The Geochemist's Workbench Release 8.0: GWB essentials guide: Champaign, Ill., Aqueous Solutions, LLC.

Breen, K.J., Révész, Kinga, Baldassare, F.J., and McAuley, S.D., 2007, Natural gases in ground water near Tioga Junction, Tioga County, North-Central PennsylvaniaOccurrence and use of isotopes to determine origins, 2005: U.S. Geological Survey Scientific Investigations Report 2007-5085, 65 p.

Carswell, L.D., and Lloyd, O.B., Jr., 1979, Geology and groundwater resources of Monroe County, Pennsylvania: Pennsylvania Geological Survey, 4th Series, Water Resource Report 47, 61 p.

Chapman, M.J., Cravotta, C.A. III, Szabo, Zoltan, and Lindsey, B.D., 2013, Naturally occurring contaminants in the Piedmont and Blue Ridge crystalline-rock aquifers and Piedmont Early Mesozoic Basin siliciclastic-rock aquifers, eastern United States, 1994-2008: U. S. Geological Survey Scientific Investigations Report 2013-5072, 74 p.

Coleman, D.D., Liu, C.L., Liu, Chao-Li, Hackley, K.C., and Pelphrey, S.R., 1995, Isotopic identification of landfill methane: Environmental Geosciences, v. 2, no. 2, p. $95-103$.

Commonwealth of Pennsylvania, 2014, The Pennsylvania code chapter 78. Oil and gas wells, accessed March 31, 2014, at http://www.pacode.com/secure/data/025/chapter78/ chap78toc.html.

Cravotta, C.A., III, and Brady, K.B.C., 2015, Priority pollutants in untreated and treated discharges from coal mines in Pennsylvania, U.S.A.: Applied Geochemistry, v. 62 , p. $108-130$.

Davis, D.K., 1989, Groundwater resources of Pike County, Pennsylvania: Pennsylvania Geological Survey, 4th Series, Water Resource Report 65, 63 p.

Davis, S., Whittemore, D., and Fabryka-Martin, J., 1998, Use of chloride/bromide ratios in studies of potable water: Ground Water, v. 36, p. 338-350. 
Delaware River Basin Commission, 2014, Natural gas drilling index page, accessed February 11, 2014, at http://www. state.nj.us/drbc/programs/natural/.

Denver, J.M., Cravotta, C.A., III, Ator, S.W., and Lindsey, B.D., 2010, Contributions of phosphorus from groundwater to streams in the Piedmont, Blue Ridge, and Valley and Ridge Physiographic Provinces, eastern United States: U.S. Geological Survey Scientific Investigations Report 20105176, 38 p.

Dresel, P.E., and Rose, A.W., 2010, Chemistry and origin of oil and gas well brines in western Pennsylvania: Pennsylvania Geological Survey, 4th ser., Open-File Report OFOG 10-01.0, 48 p.

Drever, J.I., 1997, The geochemistry of natural waterssurface and groundwater environments (3d ed.): Upper Saddle River, N.J., Prentice Hall, 436 p.

Dufor, C.N., and Becker, Edith, 1964, Public water supplies of the 100 largest cities in the United States, 1962: U.S. Geological Survey Water-Supply Paper 1812, 364 p.

Durlin, R.R, and Schaffstall, W.P., 2002, Water resources data, Pennsylvania, water year 2001, volume 1. Delaware River Basin: U.S. Geological Survey Water Data Report PA-01-1, $615 \mathrm{p}$.

Dzombak, D.A., and Morel, F.M.M., 1990, Surface complexation modeling-Hydrous ferric oxide: New York, John Wiley \& Sons, Inc., 393 p.

Eckhardt, D.A., and Sloto, R.A., 2012, Baseline groundwater quality in national park units within the Marcellus and Utica Shale gas plays, New York, Pennsylvania, and West Virginia, 2011: U.S. Geological Survey Open-File Report 2012-1150, 20 p.

Ehrlich, H.L, 1990, Geomicrobiology (2d ed.): New York, Marcel-Dekker, Inc., 646 p.

Eltschlager, K.K., Hawkins, J.W., Ehler, W.C., and Baldassare, Fred, 2001, Technical measures for the investigation and mitigation of fugitive methane hazards in areas of coal mining: U.S. Department of Interior, Office of Surface Mining Reclamation and Enforcement, 129 p., accessed June 11, 2014, at http://arblast.osmre.gov/downloads/ Mine\%20Gases\%20and\%20Dust/FINAL-Methane.pdf.

Federal Register, 1999, National primary drinking water regulations; radon-222: Federal Register, v. 64, no. 211, p. 59245-59294.

Feth, J.H., and others, 1965, Preliminary map of the conterminous United States showing depth to and quality of shallowest ground water containing more than 1,000 parts per million dissolved solids: U.S. Geological Survey Hydrologic Atlas 199.
Gross, E.L., and Cravotta, C.A., III, 2017, Groundwater quality for 75 domestic wells in Lycoming County, Pennsylvania, 2014: U.S. Geological Survey Scientific Investigations Report 2016-5143, 74 p., accessed August 24, 2017 at https://doi.org/10.3133/sir20165143.

Haluszczak, L.O., Rose, A.W., and Kump, L.R., 2013, Geochemical evaluation of flowback brine from Marcellus gas wells in Pennsylvania, USA: Applied Geochemistry, v. 28 , p. $55-61$.

Hanor, J.S., 1968, Frequency distribution of compositions in the barite-celestite series: American Mineralogist, v. 53, p. 1215-1222.

Hanshaw, B.B., and Back, William, 1979, Major geochemical processes in the evolution of carbonate-aquifer systems: Journal of Hydrology, v. 43, p. 287-312.

Hayes, T., 2009, Sampling and analysis of water streams associated with the development of Marcellus shale gas. Report by Gas Technology Institute, Des Plaines, IL, for the Marcellus Shale Coalition, accessed June 20, 2017 at http:// www.bucknell.edu/script/environmentalcenter/marcellus/ default.aspx?articleid=14.

Heisig, P.M., and Scott, Tia-Marie, 2013, Occurrence of methane in groundwater of south-central New York State, 2012 - Systematic evaluation of a glaciated region by hydrogeologic setting: U.S. Geological Survey Scientific Investigations Report 2013-5190, 32 p.

Helsel, D.R. and Hirsch, R.M., 2002, Statistical methods in water resources: U.S. Geological Survey Techniques of Water-Resources Investigations, book 4, chap. A3, 523 p.

Hem, J.D., 1985, Study and interpretation of the chemical characteristics of natural waters (3d ed.): U.S. Geological Survey Water-Supply Paper 2254, 263 p.

Johnson, J.D., Graney, J.R., Capo, R.C., and Stewart, B.W., 2015, Identification and quantification of regional brine and road salt sources in watersheds along the New York/ Pennsylvania border, USA: Applied Geochemistry, v. 60, p. $37-50$.

Joreskog, K.G., Klovan, J.E., and Reyment, R.A., 1976, Geological factor analysis: New York, Elsevier, 178 p.

Kargbo, D.M., Wilhelm, R.G., and Campbell, D.J., 2010, Natural gas plays in the Marcellus shale-Challenges and potential opportunities: Environmental Science and Technology, v. 44, p. 5679-5684.

Kerr, R.A., 2010, Natural gas from shale bursts onto the scene: Science, v. 328, p. 1624-1626. 
Kirschbaum, M.A., Schenk, C.J., Cook, T.A., Ryder, R.T., Charpentier, R.R., Klett, T.R., Gaswirth, S.B., Tennyson, M.E., and Whidden, K.J., 2012, Assessment of undiscovered oil and gas resources of the Ordovician Utica Shale of the Appalachian Basin Province, 2012: U.S. Geological Survey Fact Sheet 2012-3116, 6 p.

Klemic, Harry, 1962, Uranium occurrences in sedimentary rocks of Pennsylvania: U.S. Geological Survey Bulletin 1107-D, p. 243-288.

Kresse, T.M., Warner, N.R., Hays, P.D., Down, Adrian, Vengosh, Avner, and Jackson, R.B., 2012, Shallow groundwater quality and geochemistry in the Fayetteville Shale gas-production area, north-central Arkansas, 2011: U.S. Geological Survey Scientific Investigations Report 2012-5273, $31 \mathrm{p}$.

Langmuir, Donald, 1997, Aqueous environmental geochemistry: Prentice Hall, New Jersey, 600 p.

Llewellyn, G.T., 2014, Evidence and mechanisms for Appalachian Basin brine migration into shallow aquifers in NE Pennsylvania, USA: Hydrogeology Journal, v. 22, p. $1055-1066$.

Lohman, S.W., 1937, Groundwater in northeastern Pennsylvania: Pennsylvania Geological Survey, 4th series, Bulletin W4, 208 p.

Low, D.J., and Galeone, D.G., 2007, Reconnaissance of arsenic concentrations in ground water from bedrock and unconsolidated aquifers in eight northern-tier counties of Pennsylvania: U.S. Geological Survey Open-File Report 2006-1376, 35 p.

Macpherson, G.L., 2015, Lithium in fluids from Paleozoicaged reservoirs, Appalachian Plateau region, USA: Applied Geochemistry, v. 60, p. 72-77.

McCauley, J.F., 1961, Uranium in Pennsylvania: Pennsylvania Geological Survey, 4th series, Bulletin M3, 71 p.

McCleskey, R.B., Nordstrom, D.K., Ryan, J.N., and Ball, J.W., 2012, A new method of calculating electrical conductivity with applications to natural waters: Geochimica et Cosmochimica Acta, v. 77, p. 369-382.

McMahon, P.B, and Chapelle, F.H., 2008, Redox processes and water quality of selected principal aquifer systems: Ground Water, v. 46, p. 259-271.

Miles, C.E., and Whitefield, T.G., compilers., 2001, Bedrock geology of Pennsylvania: Pennsylvania Geological Survey, 4th series, digital dataset, scale 1:250,000.

Mullaney, J.R., Lorenz, D.L., Arntson, A.D., 2009. Chloride in groundwater and surface water in areas underlain by the glacial aquifer system, northern United States: U.S. Geological Survey Scientific Investigations Report, 2009-5086, 41 p.
National Atmospheric Deposition Program, 2016, Annual trend plots for NTN site PA72 (Milford, Pennsylvania) accessed May 18, 2016, at http://nadp.sws.uiuc.edu/data/ ntn/plots/ntntrends.html?siteID=PA72.

National Oceanic and Atmospheric Administration, 2015, Climate Data Online Annual Summaries, Annual Climatological Summary 2013 and 2014 for stations COOP: 367029-Pleasant Mount 1 W, PA US and COOP:363758 Hawley 1 E, PA US, accessed October 7, 2015, at https:// www.ncdc.noaa.gov/cdo-web/datasets\#ANNUAL.

Parkhurst, D.L., and Appelo, C.A.J., 2013, Description of input and examples for PHREEQC version 3-A computer program for speciation, batch-reaction, one-dimensional transport, and inverse geochemical calculations: U.S. Geological Survey Techniques and Methods 6-A43, 497 p.

Pennsylvania Department of Environmental Protection, 2014, PA-DEP recommended basic oil and gas pre-drill parameters: : Pennsylvania Department of Environmental Protection 8000-FS-DEP4300, revised April 2014, accessed June 21, 2017, at http://www.environmentalservicelab.com/ docs/PADEPPredrill2014.pdf.

Pennsylvania Department of Environmental Protection, 2016a, Oil and Gas Reports, Spud Data Report, Wells drilled by county, accessed September 13, 2016, at http://www.dep. pa.gov/DataandTools/Reports/Oil\%20and\%20Gas\%20 Reports/Pages/default.aspx.

Pennsylvania Department of Environmental Protection, Office of Oil and Gas Management, 2016b, Spud Data accessed September 13, 2016, at http://www.depreportingservices. state.pa.us/ReportServer/Pages/ReportViewer.aspx?/Oil_ Gas/Spud_External_Data.

Pennsylvania Department of Environmental Protection, 2016c, PA-DEP Recommended Basic Oil and Gas Pre-Drill Parameters: Pennsylvania Department of Environmental Protection 8000-FS-DEP4300, revised April 2016, accessed June 20, 2017, at http://www.elibrary.dep.state.pa.us/dsweb/ Get/Document-112316/8000-FS-DEP4300.pdf.

Pennsylvania Department of Environmental Protection, 2017, Year to date permits issued by well type, accessed June 21, 2017, at http://www.depreportingservices.state.pa.us/ ReportServer/Pages/ReportViewer.aspx?/Oil_Gas/Permits_ Issued_Count_by_Well_Type_YTD.

Pike County Conservation District, 2014, Pike County: Where people, land, and water meet; a citizen's guide to clean water: Accessed June 9, 2014, at http://www. pikeconservation.org/Resource\%20Guide/Pike\%20CD\%20 Citizens's\%20Guide\%20-\%20Full\%20Document.pdf.

Pike County Marcellus Task Force, 2011, Planning and Government Committee Meeting Minutes, February 24, 2011 accessed June 25, 2013 at http://www.pikepa.org/ marcellus.html. 
Pike County Planning Commission, 2006, Pike County Comprehensive Plan update: Pike County, PA, accessed June 20, 2017, at http://www.pikepa.org/Planning/Pike $\% 20$ Comp\%20Plan_Final\%20Plan_Full.pdf.

Piotrowski, R.G., and Harper, J.A., 1979, Black shale and sandstone facies of the Devonian "Catskill" clastic wedge in the subsurface of western Pennsylvania: United States Department of Energy Eastern Gas Shales Project, EGSP Series $13,40 \mathrm{p}$.

Pirc, Simon, and Rose, A.W., 1981, Uranium anomalies in paleo-aquifers near sandstone-type deposits in the Devonian Catskill Formation of Pennsylvania: Journal of Geochemical Exploration v. 15, p. 219-231.

Poth, Charles W., 1963. Geology and hydrology of the Mercer Quadrangle, Mercer, Lawrence, and Butler Counties, Pennsylvania: Pennsylvania Geologic Survey Water Resource Report 16, 149 p.

P-STAT, Inc., 2008, P-STAT Version 2.23 Release 11, May 2008: Hopewell, N.J., P-STAT.

Reese, S.O., Neboga, V.V., Pelepko, Seth, Kosmer, W.J., and Beattie, Stewart, 2014, Groundwater and petroleum resources of Sullivan County, Pennsylvania: Pennsylvania Geological Survey, 4th series, Water Resource Report 71, 99 p., 6 pls., 27 p. appendix.

Reilly, D., Singer, D., Jefferson, A., and Eckstein, Y., 2015, Identification of local groundwater pollution in northeastern Pennsylvania: Marcellus flowback or not?: Environmental Earth Sciences, v. 73, no.12, p. 8097-8109.

Révész, K.M., Breen, K.J., Baldassare, A.J., and Burruss, R.C., 2012, Carbon and hydrogen isotopic evidence for the origin of combustible gases in water-supply wells in northcentral Pennsylvania: Applied Geochemistry, 2010, v. 25, p. 1845-1859. Erratum: Applied Geochemistry, 2012, v. 27, p. $361-375$.

Rhodes, A.L., and Horton, N.J., 2015, Establishing baseline water quality for household wells within the Marcellus Shale gas region, Susquehanna County, Pennsylvania, U.S.A.: Applied Geochemistry, accessed August 24, 2017 at http://dx.doi.org/10.1016/j.apgeochem.2015.03.004.

Risser, D.W., Williams, J.R., Hand, K.L., and others, 2013, Geohydrologic and water-quality characterization of a fractured-rock test hole in an area of Marcellus shale development, Bradford County, Pennsylvania: Pennsylvania Geological Survey, 4th ser., Open-File Report OFMI 13-01.1, 49 p., 4 appendices.[Also available at http://www. docs.dcnr.pa.gov/cs/groups/public/documents/document/ dcnr_20028159.zip]
Rowan, E.L., Engle, M.A., Kirby, C.S., and Kraemer, T.F., 2011, Radium content of oil- and gas-field produced waters in the northern Appalachian Basin (USA)—Summary and discussion of data: U.S. Geological Survey Scientific Investigations Report 2011-5135, 31 p. [Also available at http://pubs.usgs.gov/sir/2011/5135/]

SAS Institute Inc., 2012, SAS 9.4 for Windows: Cary, N.C., SAS Institute, Inc.

Schoell, M., 1980, The hydrogen and carbon isotopic composition of methane from natural gases of various origins: Geochimica et Cosmochimica Acta, v. 44, p. 649661.

Senior, L.A., 1994, Geohydrology of, and nitrogen and chloride in, the glacial aquifer, Milford-Matamoras area, Pike County, Pennsylvania: U.S. Geological Survey WaterResources Investigations Report 93-4109, 43 p.

Senior, L.A., 2009, Groundwater-quality assessment, Pike County, Pennsylvania, 2007: U.S. Geological Survey Scientific Investigations Report 2009-5129, 53 p.

Senior, L.A., 2014, A reconnaissance spatial and temporal assessment of methane and inorganic constituents in groundwater in bedrock aquifers, Pike County, Pennsylvania, 2012-13: U.S. Geological Survey Scientific Investigations Report 2014-5117, $91 \mathrm{p}$.

Senior, L.A., , 2017, Field properties and results of laboratory analysis of groundwater samples collected from 79 wells Pike County, Pennsylvania, 1982-2015 : U.S. Geological Survey data release, https://doi.org/10.5066/F75T3JDK.

Senior, L.A., Cravotta, C.A., III, and Sloto, R.A., 2016, Baseline assessment of groundwater quality in Wayne County, Pennsylvania, 2014 (ver. 1.1, March 2017): U.S. Geological Survey Scientific Investigations Report 20165073, 136 p.

Sevon, W.D., Berg, T.M., Schultz, L.D., and Crowl, G.H., 1989, Geology and mineral resources of Pike County, Pennsylvania: Pennsylvania Geological Survey, 4th Series, County Report 65, 141 p., 2 pls.

Sevon, W.D., 2000, Physiographic provinces of Pennsylvania: Pennsylvania Geological Survey, 4th series, Map 13, 1 sheet.

Siegel, D.I., Smith, B., Perry, E., Bothun, R., and Hollingsworth, M., 2015, Pre-drilling water-quality data of groundwater prior to shale gas drilling in the Appalachian Basin: Analysis of the Chesapeake Energy Corporation dataset: Applied Geochemistry, v. 63, p. 37-57.

Sloto, R.A., 2013, Baseline groundwater quality from 20 domestic wells in Sullivan County, Pennsylvania, 2012: U.S. Geological Survey Scientific Investigations Report 2013-5085, 27 p. 
Sloto, R.A., 2014, Baseline groundwater quality from 34 wells in Wayne County, Pennsylvania, 2011 and 2013: U.S. Geological Survey Open-File Report 2014-1116, 24 p.

Snoeyink, V.L., and Jenkins, D., 1981, Water chemistry: New York, John-Wiley \& Sons, 463 p.

Stumm, Werner, and Morgan, J.J., 1996, Aquatic chemistrychemical equilibria and rates in natural waters (3d): New York, Wiley-Interscience, 1022 p.

Taylor, S.W., Lollar, B.S., and Wassenaar, L.I., 2000, Bacteriogenic ethane in near-surface aquifers: Implications for leaking hydrocarbon well bores: Environmental Science \&Technology, v. 34, p. 4727-4732.

Thyne, Geoffrey, Guler, Cuneyt, and Porter, Eileen, 2004, Sequential analysis of hydrochemical data for watershed characterization: Ground Water, v. 42, p. 711-723.

Toccalino, P.L., 2007, Development and application of healthbased screening levels for use in water-quality assessments: U.S. Geological Survey Scientific Investigations Report 2007-5106, 12 p.

Toccalino, P.L., Norman, J.E., and Schoephoester, K.M., 2014, Health-Based Screening Levels for evaluating water-quality data, accessed August 1, 2017 at https://water.usgs.gov/ nawqa/HBSL, doi:10.5066/F71C1TWP.

U.S. Census Bureau, 2017, Annual estimates of the resident population: April 1, 2010, to July 1, 2016, accessed July 28, 2017 at https://factfinder.census.gov/faces/tableservices/jsf/ pages/productview.xhtml?src=CF.

U.S. Department of Agriculture, 2012, Census of agriculture, 2012 census volume 1, chapter 2: county level data, Pennsylvania: accessed May 5, 2014, at http://agcensus.usda.gov/Publications/2012/Full_report/ Volume1,Chapter_2_County_Level/Pennsylvania/ st42_2_001_00.

U.S. Environmental Protection Agency, 2001, Ambient water quality criteria recommendations information supporting the development of state and Tribal nutrient criteria rivers and streams in Nutrient Ecoregion VIII: U.S. Environmental Protection Agency EPA-822-B-01-015, accessed April 11, 2016, at https://www.epa.gov/sites/production/files/ documents/rivers8.pdf.

U.S. Environmental Protection Agency (EPA), 2012, 2012 Edition of the drinking water standards and health advisories: U.S. Environmental Protection Agency EPA 822-S-12-001, accessed June 21, 2017, at https://www. epa.gov/sites/production/files/2015-09/documents/ dwstandards2012.pdf.
U.S. Environmental Protection Agency, 2014, Natural gas extraction-hydraulic fracturing, accessed February 12, 2014, at http://water.epa.gov/type/groundwater/uic/class2/ hydraulicfracturing/.

U.S. Environmental Protection Agency, 2015, Assessment of the potential impacts of hydraulic fracturing for oil and gas on drinking water resources (external review draft): U.S. Environmental Protection Agency EPA/600/R-15/047a June 2015, accessed November 30, 2016 at https://cfpub.epa.gov/ ncea/hfstudy/recordisplay.cfm?deid=244651.

U.S. Environmental Protection Agency, 2016, Hydraulic fracturing for oil and gas: Impacts from the hydraulic fracturing water cycle on drinking water resources in the United States (Final Report). U.S. Environmental Protection Agency, Washington, D.C., EPA/600/R-16/236F, 2016, accessed June 21, 2017, at https://cfpub.epa.gov/ncea/ hfstudy/recordisplay.cfm?deid=332990.

U.S. Geological Survey, variously dated, National field manual for the collection of water-quality data: U.S. Geological Survey Techniques of Water-Resources Investigations, book 9, chap. A1-A9, accessed December 5, 2012, at http://pubs.water.usgs.gov/twri9A/.

U.S. Geological Survey, 2014a, National Water Quality Laboratory, accessed February 11, 2014, at http://nwql.usgs. gov/.

U.S. Geological Survey, 2014b, USGS water data for Pennsylvania, accessed February 11, 2014, at http:// waterdata.usgs.gov/pa/nwis/nwis.

Velleman, P.F., and Hoaglin, D., 1981, Applications, basics, and computing of exploratory data analysis: Boston, Mass., Duxbury Press, 354 p.

Warner, N.R., Jackson, R.B., Darrah, T.H., Osborn, S.G., Down, Adrian, Zhao, Kaiguang, White, Alissa, and Vengosh, Avner, 2012, Geochemical evidence for possible natural migration of Marcellus Formation brine to shallow aquifers in Pennsylvania: Proceedings of the National Academy of Sciences, v. 109, no. 30, p. 11961-11966.

Welch, A.H., Westjohn, D.B., Helsel, D.R., and Wanty, R.B., 2000, Arsenic in ground water of the United StatesOccurrence and geochemistry: Ground Water, v. 38, p. 589-604.

Whittemore, D.O., 2007, Fate and identification of oil-brine contamination in different hydrogeologic settings: Applied Geochemistry, v. 22, p. 2099-2114.

Wilson, B., 2014. Geologic and baseline groundwater evidence for naturally occurring, shallowly sourced, thermogenic gas in northeastern Pennsylvania: American Association of Petroleum Geologists Bulletin, v. 98, p. 37. 
Table 11. Minimum, median, and maximum of actual and percent differences in chemical and physical properties measured in the field, and concentrations of total dissolved solids, major ions, nutrients, selected minor ions and trace metals, radon-222, and methane determined in the laboratory for water samples collected from 16 wells sampled during 2011-12 and 2015 in Pike County, Pennsylvania.

[Of 16 wells sampled twice, 1 well was sampled in 2011 and 2015 and 15 wells were sampled in 2012 and 2015 . Actual difference $=2015$ result -2012 result; percent difference $=100 *(2015$ result -2012 result)/2015 result; $\mu \mathrm{S} / \mathrm{cm}$, microSiemens per centimeter at 25 degrees Celsius; $\mathrm{mg} / \mathrm{L}$, milligrams per liter; $\mathrm{CaCO}_{3}$, calcium carbonate; ${ }^{\circ} \mathrm{C}$, degrees Celsius; $\mathrm{SiO}{ }_{2}$, silica; $\mathrm{mg} / \mathrm{L}$ as $\mathrm{N}$, milligrams per liter as nitrogen; mg/L as P, milligrams per liter as phosphorus; --, no data or not applicable; <, less than]

\begin{tabular}{|c|c|c|c|c|c|c|c|c|c|c|c|c|}
\hline \multirow[t]{2}{*}{$\begin{array}{l}\text { Sample properties } \\
\text { and constituents }\end{array}$} & \multirow[t]{2}{*}{ Units } & \multirow[t]{2}{*}{$\begin{array}{l}\text { Reporting } \\
\text { level }\end{array}$} & \multirow{2}{*}{$\begin{array}{l}\text { Number } \\
\text { above } \\
\text { reporting } \\
\text { level }\end{array}$} & \multicolumn{3}{|c|}{$\begin{array}{l}\text { Actual difference } \\
\text { in concentration }\end{array}$} & \multicolumn{3}{|c|}{$\begin{array}{l}\text { Percent difference } \\
\text { in concentration }\end{array}$} & \multicolumn{3}{|c|}{$\begin{array}{c}\text { Range and median } \\
\text { of concentrations } \\
\text { above reporting level }\end{array}$} \\
\hline & & & & Minimim & Median & Maximum & Minimim & Median & Maximum & Minimim & Median & Maximum \\
\hline \multicolumn{13}{|c|}{ Field properties } \\
\hline Water temperature & ${ }^{\circ} \mathrm{C}$ & 0.1 & 16 & -0.8 & -0.1 & 1 & -7.2 & -1.1 & 8.1 & 8.99 & 10.75 & 13 \\
\hline Dissolved oxygen & $\mathrm{mg} / \mathrm{L}$ & $<0.1$ & 16 & -2.65 & 0.1 & 2.7 & -93.0 & 39.0 & $1,110.0$ & 0.1 & 0.2 & 10.38 \\
\hline Specific conductance, field & $\mu \mathrm{S} / \mathrm{cm}$ & $<10$ & 16 & -26 & 5 & 75 & -23.0 & 2.5 & 59.0 & 64 & 186 & 458 \\
\hline $\mathrm{pH}$, field & $\mathrm{pH}$ units & 0.1 & 16 & -0.21 & -0.03 & 1 & -2.8 & -0.4 & 12.3 & 5.75 & 7.2 & 9.1 \\
\hline \multicolumn{13}{|c|}{ Laboratory analyses ${ }^{2,3}$} \\
\hline Specific conductance, laboratory & $\mu \mathrm{S} / \mathrm{cm}$ & $<5$ & 16 & -22 & 7 & 77 & -20.4 & 3.6 & 48.1 & 69 & 214 & 458 \\
\hline Total dissolved solids & $\mathrm{mg} / \mathrm{L}$ & $<20$ & 16 & -28 & -3.5 & 50 & -41.0 & -2.2 & 50.7 & 38 & 121.0 & 280.0 \\
\hline \multicolumn{13}{|c|}{ Major ions (dissolved) } \\
\hline Calcium, dissolved & $\mathrm{mg} / \mathrm{L}$ & $<0.22$ & 16 & -2.59 & 0.6 & 8.8 & -19.5 & 3.9 & 35.8 & 4.2 & 13.25 & 60.17 \\
\hline Magnesium, dissolved & $\mathrm{mg} / \mathrm{L}$ & $<0.011$ & 16 & -0.46 & 0.01 & 2.554 & -19.4 & -0.1 & 39.3 & 0.9 & 4.197 & 10.08 \\
\hline Sodium, dissolved & $\mathrm{mg} / \mathrm{L}$ & $<0.06$ & 16 & -1.31 & 0.34 & 4 & -21.5 & 2.8 & 79.1 & 1.361 & 8.125 & 69.42 \\
\hline Potassium, dissolved & $\mathrm{mg} / \mathrm{L}$ & $<0.03$ & 16 & -0.05 & 0.34 & 0.118 & -11.7 & 5.3 & 17.6 & 0.239 & 0.608 & 1.228 \\
\hline Alkalinity (dissolved) & $\begin{array}{l}\mathrm{mg} / \mathrm{L} \text { as } \\
\mathrm{CaCO}_{3}\end{array}$ & $<4.6$ & 16 & -5.2 & -0.5 & 123.1 & -21.4 & -0.8 & 3.5 & 12.6 & 65 & 126.8 \\
\hline Bromide, dissolved & $\mu \mathrm{g} / \mathrm{L}$ & $<10$ & 16 & -4.400 & 4 & 40 & -27.0 & 10.0 & 154.0 & 13 & 27 & 360 \\
\hline Chloride, dissolved & $\mathrm{mg} / \mathrm{L}$ & $<0.02$ & 16 & -3.50 & 0.98 & 23 & -25.9 & 12.6 & 199.0 & 0.467 & 5.543 & 69 \\
\hline Fluoride, dissolved & $\mathrm{mg} / \mathrm{L}$ & $<0.04$ & 15 & -0.025 & -0.01 & 0.016 & -23.3 & -6.9 & 18.0 & 0.025 & 0.1 & 0.5 \\
\hline Sulfate, dissolved & $\mathrm{mg} / \mathrm{L}$ & $<0.02$ & 16 & -2.30 & -0.32 & 0 & -7.9 & 5.5 & 11.1 & 0.376 & 7.405 & 17.4 \\
\hline Silica, dissolved & $\begin{array}{c}\mathrm{mg} / \mathrm{L} \text { as } \\
\mathrm{SiO}_{2}\end{array}$ & $<0.018$ & 16 & -0.72 & 0.63 & 1.0 & -7.9 & 5.5 & 11.1 & 4.31 & 9.28 & 17.24 \\
\hline \multicolumn{13}{|c|}{ Nutrients (dissolved) } \\
\hline Ammonia, dissolved & $\mathrm{mg} / \mathrm{L}$ as $\mathrm{N}$ & $<0.01$ & 6 & -0.002 & 0.0018 & 0.038 & -2.4 & 3.8 & 13.2 & 0.038 & 0.1 & 0.3 \\
\hline Nitrite, dissolved & $\mathrm{mg} / \mathrm{L}$ as $\mathrm{N}$ & $<0.001$ & 0 & $<0.001$ & $<0.001$ & $<0.001$ & -- & -- & -- & -- & -- & -- \\
\hline Nitrate + nitrite, dissolved & $\mathrm{mg} / \mathrm{L}$ as $\mathrm{N}$ & $<0.04$ & 5 & -0.1 & -0.00958 & 0.10966 & -24.5 & 0.0 & 21.8 & 0.02 & 0.0 & 0.9 \\
\hline Orthophosphate, dissolved & $\mathrm{mg} / \mathrm{L}$ as $\mathrm{P}$ & $<0.004$ & 15 & -0.0089 & 0.0011 & 0.00735 & -35.2 & 8.9 & 46.5 & $<0.004$ & 0.02 & 0.178 \\
\hline
\end{tabular}


Table 11. Minimum, median, and maximum of actual and percent differences in chemical and physical properties measured in the field, and concentrations of total dissolved solids, major ions, nutrients, selected minor ions and trace metals, radon-222, and methane determined in the laboratory for water samples collected from 16 wells sampled during 2011-12 and 2015 in Pike County, Pennsylvania.-Continued

[Of 16 wells sampled twice, 1 well was sampled in 2011 and 2015 and 15 wells were sampled in 2012 and 2015. Actual difference $=2015$ result -2012 result; percent difference $=100 *(2015$ result -2012 result $/ 2015$ result; $\mu \mathrm{S} / \mathrm{cm}$, microSiemens per centimeter at 25 degrees Celsius; $\mathrm{mg} / \mathrm{L}$, milligrams per liter; $\mathrm{CaCO}_{3}$, calcium carbonate; ${ }^{\circ} \mathrm{C}$, degrees $\mathrm{Celsius;} \mathrm{SiO}{ }_{2}$, silica; $\mathrm{mg} / \mathrm{L}$ as $\mathrm{N}$, milligrams per liter as nitrogen; mg/L as P, milligrams per liter as phosphorus; --, no data or not applicable; <, less than]

\begin{tabular}{|c|c|c|c|c|c|c|c|c|c|c|c|c|}
\hline \multirow[t]{2}{*}{$\begin{array}{l}\text { Sample properties } \\
\text { and constituents }\end{array}$} & \multirow[t]{2}{*}{ Units } & \multirow[t]{2}{*}{$\begin{array}{l}\text { Reporting } \\
\text { level }\end{array}$} & \multirow{2}{*}{$\begin{array}{l}\text { Number } \\
\text { above } \\
\text { reporting } \\
\text { level }\end{array}$} & \multicolumn{3}{|c|}{$\begin{array}{l}\text { Actual difference } \\
\text { in concentration }\end{array}$} & \multicolumn{3}{|c|}{$\begin{array}{l}\text { Percent difference } \\
\text { in concentration }\end{array}$} & \multicolumn{3}{|c|}{$\begin{array}{l}\text { Range and median } \\
\text { of concentrations } \\
\text { above reporting level }\end{array}$} \\
\hline & & & & Minimim & Median & Maximum & Minimim & Median & Maximum & Minimim & Median & Maximum \\
\hline \multicolumn{13}{|c|}{ Selected dissolved and total trace constituents (filtered and unfiltered samples) } \\
\hline Arsenic, dissolved & $\mu \mathrm{g} / \mathrm{L}$ & $<0.1$ & 13 & -2.28 & -0.024 & 0.1775 & -33.9 & -6.0 & 95.4 & 0.03 & 0.33 & 30.1 \\
\hline Barium, dissolved & $\mu \mathrm{g} / \mathrm{L}$ & $<0.25$ & 16 & -22 & 0.033 & 51.1 & -31.7 & 1.0 & 55.3 & 2.63 & 46.88 & 318.1 \\
\hline Boron & $\mu \mathrm{g} / \mathrm{L}$ & $<5$ & 12 & -11.9 & -1 & 0.7 & -69.5 & -3.3 & 6.9 & $<3$ & 11.6 & 264 \\
\hline Iron, total & $\mu \mathrm{g} / \mathrm{L}$ & $<4.6$ & 11 & -190 & 4.5 & 4,864 & -84.7 & 83.2 & 427.0 & $<4.5$ & 74.4 & 6,170 \\
\hline Iron, dissolved & $\mu \mathrm{g} / \mathrm{L}$ & $<4$ & 10 & -76.5 & -0.8 & 80 & -91.2 & 0.0 & 174.0 & $<3.2$ & 9.9 & 132 \\
\hline Lithium, dissolved & $\mu \mathrm{g} / \mathrm{L}$ & $<0.13$ & 16 & -2 & 1.1 & 41.75 & -26.9 & 9.4 & 121.1 & 0.975 & 12.86 & 289.4 \\
\hline Manganese, total & $\mu \mathrm{g} / \mathrm{L}$ & $<0.5$ & 15 & -30.3 & 0.327 & 255 & -89.4 & 11.2 & 195.0 & 0.2 & 20.4 & 901 \\
\hline Manganese, dissolved & $\mu \mathrm{g} / \mathrm{L}$ & $<0.4$ & 14 & -34.5 & -0.38 & 100.5 & -82.2 & -0.9 & 95.4 & 0.2 & 8.8 & 715 \\
\hline Molybdenum & $\mu \mathrm{g} / \mathrm{L}$ & $<0.014,<0.05$ & 11 & -3.39 & -0.0119 & 0.1152 & -98.3 & -3.1 & 32.8 & 0.14 & 0.322 & 3.45 \\
\hline Strontium, dissolved & $\mu \mathrm{g} / \mathrm{L}$ & $<0.8$ & 16 & -351 & 3.4 & 130 & -81.8 & 2.5 & 39.5 & 13.87 & 331.3 & 986.7 \\
\hline Uranium (natural) & $\mu \mathrm{g} / \mathrm{L}$ & $<0.014$ & 14 & -0.619 & -0.0019 & 0.079 & -44.3 & -4.8 & 65.6 & $<0.004$ & 0.095 & 1.21 \\
\hline Radon-222 & $\mathrm{pCi} / \mathrm{L}$ & & 16 & $-1,500$ & -120 & 366 & -39.7 & -9.0 & 41.7 & 73 & 1243 & 4,130 \\
\hline Methane $^{1}$ & $\mathrm{mg} / \mathrm{L}$ & $<0.01$ & 3 & -0.003 & -1.01 & -1.56 & -23.0 & -36.0 & -38.0 & 0.012 & 2.8 & 4.1 \\
\hline
\end{tabular}

${ }^{1}$ Methane determined by TestAmerica Laboratories, Inc., in 2012 and Seewald Laboratories, Inc., in 2015.

${ }^{2}$ Laboratory analysis for dissolved concentrations in filtered samples done by U.S. Geological Survey National Water Quality Laboratory (NWQL).

${ }^{3}$ Laboratory analysis for total concentrations in unfiltered samples done by contract laboratories using drinking-water methods (see Appendix 2). 
Table 12. Land-surface altitude, well depth, and geologic unit (aquifer) code for 79 wells sampled in 2015 in Pike County, Pennsylvania.

[USGS, U.S. Geological Survey; NAVD 88, North American Vertical Datum of 1988; --, no data or not applicable; Geologic units: 341, PGPK, Poplar Gap and Packerton Members of Catskill Formation, undivided; 341DLRV, Delaware River Member of the Catskill Formation; 341LCXX, Lackawaxen Member of the Catskill Formation; 341TMSG, Towamensing Member of the Catskill formation; 341TMRK, Trimmers Rock Formation; 344MNNG, Mahantango Formation;344MRCL, Marcellus Shale]

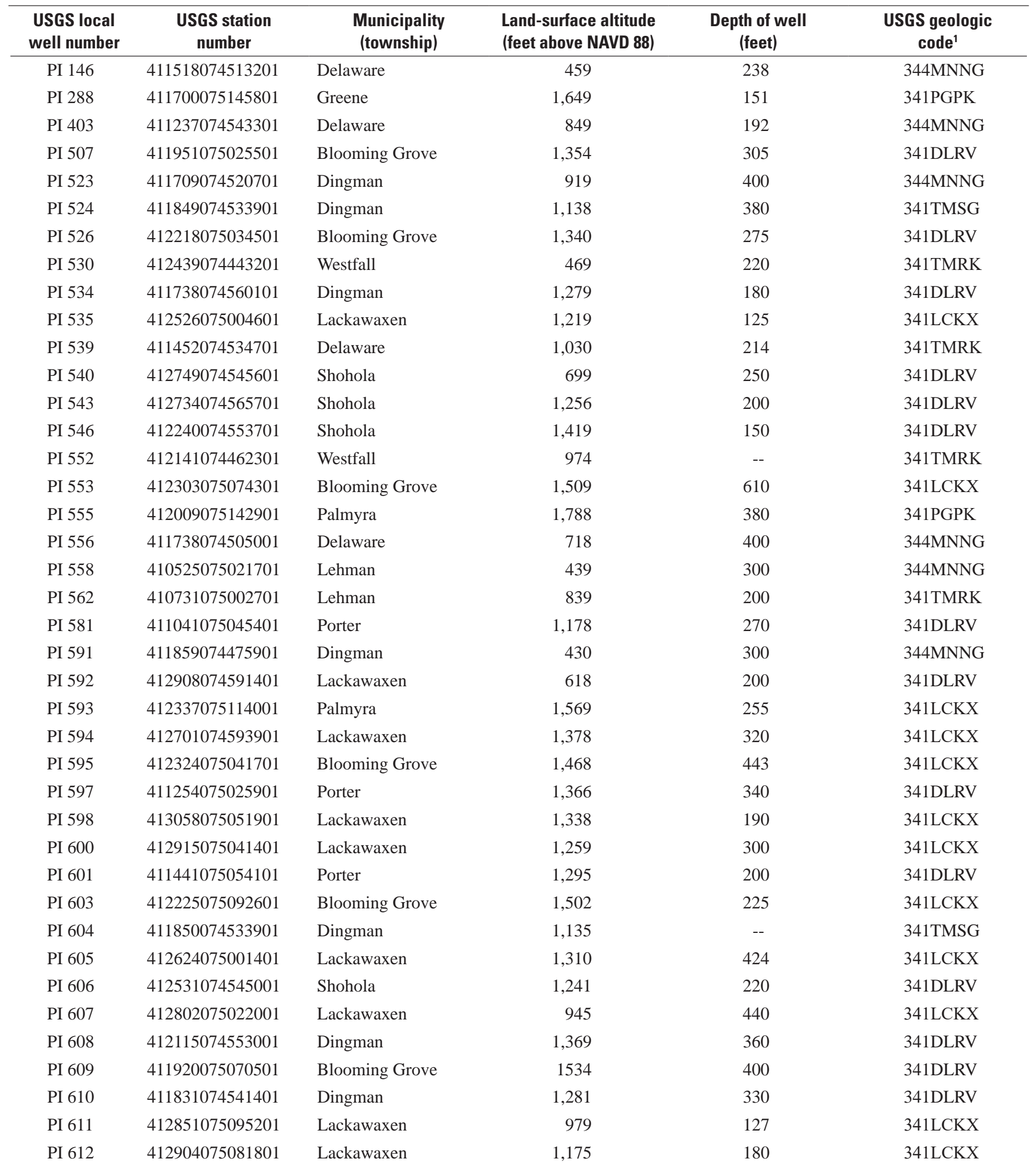


Table 12. Land-surface altitude, well depth, and geologic unit (aquifer) code for 79 wells sampled in 2015 in Pike County, Pennsylvania.-Continued

[USGS, U.S. Geological Survey; NAVD 88, North American Vertical Datum of 1988; --, no data or not applicable; Geologic units: 341, PGPK, Poplar Gap and Packerton Members of Catskill Formation, undivided; 341DLRV, Delaware River Member of the Catskill Formation; 341LCXX, Lackawaxen Member of the Catskill Formation; 341TMSG, Towamensing Member of the Catskill formation; 341TMRK, Trimmers Rock Formation; 344MNNG, Mahantango Formation;344MRCL, Marcellus Shale]

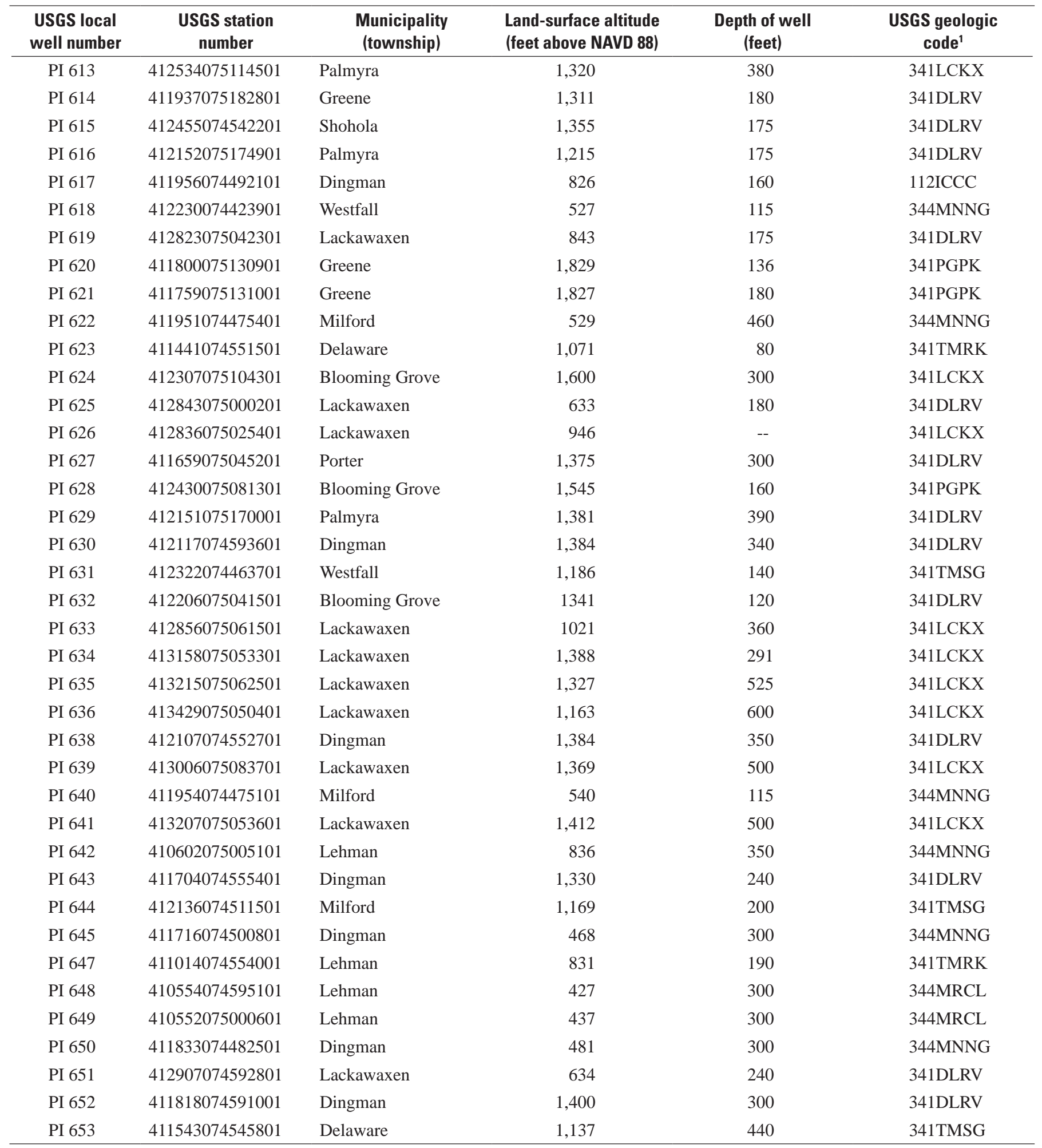

${ }^{1}$ Geologic units mapped as 341DLRV and 341LCXX by Sevon and others (1989) are mapped as LongRun, Beaverdam Run, Walckville Members of Catskill Formation, Undivided (341LRBW) by Berg and others (1981). 
Table 13. Field measurements and results of laboratory analyses for major and minor ions, nutrients, bacteria, trace metals, volatile organic compounds radioactivity, radon-222, and dissolved gases for water samples collected from 79 wells in 2015 in Pike County, Pennsylvania. Constituents listed with associated 5-digit U.S. Geological Survey parameter code. Sample times offset by 1 minute indicate environmental relicate.

$\left[\mathrm{mm} \mathrm{Hg}\right.$, millimeters of mercury; ${ }^{\circ} \mathrm{C}$, degrees Celsius; mg/L, milligrams per liter; $\mu \mathrm{S} / \mathrm{cm}$, microsiemens per centimeter; $\mathrm{CaCO}, \mu \mathrm{g} / \mathrm{L}, \mathrm{micrograms}$ per liter; ANC, acid neutralizing capacity; pCi/L, picocuries per liter; --, no data; <, less than; >, greater than; E, estimated; M, presence verified but not quantified; $\mathrm{R}$, non-detect for radiological analysis; $\mathrm{U}$, analyzed for but not detected]

\begin{tabular}{|c|c|c|c|c|c|c|c|c|}
\hline $\begin{array}{l}\text { Local } \\
\text { identifier }\end{array}$ & Station number & Date & $\begin{array}{c}\text { Sample } \\
\text { start } \\
\text { time }\end{array}$ & $\begin{array}{l}\text { Dissolved } \\
\text { oxygen, } \\
\text { water, } \\
\text { unfiltered } \\
\text { (mg/L) }\end{array}$ & $\begin{array}{l}\text { pH, water, } \\
\text { unfiltered, } \\
\text { field } \\
\text { (standard } \\
\text { units) }\end{array}$ & $\begin{array}{l}\text { pH, water, } \\
\text { unfiltered, } \\
\text { laboratory } \\
\text { (standard } \\
\text { units) }\end{array}$ & $\begin{array}{c}\text { Specific } \\
\text { conductance, } \\
\text { water, unfiltered, } \\
\text { laboratory } \\
\left(\mu \mathrm{S} / \mathrm{cm} \text { at } 25^{\circ} \mathrm{C}\right)\end{array}$ & $\begin{array}{c}\text { Specific } \\
\text { conductance, } \\
\text { water, unfiltered } \\
\left(\mu \mathrm{S} / \mathrm{cm} \text { at } 25^{\circ} \mathrm{C}\right)\end{array}$ \\
\hline & & & & 00300 & 00400 & 00403 & 90095 & 00095 \\
\hline PI 146 & 411518074513201 & $8 / 6 / 2015$ & 1400 & 0.1 & 9.1 & 8.9 & 265 & 251 \\
\hline PI 507 & 411951075025501 & 6/23/2015 & 1100 & 5.5 & 6.6 & 7 & 296 & 276 \\
\hline PI 523 & 411709074520701 & 9/21/2015 & 1200 & 0.5 & 7.4 & 7.8 & 354 & 326 \\
\hline PI 524 & 411849074533901 & $6 / 25 / 2015$ & 1500 & $<0.01$ & 8.2 & 8.4 & 302 & 287 \\
\hline PI 524 & 411849074533901 & 9/22/2015 & 1330 & 0.1 & 8.4 & 8.4 & 297 & 275 \\
\hline PI 524 & 411849074533901 & 9/22/2015 & 1331 & -- & -- & 8.3 & 293 & -- \\
\hline PI 539 & 411452074534701 & 8/5/2015 & 1100 & 0.4 & 7.3 & 8 & 200 & 194 \\
\hline PI 540 & 412749074545601 & 8/5/2015 & 1030 & 0.1 & 8.1 & 8.2 & 218 & 207 \\
\hline PI 543 & 412734074565701 & 8/3/2015 & 1500 & 4.8 & 6.7 & 7.2 & 101 & 99 \\
\hline PI 546 & 412240074553701 & 8/4/2015 & 1000 & 2.9 & 6.5 & E7.0 & E68 & 68 \\
\hline PI 552 & 412141074462301 & $6 / 24 / 2015$ & 1445 & 0.1 & 7.1 & 7.8 & 220 & 212 \\
\hline PI 553 & 412303075074301 & $6 / 23 / 2015$ & 1400 & 0.1 & 7.2 & E7.7 & E92 & 91 \\
\hline PI 555 & 412009075142901 & $6 / 23 / 2015$ & 1100 & 5.3 & 7 & 7.7 & 146 & 145 \\
\hline PI 556 & 411738074505001 & 8/6/2015 & 1030 & 0.2 & 8.3 & 8.2 & 190 & 187 \\
\hline PI 558 & 410525075021701 & $6 / 23 / 2015$ & 1500 & 8.6 & 6.6 & E7.1 & E86 & 85 \\
\hline PI 562 & 410731075002701 & 9/23/2015 & 900 & 0.1 & 7.4 & 7.8 & 178 & 172 \\
\hline PI 597 & 411254075025901 & 7/8/2015 & 1000 & 0.3 & 7.5 & 7.9 & 156 & 156 \\
\hline PI 598 & 413058075051901 & $6 / 22 / 2015$ & 1600 & 0.1 & 6.7 & 7.4 & 126 & 114 \\
\hline PI 600 & 412915075041401 & $6 / 24 / 2015$ & 1400 & 0.1 & 8 & 8.1 & 230 & 226 \\
\hline PI 601 & 411441075054101 & $6 / 25 / 2015$ & 1000 & 0.6 & 7.7 & 8 & 146 & 141 \\
\hline PI 603 & 412225075092601 & 7/6/2015 & 1230 & 0.3 & 7.3 & 7.7 & 128 & 122 \\
\hline PI 604 & 411850074533901 & 9/21/2015 & 1500 & 1.9 & 7.8 & 8.1 & 228 & 215 \\
\hline PI 605 & 412624075001401 & 7/8/2015 & 1100 & 6.2 & 6 & 6.5 & 116 & 118 \\
\hline PI 606 & 412531074545001 & 6/24/2015 & 1100 & $<0.01$ & 7.1 & 7.8 & 250 & 244 \\
\hline PI 607 & 412802075022001 & 7/7/2015 & 1530 & 7.4 & 7 & 7.5 & 147 & 146 \\
\hline PI 608 & 412115074553001 & 7/15/2015 & 930 & M & 7.5 & 7.8 & 218 & 208 \\
\hline PI 609 & 411920075070501 & 7/8/2015 & 1300 & 1.4 & 9.2 & 9 & 231 & 228 \\
\hline PI 610 & 411831074541401 & $7 / 14 / 2015$ & 1300 & 6.7 & 6 & 6.4 & 178 & 172 \\
\hline PI 611 & 412851075095201 & 7/7/2015 & 1230 & 0.2 & 7.2 & 7.7 & 247 & 248 \\
\hline PI 612 & 412904075081801 & 7/7/2015 & 1230 & 7.1 & 6.2 & 6.6 & 168 & 165 \\
\hline
\end{tabular}


Table 13. Field measurements and results of laboratory analyses for major and minor ions, nutrients, bacteria, trace metals, volatile organic compounds radioactivity, radon-222, and dissolved gases for water samples collected from 79 wells in 2015 in Pike County, Pennsylvania. Constituents listed with associated 5-digit U.S. Geological Survey parameter code. Sample times offset by 1 minute indicate environmental relicate.-Continued

[mm Hg, millimeters of mercury; ${ }^{\circ} \mathrm{C}$, degrees Celsius; mg/L, milligrams per liter $\mu \mathrm{S} / \mathrm{cm}$; microsiemens per centimeter; $\mathrm{CaCO}_{3}, \mu \mathrm{g} / \mathrm{L}, \mathrm{micrograms}$ per liter; ANC, acid neutralizing capacity; $\mathrm{pCi} / \mathrm{L}$, picocuries per liter; --, no data; <, less than; >, greater than; $\mathrm{E}$, estimated; M, presence verified but not quantified; $\mathrm{R}$, non-detect for radiological analysis; $\mathrm{U}$, analyzed for but not detected]

\begin{tabular}{|c|c|c|c|c|c|c|c|c|}
\hline $\begin{array}{l}\text { Local } \\
\text { identifier }\end{array}$ & Station number & Date & $\begin{array}{c}\text { Sample } \\
\text { start } \\
\text { time }\end{array}$ & $\begin{array}{l}\text { Dissolved } \\
\text { oxygen, } \\
\text { water, } \\
\text { unfiltered } \\
\text { (mg/L) }\end{array}$ & $\begin{array}{c}\text { pH, water, } \\
\text { unfiltered, } \\
\text { field } \\
\text { (standard } \\
\text { units) }\end{array}$ & $\begin{array}{l}\text { pH, water, } \\
\text { unfiltered, } \\
\text { laboratory } \\
\text { (standard } \\
\text { units) }\end{array}$ & $\begin{array}{c}\text { Specific } \\
\text { conductance, } \\
\text { water, unfiltered, } \\
\text { laboratory } \\
\left(\mu \mathrm{S} / \mathrm{cm} \text { at } 25^{\circ} \mathrm{C}\right)\end{array}$ & $\begin{array}{c}\text { Specific } \\
\text { conductance, } \\
\text { water, unfiltered } \\
\left(\mu \mathrm{S} / \mathrm{cm} \text { at } 25^{\circ} \mathrm{C}\right)\end{array}$ \\
\hline & & & & 00300 & 00400 & 00403 & 90095 & 00095 \\
\hline PI 613 & 412534075114501 & $7 / 6 / 2015$ & 1500 & 1 & 7.2 & 7.7 & 447 & 427 \\
\hline PI 616 & 412152075174901 & $6 / 22 / 2015$ & 1530 & 7.5 & 6.5 & 7 & 220 & 207 \\
\hline PI 617 & 411956074492101 & 7/9/2015 & 1230 & 9.1 & 6.4 & 7 & 312 & 315 \\
\hline PI 618 & 412230074423901 & 7/9/2015 & 1000 & 0.8 & 7.2 & 8 & 227 & 226 \\
\hline PI 619 & 412823075042301 & 7/7/2015 & 1000 & 1.7 & 7.7 & 7.9 & 162 & 160 \\
\hline PI 620 & 411800075130901 & 7/16/2015 & 1000 & 9.4 & 5.5 & E6.6 & E65 & 71 \\
\hline PI 625 & 412843075000201 & 7/15/2015 & 1000 & 0.2 & 8.1 & 8.2 & 165 & 164 \\
\hline PI 626 & 412836075025401 & 7/7/2015 & 1530 & 1.1 & 7.7 & 7.9 & 149 & 149 \\
\hline PI 627 & 411659075045201 & 7/8/2015 & 1300 & 0.2 & 7.6 & 7.9 & 151 & 152 \\
\hline PI 628 & 412430075081301 & 7/8/2015 & 1430 & 9.8 & 5.5 & E6.3 & E45 & 47 \\
\hline PI 629 & 412151075170001 & 7/14/2015 & 1430 & 6 & 6.6 & 7.2 & 292 & 290 \\
\hline PI 630 & 412117074593601 & 7/15/2015 & 1500 & 8.9 & 6 & E6.5 & E53 & 52 \\
\hline PI 631 & 412322074463701 & $7 / 15 / 2015$ & 1230 & 0.1 & 6.6 & 7 & 191 & 191 \\
\hline PI 632 & 412206075041501 & 8/3/2015 & 1230 & 8.8 & 5.7 & E6.2 & E93 & 89 \\
\hline PI 633 & 412856075061501 & 8/6/2015 & 1000 & 3 & 7.5 & 8 & 185 & 179 \\
\hline PI 634 & 413158075053301 & $8 / 4 / 2015$ & 930 & 5.6 & 7.1 & 7.5 & 228 & 215 \\
\hline PI 643 & 411704074555401 & 9/24/2015 & 900 & 2.9 & 7 & 7.7 & 313 & 299 \\
\hline PI 644 & 412136074511501 & 9/21/2015 & 1130 & 2.9 & 7.1 & 7.5 & 205 & 195 \\
\hline PI 645 & 411716074500801 & 9/23/2015 & 1000 & 7.2 & 6.4 & 7.2 & 207 & 190 \\
\hline PI 647 & 411014074554001 & 9/23/2015 & 1500 & 0.2 & 8.3 & 8.3 & 181 & 173 \\
\hline PI 647 & 411014074554001 & 9/23/2015 & 1501 & -- & -- & -- & -- & -- \\
\hline PI 648 & 410554074595101 & 9/24/2015 & 1300 & 5.9 & 9 & 8.9 & 245 & 229 \\
\hline PI 649 & 410552075000601 & 9/24/2015 & 1030 & 5.6 & 6.4 & 7.2 & 252 & 235 \\
\hline PI 650 & 411833074482501 & 9/23/2015 & 1100 & 0.1 & 9.1 & 8.7 & 1,580 & 1,320 \\
\hline PI 651 & 412907074592801 & 9/22/2015 & 1100 & 0.1 & 8.7 & 8.6 & 277 & 267 \\
\hline PI 652 & 411818074591001 & 9/23/2015 & 1330 & 5.4 & 6.1 & 6.7 & 148 & 146 \\
\hline PI 653 & 411543074545801 & $9 / 24 / 2015$ & 1130 & 0.1 & 7.7 & 8 & 1,090 & 1,060 \\
\hline
\end{tabular}


Table 13. Field measurements and results of laboratory analyses for major and minor ions, nutrients, bacteria, trace metals, volatile organic compounds radioactivity, radon-222, and dissolved gases for water samples collected from 79 wells in 2015 in Pike County, Pennsylvania. Constituents listed with associated 5-digit U.S. Geological Survey parameter code. Sample times offset by 1 minute indicate environmental relicate.-Continued

[mm Hg, millimeters of mercury; ${ }^{\circ} \mathrm{C}$, degrees Celsius; mg/L, milligrams per liter $\mu \mathrm{S} / \mathrm{cm}$; microsiemens per centimeter; $\mathrm{CaCO}_{3}, \mu \mathrm{g} / \mathrm{L}, \mathrm{micrograms}$ per liter; ANC, acid neutralizing capacity; $\mathrm{pCi} / \mathrm{L}$, picocuries per liter; --, no data; <, less than; >, greater than; E, estimated; M, presence verified but not quantified; $\mathrm{R}$, non-detect for radiological analysis; $\mathrm{U}$, analyzed for but not detected]

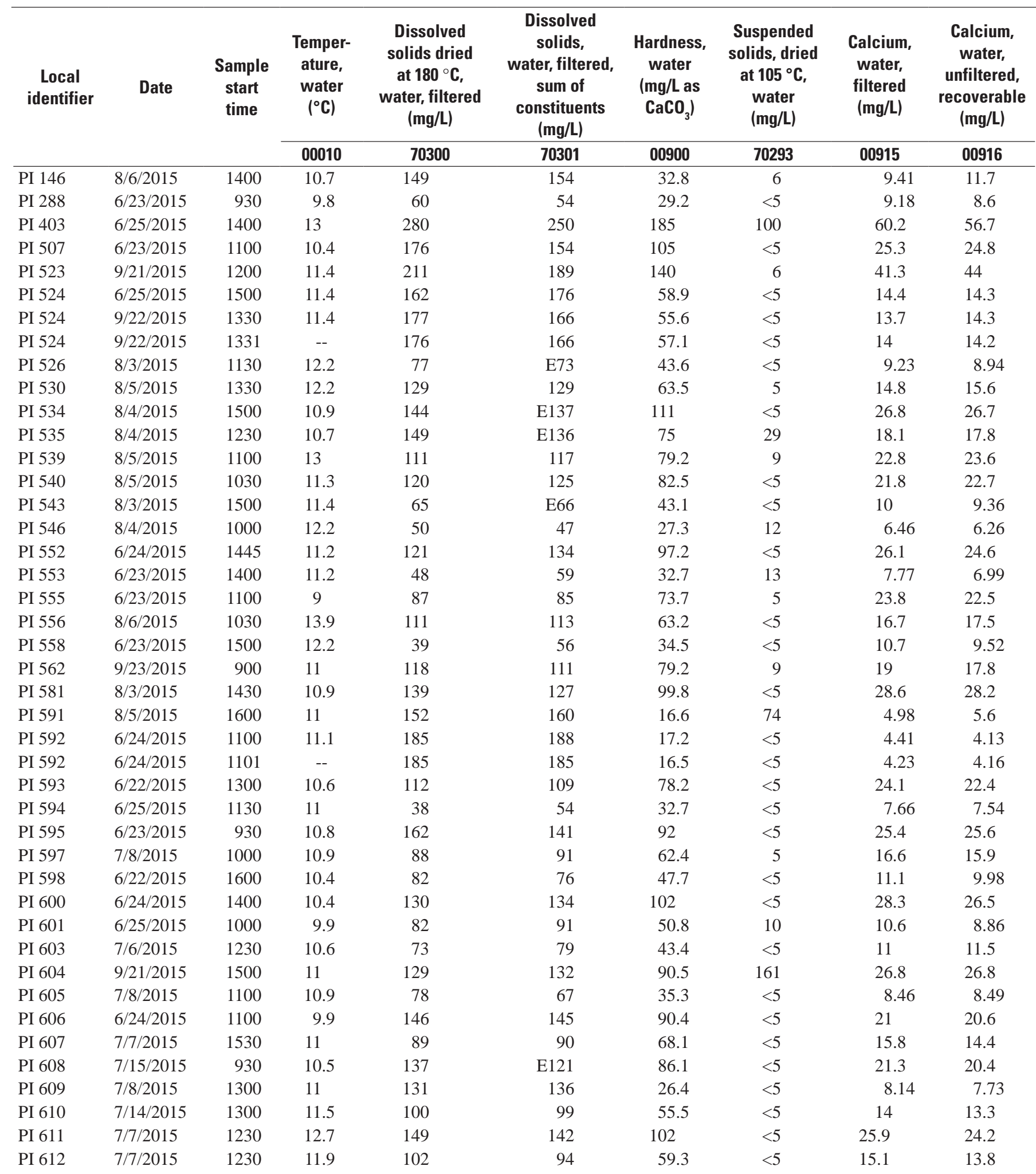


Table 13. Field measurements and results of laboratory analyses for major and minor ions, nutrients, bacteria, trace metals, volatile organic compounds radioactivity, radon-222, and dissolved gases for water samples collected from 79 wells in 2015 in Pike County, Pennsylvania. Constituents listed with associated 5-digit U.S. Geological Survey parameter code. Sample times offset by 1 minute indicate environmental relicate.-Continued

$\left[\mathrm{mm} \mathrm{Hg}\right.$, millimeters of mercury; ${ }^{\circ} \mathrm{C}$, degrees Celsius; mg $/ \mathrm{L}$, milligrams per liter $\mu \mathrm{S} / \mathrm{cm}$; microsiemens per centimeter; $\mathrm{CaCO}_{3}, \mu \mathrm{g} / \mathrm{L}, \mathrm{micrograms}$ per liter; ANC, acid neutralizing capacity; pCi/L, picocuries per liter; --, no data; <, less than; >, greater than; E, estimated; M, presence verified but not quantified; $\mathrm{R}$, non-detect for radiological analysis; $\mathrm{U}$, analyzed for but not detected]

\begin{tabular}{|c|c|c|c|c|c|c|c|c|c|}
\hline $\begin{array}{l}\text { Local } \\
\text { identifier }\end{array}$ & Date & $\begin{array}{c}\text { Sample } \\
\text { start } \\
\text { time }\end{array}$ & $\begin{array}{l}\text { Temper- } \\
\text { ature, } \\
\text { water } \\
\left({ }^{\circ} \mathrm{C}\right)\end{array}$ & $\begin{array}{c}\text { Dissolved } \\
\text { solids dried } \\
\text { at } 180^{\circ} \mathrm{C} \text {, } \\
\text { water, filtered } \\
\text { (mg/L) }\end{array}$ & $\begin{array}{c}\text { Dissolved } \\
\text { solids, } \\
\text { water, filtered, } \\
\text { sum of } \\
\text { constituents } \\
\text { (mg/L) } \\
\end{array}$ & $\begin{array}{c}\text { Hardness, } \\
\text { water } \\
\text { (mg/L as } \\
\mathrm{CaCO}_{3} \text { ) }\end{array}$ & $\begin{array}{l}\text { Suspended } \\
\text { solids, dried } \\
\text { at } 105{ }^{\circ} \mathrm{C} \text {, } \\
\text { water } \\
\text { (mg/L) }\end{array}$ & $\begin{array}{c}\text { Calcium, } \\
\text { water, } \\
\text { filtered } \\
\text { (mg/L) }\end{array}$ & $\begin{array}{c}\text { Calcium, } \\
\text { water, } \\
\text { unfiltered, } \\
\text { recoverable } \\
\text { (mg/L) }\end{array}$ \\
\hline & & & 00010 & 70300 & 70301 & 00900 & 70293 & 00915 & 00916 \\
\hline PI 613 & 7/6/2015 & 1500 & 11 & 262 & 248 & 185 & $<5$ & 50.4 & 53.4 \\
\hline PI 615 & 7/8/2015 & 1530 & 10.4 & 45 & 40 & 19.6 & $<5$ & 4.55 & 4.45 \\
\hline PI 616 & 6/22/2015 & 1530 & 9.6 & 127 & 116 & 79.1 & $<5$ & 24.8 & 23.2 \\
\hline PI 617 & 7/9/2015 & 1230 & 11.6 & 185 & 159 & 90.2 & $<5$ & 23.1 & 21.8 \\
\hline PI 618 & 7/9/2015 & 1000 & 11.9 & 129 & 128 & 89.5 & $<5$ & 23.9 & 23 \\
\hline PI 619 & 7/7/2015 & 1000 & 11.1 & 103 & 98 & 74.6 & 22 & 17.7 & 15.5 \\
\hline PI 624 & 7/14/2015 & 1230 & 12 & 107 & 106 & 72.2 & 5 & 23 & 22.5 \\
\hline PI 625 & 7/15/2015 & 1000 & 12.4 & 103 & 101 & 66.3 & $<5$ & 17.6 & 17.6 \\
\hline PI 626 & 7/7/2015 & 1530 & 11.9 & 98 & 91 & 66.4 & $<5$ & 16.2 & 15.2 \\
\hline PI 627 & 7/8/2015 & 1300 & 10.4 & 85 & 90 & 60.7 & $<5$ & 15.7 & 15.5 \\
\hline PI 628 & 7/8/2015 & 1430 & 9.6 & 28 & 33 & 14.2 & 9 & 3.67 & 3.63 \\
\hline PI 629 & 7/14/2015 & 1430 & 12.9 & 207 & 165 & 128 & $<5$ & 41.4 & 40 \\
\hline PI 630 & 7/15/2015 & 1500 & 11 & 36 & 33 & 21 & $<5$ & 5.28 & 5.17 \\
\hline PI 631 & 7/15/2015 & 1230 & 10.8 & 134 & 115 & 73.2 & $<5$ & 17.4 & 17.2 \\
\hline PI 632 & 8/3/2015 & 1230 & 10.8 & 52 & 55 & 28.8 & $<5$ & 6.2 & 6.06 \\
\hline PI 633 & 8/6/2015 & 1000 & 10.8 & 103 & 107 & 79 & $<5$ & 16.1 & 16.7 \\
\hline PI 634 & 8/4/2015 & 930 & 11.1 & 133 & E135 & 89.8 & $<5$ & 26.9 & 25.8 \\
\hline PI 643 & 9/24/2015 & 900 & 10.6 & 172 & 162 & 128 & $<5$ & 31.6 & 32.4 \\
\hline PI 644 & 9/21/2015 & 1130 & 10.9 & 119 & 119 & 93.6 & 44 & 27 & 27.7 \\
\hline PI 645 & 9/23/2015 & 1000 & 11.4 & 147 & 115 & 70.9 & $<5$ & 17.7 & 18.4 \\
\hline PI 647 & 9/23/2015 & 1500 & 10.7 & 124 & 110 & 63 & 7 & 16.4 & 16.8 \\
\hline PI 647 & 9/23/2015 & 1501 & -- & -- & -- & -- & -- & -- & -- \\
\hline PI 648 & 9/24/2015 & 1300 & 12.2 & 153 & 149 & 18.1 & 5 & 5.79 & 5.85 \\
\hline PI 649 & 9/24/2015 & 1030 & 12.2 & 146 & 148 & 86.4 & $<5$ & 25.7 & 24.8 \\
\hline PI 650 & 9/23/2015 & 1100 & 11.5 & 940 & 975 & 79.4 & $<5$ & 14.5 & 12.5 \\
\hline PI 651 & 9/22/2015 & 1100 & 12.4 & 157 & 161 & 23.4 & 5 & 6.26 & 6.56 \\
\hline PI 652 & 9/23/2015 & 1330 & 10.5 & 94 & 85 & 47.8 & $<5$ & 11.9 & 11.2 \\
\hline PI 653 & 9/24/2015 & 1130 & 11 & 608 & 547 & 392 & $<5$ & 103 & 106 \\
\hline
\end{tabular}


Table 13. Field measurements and results of laboratory analyses for major and minor ions, nutrients, bacteria, trace metals, volatile organic compounds radioactivity, radon-222, and dissolved gases for water samples collected from 79 wells in 2015 in Pike County, Pennsylvania. Constituents listed with associated 5-digit U.S. Geological Survey parameter code. Sample times offset by 1 minute indicate environmental relicate.-Continued

[mm Hg, millimeters of mercury; ${ }^{\circ} \mathrm{C}$, degrees Celsius; mg/L, milligrams per liter $\mu \mathrm{S} / \mathrm{cm}$; , microsiemens per centimeter; $\mathrm{CaCO}, \mu \mathrm{g} / \mathrm{L}, \mathrm{micrograms}$ per liter; ANC, acid neutralizing capacity; $\mathrm{pCi} / \mathrm{L}$, picocuries per liter; --, no data; <, less than; >, greater than; E, estimated; M, presence verified but not quantified; $\mathrm{R}$, non-detect for radiological analysis; $\mathrm{U}$, analyzed for but not detected]

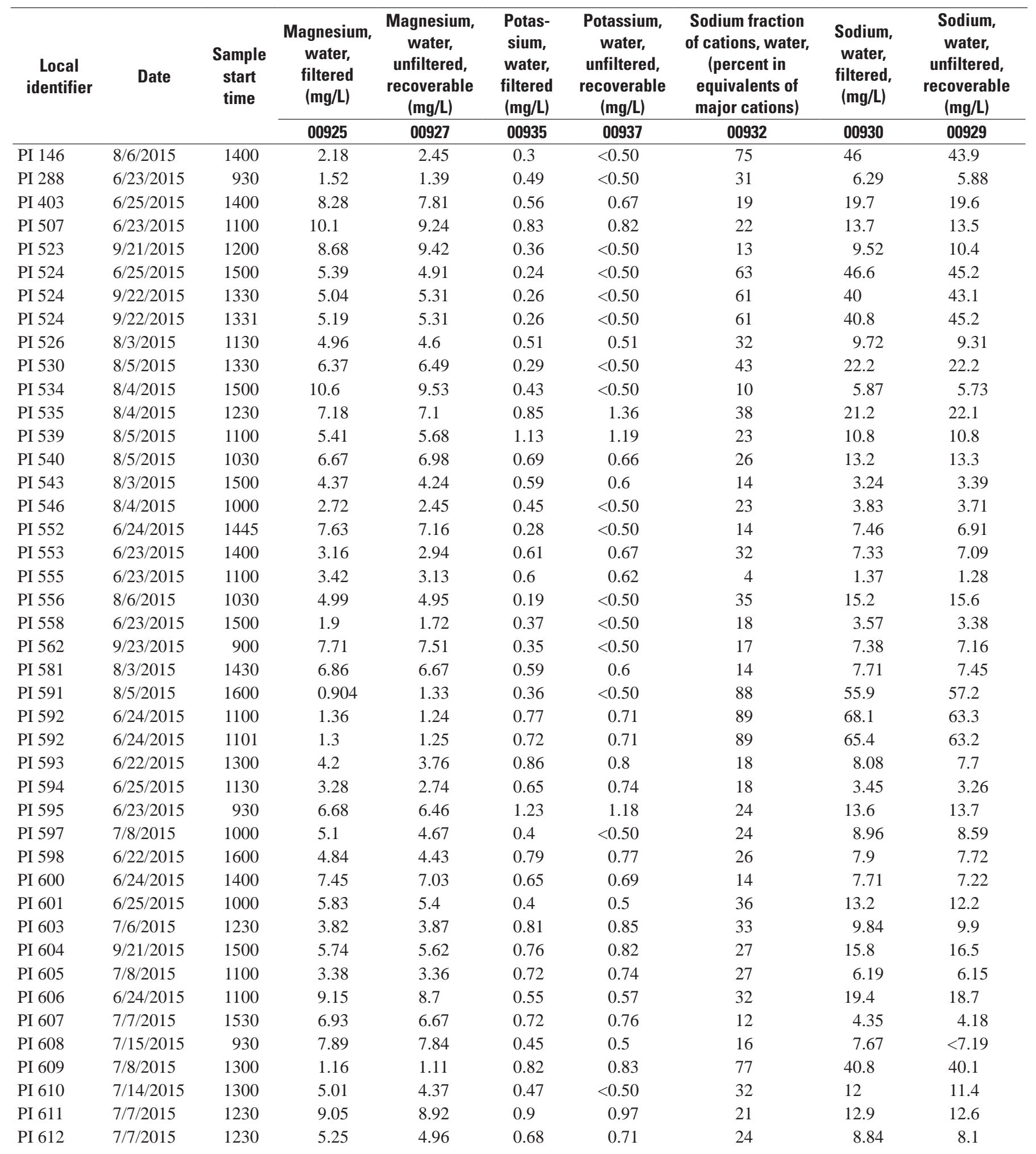


Table 13. Field measurements and results of laboratory analyses for major and minor ions, nutrients, bacteria, trace metals, volatile organic compounds radioactivity, radon-222, and dissolved gases for water samples collected from 79 wells in 2015 in Pike County, Pennsylvania. Constituents listed with associated 5-digit U.S. Geological Survey parameter code. Sample times offset by 1 minute indicate environmental relicate.-Continued

$\left[\mathrm{mm} \mathrm{Hg}\right.$, millimeters of mercury; ${ }^{\circ} \mathrm{C}$, degrees Celsius; mg/L, milligrams per liter $\mu \mathrm{S} / \mathrm{cm}$;, microsiemens per centimeter; $\mathrm{CaCO}_{3}, \mu \mathrm{g} / \mathrm{L}$, micrograms per liter; ANC, acid neutralizing capacity; pCi/L, picocuries per liter; --, no data; <, less than; >, greater than; E, estimated; M, presence verified but not quantified; $\mathrm{R}$, non-detect for radiological analysis; $\mathrm{U}$, analyzed for but not detected]

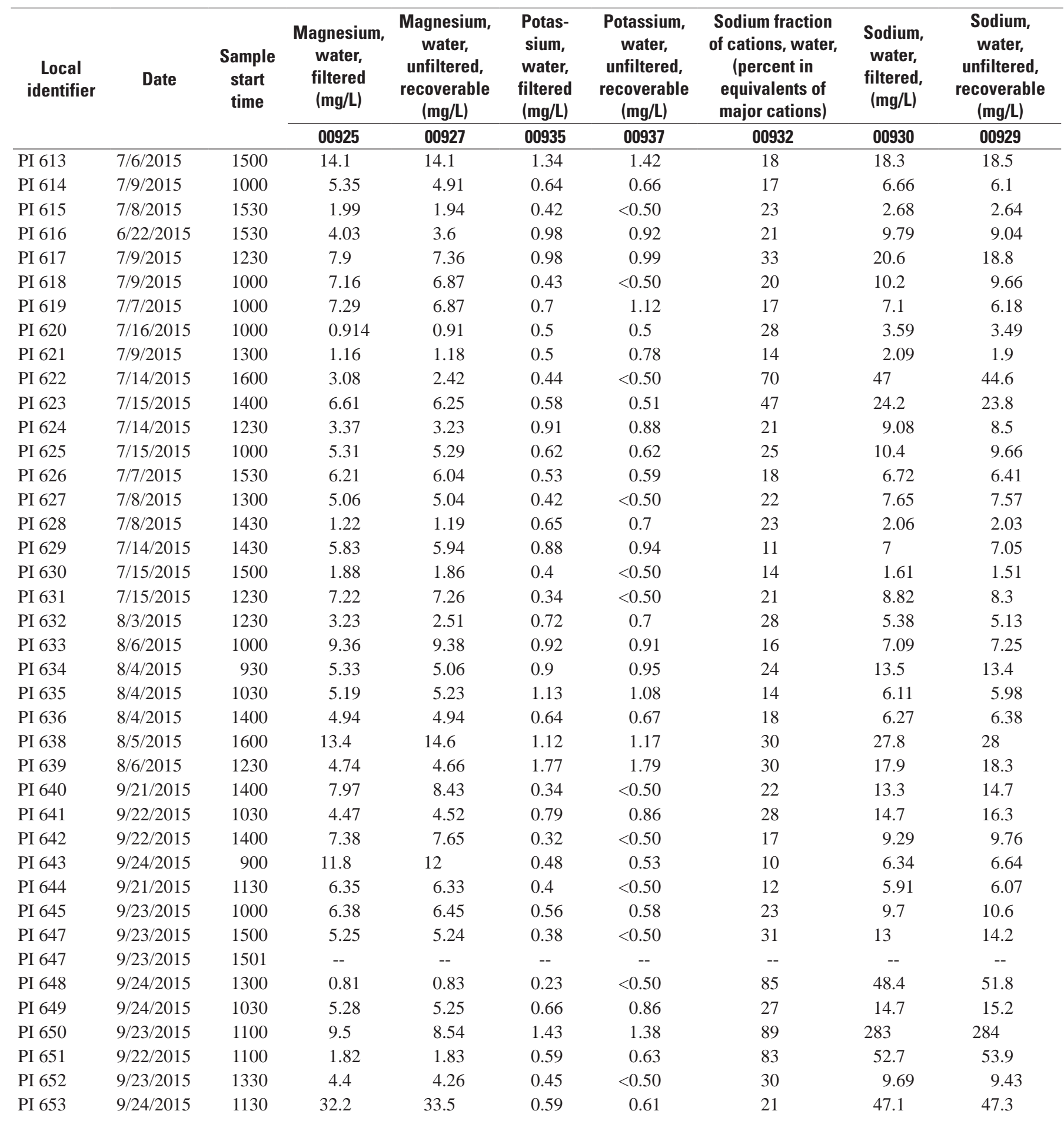


Table 13. Field measurements and results of laboratory analyses for major and minor ions, nutrients, bacteria, trace metals, volatile organic compounds radioactivity, radon-222, and dissolved gases for water samples collected from 79 wells in 2015 in Pike County, Pennsylvania. Constituents listed with associated 5-digit U.S. Geological Survey parameter code. Sample times offset by 1 minute indicate environmental relicate.-Continued

[mm Hg, millimeters of mercury; ${ }^{\circ} \mathrm{C}$, degrees Celsius; mg/L, milligrams per liter $\mu \mathrm{S} / \mathrm{cm}$; , microsiemens per centimeter; $\mathrm{CaCO}, \mu \mathrm{g} / \mathrm{L}, \mathrm{micrograms}$ per liter; ANC, acid neutralizing capacity; pCi/L, picocuries per liter; --, no data; <, less than; >, greater than; E, estimated; M, presence verified but not quantified; $\mathrm{R}$, non-detect for radiological analysis; U, analyzed for but not detected]

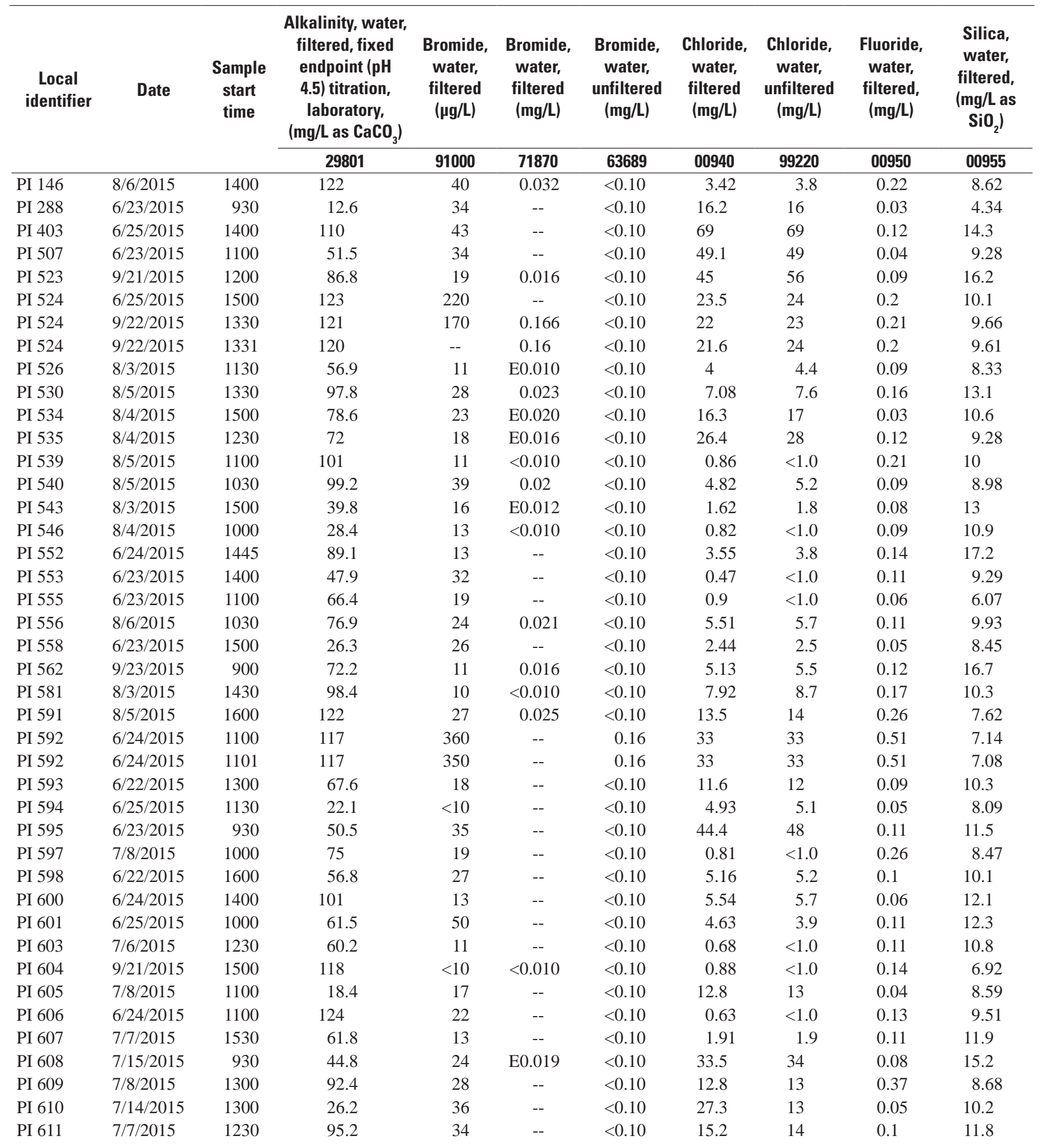


Table 13. Field measurements and results of laboratory analyses for major and minor ions, nutrients, bacteria, trace metals, volatile organic compounds radioactivity, radon-222, and dissolved gases for water samples collected from 79 wells in 2015 in Pike County, Pennsylvania. Constituents listed with associated 5-digit U.S. Geological Survey parameter code. Sample times offset by 1 minute indicate environmental relicate.-Continued

$\left[\mathrm{mm} \mathrm{Hg}\right.$, millimeters of mercury; ${ }^{\circ} \mathrm{C}$, degrees Celsius; mg/L, milligrams per liter $\mu \mathrm{S} / \mathrm{cm}$;, microsiemens per centimeter; $\mathrm{CaCO}_{3}, \mu \mathrm{g} / \mathrm{L}$, micrograms per liter; ANC, acid neutralizing capacity; pCi/L, picocuries per liter; --, no data; <, less than; >, greater than; E, estimated; M, presence verified but not quantified; $\mathrm{R}$, non-detect for radiological analysis; U, analyzed for but not detected]

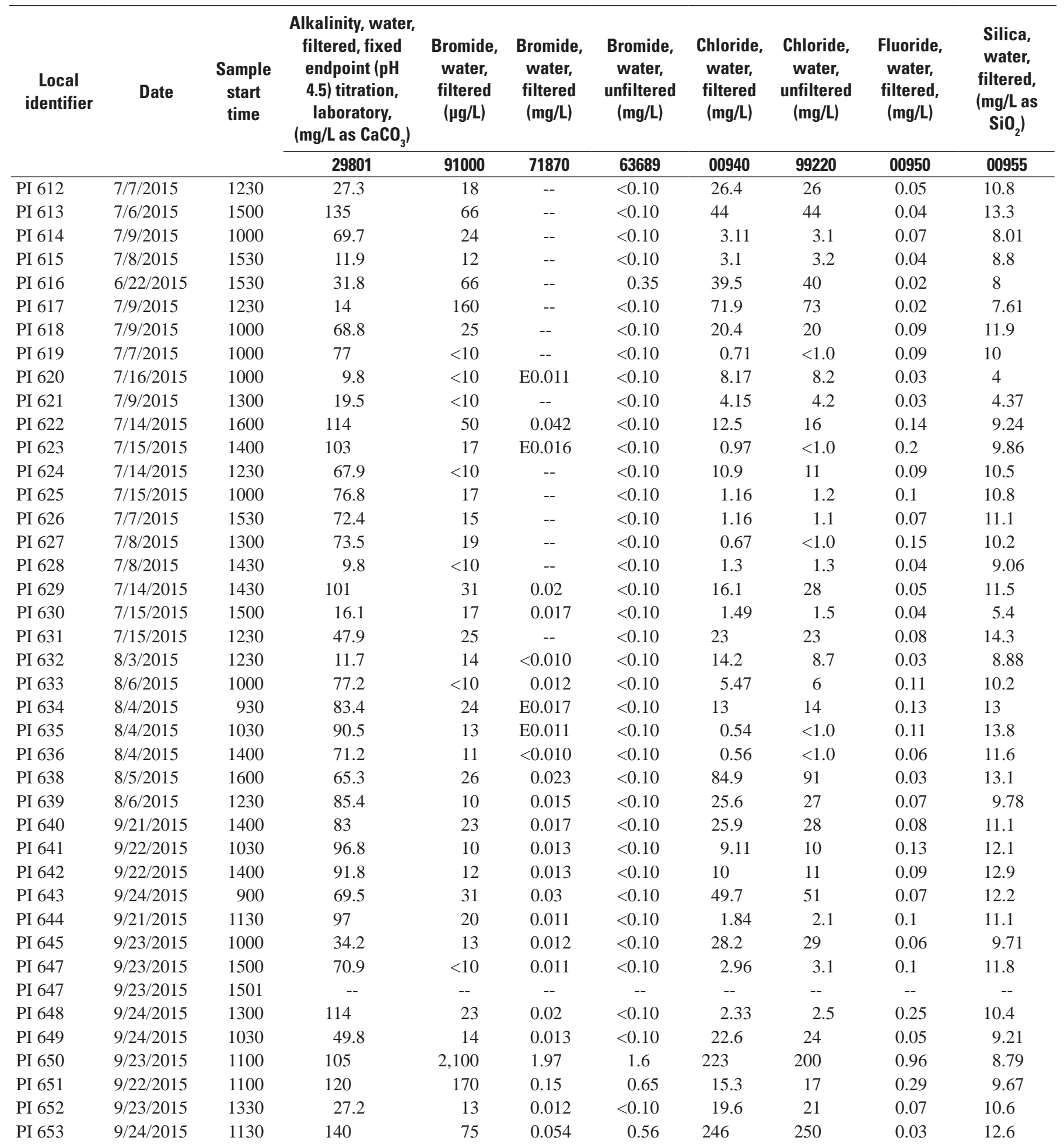


Table 13. Field measurements and results of laboratory analyses for major and minor ions, nutrients, bacteria, trace metals, volatile organic compounds radioactivity, radon-222, and dissolved gases for water samples collected from 79 wells in 2015 in Pike County, Pennsylvania. Constituents listed with associated 5-digit U.S. Geological Survey parameter code. Sample times offset by 1 minute indicate environmental relicate.-Continued

$\left[\mathrm{mm} \mathrm{Hg}\right.$, millimeters of mercury; ${ }^{\circ} \mathrm{C}$, degrees Celsius; mg $/ \mathrm{L}$, milligrams per liter $\mu \mathrm{S} / \mathrm{cm}$; , microsiemens per centimeter; $\mathrm{CaCO}_{3}, \mu \mathrm{g} / \mathrm{L}, \mathrm{micrograms}$ per liter; ANC, acid neutralizing capacity; pCi/L, picocuries per liter; --, no data; <, less than; >, greater than; E, estimated; M, presence verified but not quantified; $\mathrm{R}$, non-detect for radiological analysis; $\mathrm{U}$, analyzed for but not detected]

\begin{tabular}{|c|c|c|c|c|c|c|c|c|c|c|}
\hline $\begin{array}{c}\text { Local } \\
\text { identifier }\end{array}$ & Date & $\begin{array}{c}\text { Sample } \\
\text { start } \\
\text { time }\end{array}$ & $\begin{array}{c}\text { Sulfate, } \\
\text { water, } \\
\text { filtered } \\
(\mathrm{mg} / \mathrm{L})\end{array}$ & $\begin{array}{c}\text { Sulfate, } \\
\text { water, } \\
\text { unfiltered } \\
\text { (mg/L) }\end{array}$ & $\begin{array}{c}\text { Ammonia, } \\
\text { water, } \\
\text { filtered } \\
\text { (mg/L as } \\
\text { nitrogen) }\end{array}$ & $\begin{array}{c}\text { Nitrate } \\
\text { plus nitrite, } \\
\text { water, } \\
\text { filtered } \\
\text { (mg/L as } \\
\text { nitrogen) }\end{array}$ & $\begin{array}{c}\text { Nitrate, } \\
\text { water, } \\
\text { filtered } \\
\text { (mg/L as } \\
\text { nitrogen) }\end{array}$ & $\begin{array}{c}\text { Nitrite, } \\
\text { water, } \\
\text { filtered } \\
\text { (mg/L as } \\
\text { nitrogen) }\end{array}$ & $\begin{array}{c}\text { Ortho- } \\
\text { phosphate, } \\
\text { water, } \\
\text { filtered } \\
\text { (mg/L as } \\
\text { phosphorus) }\end{array}$ & $\begin{array}{c}\text { Escherichia } \\
\text { coli, water, } \\
\text { most } \\
\text { probable } \\
\text { number per } \\
100 \text { milliliters }\end{array}$ \\
\hline & & & 00945 & 00946 & 00608 & 00631 & 00618 & 00613 & 00671 & 31689 \\
\hline PI 146 & 8/6/2015 & 1400 & 9.91 & 9.1 & 0.17 & $<0.040$ & $<0.040$ & $<0.001$ & 0.042 & $<1$ \\
\hline PI 403 & 6/25/2015 & 1400 & 10.5 & 11.3 & 0.05 & $<0.040$ & $<0.040$ & $<0.001$ & 0.028 & $<1$ \\
\hline PI 507 & 6/23/2015 & 1100 & 11.1 & 11.3 & $<0.01$ & 0.612 & 0.612 & $<0.001$ & 0.013 & $<1$ \\
\hline PI 523 & 9/21/2015 & 1200 & 13.5 & 13.6 & 0.07 & $<0.040$ & $<0.040$ & $<0.001$ & 0.024 & $<1$ \\
\hline PI 524 & 6/25/2015 & 1500 & 0.89 & $<1.0$ & 0.07 & $<0.040$ & $<0.040$ & $<0.001$ & 0.029 & $<1$ \\
\hline PI 524 & 9/22/2015 & 1330 & 1.11 & $<1.0$ & 0.06 & $<0.040$ & $<0.040$ & $<0.001$ & 0.027 & $<1$ \\
\hline PI 535 & 8/4/2015 & 1230 & 7.64 & 8.1 & $<0.01$ & 0.422 & 0.422 & $<0.001$ & 0.031 & $<1$ \\
\hline PI 539 & 8/5/2015 & 1100 & 4.28 & 4.7 & 0.03 & $<0.040$ & $<0.040$ & $<0.001$ & 0.043 & $<1$ \\
\hline PI 540 & 8/5/2015 & 1030 & 8.61 & 9.6 & $<0.01$ & $<0.040$ & $<0.040$ & $<0.001$ & 0.007 & $<1$ \\
\hline PI 543 & 8/3/2015 & 1500 & 7.59 & 8.1 & $<0.01$ & 0.206 & 0.206 & $<0.001$ & 0.044 & $<1$ \\
\hline PI 546 & 8/4/2015 & 1000 & 4.92 & 5.4 & $<0.01$ & $<0.040$ & $<0.040$ & $<0.001$ & 0.032 & $<1$ \\
\hline PI 552 & 6/24/2015 & 1445 & 17.4 & 18.6 & 0.04 & $<0.040$ & $<0.040$ & $<0.001$ & 0.011 & $<1$ \\
\hline PI 553 & 6/23/2015 & 1400 & 0.85 & $<1.0$ & $<0.01$ & $<0.040$ & $<0.040$ & $<0.001$ & 0.018 & $<1$ \\
\hline PI 555 & 6/23/2015 & 1100 & 7.75 & 8 & $<0.01$ & 0.323 & 0.323 & $<0.001$ & 0.016 & $<1$ \\
\hline PI 556 & 8/6/2015 & 1030 & 13.1 & 13.6 & 0.09 & $<0.040$ & $<0.040$ & $<0.001$ & 0.019 & $<1$ \\
\hline PI 558 & 6/23/2015 & 1500 & 12.1 & 12 & $<0.01$ & 0.088 & 0.088 & $<0.001$ & 0.014 & $<1$ \\
\hline PI 562 & 9/23/2015 & 900 & 11.1 & 12 & 0.02 & $<0.040$ & $<0.040$ & $<0.001$ & 0.014 & $<1$ \\
\hline PI 597 & 7/8/2015 & 1000 & 5.31 & $<5.8$ & $<0.01$ & $<0.040$ & $<0.040$ & $<0.001$ & 0.05 & $<1$ \\
\hline PI 598 & 6/22/2015 & 1600 & 0.77 & $<1.0$ & 0.09 & $<0.040$ & $<0.040$ & $<0.001$ & 0.083 & $<1$ \\
\hline PI 600 & 6/24/2015 & 1400 & 10.9 & 11.1 & $<0.01$ & $<0.040$ & $<0.040$ & $<0.001$ & 0.006 & $<1$ \\
\hline PI 601 & 6/25/2015 & 1000 & 6.44 & 7.6 & $<0.01$ & $<0.040$ & $<0.040$ & $<0.001$ & 0.029 & $<1$ \\
\hline PI 603 & 7/6/2015 & 1230 & 5.05 & 5.6 & $<0.01$ & $<0.040$ & $<0.040$ & $<0.001$ & 0.024 & $<1$ \\
\hline PI 604 & 9/21/2015 & 1500 & 3.93 & 4.3 & 0.04 & $<0.040$ & $<0.040$ & $<0.001$ & 0.023 & $<1$ \\
\hline PI 605 & 7/8/2015 & 1100 & 10.2 & 10.4 & $<0.01$ & 1.09 & 1.09 & $<0.001$ & 0.031 & $<1$ \\
\hline PI 606 & 6/24/2015 & 1100 & 9.69 & 10.2 & $<0.01$ & $<0.040$ & $<0.040$ & $<0.001$ & 0.027 & $<1$ \\
\hline PI 607 & 7/7/2015 & 1530 & 9.53 & 9.5 & $<0.01$ & 0.237 & 0.237 & $<0.001$ & 0.025 & $<1$ \\
\hline PI 608 & $7 / 15 / 2015$ & 930 & 7.5 & 8.2 & 0.01 & $<0.040$ & $<0.040$ & $<0.001$ & 0.007 & $<1$ \\
\hline PI 609 & 7/8/2015 & 1300 & 6.42 & 6.1 & 0.07 & $<0.040$ & $<0.040$ & $<0.001$ & 0.017 & $<1$ \\
\hline PI 610 & 7/14/2015 & 1300 & 6.79 & 10 & $<0.01$ & 1.72 & 1.72 & $<0.001$ & 0.019 & $<1$ \\
\hline PI 611 & 7/7/2015 & 1230 & 8.34 & 8.1 & $<0.01$ & $<0.040$ & $<0.040$ & $<0.001$ & 0.02 & $<1$ \\
\hline PI 612 & 7/7/2015 & 1230 & 8.71 & 8.7 & $<0.01$ & 0.36 & 0.36 & $<0.001$ & 0.027 & $<1$ \\
\hline
\end{tabular}


Table 13. Field measurements and results of laboratory analyses for major and minor ions, nutrients, bacteria, trace metals, volatile organic compounds radioactivity, radon-222, and dissolved gases for water samples collected from 79 wells in 2015 in Pike County, Pennsylvania. Constituents listed with associated 5-digit U.S. Geological Survey parameter code. Sample times offset by 1 minute indicate environmental relicate.-Continued

[mm Hg, millimeters of mercury; ${ }^{\circ} \mathrm{C}$, degrees Celsius; $\mathrm{mg} / \mathrm{L}$, milligrams per liter $\mu \mathrm{S} / \mathrm{cm}$; , microsiemens per centimeter; $\mathrm{CaCO}_{3}, \mu \mathrm{g} / \mathrm{L}$, micrograms per liter; ANC, acid neutralizing capacity; pCi/L, picocuries per liter; --, no data; <, less than; >, greater than; E, estimated; M, presence verified but not quantified; $\mathrm{R}$, non-detect for radiological analysis; $\mathrm{U}$, analyzed for but not detected]

\begin{tabular}{|c|c|c|c|c|c|c|c|c|c|c|}
\hline $\begin{array}{c}\text { Local } \\
\text { identifier }\end{array}$ & Date & $\begin{array}{c}\text { Sample } \\
\text { start } \\
\text { time }\end{array}$ & $\begin{array}{c}\text { Sulfate, } \\
\text { water, } \\
\text { filtered } \\
(\mathrm{mg} / \mathrm{L})\end{array}$ & $\begin{array}{c}\text { Sulfate, } \\
\text { water, } \\
\text { unfiltered } \\
\text { (mg/L) }\end{array}$ & $\begin{array}{c}\text { Ammonia, } \\
\text { water, } \\
\text { filtered } \\
\text { (mg/L as } \\
\text { nitrogen) }\end{array}$ & $\begin{array}{c}\text { Nitrate } \\
\text { plus nitrite, } \\
\text { water, } \\
\text { filtered } \\
\text { (mg/L as } \\
\text { nitrogen) }\end{array}$ & $\begin{array}{c}\text { Nitrate, } \\
\text { water, } \\
\text { filtered } \\
\text { (mg/L as } \\
\text { nitrogen) }\end{array}$ & $\begin{array}{c}\text { Nitrite, } \\
\text { water, } \\
\text { filtered } \\
\text { (mg/L as } \\
\text { nitrogen) }\end{array}$ & $\begin{array}{c}\text { Ortho- } \\
\text { phosphate, } \\
\text { water, } \\
\text { filtered } \\
\text { (mg/L as } \\
\text { phosphorus) }\end{array}$ & $\begin{array}{c}\text { Escherichia } \\
\text { coli, water, } \\
\text { most } \\
\text { probable } \\
\text { number per } \\
100 \text { milliliters }\end{array}$ \\
\hline & & & 00945 & 00946 & 00608 & 00631 & 00618 & 00613 & 00671 & 31689 \\
\hline PI 613 & $7 / 6 / 2015$ & 1500 & 24.1 & 24.6 & 0.02 & 0.048 & 0.048 & $<0.001$ & 0.007 & $<1$ \\
\hline PI 615 & 7/8/2015 & 1530 & 9.89 & 9.9 & $<0.01$ & 0.191 & 0.191 & $<0.001$ & 0.021 & $<1$ \\
\hline PI 616 & 6/22/2015 & 1530 & 7.37 & 7.6 & $<0.01$ & 0.507 & 0.507 & $<0.001$ & $<0.004$ & $<1$ \\
\hline PI 617 & 7/9/2015 & 1230 & 8.44 & 8.5 & 0.05 & 1.91 & 1.89 & 0.019 & $<0.004$ & $<1$ \\
\hline PI 618 & 7/9/2015 & 1000 & 11 & 11.2 & $<0.01$ & 0.279 & 0.279 & $<0.001$ & 0.013 & $<1$ \\
\hline PI 619 & 7/7/2015 & 1000 & 7.57 & 8 & $<0.01$ & $<0.040$ & $<0.040$ & $<0.001$ & 0.016 & $<1$ \\
\hline PI 624 & 7/14/2015 & 1230 & 6.55 & 7.1 & 0.01 & 0.043 & 0.043 & $<0.001$ & 0.004 & $<1$ \\
\hline PI 625 & $7 / 15 / 2015$ & 1000 & 8.06 & 8.7 & 0.01 & $<0.040$ & $<0.040$ & $<0.001$ & 0.01 & $<1$ \\
\hline PI 626 & 7/7/2015 & 1530 & 4.69 & 4.6 & $<0.01$ & 0.074 & 0.074 & $<0.001$ & 0.015 & $<1$ \\
\hline PI 627 & 7/8/2015 & 1300 & 5 & 5.5 & 0.01 & $<0.040$ & $<0.040$ & $<0.001$ & 0.009 & $<1$ \\
\hline PI 628 & 7/8/2015 & 1430 & 8.7 & 9.1 & $<0.01$ & $<0.040$ & $<0.040$ & $<0.001$ & 0.054 & $<1$ \\
\hline PI 629 & 7/14/2015 & 1430 & 14.2 & 6.9 & $<0.01$ & 1.69 & 1.69 & $<0.001$ & 0.015 & $<1$ \\
\hline PI 630 & 7/15/2015 & 1500 & 6.04 & 6.3 & $<0.01$ & 0.299 & 0.299 & $<0.001$ & 0.014 & $<1$ \\
\hline PI 631 & 7/15/2015 & 1230 & 9.84 & 10.5 & 0.04 & $<0.040$ & $<0.040$ & $<0.001$ & 0.03 & $<1$ \\
\hline PI 632 & 8/3/2015 & 1230 & 5.96 & 5.5 & $<0.01$ & 0.713 & 0.713 & $<0.001$ & 0.024 & $<1$ \\
\hline PI 633 & 8/6/2015 & 1000 & 9.9 & 12 & $<0.01$ & 0.203 & 0.203 & $<0.001$ & 0.011 & $<1$ \\
\hline PI 634 & 8/4/2015 & 930 & 11 & 11.7 & $<0.01$ & 0.145 & 0.145 & $<0.001$ & 0.019 & $<1$ \\
\hline PI 643 & 9/24/2015 & 900 & 5.86 & 6.2 & $<0.01$ & 0.371 & 0.371 & $<0.001$ & 0.028 & $<1$ \\
\hline PI 644 & $9 / 21 / 2015$ & 1130 & 7.32 & 7.7 & $<0.01$ & 0.069 & 0.069 & $<0.001$ & 0.016 & $<1$ \\
\hline PI 645 & 9/23/2015 & 1000 & 20.2 & 21.2 & $<0.01$ & 0.255 & 0.255 & $<0.001$ & 0.019 & $<1$ \\
\hline PI 647 & 9/23/2015 & 1500 & 17.2 & 18.5 & 0.05 & $<0.040$ & $<0.040$ & $<0.001$ & 0.022 & $<1$ \\
\hline PI 647 & 9/23/2015 & 1501 & -- & -- & -- & -- & -- & -- & -- & -- \\
\hline PI 648 & 9/24/2015 & 1300 & 11.7 & 12.7 & 0.12 & $<0.040$ & $<0.040$ & $<0.001$ & 0.017 & -- \\
\hline PI 649 & 9/24/2015 & 1030 & 37.8 & 38 & $<0.01$ & 0.204 & 0.204 & $<0.001$ & 0.026 & -- \\
\hline PI 650 & 9/23/2015 & 1100 & 362 & 322 & 0.63 & $<0.040$ & $<0.040$ & $<0.001$ & 0.009 & $<1$ \\
\hline PI 651 & 9/22/2015 & 1100 & 1.99 & 2.1 & 0.01 & $<0.040$ & $<0.040$ & $<0.001$ & 0.037 & $<1$ \\
\hline PI 652 & 9/23/2015 & 1330 & 8.61 & 9.3 & $<0.01$ & 0.699 & 0.699 & $<0.001$ & 0.021 & $<1$ \\
\hline PI 653 & 9/24/2015 & 1130 & 18 & 20.5 & 0.04 & $<0.040$ & $<0.040$ & $<0.001$ & 0.009 & -- \\
\hline
\end{tabular}


Table 13. Field measurements and results of laboratory analyses for major and minor ions, nutrients, bacteria, trace metals, volatile organic compounds radioactivity, radon-222, and dissolved gases for water samples collected from 79 wells in 2015 in Pike County, Pennsylvania. Constituents listed with associated 5-digit U.S. Geological Survey parameter code. Sample times offset by 1 minute indicate environmental relicate.-Continued

[mm Hg, millimeters of mercury; ${ }^{\circ} \mathrm{C}$, degrees Celsius; mg/L, milligrams per liter $\mu \mathrm{S} / \mathrm{cm}$; , microsiemens per centimeter; $\mathrm{CaCO}, \mu \mathrm{g} / \mathrm{L}, \mathrm{micrograms}$ per liter; ANC, acid neutralizing capacity; $\mathrm{pCi} / \mathrm{L}$, picocuries per liter; --, no data; <, less than; >, greater than; E, estimated; M, presence verified but not quantified; $\mathrm{R}$, non-detect for radiological analysis; $\mathrm{U}$, analyzed for but not detected]

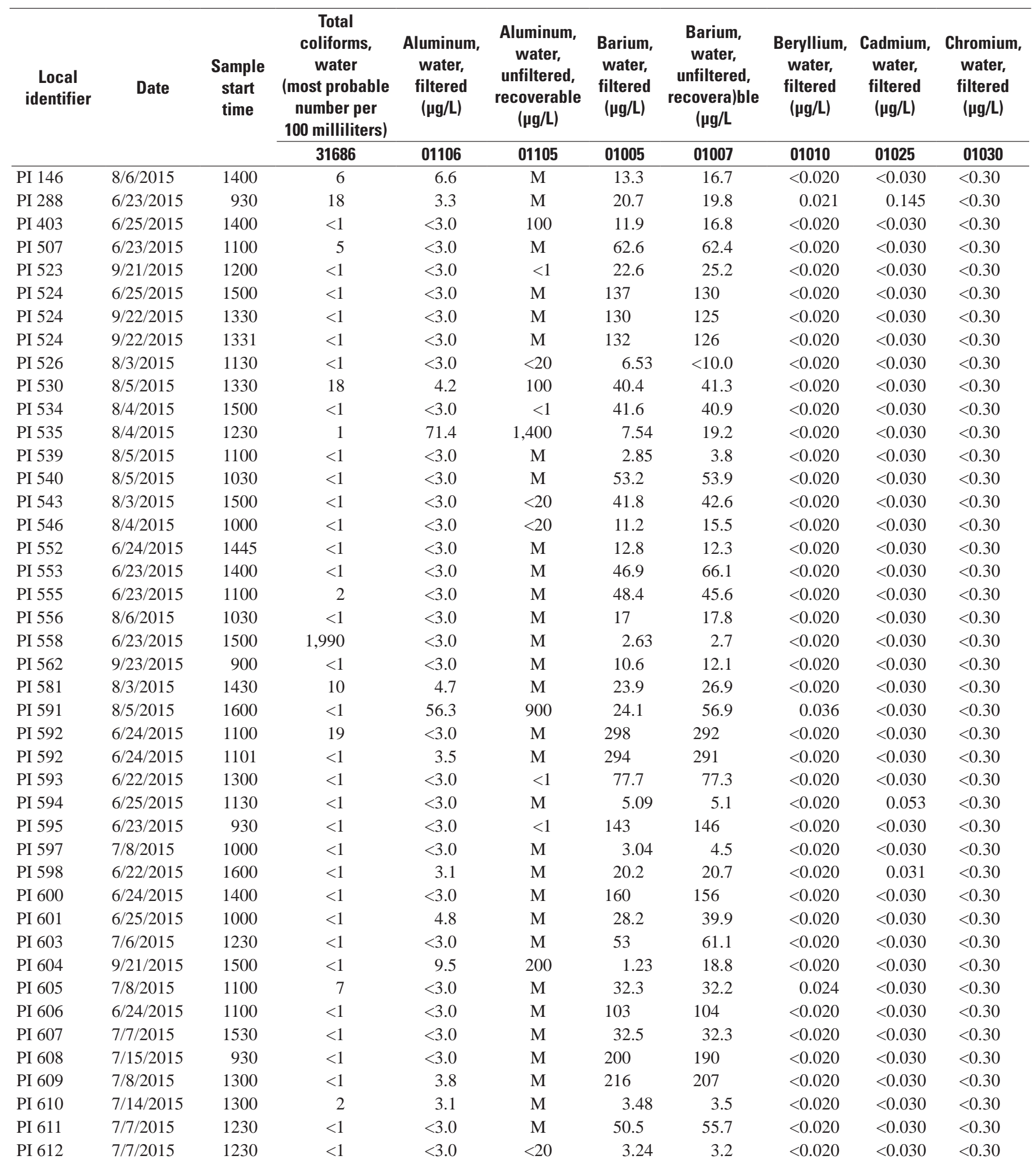


Table 13. Field measurements and results of laboratory analyses for major and minor ions, nutrients, bacteria, trace metals, volatile organic compounds radioactivity, radon-222, and dissolved gases for water samples collected from 79 wells in 2015 in Pike County, Pennsylvania. Constituents listed with associated 5-digit U.S. Geological Survey parameter code. Sample times offset by 1 minute indicate environmental relicate.-Continued

$\left[\mathrm{mm} \mathrm{Hg}\right.$, millimeters of mercury; ${ }^{\circ} \mathrm{C}$, degrees Celsius; mg/L, milligrams per liter $\mu \mathrm{S} / \mathrm{cm}$;, microsiemens per centimeter; $\mathrm{CaCO}_{3}, \mu \mathrm{g} / \mathrm{L}$, micrograms per liter; ANC, acid neutralizing capacity; pCi/L, picocuries per liter; --, no data; <, less than; >, greater than; E, estimated; M, presence verified but not quantified; $\mathrm{R}$, non-detect for radiological analysis; U, analyzed for but not detected]

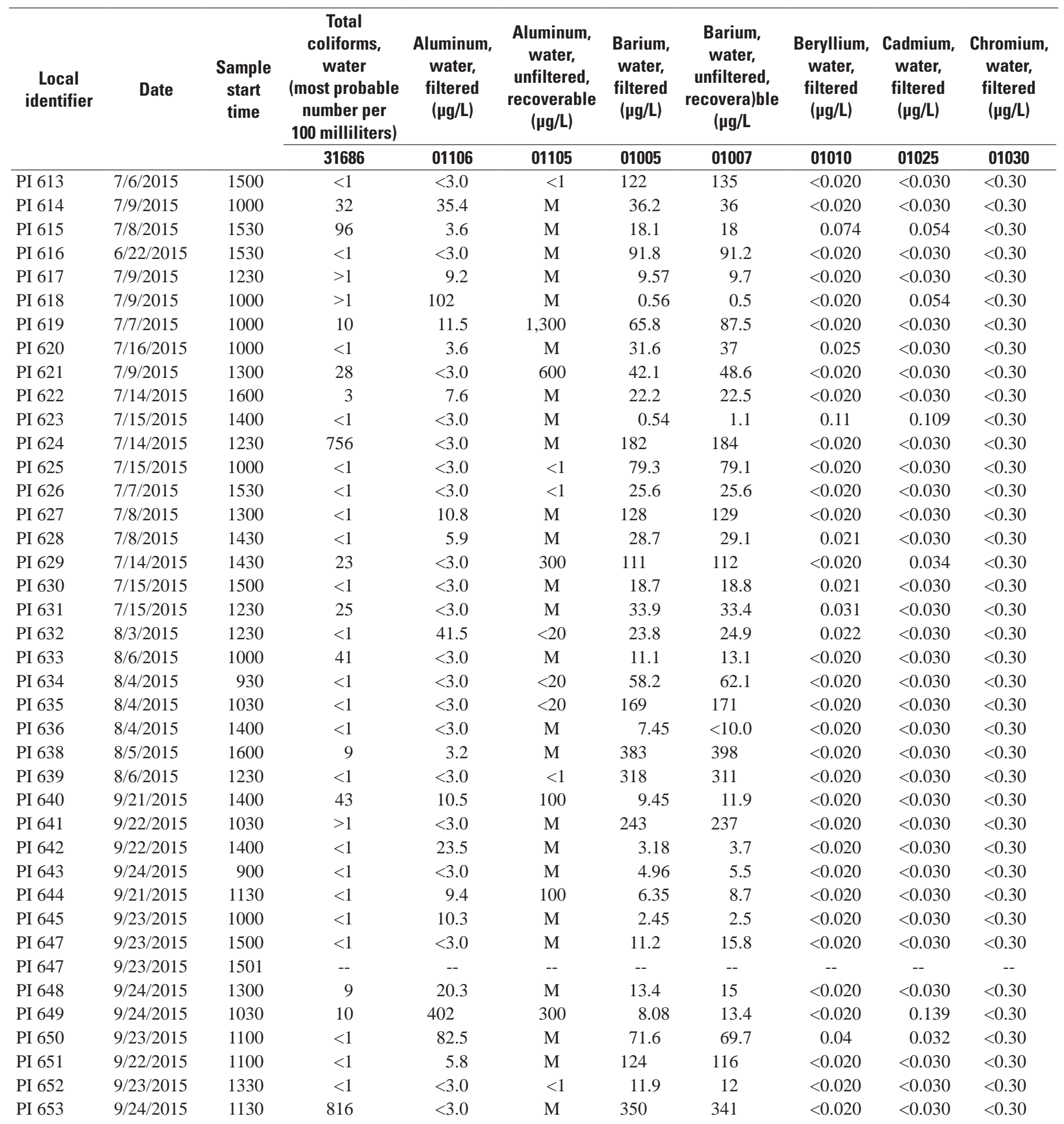


Table 13. Field measurements and results of laboratory analyses for major and minor ions, nutrients, bacteria, trace metals, volatile organic compounds radioactivity, radon-222, and dissolved gases for water samples collected from 79 wells in 2015 in Pike County, Pennsylvania. Constituents listed with associated 5-digit U.S. Geological Survey parameter code. Sample times offset by 1 minute indicate environmental relicate.-Continued

$\left[\mathrm{mm} \mathrm{Hg}\right.$, millimeters of mercury; ${ }^{\circ} \mathrm{C}$, degrees Celsius; $\mathrm{mg} / \mathrm{L}$, milligrams per liter $\mu \mathrm{S} / \mathrm{cm}$; microsiemens per centimeter; $\mathrm{CaCO}, \mu \mathrm{g} / \mathrm{L}, \mathrm{micrograms} \mathrm{per} \mathrm{liter;}$ ANC, acid neutralizing capacity; pCi/L, picocuries per liter; --, no data; <, less than; >, greater than; E, estimated; M, presence verified but not quantified; $\mathrm{R}$, non-detect for radiological analysis; $\mathrm{U}$, analyzed for but not detected]

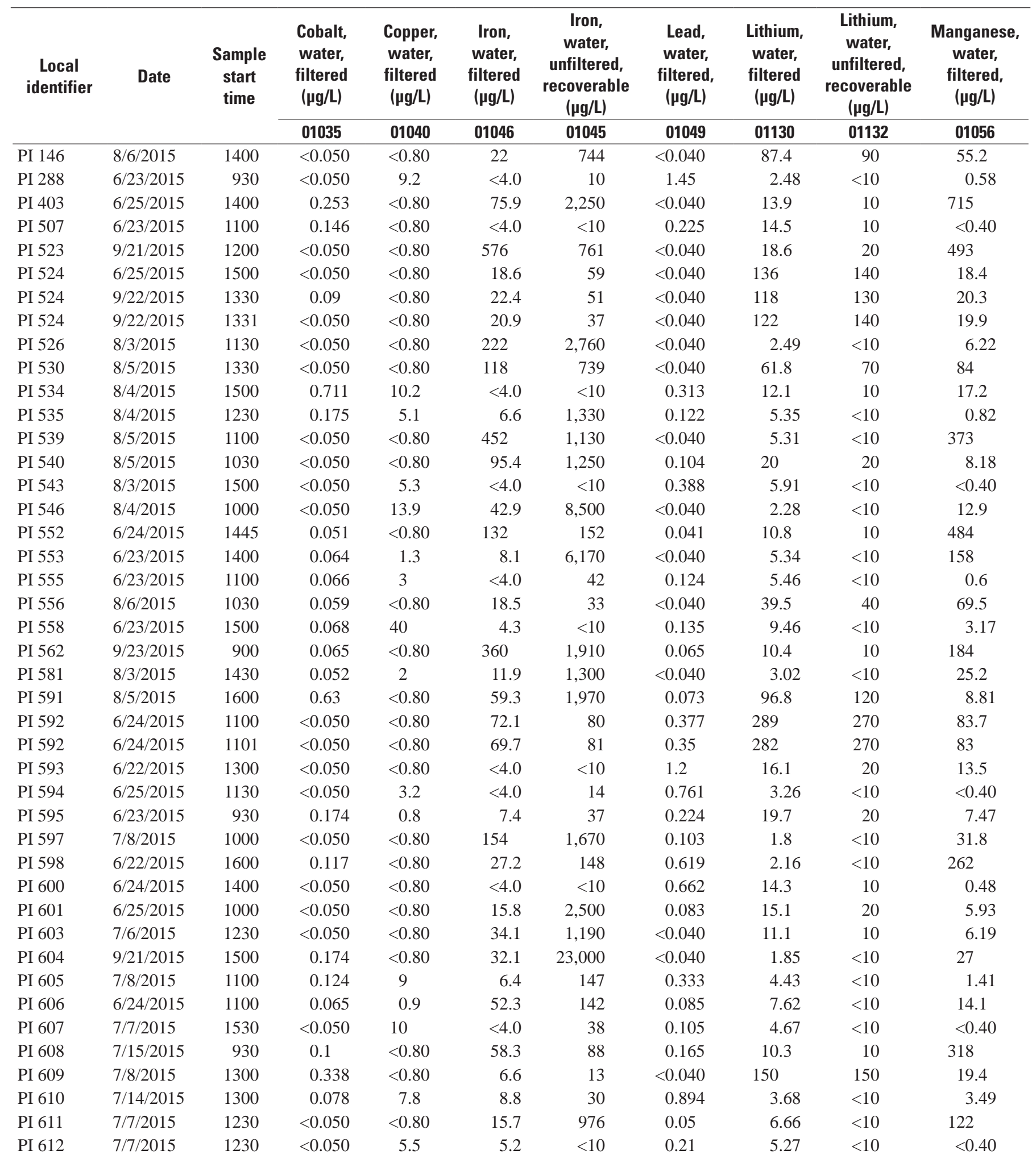


Table 13. Field measurements and results of laboratory analyses for major and minor ions, nutrients, bacteria, trace metals, volatile organic compounds radioactivity, radon-222, and dissolved gases for water samples collected from 79 wells in 2015 in Pike County, Pennsylvania. Constituents listed with associated 5-digit U.S. Geological Survey parameter code. Sample times offset by 1 minute indicate environmental relicate.-Continued

$\left[\mathrm{mm} \mathrm{Hg}\right.$, millimeters of mercury; ${ }^{\circ} \mathrm{C}$, degrees Celsius; mg/L, milligrams per liter $\mu \mathrm{S} / \mathrm{cm}$;, microsiemens per centimeter; $\mathrm{CaCO}_{3}, \mu \mathrm{g} / \mathrm{L}$, micrograms per liter; ANC, acid neutralizing capacity; pCi/L, picocuries per liter; --, no data; <, less than; >, greater than; E, estimated; M, presence verified but not quantified; $\mathrm{R}$, non-detect for radiological analysis; U, analyzed for but not detected]

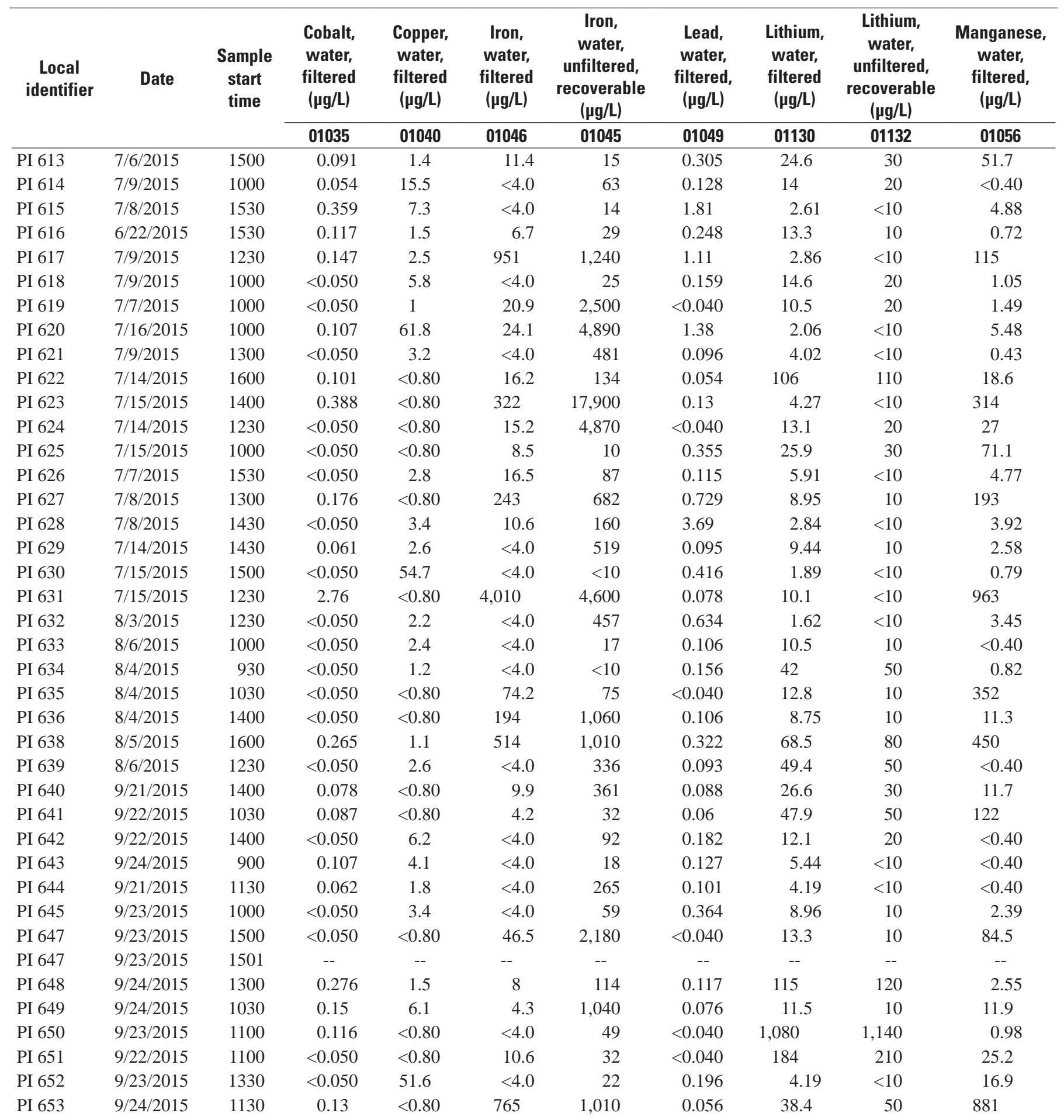


Table 13. Field measurements and results of laboratory analyses for major and minor ions, nutrients, bacteria, trace metals, volatile organic compounds radioactivity, radon-222, and dissolved gases for water samples collected from 79 wells in 2015 in Pike County, Pennsylvania. Constituents listed with associated 5-digit U.S. Geological Survey parameter code. Sample times offset by 1 minute indicate environmental relicate.-Continued

[mm Hg, millimeters of mercury; ${ }^{\circ} \mathrm{C}$, degrees Celsius; mg/L, milligrams per liter $\mu \mathrm{S} / \mathrm{cm}$; , microsiemens per centimeter; $\mathrm{CaCO}, \mu \mathrm{g} / \mathrm{L}, \mathrm{micrograms}$ per liter; ANC, acid neutralizing capacity; pCi/L, picocuries per liter; --, no data; <, less than; >, greater than; E, estimated; M, presence verified but not quantified; $\mathrm{R}$, non-detect for radiological analysis; $\mathrm{U}$, analyzed for but not detected]

\begin{tabular}{|c|c|c|c|c|c|c|c|c|c|c|}
\hline $\begin{array}{l}\text { Local } \\
\text { identifier }\end{array}$ & Date & $\begin{array}{c}\text { Sample } \\
\text { start } \\
\text { time }\end{array}$ & $\begin{array}{c}\text { Manga- } \\
\text { nese, water, } \\
\text { unfiltered, } \\
\text { recoverable } \\
(\mu \mathrm{g} / \mathrm{L})\end{array}$ & $\begin{array}{c}\text { Molyb- } \\
\text { denum, } \\
\text { water, } \\
\text { filtered } \\
(\mu \mathrm{g} / \mathrm{L})\end{array}$ & $\begin{array}{c}\text { Nickel, } \\
\text { water, } \\
\text { filtered } \\
\text { ( } \mu \mathrm{g} / \mathrm{L} \text { ) }\end{array}$ & $\begin{array}{c}\text { Strontium, } \\
\text { water, } \\
\text { filtered } \\
\text { ( } \mu \mathrm{g} / \mathrm{L})\end{array}$ & $\begin{array}{l}\text { Strontium, } \\
\text { water, } \\
\text { unfiltered, } \\
\text { recoverable } \\
(\mu \mathrm{g} / \mathrm{L})\end{array}$ & $\begin{array}{c}\text { Zinc, } \\
\text { water, } \\
\text { filtered } \\
\text { ( } \mu \mathrm{g} / \mathrm{L})\end{array}$ & $\begin{array}{c}\text { Zinc, } \\
\text { water, } \\
\text { unfiltered, } \\
\text { recoverable } \\
(\mu \mathrm{g} / \mathrm{L})\end{array}$ & $\begin{array}{c}\text { Antimony, } \\
\text { water, } \\
\text { filtered } \\
(\mu \mathrm{g} / \mathrm{L})\end{array}$ \\
\hline & & & 01055 & 01060 & 01065 & 01080 & 01082 & 01090 & 01092 & 01095 \\
\hline PI 146 & 8/6/2015 & 1400 & 145 & 0.441 & $<0.20$ & 250 & 261 & $<2.0$ & 40 & $<0.027$ \\
\hline PI 507 & 6/23/2015 & 1100 & $<0.5$ & $<0.050$ & 0.31 & 460 & 462 & 35.8 & 30 & 0.038 \\
\hline PI 523 & 9/21/2015 & 1200 & 617 & 0.102 & $<0.20$ & 550 & 612 & $<2.0$ & M & $<0.027$ \\
\hline PI 524 & 6/25/2015 & 1500 & 18.4 & 0.353 & $<0.20$ & 488 & 490 & $<2.0$ & $<0.5$ & $<0.027$ \\
\hline PI 524 & 9/22/2015 & 1330 & 18.9 & 0.367 & $<0.20$ & 472 & 485 & $<2.0$ & $<0.5$ & $<0.027$ \\
\hline PI 524 & 9/22/2015 & 1331 & 18.2 & 0.371 & $<0.20$ & 475 & 500 & $<2.0$ & $<0.5$ & $<0.027$ \\
\hline PI 539 & 8/5/2015 & 1100 & 354 & 1.54 & $<0.20$ & 47.7 & 50 & $<2.0$ & M & 0.054 \\
\hline PI 540 & 8/5/2015 & 1030 & 9.6 & 0.507 & $<0.20$ & 586 & 612 & $<2.0$ & $\mathrm{M}$ & 0.09 \\
\hline PI 543 & 8/3/2015 & 1500 & $<10.0$ & 0.064 & $<0.20$ & 70 & 72 & 2.6 & $<5$ & $<0.027$ \\
\hline PI 546 & 8/4/2015 & 1000 & 72.3 & 0.095 & 0.2 & 17.6 & 18 & 2 & $<5$ & $<0.027$ \\
\hline PI 552 & 6/24/2015 & 1445 & 471 & 0.347 & $<0.20$ & 410 & 379 & 2.1 & M & $<0.027$ \\
\hline PI 553 & 6/23/2015 & 1400 & 446 & 0.064 & $<0.20$ & 188 & 178 & $<2.0$ & M & 0.041 \\
\hline PI 555 & 6/23/2015 & 1100 & 22 & 0.06 & $<0.20$ & 77.8 & 76 & $<2.0$ & M & 0.067 \\
\hline PI 556 & 8/6/2015 & 1030 & 64.3 & 0.07 & $<0.20$ & 820 & 873 & $<2.0$ & M & 0.029 \\
\hline PI 558 & $6 / 23 / 2015$ & 1500 & 2.8 & $<0.050$ & 0.52 & 69 & 68 & 6.7 & M & $<0.027$ \\
\hline PI 562 & 9/23/2015 & 900 & 235 & $<0.050$ & $<0.20$ & 60 & 61 & $<2.0$ & M & $<0.027$ \\
\hline PI 597 & 7/8/2015 & 1000 & 31.8 & 0.741 & $<0.20$ & 27.2 & 28 & 9.1 & 20 & $<0.027$ \\
\hline PI 598 & 6/22/2015 & 1600 & 282 & 0.066 & $<0.20$ & 31.3 & 31 & 16.1 & 20 & $<0.027$ \\
\hline PI 600 & 6/24/2015 & 1400 & 1.2 & 0.466 & $<0.20$ & 803 & 810 & $<2.0$ & M & 0.069 \\
\hline PI 601 & $6 / 25 / 2015$ & 1000 & 73.3 & 1.99 & $<0.20$ & 332 & 338 & 3.7 & M & 0.036 \\
\hline PI 603 & 7/6/2015 & 1230 & 22.4 & 0.127 & $<0.20$ & 259 & 279 & $<2.0$ & M & 0.033 \\
\hline PI 604 & $9 / 21 / 2015$ & 1500 & 1,850 & 0.827 & 0.4 & 40.2 & 46 & $<2.0$ & M & 0.087 \\
\hline PI 605 & 7/8/2015 & 1100 & 3.3 & $<0.050$ & 0.38 & 241 & 246 & 7.3 & M & $<0.027$ \\
\hline PI 606 & $6 / 24 / 2015$ & 1100 & 12.5 & 0.397 & $<0.20$ & 173 & 172 & $<2.0$ & M & $<0.027$ \\
\hline PI 607 & 7/7/2015 & 1530 & 13.8 & 0.086 & 0.33 & 62.9 & 63 & $<2.0$ & M & $<0.027$ \\
\hline PI 608 & 7/15/2015 & 930 & 331 & $<0.050$ & $<0.20$ & 334 & 339 & $<2.0$ & $\mathrm{M}$ & 0.053 \\
\hline PI 609 & 7/8/2015 & 1300 & 17.7 & 0.68 & $<0.20$ & 1,020 & 977 & $<2.0$ & 50 & 0.088 \\
\hline PI 610 & 7/14/2015 & 1300 & 4 & $<0.050$ & 0.57 & 33.8 & 33 & 10.7 & 10 & 0.036 \\
\hline PI 611 & 7/7/2015 & 1230 & 304 & 0.352 & 0.31 & 115 & 121 & 4.1 & 10 & $<0.027$ \\
\hline PI 612 & 7/7/2015 & 1230 & $<10.0$ & $<0.050$ & $<0.20$ & 38.8 & 39 & 7 & M & $<0.027$ \\
\hline
\end{tabular}


Table 13. Field measurements and results of laboratory analyses for major and minor ions, nutrients, bacteria, trace metals, volatile organic compounds radioactivity, radon-222, and dissolved gases for water samples collected from 79 wells in 2015 in Pike County, Pennsylvania. Constituents listed with associated 5-digit U.S. Geological Survey parameter code. Sample times offset by 1 minute indicate environmental relicate.-Continued

$\left[\mathrm{mm} \mathrm{Hg}\right.$, millimeters of mercury; ${ }^{\circ} \mathrm{C}$, degrees Celsius; mg/L, milligrams per liter $\mu \mathrm{S} / \mathrm{cm}$;, microsiemens per centimeter; $\mathrm{CaCO}_{3}, \mu \mathrm{g} / \mathrm{L}$, micrograms per liter; ANC, acid neutralizing capacity; pCi/L, picocuries per liter; --, no data; <, less than; >, greater than; E, estimated; M, presence verified but not quantified; $\mathrm{R}$, non-detect for radiological analysis; $\mathrm{U}$, analyzed for but not detected]

\begin{tabular}{|c|c|c|c|c|c|c|c|c|c|c|}
\hline $\begin{array}{l}\text { Local } \\
\text { identifier }\end{array}$ & Date & $\begin{array}{c}\text { Sample } \\
\text { start } \\
\text { time }\end{array}$ & $\begin{array}{l}\text { Manga- } \\
\text { nese, water, } \\
\text { unfiltered, } \\
\text { recoverable } \\
(\mu \mathrm{g} / \mathrm{L})\end{array}$ & $\begin{array}{c}\text { Molyb- } \\
\text { denum, } \\
\text { water, } \\
\text { filtered } \\
(\mu \mathrm{g} / \mathrm{L})\end{array}$ & $\begin{array}{c}\text { Nickel, } \\
\text { water, } \\
\text { filtered } \\
(\mu \mathrm{g} / \mathrm{L})\end{array}$ & $\begin{array}{c}\text { Strontium, } \\
\text { water, } \\
\text { filtered } \\
(\mu \mathrm{g} / \mathrm{L})\end{array}$ & $\begin{array}{c}\text { Strontium, } \\
\text { water, } \\
\text { unfiltered, } \\
\text { recoverable } \\
(\mu \mathrm{g} / \mathrm{L})\end{array}$ & $\begin{array}{c}\begin{array}{c}\text { Zinc, } \\
\text { water, } \\
\text { filtered } \\
(\mu \mathrm{g} / \mathrm{L})\end{array}\end{array}$ & $\begin{array}{c}\text { Zinc, } \\
\text { water, } \\
\text { unfiltered, } \\
\text { recoverable } \\
(\mu \mathrm{g} / \mathrm{L})\end{array}$ & $\begin{array}{c}\text { Antimony, } \\
\text { water, } \\
\text { filtered } \\
(\mu \mathrm{g} / \mathrm{L})\end{array}$ \\
\hline & & & 01055 & 01060 & 01065 & 01080 & 01082 & 01090 & 01092 & 01095 \\
\hline PI 613 & $7 / 6 / 2015$ & 1500 & 70.6 & $<0.050$ & 0.29 & 1,300 & 1,470 & $<2.0$ & $\mathrm{M}$ & 0.064 \\
\hline PI 616 & 6/22/2015 & 1530 & 0.7 & $<0.050$ & 0.23 & 525 & 524 & 2.4 & M & 0.044 \\
\hline PI 617 & 7/9/2015 & 1230 & 99.3 & 0.067 & 0.46 & 57.2 & 58 & 3.5 & M & $<0.027$ \\
\hline PI 618 & 7/9/2015 & 1000 & 6.3 & 0.074 & 0.31 & 209 & 222 & 2.8 & M & $<0.027$ \\
\hline PI 619 & 7/7/2015 & 1000 & 56.5 & 0.299 & $<0.20$ & 352 & 352 & $<2.0$ & M & 0.037 \\
\hline PI 620 & 7/16/2015 & 1000 & 16.8 & $<0.050$ & 0.78 & 10.8 & 11 & 9.7 & 10 & 0.038 \\
\hline PI 625 & 7/15/2015 & 1000 & 66.5 & 0.31 & $<0.20$ & 391 & 403 & $<2.0$ & M & 0.067 \\
\hline PI 626 & 7/7/2015 & 1530 & 5.9 & 0.212 & 0.5 & 257 & 270 & $<2.0$ & M & 0.038 \\
\hline PI 627 & 7/8/2015 & 1300 & 209 & 0.301 & $<0.20$ & 562 & 578 & 7.3 & M & 0.072 \\
\hline PI 628 & 7/8/2015 & 1430 & 4.9 & $<0.050$ & 0.58 & 28.5 & 29 & 43.2 & 40 & 0.035 \\
\hline PI 629 & 7/14/2015 & 1430 & 20.5 & $<0.050$ & 0.64 & 179 & 175 & 43.6 & 50 & 0.071 \\
\hline PI 630 & 7/15/2015 & 1500 & 2.3 & $<0.050$ & $<0.20$ & 64 & 65 & 4 & M & $<0.027$ \\
\hline PI 631 & 7/15/2015 & 1230 & 1,030 & 0.196 & 0.83 & 82.9 & 86 & 5.2 & M & 0.037 \\
\hline PI 632 & 8/3/2015 & 1230 & $<10.0$ & $<0.050$ & 0.86 & 27.4 & 28 & 4.6 & M & $<0.027$ \\
\hline PI 633 & 8/6/2015 & 1000 & 13.5 & 0.08 & $<0.20$ & 184 & 192 & $<2.0$ & M & $<0.027$ \\
\hline PI 634 & 8/4/2015 & 930 & $<10.0$ & 0.127 & $<0.20$ & 448 & 459 & 3.4 & $<5$ & 0.057 \\
\hline PI 643 & 9/24/2015 & 900 & 4.2 & 0.092 & $<0.20$ & 51.7 & 51 & 5 & $\mathrm{M}$ & 0.041 \\
\hline PI 644 & 9/21/2015 & 1130 & 37.5 & 0.235 & $<0.20$ & 65 & 63 & 14.5 & 20 & 0.073 \\
\hline PI 645 & 9/23/2015 & 1000 & 4.9 & $<0.050$ & 0.33 & 282 & 289 & 4.9 & M & $<0.027$ \\
\hline PI 647 & 9/23/2015 & 1500 & 242 & 0.089 & $<0.20$ & 326 & 335 & $<2.0$ & M & $<0.027$ \\
\hline PI 647 & 9/23/2015 & 1501 & -- & -- & -- & -- & -- & -- & -- & -- \\
\hline PI 648 & 9/24/2015 & 1300 & 3.2 & 0.081 & 0.23 & 264 & 260 & $<2.0$ & $<0.5$ & 0.05 \\
\hline PI 649 & 9/24/2015 & 1030 & 193 & $<0.050$ & 1.4 & 402 & 369 & 6.4 & 20 & $<0.027$ \\
\hline PI 650 & 9/23/2015 & 1100 & 0.8 & 0.942 & $<0.20$ & 3,420 & 2,700 & $<2.0$ & M & $<0.027$ \\
\hline PI 651 & 9/22/2015 & 1100 & 23.2 & 0.371 & $<0.20$ & 185 & 194 & $<2.0$ & M & $<0.027$ \\
\hline PI 652 & 9/23/2015 & 1330 & 14.6 & $<0.050$ & 0.48 & 49.9 & 50 & 7.5 & M & $<0.027$ \\
\hline PI 653 & 9/24/2015 & 1130 & 887 & 0.107 & 0.35 & 1,930 & 1,900 & 3.1 & M & 0.054 \\
\hline
\end{tabular}


Table 13. Field measurements and results of laboratory analyses for major and minor ions, nutrients, bacteria, trace metals, volatile organic compounds radioactivity, radon-222, and dissolved gases for water samples collected from 79 wells in 2015 in Pike County, Pennsylvania. Constituents listed with associated 5-digit U.S. Geological Survey parameter code. Sample times offset by 1 minute indicate environmental relicate.-Continued

[mm Hg, millimeters of mercury; ${ }^{\circ} \mathrm{C}$, degrees Celsius; $\mathrm{mg} / \mathrm{L}$, milligrams per liter $\mu \mathrm{S} / \mathrm{cm}$; , microsiemens per centimeter; $\mathrm{CaCO}_{3}, \mu \mathrm{g} / \mathrm{L}$, micrograms per liter; ANC, acid neutralizing capacity; pCi/L, picocuries per liter; --, no data; <, less than; >, greater than; E, estimated; M, presence verified but not quantified; $\mathrm{R}$, non-detect for radiological analysis; $\mathrm{U}$, analyzed for but not detected]

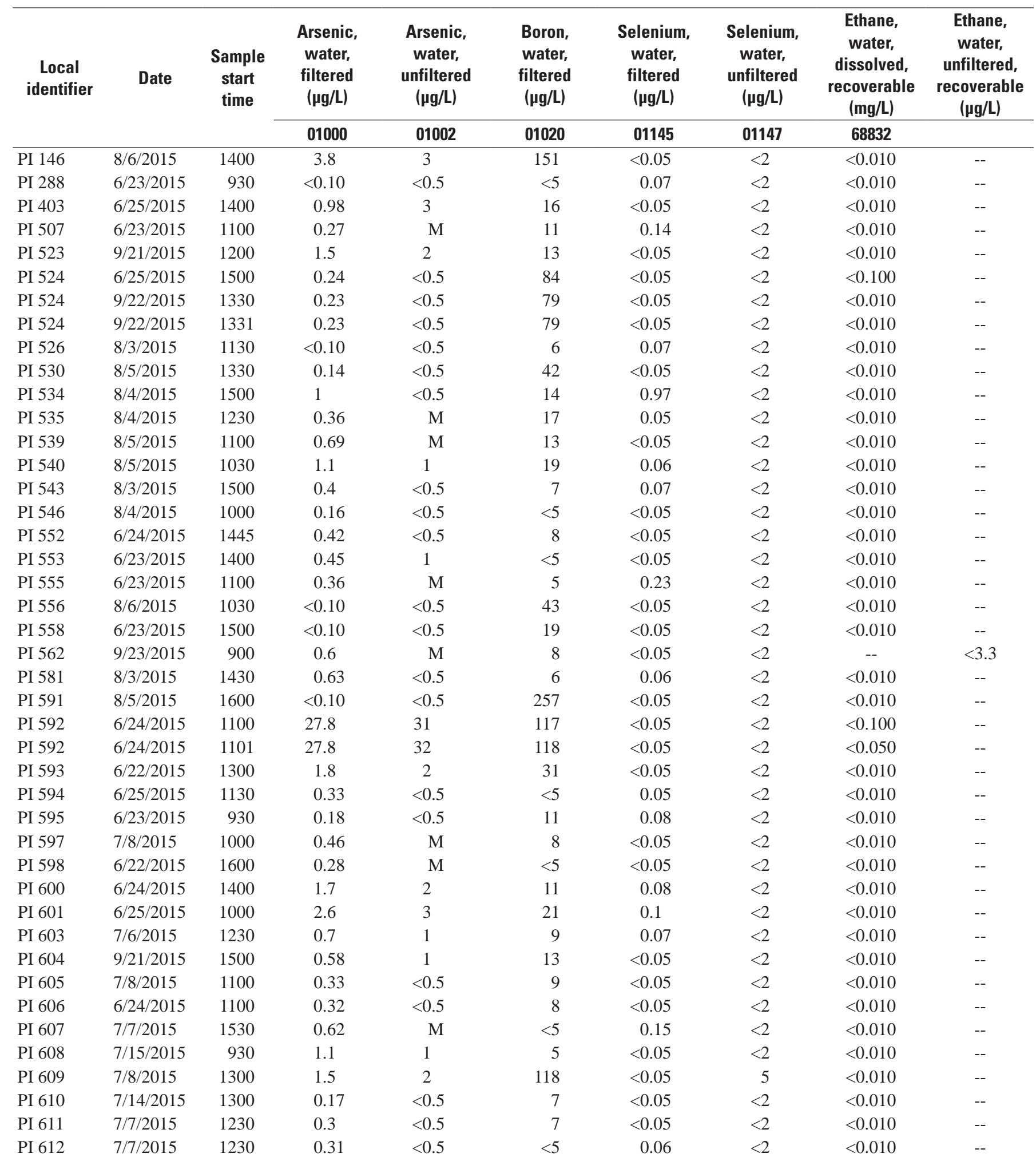


Table 13. Field measurements and results of laboratory analyses for major and minor ions, nutrients, bacteria, trace metals, volatile organic compounds radioactivity, radon-222, and dissolved gases for water samples collected from 79 wells in 2015 in Pike County, Pennsylvania. Constituents listed with associated 5-digit U.S. Geological Survey parameter code. Sample times offset by 1 minute indicate environmental relicate.-Continued

[mm Hg, millimeters of mercury; ${ }^{\circ} \mathrm{C}$, degrees Celsius; $\mathrm{mg} / \mathrm{L}$, milligrams per liter $\mu \mathrm{S} / \mathrm{cm}$; , microsiemens per centimeter; $\mathrm{CaCO}, \mu \mathrm{gg} / \mathrm{L}$, micrograms per liter; $\mathrm{ANC}$, acid neutralizing capacity; $\mathrm{pCi} / \mathrm{L}$, picocuries per liter; --, no data; <, less than; >, greater than; $\mathrm{E}$, estimated; M, presence verified but not quantified; $\mathrm{R}$, non-detect for radiological analysis; $\mathrm{U}$, analyzed for but not detected]

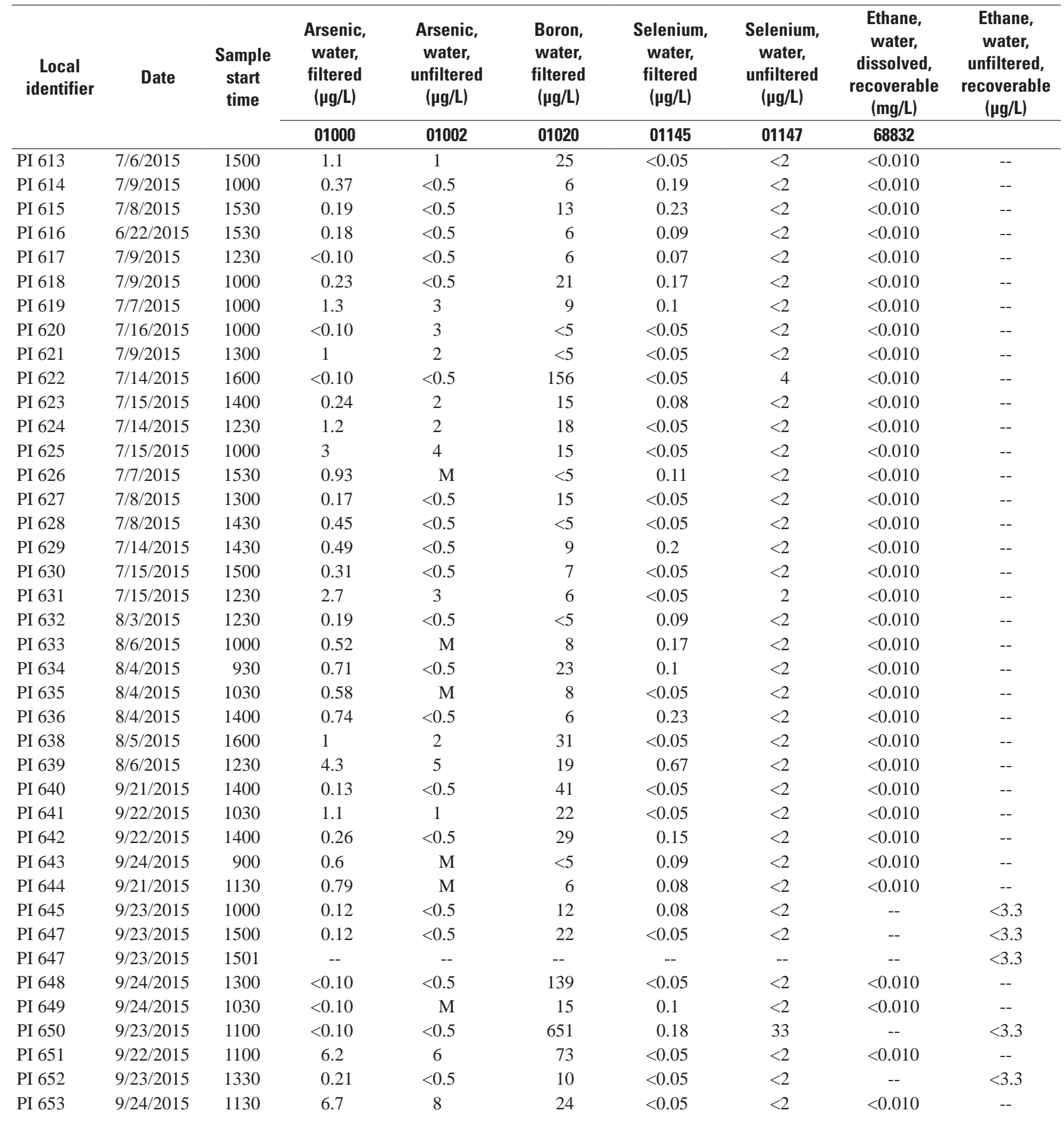


Table 13. Field measurements and results of laboratory analyses for major and minor ions, nutrients, bacteria, trace metals, volatile organic compounds radioactivity, radon-222, and dissolved gases for water samples collected from 79 wells in 2015 in Pike County, Pennsylvania. Constituents listed with associated 5-digit U.S. Geological Survey parameter code. Sample times offset by 1 minute indicate environmental relicate.-Continued

[mm Hg, millimeters of mercury; ${ }^{\circ} \mathrm{C}$, degrees Celsius; mg/L, milligrams per liter $\mu \mathrm{S} / \mathrm{cm}$; , microsiemens per centimeter; $\mathrm{CaCO}, \mu \mathrm{g} / \mathrm{L}, \mathrm{micrograms}$ per liter; ANC, acid neutralizing capacity; $\mathrm{pCi} / \mathrm{L}$, picocuries per liter; --, no data; <, less than; >, greater than; E, estimated; M, presence verified but not quantified; $\mathrm{R}$, non-detect for radiological analysis; $\mathrm{U}$, analyzed for but not detected]

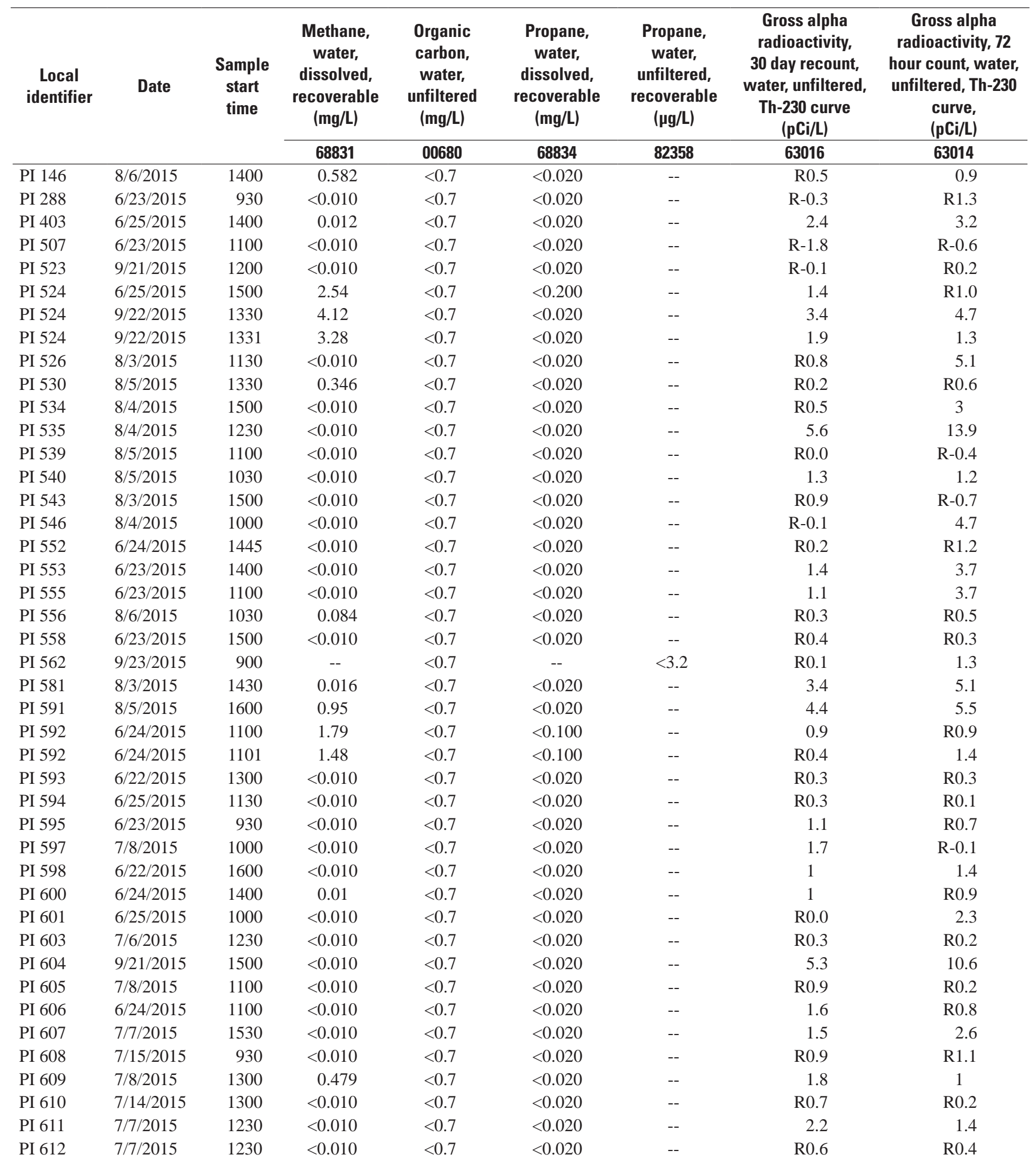


Table 13. Field measurements and results of laboratory analyses for major and minor ions, nutrients, bacteria, trace metals, volatile organic compounds radioactivity, radon-222, and dissolved gases for water samples collected from 79 wells in 2015 in Pike County, Pennsylvania. Constituents listed with associated 5-digit U.S. Geological Survey parameter code. Sample times offset by 1 minute indicate environmental relicate.-Continued

$\left[\mathrm{mm} \mathrm{Hg}\right.$, millimeters of mercury; ${ }^{\circ} \mathrm{C}$, degrees Celsius; mg/L, milligrams per liter $\mu \mathrm{S} / \mathrm{cm}$;, microsiemens per centimeter; $\mathrm{CaCO}_{3}, \mu \mathrm{g} / \mathrm{L}$, micrograms per liter; ANC, acid neutralizing capacity; pCi/L, picocuries per liter; --, no data; <, less than; >, greater than; E, estimated; M, presence verified but not quantified; $\mathrm{R}$, non-detect for radiological analysis; U, analyzed for but not detected]

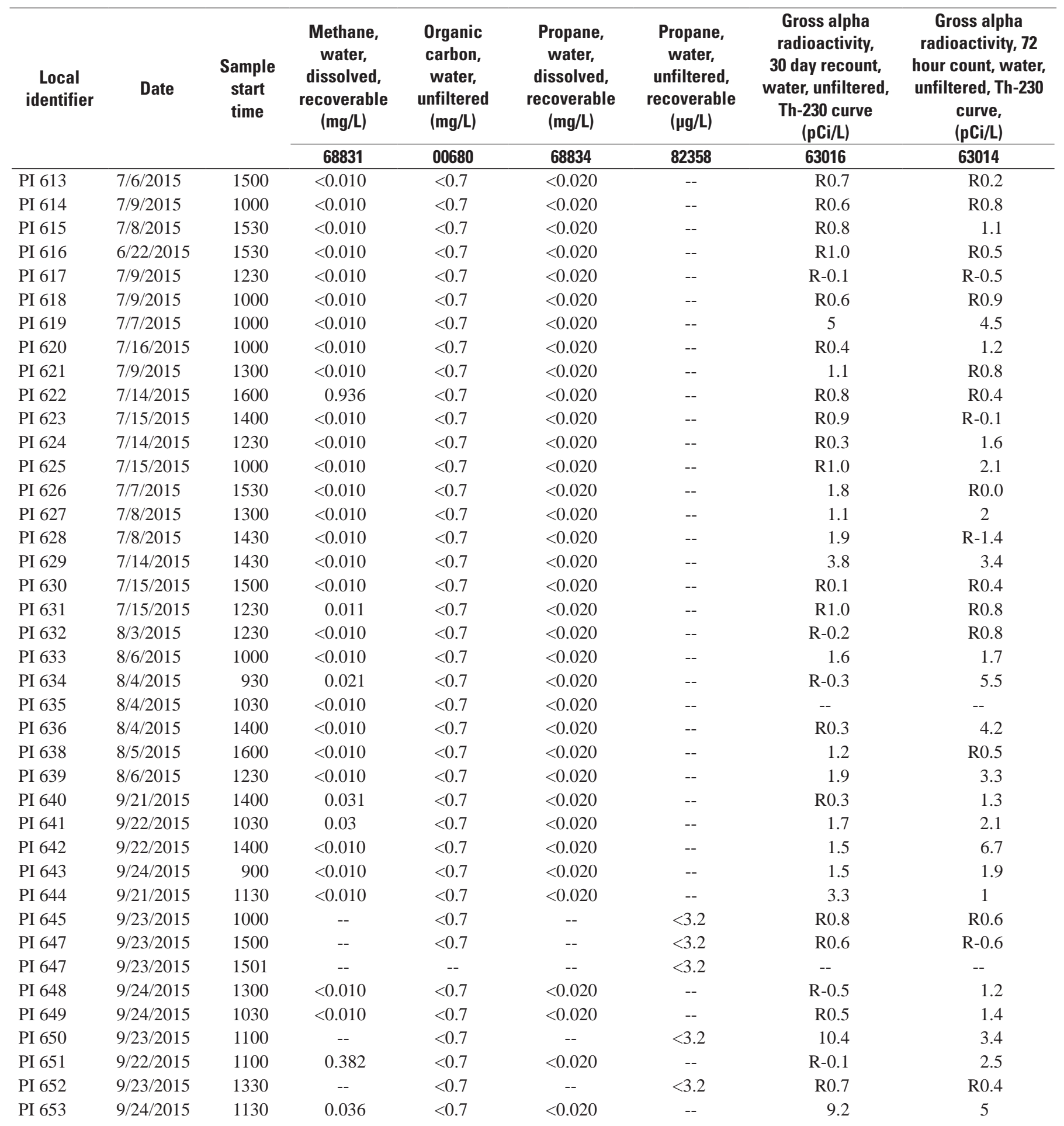


Table 13. Field measurements and results of laboratory analyses for major and minor ions, nutrients, bacteria, trace metals, volatile organic compounds radioactivity, radon-222, and dissolved gases for water samples collected from 79 wells in 2015 in Pike County, Pennsylvania. Constituents listed with associated 5-digit U.S. Geological Survey parameter code. Sample times offset by 1 minute indicate environmental relicate.-Continued

[mm Hg, millimeters of mercury; ${ }^{\circ} \mathrm{C}$, degrees Celsius; mg/L, milligrams per liter $\mu \mathrm{S} / \mathrm{cm}$; , microsiemens per centimeter; $\mathrm{CaCO}, \mu \mathrm{g} / \mathrm{L}, \mathrm{micrograms}$ per liter; ANC, acid neutralizing capacity; $\mathrm{pCi} / \mathrm{L}$, picocuries per liter; --, no data; <, less than; >, greater than; E, estimated; M, presence verified but not quantified; $\mathrm{R}$, non-detect for radiological analysis; $\mathrm{U}$, analyzed for but not detected]

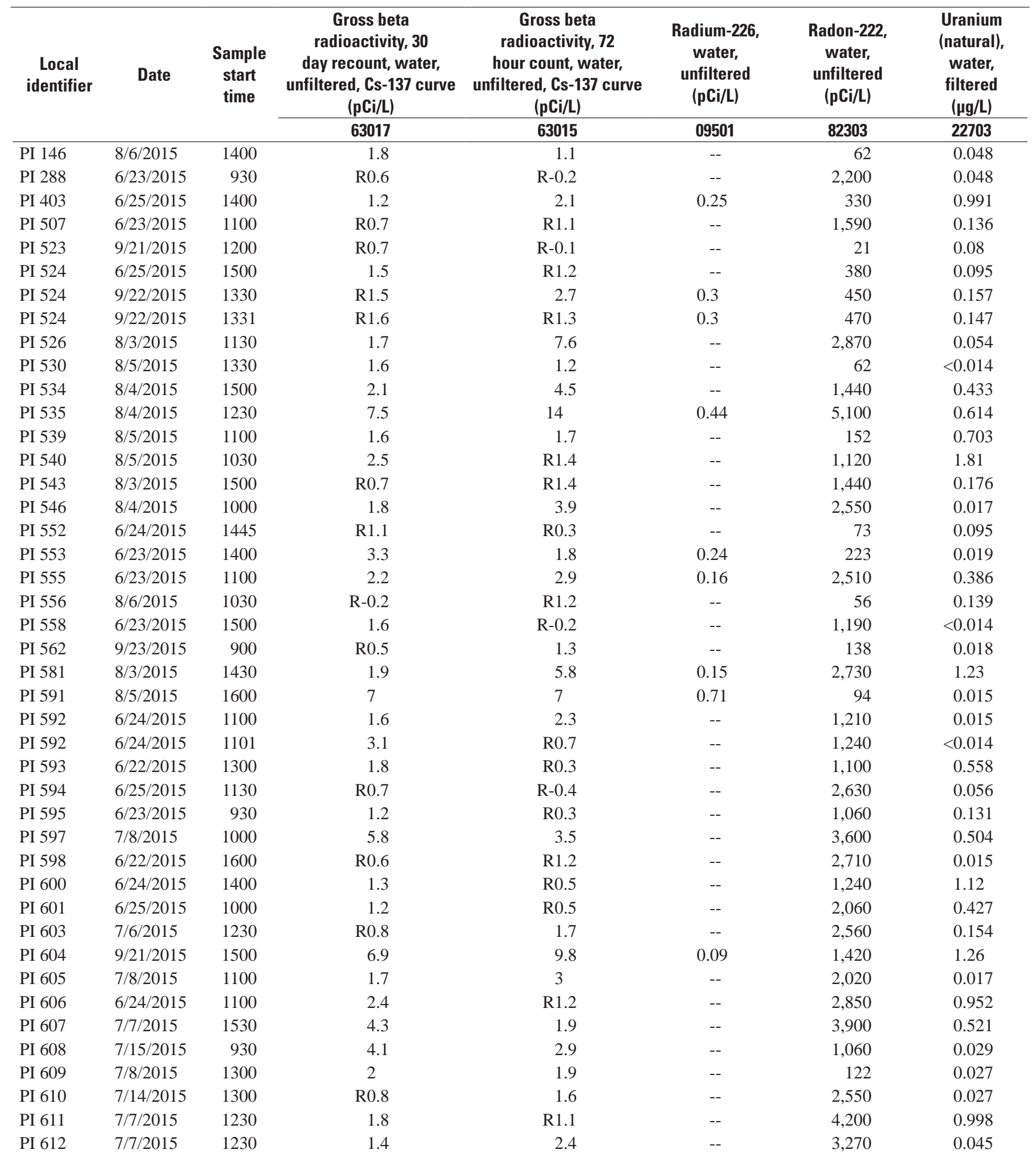


Table 13. Field measurements and results of laboratory analyses for major and minor ions, nutrients, bacteria, trace metals, volatile organic compounds radioactivity, radon-222, and dissolved gases for water samples collected from 79 wells in 2015 in Pike County, Pennsylvania. Constituents listed with associated 5-digit U.S. Geological Survey parameter code. Sample times offset by 1 minute indicate environmental relicate.-Continued

$\left[\mathrm{mm} \mathrm{Hg}\right.$, millimeters of mercury; ${ }^{\circ} \mathrm{C}$, degrees Celsius; mg/L, milligrams per liter $\mu \mathrm{S} / \mathrm{cm}$;, microsiemens per centimeter; $\mathrm{CaCO}_{3}, \mu \mathrm{g} / \mathrm{L}$, micrograms per liter; ANC, acid neutralizing capacity; pCi/L, picocuries per liter; --, no data; <, less than; >, greater than; E, estimated; M, presence verified but not quantified; $\mathrm{R}$, non-detect for radiological analysis; U, analyzed for but not detected]

\begin{tabular}{|c|c|c|c|c|c|c|c|}
\hline $\begin{array}{l}\text { Local } \\
\text { identifier }\end{array}$ & Date & $\begin{array}{c}\text { Sample } \\
\text { start } \\
\text { time }\end{array}$ & $\begin{array}{c}\text { Gross beta } \\
\text { radioactivity, } 30 \\
\text { day recount, water, } \\
\text { unfiltered, } \mathrm{Cs-137} \text { curve } \\
(\mathrm{pC} / \mathrm{L}) \mathrm{L})\end{array}$ & $\begin{array}{c}\text { Gross beta } \\
\text { radioactivity, } 72 \\
\text { hour count, water, } \\
\text { unfiltered, Cs-137 curve } \\
\text { (pCi/L) }\end{array}$ & $\begin{array}{l}\text { Radium-226, } \\
\text { water, } \\
\text { unfiltered } \\
\text { (pCi/L) }\end{array}$ & $\begin{array}{l}\text { Radon-222, } \\
\text { water, } \\
\text { unfiltered } \\
\text { (pCi/L) }\end{array}$ & $\begin{array}{c}\text { Uranium } \\
\text { (natural), } \\
\text { water, } \\
\text { filtered } \\
(\mu \mathrm{g} / \mathrm{L})\end{array}$ \\
\hline & & & 63017 & 63015 & 09501 & 82303 & 22703 \\
\hline PI 613 & 7/6/2015 & 1500 & 2.2 & 2.8 & -- & 840 & 0.417 \\
\hline PI 614 & 7/9/2015 & 1000 & 3.1 & R0.7 & -- & 2,760 & 0.601 \\
\hline PI 615 & 7/8/2015 & 1530 & 1.1 & R0.4 & -- & 2,430 & 0.049 \\
\hline PI 616 & 6/22/2015 & 1530 & 1.9 & 1.9 & -- & 1,900 & 0.032 \\
\hline PI 617 & 7/9/2015 & 1230 & 1.3 & 1.5 & -- & 830 & $<0.014$ \\
\hline PI 618 & 7/9/2015 & 1000 & 1.5 & R0.7 & -- & 1,880 & 0.104 \\
\hline PI 619 & 7/7/2015 & 1000 & 4.8 & 5.3 & 0.23 & 2,290 & 1.69 \\
\hline PI 620 & 7/16/2015 & 1000 & 4.2 & 2.9 & -- & 1,060 & $<0.014$ \\
\hline PI 621 & 7/9/2015 & 1300 & 2.3 & 2.3 & -- & 2,360 & 0.123 \\
\hline PI 622 & 7/14/2015 & 1600 & 1.9 & R0.7 & -- & 34 & 0.049 \\
\hline PI 623 & 7/15/2015 & 1400 & R0.7 & R0.8 & -- & 2,170 & 0.182 \\
\hline PI 624 & 7/14/2015 & 1230 & 2 & 1.6 & -- & 1,880 & 0.39 \\
\hline PI 625 & 7/15/2015 & 1000 & 6.8 & 1.4 & -- & 700 & 0.652 \\
\hline PI 626 & 7/7/2015 & 1530 & $\mathrm{R} 0.7$ & R0.6 & -- & 2,890 & 0.766 \\
\hline PI 627 & 7/8/2015 & 1300 & 1.5 & $\mathrm{R}-0.5$ & -- & 950 & 0.182 \\
\hline PI 628 & 7/8/2015 & 1430 & 1.6 & 1.3 & -- & 1,080 & $<0.014$ \\
\hline PI 629 & 7/14/2015 & 1430 & 2.7 & 3.6 & -- & 1,630 & 0.972 \\
\hline PI 630 & 7/15/2015 & 1500 & 2.4 & 1.1 & -- & 1,700 & 0.029 \\
\hline PI 631 & 7/15/2015 & 1230 & 1.4 & R1.0 & -- & 290 & 0.048 \\
\hline PI 632 & 8/3/2015 & 1230 & R1.0 & 1.6 & -- & 3,410 & $<0.014$ \\
\hline PI 633 & 8/6/2015 & 1000 & 2.5 & 2.6 & -- & 2,490 & 0.879 \\
\hline PI 634 & 8/4/2015 & 930 & 1.6 & 4.9 & -- & 1,730 & 0.198 \\
\hline PI 635 & 8/4/2015 & 1030 & -- & -- & -- & 180 & 0.016 \\
\hline PI 636 & 8/4/2015 & 1400 & R1.5 & 5.1 & -- & 1,920 & 0.36 \\
\hline PI 638 & 8/5/2015 & 1600 & 1.9 & 3.7 & -- & 1,160 & 0.038 \\
\hline PI 639 & 8/6/2015 & 1230 & 4.7 & 3.1 & -- & 560 & 0.359 \\
\hline PI 640 & 9/21/2015 & 1400 & 1.5 & R0.4 & -- & 1,310 & 0.188 \\
\hline PI 641 & 9/22/2015 & 1030 & 2.7 & 3.4 & 0.45 & 105 & 0.136 \\
\hline PI 642 & 9/22/2015 & 1400 & R1.4 & 7.3 & 0.2 & 2,020 & 0.483 \\
\hline PI 643 & 9/24/2015 & 900 & R0.6 & R1.1 & -- & 3,600 & 0.413 \\
\hline PI 644 & 9/21/2015 & 1130 & 3 & 3.6 & -- & 2,290 & 0.853 \\
\hline PI 645 & 9/23/2015 & 1000 & R1.1 & R0.5 & -- & 520 & 0.042 \\
\hline PI 647 & 9/23/2015 & 1500 & 1.2 & R1.0 & -- & 240 & 0.025 \\
\hline PI 647 & 9/23/2015 & 1501 & -- & -- & -- & -- & -- \\
\hline PI 648 & 9/24/2015 & 1300 & R0.1 & R0.3 & -- & 70 & 0.027 \\
\hline PI 649 & 9/24/2015 & 1030 & 2.2 & 2.4 & -- & 480 & 0.11 \\
\hline PI 650 & 9/23/2015 & 1100 & 5 & 2.9 & 1.8 & 12 & $<0.014$ \\
\hline PI 651 & 9/22/2015 & 1100 & 1.9 & 4.1 & -- & 1,030 & 0.187 \\
\hline PI 652 & 9/23/2015 & 1330 & 1.8 & R1.0 & -- & 2,970 & 0.031 \\
\hline PI 653 & 9/24/2015 & 1130 & 4.4 & 1.8 & 1.2 & 250 & 1.31 \\
\hline
\end{tabular}


Table 14. Results of dissolved gas analysis and isotopic characterization of methane by Isotech Laboratories, Inc. for water samples collected from 17 wells in Pike County, 2015. Results listed by geologic unit. One well (PI-524) was sampled twice. Replicates (shaded in gray) collected from three wells (PI-592, PI-524, PI-647) are listed with time offset of 1 minute.

[USGS, U.S. Geological Survey; na, not analyzed; nd, not detected; --, no data; \%, mole percent; \%, per mil or parts per trillion; cc/L, cubic centimeters per liter; mg/L, milligrams per liter; Geologic units: DLRV, Deleware River Member of Catskill Formation; LCSS, Lackawaxen Member of Catskill Formation; 341TMSG, Towamensing Member of the Catskill formation; 341TMRK, Trimmers Rock Formation; 344MRCL, Marcellus Shale. He, helium; $\mathrm{H}_{2}$, hydrogen; $\mathrm{Ar}$, argon; $\mathrm{O}_{2}$, oxygen; $\mathrm{CO}_{2}$, carbon dioxide; $\mathrm{N}_{2}$, nitrogen; $\mathrm{CO}$, carbon monoxide; $\mathrm{C}_{1}$, methane; $\mathrm{C}_{2}$, ethane; $\mathrm{C}_{2} \mathrm{H}_{4}$, ethene; $\mathrm{C}_{3}$, propane; $\mathrm{iC}_{4}$, $\mathrm{nC}_{4}$, $\mathrm{iC}_{5}$, $\mathrm{nC}_{5}$, $\mathrm{C}_{6}+$, hydrocarbons with 4,5 , and 6 carbon atome per molecule, respectively; $\delta^{13} \mathrm{C}_{1}$, carbon- 13 and carbon-12 isotopic composition of methane; $\delta \mathrm{DC}$, deuterium and hydrogen isotopic composition of methane; $\mathrm{CH}_{4}$, methane; $\mathrm{C}_{2} \mathrm{H}_{6}$, ethane; $\mathrm{C}_{3} \mathrm{H}_{8}$, propane. Isotopic composition of carbon is relative to Vienna Pee Dee Belemnite (VPDB). Isotopic composition of hydrogen is relative to Vienna Standard Mean Ocean Water (VSMOW)]

\begin{tabular}{|c|c|c|c|c|c|c|c|c|c|c|c|c|c|c|c|c|c|c|c|}
\hline $\begin{array}{l}\text { USGS } \\
\text { local } \\
\text { name }\end{array}$ & $\begin{array}{c}\text { Geologic } \\
\text { unit }\end{array}$ & $\begin{array}{c}\text { Sample } \\
\text { date }\end{array}$ & $\begin{array}{c}\text { Sample } \\
\text { time }\end{array}$ & $\begin{array}{c}\text { GC } \\
\text { date }\end{array}$ & $\begin{array}{l}\mathrm{He} \\
(\%)\end{array}$ & $\begin{array}{c}\mathrm{H}_{2} \\
(\%)\end{array}$ & $\begin{array}{c}\mathrm{Ar} \\
(\%)\end{array}$ & $\begin{array}{c}0_{2} \\
(\%)\end{array}$ & $\begin{array}{l}\mathrm{CO}_{2} \\
(\%)\end{array}$ & $\begin{array}{l}\text { C1 } \\
(\%)\end{array}$ & $\begin{array}{l}\text { C2 } \\
(\%)\end{array}$ & $\begin{array}{l}\mathrm{C}_{2} \mathrm{H}_{4} \\
(\%)\end{array}$ & $\begin{array}{c}\mathrm{C}_{3} \\
(\%)\end{array}$ & $\begin{array}{l}\mathrm{C}_{3} \mathrm{H}_{6} \\
(\%)\end{array}$ & $\begin{array}{l}\mathrm{iC}_{4} \\
(\%)\end{array}$ & $\begin{array}{l}\mathrm{nC}_{4} \\
(\%)\end{array}$ & $\begin{array}{l}\mathrm{iC}_{5} \\
(\%)\end{array}$ & $\begin{array}{l}\mathrm{nC}_{5} \\
(\%)\end{array}$ & $\begin{array}{l}\mathrm{C}_{6}+ \\
(\%)\end{array}$ \\
\hline PI 592 & 341DLRV & 6/24/2015 & $11: 05$ & 9/24/2015 & na & nd & 1.44 & 4.37 & 0.19 & 16.17 & 0.0012 & nd & nd & nd & nd & nd & nd & nd & nd \\
\hline PI 592 & 341DLRV & $6 / 24 / 2015$ & 11:06 & 9/24/2015 & na & nd & 1.44 & 3.72 & 0.14 & 16.46 & 0.0014 & nd & nd & nd & nd & nd & nd & nd & nd \\
\hline PI 609 & 341DLRV & 7/8/2015 & $13: 05$ & 9/24/2015 & na & nd & 1.76 & 5.05 & 0.046 & 2.19 & nd & nd & nd & nd & nd & nd & nd & nd & nd \\
\hline PI 625 & 341DLRV & $7 / 15 / 2015$ & $10: 05$ & $9 / 25 / 2015$ & na & nd & 1.87 & 4.49 & 0.52 & 0.0075 & nd & nd & nd & nd & nd & nd & nd & nd & nd \\
\hline PI 641 & 341DLRV & 9/22/2015 & $10: 35$ & 11/19/2015 & na & nd & 1.81 & 3.02 & 0.72 & 0.287 & nd & nd & nd & nd & nd & nd & nd & nd & nd \\
\hline PI 651 & 341DLRV & 9/22/2015 & $11: 05$ & 11/19/2015 & na & nd & 1.73 & 3.61 & 0.25 & 3.23 & nd & nd & nd & nd & nd & nd & nd & nd & nd \\
\hline PI 524 & 341TMSG & $6 / 25 / 2015$ & $15: 05$ & 9/24/2015 & na & nd & 1.31 & 5.37 & 0.29 & 20.18 & 0.0021 & nd & nd & nd & nd & nd & nd & nd & nd \\
\hline PI 524 & 341TMSG & 9/22/2015 & $13: 35$ & 11/19/2015 & na & nd & 1.41 & 1.57 & 0.30 & 20.21 & 0.0029 & nd & nd & nd & nd & nd & nd & nd & nd \\
\hline PI 524 & 341TMSG & 9/22/2015 & $13: 36$ & $11 / 19 / 2015$ & na & nd & 1.39 & 1.71 & 0.33 & 21.89 & 0.0035 & nd & nd & nd & nd & nd & nd & nd & nd \\
\hline PI 604 & 341TMSG & $9 / 21 / 2015$ & $15: 05$ & 11/19/2015 & na & nd & 1.82 & 5.68 & 1.25 & 0.0052 & nd & nd & nd & nd & nd & nd & nd & nd & nd \\
\hline PI 653 & 341TMSG & 9/24/2015 & $11: 35$ & $11 / 19 / 2015$ & na & nd & 1.68 & 3.65 & 2.05 & 0.317 & nd & nd & nd & nd & nd & nd & nd & nd & nd \\
\hline PI 530 & 341TMRK & 8/5/2015 & 13:305 & $9 / 25 / 2015$ & na & nd & 1.73 & 4.11 & 0.54 & 1.78 & nd & nd & nd & nd & nd & nd & nd & nd & nd \\
\hline PI 647 & 341TMRK & 9/23/2015 & $15: 05$ & 11/19/2015 & na & nd & 1.80 & 4.17 & 0.36 & 0.125 & nd & nd & nd & nd & nd & nd & nd & nd & nd \\
\hline PI 647 & 341TMRK & 9/23/2015 & $15: 06$ & $11 / 19 / 2015$ & na & nd & 1.84 & 3.84 & 0.37 & 0.133 & nd & nd & nd & nd & nd & nd & nd & nd & nd \\
\hline PI 146 & 344MNNG & 8/6/2015 & 14:05 & 9/24/2015 & na & nd & 1.63 & 3.79 & 0.10 & 7.17 & nd & nd & nd & nd & nd & nd & nd & nd & nd \\
\hline PI 556 & 344MNNG & 8/6/2015 & $10: 35$ & 9/25/2015 & na & nd & 1.86 & 4.52 & 0.54 & 0.614 & nd & nd & nd & nd & nd & nd & nd & nd & nd \\
\hline PI 591 & 344MNNG & 8/5/2015 & $16: 05$ & 9/24/2015 & na & nd & 1.52 & 3.01 & 0.074 & 8.39 & 0.0007 & nd & nd & nd & nd & nd & nd & nd & nd \\
\hline PI 622 & 344MNNG & 7/14/2015 & $16: 05$ & 9/24/2015 & na & nd & 1.54 & 2.28 & 0.16 & 7.38 & 0.0013 & nd & nd & nd & nd & nd & nd & nd & nd \\
\hline PI 642 & 344MNNG & 9/22/2015 & $14: 05$ & 11/19/2015 & na & nd & 1.78 & 7.93 & 1.98 & 0.0020 & nd & nd & nd & nd & nd & nd & nd & nd & nd \\
\hline PI 650 & 344MNNG & 9/23/2015 & 11:05 & $11 / 19 / 2015$ & na & nd & 1.57 & 0.079 & 0.064 & 2.99 & 0.0023 & nd & nd & nd & nd & nd & nd & nd & nd \\
\hline PI 648 & 344MRCL & 9/24/2015 & $13: 05$ & $11 / 19 / 2015$ & na & nd & 1.84 & 13.93 & 0.098 & 0.0102 & nd & nd & nd & nd & nd & nd & nd & nd & nd \\
\hline
\end{tabular}


Table 14. Results of dissolved gas analysis and isotopic characterization of methane by Isotech Laboratories, Inc. for water samples collected from 17 wells in Pike County, 2015. Results listed by geologic unit. One well (PI-524) was sampled twice. Replicates (shaded in gray) collected from three wells (PI-592, PI-524, PI-647) are listed with time offset of 1 minute.-Continued

[USGS, U.S. Geological Survey; na, not analyzed; nd, not detected; --, no data; \%, mole percent; \%o, per mil or parts per trillion; cc/L, cubic centimeters per liter; mg/L, milligrams per liter; Geologic units: DLRV, Deleware River Member of Catskill Formation; LCSS, Lackawaxen Member of Catskill Formation; 341TMSG, Towamensing Member of the Catskill formation; 341 TMRK, Trimmers Rock Formation; 344MRCL, Marcellus Shale. He, helium; $\mathrm{H}_{2}$, hydrogen; Ar, argon; $\mathrm{O}_{2}$, oxygen; $\mathrm{CO}_{2}$, carbon dioxide; $\mathrm{N}_{2}$, nitrogen; $\mathrm{CO}$, carbon monoxide; $\mathrm{C}_{1}$, methane; $\mathrm{C}_{2}$, ethane; $\mathrm{C}_{2} \mathrm{H}_{4}$, ethene; $\mathrm{C}_{3}$, propane; $\mathrm{iC}_{4}, \mathrm{nC}_{4}, \mathrm{iC}_{5}$, $\mathrm{nC}_{5}$, $\mathrm{C}_{6}+$, hydrocarbons with 4,5 , and 6 carbon atome per molecule, respectively; $\delta^{13} \mathrm{C}_{1}$, carbon-13 and carbon-12 isotopic composition of methane; $\delta \mathrm{DC}$, deuterium and hydrogen isotopic composition of methane; $\mathrm{CH}_{4}$, methane; $\mathrm{C}_{2} \mathrm{H}_{6}$, ethane; $\mathrm{C}_{3} \mathrm{H}_{8}$, propane. Isotopic composition of carbon is relative to Vienna Pee Dee Belemnite (VPDB). Isotopic composition of hydrogen is relative to Vienna Standard Mean Ocean Water (VSMOW)]

\begin{tabular}{|c|c|c|c|c|c|c|c|c|c|c|c|c|c|c|c|}
\hline \multirow{2}{*}{$\begin{array}{l}\text { USGS } \\
\text { local } \\
\text { name }\end{array}$} & \multirow{2}{*}{$\begin{array}{c}\text { Geologic } \\
\text { unit }\end{array}$} & \multirow{2}{*}{$\begin{array}{l}\text { Sample } \\
\text { date }\end{array}$} & \multirow{2}{*}{$\begin{array}{c}\text { Sam- } \\
\text { ple } \\
\text { time }\end{array}$} & \multirow{2}{*}{$\begin{array}{l}\text { MS } \\
\text { date }\end{array}$} & \multirow{2}{*}{$\begin{array}{l}\mathbf{d}^{13} \mathbf{C}_{1} \\
(\%)\end{array}$} & \multirow{2}{*}{$\begin{array}{l}\mathrm{dDC}_{1} \\
(\%)\end{array}$} & \multirow{2}{*}{$\begin{array}{c}\text { Specific } \\
\text { gravity }\end{array}$} & \multirow{2}{*}{ BTU } & \multicolumn{2}{|c|}{ Dissolved $\mathrm{CH}_{4}$} & \multicolumn{2}{|c|}{ Dissolved $\mathrm{C}_{2} \mathrm{H}_{6}$} & \multicolumn{2}{|c|}{ Dissolved $\mathrm{C}_{3} \mathrm{H}_{8}$} & \multirow{2}{*}{$\begin{array}{l}\text { Helium } \\
\text { dilution } \\
\text { factor * }\end{array}$} \\
\hline & & & & & & & & & cc/L & $\mathrm{mg} / \mathrm{L}$ & cc/L & $\mathrm{mg} / \mathrm{L}$ & cc/L & $\mathrm{mg} / \mathrm{L}$ & \\
\hline PI 592 & 341DLRV & 6/24/2015 & $11: 05$ & 9/30/2015 & -63.25 & -198.0 & 0.913 & 164 & 6.1 & 4.1 & 0.00047 & 0.00059 & $<0.0001$ & $<0.0003$ & 0.74 \\
\hline PI 592 & 341DLRV & $6 / 24 / 2015$ & $11: 06$ & 9/30/2015 & -63.32 & -199.7 & 0.911 & 167 & 6.0 & 4.0 & 0.00055 & 0.00069 & $<0.0001$ & $<0.0002$ & 0.71 \\
\hline PI 609 & 341DLRV & 7/8/2015 & $13: 05$ & 10/1/2015 & -59.11 & -162.4 & 0.973 & 22 & 0.61 & 0.41 & $<0.0001$ & $<0.0002$ & $<0.0001$ & $<0.0002$ & 0.75 \\
\hline PI 625 & 341DLRV & 7/15/2015 & $10: 05$ & -- & -- & -- & 0.984 & 0 & 0.0020 & 0.0013 & $<0.0001$ & $<0.0002$ & $<0.0001$ & $<0.0002$ & 0.79 \\
\hline PI 641 & 341DLRV & $9 / 22 / 2015$ & $10: 35$ & -- & -- & -- & 0.982 & 3 & 0.083 & 0.055 & $<0.0002$ & $<0.0002$ & $<0.0001$ & $<0.0003$ & 0.80 \\
\hline PI 651 & 341DLRV & 9/22/2015 & $11: 05$ & 12/9/2015 & -54.41 & -121.7 & 0.967 & 33 & 0.95 & 0.64 & $<0.0002$ & $<0.0002$ & $<0.0002$ & $<0.0003$ & 0.80 \\
\hline PI 524 & 341TMSG & 6/25/2015 & $15: 05$ & 9/30/2015 & -63.44 & -219.4 & 0.898 & 204 & 8.9 & 5.9 & 0.0010 & 0.0013 & $<0.0001$ & $<0.0002$ & 0.67 \\
\hline PI 524 & 341TMSG & 9/22/2015 & 13:35 & 12/9/2015 & -63.28 & -221.2 & 0.893 & 205 & 7.9 & 5.3 & 0.0012 & 0.0016 & $<0.0001$ & $<0.0002$ & 0.69 \\
\hline PI 524 & 341TMSG & 9/22/2015 & 13:36 & 12/8/2015 & -63.12 & -221.6 & 0.887 & 222 & 8.8 & 5.9 & 0.0015 & 0.0019 & $<0.0001$ & $<0.0003$ & 0.71 \\
\hline PI 604 & 341TMSG & $9 / 21 / 2015$ & $15: 05$ & -- & -- & -- & 0.989 & 0 & 0.0014 & 0.00095 & $<0.0002$ & $<0.0002$ & $<0.0001$ & $<0.0003$ & 0.81 \\
\hline PI 653 & 341TMSG & 9/24/2015 & $11: 35$ & -- & -- & -- & 0.989 & 3 & 0.086 & 0.058 & $<0.0002$ & $<0.0002$ & $<0.0001$ & $<0.0003$ & 0.80 \\
\hline PI 530 & 341TMRK & 8/5/2015 & 13:305 & 10/1/2015 & -62.58 & -151.2 & 0.976 & 18 & 0.51 & 0.34 & $<0.0001$ & $<0.0002$ & $<0.0001$ & $<0.0002$ & 0.78 \\
\hline PI 647 & 341TMRK & 9/23/2015 & $15: 05$ & -- & -- & -- & 0.982 & 1 & 0.034 & 0.023 & $<0.0001$ & $<0.0002$ & $<0.0001$ & $<0.0002$ & 0.79 \\
\hline PI 647 & 341TMRK & $9 / 23 / 2015$ & $15: 06$ & -- & -- & -- & 0.982 & 1 & 0.035 & 0.023 & $<0.0001$ & $<0.0002$ & $<0.0001$ & $<0.0003$ & 0.81 \\
\hline PI 146 & 344MNNG & 8/6/2015 & $14: 05$ & 9/30/2015 & -58.89 & -175.3 & 0.950 & 73 & 2.3 & 1.5 & $<0.0001$ & $<0.0002$ & $<0.0001$ & $<0.0002$ & 0.76 \\
\hline PI 556 & 344MNNG & 8/6/2015 & $10: 35$ & 10/1/2015 & -48.04 & -- & 0.982 & 6 & 0.16 & 0.11 & $<0.0002$ & $<0.0002$ & $<0.0001$ & $<0.0003$ & 0.82 \\
\hline PI 591 & 344MNNG & 8/5/2015 & $16: 05$ & 9/30/2015 & -58.97 & -203.2 & 0.943 & 85 & 3.5 & 2.3 & 0.00033 & 0.00041 & $<0.0002$ & $<0.0003$ & 0.73 \\
\hline PI 622 & 344MNNG & 7/14/2015 & $16: 05$ & 9/30/2015 & -40.99 & -175.0 & 0.947 & 75 & 2.8 & 1.9 & 0.00054 & 0.00067 & $<0.0001$ & $<0.0002$ & 0.69 \\
\hline PI 642 & 344MNNG & 9/22/2015 & $14: 05$ & -- & -- & -- & 0.996 & 0 & 0.00055 & 0.00036 & $<0.0001$ & $<0.0002$ & $<0.0001$ & $<0.0003$ & 0.80 \\
\hline PI 650 & 344MNNG & 9/23/2015 & $11: 05$ & $12 / 9 / 2015$ & -57.74 & -193.9 & 0.962 & 30 & 1.2 & 0.78 & 0.00096 & 0.0012 & $<0.0002$ & $<0.0003$ & 0.74 \\
\hline PI 648 & 344MRCL & 9/24/2015 & 13:05 & -- & -- & -- & 0.994 & 0 & 0.0033 & 0.0022 & $<0.0002$ & $<0.0002$ & $<0.0001$ & $<0.0003$ & 0.77 \\
\hline
\end{tabular}

${ }^{*}$ Analysis is of gas extracted from water by headspace equilibration. Analysis has been corrected for helium added to create headspace.

*Addition of helium negates the ability to detect native helium and may negate the ability to detect hydrogen.

Samples without He dilution factor had sufficient headspace to be extracted directly. 



\section{Appendixes 1-5}

Appendix 1. Analytical methods and reporting levels for constituents analyzed, by laboratory.

Appendix 2. Quality assurance and quality control data.

Appendix 3. Spearman rho correlations and boxplots showing sample compositions by groups (ranges of $\mathrm{pH}$, specific conductance, and redox values, principal components, and geologic units) for groundwater samples collected from 79 wells in Pike County, Pennsylvania, 2015.

Appendix 4. Field measurements and results of laboratory analyses for major and minor ions, nutrients, bacteria, trace metals, radioactivity, radon-222, and dissolved gases in groundwater samples collected from 7 pairs of closely spaced wells in Pike County, Pennsylvania, 2015.

Appendix 5. Field measurements and results of laboratory analyses for major and minor ions, nutrients, trace metals, radioactivity, radon-222 in groundwater samples collected from 18 wells in Pike County, Pennsylvania, 2007-15. 
Table A1-1. Methods used for determination of dissolved major ions, trace constituents, nutrients, alkalinity, and total organic carbon by the U.S. Geological Survey National Water Quality Laboratory and Weck Laboratories, Inc. in filtered groundwater samples collected from wells in Pike County, Pennsylvania, 2015.

[RL, reporting level; USGS, U.S. Geological Survey; NWQL, NationaL Water Quality Laboratory; $\mu \mathrm{g} / \mathrm{L}$, micrograms per liter; mg/L, milligrams per liter, $\mu \mathrm{S} / \mathrm{cm}$, microSiemens per centimeter; ICP-MS, Inductively coupled plasma mass spectrometry]

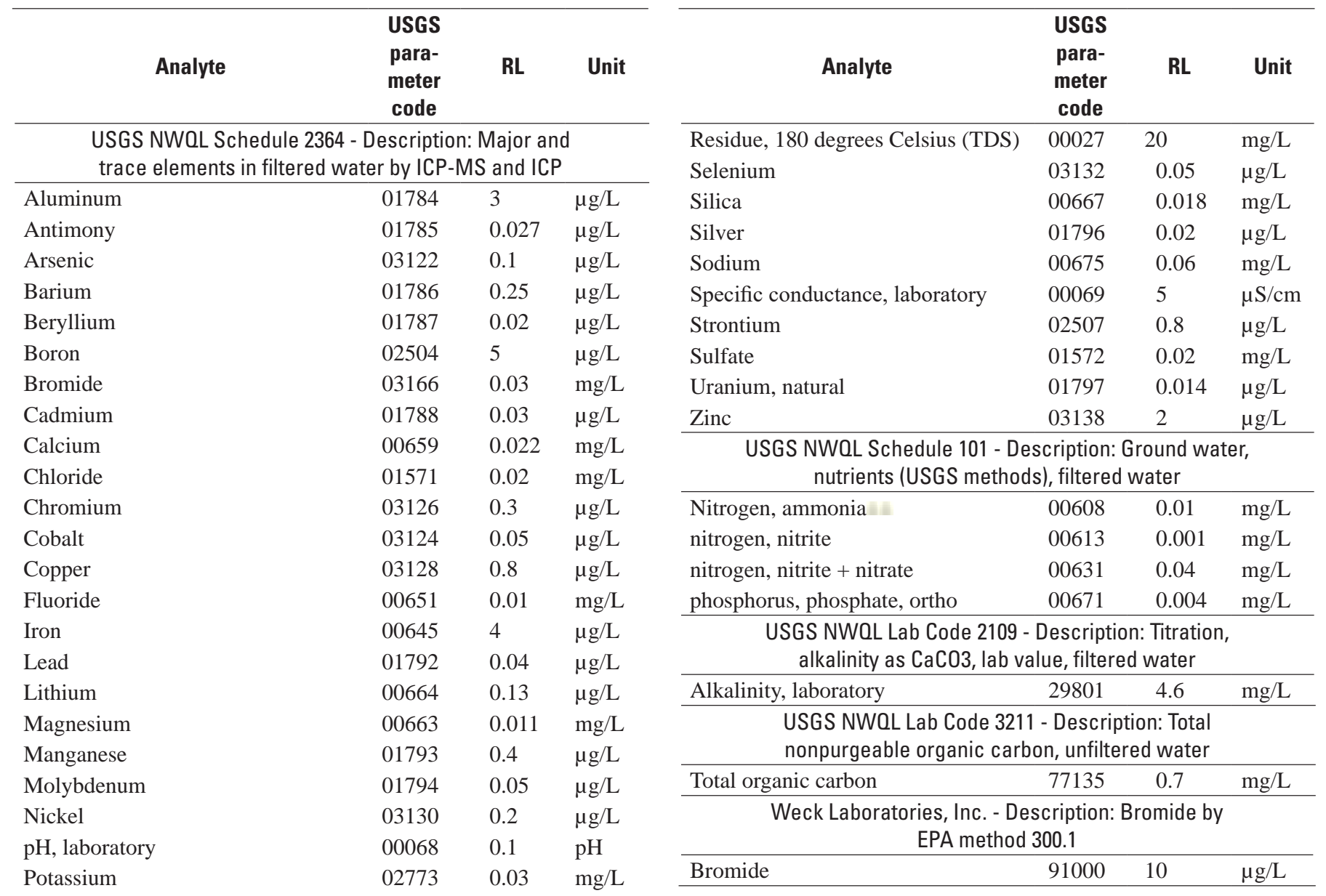


Table A1-2. Methods and reporting levels used for determination of gross alpha and beta radioactivity, radon-222, and radium-226 by the U.S. Geological Survey National Water Quality Laboratory in unfiltered groundwater samples collected from wells in Pike County, Pennsylvania, 2015.

[RL, reporting level; USGS, U.S. Geological Survey; NWQL, National Water Quality Laboratory; pCi/L, picocuries per liter; Th-230, thorium-230; Cs-137, cesium-137]

\begin{tabular}{|c|c|c|c|}
\hline Analyte & $\begin{array}{l}\text { USGS } \\
\text { para- } \\
\text { meter } \\
\text { code }\end{array}$ & $\mathbf{R L}$ & Unit \\
\hline \multicolumn{4}{|c|}{$\begin{array}{l}\text { USGS NWQL Lab Code } 2806 \text { - Gross-Alpha (Th-230 curve)/ } \\
\text { Beta (Cs-137 curve), } 72 \text { hr and } 30 \text { day, water, unfiltered }\end{array}$} \\
\hline Gross-alpha radioactivity, 72 hour count & 63014 & 3 & $\mathrm{pCi} / \mathrm{L}$ \\
\hline Gross-alpha radioactivity, 30 day count & 63016 & 3 & $\mathrm{pCi} / \mathrm{L}$ \\
\hline Gross-beta radioactivity, 72 hour count & 63015 & 4 & $\mathrm{pCi} / \mathrm{L}$ \\
\hline Gross-beta radioactivity, 30 day count & 63017 & 4 & $\mathrm{pCi} / \mathrm{L}$ \\
\hline \multicolumn{4}{|c|}{$\begin{array}{l}\text { USGS NWQL Lab Code } 1369 \text { - Description: Radon-222, } \\
\text { water, unfiltered, by liquid scintillation }\end{array}$} \\
\hline Radon-222 & 82303 & 20 & $\mathrm{pCi} / \mathrm{L}$ \\
\hline \multicolumn{4}{|c|}{$\begin{array}{c}\text { USGS NWQL Lab Code } 2622 \text { - Description: Radium-226, } \\
\text { water, unfiltered } 1\end{array}$} \\
\hline Radium-226 & 09501 & 0.1 & $\mathrm{pCi} / \mathrm{L}$ \\
\hline
\end{tabular}


Table A1-3. Methods used for determination of total concentrations of major ions, trace constituents, and constituents determined by Seewald Laboratories, Inc., in unfiltered groundwater samples collected from wells in Pike County, Pennsylvania, 2015.

[USGS, U.S.Geological Survey; MRL, laboratory minumum reporting level; mg/L, milligrams per liter; $\mu \mathrm{g} / \mathrm{L}$, micrograms per liter; MPN/100 mL, most probable number per 100 milliliters; PADEP, Pennsylvania Department of Environmental Protection; SM, standard method; EPA, U.S. Environmental Protection Agency; VOC, volatile organic compound]

\begin{tabular}{|c|c|c|c|c|}
\hline Analyte & $\begin{array}{l}\text { USGS } \\
\text { para- } \\
\text { meter } \\
\text { code }\end{array}$ & MRL & Unit & Method \\
\hline \multicolumn{5}{|c|}{$\begin{array}{l}\text { Seewald Laboratories, Inc. - dissolved gases by } \\
\text { method PADEP } 3686\end{array}$} \\
\hline Ethane & 68832 & 0.01 & $\mathrm{mg} / \mathrm{L}$ & $\begin{array}{r}\text { PADEP } \\
3686\end{array}$ \\
\hline Methane & 68831 & 0.01 & $\mathrm{mg} / \mathrm{L}$ & $\begin{array}{r}\text { PADEP } \\
3686\end{array}$ \\
\hline Propane & 68834 & 0.02 & $\mathrm{mg} / \mathrm{L}$ & $\begin{array}{r}\text { PADEP } \\
3686 \\
\end{array}$ \\
\hline \multicolumn{5}{|c|}{$\begin{array}{l}\text { Seewald Laboratories, Inc. - various inorganic analytes by } \\
\text { various drinking-water methods }\end{array}$} \\
\hline $\begin{array}{l}\text { Total dissolved } \\
\text { solids (residue, } \\
\text { filterable) }\end{array}$ & 70300 & 5 & $\mathrm{mg} / \mathrm{L}$ & SM 2540C \\
\hline $\begin{array}{l}\text { Total suspended } \\
\quad \text { solids }\end{array}$ & 70293 & 5 & $\mathrm{mg} / \mathrm{L}$ & SM 2540D \\
\hline Calcium & 00916 & 0.3 & $\mathrm{mg} / \mathrm{L}$ & EPA 200.7 \\
\hline Iron & 01045 & 0.01 & $\mathrm{mg} / \mathrm{L}$ & EPA 200.7 \\
\hline Lithium & 01132 & 0.01 & $\mathrm{mg} / \mathrm{L}$ & EPA 200.7 \\
\hline Magnesium & 00927 & 0.01 & $\mathrm{mg} / \mathrm{L}$ & EPA 200.7 \\
\hline Potassium & 00937 & 0.05 & $\mathrm{mg} / \mathrm{L}$ & EPA 200.7 \\
\hline Sodium & 00932 & 0.05 & $\mathrm{mg} / \mathrm{L}$ & EPA 200.7 \\
\hline Strontium & 01082 & 0.01 & $\mathrm{mg} / \mathrm{L}$ & EPA 200.7 \\
\hline Aluminum & 01105 & 0.001 & $\mathrm{mg} / \mathrm{L}$ & EPA 200.8 \\
\hline Arsenic & 01002 & 0.0005 & $\mathrm{mg} / \mathrm{L}$ & EPA 200.8 \\
\hline Barium & 01007 & 0.0005 & $\mathrm{mg} / \mathrm{L}$ & EPA 200.8 \\
\hline Manganese & 01055 & 0.0005 & $\mathrm{mg} / \mathrm{L}$ & EPA 200.8 \\
\hline Selenium & 01147 & 0.0025 & $\mathrm{mg} / \mathrm{L}$ & EPA 200.8 \\
\hline Zinc & 01092 & 0.0005 & $\mathrm{mg} / \mathrm{L}$ & EPA 200.8 \\
\hline Bromide & 63689 & 0.1 & $\mathrm{mg} / \mathrm{L}$ & EPA 300.0 \\
\hline Chloride & 99220 & 1 & $\mathrm{mg} / \mathrm{L}$ & EPA 300.0 \\
\hline Sulfate & 00946 & 1 & $\mathrm{mg} / \mathrm{L}$ & EPA 300.0 \\
\hline \multicolumn{5}{|c|}{ Seewald Laboratories, Inc. - VOCs by EPA method 542.2} \\
\hline \multicolumn{4}{|c|}{$\begin{array}{l}\text { - see table } 6 \text { for listing of analytes and reporting levels } \\
\text { Seewald Laboratories, Inc. - Bacteria enumeration }\end{array}$} & EPA 524.2 \\
\hline $\begin{array}{l}\text { Total coliform } \\
\text { bacteria }\end{array}$ & 31686 & 1 & $\begin{array}{l}\mathrm{MPN} / 100 \\
\mathrm{~mL}\end{array}$ & $\begin{array}{l}\text { SM } 9223 \\
\text { Colilert } \\
\text { total }\end{array}$ \\
\hline E. Coli & 31689 & 1 & $\begin{array}{l}\mathrm{MPN} / 100 \\
\quad \mathrm{~mL}\end{array}$ & $\begin{array}{l}\text { SM } 9223 \\
\text { Colilert } \\
\text { total }\end{array}$ \\
\hline
\end{tabular}


Table A2-1. Results of laboratory analysis in replicate groundwater samples collected from 3 wells (identified by U.S. Geological Survey well name and station number) in Pike County, Pennsylvania, 2015.

[Analyses for major and minor ions, volatile organic compounds, and dissolved gases (methane, ethane, propane) on unfiltered samples done by Seewald Laboratories, Inc. and other analyses done by U.S. Geological Survey (USGS) National Water Quality Laboratory (NWQL); percent difference $=100 \mathrm{x}(\mathrm{c} 1-\mathrm{c} 2) /[\mathrm{c} 1+\mathrm{c} 2) / 2]$, where $\mathrm{c} 1$ and $\mathrm{c} 2$ are concentrations in first and second sample of replicates; std. units, standard units; mg/L, milligrams per liter; $\mathrm{CaCO}_{3}$, calcium carbonate; $\mu \mathrm{g} / \mathrm{L}$, micrograms per liter; as N, as nitrogen; as $\mathrm{P}$, as phosphorus; $\mathrm{MPN} / 100 \mathrm{~mL}$, most probable number per 100 milliliters; $\mathrm{pCi} / \mathrm{L}$, picocuries per liter; \%, percent; -, no data; <, less than; R, non-detect for radiological analysis]

\begin{tabular}{|c|c|c|c|c|c|c|c|c|c|c|c|c|c|}
\hline \multicolumn{3}{|c|}{ USGS well number and station number } & \multicolumn{5}{|c|}{ PI $524 \quad 411849074533901$} & \multicolumn{3}{|c|}{ PI $592 \quad 412908074591401$} & \multicolumn{3}{|c|}{ PI $647 \quad 411014074554001$} \\
\hline Constituent & $\begin{array}{l}\text { Reporting } \\
\text { unit }\end{array}$ & $\begin{array}{l}\text { USGS } \\
\text { para- } \\
\text { meter } \\
\text { code }\end{array}$ & $\begin{array}{l}\text { Sample } \\
\text { date } \\
\text { (time) } \\
6 / 25 / 2015 \\
(1500)\end{array}$ & $\begin{array}{c}\text { Sample } \\
\text { date } \\
\text { (time) } \\
9 / 22 / 2015 \\
(1300)\end{array}$ & $\begin{array}{c}\text { Sample } \\
\text { date } \\
\text { (time) } \\
9 / 22 / 2015 \\
\text { (1331) }\end{array}$ & $\begin{array}{l}\text { Percent } \\
\text { difference, } \\
\text { replicate } \\
\text { samples }\end{array}$ & $\begin{array}{c}\text { Percent } \\
\text { difference, } \\
\text { June and } \\
\text { September } \\
\text { samples }\end{array}$ & $\begin{array}{l}\text { Sample } \\
\text { date } \\
\text { (time) } \\
6 / 24 / 2015 \\
(1100)\end{array}$ & $\begin{array}{l}\text { Sample } \\
\text { date } \\
\text { (time) } \\
6 / 24 / 2015 \\
\text { (1101) }\end{array}$ & $\begin{array}{l}\text { Percent } \\
\text { difference } \\
\text { between } \\
\text { replicate } \\
\text { samples }\end{array}$ & $\begin{array}{l}\text { Sample } \\
\text { date } \\
\text { (time) } \\
9 / 23 / 2015 \\
\text { (1500) }\end{array}$ & $\begin{array}{l}\text { Sample } \\
\text { date } \\
\text { (time) } \\
9 / 23 / 2015 \\
\text { (1501) }\end{array}$ & $\begin{array}{c}\text { Percent } \\
\text { difference } \\
\text { between } \\
\text { replicate } \\
\text { samples }\end{array}$ \\
\hline $\begin{array}{l}\text { Dissolved oxygen, } \\
\text { water, unfiltered }\end{array}$ & $\mathrm{mg} / \mathrm{L}$ & 00300 & $<0.01$ & 0.13 & -- & -- & -- & 0.17 & -- & -- & 0.16 & -- & -- \\
\hline $\begin{array}{l}\mathrm{pH} \text {, water, unfiltered, } \\
\text { field }\end{array}$ & std. units & 00400 & 8.24 & 8.39 & -- & -- & -1.80 & 8.74 & -- & -- & 8.34 & -- & -- \\
\hline $\begin{array}{l}\mathrm{pH} \text {, water, unfiltered, } \\
\text { laboratory }\end{array}$ & std. units & 00403 & 8.39 & 8.37 & 8.33 & 0.48 & 0.24 & 8.53 & 8.59 & -0.70 & 8.27 & -- & -- \\
\hline $\begin{array}{l}\text { Calcium, water, } \\
\text { filtered }\end{array}$ & $\mathrm{mg} / \mathrm{L}$ & 00915 & 14.43 & 13.71 & 14.03 & -2.31 & 5.12 & 4.412 & 4.228 & 4.26 & 16.41 & -- & -- \\
\hline $\begin{array}{l}\text { Magnesium, water, } \\
\text { unfiltered, } \\
\text { recoverable }\end{array}$ & $\mathrm{mg} / \mathrm{L}$ & 00927 & 4.91 & 5.31 & 5.31 & 0.00 & -7.83 & 1.24 & 1.25 & -0.80 & 5.24 & -- & -- \\
\hline $\begin{array}{l}\text { Potassium, water, } \\
\text { unfiltered, } \\
\text { recoverable }\end{array}$ & $\mathrm{mg} / \mathrm{L}$ & 00937 & $<0.5$ & $<0.5$ & $<0.5$ & -- & -- & 0.712 & 0.709 & 0.42 & $<0.5$ & -- & -- \\
\hline $\begin{array}{l}\text { Sodium, water, } \\
\text { filtered }\end{array}$ & $\mathrm{mg} / \mathrm{L}$ & 00930 & 46.57 & 39.99 & 40.83 & -2.08 & 15.20 & 68.11 & 65.39 & 4.07 & 13.01 & -- & -- \\
\hline $\begin{array}{l}\text { Alkalinity, water, } \\
\text { filtered, fixed } \\
\text { endpoint (pH } \\
\text { 4.5) titration, } \\
\text { laboratory }\end{array}$ & $\begin{array}{l}\mathrm{mg} / \mathrm{L} \text { as } \\
\mathrm{CaCO}_{3}\end{array}$ & 29801 & 123.1 & 121.1 & 120.5 & 0.50 & 1.64 & 117.4 & 117.4 & 0.00 & 70.92 & -- & -- \\
\hline $\begin{array}{l}\text { Bromide, water, } \\
\text { filtered }\end{array}$ & $\mu \mathrm{g} / \mathrm{L}$ & 91000 & 220 & 170 & -- & -- & 25.64 & 360 & 350 & 2.82 & $<10$ & -- & -- \\
\hline $\begin{array}{l}\text { Bromide, water, } \\
\text { unfiltered }\end{array}$ & $\mathrm{mg} / \mathrm{L}$ & 63689 & $<0.1$ & $<0.1$ & $<0.1$ & -- & -- & 0.159 & 0.158 & 0.63 & $<0.1$ & -- & -- \\
\hline $\begin{array}{l}\text { Chloride, water, } \\
\text { filtered }\end{array}$ & $\mathrm{mg} / \mathrm{L}$ & 00940 & 23.529 & 22.028 & 21.587 & 2.02 & 6.59 & 33.035 & 33.016 & 0.06 & 2.962 & -- & -- \\
\hline $\begin{array}{l}\text { Chloride, water, } \\
\text { unfiltered }\end{array}$ & $\mathrm{mg} / \mathrm{L}$ & 99220 & 23.7 & 23 & 23.5 & -2.15 & 3.00 & 33.2 & 33.1 & 0.30 & 3.12 & -- & -- \\
\hline $\begin{array}{l}\text { Fluoride, water, } \\
\text { filtered }\end{array}$ & $\mathrm{mg} / \mathrm{L}$ & 00950 & 0.201 & 0.208 & 0.2 & 3.92 & -3.42 & 0.514 & 0.507 & 1.37 & 0.098 & -- & -- \\
\hline $\begin{array}{l}\text { Silica, water, filtered, } \\
\text { as } \mathrm{SiO}_{2}\end{array}$ & $\mathrm{mg} / \mathrm{L}$ & 00955 & 10.07 & 9.657 & 9.614 & 0.45 & 4.19 & 7.139 & 7.085 & 0.76 & 11.78 & -- & -- \\
\hline
\end{tabular}


Table A2-1. Results of laboratory analysis in replicate groundwater samples collected from 3 wells (identified by U.S. Geological Survey well name and station number) in Pike County, Pennsylvania, 2015.-Continued

[Analyses for major and minor ions, volatile organic compounds, and dissolved gases (methane, ethane, propane) on unfiltered samples done by Seewald Laboratories, Inc. and other analyses done by U.S Geological Survey (USGS) National Water Quality Laboratory (NWQL); percent difference $=100 \mathrm{x}(\mathrm{c} 1-\mathrm{c} 2) /[\mathrm{c} 1+\mathrm{c} 2) / 2]$, where $\mathrm{c} 1$ and $\mathrm{c} 2$ are concentrations in first and second sample of replicates; std. units, standard units; mg/L, milligrams per liter; $\mathrm{CaCO}_{3}$, calcium carbonate; $\mu \mathrm{g} / \mathrm{L}$, micrograms per liter; as N, as nitrogen; as $\mathrm{P}$, as phosphorus; MPN/100 mL, most probable number per 100 milliliters; $\mathrm{pCi} / \mathrm{L}$, picocuries per liter; \%, percent; -, no data; <, less than; R, non-detect for radiological analysis]

\begin{tabular}{|c|c|c|c|c|c|c|c|c|c|c|c|c|c|}
\hline \multicolumn{3}{|c|}{ USGS well number and station number } & \multicolumn{5}{|c|}{ PI $524 \quad 411849074533901$} & \multicolumn{3}{|c|}{ PI $592 \quad 412908074591401$} & \multicolumn{3}{|c|}{ PI $647 \quad 411014074554001$} \\
\hline Constituent & $\begin{array}{l}\text { Reporting } \\
\text { unit }\end{array}$ & $\begin{array}{l}\text { USGS } \\
\text { para- } \\
\text { meter } \\
\text { code }\end{array}$ & $\begin{array}{c}\text { Sample } \\
\text { date } \\
\text { (time) } \\
6 / 25 / 2015 \\
(1500)\end{array}$ & $\begin{array}{c}\text { Sample } \\
\text { date } \\
\text { (time) } \\
9 / 22 / 2015 \\
(1300)\end{array}$ & $\begin{array}{c}\text { Sample } \\
\text { date } \\
\text { (time) } \\
9 / 22 / 2015 \\
\text { (1331) }\end{array}$ & $\begin{array}{l}\text { Percent } \\
\text { difference, } \\
\text { replicate } \\
\text { samples }\end{array}$ & $\begin{array}{c}\text { Percent } \\
\text { difference, } \\
\text { June and } \\
\text { September } \\
\text { samples }\end{array}$ & $\begin{array}{c}\text { Sample } \\
\text { date } \\
\text { (time) } \\
6 / 24 / 2015 \\
(1100)\end{array}$ & $\begin{array}{c}\text { Sample } \\
\text { date } \\
\text { (time) } \\
6 / 24 / 2015 \\
(1101)\end{array}$ & $\begin{array}{l}\text { Percent } \\
\text { difference } \\
\text { between } \\
\text { replicate } \\
\text { samples }\end{array}$ & $\begin{array}{c}\text { Sample } \\
\text { date } \\
\text { (time) } \\
9 / 23 / 2015 \\
(1500)\end{array}$ & $\begin{array}{c}\text { Sample } \\
\text { date } \\
\text { (time) } \\
\text { 9/23/2015 } \\
\text { (1501) }\end{array}$ & $\begin{array}{c}\text { Percent } \\
\text { difference } \\
\text { between } \\
\text { replicate } \\
\text { samples }\end{array}$ \\
\hline $\begin{array}{l}\text { Sulfate, water, } \\
\text { filtered }\end{array}$ & $\mathrm{mg} / \mathrm{L}$ & 00945 & 0.887 & 1.112 & 1.154 & -3.71 & -22.51 & 0.391 & 0.39 & 0.26 & 17.236 & -- & -- \\
\hline $\begin{array}{l}\text { Sulfate, water, } \\
\text { unfiltered }\end{array}$ & $\mathrm{mg} / \mathrm{L}$ & 00946 & $<1$ & $<1$ & $<1$ & -- & -- & $<1$ & $<1$ & -- & 18.5 & -- & -- \\
\hline $\begin{array}{l}\text { Ammonia, water, } \\
\text { filtered, as } \\
\text { nitrogen }\end{array}$ & $\mathrm{mg} / \mathrm{L}$ as $\mathrm{N}$ & 00608 & 0.06591 & 0.06301 & 0.0608 & 3.57 & 4.50 & 0.05913 & 0.05963 & -0.84 & 0.04529 & -- & -- \\
\hline $\begin{array}{l}\text { Nitrate plus nitrite, } \\
\text { water, filtered }\end{array}$ & $\mathrm{mg} / \mathrm{L}$ as $\mathrm{N}$ & 00631 & $<0.04$ & $<0.04$ & $<0.04$ & -- & -- & $<0.04$ & $<0.04$ & -- & $<0.04$ & -- & -- \\
\hline Nitrite, water, filtered & $\mathrm{mg} / \mathrm{L}$ as $\mathrm{N}$ & 00613 & $<0.0010$ & $<0.001$ & $<0.001$ & -- & -- & $<0.0010$ & $<0.0010$ & -- & $<0.001$ & -- & -- \\
\hline $\begin{array}{l}\text { Orthophosphate, } \\
\text { water, filtered }\end{array}$ & $\mathrm{mg} / \mathrm{L}$ as $\mathrm{P}$ & 00671 & 0.02866 & 0.02661 & 0.02744 & -3.07 & 7.42 & 0.1744 & 0.178 & -2.04 & 0.02216 & -- & -- \\
\hline $\begin{array}{l}\text { Escherichia coli, } \\
\text { water }\end{array}$ & MPN/100 mL & 31689 & $<1$ & $<1$ & $<1$ & -- & -- & $<1$ & $<1$ & -- & $<1$ & -- & -- \\
\hline $\begin{array}{l}\text { Total coliforms, } \\
\text { water }\end{array}$ & MPN/100 mL & 31686 & $<1$ & $<1$ & $<1$ & -- & -- & 19 & $<1$ & -- & $<1$ & -- & -- \\
\hline $\begin{array}{l}\text { Aluminum, water, } \\
\text { filtered }\end{array}$ & $\mu \mathrm{g} / \mathrm{L}$ & 01106 & $<3.0$ & $<3$ & $<3$ & -- & -- & $<3.0$ & 3.469 & -- & $<3$ & -- & -- \\
\hline $\begin{array}{l}\text { Aluminum, water, } \\
\text { unfiltered, } \\
\text { recoverable }\end{array}$ & $\mu g / L$ & 01105 & 2.62 & 2.56 & 1.89 & 30.11 & 2.32 & 1.04 & 1.19 & -13.45 & 2.52 & -- & -- \\
\hline $\begin{array}{l}\text { Barium, water, } \\
\text { filtered }\end{array}$ & $\mu \mathrm{g} / \mathrm{L}$ & 01005 & 136.8 & 130.4 & 132.3 & -1.45 & 4.79 & 298.5 & 294.5 & 1.35 & 11.24 & -- & -- \\
\hline $\begin{array}{l}\text { Barium, water, } \\
\text { unfiltered, } \\
\text { recoverable }\end{array}$ & $\mu \mathrm{g} / \mathrm{L}$ & 01007 & 130 & 125 & 126 & -0.80 & 3.92 & 292 & 291 & 0.34 & 15.8 & -- & -- \\
\hline $\begin{array}{l}\text { Beryllium, water, } \\
\text { filtered }\end{array}$ & $\mu \mathrm{g} / \mathrm{L}$ & 01010 & $<0.02$ & $<0.02$ & $<0.02$ & -- & -- & $<0.02$ & $<0.02$ & -- & $<0.02$ & -- & -- \\
\hline $\begin{array}{l}\text { Cadmium, water, } \\
\text { filtered }\end{array}$ & $\mu \mathrm{g} / \mathrm{L}$ & 01025 & $<0.03$ & $<0.03$ & $<0.03$ & -- & -- & $<0.03$ & $<0.03$ & -- & $<0.03$ & -- & -- \\
\hline $\begin{array}{l}\text { Chromium, water, } \\
\text { filtered }\end{array}$ & $\mu \mathrm{g} / \mathrm{L}$ & 01030 & $<0.3$ & $<0.3$ & $<0.3$ & -- & -- & $<0.3$ & $<0.3$ & -- & $<0.3$ & -- & -- \\
\hline Cobalt, water, filtered & $\mu \mathrm{g} / \mathrm{L}$ & 01035 & $<0.05$ & 0.0903 & $<0.05$ & -- & -- & $<0.05$ & $<0.05$ & -- & $<0.05$ & -- & -- \\
\hline
\end{tabular}


Table A2-1. Results of laboratory analysis in replicate groundwater samples collected from 3 wells (identified by U.S. Geological Survey well name and station number) in Pike County, Pennsylvania, 2015.-Continued

[Analyses for major and minor ions, volatile organic compounds, and dissolved gases (methane, ethane, propane) on unfiltered samples done by Seewald Laboratories, Inc. and other analyses done by U.S Geological Survey (USGS) National Water Quality Laboratory (NWQL); percent difference = 100x(c1-c2)/[c1+c2)/2], where c1 and c2 are concentrations in first and second sample of replicates; std. units, standard units; mg/L, milligrams per liter; $\mathrm{CaCO}_{3}$, calcium carbonate; $\mu \mathrm{g} / \mathrm{L}$, micrograms per liter; as N, as nitrogen; as $\mathrm{P}$, as phosphorus; $\mathrm{MPN} / 100 \mathrm{~mL}$, most probable number per 100 milliliters; pCi/L,

picocuries per liter; \%, percent; -, no data; $<$, less than; R, non-detect for radiological analysis]

\begin{tabular}{|c|c|c|c|c|c|c|c|c|c|c|c|c|c|}
\hline \multicolumn{3}{|c|}{ USGS well number and station number } & \multicolumn{5}{|c|}{ PI $524 \quad 411849074533901$} & \multicolumn{3}{|c|}{ PI 592412908074591401} & \multicolumn{3}{|c|}{ PI $647 \quad 411014074554001$} \\
\hline Constituent & $\begin{array}{l}\text { Reporting } \\
\text { unit }\end{array}$ & $\begin{array}{l}\text { USGS } \\
\text { para- } \\
\text { meter } \\
\text { code }\end{array}$ & $\begin{array}{c}\text { Sample } \\
\text { date } \\
\text { (time) } \\
6 / 25 / 2015 \\
(1500)\end{array}$ & $\begin{array}{c}\text { Sample } \\
\text { date } \\
\text { (time) } \\
9 / 22 / 2015 \\
(1300)\end{array}$ & $\begin{array}{c}\text { Sample } \\
\text { date } \\
\text { (time) } \\
9 / 22 / 2015 \\
\text { (1331) }\end{array}$ & $\begin{array}{l}\text { Percent } \\
\text { difference, } \\
\text { replicate } \\
\text { samples }\end{array}$ & $\begin{array}{c}\text { Percent } \\
\text { difference, } \\
\text { June and } \\
\text { September } \\
\text { samples }\end{array}$ & $\begin{array}{c}\text { Sample } \\
\text { date } \\
\text { (time) } \\
6 / 24 / 2015 \\
(1100)\end{array}$ & $\begin{array}{c}\text { Sample } \\
\text { date } \\
\text { (time) } \\
6 / 24 / 2015 \\
\text { (1101) }\end{array}$ & $\begin{array}{c}\text { Percent } \\
\text { difference } \\
\text { between } \\
\text { replicate } \\
\text { samples }\end{array}$ & $\begin{array}{c}\text { Sample } \\
\text { date } \\
\text { (time) } \\
9 / 23 / 2015 \\
(1500)\end{array}$ & $\begin{array}{c}\text { Sample } \\
\text { date } \\
\text { (time) } \\
9 / 23 / 2015 \\
\text { (1501) }\end{array}$ & $\begin{array}{c}\text { Percent } \\
\text { difference } \\
\text { between } \\
\text { replicate } \\
\text { samples }\end{array}$ \\
\hline $\begin{array}{l}\text { Copper, water, } \\
\text { filtered }\end{array}$ & $\mu \mathrm{g} / \mathrm{L}$ & 01040 & $<0.8$ & $<0.8$ & $<0.8$ & -- & -- & $<0.8$ & $<0.8$ & -- & $<0.8$ & -- & -- \\
\hline Iron, water, filtered & $\mu \mathrm{g} / \mathrm{L}$ & 01046 & 18.57 & 22.41 & 20.92 & 6.88 & -18.74 & 72.08 & 69.65 & 3.43 & 46.51 & -- & -- \\
\hline $\begin{array}{l}\text { Iron, water, } \\
\text { unfiltered, } \\
\text { recoverable }\end{array}$ & $\mu \mathrm{g} / \mathrm{L}$ & 01045 & 58.8 & 50.8 & 37.2 & 30.91 & 14.60 & 80.3 & 80.9 & -0.74 & 2,180 & -- & -- \\
\hline Lead, water, filtered & $\mu g / L$ & 01049 & $<0.04$ & $<0.04$ & $<0.04$ & -- & -- & 0.3772 & 0.3499 & 7.51 & $<0.04$ & -- & -- \\
\hline $\begin{array}{l}\text { Lithium, water, } \\
\text { filtered }\end{array}$ & $\mu \mathrm{g} / \mathrm{L}$ & 01130 & 136.4 & 117.7 & 122.4 & -3.92 & 14.72 & 289.4 & 281.9 & 2.63 & 13.3 & -- & -- \\
\hline $\begin{array}{l}\text { Lithium, water, } \\
\text { unfiltered, } \\
\text { recoverable }\end{array}$ & $\mu \mathrm{g} / \mathrm{L}$ & 01132 & 138 & 133 & 140 & -5.13 & 3.69 & 268 & 270 & -0.74 & 14.4 & -- & -- \\
\hline $\begin{array}{l}\text { Manganese, water, } \\
\text { filtered }\end{array}$ & $\mu \mathrm{g} / \mathrm{L}$ & 01056 & 18.42 & 20.31 & 19.92 & 1.94 & -9.76 & 83.72 & 82.98 & 0.89 & 84.52 & -- & -- \\
\hline $\begin{array}{l}\text { Manganese, water, } \\
\text { unfiltered, } \\
\text { recoverable }\end{array}$ & $\mu \mathrm{g} / \mathrm{L}$ & 01055 & 18.4 & 18.9 & 18.2 & 3.77 & -2.68 & 80.9 & 80.4 & 0.62 & 242 & -- & -- \\
\hline $\begin{array}{l}\text { Molybdenum, water, } \\
\text { filtered }\end{array}$ & $\mu \mathrm{g} / \mathrm{L}$ & 01060 & 0.3528 & 0.3673 & 0.3711 & -1.03 & -4.03 & 0.606 & 0.6225 & -2.69 & 0.0893 & -- & -- \\
\hline Nickel, water, filtered & $\mu \mathrm{g} / \mathrm{L}$ & 01065 & $<0.20$ & $<0.2$ & $<0.2$ & -- & -- & $<0.20$ & $<0.20$ & -- & $<0.2$ & -- & -- \\
\hline $\begin{array}{l}\text { Strontium, water, } \\
\text { filtered }\end{array}$ & $\mu \mathrm{g} / \mathrm{L}$ & 01080 & 487.5 & 472.3 & 475.2 & -0.61 & 3.17 & 331.3 & 330.7 & 0.18 & 326.1 & -- & -- \\
\hline $\begin{array}{l}\text { Strontium, water, } \\
\text { unfiltered, } \\
\text { recoverable }\end{array}$ & $\mu \mathrm{g} / \mathrm{L}$ & 01082 & 490 & 485 & 500 & -3.05 & 1.03 & 325 & 327 & -0.61 & 335 & -- & -- \\
\hline Zinc, water, filtered & $\mu \mathrm{g} / \mathrm{L}$ & 01090 & $<2.0$ & $<2$ & $<2$ & -- & -- & $<2.0$ & $<2.0$ & -- & $<2$ & -- & -- \\
\hline $\begin{array}{l}\text { Zinc, water, } \\
\text { unfiltered, } \\
\text { recoverable }\end{array}$ & $\mu \mathrm{g} / \mathrm{L}$ & 01092 & $<0.5$ & $<0.5$ & $<0.5$ & -- & -- & 16.3 & 18.1 & -10.47 & 1.64 & -- & -- \\
\hline $\begin{array}{l}\text { Antimony, water, } \\
\text { filtered }\end{array}$ & $\mu \mathrm{g} / \mathrm{L}$ & 01095 & $<0.027$ & $<0.027$ & $<0.027$ & -- & -- & $<0.027$ & $<0.027$ & -- & $<0.027$ & -- & -- \\
\hline $\begin{array}{l}\text { Arsenic, water, } \\
\text { filtered }\end{array}$ & $\mu \mathrm{g} / \mathrm{L}$ & 01000 & 0.2355 & 0.2321 & 0.2341 & -0.86 & 1.45 & 27.83 & 27.76 & 0.25 & 0.1203 & -- & -- \\
\hline
\end{tabular}


Table A2-1. Results of laboratory analysis in replicate groundwater samples collected from 3 wells (identified by U.S. Geological Survey well name and station number) in Pike County, Pennsylvania, 2015.-Continued

[Analyses for major and minor ions, volatile organic compounds, and dissolved gases (methane, ethane, propane) on unfiltered samples done by Seewald Laboratories, Inc. and other analyses done by U.S Geological Survey (USGS) National Water Quality Laboratory (NWQL); percent difference $=100 \mathrm{x}(\mathrm{c} 1-\mathrm{c} 2) /[\mathrm{c} 1+\mathrm{c} 2) / 2]$, where $\mathrm{c} 1$ and $\mathrm{c} 2$ are concentrations in first and second sample of replicates; std. units, standard units; mg/L, milligrams per liter; $\mathrm{CaCO}_{3}$, calcium carbonate; $\mu \mathrm{g} / \mathrm{L}$, micrograms per liter; as N, as nitrogen; as $\mathrm{P}$, as phosphorus; MPN/100 mL, most probable number per 100 milliliters; $\mathrm{pCi} / \mathrm{L}$, picocuries per liter; \%, percent; -, no data; <, less than; R, non-detect for radiological analysis]

\begin{tabular}{|c|c|c|c|c|c|c|c|c|c|c|c|c|c|}
\hline \multicolumn{3}{|c|}{ USGS well number and station number } & \multicolumn{5}{|c|}{ PI $524 \quad 411849074533901$} & \multicolumn{3}{|c|}{ PI $592 \quad 412908074591401$} & \multicolumn{3}{|c|}{ PI $647 \quad 411014074554001$} \\
\hline Constituent & $\begin{array}{l}\text { Reporting } \\
\text { unit }\end{array}$ & $\begin{array}{l}\text { USGS } \\
\text { para- } \\
\text { meter } \\
\text { code }\end{array}$ & $\begin{array}{c}\text { Sample } \\
\text { date } \\
\text { (time) } \\
6 / 25 / 2015 \\
(1500)\end{array}$ & $\begin{array}{c}\text { Sample } \\
\text { date } \\
\text { (time) } \\
9 / 22 / 2015 \\
(1300) \\
\end{array}$ & $\begin{array}{c}\text { Sample } \\
\text { date } \\
\text { (time) } \\
9 / 22 / 2015 \\
\text { (1331) } \\
\end{array}$ & $\begin{array}{l}\text { Percent } \\
\text { difference, } \\
\text { replicate } \\
\text { samples }\end{array}$ & $\begin{array}{c}\text { Percent } \\
\text { difference, } \\
\text { June and } \\
\text { September } \\
\text { samples }\end{array}$ & $\begin{array}{l}\text { Sample } \\
\text { date } \\
\text { (time) } \\
6 / 24 / 2015 \\
(1100)\end{array}$ & $\begin{array}{c}\text { Sample } \\
\text { date } \\
\text { (time) } \\
6 / 24 / 2015 \\
(1101) \\
\end{array}$ & $\begin{array}{c}\text { Percent } \\
\text { difference } \\
\text { between } \\
\text { replicate } \\
\text { samples }\end{array}$ & $\begin{array}{c}\text { Sample } \\
\text { date } \\
\text { (time) } \\
9 / 23 / 2015 \\
(1500)\end{array}$ & $\begin{array}{c}\text { Sample } \\
\text { date } \\
\text { (time) } \\
9 / 23 / 2015 \\
(1501)\end{array}$ & $\begin{array}{r}\text { Percent } \\
\text { difference } \\
\text { between } \\
\text { replicate } \\
\text { samples }\end{array}$ \\
\hline $\begin{array}{l}\text { Arsenic, water, } \\
\text { unfiltered }\end{array}$ & $\mu \mathrm{g} / \mathrm{L}$ & 01002 & $<0.5$ & $<0.5$ & $<0.5$ & -- & -- & 30.7 & 31.8 & -3.52 & $<0.5$ & -- & -- \\
\hline Boron, water, filtered & $\mu g / L$ & 01020 & 83.94 & 79.47 & 79.11 & 0.45 & 5.47 & 117.3 & 118.3 & -0.85 & 21.68 & -- & -- \\
\hline $\begin{array}{l}\text { Selenium, water, } \\
\text { filtered }\end{array}$ & $\mu \mathrm{g} / \mathrm{L}$ & 01145 & $<0.05$ & $<0.05$ & $<0.05$ & -- & -- & $<0.05$ & $<0.05$ & -- & $<0.05$ & -- & -- \\
\hline $\begin{array}{l}\text { Selenium, water, } \\
\text { unfiltered }\end{array}$ & $\mu \mathrm{g} / \mathrm{L}$ & 01147 & $<2.5$ & $<2.5$ & $<2.5$ & -- & -- & $<2.5$ & $<2.5$ & -- & $<2.5$ & -- & -- \\
\hline $\begin{array}{l}\text { Ethane, water, } \\
\text { dissolved, } \\
\text { recoverable }\end{array}$ & $\mathrm{mg} / \mathrm{L}$ & 68832 & $<0.1$ & $<0.01$ & $<0.01$ & -- & -- & $<0.1$ & $<0.05$ & -- & -- & -- & -- \\
\hline $\begin{array}{l}\text { Ethane, water, } \\
\text { unfiltered, } \\
\text { recoverable }\end{array}$ & ug/L & 82045 & -- & -- & -- & -- & -- & -- & -- & -- & $<3.3$ & $<3.3$ & -- \\
\hline $\begin{array}{l}\text { Methane, water, } \\
\text { dissolved, } \\
\text { recoverable }\end{array}$ & $\mathrm{mg} / \mathrm{L}$ & 68831 & 2.54 & 4.12 & 3.28 & 22.70 & -47.45 & 1.79 & 1.48 & 18.96 & -- & -- & -- \\
\hline $\begin{array}{l}\text { Methane, water, } \\
\text { unfiltered, } \\
\text { recoverable }\end{array}$ & $\mathrm{mg} / \mathrm{L}$ & 76994 & -- & -- & -- & -- & -- & -- & -- & -- & 2.2 & 2.9 & -27.45 \\
\hline $\begin{array}{l}\text { Propane, water, } \\
\text { dissolved, } \\
\text { recoverable }\end{array}$ & $\mathrm{mg} / \mathrm{L}$ & 68834 & $<0.2$ & $<0.02$ & $<0.02$ & -- & -- & $<0.1$ & $<0.1$ & -- & -- & -- & -- \\
\hline $\begin{array}{l}\text { Propane, water, } \\
\text { unfiltered, } \\
\text { recoverable }\end{array}$ & $\mu \mathrm{g} / \mathrm{L}$ & 82358 & -- & -- & -- & -- & -- & -- & -- & -- & $<3.2$ & $<3.2$ & -- \\
\hline $\begin{array}{l}\text { Gross alpha } \\
\text { radioactivity, } 30 \\
\text { day recount, water, } \\
\text { unfiltered, Th-230 } \\
\text { curve }\end{array}$ & $\mathrm{pCi} / \mathrm{L}$ & 63016 & 1.39 & 3.4 & 1.87 & 58.06 & -83.92 & 0.94 & R0.35 & -- & R0.61 & -- & -- \\
\hline $\begin{array}{l}\text { Gross alpha } \\
\text { radioactivity, } 72 \\
\text { hour count, water, } \\
\text { unfiltered, Th-230 } \\
\text { curve }\end{array}$ & $\mathrm{pCi} / \mathrm{L}$ & 63014 & R0.98 & 4.73 & 1.27 & 115.33 & -- & R0.93 & 1.44 & -- & R-0.58 & -- & -- \\
\hline
\end{tabular}

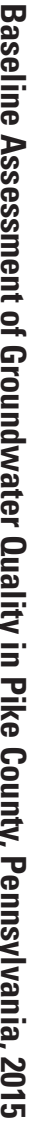


Table A2-1. Results of laboratory analysis in replicate groundwater samples collected from 3 wells (identified by U.S. Geological Survey well name and station number) in Pike County, Pennsylvania, 2015.-Continued

[Analyses for major and minor ions, volatile organic compounds, and dissolved gases (methane, ethane, propane) on unfiltered samples done by Seewald Laboratories, Inc. and other analyses done by U.S Geological Survey (USGS) National Water Quality Laboratory (NWQL); percent difference = 100x(c1-c2)/[c1+c2)/2], where c1 and c2 are concentrations in first and second sample of replicates; std. units, standard units; mg/L, milligrams per liter; $\mathrm{CaCO}_{3}$, calcium carbonate; $\mu \mathrm{g} / \mathrm{L}$, micrograms per liter; as N, as nitrogen; as $\mathrm{P}$, as phosphorus; $\mathrm{MPN} / 100 \mathrm{~mL}$, most probable number per 100 milliliters; $\mathrm{pCi} / \mathrm{L}$,

picocuries per liter; \%, percent; -, no data; <, less than; R, non-detect for radiological analysis]

\begin{tabular}{|c|c|c|c|c|c|c|c|c|c|c|c|c|c|}
\hline \multicolumn{3}{|c|}{ USGS well number and station number } & \multicolumn{5}{|c|}{ PI $524 \quad 411849074533901$} & \multicolumn{3}{|c|}{ PI $592 \quad 412908074591401$} & \multicolumn{3}{|c|}{ PI $647 \quad 411014074554001$} \\
\hline Constituent & $\begin{array}{l}\text { Reporting } \\
\text { unit }\end{array}$ & $\begin{array}{l}\text { USGS } \\
\text { para- } \\
\text { meter } \\
\text { code }\end{array}$ & $\begin{array}{l}\text { Sample } \\
\text { date } \\
\text { (time) } \\
6 / 25 / 2015 \\
(1500)\end{array}$ & $\begin{array}{l}\text { Sample } \\
\text { date } \\
\text { (time) } \\
9 / 22 / 2015 \\
(1300)\end{array}$ & $\begin{array}{c}\text { Sample } \\
\text { date } \\
\text { (time) } \\
9 / 22 / 2015 \\
\text { (1331) }\end{array}$ & $\begin{array}{l}\text { Percent } \\
\text { difference, } \\
\text { replicate } \\
\text { samples }\end{array}$ & $\begin{array}{c}\text { Percent } \\
\text { difference, } \\
\text { June and } \\
\text { September } \\
\text { samples }\end{array}$ & $\begin{array}{c}\text { Sample } \\
\text { date } \\
\text { (time) } \\
6 / 24 / 2015 \\
(1100)\end{array}$ & $\begin{array}{c}\text { Sample } \\
\text { date } \\
\text { (time) } \\
6 / 24 / 2015 \\
(1101)\end{array}$ & $\begin{array}{c}\text { Percent } \\
\text { difference } \\
\text { between } \\
\text { replicate } \\
\text { samples }\end{array}$ & $\begin{array}{l}\text { Sample } \\
\text { date } \\
\text { (time) } \\
9 / 23 / 2015 \\
(1500)\end{array}$ & $\begin{array}{l}\text { Sample } \\
\text { date } \\
\text { (time) } \\
9 / 23 / 2015 \\
\text { (1501) }\end{array}$ & $\begin{array}{c}\text { Percent } \\
\text { difference } \\
\text { between } \\
\text { replicate } \\
\text { samples }\end{array}$ \\
\hline $\begin{array}{l}\text { Gross beta } \\
\text { radioactivity, } 30 \\
\text { day recount, water, } \\
\text { unfiltered, Cs-137 } \\
\text { curve }\end{array}$ & $\mathrm{pCi} / \mathrm{L}$ & 63017 & 1.49 & $\mathrm{R} 1.53$ & R1.60 & -- & -- & 1.55 & 3.05 & -65.22 & 1.2 & -- & -- \\
\hline $\begin{array}{l}\text { Gross beta } \\
\text { radioactivity, } 72 \\
\text { hour count, water, } \\
\text { unfiltered, Cs-137 } \\
\text { curve }\end{array}$ & $\mathrm{pCi} / \mathrm{L}$ & 63015 & $\mathrm{R} 1.22$ & 2.74 & R1.30 & -- & -- & 2.27 & R0.66 & -- & R0.95 & -- & -- \\
\hline $\begin{array}{l}\text { Radium-226, water, } \\
\text { unfiltered }\end{array}$ & $\mathrm{pCi} / \mathrm{L}$ & 09501 & -- & 0.303 & 0.304 & -0.33 & -- & -- & -- & -- & -- & -- & -- \\
\hline $\begin{array}{l}\text { Radon-222, water, } \\
\text { unfiltered }\end{array}$ & $\mathrm{pCi} / \mathrm{L}$ & 82303 & 375 & 452 & 472 & -4.33 & -18.62 & 1,212 & 1,242 & -2.44 & 240 & -- & -- \\
\hline $\begin{array}{l}\text { Uranium (natural), } \\
\text { water, filtered }\end{array}$ & ug/L & 22703 & 0.0947 & 0.157 & 0.1469 & 6.65 & -49.50 & 0.0152 & $<0.014$ & -- & 0.0253 & -- & -- \\
\hline $\begin{array}{l}\text { Organic carbon, } \\
\text { water, unfiltered }\end{array}$ & $\mathrm{mg} / \mathrm{L}$ & 00680 & $<0.7$ & $<0.7$ & $<0.7$ & -- & -- & $<0.7$ & $<0.7$ & -- & $<0.7$ & -- & \\
\hline $\begin{array}{c}\text { VOCs - see table 7; } \\
\text { VOC surrogates, } \\
\text { unfiltered water }\end{array}$ & $\mu \mathrm{g} / \mathrm{L}$ & & & -- & -- & -- & -- & $<0.5$ & $<0.5$ & -- & & -- & -- \\
\hline $\begin{array}{l}\text { 1-Bromo-4- } \\
\text { fluorobenzene, } \\
\text { surrogate }\end{array}$ & $\%$ recovery & 99834 & & -- & -- & -- & -- & 90 & 90 & 0.00 & -- & -- & -- \\
\hline $\begin{array}{l}\text { 1,2-Dichloroben- } \\
\text { zene-d4, gasoline- } \\
\text { range organic } \\
\text { surrogate }\end{array}$ & $\%$ recovery & 90475 & & -- & -- & -- & -- & 94 & 88 & 6.59 & -- & -- & -- \\
\hline
\end{tabular}



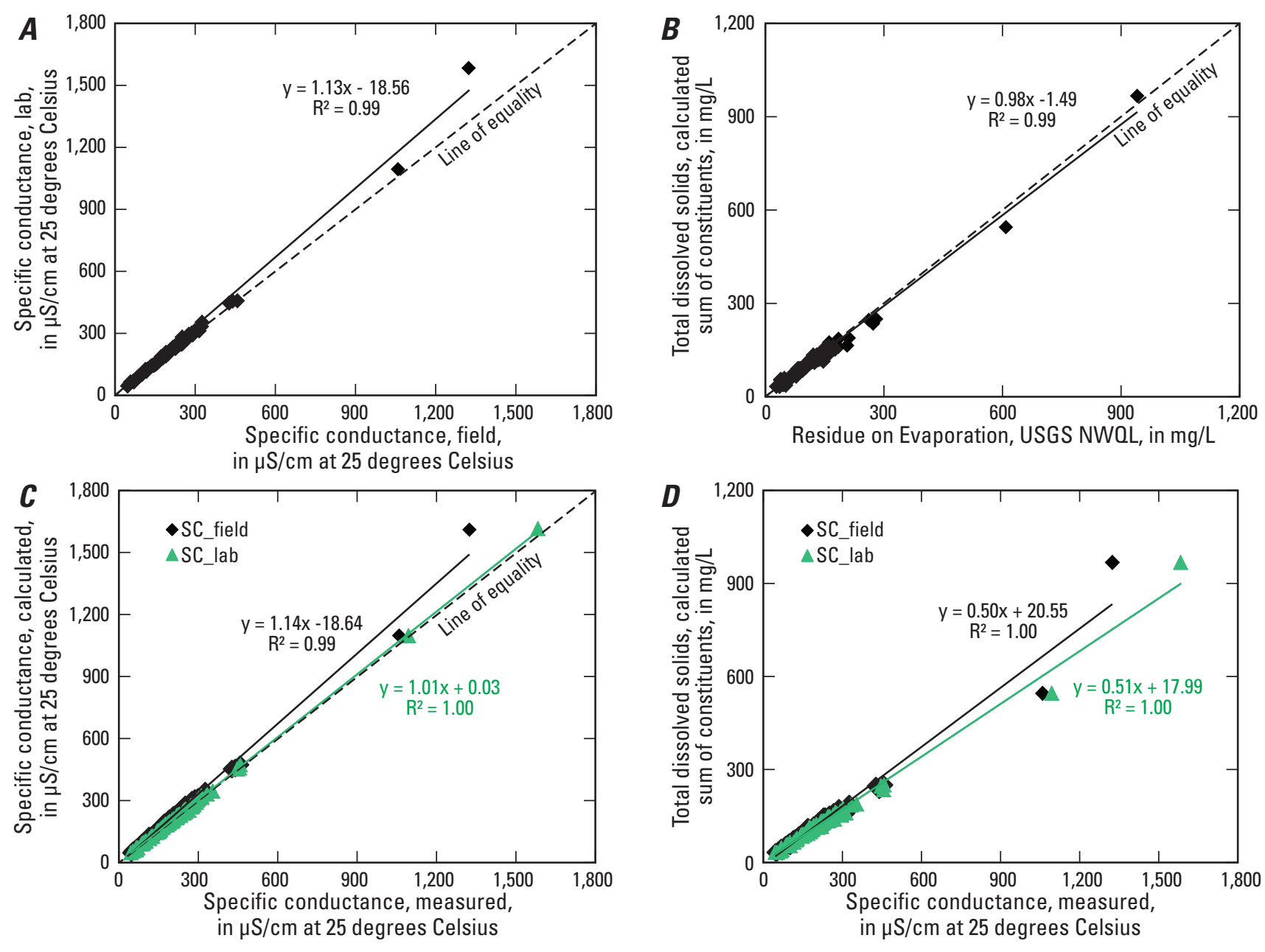

NWQL, National Water Quality Laboratory

Figure 2-1. Relations between $A$, Field and laboratory measured specific conductance, $B$, Measured residue on evaporation and calculated sum of total dissolved solids, $C$, Measured (field and laboratory) and calculated (from dissolved ions) specific conductance, and $D$, Measured (field and laboratory) specific conductance and calculated sum of total dissolved solids for groundwater samples collected from 79 wells in Pike County, Pennsylvania, 2015. [HS/cm, microsiemens per centimeter] 
Table A2-2. Results of laboratory analysis by Seewald Laboratories, Inc. of U.S. Geological Survey reference water samples and defined reference water-sample concentrations, 2015.

[USGS, U.S. Geological Survey; Seewald, Seewald Laboratories, Inc.; mg/L, milligrams per liter; $\mu$ g/L, micrograms per liter; --, no data; <, less than; percent difference calculated as $100 *$ (Seewald result - reference value)/reference value]

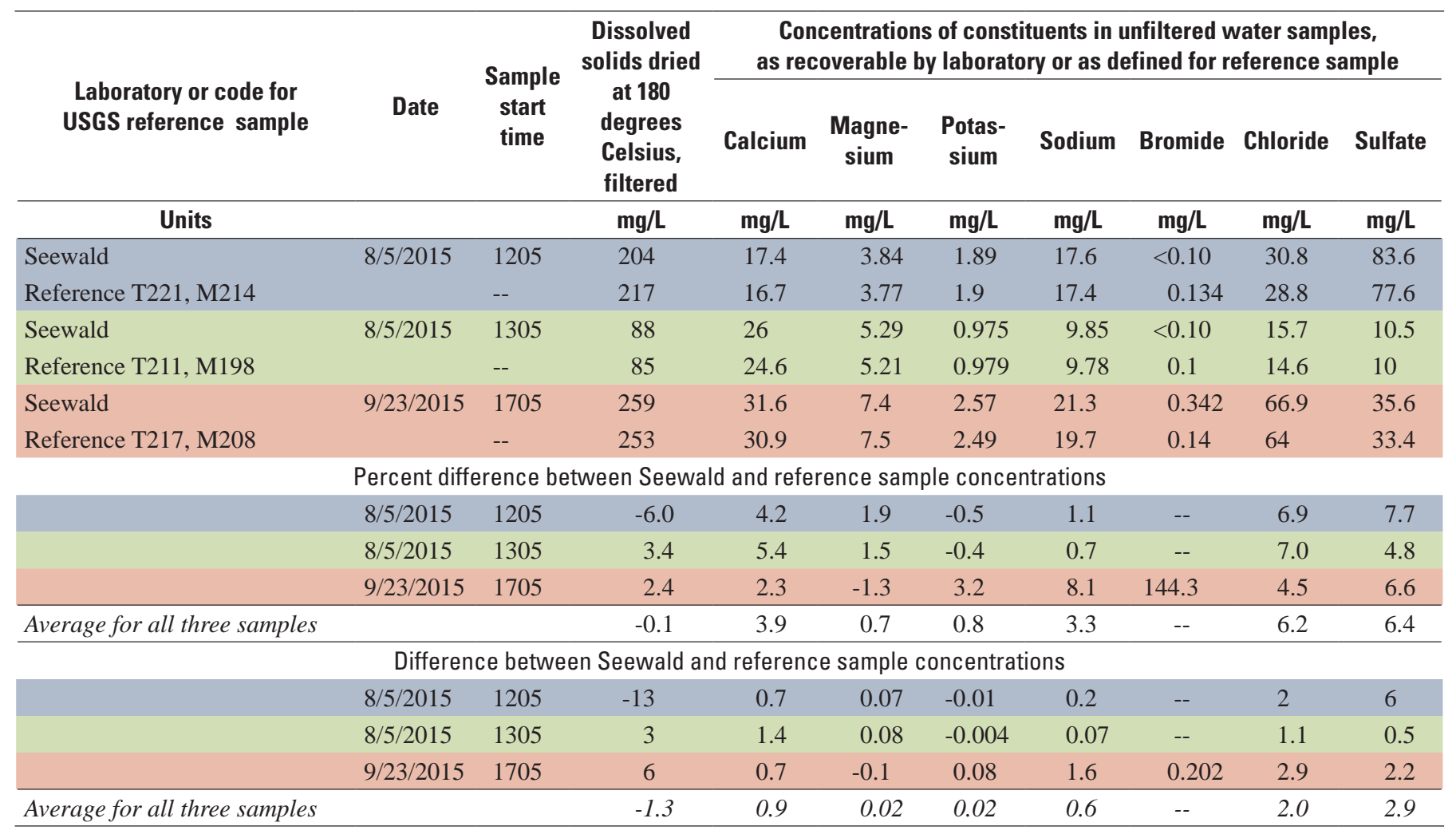

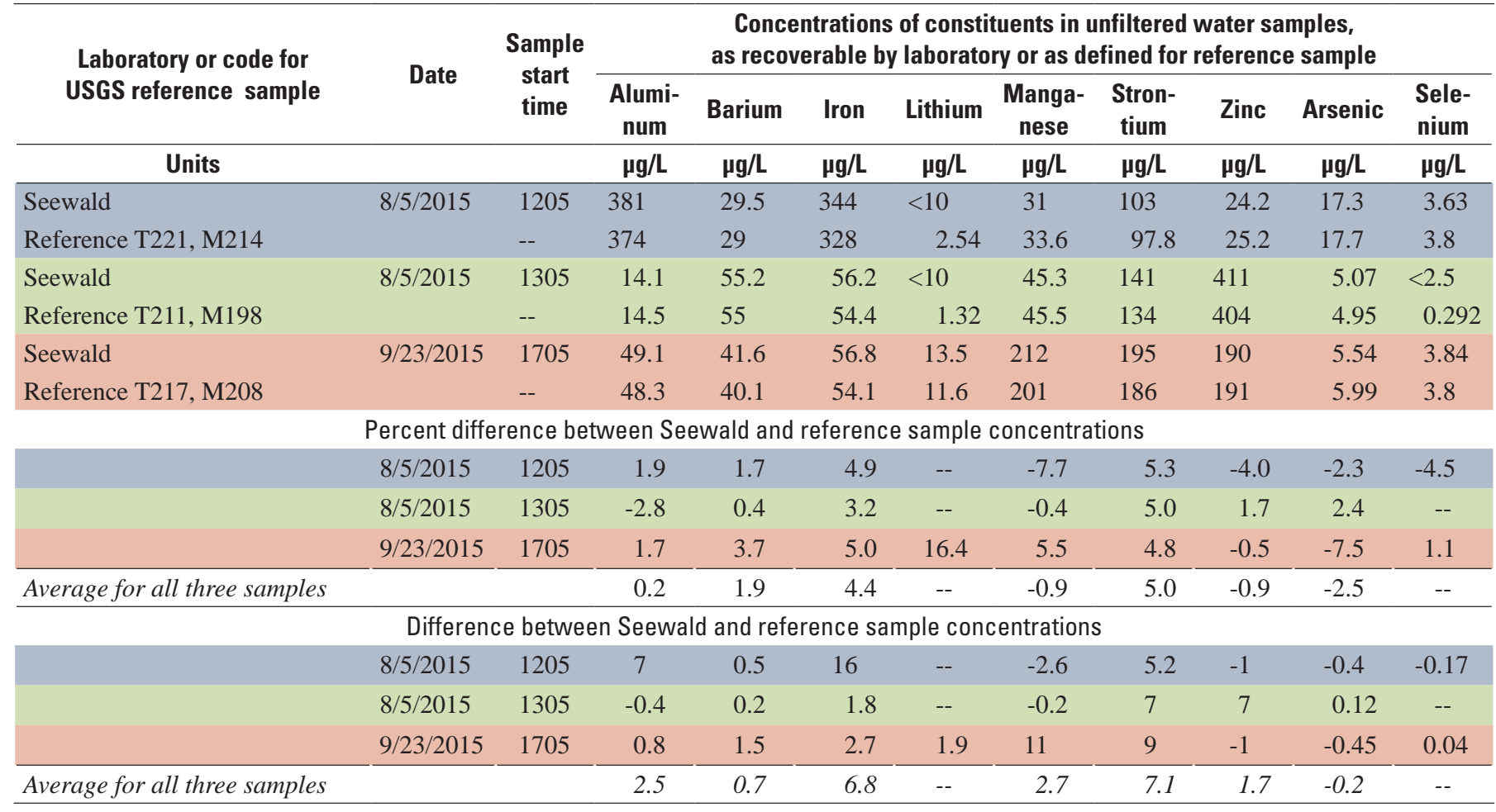




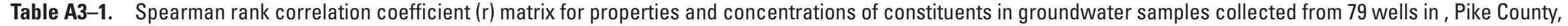
Pennsylvania, 2015.

[Analysis included dissolved concentrations of all inorganic constituents except gross alpha and beta activities which were determined in unfiltered samples; Spearman rank correlation coefficient r-values multiplied by 100 and rounded; only values significant at $\mathrm{a}=0.001$ shown; --, not significant; parameters in red-italics use a lower common detection limit than corresponding parameter]

\begin{tabular}{|c|c|c|c|c|c|c|c|c|c|c|c|c|c|c|c|c|c|c|c|c|c|c|c|c|c|c|c|c|c|c|}
\hline 흘 & & 1 & 2 & 3 & 4 & 5 & 6 & 7 & 8 & 9 & 10 & 11 & 12 & 13 & 14 & 15 & 16 & 17 & 18 & 19 & 20 & 21 & 22 & 23 & 24 & 25 & 26 & 27 & 28 & 29 \\
\hline 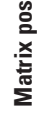 & 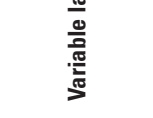 & $\bar{\Xi}$ & ডั้ & 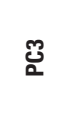 & J & 념 & 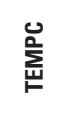 & 좀 & 总 & $\begin{array}{l}\text { 咭 } \\
\text { 岂 }\end{array}$ & 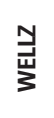 & 좀 & 폴 & 岕 & 岕 & 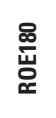 & $\stackrel{n}{n}$ & $\begin{array}{l}\text { 픈 } \\
\text { 포 }\end{array}$ & త & $\sum^{\pi}$ & 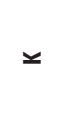 & $\frac{\pi}{2}$ & 兑 & $\grave{\infty}$ & ভ & $\leftarrow$ & 宓 & 芯 & $\begin{array}{l}\frac{2}{m} \\
\frac{m}{2}\end{array}$ & zo \\
\hline 1 & PC1 & 100 & & & & & & -56 & & & & 84 & 85 & & & & & & & & 52 & 81 & & & 85 & & & & -61 & \\
\hline 2 & PC2 & & 100 & & & & & & & & & & & & & & & & & & & & & & & & 68 & & & \\
\hline 3 & PC3 & & & 100 & & & & & & & & & & 48 & 49 & 50 & 47 & 93 & 88 & 89 & & & & & & 73 & 50 & & & \\
\hline 4 & PC4 & & & & 100 & & & -56 & & & & & & & & & & & & & & & & & & & & 53 & -66 & \\
\hline 5 & PC5 & & & & & 100 & & & & & & & & 70 & 70 & 68 & 66 & & & & 66 & & 81 & 78 & & & & & & \\
\hline 6 & TEMPC & & & & & & 100 & & -55 & -54 & & & & & & & & & & & & & & & & & & & & \\
\hline 7 & DOX & -56 & & & -56 & & & 100 & & & & -70 & -67 & & & & -43 & & & & -46 & -59 & & & -55 & & & -54 & 75 & \\
\hline 8 & LSELEV & & & & & & -55 & & 100 & 90 & & & -45 & & & & -45 & & & & -45 & -45 & & & & & & & & \\
\hline 9 & WELLZALT & & & & & & -54 & & 90 & 100 & & -48 & -51 & -45 & -44 & -45 & -49 & & & & -48 & -48 & & & & & & & & \\
\hline 10 & WELLZ & & & & & & & & & & 100 & & & & & & & & & & & & & & & & & & & \\
\hline 11 & $\mathrm{pH}$ & 84 & & & & & & -70 & & -48 & & 100 & 97 & & & & 46 & & & & 55 & 76 & & & 72 & & & 59 & -69 & \\
\hline 12 & pHL & 85 & & & & & & -67 & -45 & -51 & & 97 & 100 & 45 & 45 & & 49 & & & & 59 & 78 & & & 72 & & & 57 & -64 & \\
\hline 13 & SCL & & & 48 & & 70 & & & & -45 & & & 45 & 100 & 100 & 99 & 99 & 62 & 60 & 54 & 75 & 68 & 52 & 65 & & & & 47 & & \\
\hline 14 & SCF & & & 49 & & 70 & & & & -44 & & & 45 & 100 & 100 & 98 & 99 & 62 & 59 & 55 & 75 & 68 & 52 & 65 & & & & 47 & & \\
\hline 15 & ROE180 & & & 50 & & 68 & & & & -45 & & & & 99 & 98 & 100 & 98 & 62 & 59 & 55 & 73 & 64 & 50 & 67 & & & & 47 & & \\
\hline 16 & TDS & & & 47 & & 66 & & -43 & -45 & -49 & & 46 & 49 & 99 & 99 & 98 & 100 & 60 & 57 & 53 & 76 & 72 & 52 & 60 & & & & 52 & & \\
\hline 17 & Hard & & & 93 & & & & & & & & & & 62 & 62 & 62 & 60 & 100 & 97 & 86 & & & & & & 54 & 48 & & & \\
\hline 18 & $\mathrm{Ca}$ & & & 88 & & & & & & & & & & 60 & 59 & 59 & 57 & 97 & 100 & 75 & & & & & & 51 & 46 & & & \\
\hline 19 & $\mathrm{Mg}$ & & & 89 & & & & & & & & & & 54 & 55 & 55 & 53 & 86 & 75 & 100 & & & & & & 56 & & & & \\
\hline 20 & K & & & & & & & & & & & & & & & & & & & & & & & & & & & & & \\
\hline 21 & $\mathrm{Na}$ & 52 & & & & 66 & & -46 & -45 & -48 & & 55 & 59 & 75 & 75 & 73 & 76 & & & & 100 & 62 & 51 & 43 & 51 & & & 61 & & \\
\hline 22 & ALK & 81 & & & & & & -59 & -45 & -48 & & 76 & 78 & 68 & 68 & 64 & 72 & & & & 62 & 100 & & & 66 & & & 53 & -55 & \\
\hline 23 & $\mathrm{Br}$ & & & & & 81 & & & & & & & & 52 & 52 & 50 & 52 & & & & 51 & & 100 & 51 & & & & & & \\
\hline 24 & $\mathrm{Cl}$ & & & & & 78 & & & & & & & & 65 & 65 & 67 & 60 & & & & 43 & & 51 & 100 & & & & & & \\
\hline 25 & $\mathrm{~F}$ & 85 & & & & & & -55 & & & & 72 & 72 & & & & & & & & 51 & 66 & & & 100 & & & 51 & -68 & \\
\hline 26 & SIO2 & & & 73 & & & & & & & & & & & & & & 54 & 51 & 56 & & & & & & 100 & & & & \\
\hline 27 & SO4 & & 68 & 50 & & & & & & & & & & & & & & 48 & 46 & & & & & & & & 100 & & & \\
\hline 28 & NH3N & & & & 53 & & & -54 & & & & 59 & 57 & 47 & 47 & 47 & 52 & & & & 61 & 53 & & & 51 & & & 100 & -56 & \\
\hline
\end{tabular}


Table A3-1. Spearman rank correlation coefficient ( $r$ ) matrix for properties and concentrations of constituents in groundwater samples collected from 79 wells in , Pike County, Pennsylvania, 2015.-Continued

[Analysis included dissolved concentrations of all inorganic constituents except gross alpha and beta activities which were determined in unfiltered samples; Spearman rank correlation coefficient r-values multiplied by 100 and rounded; only values significant at a $=0.001$ shown; --, not significant; parameters in red-italics use a lower common detection limit than corresponding parameter]

\begin{tabular}{|c|c|c|c|c|c|c|c|c|c|c|c|c|c|c|c|c|c|c|c|c|c|c|c|c|c|c|c|c|}
\hline \multirow{2}{*}{ 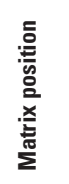 } & \multirow{2}{*}{ 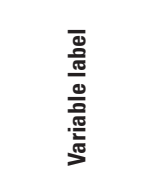 } & \multirow{2}{*}{$\begin{array}{l}30 \\
\frac{\ddagger}{0}\end{array}$} & \multirow{2}{*}{$\begin{array}{l}31 \\
: \bar{\partial} \\
\stackrel{0}{\circ}\end{array}$} & \multirow{2}{*}{$\begin{array}{l}32 \\
\overline{<}\end{array}$} & \multirow{2}{*}{33} & \multirow{2}{*}{$\begin{array}{l}34 \\
\infty\end{array}$} & \multirow{2}{*}{$\begin{array}{l}35 \\
\text { 펀 }\end{array}$} & \multirow{2}{*}{36} & \multirow{2}{*}{$\begin{array}{l}37 \\
\bar{\Xi}\end{array}$} & \multirow{2}{*}{$\begin{array}{l}38 \\
\text { \& }\end{array}$} & \multirow{2}{*}{$\begin{array}{l}39 \\
20\end{array}$} & \multirow{2}{*}{$\begin{array}{l}40 \\
=\end{array}$} & \multirow{2}{*}{$\begin{array}{l}41 \\
\sum\end{array}$} & \multirow{2}{*}{$\begin{array}{l}42 \\
\stackrel{0}{\Sigma}\end{array}$} & \multirow{2}{*}{$\begin{array}{l}43 \\
\bar{z}\end{array}$} & \multirow{2}{*}{44} & \multirow{2}{*}{$\begin{array}{l}45 \\
\bar{N}\end{array}$} & \multirow{2}{*}{$\begin{array}{l}46 \\
\text { के }\end{array}$} & \multirow{2}{*}{47} & 48 & 49 & 50 & 51 & 52 & 53 & 54 & 55 & 56 \\
\hline & & & & & & & & & & & & & & & & & & & & $\infty$ & $\ddot{\infty}$ & $\begin{array}{l}\text { 哭 } \\
\frac{\bar{c}}{\bar{\alpha}} \\
\end{array}$ & 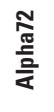 & 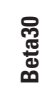 & 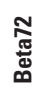 & 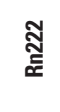 & 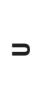 & 퐁 \\
\hline 1 & PC1 & & & & & & & & -55 & & -53 & 48 & & 77 & -53 & & -60 & & & 54 & & & & & & & & 48 \\
\hline 2 & PC2 & & & & & & & & & & & 70 & & & & 74 & & & & 66 & & & & & & -76 & & \\
\hline 3 & РC3 & & & & & & & & & & & & & & & & & & & & & & & & & & 55 & \\
\hline 4 & PC4 & & & & & & & & -56 & 90 & & & 90 & & & & & & & & -64 & & & & & & & \\
\hline 5 & PC5 & & & & & & & & & & & & & & & & & & & & & & & & & & & \\
\hline 6 & TEMPC & & & & & & & & & & & & & & & & & & & & & & & & & & & \\
\hline 7 & DOX & & & & & & & & 74 & -52 & 48 & -53 & -62 & -50 & 47 & -52 & 57 & & & -44 & & & & & & & & \\
\hline 8 & LSELEV & & & & & & & & & & & & & & & & & & & -44 & & & & & & & & \\
\hline 9 & WELLZALT & & & & & & & & & & & -49 & & & & & & & & -51 & & & & & & 50 & & \\
\hline 10 & WELLZ & & & & & & & & & & & & & & & 47 & & & & & & & & & & & & \\
\hline 11 & $\mathrm{pH}$ & & & & & & & & -70 & & -55 & 69 & & 67 & -54 & 59 & -73 & & & 65 & & & & & & -49 & & 55 \\
\hline 12 & pHL & & & & & & & & -64 & & -54 & 70 & & 67 & -52 & 55 & -71 & & & 67 & & & & & & -49 & & 54 \\
\hline 13 & SCL & & & & & & & & & & & 65 & & & & 58 & & & & 60 & & & & & & & & 47 \\
\hline 14 & SCF & & & & & & & & & & & 65 & & & & 57 & & & & 60 & & & & & & & & 46 \\
\hline 15 & ROE180 & & & & & & & & & & & 64 & & & & 57 & & & & 58 & & & & & & & & 45 \\
\hline 16 & TDS & & & & & & & & & & & 68 & & & & 59 & & & & 63 & & & & & & -44 & & 49 \\
\hline 17 & Hard & & & & & & & & & & & & & & & & & & & & & & & & & & 56 & \\
\hline 18 & $\mathrm{Ca}$ & & & & & -45 & & & & & & & & & & 43 & & & & & & & & & & & 58 & \\
\hline 19 & $\mathrm{Mg}$ & & & & & & & & & & & & & & & & & & & & & & & & & & 46 & \\
\hline 20 & $\mathrm{~K}$ & & & & & & & & & & & & & & & & & & & & & & & & & & & \\
\hline 21 & $\mathrm{Na}$ & & & & & & & & -54 & & & 66 & & 44 & & 52 & & & & 75 & & & & & & -44 & & 56 \\
\hline 22 & ALK & & & & & & & & -57 & & -53 & 60 & & 66 & & 47 & -53 & & & 63 & & & & & & & 45 & 54 \\
\hline 23 & $\mathrm{Br}$ & & & & & & & & & & & 45 & & & & & & & & & & & & & & & & \\
\hline 24 & $\mathrm{Cl}$ & & & & & & & & & & & & & & & & & & & & & & & & & & & \\
\hline 25 & $\mathrm{~F}$ & & & & & & & & -58 & & -59 & & & 68 & -45 & & -47 & & & 48 & & & & & & & & 48 \\
\hline 26 & SIO2 & & & & & & & & & & & & & & & & & & & & & & & & & & & \\
\hline 27 & SO4 & & & & & & & & & & & & & & & 43 & & & & & & & & & & & & \\
\hline 28 & NH3N & & & & & & & & -63 & 54 & & 51 & 65 & & & & & & & 56 & -54 & & & & & -72 & & 58 \\
\hline
\end{tabular}


Table A3-1. Spearman rank correlation coefficient (r) matrix for properties and concentrations of constituents in groundwater samples collected from 79 wells in , Pike County, Pennsylvania, 2015.-Continued

[Analysis included dissolved concentrations of all inorganic constituents except gross alpha and beta activities which were determined in unfiltered samples; Spearman rank correlation coefficient r-values multiplied by 100 and rounded; only values significant at a $=0.001$ shown; --, not significant; parameters in red-italics use a lower common detection limit than corresponding parameter]

\begin{tabular}{|c|c|c|c|c|c|c|c|c|c|c|c|c|c|c|c|c|c|c|c|c|c|c|c|c|c|c|c|c|c|c|}
\hline \multirow{2}{*}{ 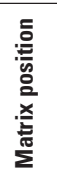 } & \multirow{2}{*}{ 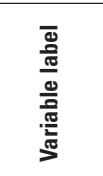 } & 1 & 2 & 3 & 4 & 5 & 6 & 7 & 8 & 9 & 10 & 11 & 12 & 13 & 14 & 15 & 16 & 17 & 18 & 19 & 20 & 21 & 22 & 23 & 24 & 25 & 26 & 27 & 28 & 29 \\
\hline & & $\bar{\Xi}$ & ฐั้ & $\dddot{3}$ & J & 놈 & $\sum_{\text {䓵 }}^{0}$ & 좀 & 恚 & 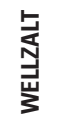 & 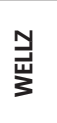 & 좀 & 폼 & త్ & 岕 & 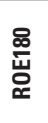 & 吕 & 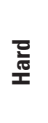 & ฮ & $\sum$ & $\simeq$ & $\underline{z}$ & 兑 & $\grave{n}$ & $\overline{\mathrm{J}}$ & $\leftarrow$ & 宓 & ఫ্口 & $\begin{array}{l}z_{m} \\
\text { 竞 }\end{array}$ & zo \\
\hline 29 & NO3N & -61 & & & -66 & & & 75 & & & & -69 & -64 & & & & & & & & & -55 & & & -68 & & & -56 & 100 & \\
\hline 30 & PO4P & & & & & & & & & & & & & & & & & & & & & & & & & & & & & \\
\hline 31 & Tcoli & & & & & & & & & & & & & & & & & & & & & & & & & & & & & \\
\hline 32 & $\mathrm{Al}$ & & & & & & & & & & & & & & & & & & & & & & & & & & & & & \\
\hline 33 & $\mathrm{Ba}$ & & & & & & & & & & & & & & & & & & & & & & & & & & & & & \\
\hline 34 & $\mathrm{Be}$ & & & & & & & & & & & & & & & & & & -45 & & & & & & & & & & & \\
\hline 35 & $\mathrm{Cd}$ & & & & & & & & & & & & & & & & & & & & & & & & & & & & & \\
\hline 36 & Co & & & & & & & & & & & & & & & & & & & & & & & & & & & & & \\
\hline 37 & $\mathrm{Cu}$ & -55 & & & -56 & & & 74 & & & & -70 & -64 & & & & & & & & -54 & -57 & & & -58 & & & -63 & 76 & \\
\hline 38 & $\mathrm{Fe}$ & & & & 90 & & & -52 & & & & & & & & & & & & & & & & & & & & 54 & -63 & \\
\hline 39 & $\mathrm{~Pb}$ & -53 & & & & & & 48 & & & & -55 & -54 & & & & & & & & & -53 & & & -59 & & & & 55 & \\
\hline 40 & $\mathrm{Li}$ & 48 & 70 & & & & & -53 & & -49 & & 69 & 70 & 65 & 65 & 64 & 68 & & & & 66 & 60 & 45 & & & & & 51 & & \\
\hline 41 & $\mathrm{Mn}$ & & & & 90 & & & -62 & & & & & & & & & & & & & & & & & & & & 65 & -64 & \\
\hline 42 & Mo & 77 & & & & & & -50 & & & & 67 & 67 & & & & & & & & 44 & 66 & & & 68 & & & & -56 & \\
\hline 43 & $\mathrm{Ni}$ & -53 & & & & & & 47 & & & & -54 & -52 & & & & & & & & & & & & -45 & & & & & \\
\hline 44 & $\mathrm{Sr}$ & & 74 & & & & & -52 & & & 47 & 59 & 55 & 58 & 57 & 57 & 59 & & 43 & & 52 & 47 & & & & & 43 & & & \\
\hline 45 & $\mathrm{Zn}$ & -60 & & & & & & 57 & & & & -73 & -71 & & & & & & & & & -53 & & & -47 & & & & 53 & \\
\hline 46 & $\mathrm{Sb}$ & & & & & & & & & & & & & & & & & & & & & & & & & & & & & \\
\hline 47 & As & & & & & & & & & & & & & & & & & & & & & & & & & & & & & \\
\hline 48 & B & 54 & 66 & & & & & -44 & -44 & -51 & & 65 & 67 & 60 & 60 & 58 & 63 & & & & 75 & 63 & & & 48 & & & 56 & & \\
\hline 49 & Se & & & & -64 & & & & & & & & & & & & & & & & & & & & & & & -54 & 49 & \\
\hline 50 & Alpha30 & & & & & & & & & & & & & & & & & & & & & & & & & & & & & \\
\hline 51 & Alpha72 & & & & & & & & & & & & & & & & & & & & & & & & & & & & & \\
\hline 52 & Beta30 & & & & & & & & & & & & & & & & & & & & & & & & & & & & & \\
\hline 53 & Beta72 & & & & & & & & & & & & & & & & & & & & & & & & & & & & & \\
\hline 54 & Rn222 & & -76 & & & & & & & 50 & & -49 & -49 & & & & -44 & & & & -44 & & & & & & & -72 & 45 & \\
\hline 55 & $\mathrm{U}$ & & & 55 & & & & & & & & & & & & & & 56 & 58 & 46 & & 45 & & & & & & & & \\
\hline 56 & $\mathrm{CH} 4$ & 48 & & & & & & & & & & 55 & 54 & 47 & 46 & 45 & 49 & & & & 56 & 54 & & & 48 & & & 58 & & \\
\hline
\end{tabular}


Table A3-1. Spearman rank correlation coefficient ( $r$ ) matrix for properties and concentrations of constituents in groundwater samples collected from 79 wells in , Pike County, Pennsylvania, 2015.-Continued

[Analysis included dissolved concentrations of all inorganic constituents except gross alpha and beta activities which were determined in unfiltered samples; Spearman rank correlation coefficient r-values multiplied by 100 and rounded; only values significant at a $=0.001$ shown; --, not significant; parameters in red-italics use a lower common detection limit than corresponding parameter]

\begin{tabular}{|c|c|c|c|c|c|c|c|c|c|c|c|c|c|c|c|c|c|c|c|c|c|c|c|c|c|c|c|c|}
\hline \multirow{2}{*}{ 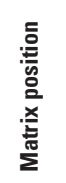 } & \multirow{2}{*}{ 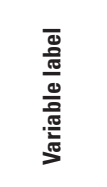 } & 30 & 31 & 32 & 33 & 34 & 35 & 36 & 37 & 38 & 39 & 40 & 41 & 42 & 43 & 44 & 45 & 46 & 47 & 48 & 49 & 50 & 51 & 52 & 53 & 54 & 55 & 56 \\
\hline & & 옴 & $\begin{array}{l}\overline{\bar{o}} \\
\dot{0}\end{array}$ & $\bar{\alpha}$ & ๓ & Ф & $\overline{0}$ & ن̊ & $\bar{G}$ & ฆ & $\overline{2}$ & $=$ & $\Sigma$ & $\stackrel{0}{\Sigma}$ & $\bar{z}$ & के & $\bar{N}$ & के & \& & $\infty$ & $\ddot{~}$ & 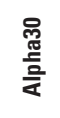 & 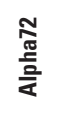 & 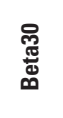 & 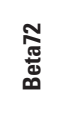 & 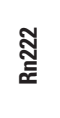 & $د$ & 퐁 \\
\hline 29 & NO3N & & & & & & & & 76 & -63 & 55 & & -64 & -56 & & & 53 & & & & 49 & & & & & 45 & & \\
\hline 30 & РО4P & 100 & & & & & & & & & & & & & & -47 & & & & & & & & & & & & \\
\hline 31 & Tcoli & & 100 & & & & & & & & & & & & & & & & & & & & & & & & & \\
\hline 32 & $\mathrm{Al}$ & & & 100 & & & & & & & & & & & & & & & & & & & & & & & & \\
\hline 33 & $\mathrm{Ba}$ & & & & 100 & & & & & & & 50 & & & & 58 & & & 45 & & & & & & & & & \\
\hline 34 & Be & & & & & 100 & & & & & & & & & 44 & & & & & & & & & & & & & \\
\hline 35 & $\mathrm{Cd}$ & & & & & & 100 & & & & & & & & & & & & & & & & & & & & & \\
\hline 36 & Co & & & & & & & 100 & & & & & & & 43 & & & 43 & & & & & & & & & & \\
\hline 37 & $\mathrm{Cu}$ & & & & & & & & 100 & -59 & 49 & -48 & -62 & -52 & 43 & -46 & 43 & & & -44 & & & & & & 46 & & -45 \\
\hline 38 & $\mathrm{Fe}$ & & & & & & & & -59 & 100 & & & 79 & & & & & & & & -52 & & & & & & & \\
\hline 39 & $\mathrm{~Pb}$ & & & & & & & & 49 & & 100 & & & -43 & & & 50 & & & & & & & & & & & \\
\hline 40 & $\mathrm{Li}$ & & & & 50 & & & & -48 & & & 100 & & & & 83 & -47 & & & 80 & & & & & & -62 & & 60 \\
\hline 41 & Mn & & & & & & & & -62 & 79 & & & 100 & & & & & & & & -63 & & & & & -49 & & \\
\hline 42 & Mo & & & & & & & & -52 & & -43 & & & 100 & & & -43 & & & 44 & & & & & & & 45 & \\
\hline 43 & $\mathrm{Ni}$ & & & & & 44 & & 43 & 43 & & & & & & 100 & & 44 & & & & & & & & & & & \\
\hline 44 & $\mathrm{Sr}$ & -47 & & & 58 & & & & -46 & & & 83 & & & & 100 & & & & 66 & & & & & & -56 & & \\
\hline 45 & $\mathrm{Zn}$ & & & & & & & & 43 & & 50 & -47 & & -43 & 44 & & 100 & & & & & & & & & & & \\
\hline 46 & $\mathrm{Sb}$ & & & & & & & 43 & & & & & & & & & & 100 & & & & & & & & & & \\
\hline 47 & As & & & & 45 & & & & & & & & & & & & & & 100 & & & & & & & & 47 & \\
\hline 48 & B & & & & & & & & -44 & & & 80 & & 44 & & 66 & & & & 100 & & & & & & -58 & & 58 \\
\hline 49 & Se & & & & & & & & & -52 & & & -63 & & & & & & & & 100 & & & & & & & \\
\hline 50 & Alpha30 & & & & & & & & & & & & & & & & & & & & & 100 & 47 & 47 & & & & \\
\hline 51 & Alpha72 & & & & & & & & & & & & & & & & & & & & & 47 & 100 & & 60 & & & \\
\hline 52 & Beta30 & & & & & & & & & & & & & & & & & & & & & 47 & & 100 & 55 & & & \\
\hline 53 & Beta72 & & & & & & & & & & & & & & & & & & & & & & 60 & 55 & 100 & & & \\
\hline 54 & $\mathrm{Rn} 222$ & & & & & & & & 46 & & & -62 & -49 & & & -56 & & & & -58 & & & & & & 100 & & -47 \\
\hline 55 & $\mathrm{U}$ & & & & & & & & & & & & & 45 & & & & & 47 & & & & & & & & 100 & \\
\hline 56 & $\mathrm{CH} 4$ & & & & & & & & -45 & & & 60 & & & & & & & & 58 & & & & & & -47 & & 100 \\
\hline
\end{tabular}


Table A3-1. Spearman rank correlation coefficient (r) matrix for properties and concentrations of constituents in groundwater samples collected from 79 wells in , Pike County, Pennsylvania, 2015.-Continued

[Analysis included dissolved concentrations of all inorganic constituents except gross alpha and beta activities which were determined in unfiltered samples; Spearman rank correlation coefficient r-values multiplied by 100 and rounded; only values significant at a $=0.001$ shown; --, not significant; parameters in red-italics use a lower common detection limit than corresponding parameter]

\begin{tabular}{|c|c|c|c|}
\hline Variable label & Explanation of variable label abbreviation & Variable label & Explanation of variable label abbreviation \\
\hline PC1 & principal component & $\mathrm{Al}$ & aluminum \\
\hline TEMPC & water temperature in degrees Celsius & $\mathrm{Ba}$ & barium \\
\hline DOX & dissolved oxygen & $\mathrm{Be}$ & berrylium \\
\hline LSELEV & land surfacde elevation & $\mathrm{Cd}$ & cadmium \\
\hline WELLZALT & altitude of bootom of well & Co & cobalt \\
\hline WELLZ & well depth & $\mathrm{Cu}$ & copper \\
\hline pHL & laboratory pH & $\mathrm{Fe}$ & iron \\
\hline SCL & laboratory specific conductance & $\mathrm{Pb}$ & lead \\
\hline SCF & field specific conductance & $\mathrm{Li}$ & lithium \\
\hline ROE180 & residue on evaporation at 180 degrees Celsius & $\mathrm{Mn}$ & manganese \\
\hline TDS & total dissolved solids & Mo & molybdenum \\
\hline Hard & hardness & $\mathrm{Ni}$ & nickel \\
\hline $\mathrm{Ca}$ & calcium & $\mathrm{Sr}$ & strontium \\
\hline $\mathrm{Mg}$ & magnesium & $\mathrm{Zn}$ & zinc \\
\hline K & potassium & $\mathrm{Sb}$ & antimony \\
\hline $\mathrm{Na}$ & sodium & As & arsenic \\
\hline ALK & alkalinity & B & boron \\
\hline $\mathrm{Br}$ & bromide & Se & selenium \\
\hline $\mathrm{Cl}$ & chloride & Alpha30 & gross alpha activity 30-day count \\
\hline $\mathrm{F}$ & fluoride & Alpha72 & gross alpha activity 72-hour count \\
\hline $\mathrm{SIO} 2$ & silica & Beta30 & gross beta activity 30 -day count \\
\hline SO4 & sulfate & Beta72 & gross beta activity 72-hour count \\
\hline NH3N & ammonia as nitrogen & Rn-222 & radon-222 \\
\hline NO3N & nitrate as nitrogen & $\mathrm{U}$ & uranium \\
\hline PO4P & orthophosphate as phospohorous & $\mathrm{CH} 4$ & methane \\
\hline Tcoli & total coliform bacteria & & \\
\hline
\end{tabular}



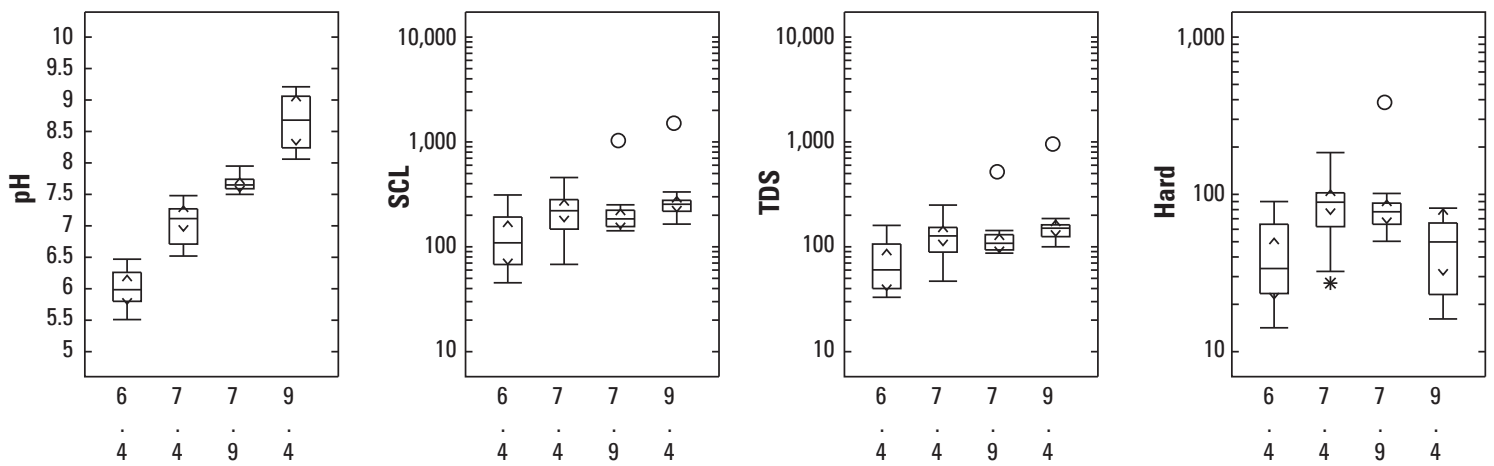

EXPLANATION

O Outlier data value greater than 3 times the interquartile range outside the quartile

* Outlier data value less than or equal to 3 and greater than 1.5 times the interquartile range outside the quartile Data value less than or equal to 1.5 times the interquartile range outside the quartile
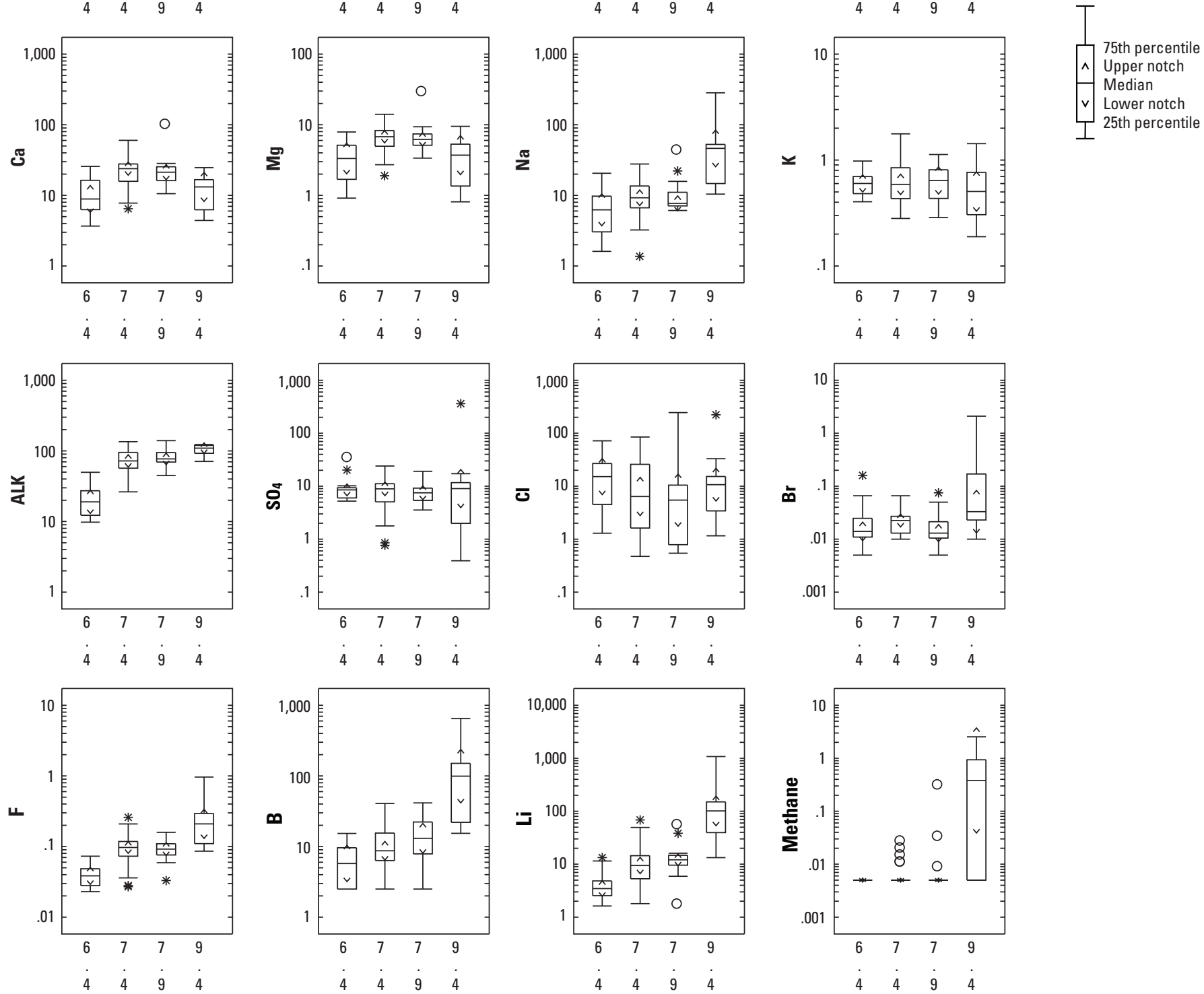

Abbreviations: $\mathrm{mg} / \mathrm{L}$, milligrams per liter; ug/L, micrograms per liter; $\mathrm{CaCO}_{3}$, calcium carbonate; $\mathrm{SCL}$, laboratory specific conductance in microsiemens per centimeter at 25 degrees Celsius; TDS, Total dissolved solids in mg/L; Hard, hardness in $\mathrm{mg} / \mathrm{L}$ as $\mathrm{CaCO}_{3} ; \mathrm{Ca}$, calcium in mg/L; $\mathrm{Mg}$, magnesium in $\mathrm{mg} / \mathrm{L} ; \mathrm{Na}$, sodium in mg/L; $\mathrm{K}$, potassium in mg/L; ALK, alkalinity in $\mathrm{mg} / \mathrm{L}$ as $\mathrm{CaCO}_{3} ; \mathrm{SO}_{4}$, sulfate in $\mathrm{mg} / \mathrm{L} ; \mathrm{Cl}$, chloride in $\mathrm{mg} / \mathrm{L} ; \mathrm{Br}$, bromide in $\mathrm{mg} / \mathrm{L} ; \mathrm{F}$, fluoride in $\mathrm{mg} / \mathrm{L} ; \mathrm{B}$, boron in $\mu \mathrm{g} / \mathrm{L} ; \mathrm{Li}$, lithium in ug/L; Methane in $\mathrm{mg} / \mathrm{L}$.

\section{Figure 3-1}



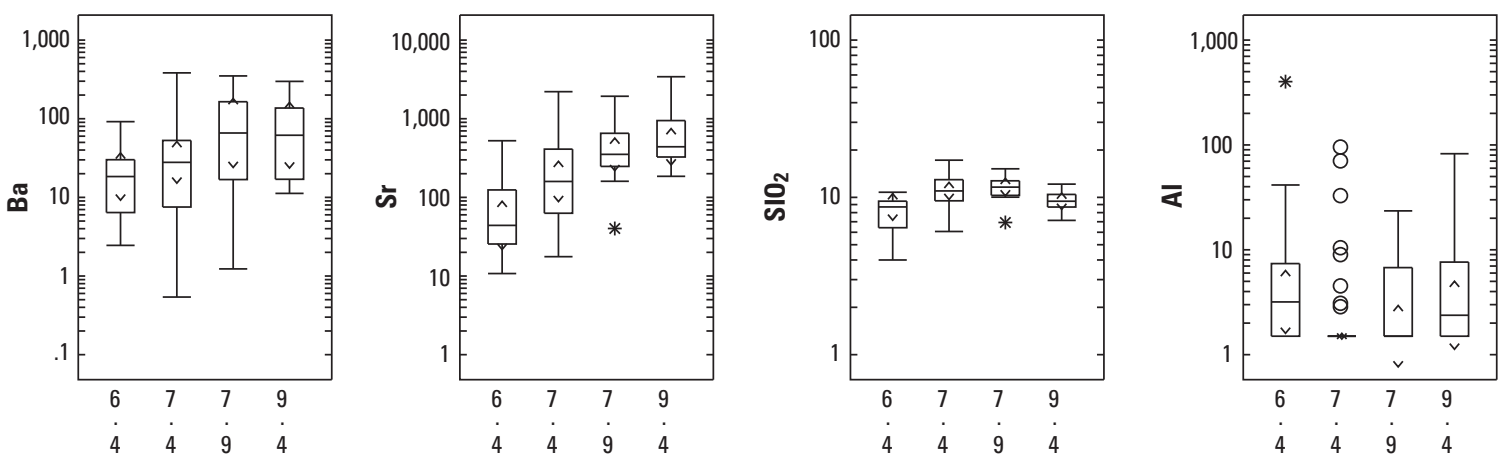

EXPLANATION

- Outlier data value

greater than 3 times

the interquartile range

outside the quartile

* Outlier data value less than or equal to 3 and greater than 1.5 times the interquartile range outside the quartile Data value less than or equal to 1.5 times the interquartile range outside the quartile
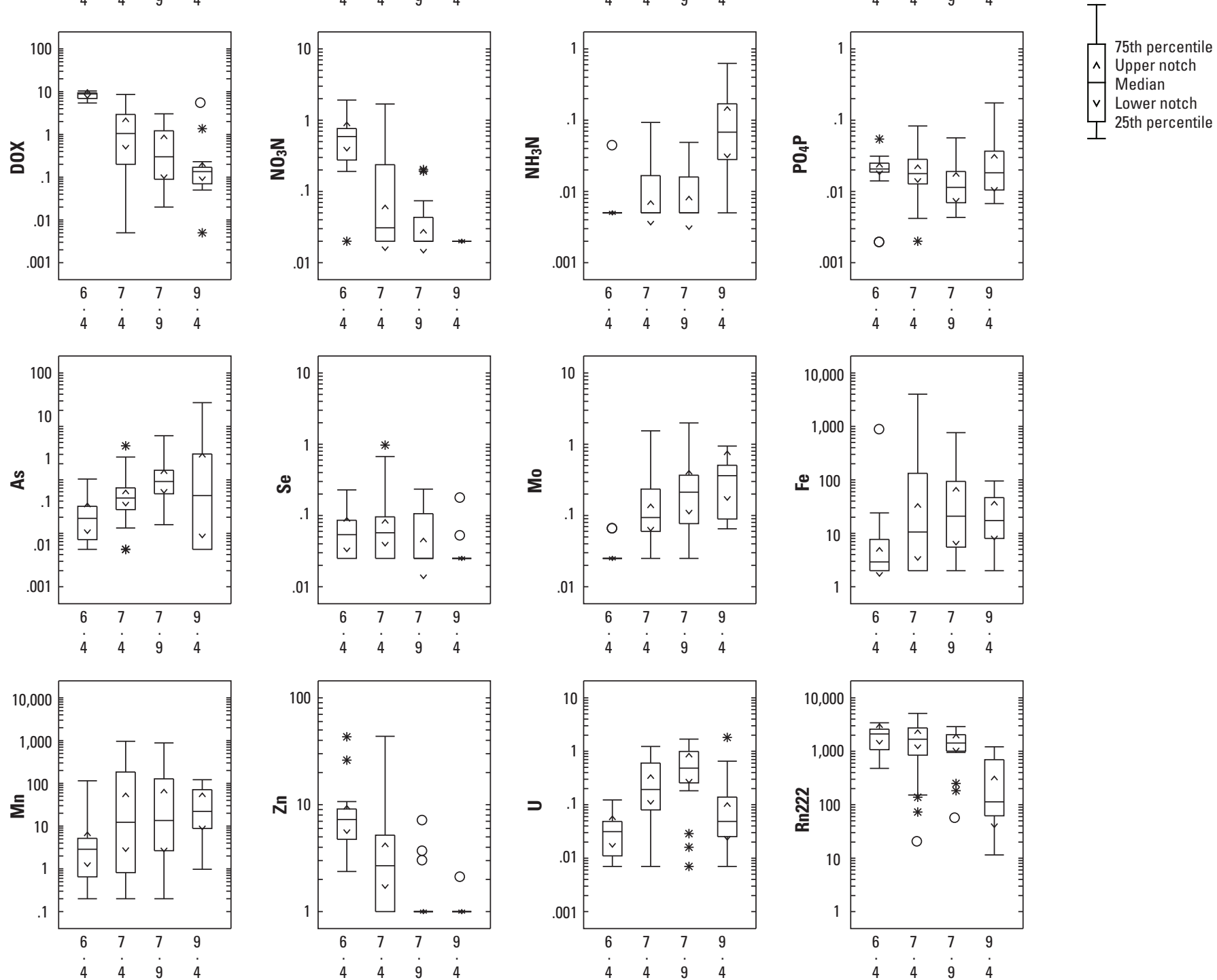

Abbreviations: $\mathrm{mg} / \mathrm{L}$, milligrams per liter; ug/L, micrograms per liter; $\mathrm{pCi} / \mathrm{L}$, picocuries per liter; $\mathrm{Ba}$, barium in ug/L; Sr, strontium in ug/L; SIO2, silica in mg/L; $\mathrm{Al}$, aluminum in ug/L; DOX, dissolved oxygen in mg/L; NO3N, nitrate in mg/L as nitrogen; NH3N, ammonia in mg/L as nitrogen; P04P, orthophosphate in mg/L as phosphorus; As, arsenic in ug/L; Se, selenium in ug/L; Mo, molybdenum in $\mu \mathrm{g} / \mathrm{L} ; \mathrm{Fe}$, iron in ug/L; Mn, manganese in ug/L; Zn, zinc in ug/L; U, uranium in ug/L; Rn222, radon-222 in pCi/L.

Figure 3-1-Continued 

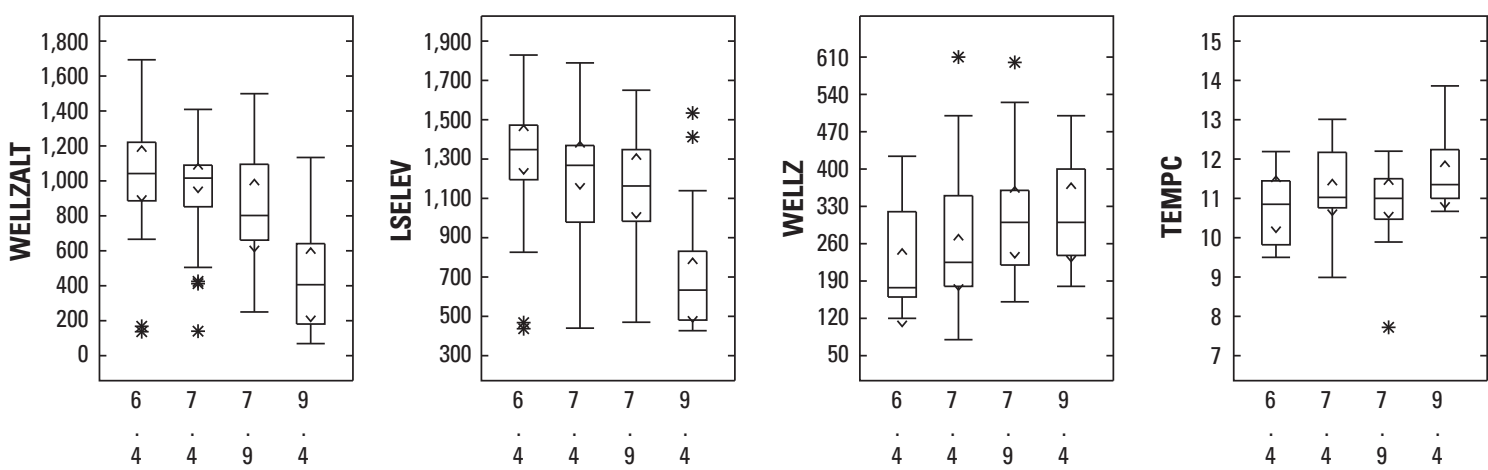

EXPLANATION

O Outlier data value greater than 3 times the interquartile range

outside the quartile

* Outlier data value less than or equal to 3 and greater than 1.5 times the interquartile range outside the quartile

Data value less than or equal to 1.5 times the interquartile range outside the quartile
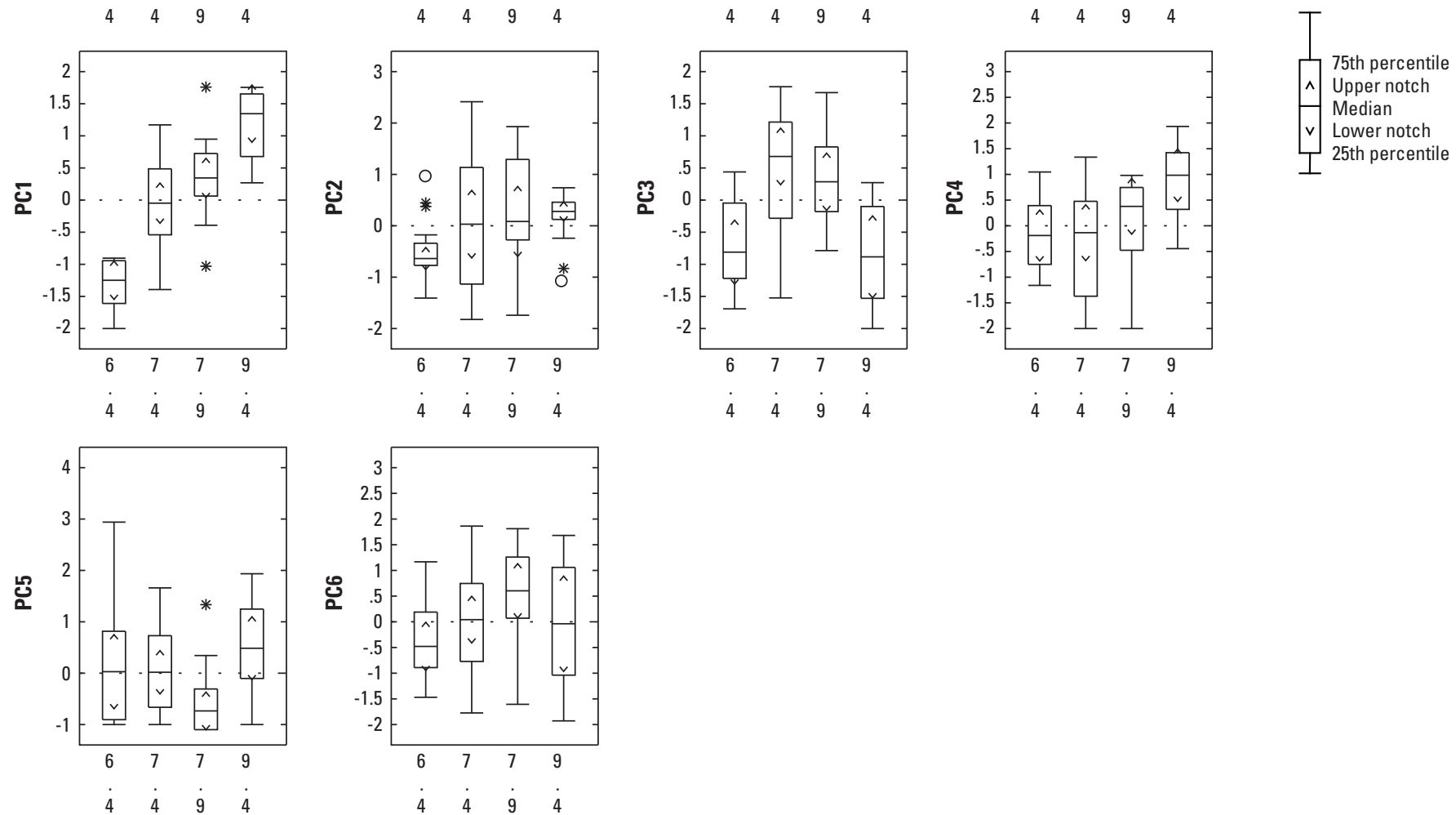

Abbreviations: $\mathrm{ft}$, feet; WELLZALT, altitude of well bottom in $\mathrm{ft}$ above NAVD 88; LSELEV, land-surface elevation in $\mathrm{ft}$ above NAVD 88; WELLZ, depth of well in $\mathrm{ft}$ below land surface; TEMPC, water temperature in degrees Celsius; PC, principal component.

Figure 3-1-Continued 

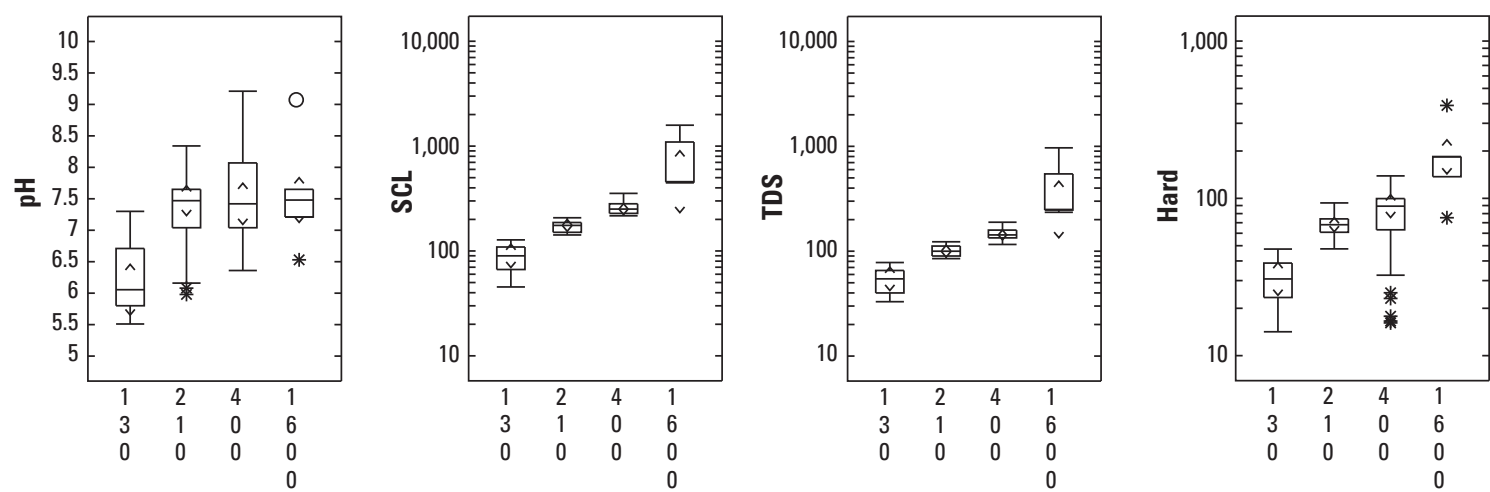

EXPLANATION

O Outlier data value greater than 3 times the interquartile range outside the quartile

* Outlier data value less than or equal to 3 and greater than 1.5 times the interquartile range outside the quartile Data value less than or equal to 1.5 times the interquartile range outside the quartile
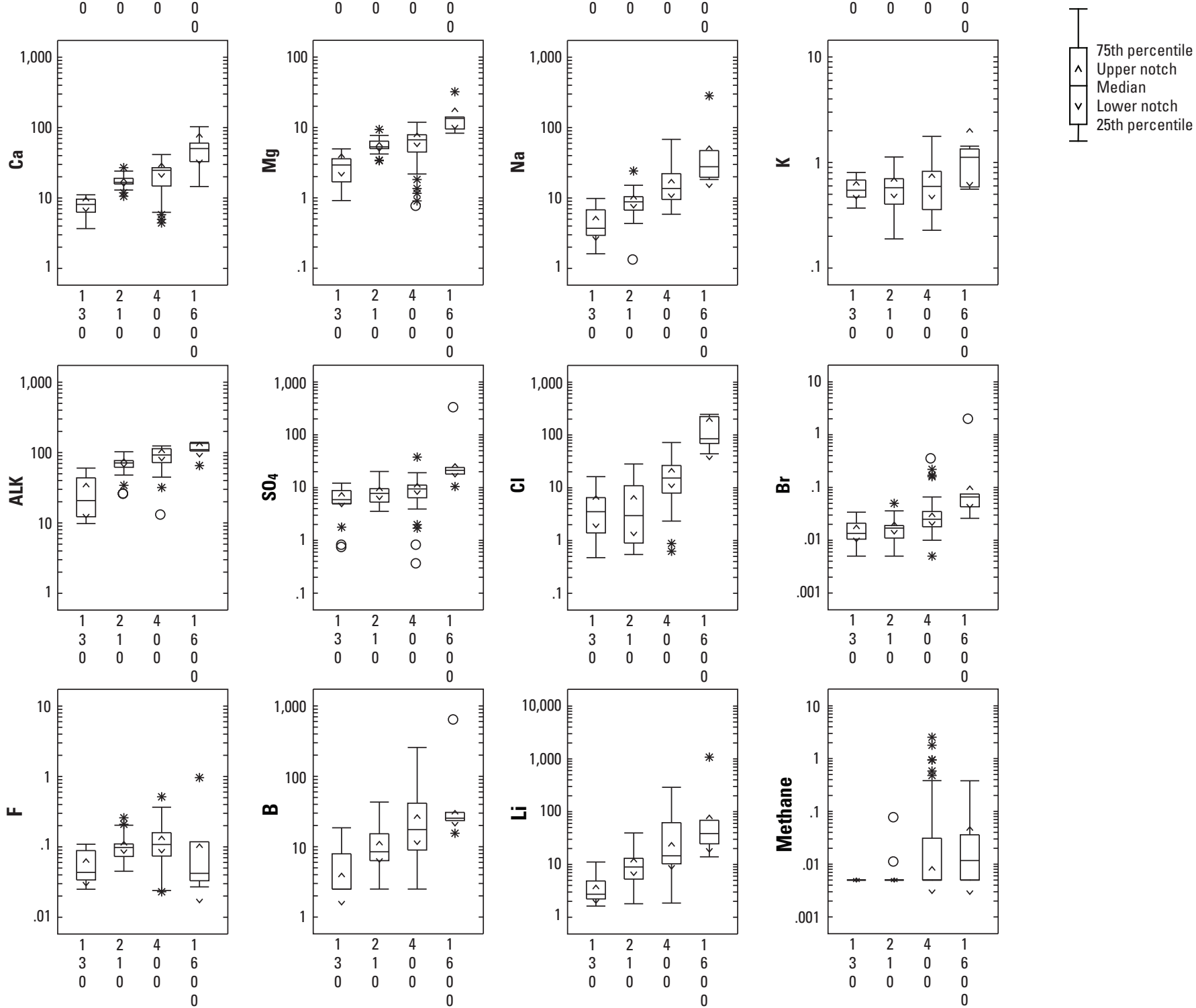

Abbreviations: $\mathrm{mg} / \mathrm{L}$, milligrams per liter; $\mathrm{ug} / \mathrm{L}$, micrograms per liter; $\mathrm{CaCO}_{3}$, calcium carbonate; $\mathrm{SCL}$, laboratory specific conductance in microsiemens per centimeter at 25 degrees Celsius; TDS, Total dissolved solids in $\mathrm{mg} / \mathrm{L} ; \mathrm{Hard}$, hardness in $\mathrm{mg} / \mathrm{L}$ as $\mathrm{CaCO}_{3}$; Ca, calcium in $\mathrm{mg} / \mathrm{L} ; \mathrm{Mg}$, magnesium in mg/L; $\mathrm{Na}$, sodium in $\mathrm{mg} / \mathrm{L} ; \mathrm{K}$, potassium in $\mathrm{mg} / \mathrm{L} ; \mathrm{ALK}$, alkalinity in $\mathrm{mg} / \mathrm{L}$ as $\mathrm{CaCO}_{3} ; \mathrm{SO}_{4}$, sulfate in $\mathrm{mg} / \mathrm{L} ; \mathrm{Cl}$, chloride in $\mathrm{mg} / \mathrm{L} ; \mathrm{Br}$, bromide in $\mathrm{mg} / \mathrm{L} ; \mathrm{F}$, fluoride in $\mathrm{mg} / \mathrm{L} ; \mathrm{B}$, boron in $\mu \mathrm{g} / \mathrm{L}$; $\mathrm{Li}$, lithium in ug/L; Methane in $\mathrm{mg} / \mathrm{L}$.

Figure 3-2 

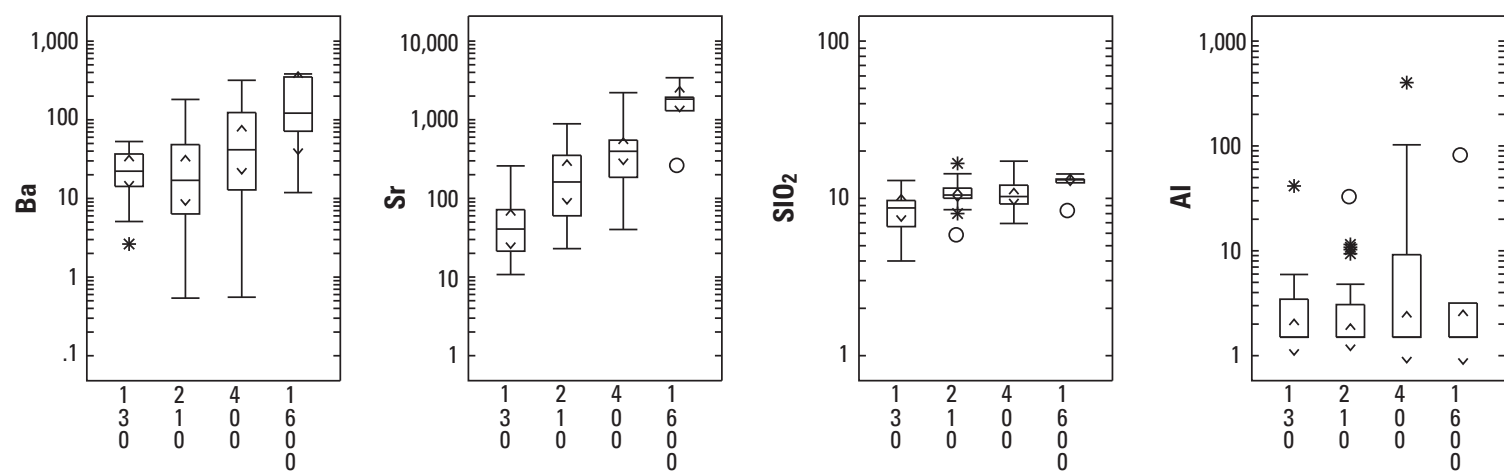

EXPLANATION

O Outlier data value greater than 3 times

the interquartile range

outside the quartile

* Outlier data value less than or equal to 3 and greater than 1.5 times the interquartile range

the interquartile rang
outside the quartile

Data value less than

or equal to 1.5 times

the interquartile range

outside the quartile
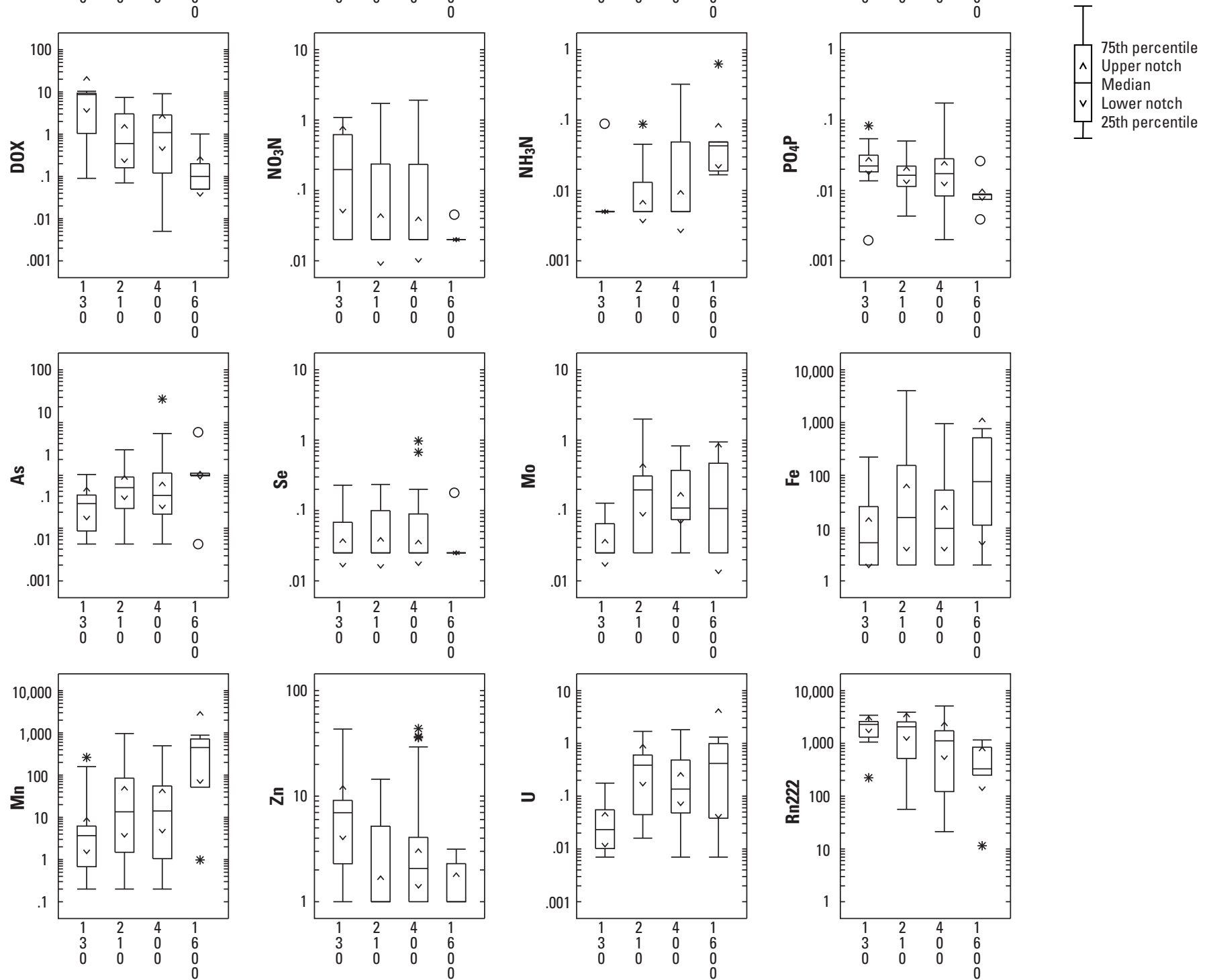

Abbreviations: $\mathrm{mg} / \mathrm{L}$, milligrams per liter; ug/L, micrograms per liter; $\mathrm{pCi} / \mathrm{L}$, picocuries per liter; $\mathrm{Ba}$, barium in ug/L; $\mathrm{Sr}$, strontium in ug/L; $\mathrm{SIO}$, silica in $\mathrm{mg} / \mathrm{L} ; \mathrm{Al}$, aluminum in ug/L; $\mathrm{DOX}$ dissolved oxygen in $\mathrm{mg} / \mathrm{L} ; \mathrm{NO}_{3} \mathrm{~N}$, nitrate in $\mathrm{mg} / \mathrm{L}$ as nitrogen; $\mathrm{NH}_{3} \mathrm{~N}$, ammonia in $\mathrm{mg} / \mathrm{L}$ as nitrogen; $\mathrm{PO}_{4} \mathrm{P}$, orthophosphate in $\mathrm{mg} / \mathrm{L}$ as phosphorus; As, arsenic in ug/L; Se, selenium in ug/L; Mo, molybdenum in $\mu \mathrm{g} / \mathrm{L} ; \mathrm{Fe}$, iron in ug/L; Mn, manganese in ug/L; $\mathrm{Zn}$, zinc in ug/L; U, uranium in ug/L; Rn222, radon-222 in $\mathrm{pCi} / \mathrm{L}$.

\section{Figure 3-2-Continued}



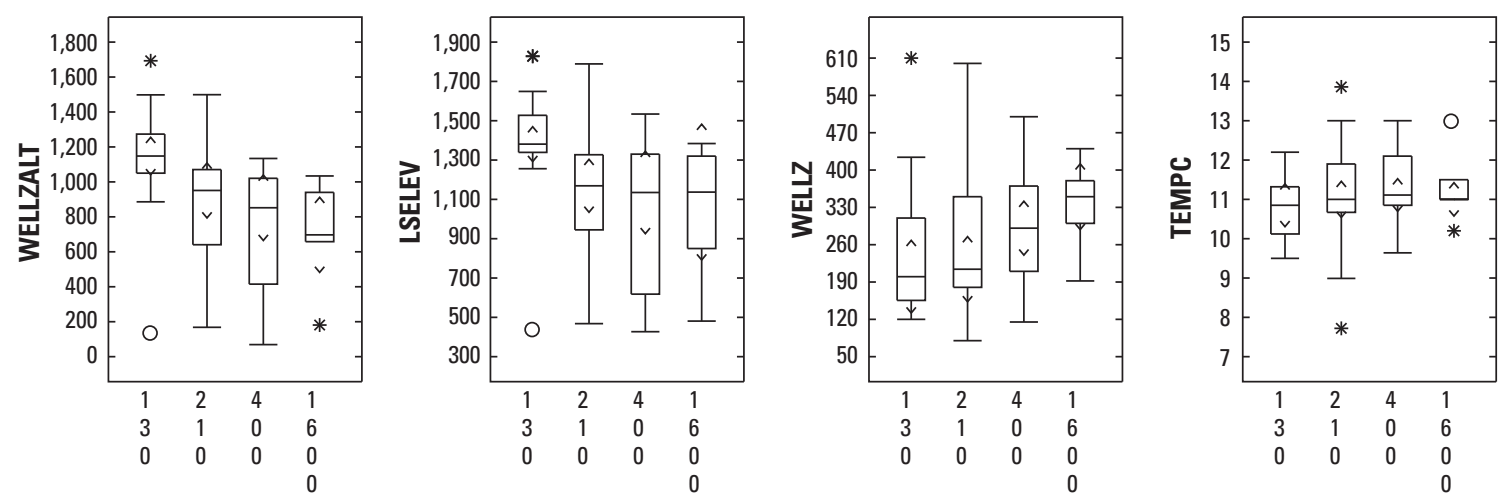

EXPLANATION

O Outlier data value greater than 3 times

the interquartile range

outside the quartile

* Outlier data value less than or equal to 3 and greater than 1.5 times the interquartile range

outside the quartile

Data value less than

or equal to 1.5 times

the interquartile range
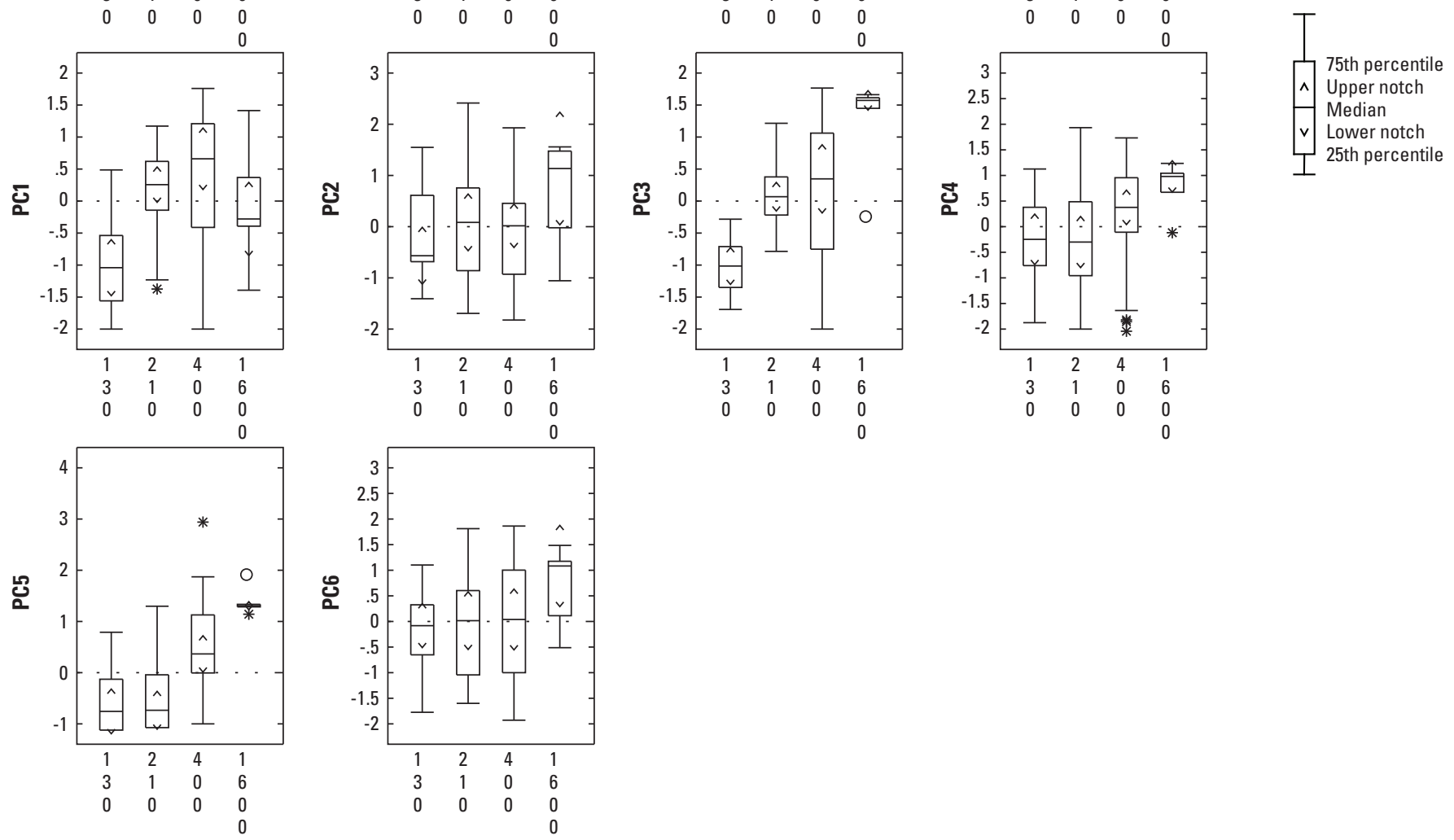

Abbreviations: $\mathrm{ft}$, feet; $\mathrm{SiO}_{2}$, silica in $\mathrm{mg} / \mathrm{L}$; WELLZALT, altitude of well bottom in $\mathrm{ft}$ above North American Vertical Datum, 1988 (NAV NAVD 88; WELLZ, depth of well in ft below land surface; TEMPC, water temperature in degrees Celsius; PC, principal component.

Figure 3-2-Continued 

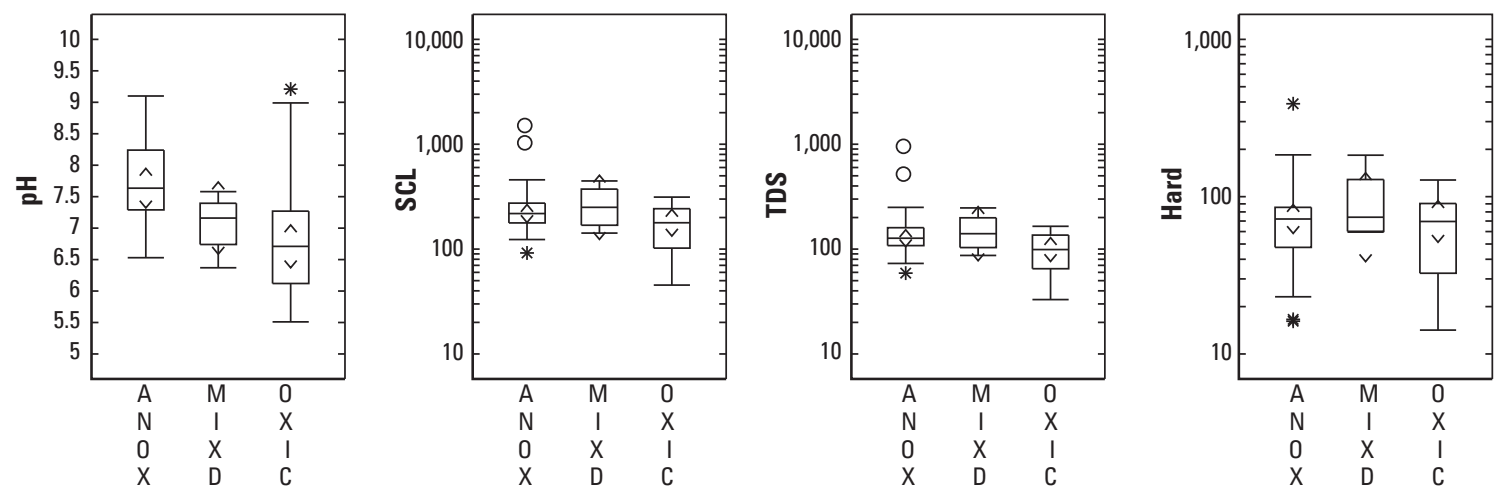

EXPLANATION

- Outlier data value

greater than 3 times

the interquartile range

outside the quartile

* Outlier data value less than or equal to 3 and

greater than 1.5 times

the interquartile range

outside the quartile

Data value less than

or equal to 1.5 times

the interquartile range

outside the quartile
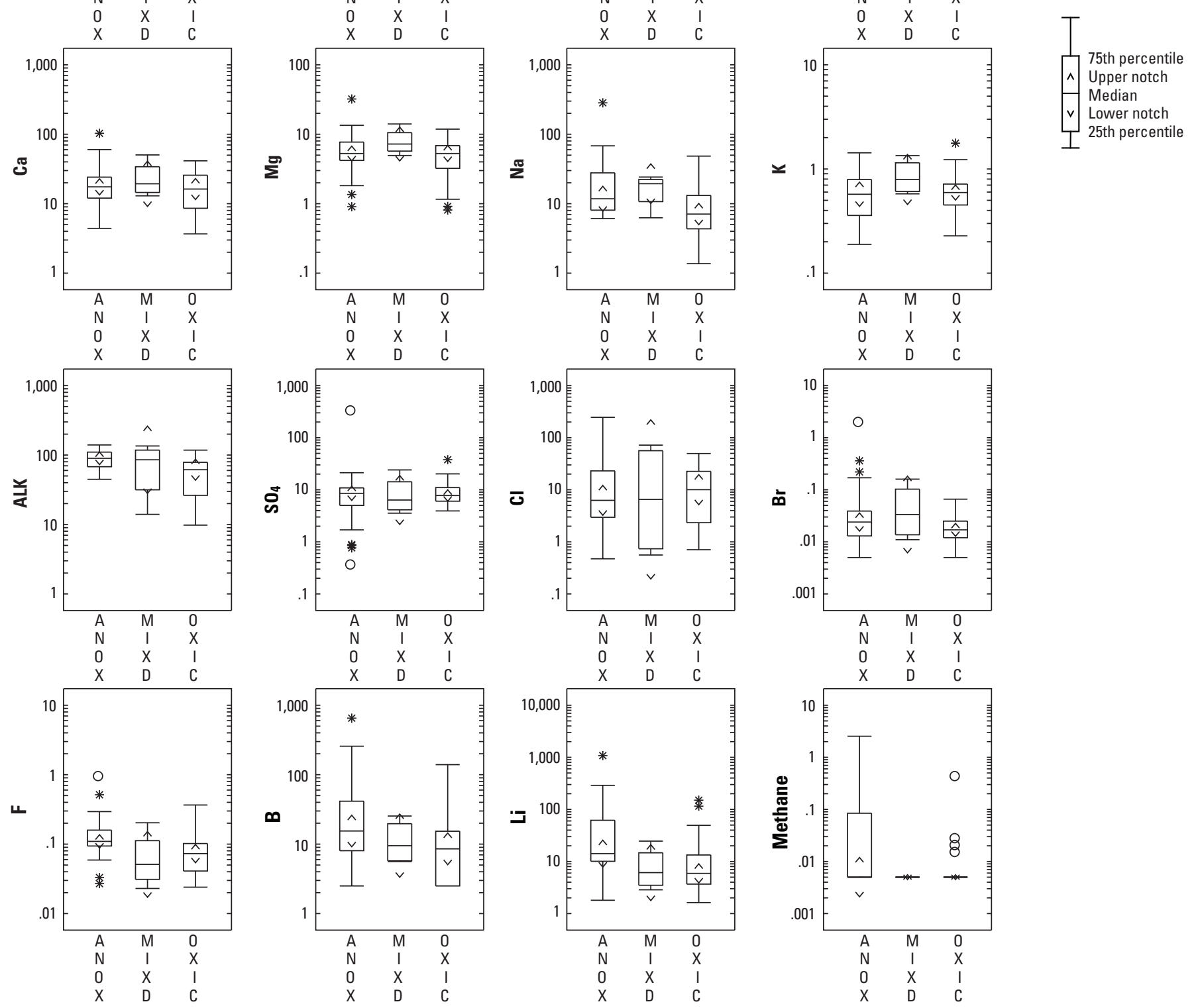

Abbreviations: $\mathrm{mg} / \mathrm{L}$, milligrams per liter; ug/L, micrograms per liter; $\mathrm{CaCO}_{3}$, calcium carbonate; $\mathrm{SCL}$, laboratory specific conductance in microsiemens per centimeter at 25 degrees Celsius; TDS, Total dissolved solids in $\mathrm{mg} / \mathrm{L} ; \mathrm{Hard}$, hardness in $\mathrm{mg} / \mathrm{L}$ as $\mathrm{CaCO}_{3} ; \mathrm{Ca}$, calcium in $\mathrm{mg} / \mathrm{L} ; \mathrm{Mg}$, magnesium in $\mathrm{mg} / \mathrm{L} ; \mathrm{Na}$, sodium in $\mathrm{mg} / \mathrm{L} ; \mathrm{K}$, potassium in $\mathrm{mg} / \mathrm{L} ; \mathrm{ALK}$, alkalinity in $\mathrm{mg} / \mathrm{L}$ as $\mathrm{CaCO}_{3} ; \mathrm{SO}_{4}$, sulfate in $\mathrm{mg} / \mathrm{L} ; \mathrm{Cl}$, chloride in $\mathrm{mg} / \mathrm{L} ; \mathrm{Br}$, bromide in $\mathrm{mg} / \mathrm{L} ; \mathrm{F}$, fluoride in $\mathrm{mg} / \mathrm{L} ; \mathrm{B}$, boron in $\mu \mathrm{g} / \mathrm{L} ; \mathrm{Li}$, lithium in ug/L; Methane in $\mathrm{mg} / \mathrm{L}$

Figure 3-3 

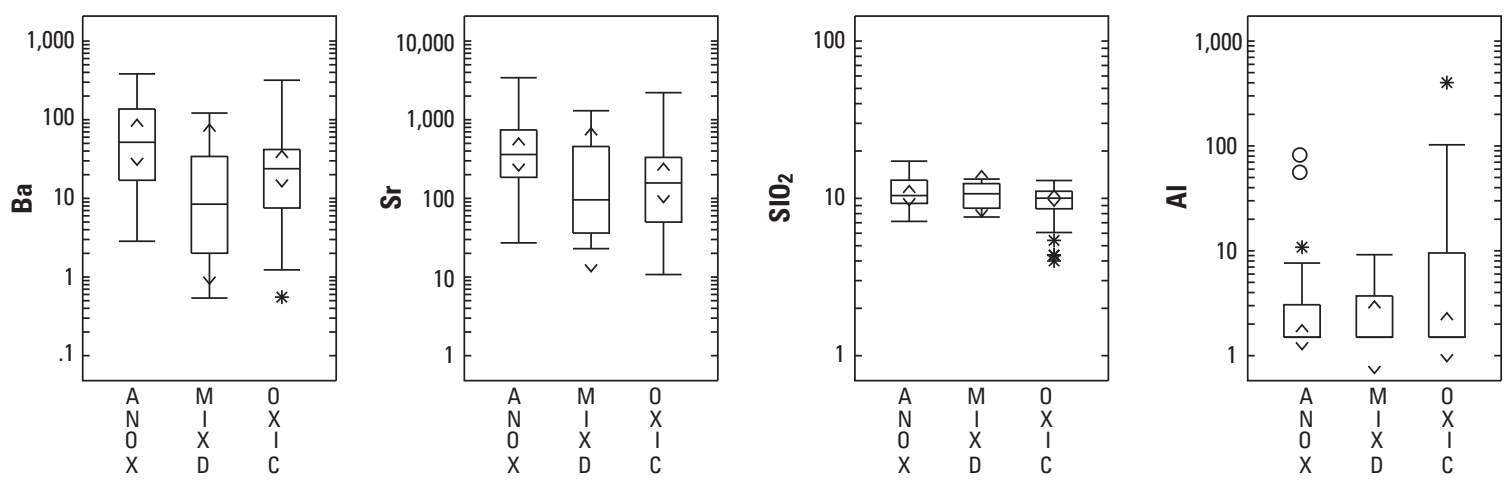

EXPLANATION

- Outlier data value

greater than 3 times

the interquartile range

outside the quartile

* Outlier data value less than or equal to 3 and

greater than 1.5 times

the interquartile range

outside the quartile

Data value less than

or equal to 1.5 times

the interquartile range

outside the quartile
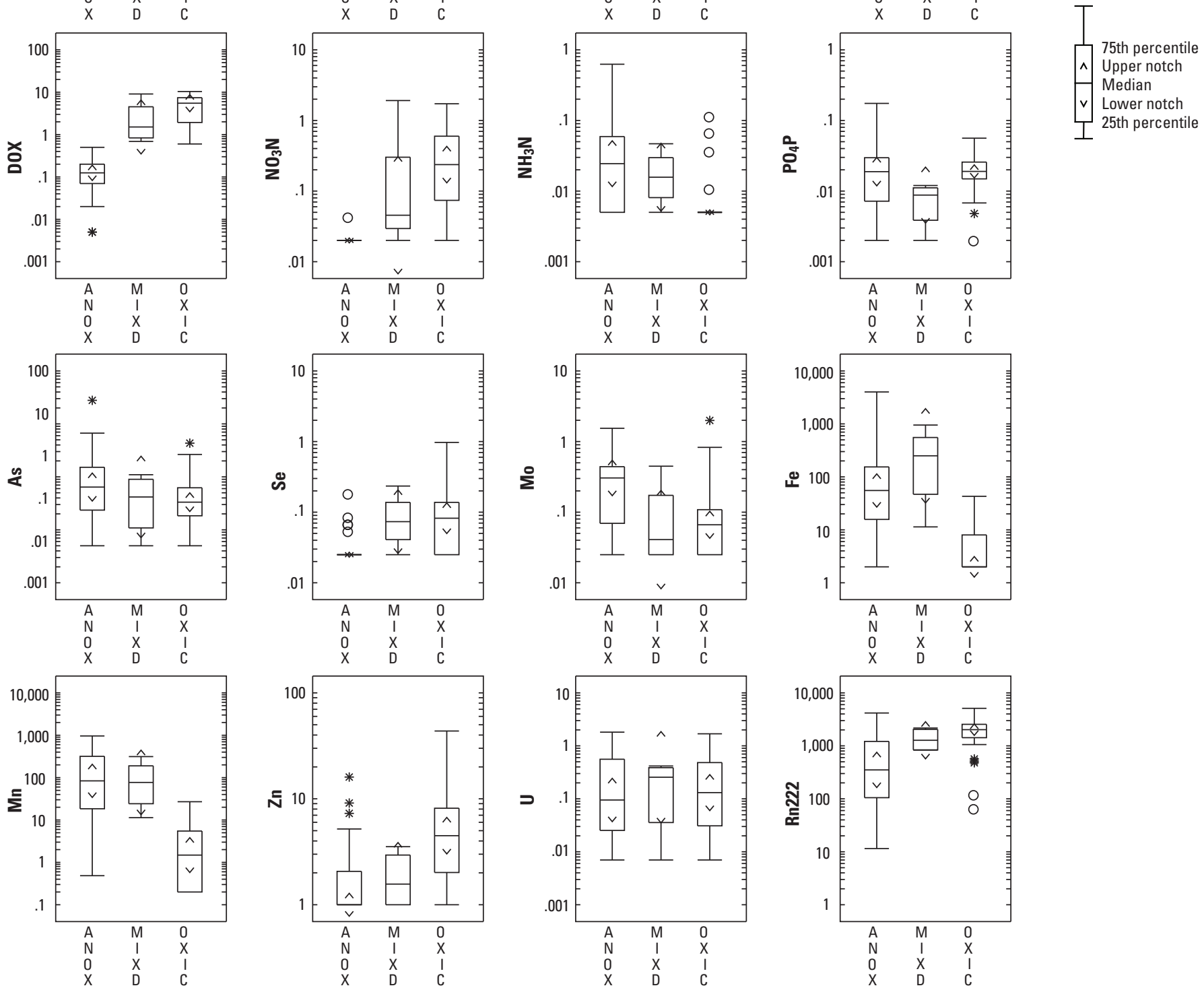

Abbreviations: $\mathrm{mg} / \mathrm{L}$, milligrams per liter; ug/L, micrograms per liter; $\mathrm{pCi} / \mathrm{L}$, picocuries per liter; $\mathrm{Ba}$, barium in ug/L; $\mathrm{Sr}$, strontium in ug/L; $\mathrm{SIO}$, silica in $\mathrm{mg} / \mathrm{L} ; \mathrm{Al}$, aluminum in ug/L; $\mathrm{DOX}$ dissolved oxygen in $\mathrm{mg} / \mathrm{L} ; \mathrm{NO}_{3} \mathrm{~N}$, nitrate in $\mathrm{mg} / \mathrm{L}$ as nitrogen; $\mathrm{NH}_{3} \mathrm{~N}$, ammonia in $\mathrm{mg} / \mathrm{L}$ as nitrogen; $\mathrm{PO}{ }_{4} \mathrm{P}$, orthophosphate in $\mathrm{mg} / \mathrm{L}$ as phosphorus; $\mathrm{As}$, arsenic in ug/L; Se, selenium in ug/L; Mo, molybdenum in $\mu \mathrm{g} / \mathrm{L} ; \mathrm{Fe}$, iron in ug/L; Mn, manganese in ug/L; Zn, zinc in ug/L; U, uranium in ug/L; Rn222, radon-222 in $\mathrm{pCi} / \mathrm{L}$.

Figure 3-3-Continued 

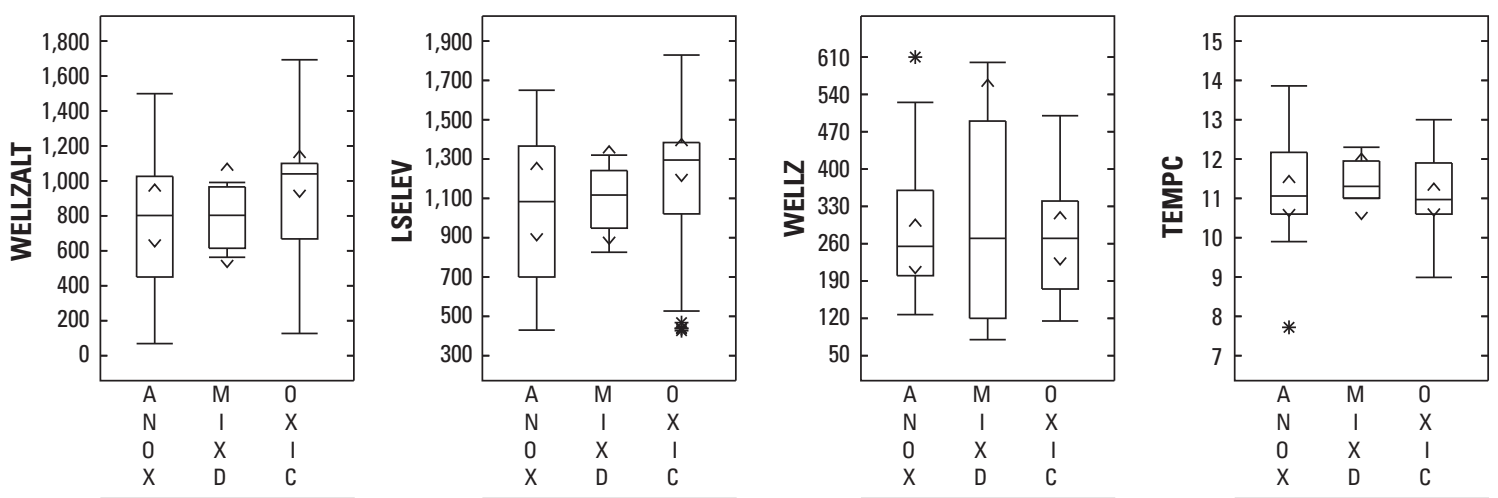

EXPLANATION

○ Outlier data value greater than 3 times the interquartile range outside the quartile

* Outlier data value less than or equal to 3 and greater than 1.5 times the interquartile range outside the quartile Data value less than or equal to 1.5 times the interquartile range outside the quartile
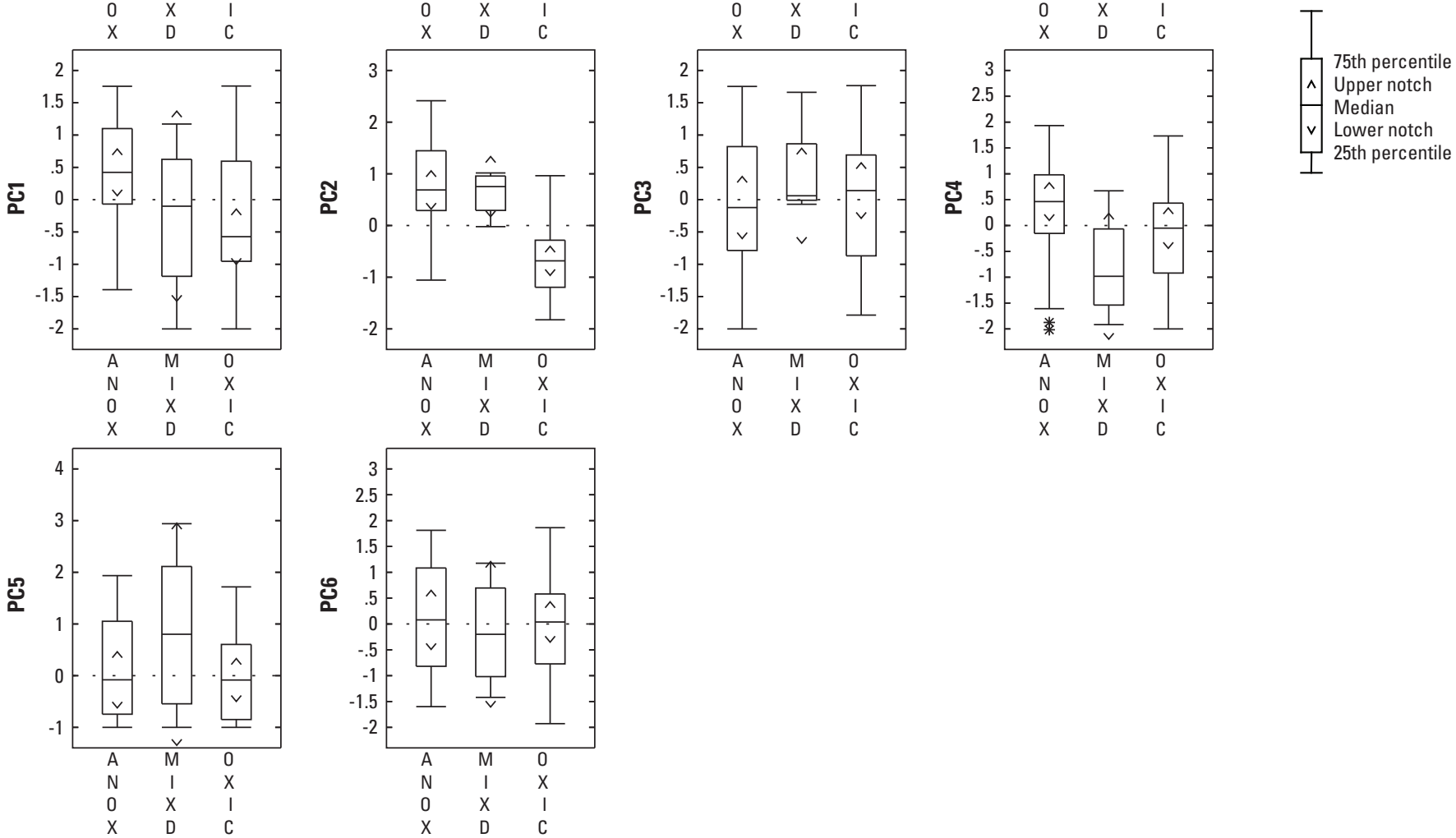

Abbreviations: $\mathrm{ft}$, feet; WELLZALT, altitude of well bottom in $\mathrm{ft}$ above North American Vertical Datum, 1988 (NAVD 88); LSELEV, land-surface elevation in $\mathrm{ft}$ above NAVD 88; WELLZ, depth of well in $\mathrm{ft}$ below land surface; TEMPC, water temperature in degrees Celsius; PC, principal component.

\section{Figure 3-3-Continued}



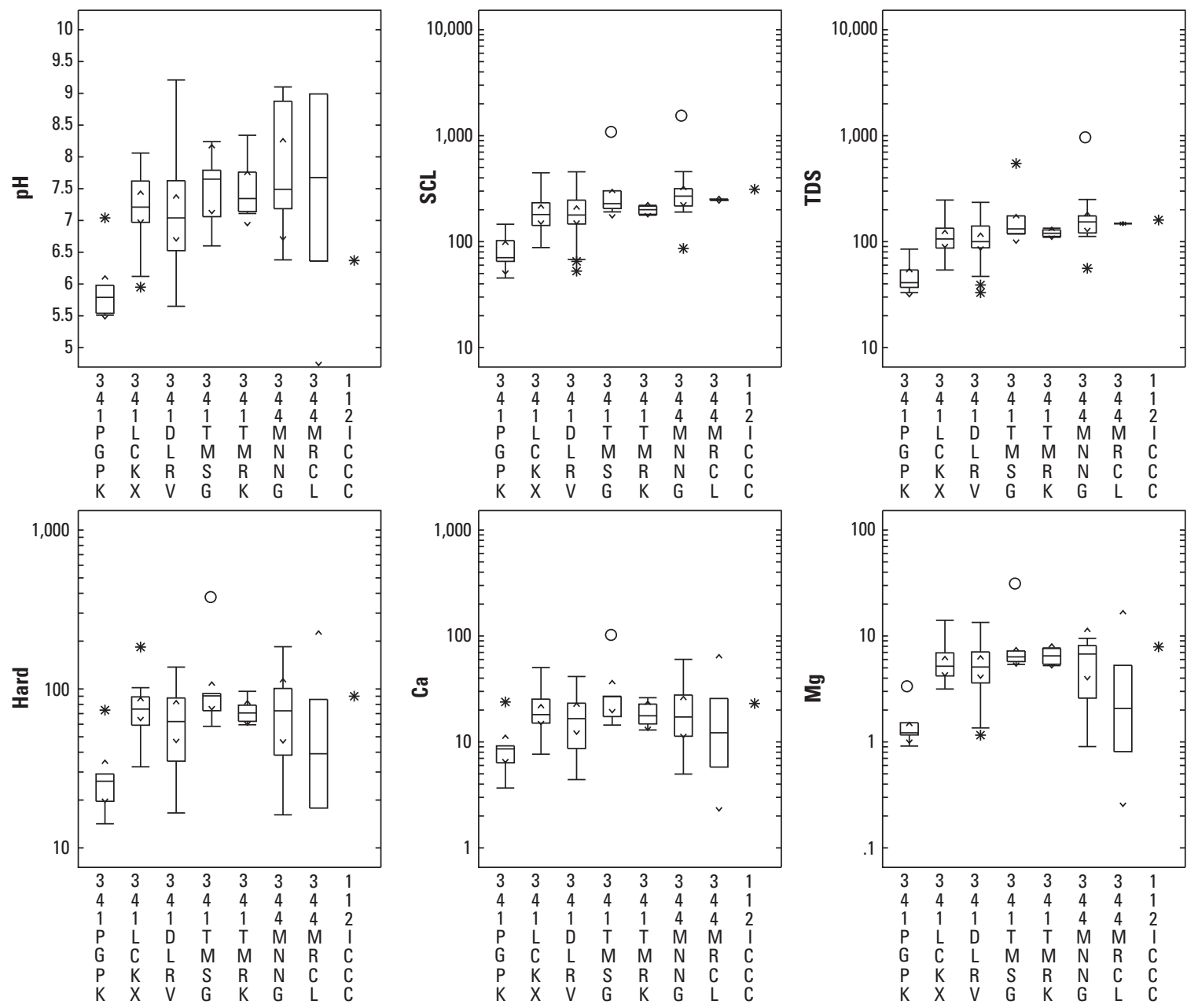

\section{EXPLANATION}

O Outlier data value greater than 3 times the interquartile range outside the quartile

* Outlier data value less than or equal to 3 and greater than 1.5 times the interquartile range outside the quartile

Data value less than

or equal to 1.5 times

the interquartile range

outside the quartile
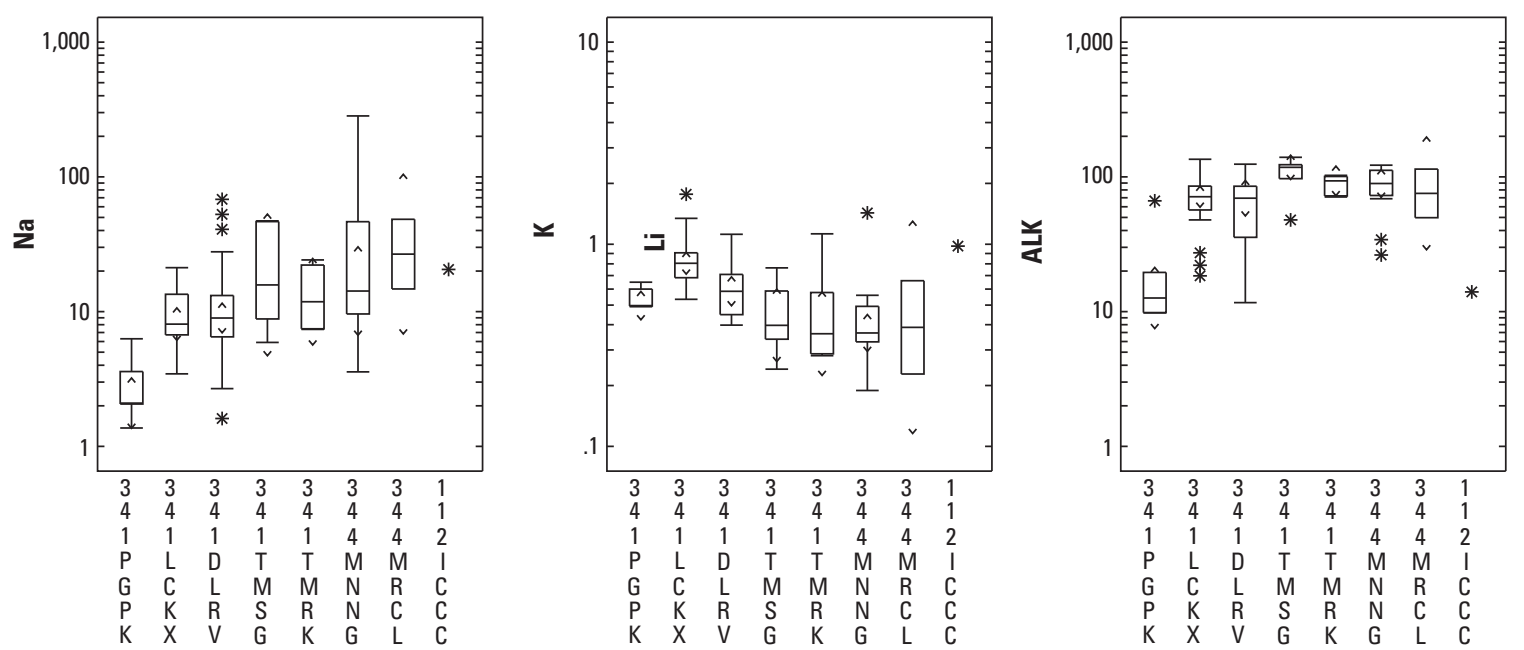

Abbreviations: $\mathrm{mg} / \mathrm{L}$, milligrams per liter; ug/L, micrograms per liter; $\mathrm{CaCO}_{3}$, calcium carbonate; $\mathrm{pCi} / \mathrm{L}$, picocuries per liter; $\mathrm{ft}$, feet; $\mathrm{SCL}$, laboratory specific conductance in microsiemens per centimeter at 25 degrees Celsius; TDS, Total dissolved solids in $\mathrm{mg} / \mathrm{L} ;$ Hard, hardness in $\mathrm{mg} / \mathrm{L}$ as $\mathrm{CaCO}_{3} ; \mathrm{Ca}$, calcium in $\mathrm{mg} / \mathrm{L} ; \mathrm{Mg}$, magnesium in $\mathrm{mg} / \mathrm{L} ; \mathrm{Na}$, sodium in $\mathrm{mg} / \mathrm{L} ; \mathrm{K}$, potassium in $\mathrm{mg} / \mathrm{L} ; \mathrm{ALK}$, alkalinity in $\mathrm{mg} / \mathrm{L}$ as $\mathrm{CaCO}_{3}$. Geologic unit codes: 341, PGPK, Poplar Gap and Packerton Members of Catskill Formation, undivided; 341DLRV, Delaware River Member of the Catskill Formation; 341LCXX, Lackawaxen Member of the Catskill Formation; 341TMSG, Towamensing Member of the Catskill formation; 341TMRK, Trimmers Rock Formation; 344MNNG, Mahan- tango Formation; 344MRCL, Marcellus Shale; 112 ICCC, Ice-contact deposits.

Figure 3-3-Continued 

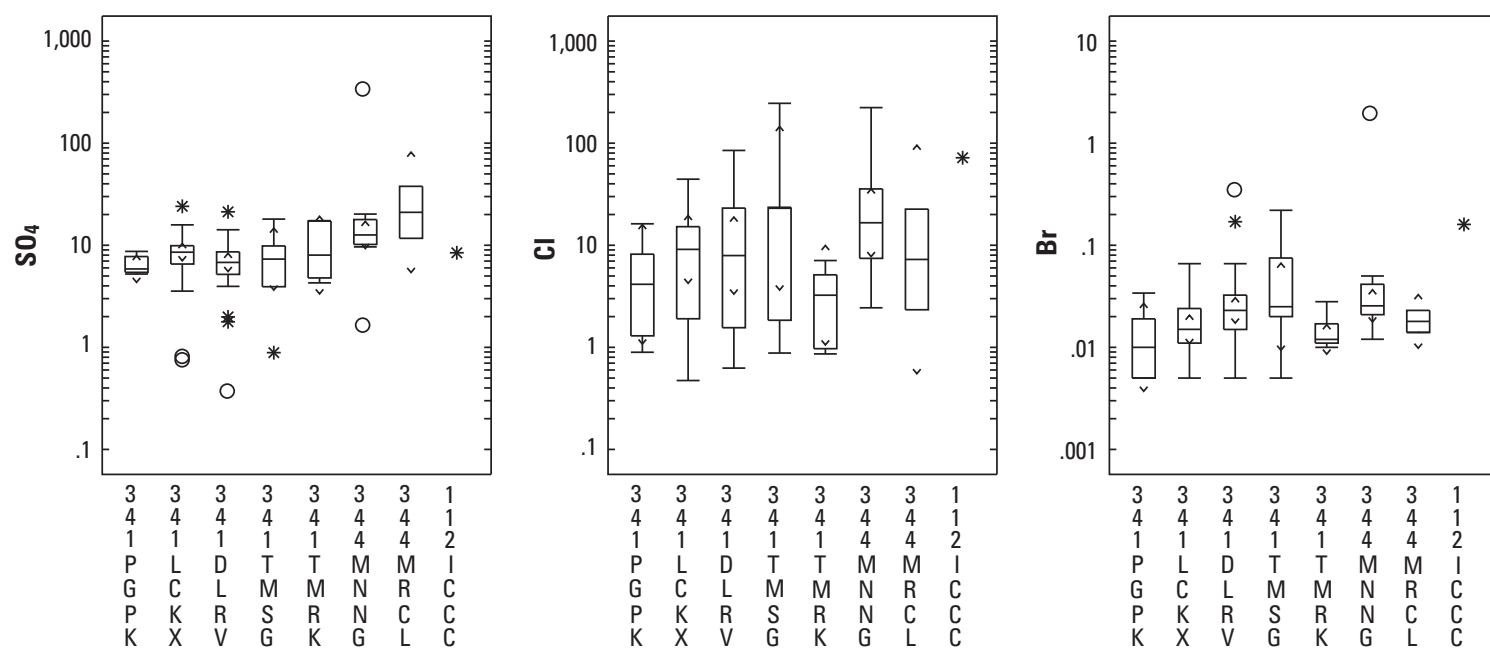

EXPLANATION

O Outlier data value greater than 3 times the interquartile range outside the quartile

* Outlier data value less than or equal to 3 and greater than 1.5 times the interquartile range outside the quartile Data value less than or equal to 1.5 times the interquartile range outside the quartile
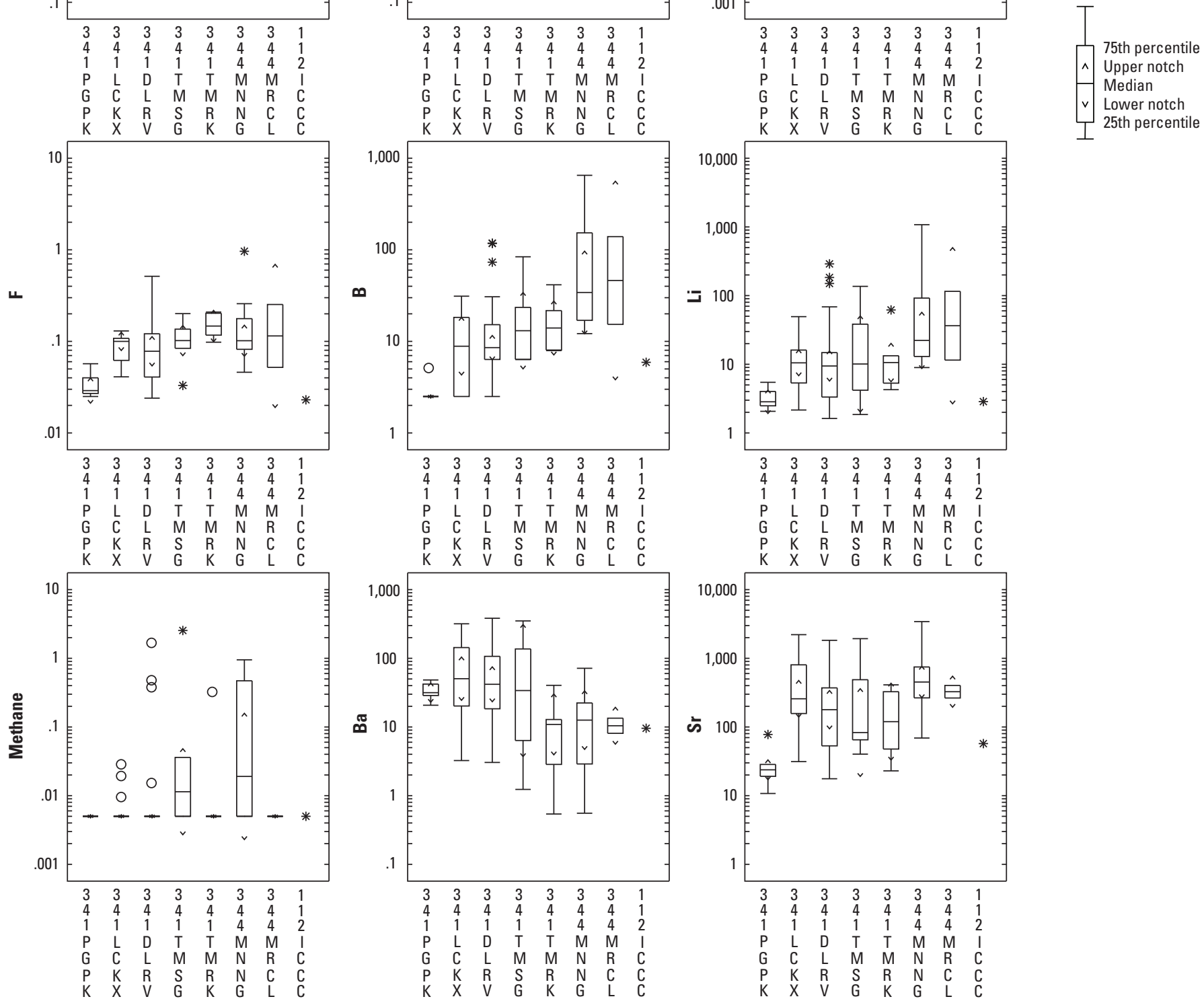

Abbreviations: $\mathrm{mg} / \mathrm{L}$, milligrams per liter; ug/ $\mathrm{L}$, micrograms per liter; $\mathrm{SO}_{4}$, sulfate in $\mathrm{mg} / \mathrm{L}$; $\mathrm{Cl}$, chloride in $\mathrm{mg} / \mathrm{L} ; \mathrm{Br}$, bromide in $\mathrm{mg} / \mathrm{L} ; \mathrm{F}$, fluoride in $\mathrm{mg} / \mathrm{L} ; \mathrm{B}$, boron in $\mu \mathrm{g} / \mathrm{L}$; $\mathrm{Li}$, lithium in ug/ $\mathrm{L}$; Methane in $\mathrm{mg} / \mathrm{L} ; \mathrm{Ba}$, barium in ug/L; Sr, strontium in ug/L. Geologic unit codes: 341, PGPK, Poplar Gap and Packerton Members of Catskill Formation, undivided; 341DLRV, Delaware River Member of the Catskill Formation; 341LCXX, Lackawaxen Member of the Catskill Formation; 341TMSG, Towamensing Member of the Catskill formation; 341TMRK, Trimmers Rock Formation; 344MNNG, Mahantango Formation; 344MRCL, Marcellus Shale; 112 ICCC, Ice-contact deposits.

\section{Figure 3-3-Continued}



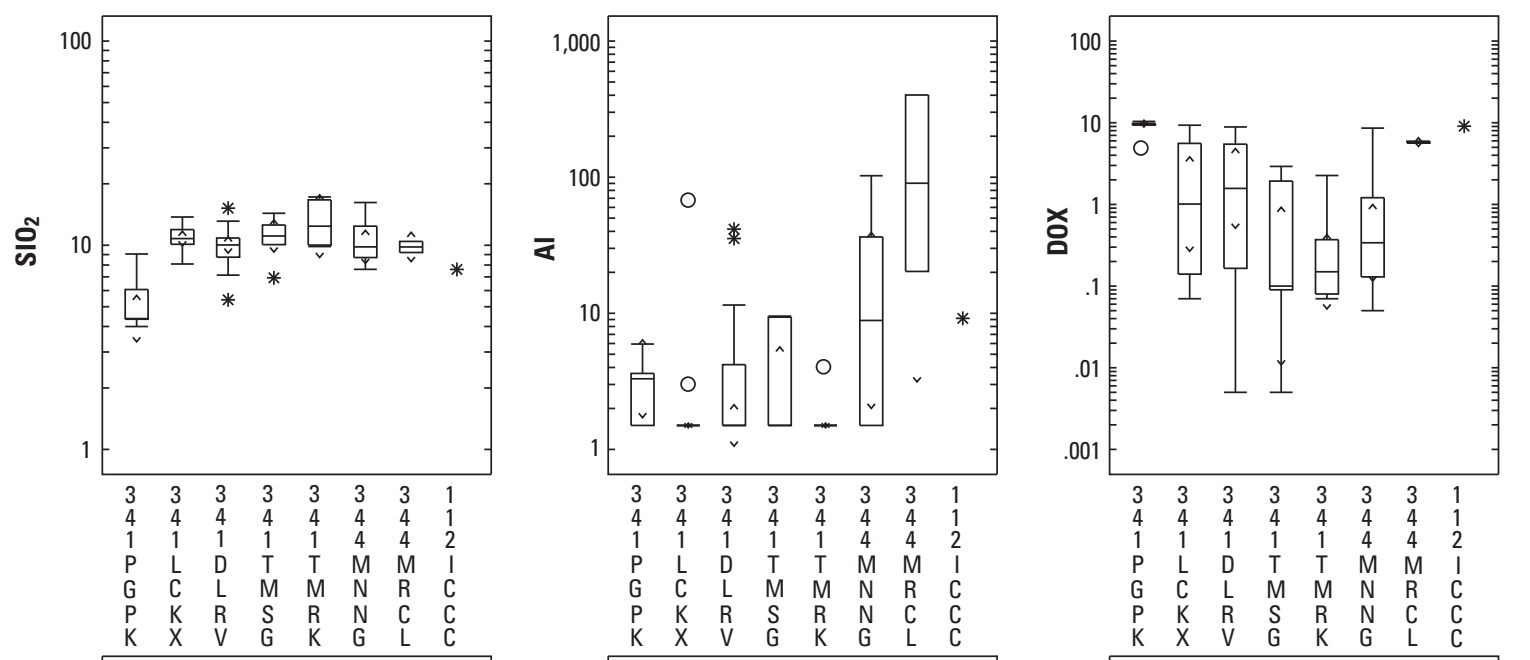

EXPLANATION

O Outlier data value greater than 3 times the interquartile range outside the quartile

* Outlier data value less than or equal to 3 and greater than 1.5 times the interquartile range outside the quartile Data value less than or equal to 1.5 times the interquartile range outside the quartile
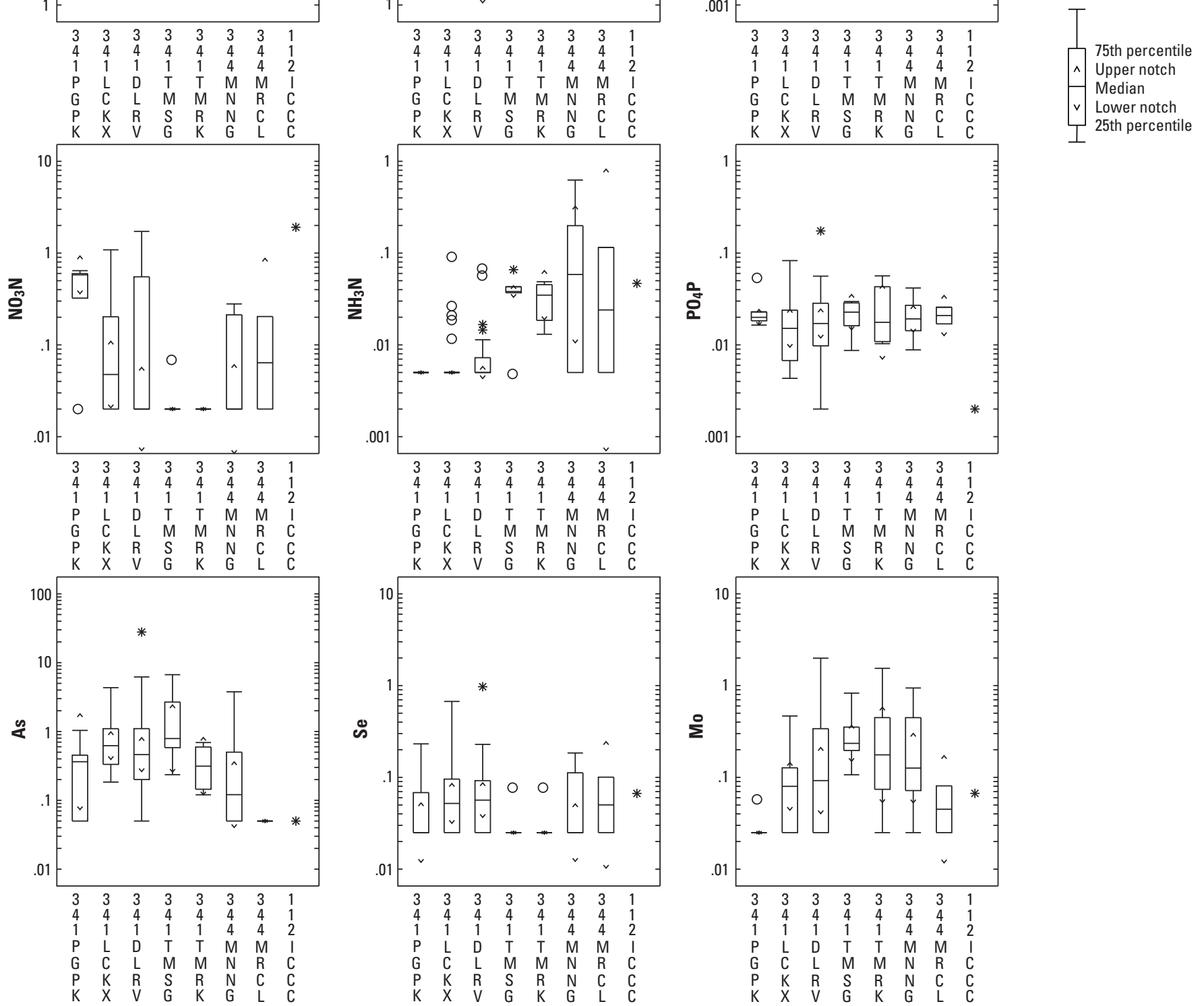

Abbreviations: $\mathrm{mg} / \mathrm{L}$, milligrams per liter; ug/L, micrograms per liter; $\mathrm{SIO}_{2}$, silica in $\mathrm{mg} / \mathrm{L} ; \mathrm{Al}$, aluminum in ug/L; $\mathrm{DOX}$, dissolved oxygen in $\mathrm{mg} / \mathrm{L} ; \mathrm{NO}_{3} \mathrm{~N}$, nitrate in $\mathrm{mg} / \mathrm{L}$ as nitrogen; $\mathrm{NH}_{3} \mathrm{~N}$, ammonia in $\mathrm{mg} / \mathrm{L}$ as nitrogen; $\mathrm{PO}_{4} \mathrm{P}$, orthophosphate in $\mathrm{mg} / \mathrm{L}$ as phosphorus; $\mathrm{As}$, arsenic in ug/L; Se, selenium in ug/L; Mo, molybdenum in $\mu \mathrm{g} / \mathrm{L}$. Geologic unit codes: 341 , PGPK, Poplar Gap and Packerton Members of Catskill Formation, undivided; 341DLRV, Delaware River Member of the Catskill Formation; 341LCXX, Lackawaxen Member of the Catskill Formation; 341TMSG, Towamensing Member of the Catskill formation; 341TMRK, Trimmers Rock Formation; 344MNNG, Mahantango Formation; 344MRCL, Marcellus ShaleShale; 112 ICCC, Icecontact deposits.

Figure 3-3-Continued 

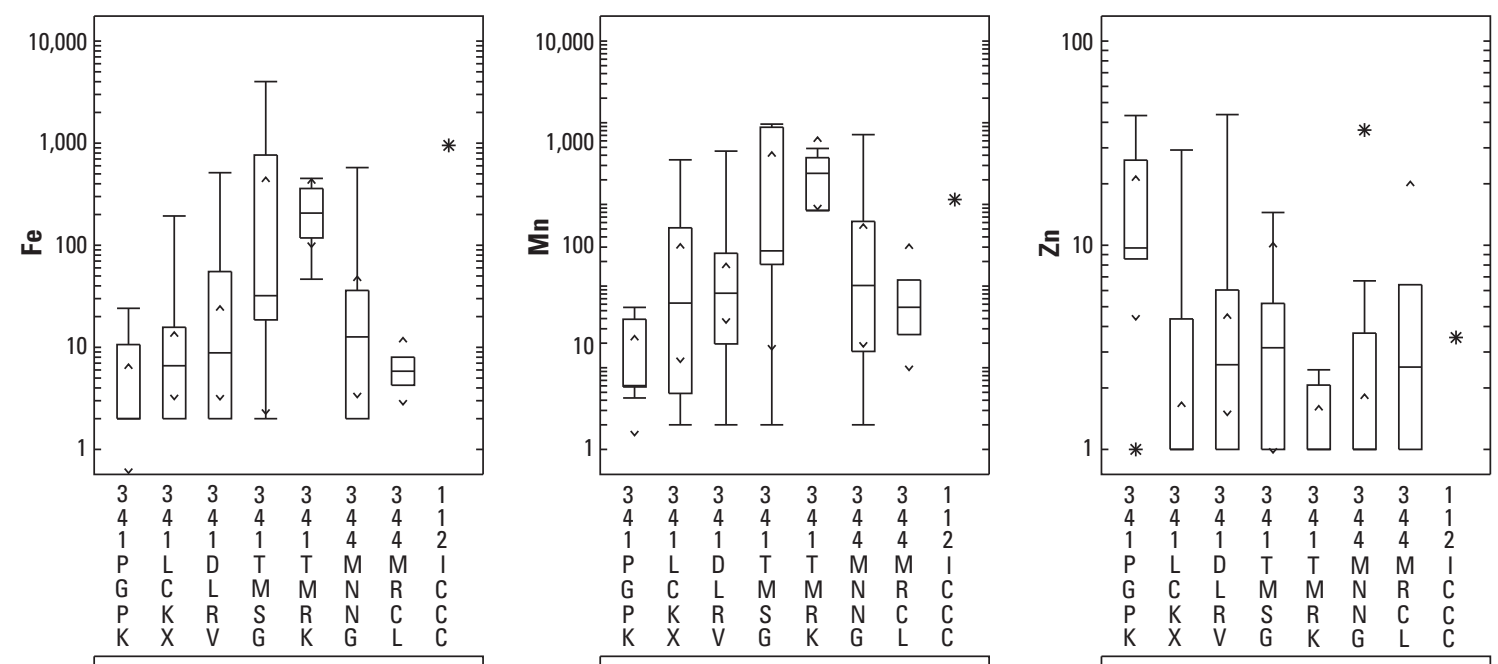

EXPLANATION

O Outlier data value

greater than 3 times

the interquartile range

outside the quartile

* Outlier data value less than or equal to 3 and greater than 1.5 times

the interquartile range outside the quartile

Data value less than

or equal to 1.5 times

the interquartile range

outside the quartile
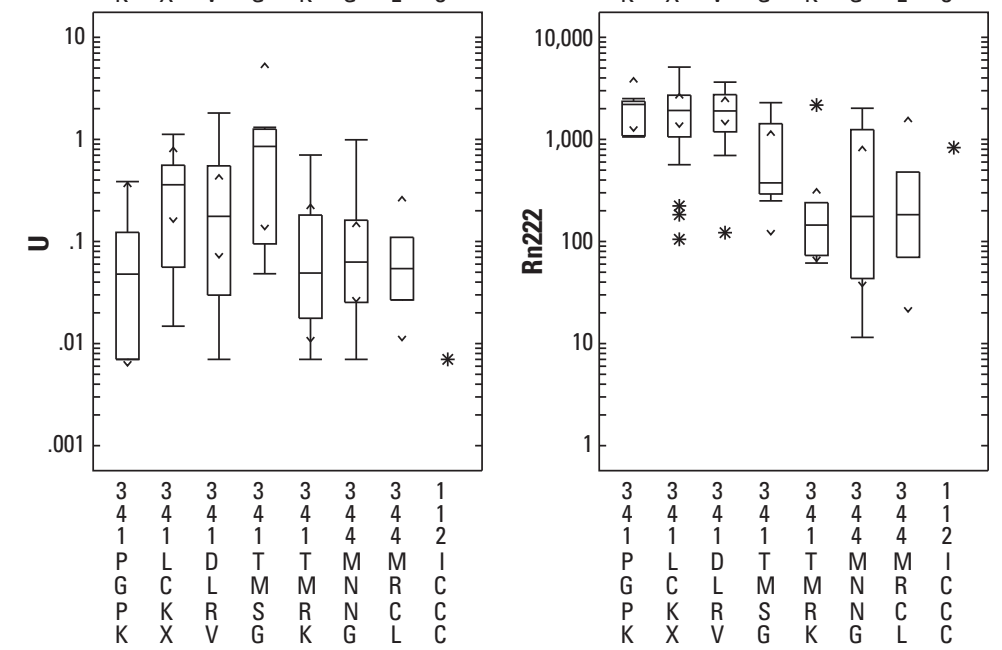

1800
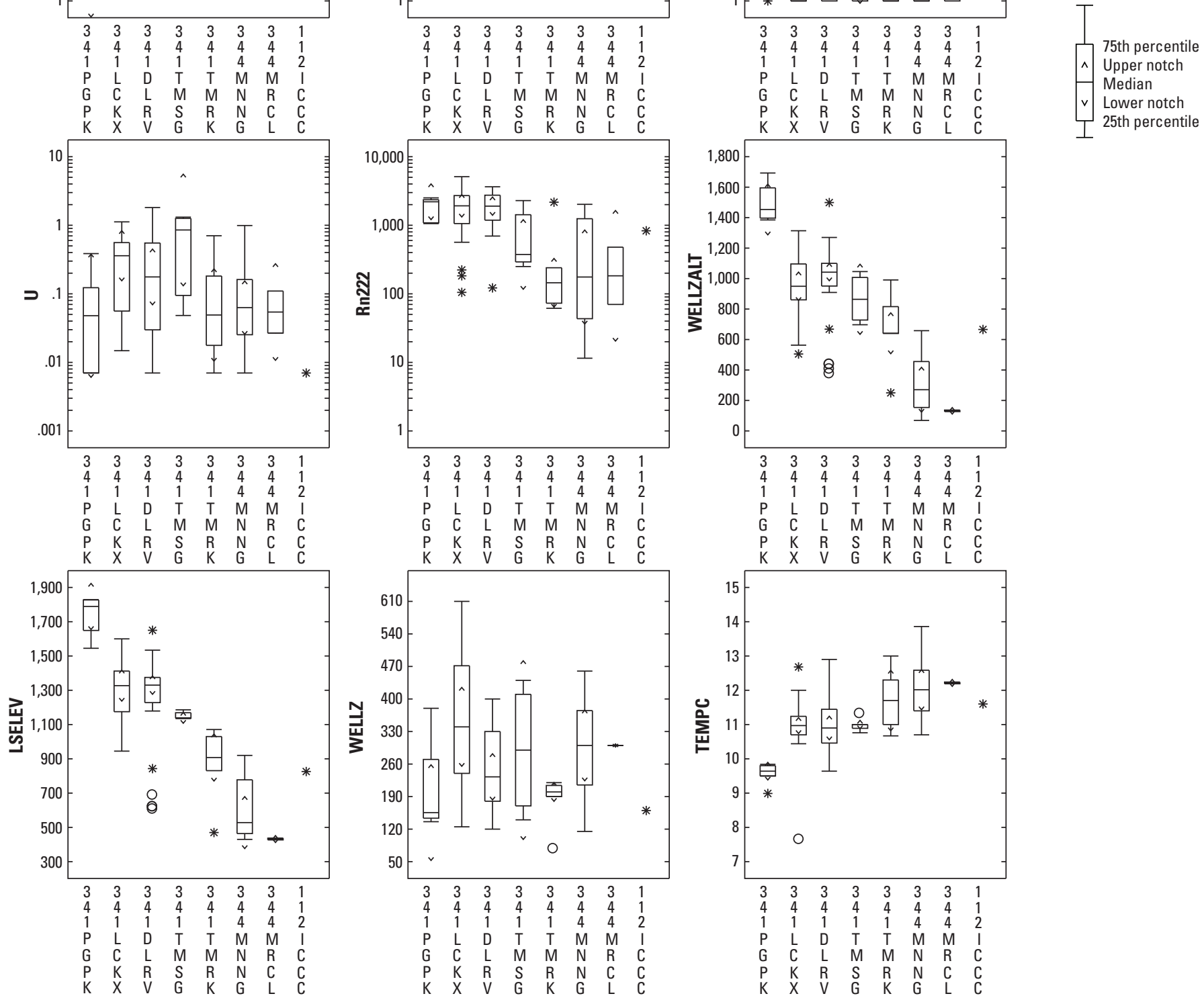

Abbreviations: ug/L, micrograms per liter; $\mathrm{pCi} / \mathrm{L}$, picocuries per liter; $\mathrm{ft}$, feet; Fe, iron in ug/L; $\mathrm{Mn}$, manganese in ug/L; $\mathrm{Zn}$, zinc in ug/L; U, uranium in ug/L; Rn222, radon-222 in $\mathrm{pCi} / \mathrm{L}$; WELLZALT, altitude of well bottom in ft above North American Vertical Datum, 1988 (NAVD 88); LSELEV, land-surface elevation in $\mathrm{ft}$ above NAVD 88 ; WELLZ, depth of well in $\mathrm{ft}$ below land surface; TEMPC, water temperature in degrees Celsius. Geologic unit codes: 341, PGPK, Poplar Gap and Packerton Members of Catskill Formation, undivided; 341DLRV, Delaware River Member of the Catskill Formation; 341LCXX, Lackawaxen Member of the Catskill Formation; 341TMSG, Towamensing Member of the Catskill formation; 341TMRK, Trimmers Rock

Formation; 344MNNG, Mahantango Formation; 344MRCL, Marcellus Shale; 112 ICCC, Ice-contact deposits.

Figure 3-3-Continued 

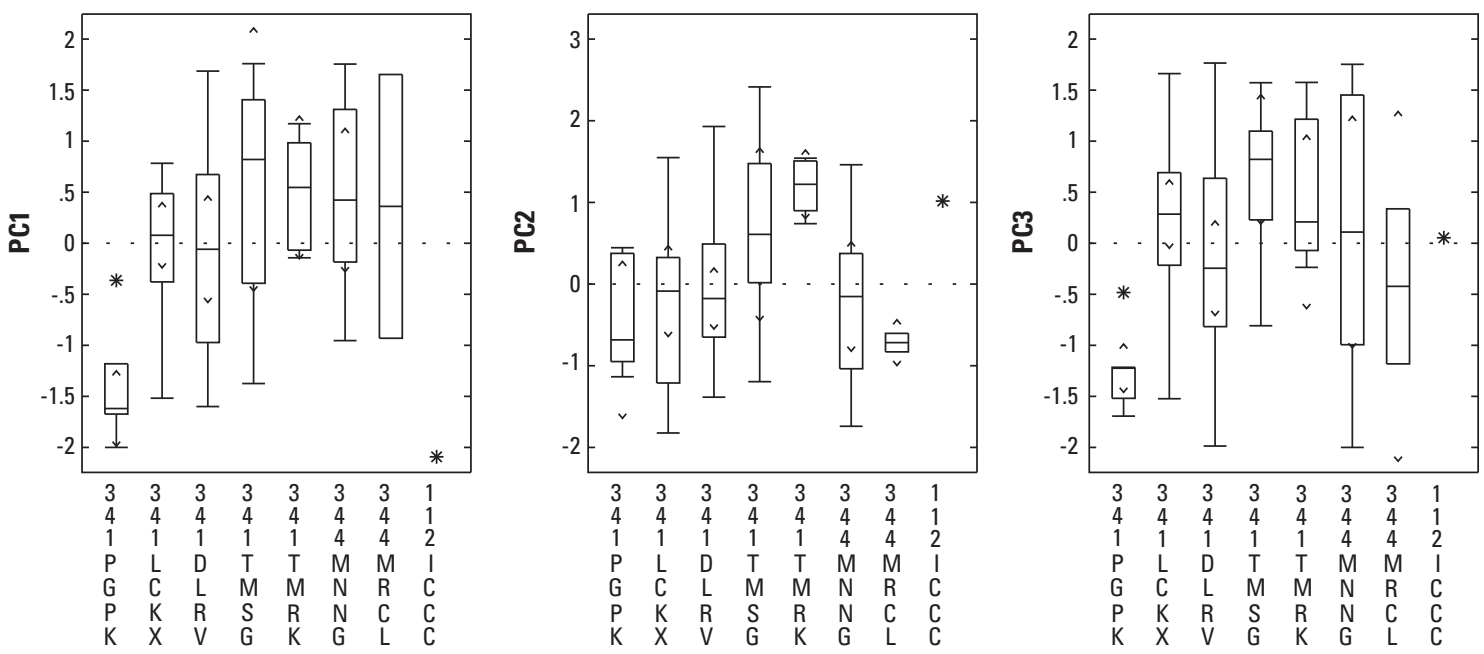

EXPLANATION

O Outlier data value greater than 3 times the interquartile range outside the quartile

* Outlier data value less than or equal to 3 and greater than 1.5 times the interquartile range outside the quartile Data value less than

or equal to 1.5 times

the interquartile range outside the quartile
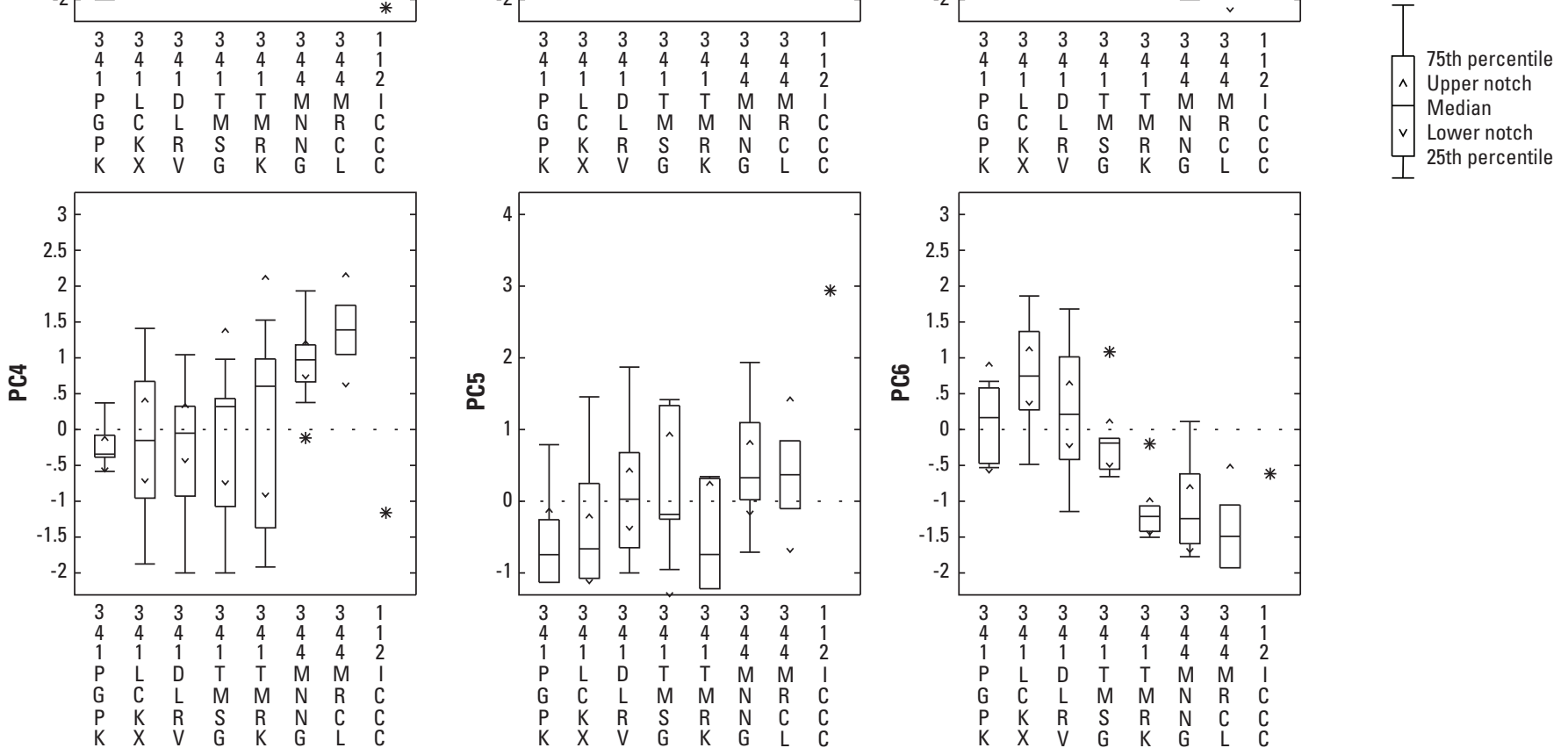

Abbreviations: PC, principal component. Geologic unit codes: 341, PGPK, Poplar Gap and Packerton Members of Catskill Formation, undivided; 341 DLRV, Delaware River Member of the Catskill Formation; 341LCXX, Lackawaxen Member of the Catskill Formation; 341TMSG, Towamensing Member of the Catskill formation; 341TMRK, Trimmers Rock Formation; 344MNNG, Mahantango Formation; 344MRCL, Marcellus Shale; 112 ICCC, Ice-contact deposits.

\section{Figure 3-3-Continued}



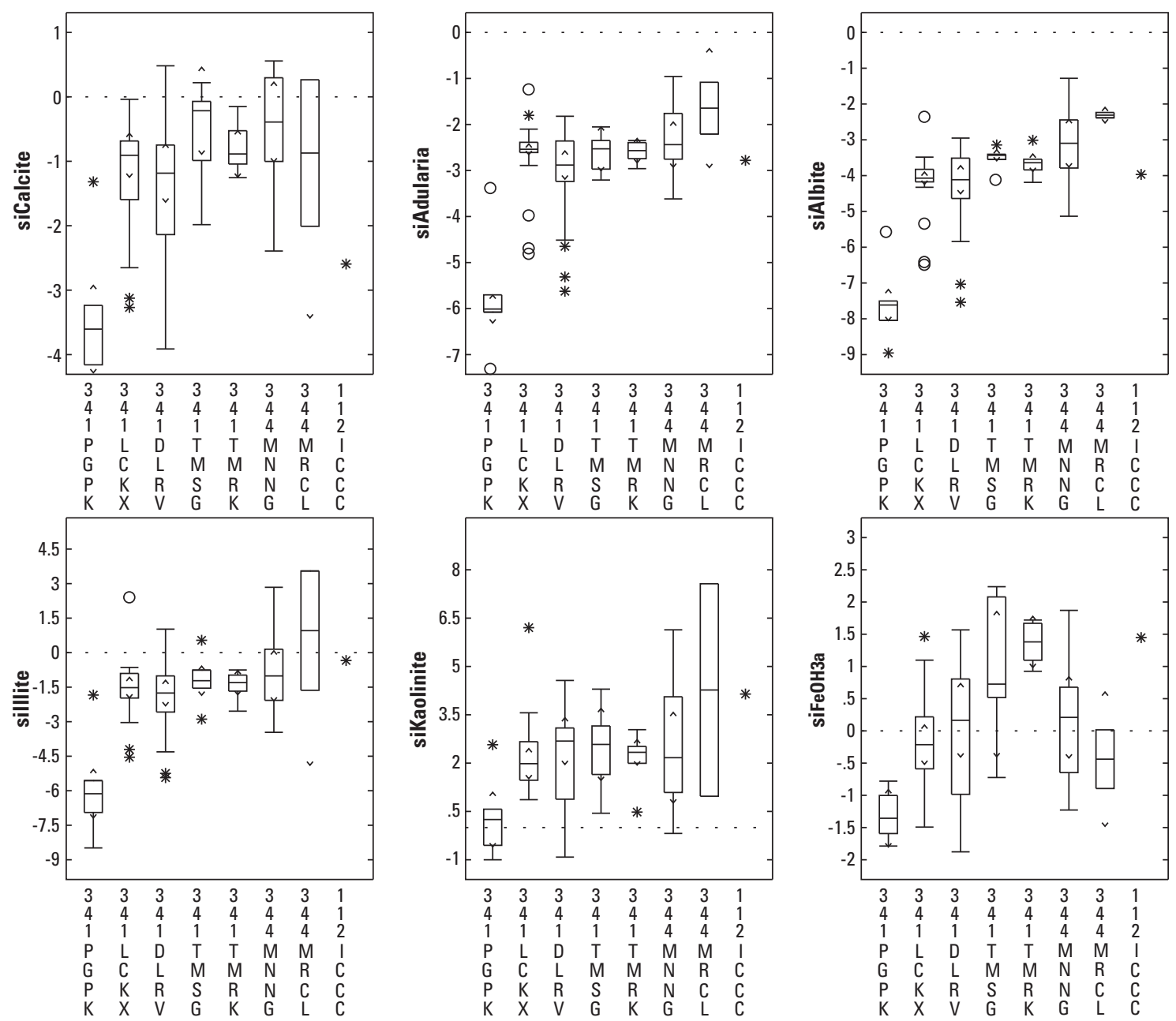

EXPLANATION

O Outlier data value

greater than 3 times

the interquartile range outside the quartile

* Outlier data value less than or equal to 3 and greater than 1.5 times the interquartile range outside the quartile Data value less than

or equal to 1.5 times

the interquartile range

outside the quartile
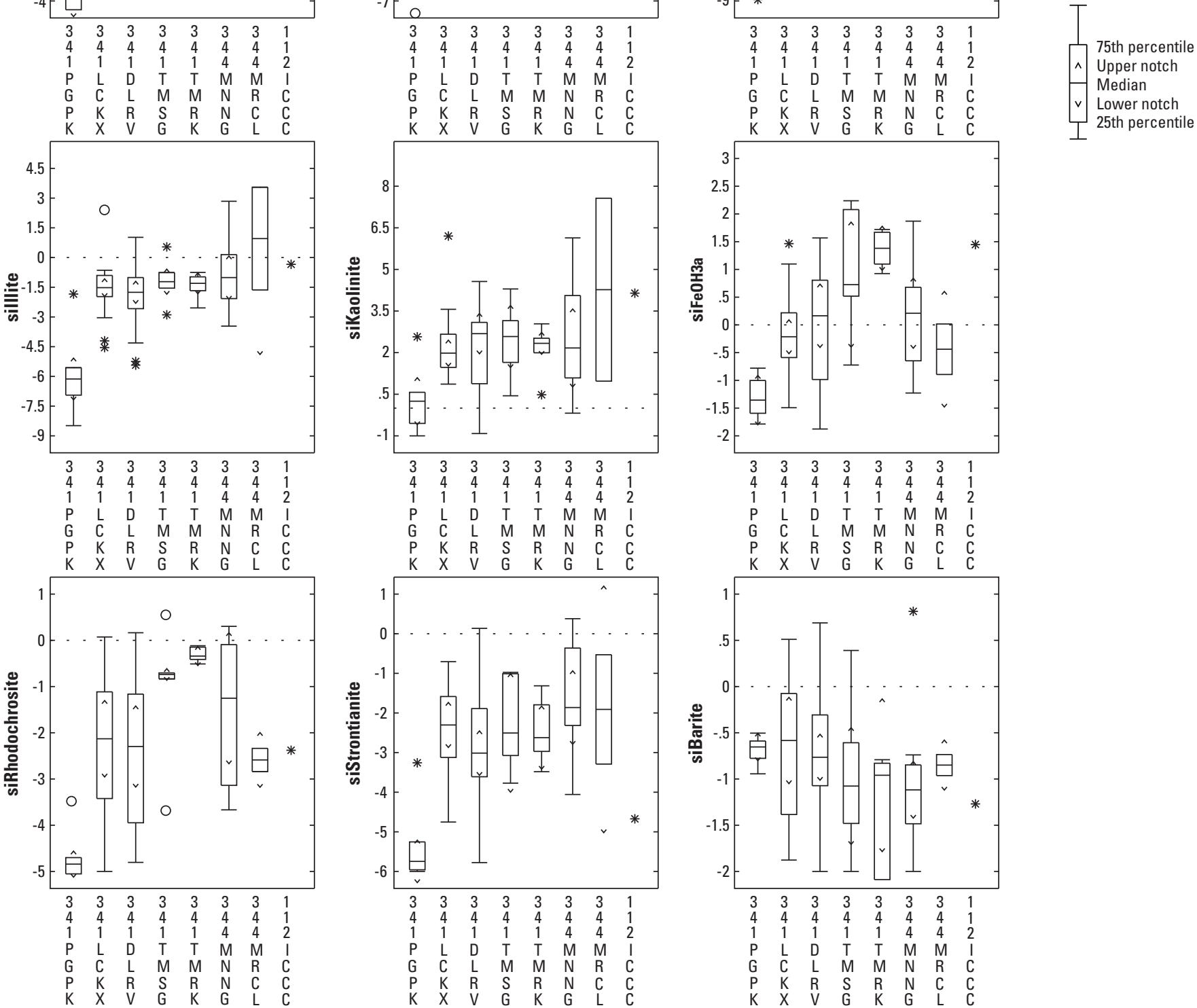

Abbreviations: Si, saturation index of mineral. Geologic unit codes: 341, PGPK, Poplar Gap and Packerton Members of Catskill Formation, undivided; 341DLRV, Delaware River Member of the Catskill Formation; 341LCXX, Lackawaxen Member of the Catskill Formation; 341TMSG, Towamensing Member of the Catskill formation; 341TMRK, Trimmers Rock Formation; 344MNNG, Mahantango Formation; 344MRCL, Marcellus Shale; 112 ICCC, Ice-contact deposits.

Figure 3-3-Continued 
Table A4-1. Field measurements and results of laboratory analyses for major and minor ions, nutrients, bacteria, trace metals, radioactivity, radon-222, and dissolved gases in groundwater samples collected from 7 pairs of two closely-spaced wells in Pike County, Pennsylvania, 2015.

[Constituents listed with associated 5-digit U.S. Geological Survey parameter code; shading indicates well pairs; --, no data; <, less than; >, greater than; E, estimated; M, presence verified but not quantified; $\mathrm{R}$, non-detect for radiological analysis; $\mathrm{U}$, analyzed for but not detected; lab, laboratory; \%, percent; $\mathrm{mg} / \mathrm{L}$, milligrams per liter; $\mu \mathrm{S} / \mathrm{cm}$, microsiemens per centimeter; ${ }^{\circ} \mathrm{C}$, degrees $\mathrm{Celsius;} \mathrm{CaCO}{ }_{3}$, calcium carbonate; $\mu \mathrm{g} / \mathrm{L}$, micrograms per liter; MPN, most probable number; pCi/L, picocuries per liter; Geologic units: 341DLRV, Delaware River Formation; 341LCKX, Lackawaxen Formation; 341PGPK, Poplar Gap and Packerton Members of Catskill Formation, Undivided; 341TMRK, Trimmers Rock Formation; 341TMSG, Towamensing Member of Catskill Formation; 344MNNG, Mahantango Formation; 344MRCL, Marcellus Shale]

\begin{tabular}{|c|c|c|c|c|c|c|c|c|c|c|c|c|c|c|c|}
\hline $\begin{array}{l}\text { Local } \\
\text { identi- } \\
\text { fier }\end{array}$ & $\begin{array}{c}\text { Pair } \\
\text { number }\end{array}$ & Date & $\begin{array}{l}\text { Sam- } \\
\text { ple } \\
\text { start } \\
\text { time }\end{array}$ & $\begin{array}{l}\text { Geologic } \\
\text { unit code }\end{array}$ & $\begin{array}{c}\text { Dissolved } \\
\text { oxygen, } \\
\text { water, } \\
\text { unfiltered, } \\
\text { mg/L }\end{array}$ & $\begin{array}{c}\text { pH, } \\
\text { water, } \\
\text { unfil- } \\
\text { tered, } \\
\text { field, } \\
\text { standard } \\
\text { units }\end{array}$ & $\begin{array}{c}\text { pH, } \\
\text { water, } \\
\text { unfil- } \\
\text { tered, } \\
\text { lab, } \\
\text { standard } \\
\text { units }\end{array}$ & $\begin{array}{c}\text { Specific } \\
\text { conduc- } \\
\text { tance, } \\
\text { water, } \\
\text { unfiltered, } \\
\text { lab, } \\
\text { HS/cm at } \\
25^{\circ} \mathrm{C}\end{array}$ & $\begin{array}{c}\text { Specific } \\
\text { conduc- } \\
\text { tance, } \\
\text { water, } \\
\text { unfiltered, } \\
\mu \mathrm{S} / \mathrm{cm} \text { at } \\
25^{\circ} \mathrm{C}\end{array}$ & $\begin{array}{l}\text { Temper- } \\
\text { ature, } \\
\text { water, } \\
{ }^{\circ} \mathrm{C}\end{array}$ & $\begin{array}{c}\text { Dis- } \\
\text { solved } \\
\text { solids } \\
\text { dried at } \\
180^{\circ} \mathrm{C}, \\
\text { water, } \\
\text { filtered, } \\
\mathrm{mg} / \mathrm{L}\end{array}$ & $\begin{array}{c}\text { Seewald } \\
\text { dissolved } \\
\text { solids } \\
\text { dried at } \\
180^{\circ} \mathrm{C}, \\
\text { water, } \\
\text { filtered, } \\
\text { mg/L }\end{array}$ & $\begin{array}{l}\text { Dissolved } \\
\text { solids, } \\
\text { water, } \\
\text { filtered, } \\
\text { sum of } \\
\text { constitu- } \\
\text { ents, } \\
\text { mg/L }\end{array}$ & $\begin{array}{c}\text { Seewald } \\
\text { dissolved } \\
\text { solids } \\
\text { dried at } \\
180^{\circ} \mathrm{C}, \\
\text { water, } \\
\text { filtered, } \\
\text { mg/L }\end{array}$ & $\begin{array}{c}\text { Dissolved } \\
\text { solids, } \\
\text { water, } \\
\text { filtered, } \\
\text { sum of } \\
\text { constitu- } \\
\text { ents, } \\
\text { mg/L }\end{array}$ \\
\hline & & & & & 00300 & 00400 & 00403 & 90095 & 00095 & 00010 & 70300 & 70300 & 70301 & 70300 & 70301 \\
\hline PI 620 & 1 & 7/16/2015 & 1000 & 341PGPK & 9.4 & 5.5 & E6.6 & E65 & 71 & 9.5 & 52 & 43 & E37 & 43 & E37 \\
\hline PI 621 & 1 & 7/9/2015 & 1300 & 341PGPK & 9.8 & 6 & E6.8 & E71 & 70 & 9.8 & 44 & 10 & 41 & 10 & 41 \\
\hline PI 634 & 2 & 8/4/2015 & 930 & 341LCKX & 5.6 & 7.1 & 7.5 & 228 & 215 & 11.1 & 133 & 118 & E135 & 118 & E135 \\
\hline PI 641 & 2 & 9/22/2015 & 1030 & 341LCKX & 0.1 & 8.1 & 8.1 & 233 & 217 & 11 & 136 & 155 & 136 & 155 & 136 \\
\hline PI 592 & 3 & 6/24/2015 & 1100 & 341DLRV & 0.2 & 8.7 & 8.5 & 333 & 324 & 11.1 & 185 & 155 & 188 & 155 & 188 \\
\hline PI 592 & 3 & $6 / 24 / 2015$ & 1101 & 341DLRV & -- & -- & 8.6 & 329 & -- & -- & 185 & 164 & 185 & 164 & 185 \\
\hline PI 651 & 3 & 9/22/2015 & 1100 & 341DLRV & 0.1 & 8.7 & 8.6 & 277 & 267 & 12.4 & 157 & 131 & 161 & 131 & 161 \\
\hline PI 608 & 4 & 7/15/2015 & 930 & 341DLRV & M & 7.5 & 7.8 & 218 & 208 & 10.5 & 137 & 157 & E121 & 157 & E121 \\
\hline PI 638 & 4 & 8/5/2015 & 1600 & 341DLRV & 0.1 & 6.5 & 7.3 & 456 & 440 & 10.2 & 272 & 253 & 237 & 253 & 237 \\
\hline PI 524 & 5 & 6/25/2015 & 1500 & 341TMSG & $<0.01$ & 8.2 & 8.4 & 302 & 287 & 11.4 & 162 & 82 & 176 & 82 & 176 \\
\hline PI 524 & 5 & 9/22/2015 & 1330 & 341TMSG & 0.1 & 8.4 & 8.4 & 297 & 275 & 11.4 & 177 & 173 & 166 & 173 & 166 \\
\hline PI 524 & 5 & 9/22/2015 & 1331 & 341TMSG & -- & -- & 8.3 & 293 & -- & -- & 176 & 179 & 166 & 179 & 166 \\
\hline PI 604 & 5 & 9/21/2015 & 1500 & 341TMSG & 1.9 & 7.8 & 8.1 & 228 & 215 & 11 & 129 & 138 & 132 & 138 & 132 \\
\hline PI 622 & 6 & $7 / 14 / 2015$ & 1600 & 344MNNG & 0.1 & 8.7 & 8.4 & 273 & 267 & 12.2 & 161 & 183 & 164 & 183 & 164 \\
\hline PI 640 & 6 & 9/21/2015 & 1400 & 344MNNG & 1.1 & 7.2 & 7.7 & 282 & 251 & 13 & 161 & 180 & 155 & 180 & 155 \\
\hline PI 648 & 7 & 9/24/2015 & 1300 & 344MRCL & 5.9 & 9 & 8.9 & 245 & 229 & 12.2 & 153 & 120 & 149 & 120 & 149 \\
\hline PI 649 & 7 & 9/24/2015 & 1030 & 344MRCL & 5.6 & 6.4 & 7.2 & 252 & 235 & 12.2 & 146 & 148 & 148 & 148 & 148 \\
\hline
\end{tabular}


Table A4-1. Field measurements and results of laboratory analyses for major and minor ions, nutrients, bacteria, trace metals, radioactivity, radon-222, and dissolved gases in groundwater samples collected from 7 pairs of two closely-spaced wells in Pike County, Pennsylvania, 2015.—Continued

[Constituents listed with associated 5-digit U.S. Geological Survey parameter code; shading indicates well pairs; --, no data; <, less than; >, greater than; E, estimated; M, presence verified but not quantified; $\mathrm{R}$, non-detect for radiological analysis; $\mathrm{U}$, analyzed for but not detected; lab, laboratory; \%, percent; $\mathrm{mg} / \mathrm{L}$, milligrams per liter; $\mu \mathrm{S} / \mathrm{cm}$, microsiemens per centimeter; ${ }^{\circ} \mathrm{C}$, degrees $\mathrm{Celsius;}$ CaCO${ }_{3}$, calcium carbonate; $\mu \mathrm{g} / \mathrm{L}$, micrograms per liter; MPN, most probable number; pCi/L, picocuries per liter; Geologic units: 341DLRV, Delaware River Formation; 341LCKX, Lackawaxen Formation; 341PGPK, Poplar Gap and Packerton Members of Catskill Formation, Undivided; 341TMRK, Trimmers Rock Formation; 341TMSG, Towamensing Member of Catskill Formation; 344MNNG, Mahantango Formation; 344MRCL, Marcellus Shale]

\begin{tabular}{|c|c|c|c|c|c|c|c|c|c|c|c|}
\hline \multirow[t]{2}{*}{$\begin{array}{c}\text { Local } \\
\text { identifier }\end{array}$} & \multirow[t]{2}{*}{$\begin{array}{c}\text { Pair } \\
\text { number }\end{array}$} & \multirow[t]{2}{*}{ Date } & \multirow[t]{2}{*}{$\begin{array}{c}\text { Sample } \\
\text { start time }\end{array}$} & \multirow[t]{2}{*}{$\begin{array}{l}\text { Geologic } \\
\text { unit code }\end{array}$} & $\begin{array}{l}\text { Hardness, } \\
\text { water, } \\
\text { mg/L as } \\
\mathrm{CaCO}_{3}\end{array}$ & $\begin{array}{c}\text { Suspended } \\
\text { solids, dried } \\
\text { at } 105^{\circ} \mathrm{C} \text {, } \\
\text { water, } \\
\text { ma/L }\end{array}$ & $\begin{array}{c}\text { Calcium, } \\
\text { water, } \\
\text { filtered, } \\
\text { mg/L }\end{array}$ & $\begin{array}{c}\text { Calcium, } \\
\text { water, } \\
\text { unfiltered, } \\
\text { recoverable, } \\
\mathrm{mq} / \mathrm{L}\end{array}$ & $\begin{array}{c}\text { Magnesium, } \\
\text { water, } \\
\text { filtered, } \\
\text { mg/L }\end{array}$ & $\begin{array}{c}\text { Magnesium, } \\
\text { water, } \\
\text { unfiltered, } \\
\text { recoverable, } \\
\text { ma/L }\end{array}$ & $\begin{array}{c}\text { Potassium, } \\
\text { water, } \\
\text { filtered, } \\
\text { mg/L }\end{array}$ \\
\hline & & & & & 00900 & 70293 & 00915 & 00916 & 00925 & 00927 & 00935 \\
\hline PI 620 & 1 & $7 / 16 / 2015$ & 1000 & 341PGPK & 19.7 & 19 & 6.36 & 6.1 & 0.914 & 0.91 & 0.5 \\
\hline PI 621 & 1 & 7/9/2015 & 1300 & 341PGPK & 26.3 & 7 & 8.6 & 8.38 & 1.16 & 1.18 & 0.5 \\
\hline PI 634 & 2 & 8/4/2015 & 930 & 341LCKX & 89.8 & $<5$ & 26.9 & 25.8 & 5.33 & 5.06 & 0.9 \\
\hline PI 641 & 2 & 9/22/2015 & 1030 & 341LCKX & 82.1 & $<5$ & 24.7 & 25.9 & 4.47 & 4.52 & 0.79 \\
\hline PI 592 & 3 & 6/24/2015 & 1100 & 341DLRV & 17.2 & $<5$ & 4.41 & 4.13 & 1.36 & 1.24 & 0.77 \\
\hline PI 592 & 3 & 6/24/2015 & 1101 & 341DLRV & 16.5 & $<5$ & 4.23 & 4.16 & 1.3 & 1.25 & 0.72 \\
\hline PI 651 & 3 & 9/22/2015 & 1100 & 341DLRV & 23.4 & 5 & 6.26 & 6.56 & 1.82 & 1.83 & 0.59 \\
\hline PI 608 & 4 & $7 / 15 / 2015$ & 930 & 341DLRV & 86.1 & $<5$ & 21.3 & 20.4 & 7.89 & 7.84 & 0.45 \\
\hline PI 638 & 4 & 8/5/2015 & 1600 & 341DLRV & 140 & $<5$ & 32.9 & 34.2 & 13.4 & 14.6 & 1.12 \\
\hline PI 524 & 5 & 6/25/2015 & 1500 & 341TMSG & 58.9 & $<5$ & 14.4 & 14.3 & 5.39 & 4.91 & 0.24 \\
\hline PI 524 & 5 & 9/22/2015 & 1330 & 341TMSG & 55.6 & $<5$ & 13.7 & 14.3 & 5.04 & 5.31 & 0.26 \\
\hline PI 524 & 5 & 9/22/2015 & 1331 & 341TMSG & 57.1 & $<5$ & 14 & 14.2 & 5.19 & 5.31 & 0.26 \\
\hline PI 604 & 5 & 9/21/2015 & 1500 & 341TMSG & 90.5 & 161 & 26.8 & 26.8 & 5.74 & 5.62 & 0.76 \\
\hline PI 622 & 6 & $7 / 14 / 2015$ & 1600 & 344MNNG & 43.8 & 36 & 12 & 11.4 & 3.08 & 2.42 & 0.44 \\
\hline PI 640 & 6 & 9/21/2015 & 1400 & 344MNNG & 103 & 5 & 27.9 & 28.8 & 7.97 & 8.43 & 0.34 \\
\hline PI 648 & 7 & 9/24/2015 & 1300 & 344MRCL & 18.1 & 5 & 5.79 & 5.85 & 0.81 & 0.83 & 0.23 \\
\hline PI 649 & 7 & 9/24/2015 & 1030 & 344MRCL & 86.4 & $<5$ & 25.7 & 24.8 & 5.28 & 5.25 & 0.66 \\
\hline
\end{tabular}


Table A4-1. Field measurements and results of laboratory analyses for major and minor ions, nutrients, bacteria, trace metals, radioactivity, radon-222, and dissolved gases in groundwater samples collected from 7 pairs of two closely-spaced wells in Pike County, Pennsylvania, 2015.-Continued

[Constituents listed with associated 5-digit U.S. Geological Survey parameter code; shading indicates well pairs; --, no data; <, less than; >, greater than; E, estimated; M, presence verified but not quantified; $\mathrm{R}$, non-detect for radiological analysis; $\mathrm{U}$, analyzed for but not detected; lab, laboratory; \%, percent; $\mathrm{mg} / \mathrm{L}$, milligrams per liter; $\mu \mathrm{S} / \mathrm{cm}$, microsiemens per centimeter; ${ }^{\circ} \mathrm{C}$, degrees $\mathrm{Celsius;} \mathrm{CaCO}{ }_{3}$, calcium carbonate; $\mu \mathrm{g} / \mathrm{L}$, micrograms per liter; MPN, most probable number; pCi/L, picocuries per liter; Geologic units: 341DLRV, Delaware River Formation; 341LCKX, Lackawaxen Formation; 341PGPK, Poplar Gap and Packerton Members of Catskill Formation, Undivided; 341TMRK, Trimmers Rock Formation; 341TMSG, Towamensing Member of Catskill Formation; 344MNNG, Mahantango Formation; 344MRCL, Marcellus Shale]

\begin{tabular}{|c|c|c|c|c|c|c|c|c|c|c|c|c|}
\hline $\begin{array}{l}\text { Local } \\
\text { identi- } \\
\text { fier }\end{array}$ & $\begin{array}{c}\text { Pair } \\
\text { number }\end{array}$ & Date & $\begin{array}{l}\text { Sam- } \\
\text { ple } \\
\text { start } \\
\text { time }\end{array}$ & $\begin{array}{l}\text { Potassium, } \\
\text { water, } \\
\text { unfiltered, } \\
\text { recoverable, } \\
\text { mg/L }\end{array}$ & $\begin{array}{c}\text { Sodium } \\
\text { adsorption } \\
\text { ratio (SAR), } \\
\text { water, } \\
\text { number }\end{array}$ & 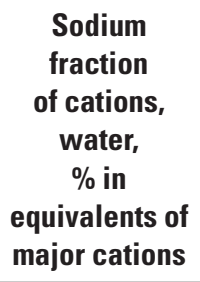 & $\begin{array}{c}\text { Sodium, } \\
\text { water, } \\
\text { filtered, } \\
\text { mg/L }\end{array}$ & $\begin{array}{c}\text { Sodium, } \\
\text { water, } \\
\text { unfiltered, } \\
\text { recoverable, } \\
\text { mg/L }\end{array}$ & $\begin{array}{c}\text { Alkalinity, } \\
\text { water, filtered, } \\
\text { fixed endpoint } \\
\text { (pH 4.5) } \\
\text { titration, lab, } \\
\text { mg/L as } \mathrm{CaCO}_{3}\end{array}$ & $\begin{array}{c}\text { Bromide, } \\
\text { water, } \\
\text { filtered, } \\
\mu \mathrm{g} / \mathrm{L}\end{array}$ & $\begin{array}{c}\text { Bromide, } \\
\text { water, } \\
\text { filtered, } \\
\text { mg/L }\end{array}$ & $\begin{array}{c}\text { Bromide, } \\
\text { water, } \\
\text { unfiltered, } \\
\text { mg/L }\end{array}$ \\
\hline & & & & 00937 & 00931 & 00932 & 00930 & 00929 & 29801 & 91000 & 71870 & 63689 \\
\hline PI 620 & 1 & $7 / 16 / 2015$ & 1000 & 0.5 & 0.35 & 28 & 3.59 & 3.49 & 9.8 & $<10$ & E0.011 & $<0.10$ \\
\hline PI 621 & 1 & 7/9/2015 & 1300 & 0.78 & 0.18 & 14 & 2.09 & 1.9 & 19.5 & $<10$ & -- & $<0.10$ \\
\hline PI 634 & 2 & 8/4/2015 & 930 & 0.95 & 0.62 & 24 & 13.5 & 13.4 & 83.4 & 24 & E0.017 & $<0.10$ \\
\hline PI 641 & 2 & 9/22/2015 & 1030 & 0.86 & 0.72 & 28 & 14.7 & 16.3 & 96.8 & 10 & 0.013 & $<0.10$ \\
\hline PI 592 & 3 & $6 / 24 / 2015$ & 1100 & 0.71 & 7.27 & 89 & 68.1 & 63.3 & 117 & 360 & -- & 0.16 \\
\hline PI 592 & 3 & $6 / 24 / 2015$ & 1101 & 0.71 & 7.13 & 89 & 65.4 & 63.2 & 117 & 350 & -- & 0.16 \\
\hline PI 651 & 3 & 9/22/2015 & 1100 & 0.63 & 4.77 & 83 & 52.7 & 53.9 & 120 & 170 & 0.15 & 0.65 \\
\hline PI 608 & 4 & $7 / 15 / 2015$ & 930 & 0.5 & 0.36 & 16 & 7.67 & $<7.19$ & 44.8 & 24 & E0.019 & $<0.10$ \\
\hline PI 638 & 4 & 8/5/2015 & 1600 & 1.17 & 1.03 & 30 & 27.8 & 28 & 65.3 & 26 & 0.023 & $<0.10$ \\
\hline PI 524 & 5 & $6 / 25 / 2015$ & 1500 & $<0.50$ & 2.66 & 63 & 46.6 & 45.2 & 123 & 220 & -- & $<0.10$ \\
\hline PI 524 & 5 & 9/22/2015 & 1330 & $<0.50$ & 2.35 & 61 & 40 & 43.1 & 121 & 170 & 0.166 & $<0.10$ \\
\hline PI 524 & 5 & 9/22/2015 & 1331 & $<0.50$ & 2.37 & 61 & 40.8 & 45.2 & 120 & -- & 0.16 & $<0.10$ \\
\hline PI 604 & 5 & $9 / 21 / 2015$ & 1500 & 0.82 & 0.72 & 27 & 15.8 & 16.5 & 118 & $<10$ & $<0.010$ & $<0.10$ \\
\hline PI 622 & 6 & $7 / 14 / 2015$ & 1600 & $<0.50$ & 3.13 & 70 & 47 & 44.6 & 114 & 50 & 0.042 & $<0.10$ \\
\hline PI 640 & 6 & 9/21/2015 & 1400 & $<0.50$ & 0.57 & 22 & 13.3 & 14.7 & 83 & 23 & 0.017 & $<0.10$ \\
\hline PI 648 & 7 & 9/24/2015 & 1300 & $<0.50$ & 5 & 85 & 48.4 & 51.8 & 114 & 23 & 0.02 & $<0.10$ \\
\hline PI 649 & 7 & 9/24/2015 & 1030 & 0.86 & 0.69 & 27 & 14.7 & 15.2 & 49.8 & 14 & 0.013 & $<0.10$ \\
\hline
\end{tabular}


Table A4-1. Field measurements and results of laboratory analyses for major and minor ions, nutrients, bacteria, trace metals, radioactivity, radon-222, and dissolved gases in groundwater samples collected from 7 pairs of two closely-spaced wells in Pike County, Pennsylvania, 2015.—Continued

[Constituents listed with associated 5-digit U.S. Geological Survey parameter code; shading indicates well pairs; --, no data; <, less than; >, greater than; E, estimated; M, presence verified but not quantified; $\mathrm{R}$, non-detect for radiological analysis; $\mathrm{U}$, analyzed for but not detected; lab, laboratory; \%, percent; $\mathrm{mg} / \mathrm{L}$, milligrams per liter; $\mu \mathrm{S} / \mathrm{cm}$, microsiemens per centimeter; ${ }^{\circ} \mathrm{C}$, degrees $\mathrm{Celsius;} \mathrm{CaCO}{ }_{3}$, calcium carbonate; $\mu \mathrm{g} / \mathrm{L}$, micrograms per liter; MPN, most probable number; pCi/L, picocuries per liter; Geologic units: 341DLRV, Delaware River Formation; 341LCKX, Lackawaxen Formation; 341PGPK, Poplar Gap and Packerton Members of Catskill Formation, Undivided; 341TMRK, Trimmers Rock Formation; 341TMSG, Towamensing Member of Catskill Formation; 344MNNG, Mahantango Formation; 344MRCL, Marcellus Shale]

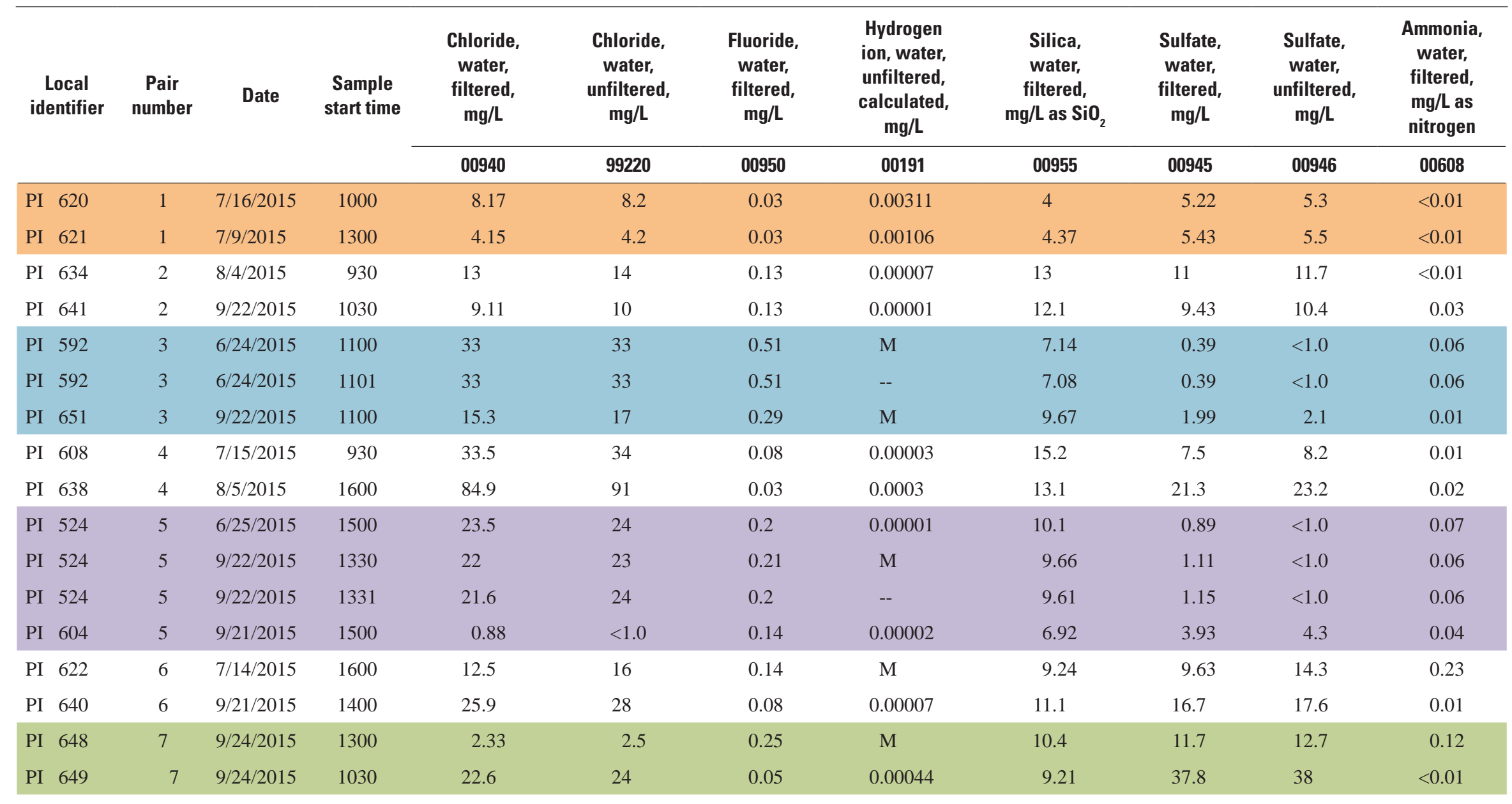


Table A4-1. Field measurements and results of laboratory analyses for major and minor ions, nutrients, bacteria, trace metals, radioactivity, radon-222, and dissolved gases in groundwater samples collected from 7 pairs of two closely-spaced wells in Pike County, Pennsylvania, 2015.-Continued

[Constituents listed with associated 5-digit U.S. Geological Survey parameter code; shading indicates well pairs; --, no data; <, less than; >, greater than; E, estimated; M, presence verified but not quantified;

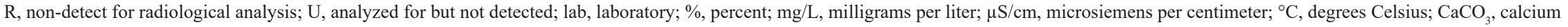
carbonate; $\mu \mathrm{g} / \mathrm{L}$, micrograms per liter; MPN, most probable number; pCi/L, picocuries per liter; Geologic units: 341DLRV, Delaware River Formation; 341LCKX, Lackawaxen Formation; 341PGPK, Poplar Gap and Packerton Members of Catskill Formation, Undivided; 341TMRK, Trimmers Rock Formation; 341TMSG, Towamensing Member of Catskill Formation; 344MNNG, Mahantango Formation; 344MRCL, Marcellus Shale]

\begin{tabular}{|c|c|c|c|c|c|c|c|c|c|c|c|}
\hline $\begin{array}{l}\text { Local } \\
\text { identifier }\end{array}$ & $\begin{array}{c}\text { Pair } \\
\text { number }\end{array}$ & Date & $\begin{array}{c}\text { Sample } \\
\text { start } \\
\text { time }\end{array}$ & $\begin{array}{c}\text { Nitrate } \\
\text { plus nitrite, } \\
\text { water, } \\
\text { filtered, } \\
\text { mg/L as } \\
\text { nitrogen }\end{array}$ & $\begin{array}{c}\text { Nitrate, } \\
\text { water, } \\
\text { filtered, } \\
\text { mg/L as } \\
\text { nitrogen }\end{array}$ & $\begin{array}{c}\text { Nitrite, } \\
\text { water, } \\
\text { filtered, } \\
\text { mg/L as } \\
\text { nitrogen }\end{array}$ & $\begin{array}{c}\text { Orthophosphate, } \\
\text { water, } \\
\text { filtered, } \\
\text { mg/L as } \\
\text { phosphorus }\end{array}$ & $\begin{array}{l}\text { Escherichia } \\
\text { coli, water, } \\
\text { MPN per } \\
100 \text { milliliters }\end{array}$ & $\begin{array}{c}\text { Total } \\
\text { coliforms, } \\
\text { water, } \\
\text { MPN per } \\
100 \text { milliliters }\end{array}$ & $\begin{array}{c}\text { Aluminum, } \\
\text { water, } \\
\text { filtered, } \\
\mu \mathrm{g} / \mathrm{L}\end{array}$ & $\begin{array}{c}\text { Aluminum, } \\
\text { water, } \\
\text { unfiltered, } \\
\text { recoverable, } \\
\mu \mathrm{g} / \mathrm{L}\end{array}$ \\
\hline & & & & 00631 & 00618 & 00613 & 00671 & 31689 & 31686 & 01106 & 01105 \\
\hline PI 620 & 1 & $7 / 16 / 2015$ & 1000 & 0.58 & 0.577 & 0.002 & 0.018 & $<1$ & $<1$ & 3.6 & M \\
\hline PI 621 & 1 & 7/9/2015 & 1300 & 0.598 & 0.598 & $<0.001$ & 0.023 & $<1$ & 28 & $<3.0$ & 600 \\
\hline PI 634 & 2 & 8/4/2015 & 930 & 0.145 & 0.145 & $<0.001$ & 0.019 & $<1$ & $<1$ & $<3.0$ & $<20$ \\
\hline PI 641 & 2 & 9/22/2015 & 1030 & $<0.040$ & $<0.040$ & $<0.001$ & 0.007 & $<1$ & $>1$ & $<3.0$ & M \\
\hline PI 592 & 3 & $6 / 24 / 2015$ & 1100 & $<0.040$ & $<0.040$ & $<0.001$ & 0.174 & $<1$ & 19 & $<3.0$ & M \\
\hline PI 592 & 3 & $6 / 24 / 2015$ & 1101 & $<0.040$ & $<0.040$ & $<0.001$ & 0.178 & $<1$ & $<1$ & 3.5 & M \\
\hline PI 651 & 3 & 9/22/2015 & 1100 & $<0.040$ & $<0.040$ & $<0.001$ & 0.037 & $<1$ & $<1$ & 5.8 & M \\
\hline PI 608 & 4 & 7/15/2015 & 930 & $<0.040$ & $<0.040$ & $<0.001$ & 0.007 & $<1$ & $<1$ & $<3.0$ & M \\
\hline PI 638 & 4 & 8/5/2015 & 1600 & $<0.040$ & $<0.040$ & $<0.001$ & 0.004 & $<1$ & 9 & 3.2 & M \\
\hline PI 524 & 5 & $6 / 25 / 2015$ & 1500 & $<0.040$ & $<0.040$ & $<0.001$ & 0.029 & $<1$ & $<1$ & $<3.0$ & M \\
\hline PI 524 & 5 & 9/22/2015 & 1330 & $<0.040$ & $<0.040$ & $<0.001$ & 0.027 & $<1$ & $<1$ & $<3.0$ & M \\
\hline PI 524 & 5 & 9/22/2015 & 1331 & $<0.040$ & $<0.040$ & $<0.001$ & 0.027 & $<1$ & $<1$ & $<3.0$ & M \\
\hline PI 604 & 5 & 9/21/2015 & 1500 & $<0.040$ & $<0.040$ & $<0.001$ & 0.023 & $<1$ & $<1$ & 9.5 & 200 \\
\hline PI 622 & 6 & 7/14/2015 & 1600 & $<0.040$ & $<0.040$ & $<0.001$ & 0.017 & $<1$ & 3 & 7.6 & M \\
\hline PI 640 & 6 & 9/21/2015 & 1400 & 0.235 & 0.235 & $<0.001$ & 0.015 & $<1$ & 43 & 10.5 & 100 \\
\hline PI 648 & 7 & 9/24/2015 & 1300 & $<0.040$ & $<0.040$ & $<0.001$ & 0.017 & -- & 9 & 20.3 & M \\
\hline PI 649 & 7 & 9/24/2015 & 1030 & 0.204 & 0.204 & $<0.001$ & 0.026 & -- & 10 & 402 & 300 \\
\hline
\end{tabular}


Table A4-1. Field measurements and results of laboratory analyses for major and minor ions, nutrients, bacteria, trace metals, radioactivity, radon-222, and dissolved gases in groundwater samples collected from 7 pairs of two closely-spaced wells in Pike County, Pennsylvania, 2015.—Continued

[Constituents listed with associated 5-digit U.S. Geological Survey parameter code; shading indicates well pairs; --, no data; <, less than; >, greater than; E, estimated; M, presence verified but not quantified; $\mathrm{R}$, non-detect for radiological analysis; $\mathrm{U}$, analyzed for but not detected; lab, laboratory; \%, percent; $\mathrm{mg} / \mathrm{L}$, milligrams per liter; $\mu \mathrm{S} / \mathrm{cm}$, microsiemens per centimeter; ${ }^{\circ} \mathrm{C}$, degrees $\mathrm{Celsius;}$ CaCO${ }_{3}$, calcium carbonate; $\mu \mathrm{g} / \mathrm{L}$, micrograms per liter; MPN, most probable number; pCi/L, picocuries per liter; Geologic units: 341DLRV, Delaware River Formation; 341LCKX, Lackawaxen Formation; 341PGPK, Poplar Gap and Packerton Members of Catskill Formation, Undivided; 341TMRK, Trimmers Rock Formation; 341TMSG, Towamensing Member of Catskill Formation; 344MNNG, Mahantango Formation; 344MRCL, Marcellus Shale]

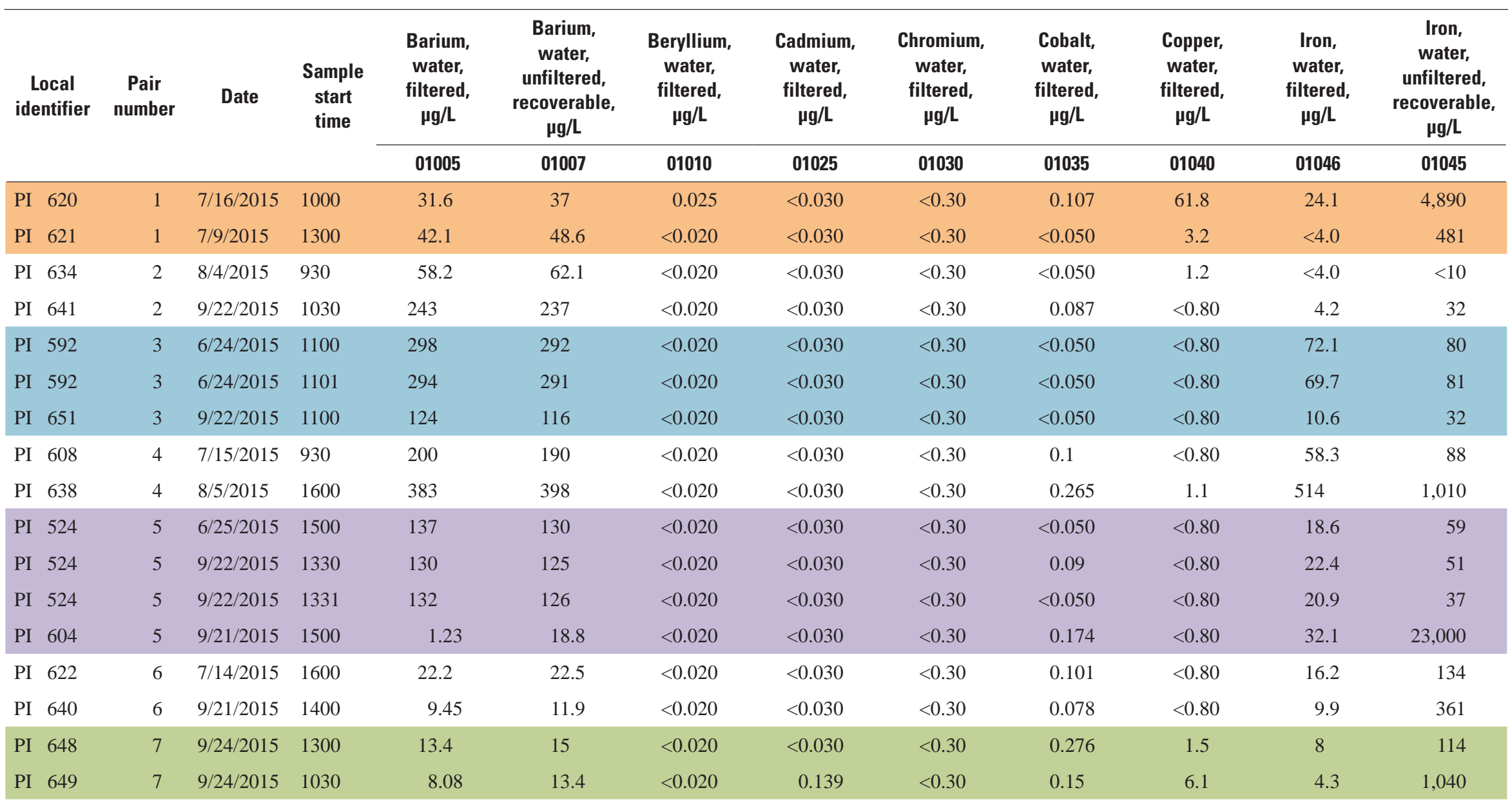


Table A4-1. Field measurements and results of laboratory analyses for major and minor ions, nutrients, bacteria, trace metals, radioactivity, radon-222, and dissolved gases in groundwater samples collected from 7 pairs of two closely-spaced wells in Pike County, Pennsylvania, 2015.-Continued

[Constituents listed with associated 5-digit U.S. Geological Survey parameter code; shading indicates well pairs; --, no data; <, less than; >, greater than; E, estimated; M, presence verified but not quantified; $\mathrm{R}$, non-detect for radiological analysis; $\mathrm{U}$, analyzed for but not detected; lab, laboratory; \%, percent; $\mathrm{mg} / \mathrm{L}$, milligrams per liter; $\mu \mathrm{S} / \mathrm{cm}$, microsiemens per centimeter; ${ }^{\circ} \mathrm{C}$, degrees $\mathrm{Celsius;} \mathrm{CaCO}{ }_{3}$, calcium carbonate; $\mu \mathrm{g} / \mathrm{L}$, micrograms per liter; MPN, most probable number; pCi/L, picocuries per liter; Geologic units: 341DLRV, Delaware River Formation; 341LCKX, Lackawaxen Formation; 341PGPK, Poplar Gap and Packerton Members of Catskill Formation, Undivided; 341TMRK, Trimmers Rock Formation; 341TMSG, Towamensing Member of Catskill Formation; 344MNNG, Mahantango Formation; 344MRCL, Marcellus Shale]

\begin{tabular}{|c|c|c|c|c|c|c|c|c|c|c|c|c|}
\hline $\begin{array}{l}\text { Local } \\
\text { identifier }\end{array}$ & $\begin{array}{c}\text { Pair } \\
\text { number }\end{array}$ & Date & $\begin{array}{c}\text { Sample } \\
\text { start } \\
\text { time }\end{array}$ & $\begin{array}{c}\text { Lead, } \\
\text { water, } \\
\text { filtered, } \\
\mu \mathrm{g} / \mathrm{L}\end{array}$ & $\begin{array}{c}\text { Lithium, } \\
\text { water, } \\
\text { filtered, } \\
\mu \mathrm{g} / \mathrm{L}\end{array}$ & $\begin{array}{c}\text { Lithium, } \\
\text { water, } \\
\text { unfiltered, } \\
\text { recoverable, } \\
\mu \mathrm{g} / \mathrm{L}\end{array}$ & $\begin{array}{c}\text { Manganese, } \\
\text { water, } \\
\text { filtered, } \\
\mu \mathrm{g} / \mathrm{L}\end{array}$ & $\begin{array}{c}\text { Manganese, } \\
\text { water, } \\
\text { unfiltered, } \\
\text { recoverable, } \\
\mu \mathrm{g} / \mathrm{L}\end{array}$ & $\begin{array}{c}\text { Molybdenum, } \\
\text { water, } \\
\text { filtered, } \\
\mu \mathrm{g} / \mathrm{L}\end{array}$ & $\begin{array}{c}\text { Nickel, } \\
\text { water, } \\
\text { filtered, } \\
\mu \mathrm{g} / \mathrm{L}\end{array}$ & $\begin{array}{c}\text { Strontium, } \\
\text { water, } \\
\text { filtered, } \\
\mu \mathrm{g} / \mathrm{L}\end{array}$ & $\begin{array}{c}\text { Strontium, } \\
\text { water, } \\
\text { unfiltered, } \\
\text { recoverable, } \\
\mu \mathrm{g} / \mathrm{L}\end{array}$ \\
\hline & & & & 01049 & 01130 & 01132 & 01056 & 01055 & 01060 & 01065 & 01080 & 01082 \\
\hline PI 620 & 1 & 7/16/2015 & 1000 & 1.38 & 2.06 & $<10$ & 5.48 & 16.8 & $<0.050$ & 0.78 & 10.8 & 11 \\
\hline PI 621 & 1 & 7/9/2015 & 1300 & 0.096 & 4.02 & $<10$ & 0.43 & 12 & $<0.050$ & $<0.20$ & 23.8 & 25 \\
\hline PI 634 & 2 & 8/4/2015 & 930 & 0.156 & 42 & 50 & 0.82 & $<10.0$ & 0.127 & $<0.20$ & 448 & 459 \\
\hline PI 641 & 2 & 9/22/2015 & 1030 & 0.06 & 47.9 & 50 & 122 & 131 & 0.065 & $<0.20$ & 1,550 & 1,590 \\
\hline PI 592 & 3 & $6 / 24 / 2015$ & 1100 & 0.377 & 289 & 270 & 83.7 & 80.9 & 0.606 & $<0.20$ & 331 & 325 \\
\hline PI 592 & 3 & $6 / 24 / 2015$ & 1101 & 0.35 & 282 & 270 & 83 & 80.4 & 0.623 & $<0.20$ & 331 & 327 \\
\hline PI 651 & 3 & $9 / 22 / 2015$ & 1100 & $<0.040$ & 184 & 210 & 25.2 & 23.2 & 0.371 & $<0.20$ & 185 & 194 \\
\hline PI 608 & 4 & 7/15/2015 & 930 & 0.165 & 10.3 & 10 & 318 & 331 & $<0.050$ & $<0.20$ & 334 & 339 \\
\hline PI 638 & 4 & 8/5/2015 & 1600 & 0.322 & 68.5 & 80 & 450 & 436 & $<0.050$ & 0.23 & 1,830 & 1,900 \\
\hline PI 524 & 5 & $6 / 25 / 2015$ & 1500 & $<0.040$ & 136 & 140 & 18.4 & 18.4 & 0.353 & $<0.20$ & 488 & 490 \\
\hline PI 524 & 5 & $9 / 22 / 2015$ & 1330 & $<0.040$ & 118 & 130 & 20.3 & 18.9 & 0.367 & $<0.20$ & 472 & 485 \\
\hline PI 524 & 5 & 9/22/2015 & 1331 & $<0.040$ & 122 & 140 & 19.9 & 18.2 & 0.371 & $<0.20$ & 475 & 500 \\
\hline PI 604 & 5 & 9/21/2015 & 1500 & $<0.040$ & 1.85 & $<10$ & 27 & 1,850 & 0.827 & 0.4 & 40.2 & 46 \\
\hline PI 622 & 6 & 7/14/2015 & 1600 & 0.054 & 106 & 110 & 18.6 & 19.2 & 0.156 & $<0.20$ & 947 & 958 \\
\hline PI 640 & 6 & 9/21/2015 & 1400 & 0.088 & 26.6 & 30 & 11.7 & 22 & 0.101 & $<0.20$ & 682 & 706 \\
\hline PI 648 & 7 & 9/24/2015 & 1300 & 0.117 & 115 & 120 & 2.55 & 3.2 & 0.081 & 0.23 & 264 & 260 \\
\hline PI 649 & 7 & 9/24/2015 & 1030 & 0.076 & 11.5 & 10 & 11.9 & 193 & $<0.050$ & 1.4 & 402 & 369 \\
\hline
\end{tabular}


Table A4-1. Field measurements and results of laboratory analyses for major and minor ions, nutrients, bacteria, trace metals, radioactivity, radon-222, and dissolved gases in groundwater samples collected from 7 pairs of two closely-spaced wells in Pike County, Pennsylvania, 2015.—Continued

[Constituents listed with associated 5-digit U.S. Geological Survey parameter code; shading indicates well pairs; --, no data; <, less than; >, greater than; E, estimated; M, presence verified but not quantified; $\mathrm{R}$, non-detect for radiological analysis; $\mathrm{U}$, analyzed for but not detected; lab, laboratory; \%, percent; $\mathrm{mg} / \mathrm{L}$, milligrams per liter; $\mu \mathrm{S} / \mathrm{cm}$, microsiemens per centimeter; ${ }^{\circ} \mathrm{C}$, degrees $\mathrm{Celsius;}$ CaCO${ }_{3}$, calcium carbonate; $\mu \mathrm{g} / \mathrm{L}$, micrograms per liter; MPN, most probable number; pCi/L, picocuries per liter; Geologic units: 341DLRV, Delaware River Formation; 341LCKX, Lackawaxen Formation; 341PGPK, Poplar Gap and Packerton Members of Catskill Formation, Undivided; 341TMRK, Trimmers Rock Formation; 341TMSG, Towamensing Member of Catskill Formation; 344MNNG, Mahantango Formation; 344MRCL, Marcellus Shale]

\begin{tabular}{|c|c|c|c|c|c|c|c|c|c|c|c|}
\hline \multirow[t]{2}{*}{$\begin{array}{c}\text { Local } \\
\text { identifier }\end{array}$} & \multirow[t]{2}{*}{$\begin{array}{c}\text { Pair } \\
\text { number }\end{array}$} & \multirow[t]{2}{*}{ Date } & \multirow[t]{2}{*}{$\begin{array}{c}\text { Sample } \\
\text { start } \\
\text { time }\end{array}$} & $\begin{array}{c}\text { Zinc, } \\
\text { water, } \\
\text { filtered, } \\
\mu \mathrm{g} / \mathrm{L}\end{array}$ & $\begin{array}{c}\text { Zinc, } \\
\text { water, } \\
\text { unfiltered, } \\
\text { recoverable, } \\
\mu \mathrm{q} / \mathrm{L}\end{array}$ & $\begin{array}{c}\text { Antimony, } \\
\text { water, } \\
\text { filtered, } \\
\mu \mathrm{g} / \mathrm{L}\end{array}$ & $\begin{array}{c}\text { Arsenic, } \\
\text { water, } \\
\text { filtered, } \\
\mu \mathrm{g} / \mathrm{L}\end{array}$ & $\begin{array}{c}\text { Arsenic, } \\
\text { water, } \\
\text { unfiltered, } \\
\mu \mathrm{g} / \mathrm{L}\end{array}$ & $\begin{array}{c}\text { Boron, } \\
\text { water, } \\
\text { filtered, } \\
\mu \mathrm{g} / \mathrm{L}\end{array}$ & $\begin{array}{c}\text { Selenium, } \\
\text { water, } \\
\text { filtered, } \\
\mu \mathrm{g} / \mathrm{L}\end{array}$ & $\begin{array}{c}\text { Selenium, } \\
\text { water, } \\
\text { unfiltered, } \\
\mu \mathrm{g} / \mathrm{L}\end{array}$ \\
\hline & & & & 01090 & 01092 & 01095 & 01000 & 01002 & 01020 & 01145 & 01147 \\
\hline PI 620 & 1 & 7/16/2015 & 1000 & 9.7 & 10 & 0.038 & $<0.10$ & 3 & $<5$ & $<0.05$ & $<2$ \\
\hline PI 621 & 1 & 7/9/2015 & 1300 & 8.6 & 10 & $<0.027$ & 1 & 2 & $<5$ & $<0.05$ & $<2$ \\
\hline PI 634 & 2 & 8/4/2015 & 930 & 3.4 & $<5$ & 0.057 & 0.71 & $<0.5$ & 23 & 0.1 & $<2$ \\
\hline PI 641 & 2 & 9/22/2015 & 1030 & 2.2 & 420 & 0.028 & 1.1 & 1 & 22 & $<0.05$ & $<2$ \\
\hline PI 592 & 3 & 6/24/2015 & 1100 & $<2.0$ & 20 & $<0.027$ & 27.8 & 31 & 117 & $<0.05$ & $<2$ \\
\hline PI 592 & 3 & 6/24/2015 & 1101 & $<2.0$ & 20 & $<0.027$ & 27.8 & 32 & 118 & $<0.05$ & $<2$ \\
\hline PI 651 & 3 & 9/22/2015 & 1100 & $<2.0$ & M & $<0.027$ & 6.2 & 6 & 73 & $<0.05$ & $<2$ \\
\hline PI 608 & 4 & 7/15/2015 & 930 & $<2.0$ & M & 0.053 & 1.1 & 1 & 5 & $<0.05$ & $<2$ \\
\hline PI 638 & 4 & 8/5/2015 & 1600 & 2.3 & M & 0.04 & 1 & 2 & 31 & $<0.05$ & $<2$ \\
\hline PI 524 & 5 & $6 / 25 / 2015$ & 1500 & $<2.0$ & $<0.5$ & $<0.027$ & 0.24 & $<0.5$ & 84 & $<0.05$ & $<2$ \\
\hline PI 524 & 5 & 9/22/2015 & 1330 & $<2.0$ & $<0.5$ & $<0.027$ & 0.23 & $<0.5$ & 79 & $<0.05$ & $<2$ \\
\hline PI 524 & 5 & 9/22/2015 & 1331 & $<2.0$ & $<0.5$ & $<0.027$ & 0.23 & $<0.5$ & 79 & $<0.05$ & $<2$ \\
\hline PI 604 & 5 & 9/21/2015 & 1500 & $<2.0$ & M & 0.087 & 0.58 & 1 & 13 & $<0.05$ & $<2$ \\
\hline PI 622 & 6 & 7/14/2015 & 1600 & $<2.0$ & M & 0.033 & $<0.10$ & $<0.5$ & 156 & $<0.05$ & 4 \\
\hline PI 640 & 6 & 9/21/2015 & 1400 & 36.7 & 70 & $<0.027$ & 0.13 & $<0.5$ & 41 & $<0.05$ & $<2$ \\
\hline PI 648 & 7 & 9/24/2015 & 1300 & $<2.0$ & $<0.5$ & 0.05 & $<0.10$ & $<0.5$ & 139 & $<0.05$ & $<2$ \\
\hline PI 649 & 7 & 9/24/2015 & 1030 & 6.4 & 20 & $<0.027$ & $<0.10$ & M & 15 & 0.1 & $<2$ \\
\hline
\end{tabular}


Table A4-1. Field measurements and results of laboratory analyses for major and minor ions, nutrients, bacteria, trace metals, radioactivity, radon-222, and dissolved gases in groundwater samples collected from 7 pairs of two closely-spaced wells in Pike County, Pennsylvania, 2015.-Continued

[Constituents listed with associated 5-digit U.S. Geological Survey parameter code; shading indicates well pairs; --, no data; <, less than; >, greater than; E, estimated; M, presence verified but not quantified;

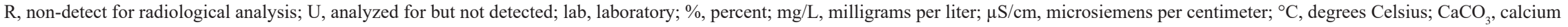
carbonate; $\mu \mathrm{g} / \mathrm{L}$, micrograms per liter; MPN, most probable number; pCi/L, picocuries per liter; Geologic units: 341DLRV, Delaware River Formation; 341LCKX, Lackawaxen Formation; 341PGPK, Poplar Gap and Packerton Members of Catskill Formation, Undivided; 341TMRK, Trimmers Rock Formation; 341TMSG, Towamensing Member of Catskill Formation; 344MNNG, Mahantango Formation; 344MRCL, Marcellus Shale]

\begin{tabular}{|c|c|c|c|c|c|c|c|c|c|c|c|c|c|c|}
\hline $\begin{array}{l}\text { Local } \\
\text { identi- } \\
\text { fier }\end{array}$ & $\begin{array}{c}\text { Pair } \\
\text { num- } \\
\text { ber }\end{array}$ & Date & $\begin{array}{l}\text { Sam- } \\
\text { ple } \\
\text { start } \\
\text { time }\end{array}$ & $\begin{array}{l}\text { Ethane, } \\
\text { water, } \\
\text { dissolved, } \\
\text { recover- } \\
\text { able, } \\
\text { mg/L }\end{array}$ & $\begin{array}{l}\text { Methane, } \\
\text { water, } \\
\text { dissolved, } \\
\text { recover- } \\
\text { able, } \\
\text { mg/L }\end{array}$ & $\begin{array}{c}\text { Organic } \\
\text { carbon, } \\
\text { water, } \\
\text { unfiltered, } \\
\text { mg/L }\end{array}$ & $\begin{array}{l}\text { Propane, } \\
\text { water, } \\
\text { dissolved, } \\
\text { recover- } \\
\text { able, } \\
\text { mg/L }\end{array}$ & $\begin{array}{l}\text { Gross } \\
\text { alpha } \\
\text { radio- } \\
\text { activity, } \\
30 \text { day } \\
\text { recount, } \\
\text { water, } \\
\text { unfiltered, } \\
\text { Th-230 } \\
\text { curve, } \\
\text { pCi/L }\end{array}$ & $\begin{array}{l}\text { Gross } \\
\text { alpha } \\
\text { radio- } \\
\text { activity, } \\
72 \text { hour } \\
\text { count, } \\
\text { water, } \\
\text { unfiltered, } \\
\text { Th-230 } \\
\text { curve, } \\
\text { pCi/L }\end{array}$ & $\begin{array}{c}\text { Gross } \\
\text { beta } \\
\text { radio- } \\
\text { activity, } \\
30 \text { day } \\
\text { recount, } \\
\text { water, } \\
\text { unfiltered, } \\
\text { Cs-137 } \\
\text { curve, } \\
\text { pCi/L }\end{array}$ & $\begin{array}{c}\text { Gross } \\
\text { beta } \\
\text { radio- } \\
\text { activity, } \\
72 \text { hour } \\
\text { count, } \\
\text { water, } \\
\text { unfiltered, } \\
\text { Cs-137 } \\
\text { curve, } \\
\text { pCi/L }\end{array}$ & $\begin{array}{c}\text { Radium- } \\
\text { 226, } \\
\text { water, } \\
\text { unfiltered, } \\
\text { pCi/L }\end{array}$ & $\begin{array}{c}\text { Radon- } \\
\text { 222, } \\
\text { water, } \\
\text { unfiltered, } \\
\text { pCi/L }\end{array}$ & $\begin{array}{c}\text { Uranium } \\
\text { (natural), } \\
\text { water, } \\
\text { filtered, } \\
\mu \mathrm{g} / \mathrm{L}\end{array}$ \\
\hline & & & & 68832 & 68831 & 00680 & 68834 & 63016 & 63014 & 63017 & 63015 & 09501 & 82303 & 22703 \\
\hline PI 620 & 1 & 7/16/2015 & 1000 & $<0.010$ & $<0.010$ & $<0.7$ & $<0.020$ & R0.4 & 1.2 & 4.2 & 2.9 & -- & 1,060 & $<0.014$ \\
\hline PI 621 & 1 & 7/9/2015 & 1300 & $<0.010$ & $<0.010$ & $<0.7$ & $<0.020$ & 1.1 & R0.8 & 2.3 & 2.3 & -- & 2,360 & 0.123 \\
\hline PI 634 & 2 & 8/4/2015 & 930 & $<0.010$ & 0.021 & $<0.7$ & $<0.020$ & R-0.3 & 5.5 & 1.6 & 4.9 & -- & 1,730 & 0.198 \\
\hline PI 641 & 2 & 9/22/2015 & 1030 & $<0.010$ & 0.03 & $<0.7$ & $<0.020$ & 1.7 & 2.1 & 2.7 & 3.4 & 0.45 & 105 & 0.136 \\
\hline PI 592 & 3 & $6 / 24 / 2015$ & 1100 & $<0.100$ & 1.79 & $<0.7$ & $<0.100$ & 0.9 & R0.9 & 1.6 & 2.3 & -- & 1,210 & 0.015 \\
\hline PI 592 & 3 & $6 / 24 / 2015$ & 1101 & $<0.050$ & 1.48 & $<0.7$ & $<0.100$ & R0.4 & 1.4 & 3.1 & R0.7 & -- & 1,240 & $<0.014$ \\
\hline PI 651 & 3 & 9/22/2015 & 1100 & $<0.010$ & 0.382 & $<0.7$ & $<0.020$ & $\mathrm{R}-0.1$ & 2.5 & 1.9 & 4.1 & -- & 1,030 & 0.187 \\
\hline PI 608 & 4 & 7/15/2015 & 930 & $<0.010$ & $<0.010$ & $<0.7$ & $<0.020$ & R0.9 & R1.1 & 4.1 & 2.9 & -- & 1,060 & 0.029 \\
\hline PI 638 & 4 & 8/5/2015 & 1600 & $<0.010$ & $<0.010$ & $<0.7$ & $<0.020$ & 1.2 & R0.5 & 1.9 & 3.7 & -- & 1,160 & 0.038 \\
\hline PI 524 & 5 & $6 / 25 / 2015$ & 1500 & $<0.100$ & 2.54 & $<0.7$ & $<0.200$ & 1.4 & R1.0 & 1.5 & $\mathrm{R} 1.2$ & -- & 380 & 0.095 \\
\hline PI 524 & 5 & $9 / 22 / 2015$ & 1330 & $<0.010$ & 4.12 & $<0.7$ & $<0.020$ & 3.4 & 4.7 & R1.5 & 2.7 & 0.3 & 450 & 0.157 \\
\hline PI 524 & 5 & $9 / 22 / 2015$ & 1331 & $<0.010$ & 3.28 & $<0.7$ & $<0.020$ & 1.9 & 1.3 & R1.6 & R1.3 & 0.3 & 470 & 0.147 \\
\hline PI 604 & 5 & $9 / 21 / 2015$ & 1500 & $<0.010$ & $<0.010$ & $<0.7$ & $<0.020$ & 5.3 & 10.6 & 6.9 & 9.8 & 0.09 & 1,420 & 1.26 \\
\hline PI 622 & 6 & 7/14/2015 & 1600 & $<0.010$ & 0.936 & $<0.7$ & $<0.020$ & R0.8 & R0.4 & 1.9 & R0.7 & -- & 34 & 0.049 \\
\hline PI 640 & 6 & $9 / 21 / 2015$ & 1400 & $<0.010$ & 0.031 & $<0.7$ & $<0.020$ & R0.3 & 1.3 & 1.5 & R0.4 & -- & 1,310 & 0.188 \\
\hline PI 648 & 7 & $9 / 24 / 2015$ & 1300 & $<0.010$ & $<0.010$ & $<0.7$ & $<0.020$ & R-0.5 & 1.2 & R0.1 & R0.3 & -- & 70 & 0.027 \\
\hline PI 649 & 7 & 9/24/2015 & 1030 & $<0.010$ & $<0.010$ & $<0.7$ & $<0.020$ & R0.5 & 1.4 & 2.2 & 2.4 & -- & 480 & 0.11 \\
\hline
\end{tabular}


Table A5-1. Field measurements and results of laboratory analyses for major and minor ions, nutrients, bacteria, trace metals, volatile organic compounds radioactivity, radon-222, and dissolved gases for groundwater samples collected from 79 wells in 2015 and from 18 of the 79 wells sampled at least once previously by USGS during 1982-2013 in Pike County, Pennsylvania.

[Constituents listed with associated 5-digit U.S. Geological Survey parameter code; 2015 methane analyses by Isotech in bold, with time offset of 5 minutes; mm $\mathrm{Hg}$, millimeters of mercury; ${ }^{\circ} \mathrm{C}$, degrees Celsius; $\mathrm{mg} / \mathrm{L}$, milligrams per liter; lab, laboratory; $\mu \mathrm{S} / \mathrm{cm}$, microsiemens per centimeter; $\mathrm{CaCO}_{3}$, calcium carbonate; $\mu \mathrm{g} / \mathrm{L}$, micrograms per liter; ANC, acid neutralizing capacity; $\mathrm{pCi} / \mathrm{L}$, picocuries per liter; --, no data; <, less than; >, greater than; E, estimated; M, presence verified but not quantified; R, non-detect for radiological analysis; U, analyzed for but not detected; VPDB, PeeDee belemnite; VSMOW, Vienna Standard Mean Ocean Water]

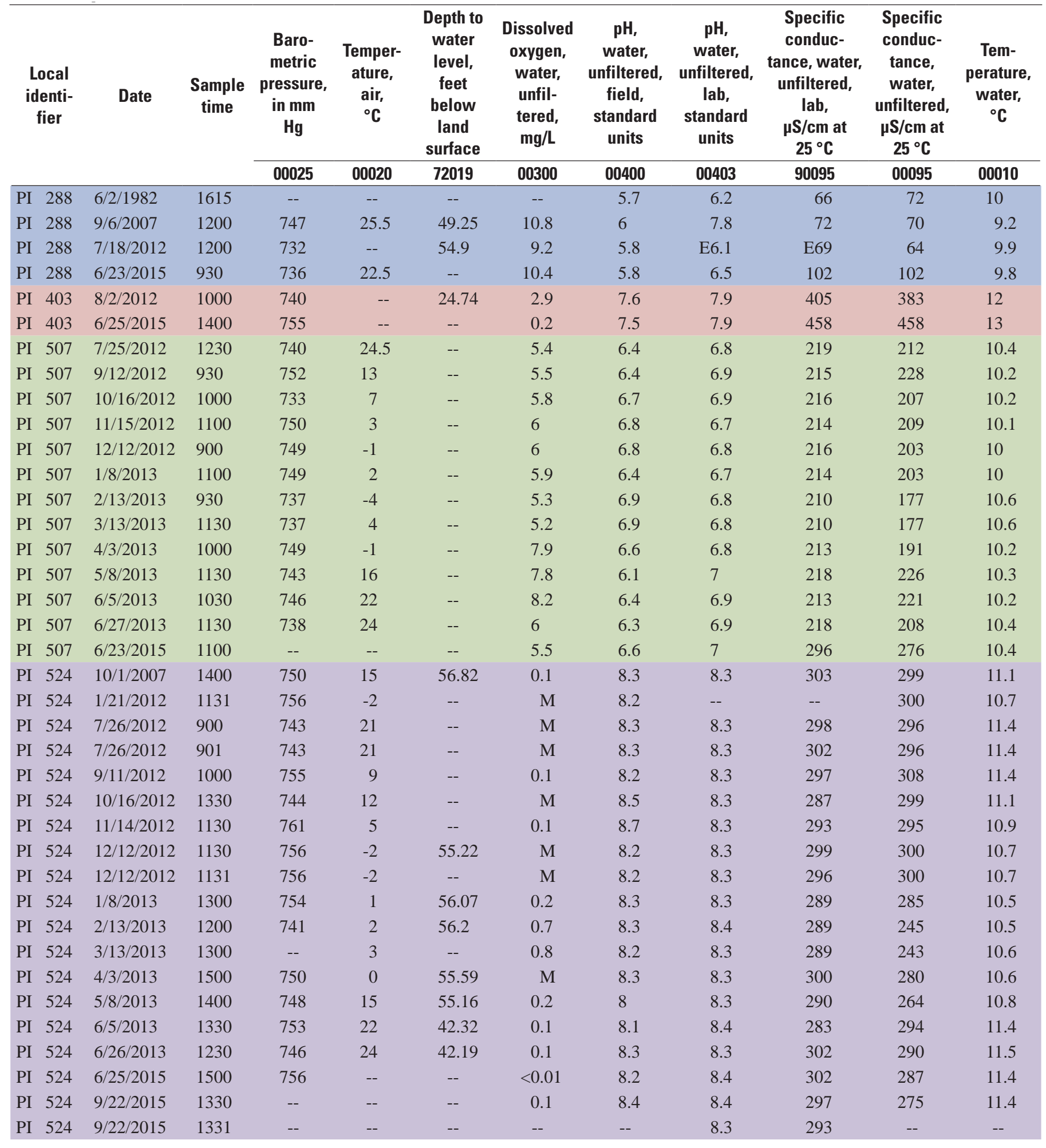


Table A5-1. Field measurements and results of laboratory analyses for major and minor ions, nutrients, bacteria, trace metals, volatile organic compounds radioactivity, radon-222, and dissolved gases for groundwater samples collected from 79 wells in 2015 and from 18 of the 79 wells sampled at least once previously by USGS during 1982-2013 in Pike County, Pennsylvania.-Continued

[Constituents listed with associated 5-digit U.S. Geological Survey parameter code; 2015 methane analyses by Isotech in bold, with time offset of 5 minutes; mm $\mathrm{Hg}$, millimeters of mercury; ${ }^{\circ} \mathrm{C}$, degrees Celsius; $\mathrm{mg} / \mathrm{L}$, milligrams per liter; lab, laboratory; $\mu \mathrm{S} / \mathrm{cm}$, microsiemens per centimeter; $\mathrm{CaCO}_{3}$, calcium carbonate; $\mu \mathrm{g} / \mathrm{L}$, micrograms per liter; ANC, acid neutralizing capacity; $\mathrm{pCi} / \mathrm{L}$, picocuries per liter; --, no data; <, less than; >, greater than; E, estimated; M, presence verified but not quantified; R, non-detect for radiological analysis; U, analyzed for but not detected; VPDB, PeeDee belemnite; VSMOW, Vienna Standard Mean Ocean Water]

\begin{tabular}{|c|c|c|c|c|c|c|c|c|c|c|c|}
\hline $\begin{array}{l}\text { Local } \\
\text { identi- } \\
\text { fier }\end{array}$ & Date & $\begin{array}{c}\text { Sample } \\
\text { time }\end{array}$ & $\begin{array}{c}\text { Baro- } \\
\text { metric } \\
\text { pressure, } \\
\text { in } \mathrm{mm} \\
\mathrm{Hg}\end{array}$ & $\begin{array}{c}\text { Temper- } \\
\text { ature, } \\
\text { air, } \\
{ }^{\circ} \mathrm{C}\end{array}$ & $\begin{array}{l}\text { Depth to } \\
\text { water } \\
\text { level, } \\
\text { feet } \\
\text { below } \\
\text { land } \\
\text { surface }\end{array}$ & $\begin{array}{c}\text { Dissolved } \\
\text { oxygen, } \\
\text { water, } \\
\text { unfil- } \\
\text { tered, } \\
\text { mg/L }\end{array}$ & $\begin{array}{c}\text { pH, } \\
\text { water, } \\
\text { unfiltered, } \\
\text { field, } \\
\text { standard } \\
\text { units }\end{array}$ & $\begin{array}{c}\text { pH, } \\
\text { water, } \\
\text { unfiltered, } \\
\text { lab, } \\
\text { standard } \\
\text { units }\end{array}$ & $\begin{array}{c}\text { Specific } \\
\text { conduc- } \\
\text { tance, water, } \\
\text { unfiltered, } \\
\text { lab, } \\
\text { S/cm at } \\
25^{\circ} \mathrm{C}\end{array}$ & $\begin{array}{c}\text { Specific } \\
\text { conduc- } \\
\text { tance, } \\
\text { water, } \\
\text { unfiltered, } \\
\mu \mathrm{S} / \mathrm{cm} \text { at } \\
25^{\circ} \mathrm{C}\end{array}$ & $\begin{array}{c}\text { Tem- } \\
\text { perature, } \\
\text { water, } \\
{ }^{\circ} \mathrm{C}\end{array}$ \\
\hline & & & 00025 & 00020 & 72019 & 00300 & 00400 & 00403 & 90095 & 00095 & 00010 \\
\hline PI 552 & 8/28/2007 & 1600 & 746 & 25 & 65.88 & 0.3 & 7.3 & 7.6 & 215 & 207 & 11 \\
\hline PI 552 & 7/24/2012 & 1530 & -- & 33.5 & 67.29 & M & 7.4 & 7.6 & 214 & 200 & 11.3 \\
\hline PI 552 & 6/24/2015 & 1445 & 753 & 22 & 65.72 & 0.1 & 7.1 & 7.8 & 220 & 212 & 11.2 \\
\hline PI 553 & 8/29/2007 & 1000 & 735 & 25 & 124.35 & 0.1 & 7.2 & 7.6 & 98 & 95 & 11.5 \\
\hline PI 553 & $7 / 25 / 2012$ & 1000 & 740 & 19 & 123.86 & 0.1 & 7.3 & 7.6 & 100 & 96 & 10.7 \\
\hline PI 553 & 6/23/2015 & 1400 & 739 & 22 & -- & 0.1 & 7.2 & E7.7 & E92 & 91 & 11.2 \\
\hline PI 555 & 8/30/2007 & 1000 & 724 & 25 & 116.92 & 4.6 & 6.8 & 7.1 & 149 & 142 & 9.2 \\
\hline PI 555 & 7/17/2012 & 1200 & 728 & 30.5 & 120.98 & 4.2 & 7.1 & 7.3 & 140 & 138 & 9.4 \\
\hline PI 555 & 6/23/2015 & 1100 & 746 & 22 & -- & 5.3 & 7 & 7.7 & 146 & 145 & 9 \\
\hline PI 556 & 8/30/2007 & 1230 & 750 & 25 & 54.05 & 0.2 & 7.7 & 7.9 & 216 & 211 & 11.5 \\
\hline PI 556 & 8/6/2015 & 1030 & 763 & -- & 31.5 & 0.2 & 8.3 & 8.2 & 190 & 187 & 13.9 \\
\hline PI 558 & 9/5/2007 & 1100 & 761 & 20.5 & 16.42 & 8.6 & 6.5 & 6.9 & 93 & 90 & 11.6 \\
\hline PI 558 & 7/25/2012 & 1000 & 770 & 30 & 16.13 & 5.9 & 6.5 & 6.9 & 108 & 111 & 11.6 \\
\hline PI 558 & 7/25/2012 & 1001 & -- & -- & -- & -- & -- & -- & -- & -- & -- \\
\hline PI 558 & 6/23/2015 & 1500 & -- & -- & -- & 8.6 & 6.6 & E7.1 & E86 & 85 & 12.2 \\
\hline PI 562 & $10 / 18 / 2007$ & 1100 & 760 & 18 & 18.06 & 0.2 & 7.3 & 7.9 & 149 & 147 & 11.7 \\
\hline PI 562 & 9/23/2015 & 900 & -- & 10 & -- & 0.1 & 7.4 & 7.8 & 178 & 172 & 11 \\
\hline PI 591 & 7/7/2011 & 1200 & -- & -- & -- & $<0.2$ & 8.1 & 8.9 & 268 & 261 & 11.2 \\
\hline PI 591 & 8/5/2015 & 1600 & -- & -- & 27.94 & 0.1 & 9.1 & 8.9 & 274 & 267 & 11 \\
\hline PI 592 & 8/17/2011 & 1200 & -- & -- & -- & $<0.2$ & 8 & 8.5 & 357 & 345 & 11.7 \\
\hline PI 592 & 7/26/2012 & 1000 & 740 & 27 & 9.51 & 0.1 & 8.7 & 8.6 & 337 & 326 & 11.7 \\
\hline PI 592 & $6 / 25 / 2013$ & 1100 & 755 & -- & 6.14 & 0.2 & 8.6 & 8.6 & 339 & 325 & 11.4 \\
\hline PI 592 & 6/24/2015 & 1100 & 768 & -- & -- & 0.2 & 8.7 & 8.5 & 333 & 324 & 11.1 \\
\hline PI 592 & 6/24/2015 & 1101 & -- & -- & -- & -- & -- & 8.6 & 329 & -- & -- \\
\hline PI 593 & $7 / 18 / 2012$ & 1500 & 733 & 32 & 45.93 & M & 8 & 8 & 179 & 171 & 10.9 \\
\hline PI 593 & 9/12/2012 & 1200 & 752 & 20 & -- & 0.1 & 7.8 & 8.1 & 178 & 185 & 10.7 \\
\hline PI 593 & $10 / 17 / 2012$ & 1430 & 744 & 9 & 43.51 & 0.4 & 8.3 & 8 & 185 & 173 & 10.5 \\
\hline PI 593 & $11 / 15 / 2012$ & 1400 & 751 & 3 & 42.51 & 0.1 & 8.3 & 7.9 & 194 & 187 & 10.3 \\
\hline PI 593 & $12 / 12 / 2012$ & 700 & 747 & -3 & 41.61 & 0.1 & 8.3 & 7.8 & 589 & 191 & 10.2 \\
\hline PI 593 & 1/9/2013 & 1130 & 741 & 1 & 42.51 & 0.1 & 8.3 & 7.9 & 377 & 191 & 10.2 \\
\hline PI 593 & 2/12/2013 & 1000 & 731 & 2 & 41.5 & 0.8 & 7.6 & 8.1 & 177 & 157 & 10.2 \\
\hline PI 593 & 3/12/2013 & 930 & 731 & 12 & -- & 0.9 & 7.7 & 8.1 & 200 & 167 & 10.2 \\
\hline PI 593 & 4/4/2013 & 1150 & 743 & 0 & 41.5 & 0 & 7.8 & 8.1 & 176 & 168 & 10.5 \\
\hline PI 593 & 4/4/2013 & 1405 & -- & -- & 41.87 & 0 & 7.7 & 8.2 & 175 & 166 & 10.4 \\
\hline PI 593 & 5/9/2013 & 1100 & 735 & 12 & 37.19 & 0.2 & 7.8 & 8.1 & 177 & 179 & 10.4 \\
\hline PI 593 & 6/4/2013 & 1000 & 740 & 20 & 41.77 & 0.1 & 7.7 & 8.1 & 194 & 184 & 10.6 \\
\hline PI 593 & 6/25/2013 & 1100 & 737 & 28 & 41.81 & 0.1 & 7.9 & 8 & 186 & 179 & 10.9 \\
\hline PI 593 & 6/22/2015 & 1300 & 743 & -- & -- & 0.1 & 7.9 & 8.1 & 187 & 172 & 10.6 \\
\hline
\end{tabular}


Table A5-1. Field measurements and results of laboratory analyses for major and minor ions, nutrients, bacteria, trace metals, volatile organic compounds radioactivity, radon-222, and dissolved gases for groundwater samples collected from 79 wells in 2015 and from 18 of the 79 wells sampled at least once previously by USGS during 1982-2013 in Pike County, Pennsylvania. - Continued

[Constituents listed with associated 5-digit U.S. Geological Survey parameter code; 2015 methane analyses by Isotech in bold, with time offset of 5 minutes; mm $\mathrm{Hg}$, millimeters of mercury; ${ }^{\circ} \mathrm{C}$, degrees Celsius; $\mathrm{mg} / \mathrm{L}$, milligrams per liter; lab, laboratory; $\mu \mathrm{S} / \mathrm{cm}$, microsiemens per centimeter; $\mathrm{CaCO}_{3}$, calcium carbonate; $\mu \mathrm{g} / \mathrm{L}$, micrograms per liter; ANC, acid neutralizing capacity; pCi/L, picocuries per liter; --, no data; <, less than; >, greater than; E, estimated; M, presence verified but not quantified; R, non-detect for radiological analysis; U, analyzed for but not detected; VPDB, PeeDee belemnite; VSMOW, Vienna Standard Mean Ocean Water]

\begin{tabular}{|c|c|c|c|c|c|c|c|c|c|c|c|}
\hline $\begin{array}{l}\text { Local } \\
\text { identi- } \\
\text { fier }\end{array}$ & Date & $\begin{array}{c}\text { Sample } \\
\text { time }\end{array}$ & $\begin{array}{c}\text { Baro- } \\
\text { metric } \\
\text { pressure, } \\
\text { in } \mathbf{~ m m} \\
\mathrm{Hg}\end{array}$ & $\begin{array}{c}\text { Temper- } \\
\text { ature, } \\
\text { air, } \\
{ }^{\circ} \mathrm{C}\end{array}$ & $\begin{array}{c}\text { Depth to } \\
\text { water } \\
\text { level, } \\
\text { feet } \\
\text { below } \\
\text { land } \\
\text { surface }\end{array}$ & $\begin{array}{c}\text { Dissolved } \\
\text { oxygen, } \\
\text { water, } \\
\text { unfil- } \\
\text { tered, } \\
\text { mg/L }\end{array}$ & $\begin{array}{c}\text { pH, } \\
\text { water, } \\
\text { unfiltered, } \\
\text { field, } \\
\text { standard } \\
\text { units }\end{array}$ & $\begin{array}{c}\text { pH, } \\
\text { water, } \\
\text { unfiltered, } \\
\text { lab, } \\
\text { standard } \\
\text { units }\end{array}$ & $\begin{array}{c}\text { Specific } \\
\text { conduc- } \\
\text { tance, water, } \\
\text { unfiltered, } \\
\text { lab, } \\
\mu \mathrm{S} / \mathrm{cm} \text { at } \\
25^{\circ} \mathrm{C} \\
\end{array}$ & $\begin{array}{c}\text { Specific } \\
\text { conduc- } \\
\text { tance, } \\
\text { water, } \\
\text { unfiltered, } \\
\mu S / c m \text { at } \\
25^{\circ} \mathrm{C} \\
\end{array}$ & $\begin{array}{c}\text { Tem- } \\
\text { perature, } \\
\text { water, } \\
{ }^{\circ} \mathrm{C}\end{array}$ \\
\hline & & & 00025 & 00020 & 72019 & 00300 & 00400 & 00403 & 90095 & 00095 & 00010 \\
\hline PI 594 & 6/25/2015 & 1130 & 749 & 22 & 146.66 & 9.3 & 6.1 & E6.9 & E88 & 84 & 11 \\
\hline PI 595 & 7/19/2012 & 1300 & 740 & -- & -- & 0.5 & 6.9 & 7.3 & 214 & 208 & 10.6 \\
\hline PI 595 & 6/23/2015 & 930 & 743 & 20 & -- & 2 & 7 & 7.5 & 270 & 268 & 10.8 \\
\hline PI 598 & 7/19/2012 & 1000 & 743 & -- & 65.92 & $\mathrm{M}$ & 6.7 & 7.2 & 117 & 111 & 10.8 \\
\hline PI 598 & $6 / 22 / 2015$ & 1600 & -- & 26 & -- & 0.1 & 6.7 & 7.4 & 126 & 114 & 10.4 \\
\hline PI 600 & $11 / 14 / 2012$ & 1400 & 760 & 7 & 142.51 & 0.1 & 8.2 & 8.1 & 222 & 217 & 10.6 \\
\hline PI 600 & $12 / 13 / 2012$ & 1100 & 754 & 1 & 162.04 & 0.2 & 8.3 & 8.1 & 221 & 207 & 10.4 \\
\hline PI 600 & 1/9/2013 & 1400 & 746 & 0 & 163.36 & 0.1 & 7.9 & 8 & 226 & 222 & 10.4 \\
\hline PI 600 & 2/12/2013 & 1400 & 740 & 0 & 151.05 & 0.6 & 7.8 & 8.1 & 218 & 183 & 10.4 \\
\hline PI 600 & $3 / 12 / 2013$ & 1200 & 738 & 10 & 149.58 & 0.4 & 7.8 & 8 & 221 & 190 & 10.4 \\
\hline PI 600 & 4/2/2013 & 1500 & 743 & 1 & 140.71 & 0.1 & 7.8 & 8.1 & 222 & 211 & 10.5 \\
\hline PI 600 & 5/7/2013 & 1300 & 748 & 20 & 141.13 & 0.5 & 7.3 & 8 & 220 & 225 & 10.5 \\
\hline PI 600 & 6/4/2013 & 1300 & 746 & 22 & 141.07 & 0.4 & 7.7 & 8.1 & 221 & 226 & 10.9 \\
\hline PI 600 & $6 / 25 / 2013$ & 1400 & 744 & 31 & 141.11 & 0.1 & 7.8 & 8 & 227 & 220 & 10.7 \\
\hline PI 600 & $6 / 24 / 2015$ & 1400 & 748 & -- & -- & 0.1 & 8 & 8.1 & 230 & 226 & 10.4 \\
\hline
\end{tabular}


Table A5-1. Field measurements and results of laboratory analyses for major and minor ions, nutrients, bacteria, trace metals, volatile organic compounds radioactivity, radon-222, and dissolved gases for groundwater samples collected from 79 wells in 2015 and from 18 of the 79 wells sampled at least once previously by USGS during 1982-2013 in Pike County, Pennsylvania. - Continued

[Constituents listed with associated 5-digit U.S. Geological Survey parameter code; 2015 methane analyses by Isotech in bold, with time offset of 5 minutes; mm $\mathrm{Hg}$, millimeters of mercury; ${ }^{\circ} \mathrm{C}$, degrees Celsius; $\mathrm{mg} / \mathrm{L}$, milligrams per liter; lab, laboratory; $\mu \mathrm{S} / \mathrm{cm}$, microsiemens per centimeter; $\mathrm{CaCO}_{3}$, calcium carbonate; $\mu \mathrm{g} / \mathrm{L}$, micrograms per liter; ANC, acid neutralizing capacity; $\mathrm{pCi} / \mathrm{L}$, picocuries per liter; --, no data; <, less than; >, greater than; E, estimated; M, presence verified but not quantified; R, non-detect for radiological analysis; U, analyzed for but not detected; VPDB, PeeDee belemnite; VSMOW, Vienna Standard Mean Ocean Water]

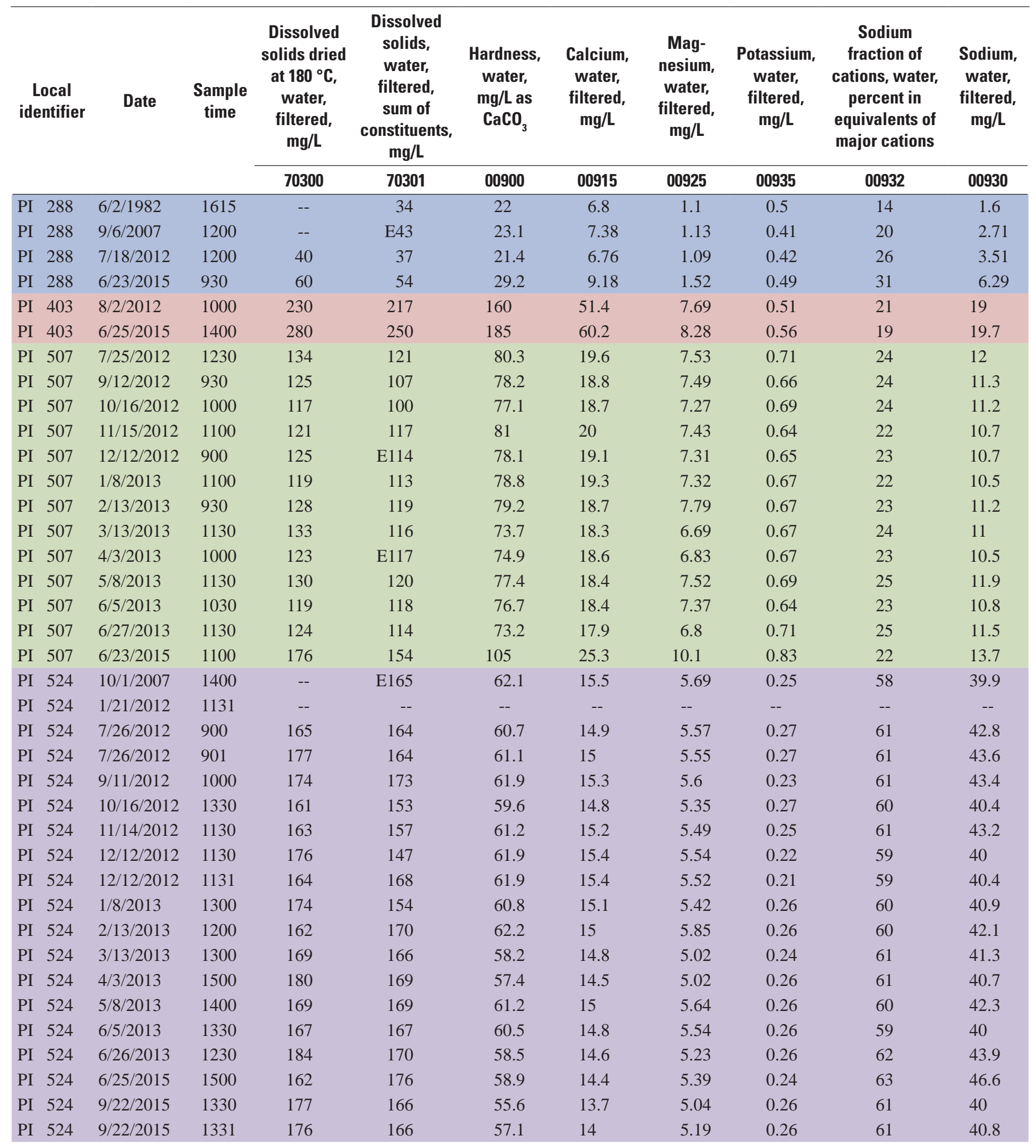


Table A5-1. Field measurements and results of laboratory analyses for major and minor ions, nutrients, bacteria, trace metals, volatile organic compounds radioactivity, radon-222, and dissolved gases for groundwater samples collected from 79 wells in 2015 and from 18 of the 79 wells sampled at least once previously by USGS during 1982-2013 in Pike County, Pennsylvania. - Continued

[Constituents listed with associated 5-digit U.S. Geological Survey parameter code; 2015 methane analyses by Isotech in bold, with time offset of 5 minutes; mm $\mathrm{Hg}$, millimeters of mercury; ${ }^{\circ} \mathrm{C}$, degrees Celsius; $\mathrm{mg} / \mathrm{L}$, milligrams per liter; lab, laboratory; $\mu \mathrm{S} / \mathrm{cm}$, microsiemens per centimeter; $\mathrm{CaCO}_{3}$, calcium carbonate; $\mu \mathrm{g} / \mathrm{L}$, micrograms per liter; ANC, acid neutralizing capacity; $\mathrm{pCi} / \mathrm{L}$, picocuries per liter; --, no data; <, less than; >, greater than; E, estimated; M, presence verified but not quantified; R, non-detect for radiological analysis; U, analyzed for but not detected; VPDB, PeeDee belemnite; VSMOW, Vienna Standard Mean Ocean Water]

\begin{tabular}{|c|c|c|c|c|c|c|c|c|c|c|c|}
\hline & $\begin{array}{l}\text { Local } \\
\text { entifier }\end{array}$ & Date & $\begin{array}{c}\text { Sample } \\
\text { time }\end{array}$ & $\begin{array}{l}\text { Dissolved } \\
\text { solids dried } \\
\text { at } 180^{\circ} \mathrm{C} \text {, } \\
\text { water, } \\
\text { filtered, }\end{array}$ & $\begin{array}{l}\text { Dissolved } \\
\text { solids, } \\
\text { water, } \\
\text { filtered, } \\
\text { sum of }\end{array}$ & $\begin{array}{c}\text { Hardness, } \\
\text { water, } \\
\text { mg/L as } \\
\mathrm{CaCO}\end{array}$ & $\begin{array}{c}\text { Calcium, } \\
\text { water, } \\
\text { filtered, } \\
\text { mg/L }\end{array}$ & $\begin{array}{l}\text { Mag- } \\
\text { nesium, } \\
\text { water, } \\
\text { filtered, }\end{array}$ & $\begin{array}{l}\text { Potassium, } \\
\text { water, } \\
\text { filtered, } \\
\text { mg/L }\end{array}$ & $\begin{array}{c}\text { Sodium } \\
\text { fraction of } \\
\text { cations, water, } \\
\text { percent in } \\
\text { equivalents of }\end{array}$ & $\begin{array}{c}\text { Sodium, } \\
\text { water, } \\
\text { filtered, } \\
\mathrm{mg} / \mathrm{L}\end{array}$ \\
\hline & & & & 70300 & 70301 & 00900 & 00915 & 00925 & 00935 & 00932 & 00930 \\
\hline PI & 552 & 7/24/2012 & 1530 & 137 & 133 & 98.5 & 26.5 & 7.74 & 0.24 & 14 & 7.24 \\
\hline PI & 552 & $6 / 24 / 2015$ & 1445 & 121 & 134 & 97.2 & 26.1 & 7.63 & 0.28 & 14 & 7.46 \\
\hline PI & 553 & 8/29/2007 & 1000 & -- & E61 & 32.8 & 8.03 & 3.1 & 0.63 & 34 & 7.8 \\
\hline PI & 553 & 7/25/2012 & 1000 & 56 & 62 & 35.6 & 8.61 & 3.37 & 0.61 & 32 & 7.73 \\
\hline PI & 553 & $6 / 23 / 2015$ & 1400 & 48 & 59 & 32.7 & 7.77 & 3.16 & 0.61 & 32 & 7.33 \\
\hline PI & 556 & 8/30/2007 & 1230 & -- & E125 & 87.1 & 24.7 & 6.18 & 0.21 & 19 & 9.32 \\
\hline PI & 556 & $8 / 6 / 2015$ & 1030 & 111 & 113 & 63.2 & 16.7 & 4.99 & 0.19 & 35 & 15.2 \\
\hline PI & 558 & 9/5/2007 & 1100 & -- & E57 & 35.7 & 11 & 1.98 & 0.39 & 16 & 3.07 \\
\hline PI & 558 & 7/25/2012 & 1000 & 67 & 63 & 42.9 & 13.2 & 2.35 & 0.4 & 19 & 4.55 \\
\hline PI & 558 & 7/25/2012 & 1001 & -- & -- & -- & -- & -- & -- & -- & -- \\
\hline PI & 558 & 6/23/2015 & 1500 & 39 & 56 & 34.5 & 10.7 & 1.9 & 0.37 & 18 & 3.57 \\
\hline PI & 562 & $10 / 18 / 2007$ & 1100 & -- & E93 & 61.1 & 14.4 & 6.08 & 0.3 & 17 & 5.59 \\
\hline PI & 562 & 9/23/2015 & 900 & 118 & 111 & 79.2 & 19 & 7.71 & 0.35 & 17 & 7.38 \\
\hline PI & 591 & 7/7/2011 & 1200 & 156 & 158 & 17.4 & 5.22 & 0.951 & 0.33 & 87 & 54.6 \\
\hline PI & 591 & 8/5/2015 & 1600 & 152 & 160 & 16.6 & 4.98 & 0.904 & 0.36 & 88 & 55.9 \\
\hline PI & 593 & 9/12/2012 & 1200 & 105 & 95 & 70.6 & 21.8 & 3.78 & 0.82 & 19 & 7.85 \\
\hline PI & 593 & 10/17/2012 & 1430 & 114 & 93 & 72 & 22.1 & 3.91 & 0.75 & 19 & 7.81 \\
\hline PI & 593 & $11 / 15 / 2012$ & 1400 & 116 & 103 & 82.2 & 25.7 & 4.2 & 0.77 & 16 & 7.37 \\
\hline PI & 593 & $12 / 12 / 2012$ & 700 & 342 & E273 & 242 & 74.7 & 13.1 & 1.22 & 11 & 13.1 \\
\hline PI & 593 & 1/9/2013 & 1130 & 207 & 183 & 153 & 47.4 & 8.14 & 1.01 & 13 & 10.3 \\
\hline PI & 593 & 2/12/2013 & 1000 & 106 & 97 & 70.9 & 21.9 & 3.79 & 0.79 & 19 & 7.86 \\
\hline PI & 593 & 3/12/2013 & 930 & 116 & 110 & 76.5 & 23.9 & 3.9 & 0.81 & 18 & 7.75 \\
\hline PI & 593 & 4/4/2013 & 1150 & 113 & 105 & 71.6 & 22.5 & 3.6 & 0.81 & 19 & 7.68 \\
\hline PI & 593 & 4/4/2013 & 1405 & 97 & 103 & 71.1 & 22.3 & 3.57 & 0.79 & 19 & 7.55 \\
\hline PI & 593 & 5/9/2013 & 1100 & 104 & 104 & 70.7 & 21.7 & 3.87 & 0.82 & 20 & 8.12 \\
\hline PI & 593 & 6/4/2013 & 1000 & 127 & 110 & 73.6 & 22.6 & 3.99 & 0.79 & 19 & 8.07 \\
\hline PI & 593 & $6 / 25 / 2013$ & 1100 & 107 & 103 & 71.7 & 22.2 & 3.78 & 0.77 & 19 & 7.62 \\
\hline PI & 593 & $6 / 22 / 2015$ & 1300 & 112 & 109 & 78.2 & 24.1 & 4.2 & 0.86 & 18 & 8.08 \\
\hline
\end{tabular}


Table A5-1. Field measurements and results of laboratory analyses for major and minor ions, nutrients, bacteria, trace metals, volatile organic compounds radioactivity, radon-222, and dissolved gases for groundwater samples collected from 79 wells in 2015 and from 18 of the 79 wells sampled at least once previously by USGS during 1982-2013 in Pike County, Pennsylvania. - Continued

[Constituents listed with associated 5-digit U.S. Geological Survey parameter code; 2015 methane analyses by Isotech in bold, with time offset of 5 minutes; mm $\mathrm{Hg}$, millimeters of mercury; ${ }^{\circ} \mathrm{C}$, degrees Celsius; $\mathrm{mg} / \mathrm{L}$, milligrams per liter; lab, laboratory; $\mu \mathrm{S} / \mathrm{cm}$, microsiemens per centimeter; $\mathrm{CaCO}_{3}$, calcium carbonate; $\mu \mathrm{g} / \mathrm{L}$, micrograms per liter; ANC, acid neutralizing capacity; $\mathrm{pCi} / \mathrm{L}$, picocuries per liter; --, no data; <, less than; >, greater than; E, estimated; M, presence verified but not quantified; R, non-detect for radiological analysis; U, analyzed for but not detected; VPDB, PeeDee belemnite; VSMOW, Vienna Standard Mean Ocean Water]

\begin{tabular}{|c|c|c|c|c|c|c|c|c|c|c|}
\hline \multirow[t]{2}{*}{$\begin{array}{l}\text { Local } \\
\text { identifier }\end{array}$} & \multirow[t]{2}{*}{ Date } & \multirow[t]{2}{*}{$\begin{array}{c}\text { Sample } \\
\text { time }\end{array}$} & $\begin{array}{l}\text { Dissolved } \\
\text { solids dried } \\
\text { at } 180^{\circ} \mathrm{C} \text {, } \\
\text { water, } \\
\text { filtered, }\end{array}$ & \multirow{2}{*}{$\begin{array}{c}\text { Dissolved } \\
\text { solids, } \\
\text { water, } \\
\text { filtered, } \\
\text { sum of } \\
\text { constituents, } \\
\text { mg/L } \\
70301\end{array}$} & \multirow{2}{*}{$\begin{array}{c}\text { Hardness, } \\
\text { water, } \\
\text { mg/L as } \\
\mathrm{CaCO}_{3} \\
00900\end{array}$} & \multirow{2}{*}{$\begin{array}{c}\text { Calcium, } \\
\text { water, } \\
\text { filtered, } \\
\text { mg/L } \\
00915\end{array}$} & \multirow{2}{*}{$\begin{array}{c}\begin{array}{c}\text { Mag- } \\
\text { nesium, } \\
\text { water, } \\
\text { filtered, } \\
\text { mg/L }\end{array} \\
00925\end{array}$} & \multirow{2}{*}{$\begin{array}{c}\text { Potassium, } \\
\text { water, } \\
\text { filtered, } \\
\text { mg/L } \\
00935\end{array}$} & \multirow{2}{*}{$\begin{array}{c}\text { Sodium } \\
\text { fraction of } \\
\text { cations, water, } \\
\text { percent in } \\
\text { equivalents of } \\
\text { major cations } \\
00932\end{array}$} & \multirow{2}{*}{$\begin{array}{c}\begin{array}{c}\text { Sodium, } \\
\text { water, } \\
\text { filtered, } \\
\text { mg/L }\end{array} \\
00930\end{array}$} \\
\hline & & & 70300 & & & & & & & \\
\hline PI 594 & $6 / 25 / 2015$ & 1130 & 38 & 54 & 32.7 & 7.66 & 3.28 & 0.65 & 18 & 3.45 \\
\hline PI 595 & 7/19/2012 & 1300 & 140 & 119 & 77.9 & 21.4 & 5.69 & 1.19 & 25 & 12.3 \\
\hline PI 595 & 6/23/2015 & 930 & 162 & 141 & 92 & 25.4 & 6.68 & 1.23 & 24 & 13.6 \\
\hline PI 598 & 7/19/2012 & 1000 & 74 & 68 & 42.7 & 9.73 & 4.46 & 0.77 & 29 & 8.12 \\
\hline PI 598 & $6 / 22 / 2015$ & 1600 & 82 & 76 & 47.7 & 11.1 & 4.84 & 0.79 & 26 & 7.9 \\
\hline PI 600 & $11 / 14 / 2012$ & 1400 & 123 & 120 & 104 & 28.8 & 7.58 & 0.67 & 13 & 7.12 \\
\hline PI 600 & $12 / 13 / 2012$ & 1100 & 127 & 120 & 106 & 29.1 & 7.75 & 0.68 & 13 & 7.28 \\
\hline PI 600 & 1/9/2013 & 1400 & 126 & 118 & 103 & 28.4 & 7.56 & 0.68 & 12 & 6.71 \\
\hline PI 600 & 2/12/2013 & 1400 & 136 & 132 & 101 & 27.6 & 7.66 & 0.65 & 13 & 6.89 \\
\hline PI 600 & 3/12/2013 & 1200 & 128 & 130 & 100 & 27.9 & 7.22 & 0.67 & 12 & 6.44 \\
\hline PI 600 & 4/2/2013 & 1500 & 128 & E131 & 96.5 & 26.6 & 7.07 & 0.7 & 14 & 7.01 \\
\hline PI 600 & 5/7/2013 & 1300 & 138 & 130 & 98.4 & 26.2 & 7.79 & 0.72 & 14 & 7.12 \\
\hline PI 600 & 6/4/2013 & 1300 & 145 & 133 & 102 & 27.8 & 7.65 & 0.7 & 13 & 6.94 \\
\hline PI 600 & 6/25/2013 & 1400 & 136 & 127 & 99.8 & 27.7 & 7.23 & 0.63 & 13 & 6.68 \\
\hline PI 600 & $6 / 24 / 2015$ & 1400 & 130 & 134 & 102 & 28.3 & 7.45 & 0.65 & 14 & 7.71 \\
\hline
\end{tabular}


Table A5-1. Field measurements and results of laboratory analyses for major and minor ions, nutrients, bacteria, trace metals, volatile organic compounds radioactivity, radon-222, and dissolved gases for groundwater samples collected from 79 wells in 2015 and from 18 of the 79 wells sampled at least once previously by USGS during 1982-2013 in Pike County, Pennsylvania. - Continued

[Constituents listed with associated 5-digit U.S. Geological Survey parameter code; 2015 methane analyses by Isotech in bold, with time offset of 5 minutes; mm $\mathrm{Hg}$, millimeters of mercury; ${ }^{\circ} \mathrm{C}$, degrees Celsius; $\mathrm{mg} / \mathrm{L}$, milligrams per liter; lab, laboratory; $\mu \mathrm{S} / \mathrm{cm}$, microsiemens per centimeter; $\mathrm{CaCO}_{3}$, calcium carbonate; $\mu \mathrm{g} / \mathrm{L}$, micrograms per liter; ANC, acid neutralizing capacity; pCi/L, picocuries per liter; --, no data; <, less than; >, greater than; E, estimated; M, presence verified but not quantified; R, non-detect for radiological analysis; U, analyzed for but not detected; VPDB, PeeDee belemnite; VSMOW, Vienna Standard Mean Ocean Water]

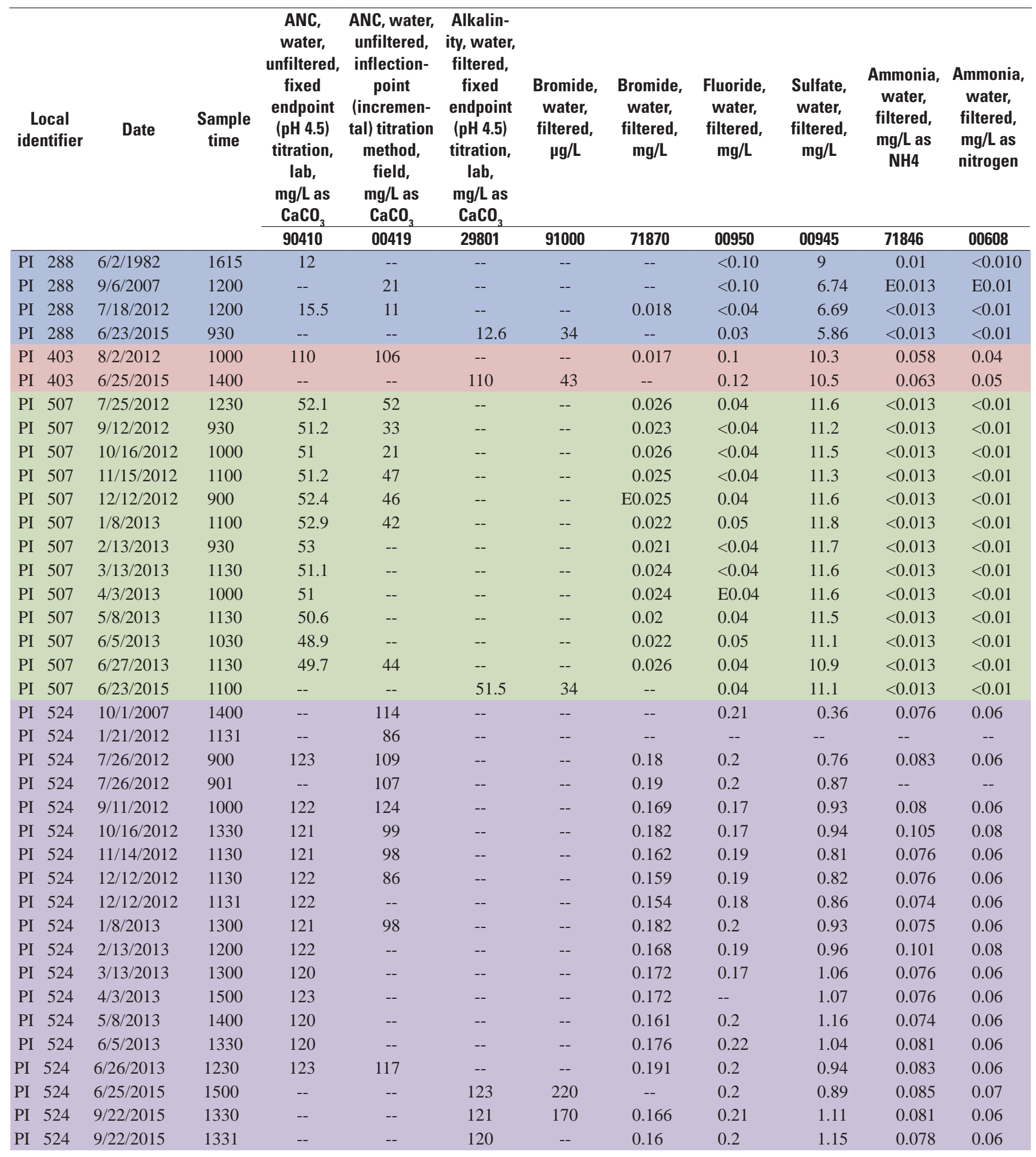


Table A5-1. Field measurements and results of laboratory analyses for major and minor ions, nutrients, bacteria, trace metals, volatile organic compounds radioactivity, radon-222, and dissolved gases for groundwater samples collected from 79 wells in 2015 and from 18 of the 79 wells sampled at least once previously by USGS during 1982-2013 in Pike County, Pennsylvania. - Continued

[Constituents listed with associated 5-digit U.S. Geological Survey parameter code; 2015 methane analyses by Isotech in bold, with time offset of 5 minutes; mm $\mathrm{Hg}$, millimeters of mercury; ${ }^{\circ} \mathrm{C}$, degrees Celsius; $\mathrm{mg} / \mathrm{L}$, milligrams per liter; lab, laboratory; $\mu \mathrm{S} / \mathrm{cm}$, microsiemens per centimeter; $\mathrm{CaCO}_{3}$, calcium carbonate; $\mu \mathrm{g} / \mathrm{L}$, micrograms per liter; ANC, acid neutralizing capacity; $\mathrm{pCi} / \mathrm{L}$, picocuries per liter; --, no data; <, less than; >, greater than; E, estimated; M, presence verified but not quantified; R, non-detect for radiological analysis; U, analyzed for but not detected; VPDB, PeeDee belemnite; VSMOW, Vienna Standard Mean Ocean Water]

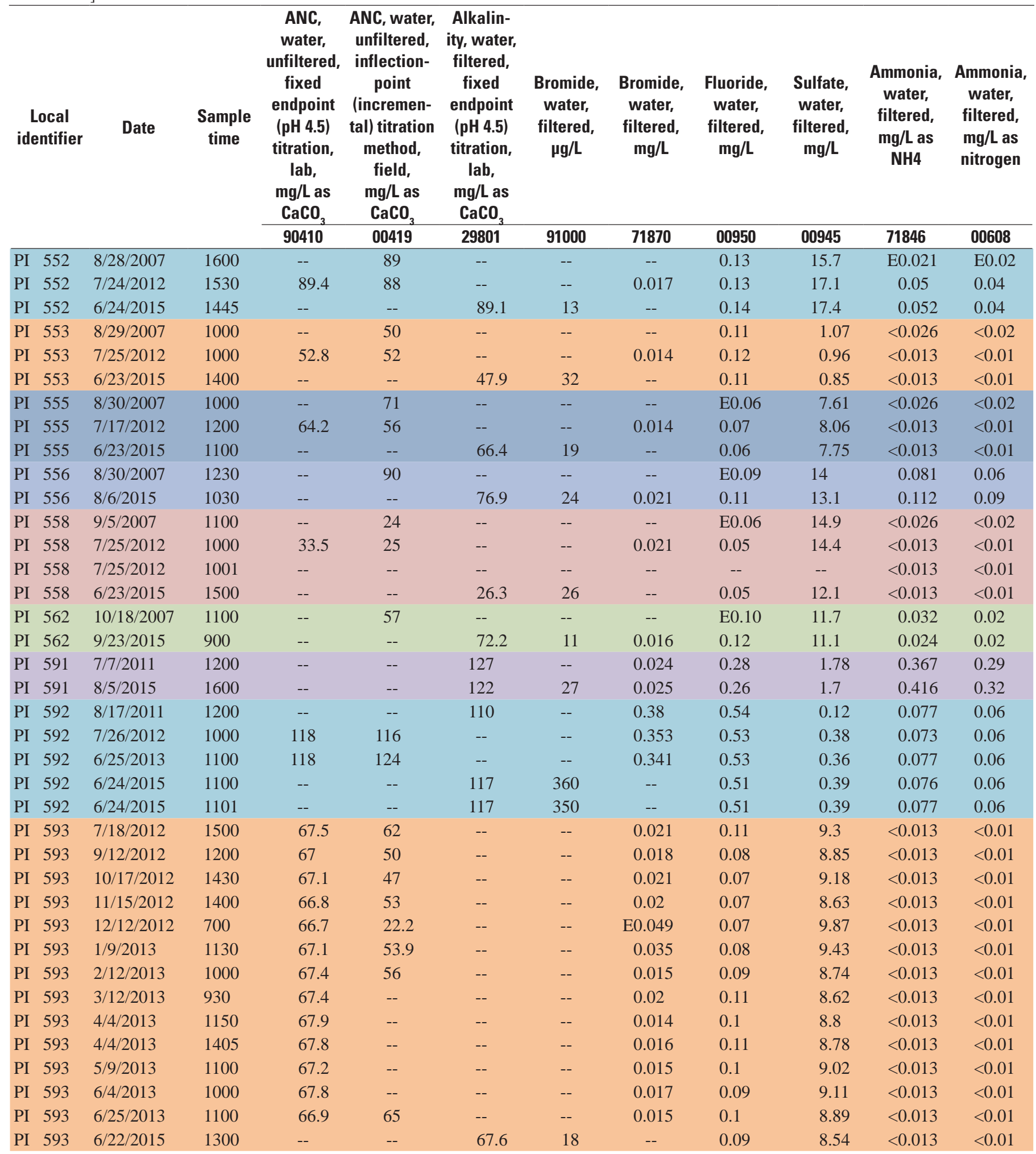


Table A5-1. Field measurements and results of laboratory analyses for major and minor ions, nutrients, bacteria, trace metals, volatile organic compounds radioactivity, radon-222, and dissolved gases for groundwater samples collected from 79 wells in 2015 and from 18 of the 79 wells sampled at least once previously by USGS during 1982-2013 in Pike County, Pennsylvania. - Continued

[Constituents listed with associated 5-digit U.S. Geological Survey parameter code; 2015 methane analyses by Isotech in bold, with time offset of 5 minutes; mm $\mathrm{Hg}$, millimeters of mercury; ${ }^{\circ} \mathrm{C}$, degrees Celsius; $\mathrm{mg} / \mathrm{L}$, milligrams per liter; lab, laboratory; $\mu \mathrm{S} / \mathrm{cm}$, microsiemens per centimeter; $\mathrm{CaCO}_{3}$, calcium carbonate; $\mu \mathrm{g} / \mathrm{L}$, micrograms per liter; ANC, acid neutralizing capacity; pCi/L, picocuries per liter; --, no data; <, less than; >, greater than; E, estimated; M, presence verified but not quantified; R, non-detect for radiological analysis; U, analyzed for but not detected; VPDB, PeeDee belemnite; VSMOW, Vienna Standard Mean Ocean Water]

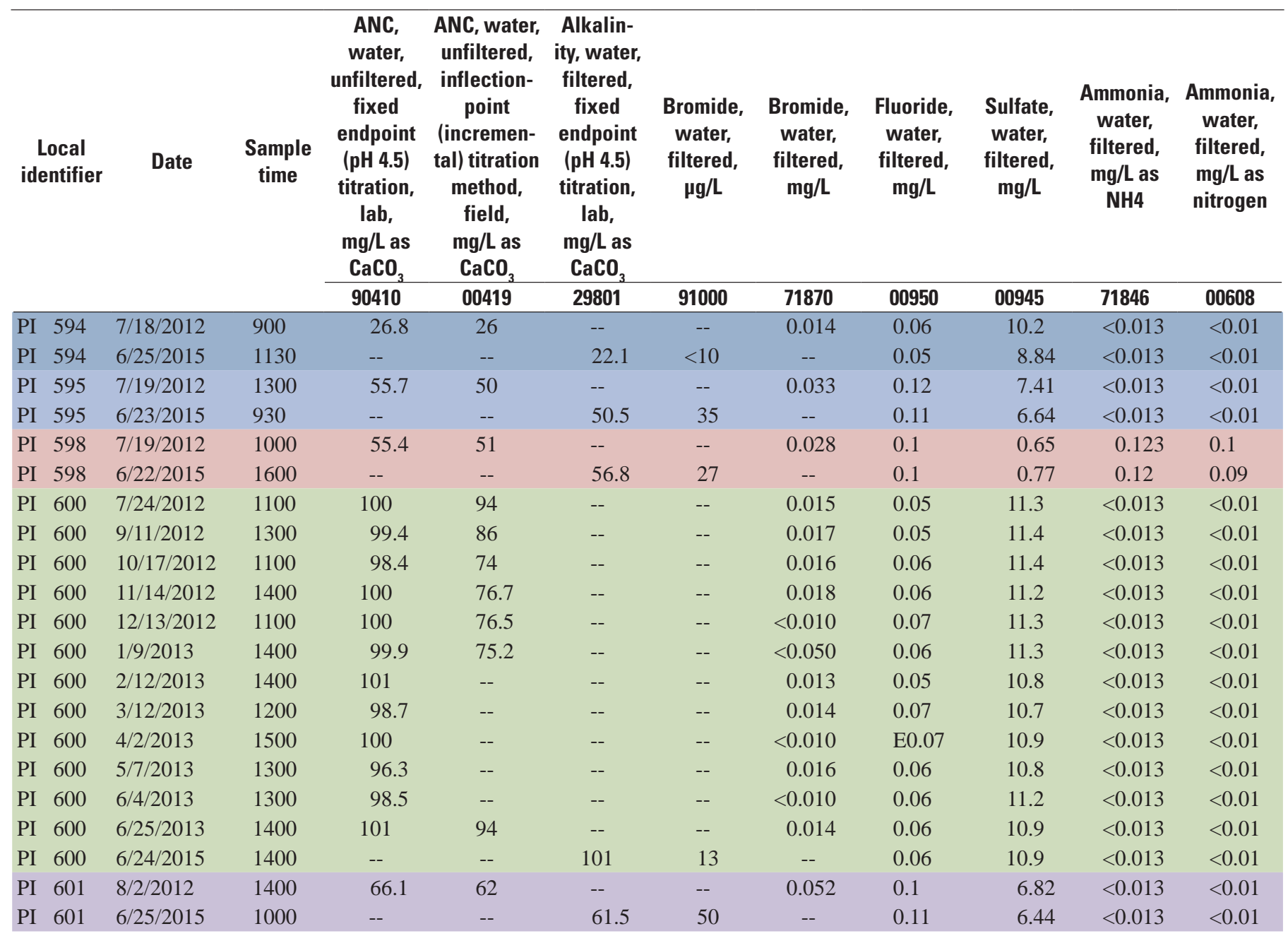


Table A5-1. Field measurements and results of laboratory analyses for major and minor ions, nutrients, bacteria, trace metals, volatile organic compounds radioactivity, radon-222, and dissolved gases for groundwater samples collected from 79 wells in 2015 and from 18 of the 79 wells sampled at least once previously by USGS during 1982-2013 in Pike County, Pennsylvania. - Continued

[Constituents listed with associated 5-digit U.S. Geological Survey parameter code; 2015 methane analyses by Isotech in bold, with time offset of 5 minutes; mm $\mathrm{Hg}$, millimeters of mercury; ${ }^{\circ} \mathrm{C}$, degrees Celsius; $\mathrm{mg} / \mathrm{L}$, milligrams per liter; lab, laboratory; $\mu \mathrm{S} / \mathrm{cm}$, microsiemens per centimeter; $\mathrm{CaCO}_{3}$, calcium carbonate; $\mu \mathrm{g} / \mathrm{L}$, micrograms per liter; ANC, acid neutralizing capacity; $\mathrm{pCi} / \mathrm{L}$, picocuries per liter; --, no data; <, less than; >, greater than; E, estimated; M, presence verified but not quantified; R, non-detect for radiological analysis; U, analyzed for but not detected; VPDB, PeeDee belemnite; VSMOW, Vienna Standard Mean Ocean Water]

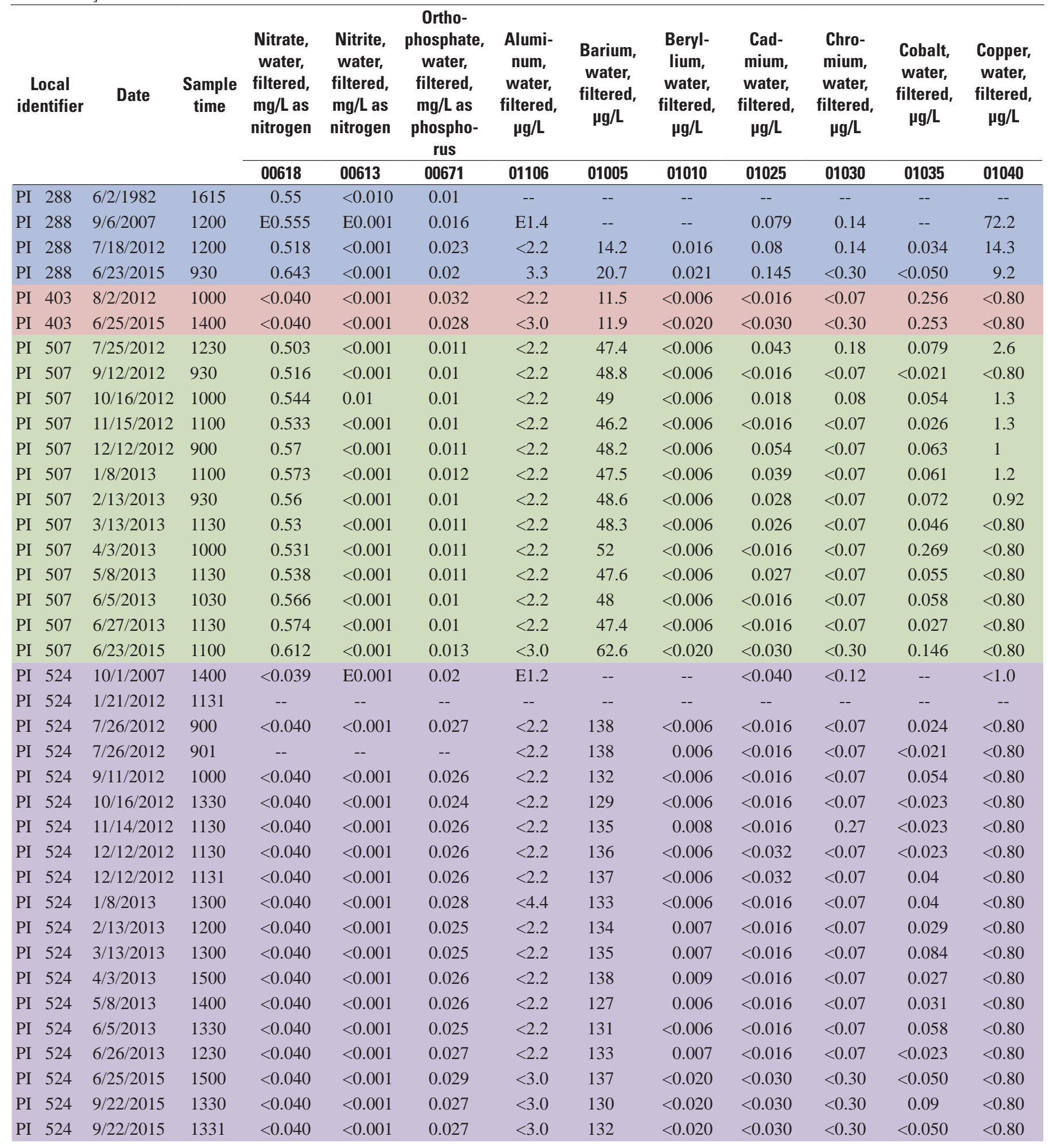


Table A5-1. Field measurements and results of laboratory analyses for major and minor ions, nutrients, bacteria, trace metals, volatile organic compounds radioactivity, radon-222, and dissolved gases for groundwater samples collected from 79 wells in 2015 and from 18 of the 79 wells sampled at least once previously by USGS during 1982-2013 in Pike County, Pennsylvania. - Continued

[Constituents listed with associated 5-digit U.S. Geological Survey parameter code; 2015 methane analyses by Isotech in bold, with time offset of 5 minutes; mm $\mathrm{Hg}$, millimeters of mercury; ${ }^{\circ} \mathrm{C}$, degrees Celsius; $\mathrm{mg} / \mathrm{L}$, milligrams per liter; lab, laboratory; $\mu \mathrm{S} / \mathrm{cm}$, microsiemens per centimeter; $\mathrm{CaCO}_{3}$, calcium carbonate; $\mu \mathrm{g} / \mathrm{L}$, micrograms per liter; ANC, acid neutralizing capacity; pCi/L, picocuries per liter; --, no data; <, less than; >, greater than; E, estimated; M, presence verified but not quantified; R, non-detect for radiological analysis; U, analyzed for but not detected; VPDB, PeeDee belemnite; VSMOW, Vienna Standard Mean Ocean Water]

\begin{tabular}{|c|c|c|c|c|c|c|c|c|c|c|c|c|}
\hline $\begin{array}{l}\text { Local } \\
\text { identifier }\end{array}$ & Date & $\begin{array}{c}\text { Sample } \\
\text { time }\end{array}$ & $\begin{array}{c}\text { Nitrate, } \\
\text { water, } \\
\text { filtered, } \\
\text { mg/L as } \\
\text { nitrogen }\end{array}$ & $\begin{array}{c}\text { Nitrite, } \\
\text { water, } \\
\text { filtered, } \\
\text { mg/L as } \\
\text { nitrogen }\end{array}$ & $\begin{array}{c}\text { Ortho- } \\
\text { phosphate, } \\
\text { water, } \\
\text { filtered, } \\
\text { mg/L as } \\
\text { phospho- } \\
\text { rus }\end{array}$ & $\begin{array}{c}\text { Alumi- } \\
\text { num, } \\
\text { water, } \\
\text { filtered, } \\
\text { } \mu \mathrm{g} / \mathrm{L}\end{array}$ & $\begin{array}{c}\text { Barium, } \\
\text { water, } \\
\text { filtered, } \\
\text { } \mu \mathrm{g} / \mathrm{L}\end{array}$ & $\begin{array}{c}\text { Beryl- } \\
\text { lium, } \\
\text { water, } \\
\text { filtered, } \\
\mu \mathrm{g} / \mathrm{L}\end{array}$ & $\begin{array}{c}\text { Cad- } \\
\text { mium, } \\
\text { water, } \\
\text { filtered, } \\
\text { Hg/L }\end{array}$ & $\begin{array}{c}\text { Chro- } \\
\text { mium, } \\
\text { water, } \\
\text { filtered, } \\
\mu \mathrm{g} / \mathrm{L}\end{array}$ & $\begin{array}{c}\text { Cobalt, } \\
\text { water, } \\
\text { filtered, } \\
\mu \mathrm{g} / \mathrm{L}\end{array}$ & $\begin{array}{c}\text { Copper, } \\
\text { water, } \\
\text { filtered, } \\
\mu \mathrm{g} / \mathrm{L}\end{array}$ \\
\hline & & & 00618 & 00613 & 00671 & 01106 & 01005 & 01010 & 01025 & 01030 & 01035 & 01040 \\
\hline PI 552 & $7 / 24 / 2012$ & 1530 & $<0.040$ & $<0.001$ & 0.007 & $<2.2$ & 11.9 & 0.009 & $<0.016$ & $<0.07$ & 0.093 & $<0.80$ \\
\hline PI 552 & 6/24/2015 & 1445 & $<0.040$ & $<0.001$ & 0.011 & $<3.0$ & 12.8 & $<0.020$ & $<0.030$ & $<0.30$ & 0.051 & $<0.80$ \\
\hline PI 553 & 8/29/2007 & 1000 & $<0.060$ & $<0.002$ & 0.02 & $<1.6$ & -- & -- & $<0.040$ & $<0.12$ & -- & 10.8 \\
\hline PI 553 & $7 / 25 / 2012$ & 1000 & $<0.040$ & $<0.001$ & 0.019 & $<2.2$ & 57.7 & $<0.006$ & $<0.016$ & 0.11 & 0.105 & 1.7 \\
\hline PI 553 & 6/23/2015 & 1400 & $<0.040$ & $<0.001$ & 0.018 & $<3.0$ & 46.9 & $<0.020$ & $<0.030$ & $<0.30$ & 0.064 & 1.3 \\
\hline PI 556 & 8/30/2007 & 1230 & E0.040 & 0.005 & 0.016 & 2.8 & -- & -- & $<0.040$ & $<0.12$ & -- & 0.97 \\
\hline PI 556 & 8/6/2015 & 1030 & $<0.040$ & $<0.001$ & 0.019 & $<3.0$ & 17 & $<0.020$ & $<0.030$ & $<0.30$ & 0.059 & $<0.80$ \\
\hline PI 558 & 9/5/2007 & 1100 & E0.040 & E0.001 & 0.018 & $<1.6$ & -- & -- & $<0.040$ & E0.07 & -- & 25.7 \\
\hline PI 558 & 7/25/2012 & 1000 & 0.107 & $<0.001$ & 0.01 & $<2.2$ & 3.51 & $<0.006$ & $<0.016$ & 0.09 & 0.059 & 38.1 \\
\hline PI 558 & $7 / 25 / 2012$ & 1001 & 0.107 & 0.002 & 0.011 & -- & -- & -- & -- & -- & -- & -- \\
\hline PI 558 & 6/23/2015 & 1500 & 0.088 & $<0.001$ & 0.014 & $<3.0$ & 2.63 & $<0.020$ & $<0.030$ & $<0.30$ & 0.068 & 40 \\
\hline PI 562 & $10 / 18 / 2007$ & 1100 & $<0.040$ & $<0.002$ & E0.004 & $<1.6$ & -- & -- & $<0.040$ & E0.11 & -- & 4.7 \\
\hline PI 562 & 9/23/2015 & 900 & $<0.040$ & $<0.001$ & 0.014 & $<3.0$ & 10.6 & $<0.020$ & $<0.030$ & $<0.30$ & 0.065 & $<0.80$ \\
\hline PI 591 & 7/7/2011 & 1200 & $<0.020$ & $<0.001$ & 0.032 & 27.9 & 20.5 & 0.007 & $<0.016$ & $<0.06$ & 0.033 & $<0.50$ \\
\hline PI 591 & 8/5/2015 & 1600 & $<0.040$ & $<0.001$ & 0.037 & 56.3 & 24.1 & 0.036 & $<0.030$ & $<0.30$ & 0.63 & $<0.80$ \\
\hline PI 593 & $10 / 17 / 2012$ & 1430 & $<0.040$ & $<0.001$ & 0.007 & $<2.2$ & 74.3 & $<0.006$ & $<0.016$ & $<0.07$ & $<0.023$ & 0.9 \\
\hline PI 593 & $11 / 15 / 2012$ & 1400 & $<0.040$ & $<0.001$ & 0.006 & $<2.2$ & 74.2 & $<0.006$ & $<0.016$ & $<0.07$ & $<0.023$ & 1 \\
\hline PI 593 & $12 / 12 / 2012$ & 700 & $<0.040$ & $<0.001$ & 0.006 & $<2.2$ & 191 & $<0.006$ & $<0.016$ & $<0.07$ & 0.182 & 1.8 \\
\hline PI 593 & 1/9/2013 & 1130 & 0.072 & $<0.001$ & 0.006 & $<2.2$ & 126 & $<0.006$ & $<0.016$ & $<0.07$ & 0.07 & $<0.80$ \\
\hline PI 593 & 2/12/2013 & 1000 & $<0.040$ & $<0.001$ & 0.006 & $<2.2$ & 75.1 & $<0.006$ & $<0.016$ & $<0.07$ & 0.04 & 1.7 \\
\hline PI 593 & 3/12/2013 & 930 & $<0.040$ & $<0.001$ & 0.005 & $<2.2$ & 75.5 & $<0.006$ & $<0.016$ & $<0.07$ & 0.044 & 1.6 \\
\hline PI 593 & $4 / 4 / 2013$ & 1150 & $<0.040$ & $<0.001$ & 0.007 & $<2.2$ & 80.8 & $<0.006$ & $<0.016$ & $<0.07$ & 0.036 & $<0.80$ \\
\hline PI 593 & 4/4/2013 & 1405 & $<0.040$ & $<0.001$ & 0.007 & 2.9 & 80.7 & $<0.006$ & $<0.016$ & $<0.07$ & $<0.023$ & $<0.80$ \\
\hline PI 593 & 5/9/2013 & 1100 & $<0.040$ & $<0.001$ & 0.007 & $<2.2$ & 72.5 & $<0.006$ & $<0.016$ & $<0.07$ & 0.296 & $<0.80$ \\
\hline PI 593 & 6/4/2013 & 1000 & $<0.040$ & $<0.001$ & 0.006 & $<2.2$ & 74.1 & $<0.006$ & $<0.016$ & $<0.07$ & 0.032 & 1.1 \\
\hline PI 593 & 6/25/2013 & 1100 & $<0.040$ & $<0.001$ & 0.006 & $<2.2$ & 71.1 & $<0.006$ & $<0.016$ & $<0.07$ & $<0.023$ & 0.88 \\
\hline PI 593 & $6 / 22 / 2015$ & 1300 & $<0.040$ & $<0.001$ & 0.007 & $<3.0$ & 77.7 & $<0.020$ & $<0.030$ & $<0.30$ & $<0.050$ & $<0.80$ \\
\hline
\end{tabular}


Table A5-1. Field measurements and results of laboratory analyses for major and minor ions, nutrients, bacteria, trace metals, volatile organic compounds radioactivity, radon-222, and dissolved gases for groundwater samples collected from 79 wells in 2015 and from 18 of the 79 wells sampled at least once previously by USGS during 1982-2013 in Pike County, Pennsylvania.-Continued

[Constituents listed with associated 5-digit U.S. Geological Survey parameter code; 2015 methane analyses by Isotech in bold, with time offset of 5 minutes; mm $\mathrm{Hg}$, millimeters of mercury; ${ }^{\circ} \mathrm{C}$, degrees Celsius; $\mathrm{mg} / \mathrm{L}$, milligrams per liter; lab, laboratory; $\mu \mathrm{S} / \mathrm{cm}$, microsiemens per centimeter; $\mathrm{CaCO}_{3}$, calcium carbonate; $\mu \mathrm{g} / \mathrm{L}$, micrograms per liter; ANC, acid neutralizing capacity; $\mathrm{pCi} / \mathrm{L}$, picocuries per liter; --, no data; <, less than; >, greater than; E, estimated; M, presence verified but not quantified; R, non-detect for radiological analysis; U, analyzed for but not detected; VPDB, PeeDee belemnite; VSMOW, Vienna Standard Mean Ocean Water]

\begin{tabular}{|c|c|c|c|c|c|c|c|c|c|c|c|c|}
\hline $\begin{array}{l}\text { Local } \\
\text { identifier }\end{array}$ & Date & $\begin{array}{c}\text { Sample } \\
\text { time }\end{array}$ & $\begin{array}{c}\text { Nitrate, } \\
\text { water, } \\
\text { filtered, } \\
\mathrm{mg} / \mathrm{L} \text { as } \\
\text { nitrogen }\end{array}$ & $\begin{array}{l}\text { Nitrite, } \\
\text { water, } \\
\text { filtered, } \\
\mathrm{mg} / \mathrm{L} \text { as } \\
\text { nitrogen }\end{array}$ & $\begin{array}{c}\text { Ortho- } \\
\text { phosphate, } \\
\text { water, } \\
\text { filtered, } \\
\text { mg/L as } \\
\text { phospho- } \\
\text { rus }\end{array}$ & $\begin{array}{c}\text { Alumi- } \\
\text { num, } \\
\text { water, } \\
\text { filtered, } \\
\mu \mathrm{gg} / \mathrm{L}\end{array}$ & $\begin{array}{c}\text { Barium, } \\
\text { water, } \\
\text { filtered, } \\
\mu \mathrm{g} / \mathrm{L}\end{array}$ & $\begin{array}{c}\text { Beryl- } \\
\text { lium, } \\
\text { water, } \\
\text { filtered, } \\
\boldsymbol{\mu g} / \mathrm{L}\end{array}$ & $\begin{array}{c}\text { Cad- } \\
\text { mium, } \\
\text { water, } \\
\text { filtered, } \\
\mu \mathrm{g} / \mathrm{L}\end{array}$ & $\begin{array}{c}\text { Chro- } \\
\text { mium, } \\
\text { water, } \\
\text { filtered, } \\
\mu \mathrm{g} / \mathrm{L}\end{array}$ & $\begin{array}{c}\text { Cobalt, } \\
\text { water, } \\
\text { filtered, } \\
\mu \mathrm{g} / \mathrm{L}\end{array}$ & $\begin{array}{c}\text { Copper, } \\
\text { water, } \\
\text { filtered, } \\
\mu \mathrm{g} / \mathrm{L}\end{array}$ \\
\hline & & & 00618 & 00613 & 00671 & 01106 & 01005 & 01010 & 01025 & 01030 & 01035 & 01040 \\
\hline PI 594 & $7 / 18 / 2012$ & 900 & 0.883 & $<0.001$ & 0.02 & $<2.2$ & 5.36 & 0.007 & 0.05 & $<0.07$ & 0.044 & 2.9 \\
\hline PI 594 & 6/25/2015 & 1130 & 0.816 & $<0.001$ & 0.022 & $<3.0$ & 5.09 & $<0.020$ & 0.053 & $<0.30$ & $<0.050$ & 3.2 \\
\hline PI 595 & 7/19/2012 & 1300 & $<0.039$ & 0.001 & $<0.004$ & $<2.2$ & 92.3 & $<0.006$ & $<0.016$ & 0.27 & 0.047 & $<0.80$ \\
\hline PI 595 & 6/23/2015 & 930 & 0.048 & $<0.001$ & 0.005 & $<3.0$ & 143 & $<0.020$ & $<0.030$ & $<0.30$ & 0.174 & 0.8 \\
\hline PI 598 & 7/19/2012 & 1000 & $<0.040$ & $<0.001$ & 0.076 & $<2.2$ & 18.1 & $<0.006$ & 0.048 & 0.26 & 0.113 & 0.83 \\
\hline PI 598 & $6 / 22 / 2015$ & 1600 & $<0.040$ & $<0.001$ & 0.083 & 3.1 & 20.2 & $<0.020$ & 0.031 & $<0.30$ & 0.117 & $<0.80$ \\
\hline PI 600 & $7 / 24 / 2012$ & 1100 & $<0.040$ & $<0.001$ & 0.005 & $<2.2$ & 162 & $<0.006$ & $<0.016$ & $<0.07$ & 0.081 & 16.5 \\
\hline PI 600 & 9/11/2012 & 1300 & $<0.040$ & $<0.001$ & 0.005 & $<2.2$ & 158 & $<0.006$ & $<0.016$ & $<0.07$ & $<0.021$ & 19.9 \\
\hline PI 600 & 10/17/2012 & 1100 & $<0.037$ & 0.003 & 0.005 & $<2.2$ & 157 & $<0.006$ & $<0.016$ & 0.1 & $<0.023$ & 27.6 \\
\hline PI 600 & $11 / 14 / 2012$ & 1400 & $<0.040$ & $<0.001$ & 0.005 & $<2.2$ & 166 & $<0.006$ & $<0.016$ & $<0.07$ & $<0.023$ & 15.9 \\
\hline PI 600 & $12 / 13 / 2012$ & 1100 & $<0.040$ & $<0.001$ & 0.007 & $<2.2$ & 165 & $<0.006$ & $<0.016$ & $<0.07$ & 0.087 & 14.9 \\
\hline PI 600 & 1/9/2013 & 1400 & $<0.040$ & $<0.001$ & 0.006 & $<2.2$ & 161 & $<0.006$ & $<0.016$ & $<0.07$ & 0.042 & 16.5 \\
\hline PI 600 & 2/12/2013 & 1400 & $<0.040$ & $<0.001$ & 0.005 & $<2.2$ & 165 & $<0.006$ & $<0.016$ & $<0.07$ & 0.06 & 13.1 \\
\hline PI 600 & $3 / 12 / 2013$ & 1200 & $<0.038$ & 0.002 & 0.005 & $<2.2$ & 159 & $<0.006$ & $<0.016$ & $<0.07$ & 0.05 & 1.4 \\
\hline PI 600 & 4/2/2013 & 1500 & $<0.040$ & $<0.001$ & 0.006 & $<2.2$ & 168 & $<0.006$ & $<0.016$ & $<0.07$ & $<0.023$ & 14.1 \\
\hline PI 600 & 5/7/2013 & 1300 & 0.054 & $<0.001$ & 0.006 & $<2.2$ & 144 & $<0.006$ & $<0.016$ & $<0.07$ & 0.122 & 2.6 \\
\hline PI 600 & 6/4/2013 & 1300 & $<0.040$ & $<0.001$ & 0.005 & $<2.2$ & 149 & $<0.006$ & $<0.016$ & $<0.07$ & 0.058 & 27.2 \\
\hline PI 600 & 6/25/2013 & 1400 & $<0.040$ & & 0.005 & $<2.2$ & 159 & $<0.006$ & $<0.016$ & $<0.07$ & $<0.023$ & 0.94 \\
\hline PI 600 & $6 / 24 / 2015$ & 1400 & $<0.040$ & $<0.001$ & 0.006 & $<3.0$ & 160 & $<0.020$ & $<0.030$ & $<0.30$ & $<0.050$ & $<0.80$ \\
\hline PI 601 & 8/2/2012 & 1400 & $<0.040$ & $<0.001$ & 0.027 & $<2.2$ & 30.2 & $<0.006$ & $<0.016$ & $<0.07$ & 0.021 & $<0.80$ \\
\hline PI 601 & $6 / 25 / 2015$ & 1000 & $<0.040$ & $<0.001$ & 0.029 & 4.8 & 28.2 & $<0.020$ & $<0.030$ & $<0.30$ & $<0.050$ & $<0.80$ \\
\hline
\end{tabular}


Table A5-1. Field measurements and results of laboratory analyses for major and minor ions, nutrients, bacteria, trace metals, volatile organic compounds radioactivity, radon-222, and dissolved gases for groundwater samples collected from 79 wells in 2015 and from 18 of the 79 wells sampled at least once previously by USGS during 1982-2013 in Pike County, Pennsylvania. - Continued

[Constituents listed with associated 5-digit U.S. Geological Survey parameter code; 2015 methane analyses by Isotech in bold, with time offset of 5 minutes; mm $\mathrm{Hg}$, millimeters of mercury; ${ }^{\circ} \mathrm{C}$, degrees Celsius; $\mathrm{mg} / \mathrm{L}$, milligrams per liter; lab, laboratory; $\mu \mathrm{S} / \mathrm{cm}$, microsiemens per centimeter; $\mathrm{CaCO}_{3}$, calcium carbonate; $\mu \mathrm{g} / \mathrm{L}$, micrograms per liter; ANC, acid neutralizing capacity; pCi/L, picocuries per liter; --, no data; <, less than; >, greater than; E, estimated; M, presence verified but not quantified; R, non-detect for radiological analysis; U, analyzed for but not detected; VPDB, PeeDee belemnite; VSMOW, Vienna Standard Mean Ocean Water]

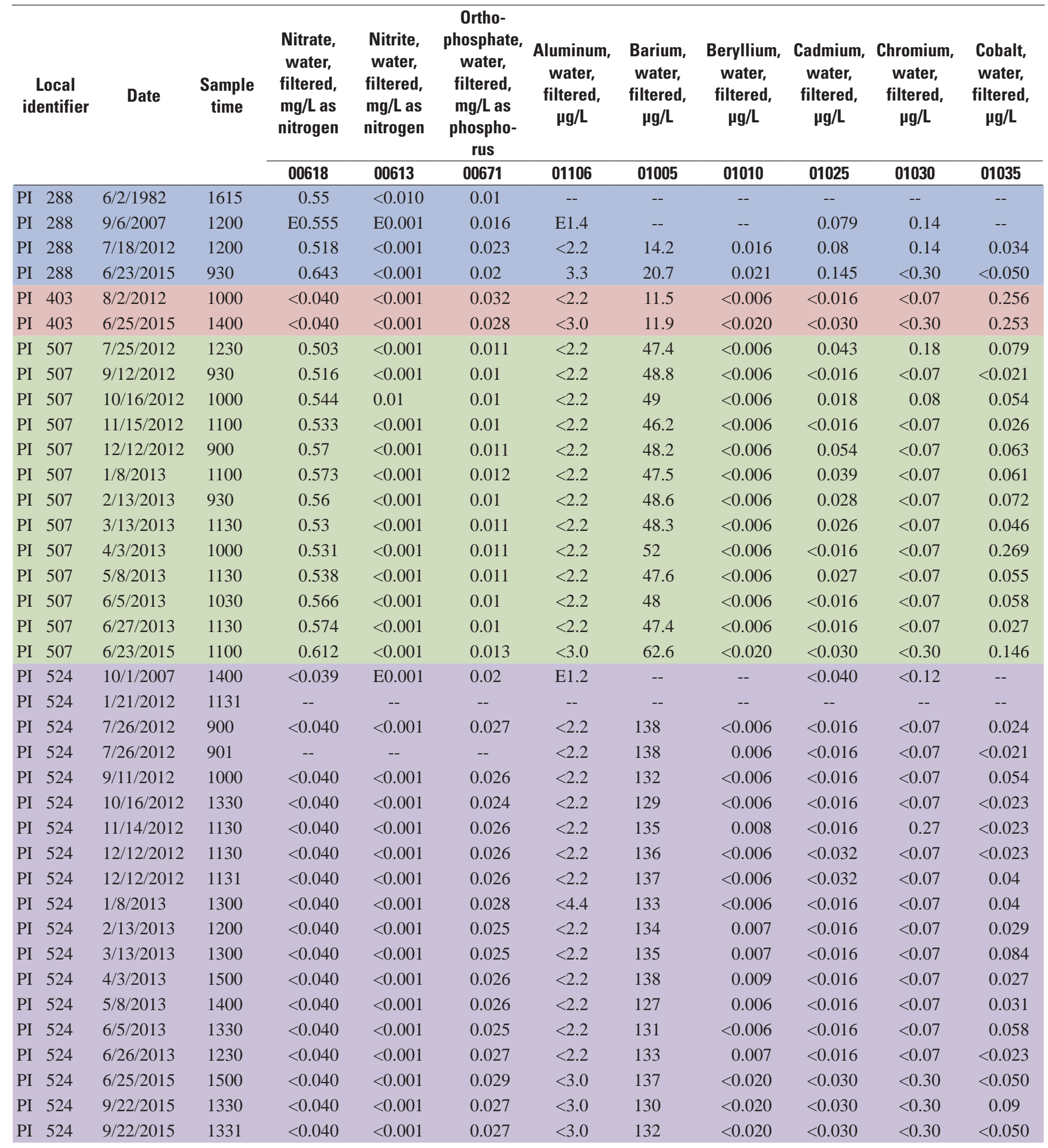


Table A5-1. Field measurements and results of laboratory analyses for major and minor ions, nutrients, bacteria, trace metals, volatile organic compounds radioactivity, radon-222, and dissolved gases for groundwater samples collected from 79 wells in 2015 and from 18 of the 79 wells sampled at least once previously by USGS during 1982-2013 in Pike County, Pennsylvania. - Continued

[Constituents listed with associated 5-digit U.S. Geological Survey parameter code; 2015 methane analyses by Isotech in bold, with time offset of 5 minutes; mm $\mathrm{Hg}$, millimeters of mercury; ${ }^{\circ} \mathrm{C}$, degrees Celsius; $\mathrm{mg} / \mathrm{L}$, milligrams per liter; lab, laboratory; $\mu \mathrm{S} / \mathrm{cm}$, microsiemens per centimeter; $\mathrm{CaCO}_{3}$, calcium carbonate; $\mu \mathrm{g} / \mathrm{L}$, micrograms per liter; ANC, acid neutralizing capacity; $\mathrm{pCi} / \mathrm{L}$, picocuries per liter; --, no data; <, less than; >, greater than; E, estimated; M, presence verified but not quantified; R, non-detect for radiological analysis; U, analyzed for but not detected; VPDB, PeeDee belemnite; VSMOW, Vienna Standard Mean Ocean Water]

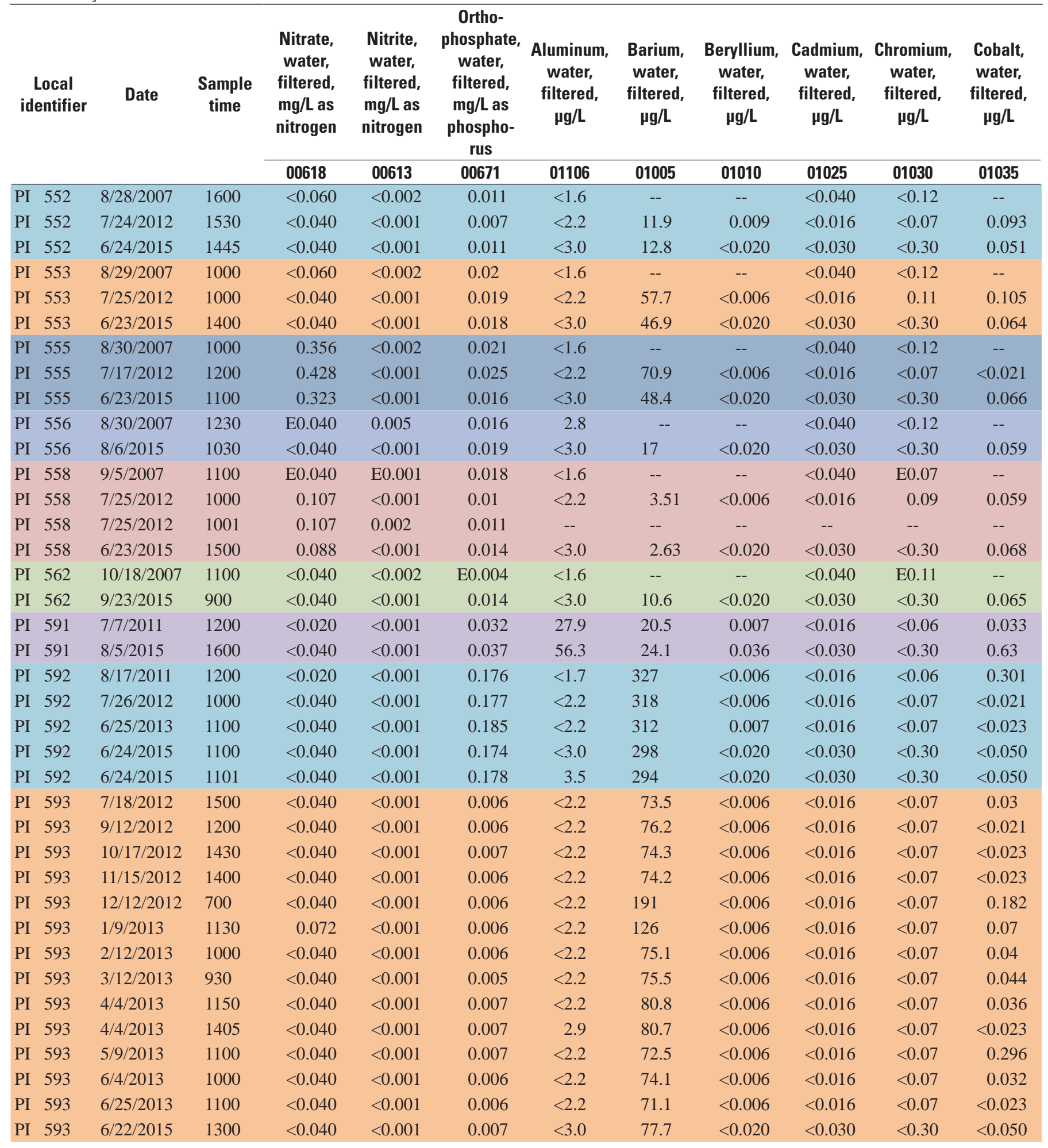


Table A5-1. Field measurements and results of laboratory analyses for major and minor ions, nutrients, bacteria, trace metals, volatile organic compounds radioactivity, radon-222, and dissolved gases for groundwater samples collected from 79 wells in 2015 and from 18 of the 79 wells sampled at least once previously by USGS during 1982-2013 in Pike County, Pennsylvania. - Continued

[Constituents listed with associated 5-digit U.S. Geological Survey parameter code; 2015 methane analyses by Isotech in bold, with time offset of 5 minutes; mm $\mathrm{Hg}$, millimeters of mercury; ${ }^{\circ} \mathrm{C}$, degrees Celsius; $\mathrm{mg} / \mathrm{L}$, milligrams per liter; lab, laboratory; $\mu \mathrm{S} / \mathrm{cm}$, microsiemens per centimeter; $\mathrm{CaCO}_{3}$, calcium carbonate; $\mu \mathrm{g} / \mathrm{L}$, micrograms per liter; ANC, acid neutralizing capacity; $\mathrm{pCi} / \mathrm{L}$, picocuries per liter; --, no data; <, less than; >, greater than; E, estimated; M, presence verified but not quantified; R, non-detect for radiological analysis; U, analyzed for but not detected; VPDB, PeeDee belemnite; VSMOW, Vienna Standard Mean Ocean Water]

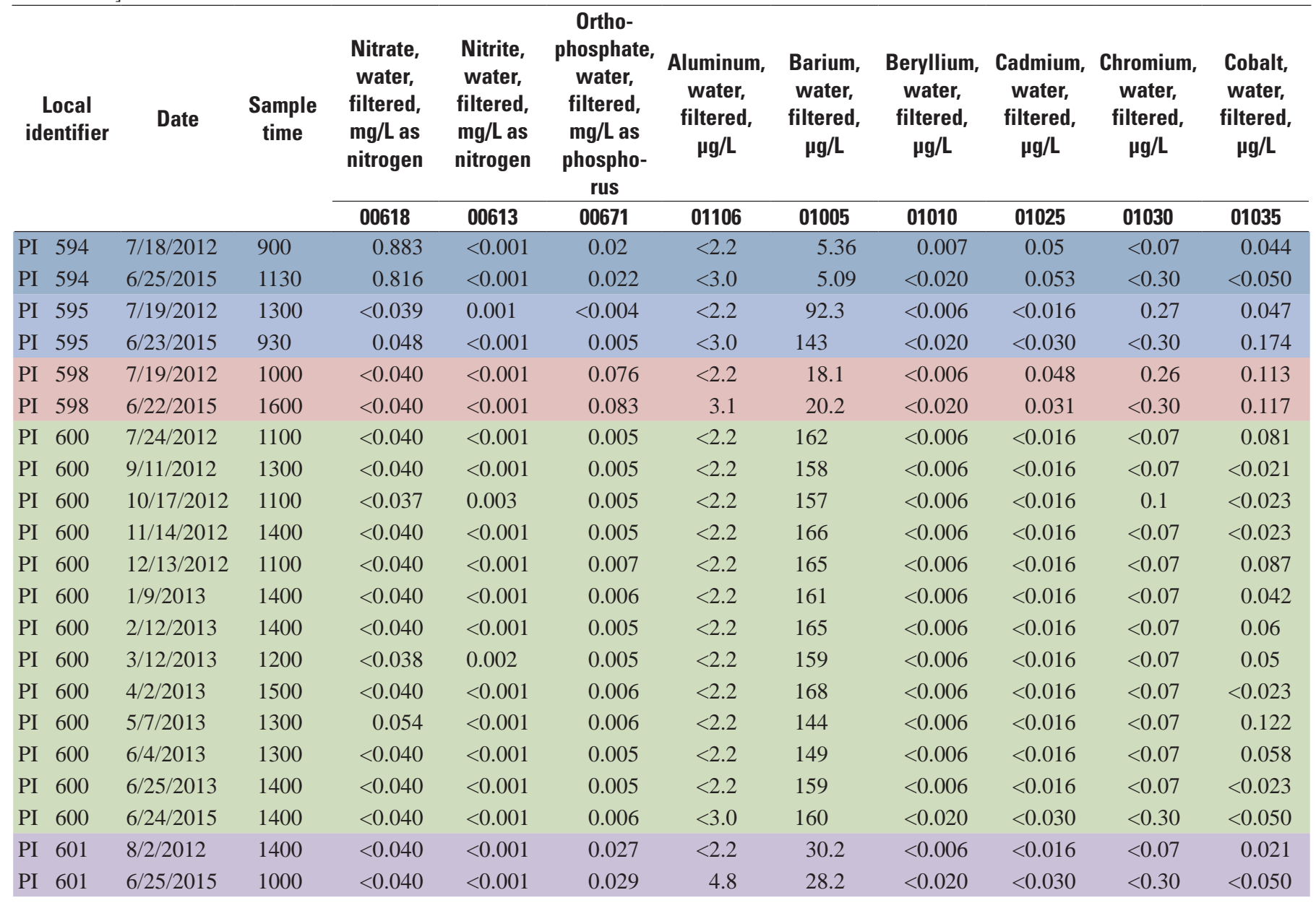


Table A5-1. Field measurements and results of laboratory analyses for major and minor ions, nutrients, bacteria, trace metals, volatile organic compounds radioactivity, radon-222, and dissolved gases for groundwater samples collected from 79 wells in 2015 and from 18 of the 79 wells sampled at least once previously by USGS during 1982-2013 in Pike County, Pennsylvania.-Continued

[Constituents listed with associated 5-digit U.S. Geological Survey parameter code; 2015 methane analyses by Isotech in bold, with time offset of 5 minutes; mm $\mathrm{Hg}$, millimeters of mercury; ${ }^{\circ} \mathrm{C}$, degrees Celsius; $\mathrm{mg} / \mathrm{L}$, milligrams per liter; lab, laboratory; $\mu \mathrm{S} / \mathrm{cm}$, microsiemens per centimeter; $\mathrm{CaCO}_{3}$, calcium carbonate; $\mu \mathrm{g} / \mathrm{L}$, micrograms per liter; ANC, acid neutralizing capacity; $\mathrm{pCi} / \mathrm{L}$, picocuries per liter; --, no data; <, less than; >, greater than; E, estimated; M, presence verified but not quantified; R, non-detect for radiological analysis; U, analyzed for but not detected; VPDB, PeeDee belemnite; VSMOW, Vienna Standard Mean Ocean Water]

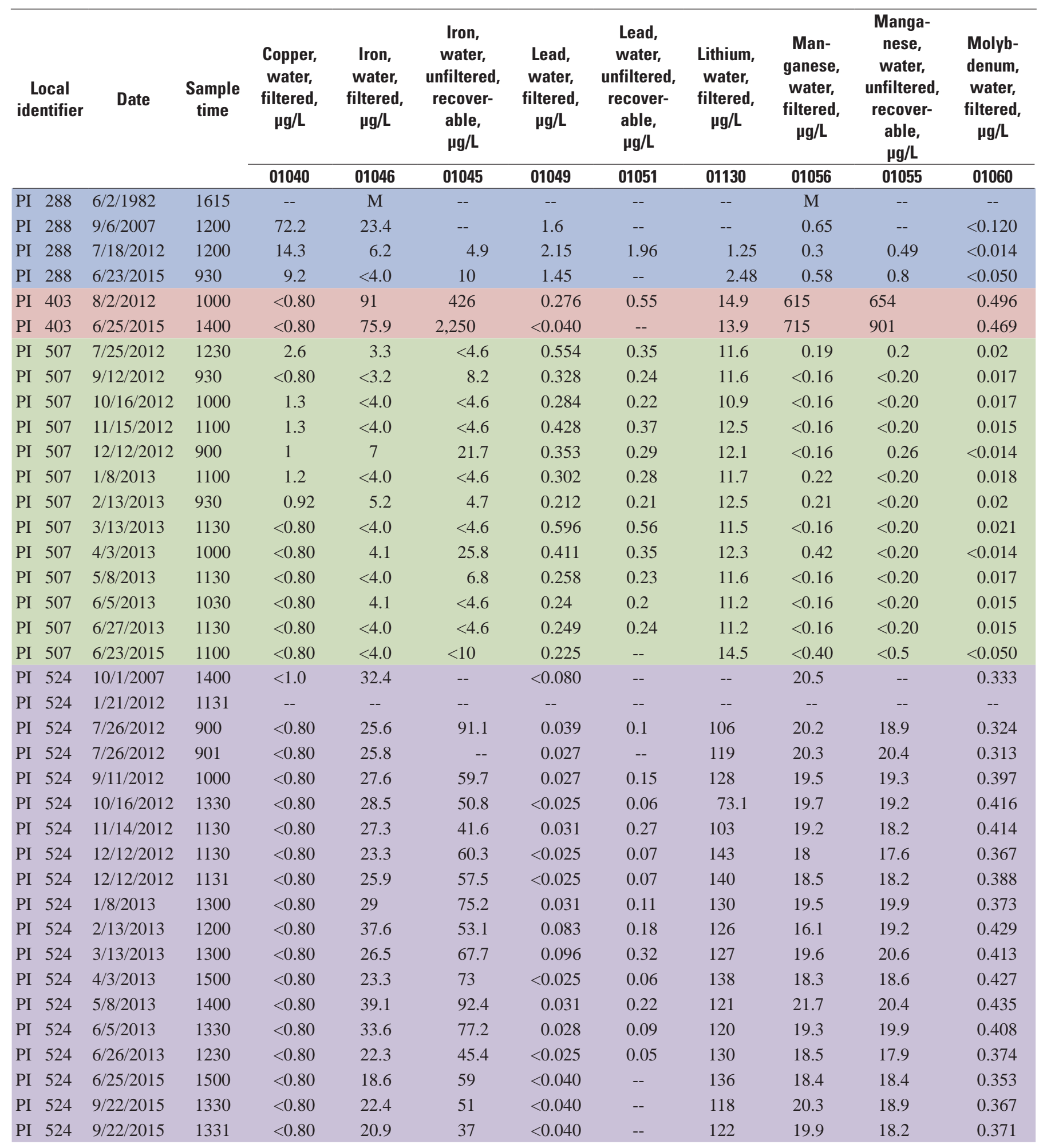


Table A5-1. Field measurements and results of laboratory analyses for major and minor ions, nutrients, bacteria, trace metals, volatile organic compounds radioactivity, radon-222, and dissolved gases for groundwater samples collected from 79 wells in 2015 and from 18 of the 79 wells sampled at least once previously by USGS during 1982-2013 in Pike County, Pennsylvania. - Continued

[Constituents listed with associated 5-digit U.S. Geological Survey parameter code; 2015 methane analyses by Isotech in bold, with time offset of 5 minutes; mm $\mathrm{Hg}$, millimeters of mercury; ${ }^{\circ} \mathrm{C}$, degrees Celsius; $\mathrm{mg} / \mathrm{L}$, milligrams per liter; lab, laboratory; $\mu \mathrm{S} / \mathrm{cm}$, microsiemens per centimeter; $\mathrm{CaCO}_{3}$, calcium carbonate; $\mu \mathrm{g} / \mathrm{L}$, micrograms per liter; ANC, acid neutralizing capacity; pCi/L, picocuries per liter; --, no data; <, less than; >, greater than; E, estimated; M, presence verified but not quantified; R, non-detect for radiological analysis; U, analyzed for but not detected; VPDB, PeeDee belemnite; VSMOW, Vienna Standard Mean Ocean Water]

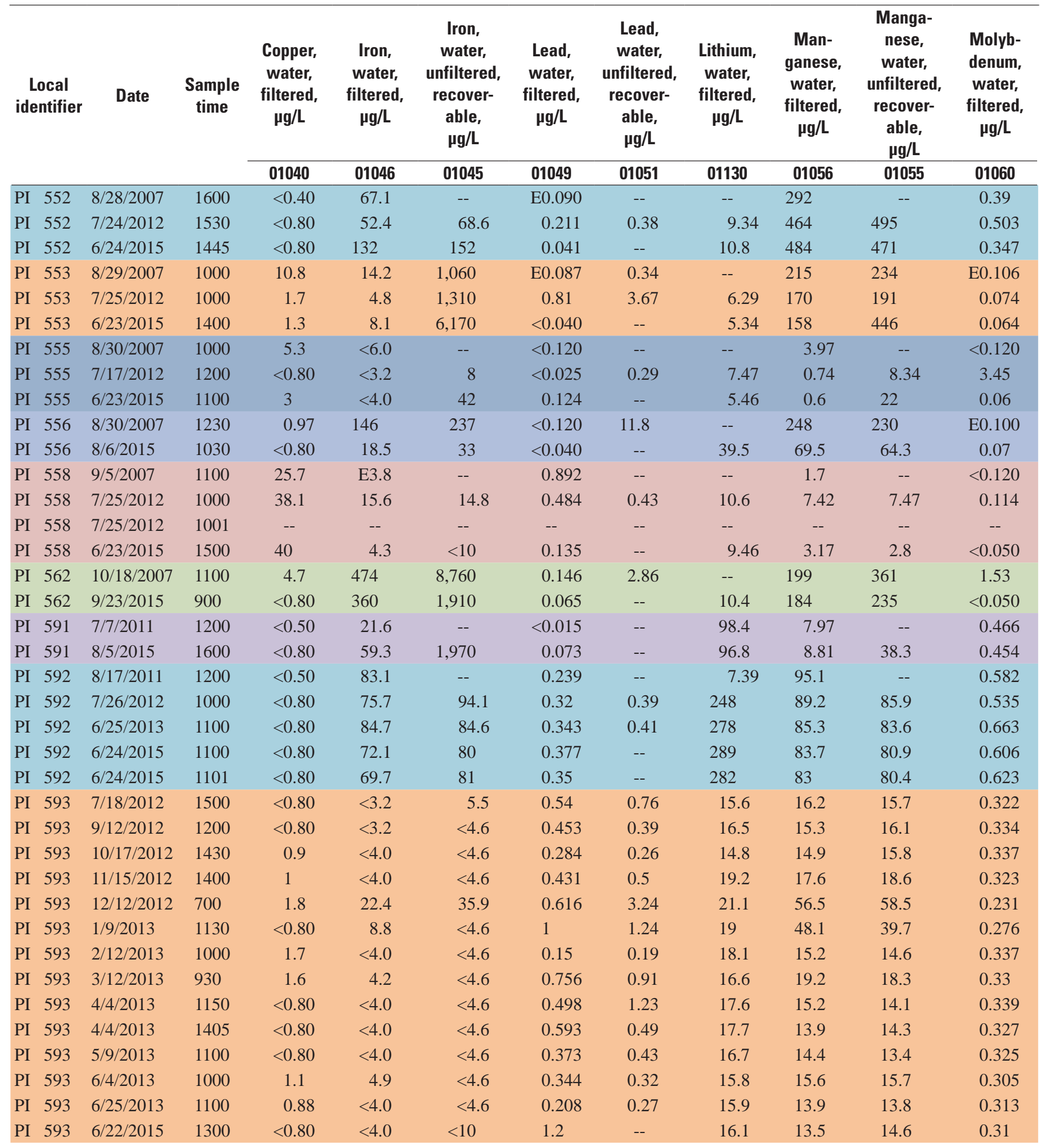


Table A5-1. Field measurements and results of laboratory analyses for major and minor ions, nutrients, bacteria, trace metals, volatile organic compounds radioactivity, radon-222, and dissolved gases for groundwater samples collected from 79 wells in 2015 and from 18 of the 79 wells sampled at least once previously by USGS during 1982-2013 in Pike County, Pennsylvania.-Continued

[Constituents listed with associated 5-digit U.S. Geological Survey parameter code; 2015 methane analyses by Isotech in bold, with time offset of 5 minutes; mm $\mathrm{Hg}$, millimeters of mercury; ${ }^{\circ} \mathrm{C}$, degrees Celsius; $\mathrm{mg} / \mathrm{L}$, milligrams per liter; lab, laboratory; $\mu \mathrm{S} / \mathrm{cm}$, microsiemens per centimeter; $\mathrm{CaCO}_{3}$, calcium carbonate; $\mu \mathrm{g} / \mathrm{L}$, micrograms per liter; ANC, acid neutralizing capacity; $\mathrm{pCi} / \mathrm{L}$, picocuries per liter; --, no data; <, less than; >, greater than; E, estimated; M, presence verified but not quantified; R, non-detect for radiological analysis; U, analyzed for but not detected; VPDB, PeeDee belemnite; VSMOW, Vienna Standard Mean Ocean Water]

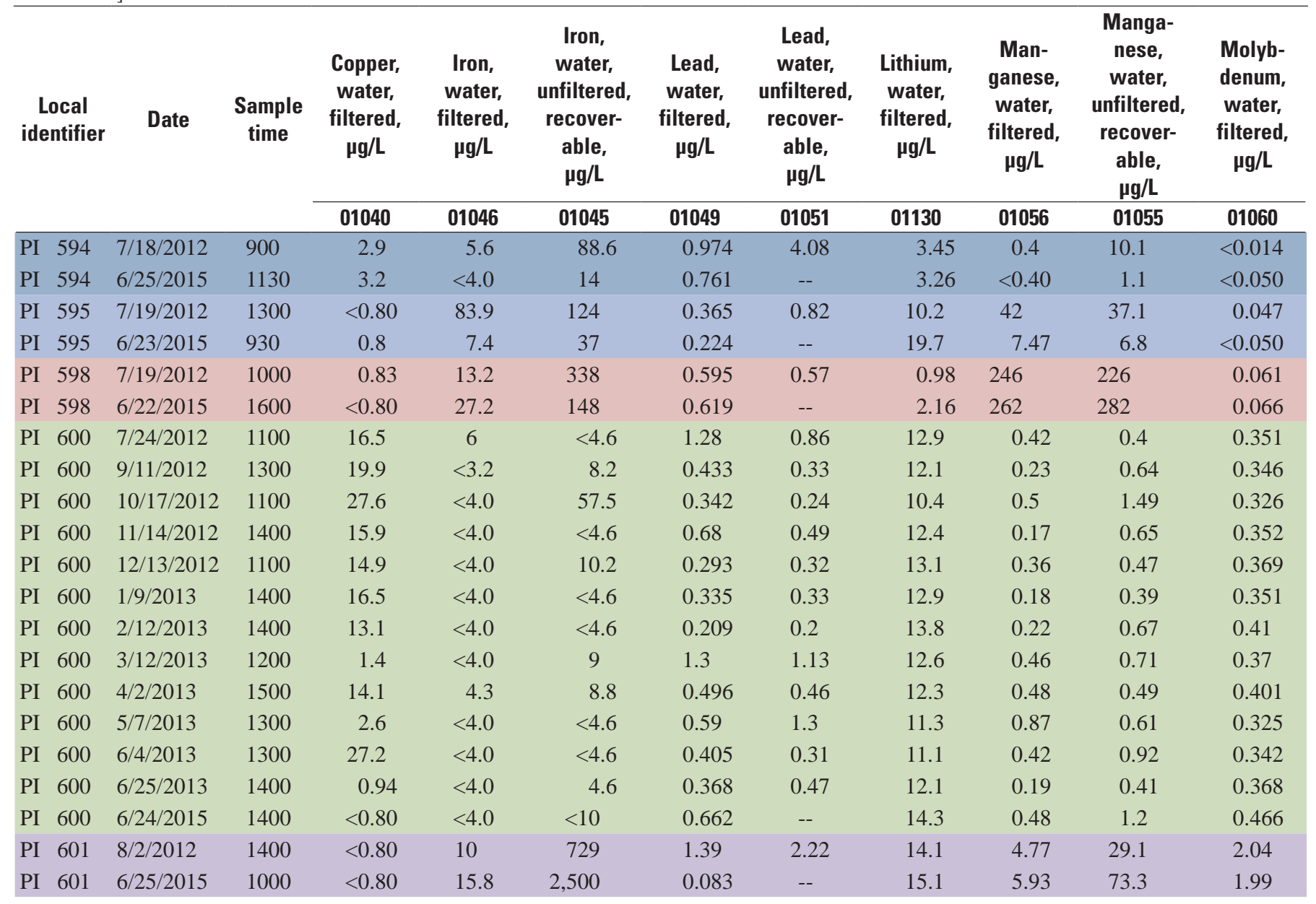


Table A5-1. Field measurements and results of laboratory analyses for major and minor ions, nutrients, bacteria, trace metals, volatile organic compounds radioactivity, radon-222, and dissolved gases for groundwater samples collected from 79 wells in 2015 and from 18 of the 79 wells sampled at least once previously by USGS during 1982-2013 in Pike County, Pennsylvania. - Continued

[Constituents listed with associated 5-digit U.S. Geological Survey parameter code; 2015 methane analyses by Isotech in bold, with time offset of 5 minutes; mm $\mathrm{Hg}$, millimeters of mercury; ${ }^{\circ} \mathrm{C}$, degrees Celsius; $\mathrm{mg} / \mathrm{L}$, milligrams per liter; lab, laboratory; $\mu \mathrm{S} / \mathrm{cm}$, microsiemens per centimeter; $\mathrm{CaCO}_{3}$, calcium carbonate; $\mu \mathrm{g} / \mathrm{L}$, micrograms per liter; ANC, acid neutralizing capacity; pCi/L, picocuries per liter; --, no data; <, less than; >, greater than; E, estimated; M, presence verified but not quantified; R, non-detect for radiological analysis; U, analyzed for but not detected; VPDB, PeeDee belemnite; VSMOW, Vienna Standard Mean Ocean Water]

\begin{tabular}{|c|c|c|c|c|c|c|c|c|c|c|c|c|}
\hline \multirow[t]{2}{*}{$\begin{array}{l}\text { Local } \\
\text { identifier }\end{array}$} & \multirow[t]{2}{*}{ Date } & \multirow[t]{2}{*}{$\begin{array}{c}\text { Sample } \\
\text { time }\end{array}$} & $\begin{array}{c}\text { Nickel, } \\
\text { water, } \\
\text { filtered, } \\
\mu \mathrm{g} / \mathrm{L}\end{array}$ & $\begin{array}{c}\text { Silver, } \\
\text { water, } \\
\text { filtered, } \\
\mu \mathrm{g} / \mathrm{L}\end{array}$ & $\begin{array}{c}\text { Stron- } \\
\text { tium, } \\
\text { water, } \\
\text { filtered, } \\
\mu \mathrm{g} / \mathrm{L}\end{array}$ & $\begin{array}{c}\text { Thallium, } \\
\text { water, } \\
\text { filtered, } \\
\mu \mathrm{g} / \mathrm{L}\end{array}$ & $\begin{array}{c}\text { Tungsten, } \\
\text { water, } \\
\text { filtered, } \\
\mu \mathrm{g} / \mathrm{L}\end{array}$ & $\begin{array}{c}\text { Vana- } \\
\text { dium, } \\
\text { water, } \\
\text { filtered, } \\
\text { g/L }\end{array}$ & $\begin{array}{c}\text { Zinc, } \\
\text { water, } \\
\text { filtered, } \\
\mu \mathrm{g} / \mathrm{L}\end{array}$ & $\begin{array}{c}\text { Antimo- } \\
\text { ny, water, } \\
\text { filtered, } \\
\mu \mathrm{g} / \mathrm{L}\end{array}$ & $\begin{array}{c}\text { Arsenic, } \\
\text { water, } \\
\text { filtered, } \\
\mu \mathrm{g} / \mathrm{L}\end{array}$ & $\begin{array}{c}\text { Arsenic, } \\
\text { water, } \\
\text { unfil- } \\
\text { tered, } \\
\text { } \mathrm{gg} / \mathrm{L}\end{array}$ \\
\hline & & & 01065 & 01075 & 01080 & 01057 & 01155 & 01085 & 01090 & 01095 & 01000 & 01002 \\
\hline PI 288 & 6/2/1982 & 1615 & -- & -- & -- & -- & -- & -- & -- & -- & -- & -- \\
\hline PI 288 & 6/23/2015 & 930 & 0.61 & -- & 19.1 & -- & -- & -- & 26.1 & $<0.027$ & $<0.10$ & $<0.5$ \\
\hline PI 403 & 8/2/2012 & 1000 & 0.42 & $<0.005$ & 272 & $<0.010$ & $<0.010$ & $<0.08$ & 2 & 0.03 & 1.1 & 1.5 \\
\hline PI 403 & $6 / 25 / 2015$ & 1400 & 0.5 & -- & 281 & -- & -- & -- & $<2.0$ & 0.028 & 0.98 & 3 \\
\hline PI 507 & 7/25/2012 & 1230 & 0.17 & $<0.005$ & 330 & $<0.010$ & $<0.010$ & $<0.08$ & 292 & 0.032 & 0.32 & 0.36 \\
\hline PI 507 & 9/12/2012 & 930 & 0.14 & $<0.005$ & 343 & $<0.010$ & $<0.010$ & $<0.08$ & 70 & $<0.027$ & 0.3 & 0.36 \\
\hline PI 507 & 1/8/2013 & 1100 & 0.25 & $<0.005$ & 334 & $<0.010$ & $<0.010$ & $<0.08$ & 294 & 0.031 & 0.3 & 0.37 \\
\hline PI 507 & 2/13/2013 & 930 & 0.25 & $<0.005$ & 350 & $<0.010$ & $<0.010$ & $<0.08$ & 175 & 0.029 & 0.31 & 0.32 \\
\hline PI 507 & 3/13/2013 & 1130 & 0.17 & $<0.005$ & 345 & $<0.010$ & $<0.010$ & $<0.08$ & 109 & $<0.027$ & 0.31 & 0.38 \\
\hline PI 507 & 4/3/2013 & 1000 & 0.23 & $<0.005$ & 337 & $<0.010$ & $<0.010$ & $<0.08$ & 86.7 & 0.04 & 0.33 & 0.39 \\
\hline PI 507 & 5/8/2013 & 1130 & 0.18 & $<0.005$ & 345 & $<0.010$ & $<0.010$ & 0.1 & 130 & 0.028 & 0.31 & 0.3 \\
\hline PI 507 & 6/5/2013 & 1030 & 0.26 & $<0.005$ & 339 & $<0.010$ & $<0.010$ & $<0.08$ & 107 & 0.03 & 0.28 & 0.3 \\
\hline PI 507 & 6/27/2013 & 1130 & 0.17 & $<0.005$ & 333 & $<0.010$ & $<0.010$ & $<0.08$ & 30.8 & $<0.027$ & 0.29 & $<0.28$ \\
\hline PI 507 & $6 / 23 / 2015$ & 1100 & 0.31 & -- & 460 & -- & -- & -- & 35.8 & 0.038 & 0.27 & M \\
\hline PI 524 & $10 / 1 / 2007$ & 1400 & $<0.20$ & -- & -- & -- & -- & -- & $<4.0$ & -- & 0.29 & -- \\
\hline PI 524 & $1 / 21 / 2012$ & 1131 & -- & -- & -- & -- & -- & -- & -- & -- & -- & -- \\
\hline PI 524 & $12 / 12 / 2012$ & 1131 & $<0.09$ & $<0.010$ & 499 & $<0.010$ & 0.047 & $<0.08$ & $<1.4$ & $<0.027$ & 0.24 & $<0.28$ \\
\hline PI 524 & 1/8/2013 & 1300 & 0.12 & $<0.005$ & 466 & $<0.010$ & 0.052 & $<0.08$ & $<1.4$ & $<0.027$ & 0.28 & 0.35 \\
\hline PI 524 & 2/13/2013 & 1200 & $<0.09$ & $<0.005$ & 484 & $<0.010$ & 0.049 & $<0.08$ & $<1.4$ & $<0.027$ & 0.31 & 0.28 \\
\hline PI 524 & 3/13/2013 & 1300 & 0.12 & $<0.005$ & 482 & $<0.010$ & 0.048 & $<0.08$ & 1.5 & $<0.054$ & 0.28 & 0.32 \\
\hline PI 524 & 4/3/2013 & 1500 & $<0.09$ & $<0.005$ & 479 & $<0.010$ & 0.051 & $<0.08$ & $<1.4$ & $<0.027$ & 0.28 & 0.31 \\
\hline PI 524 & 5/8/2013 & 1400 & 0.1 & $<0.005$ & 460 & $<0.010$ & 0.045 & $<0.08$ & $<1.4$ & $<0.027$ & 0.31 & 0.33 \\
\hline PI 524 & 6/5/2013 & 1330 & 0.19 & $<0.005$ & 462 & $<0.010$ & 0.051 & $<0.08$ & $<1.4$ & $<0.027$ & 0.29 & 0.3 \\
\hline PI 524 & 6/26/2013 & 1230 & 0.13 & $<0.005$ & 472 & $<0.010$ & 0.052 & $<0.08$ & $<1.4$ & $<0.027$ & 0.27 & $<0.28$ \\
\hline PI 524 & $6 / 25 / 2015$ & 1500 & $<0.20$ & -- & 488 & -- & -- & -- & $<2.0$ & $<0.027$ & 0.24 & $<0.5$ \\
\hline PI 524 & $9 / 22 / 2015$ & 1330 & $<0.20$ & -- & 472 & -- & -- & -- & $<2.0$ & $<0.027$ & 0.23 & $<0.5$ \\
\hline PI 524 & 9/22/2015 & 1331 & $<0.20$ & -- & 475 & -- & -- & -- & $<2.0$ & $<0.027$ & 0.23 & $<0.5$ \\
\hline
\end{tabular}


Table A5-1. Field measurements and results of laboratory analyses for major and minor ions, nutrients, bacteria, trace metals, volatile organic compounds radioactivity, radon-222, and dissolved gases for groundwater samples collected from 79 wells in 2015 and from 18 of the 79 wells sampled at least once previously by USGS during 1982-2013 in Pike County, Pennsylvania.-Continued

[Constituents listed with associated 5-digit U.S. Geological Survey parameter code; 2015 methane analyses by Isotech in bold, with time offset of 5 minutes; mm $\mathrm{Hg}$, millimeters of mercury; ${ }^{\circ} \mathrm{C}$, degrees Celsius; $\mathrm{mg} / \mathrm{L}$, milligrams per liter; lab, laboratory; $\mu \mathrm{S} / \mathrm{cm}$, microsiemens per centimeter; $\mathrm{CaCO}_{3}$, calcium carbonate; $\mu \mathrm{g} / \mathrm{L}$, micrograms per liter; ANC, acid neutralizing capacity; $\mathrm{pCi} / \mathrm{L}$, picocuries per liter; --, no data; <, less than; >, greater than; E, estimated; M, presence verified but not quantified; R, non-detect for radiological analysis; U, analyzed for but not detected; VPDB, PeeDee belemnite; VSMOW, Vienna Standard Mean Ocean Water]

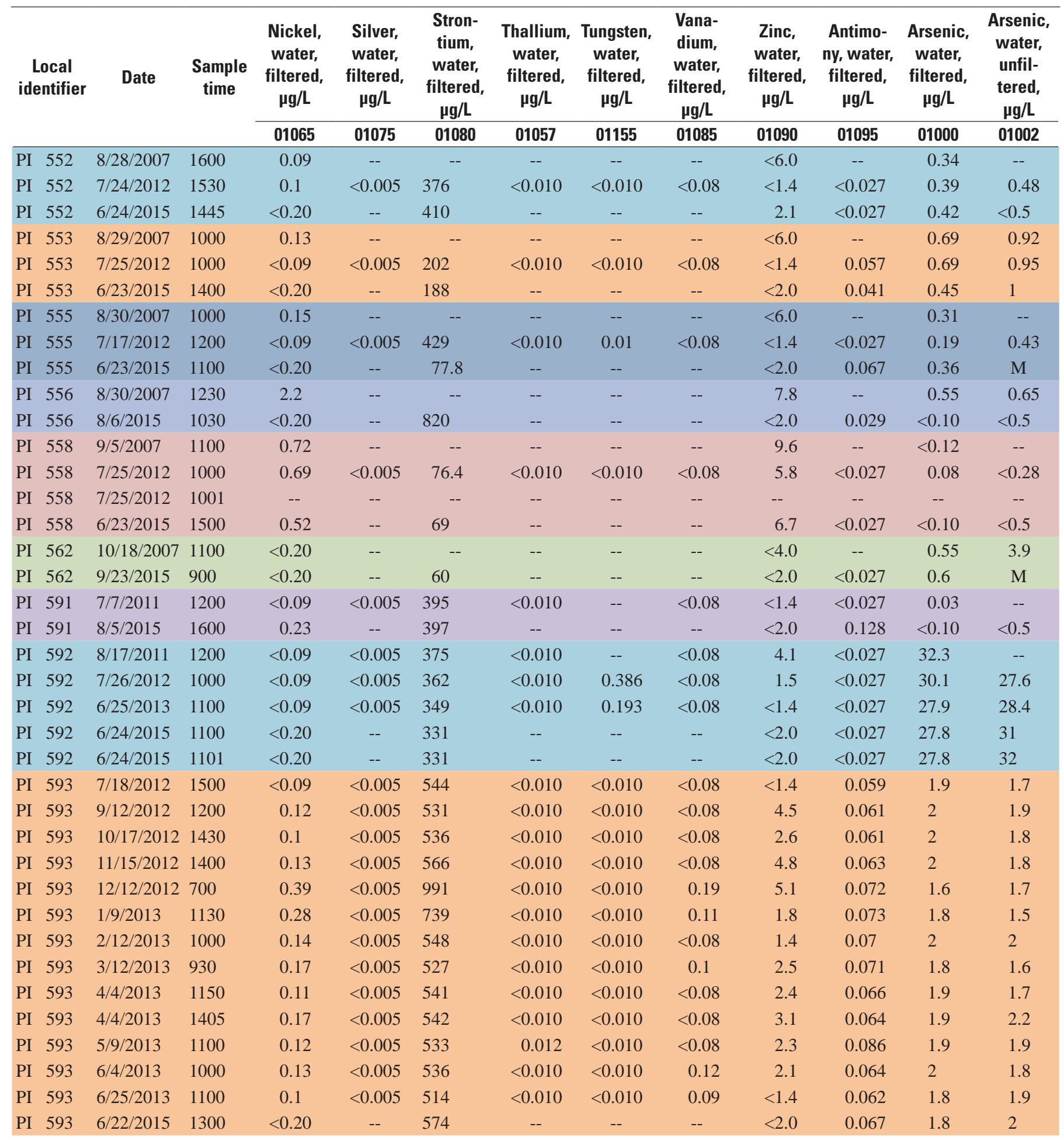


Table A5-1. Field measurements and results of laboratory analyses for major and minor ions, nutrients, bacteria, trace metals, volatile organic compounds radioactivity, radon-222, and dissolved gases for groundwater samples collected from 79 wells in 2015 and from 18 of the 79 wells sampled at least once previously by USGS during 1982-2013 in Pike County, Pennsylvania. - Continued

[Constituents listed with associated 5-digit U.S. Geological Survey parameter code; 2015 methane analyses by Isotech in bold, with time offset of 5 minutes; mm $\mathrm{Hg}$, millimeters of mercury; ${ }^{\circ} \mathrm{C}$, degrees Celsius; $\mathrm{mg} / \mathrm{L}$, milligrams per liter; lab, laboratory; $\mu \mathrm{S} / \mathrm{cm}$, microsiemens per centimeter; $\mathrm{CaCO}_{3}$, calcium carbonate; $\mu \mathrm{g} / \mathrm{L}$, micrograms per liter; ANC, acid neutralizing capacity; pCi/L, picocuries per liter; --, no data; <, less than; >, greater than; E, estimated; M, presence verified but not quantified; R, non-detect for radiological analysis; U, analyzed for but not detected; VPDB, PeeDee belemnite; VSMOW, Vienna Standard Mean Ocean Water]

\begin{tabular}{|c|c|c|c|c|c|c|c|c|c|c|c|c|}
\hline $\begin{array}{l}\text { Local } \\
\text { identifier }\end{array}$ & Date & $\begin{array}{c}\text { Sample } \\
\text { time }\end{array}$ & $\begin{array}{c}\text { Nickel, } \\
\text { water, } \\
\text { filtered, } \\
\mu \mathrm{g} / \mathrm{L}\end{array}$ & $\begin{array}{c}\text { Silver, } \\
\text { water, } \\
\text { filtered, } \\
\mu \mathrm{g} / \mathrm{L}\end{array}$ & $\begin{array}{l}\text { Stron- } \\
\text { tium, } \\
\text { water, } \\
\text { filtered, }\end{array}$ & $\begin{array}{c}\text { Thallium, } \\
\text { water, } \\
\text { filtered, } \\
\mu \mathrm{g} / \mathrm{L}\end{array}$ & $\begin{array}{c}\text { Tungsten, } \\
\text { water, } \\
\text { filtered, } \\
\mu \mathrm{g} / \mathrm{L}\end{array}$ & $\begin{array}{l}\text { Vana- } \\
\text { dium, } \\
\text { water, } \\
\text { filtered, }\end{array}$ & $\begin{array}{c}\text { Zinc, } \\
\text { water, } \\
\text { filtered, } \\
\mu \mathrm{g} / \mathrm{L}\end{array}$ & $\begin{array}{c}\text { Antimo- } \\
\text { ny, water, } \\
\text { filtered, } \\
\mu \mathrm{g} / \mathrm{L}\end{array}$ & $\begin{array}{c}\text { Arsenic, } \\
\text { water, } \\
\text { filtered, } \\
\mu \mathrm{g} / \mathrm{L}\end{array}$ & $\begin{array}{c}\text { Arsenic, } \\
\text { water, } \\
\text { unfil- } \\
\text { tered, }\end{array}$ \\
\hline & & & 01065 & 01075 & 01080 & 01057 & 01155 & 01085 & 01090 & 01095 & 01000 & 01002 \\
\hline PI 594 & $7 / 18 / 2012$ & 900 & 0.14 & $<0.005$ & 57.4 & $<0.010$ & $<0.010$ & $<0.08$ & 7.6 & $<0.027$ & 0.31 & 0.42 \\
\hline PI 595 & 6/23/2015 & 930 & 0.24 & -- & 987 & -- & -- & -- & 29.3 & 0.065 & 0.18 & $<0.5$ \\
\hline PI 598 & 7/19/2012 & 1000 & $<0.09$ & $<0.005$ & 29.7 & $<0.010$ & $<0.010$ & $<0.08$ & 23.1 & $<0.027$ & 0.27 & 0.37 \\
\hline PI 598 & $6 / 22 / 2015$ & 1600 & $<0.20$ & -- & 31.3 & -- & -- & -- & 16.1 & $<0.027$ & 0.28 & $\mathrm{M}$ \\
\hline PI 600 & $7 / 24 / 2012$ & 1100 & 0.15 & $<0.005$ & 716 & $<0.010$ & $<0.010$ & $<0.08$ & $<1.4$ & 0.099 & 1.8 & 2 \\
\hline PI 600 & 9/11/2012 & 1300 & 0.28 & $<0.005$ & 697 & $<0.010$ & $<0.010$ & $<0.08$ & 4.2 & 0.081 & 1.7 & 1.8 \\
\hline PI 600 & 1/9/2013 & 1400 & 0.27 & $<0.005$ & 748 & $<0.010$ & $<0.010$ & $<0.08$ & 3.1 & 0.081 & 1.7 & 1.6 \\
\hline PI 600 & 2/12/2013 & 1400 & 0.26 & $<0.005$ & 766 & $<0.010$ & $<0.010$ & $<0.08$ & 2.2 & 0.085 & 1.7 & 1.6 \\
\hline PI 600 & 3/12/2013 & 1200 & 0.15 & $<0.005$ & 700 & $<0.010$ & $<0.010$ & $<0.08$ & 1.7 & 0.093 & 1.8 & 1.9 \\
\hline PI 600 & 4/2/2013 & 1500 & 0.17 & $<0.005$ & 777 & $<0.010$ & $<0.010$ & $<0.08$ & 1.9 & 0.075 & 1.7 & 1.6 \\
\hline PI 600 & 5/7/2013 & 1300 & 0.27 & 0.007 & 594 & $<0.010$ & $<0.010$ & $<0.08$ & 2.3 & 0.09 & 1.5 & 1.7 \\
\hline PI 600 & $6 / 4 / 2013$ & 1300 & 0.78 & $<0.005$ & 637 & $<0.010$ & $<0.010$ & $<0.08$ & 3.3 & 0.088 & 1.7 & 1.5 \\
\hline PI 600 & $6 / 25 / 2013$ & 1400 & 0.18 & $<0.005$ & 716 & $<0.010$ & $<0.010$ & $<0.08$ & 2.4 & 0.068 & 1.5 & 1.6 \\
\hline PI 600 & 6/24/2015 & 1400 & $<0.20$ & -- & 803 & -- & -- & -- & $<2.0$ & 0.069 & 1.7 & 2 \\
\hline PI 601 & 8/2/2012 & 1400 & $<0.09$ & $<0.005$ & 326 & $<0.010$ & $<0.010$ & 0.12 & 7.2 & 0.052 & 2.5 & 2.7 \\
\hline PI 601 & $6 / 25 / 2015$ & 1000 & $<0.20$ & -- & 332 & -- & -- & -- & 3.7 & 0.036 & 2.6 & 3 \\
\hline
\end{tabular}


Table A5-1. Field measurements and results of laboratory analyses for major and minor ions, nutrients, bacteria, trace metals, volatile organic compounds radioactivity, radon-222, and dissolved gases for groundwater samples collected from 79 wells in 2015 and from 18 of the 79 wells sampled at least once previously by USGS during 1982-2013 in Pike County, Pennsylvania.-Continued

[Constituents listed with associated 5-digit U.S. Geological Survey parameter code; 2015 methane analyses by Isotech in bold, with time offset of 5 minutes; mm $\mathrm{Hg}$, millimeters of mercury; ${ }^{\circ} \mathrm{C}$, degrees Celsius; $\mathrm{mg} / \mathrm{L}$, milligrams per liter; lab, laboratory; $\mu \mathrm{S} / \mathrm{cm}$, microsiemens per centimeter; $\mathrm{CaCO}_{3}$, calcium carbonate; $\mu \mathrm{g} / \mathrm{L}$, micrograms per liter; ANC, acid neutralizing capacity; $\mathrm{pCi} / \mathrm{L}$, picocuries per liter; --, no data; <, less than; >, greater than; E, estimated; M, presence verified but not quantified; R, non-detect for radiological analysis; U, analyzed for but not detected; VPDB, PeeDee belemnite; VSMOW, Vienna Standard Mean Ocean Water]

\begin{tabular}{|c|c|c|c|c|c|c|c|c|}
\hline \multirow[t]{2}{*}{$\begin{array}{l}\text { Local } \\
\text { identifier }\end{array}$} & \multirow[t]{2}{*}{ Date } & \multirow[t]{2}{*}{$\begin{array}{c}\text { Sample } \\
\text { time }\end{array}$} & $\begin{array}{c}\text { Boron, } \\
\text { water, } \\
\text { filtered, } \\
\mu \mathrm{g} / \mathrm{L}\end{array}$ & $\begin{array}{c}\text { Selenium, } \\
\text { water, } \\
\text { filtered, } \\
\mu \mathrm{g} / \mathrm{L}\end{array}$ & $\begin{array}{c}\text { Methane, } \\
\text { water, } \\
\text { dissolved, } \\
\text { recoverable, } \\
\mu \mathrm{g} / \mathrm{L}\end{array}$ & $\begin{array}{c}\text { Methane } \\
\text { by Isotech, } \\
\text { water, dis- } \\
\text { solved, } \\
\text { recoverable, } \\
\text { mg/L }\end{array}$ & $\begin{array}{l}\text { Methane by } \\
\text { Seewald, } \\
\text { water, } \\
\text { dissolved, } \\
\text { recoverable, } \\
\text { mg/L }\end{array}$ & $\begin{array}{c}\text { Methane, } \\
\text { water, } \\
\text { dissolved, } \\
\text { recoverable, } \\
\text { mg/L }\end{array}$ \\
\hline & & & 01020 & 01145 & 76994 & 68831 & 68831 & 85574 \\
\hline PI 288 & $6 / 2 / 1982$ & 1615 & -- & -- & -- & -- & -- & -- \\
\hline PI 288 & 9/6/2007 & 1200 & 5 & 0.12 & -- & -- & -- & -- \\
\hline PI 288 & 7/18/2012 & 1200 & 4 & 0.09 & $\mathrm{U}$ & -- & -- & -- \\
\hline PI 288 & 6/23/2015 & 930 & $<5$ & 0.07 & -- & -- & $<0.010$ & -- \\
\hline PI 403 & 8/2/2012 & 1000 & 19 & $<0.03$ & 15.2 & -- & -- & -- \\
\hline PI 403 & $6 / 25 / 2015$ & 1400 & 16 & $<0.05$ & -- & -- & 0.012 & -- \\
\hline PI 507 & $7 / 25 / 2012$ & 1230 & 12 & 0.1 & 0.564 & -- & -- & -- \\
\hline PI 507 & 9/12/2012 & 930 & 12 & 0.1 & 0.585 & -- & -- & -- \\
\hline PI 507 & $10 / 16 / 2012$ & 1000 & 12 & 0.09 & 0.815 & -- & -- & -- \\
\hline PI 507 & $11 / 15 / 2012$ & 1100 & 11 & 0.09 & 0.621 & -- & -- & -- \\
\hline PI 507 & $12 / 12 / 2012$ & 900 & 12 & 0.08 & 0.766 & -- & -- & -- \\
\hline PI 507 & 1/8/2013 & 1100 & 12 & 0.1 & 0.832 & -- & -- & -- \\
\hline PI 507 & 2/13/2013 & 930 & 12 & 0.11 & E0.420 & -- & -- & -- \\
\hline PI 507 & 3/13/2013 & 1130 & 13 & 0.11 & 0.837 & -- & -- & -- \\
\hline PI 507 & 4/3/2013 & 1000 & 13 & 0.1 & 0.541 & -- & -- & -- \\
\hline PI 507 & 5/8/2013 & 1130 & 12 & 0.12 & 0.567 & -- & -- & -- \\
\hline PI 507 & 6/5/2013 & 1030 & 11 & 0.11 & 0.827 & -- & -- & -- \\
\hline PI 507 & 6/27/2013 & 1130 & 10 & 0.09 & $\mathrm{U}$ & -- & -- & -- \\
\hline PI 507 & 6/23/2015 & 1100 & 11 & 0.14 & -- & -- & $<0.010$ & -- \\
\hline PI 524 & $10 / 1 / 2007$ & 1400 & 77 & $<0.04$ & -- & -- & -- & -- \\
\hline PI 524 & $1 / 21 / 2012$ & 1131 & -- & -- & -- & -- & -- & -- \\
\hline PI 524 & 7/26/2012 & 900 & 84 & $<0.03$ & 4,650 & 5.9 & -- & -- \\
\hline PI 524 & 7/26/2012 & 901 & 83 & $<0.03$ & 4,190 & 5.7 & -- & -- \\
\hline PI 524 & 9/11/2012 & 1000 & 76 & $<0.03$ & 5,180 & 5 & -- & -- \\
\hline PI 524 & 10/16/2012 & 1330 & 76 & $<0.03$ & 5,510 & 5.4 & -- & -- \\
\hline PI 524 & $11 / 14 / 2012$ & 1130 & 86 & $<0.03$ & 4,710 & 5 & -- & -- \\
\hline PI 524 & $12 / 12 / 2012$ & 1130 & 83 & $<0.03$ & 4,820 & 5.8 & -- & -- \\
\hline PI 524 & $12 / 12 / 2012$ & 1131 & 86 & $<0.03$ & 5,090 & 5.2 & -- & -- \\
\hline PI 524 & $1 / 8 / 2013$ & 1300 & 83 & $<0.03$ & 3,980 & 5 & -- & -- \\
\hline PI 524 & 2/13/2013 & 1200 & 82 & $<0.03$ & 4,040 & 5.2 & -- & -- \\
\hline PI 524 & $3 / 13 / 2013$ & 1300 & 82 & $<0.03$ & 3,930 & 5.1 & -- & -- \\
\hline PI 524 & 4/3/2013 & 1500 & 86 & $<0.03$ & 4,010 & 5.1 & -- & -- \\
\hline PI 524 & 5/8/2013 & 1400 & 76 & $<0.03$ & 4,300 & 5.3 & -- & -- \\
\hline PI 524 & 6/5/2013 & 1330 & 72 & $<0.03$ & 4,740 & 5.6 & -- & -- \\
\hline PI 524 & 6/26/2013 & 1230 & 78 & $<0.03$ & 4,100 & 5.7 & -- & -- \\
\hline PI 524 & 6/25/2015 & $\begin{array}{l}1500 \\
1505\end{array}$ & 84 & $<0.05$ & -- & $\begin{array}{r}-- \\
5.9\end{array}$ & 2.54 & -- \\
\hline PI 524 & 9/22/2015 & $\begin{array}{l}1330 \\
1335\end{array}$ & 79 & $<0.05$ & -- & -- & 4.12 & -- \\
\hline PI 524 & 9/22/2015 & $\begin{array}{l}1331, \\
1336\end{array}$ & 79 & $<0.05$ & -- & $\begin{array}{r}-- \\
5.9\end{array}$ & 3.28 & -- \\
\hline
\end{tabular}


Table A5-1. Field measurements and results of laboratory analyses for major and minor ions, nutrients, bacteria, trace metals, volatile organic compounds radioactivity, radon-222, and dissolved gases for groundwater samples collected from 79 wells in 2015 and from 18 of the 79 wells sampled at least once previously by USGS during 1982-2013 in Pike County, Pennsylvania.-Continued

[Constituents listed with associated 5-digit U.S. Geological Survey parameter code; 2015 methane analyses by Isotech in bold, with time offset of 5 minutes; mm $\mathrm{Hg}$, millimeters of mercury; ${ }^{\circ} \mathrm{C}$, degrees Celsius; $\mathrm{mg} / \mathrm{L}$, milligrams per liter; lab, laboratory; $\mu \mathrm{S} / \mathrm{cm}$, microsiemens per centimeter; $\mathrm{CaCO}_{3}$, calcium carbonate; $\mu \mathrm{g} / \mathrm{L}$, micrograms per liter; ANC, acid neutralizing capacity; $\mathrm{pCi} / \mathrm{L}$, picocuries per liter; --, no data; <, less than; >, greater than; E, estimated; M, presence verified but not quantified; R, non-detect for radiological analysis; U, analyzed for but not detected; VPDB, PeeDee belemnite; VSMOW, Vienna Standard Mean Ocean Water]

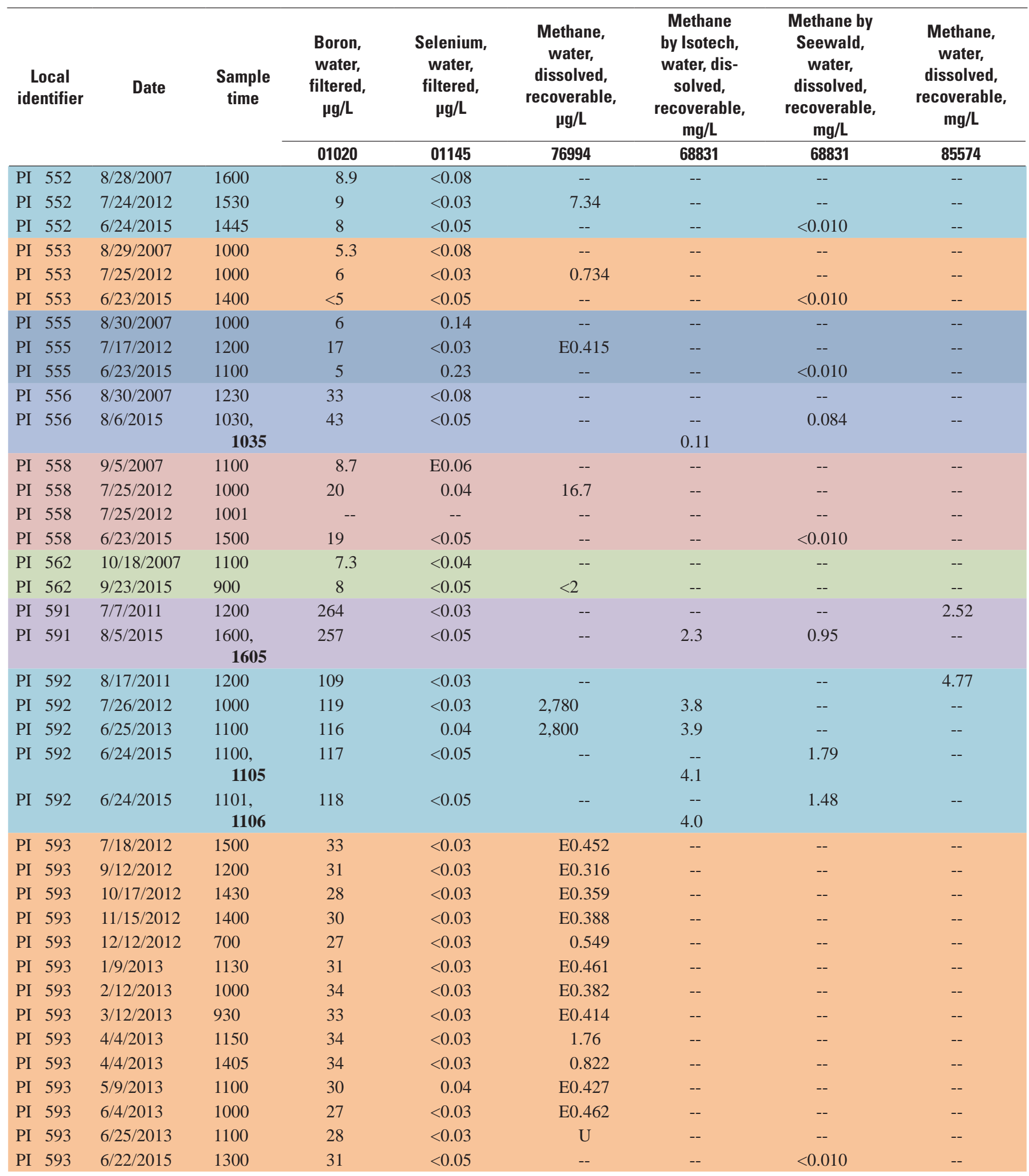


Table A5-1. Field measurements and results of laboratory analyses for major and minor ions, nutrients, bacteria, trace metals, volatile organic compounds radioactivity, radon-222, and dissolved gases for groundwater samples collected from 79 wells in 2015 and from 18 of the 79 wells sampled at least once previously by USGS during 1982-2013 in Pike County, Pennsylvania. - Continued

[Constituents listed with associated 5-digit U.S. Geological Survey parameter code; 2015 methane analyses by Isotech in bold, with time offset of 5 minutes; mm $\mathrm{Hg}$, millimeters of mercury; ${ }^{\circ} \mathrm{C}$, degrees Celsius; $\mathrm{mg} / \mathrm{L}$, milligrams per liter; lab, laboratory; $\mu \mathrm{S} / \mathrm{cm}$, microsiemens per centimeter; $\mathrm{CaCO}_{3}$, calcium carbonate; $\mu \mathrm{g} / \mathrm{L}$, micrograms per liter; ANC, acid neutralizing capacity; $\mathrm{pCi} / \mathrm{L}$, picocuries per liter; --, no data; <, less than; >, greater than; E, estimated; M, presence verified but not quantified; R, non-detect for radiological analysis; U, analyzed for but not detected; VPDB, PeeDee belemnite; VSMOW, Vienna Standard Mean Ocean Water]

\begin{tabular}{|c|c|c|c|c|c|c|c|c|}
\hline \multirow[t]{2}{*}{$\begin{array}{c}\text { Local } \\
\text { identifier }\end{array}$} & \multirow[t]{2}{*}{ Date } & \multirow[t]{2}{*}{$\begin{array}{c}\text { Sample } \\
\text { time }\end{array}$} & $\begin{array}{c}\text { Boron, } \\
\text { water, } \\
\text { filtered, } \\
\text { g/L }\end{array}$ & $\begin{array}{c}\text { Selenium, } \\
\text { water, } \\
\text { filtered, } \\
\mu \mathrm{g} / \mathrm{L}\end{array}$ & $\begin{array}{c}\text { Methane, } \\
\text { water, } \\
\text { dissolved, } \\
\text { recoverable, } \\
\mu \mathrm{g} / \mathrm{L}\end{array}$ & $\begin{array}{c}\text { Methane } \\
\text { by Isotech, } \\
\text { water, dis- } \\
\text { solved, } \\
\text { recoverable, } \\
\text { mg/L }\end{array}$ & $\begin{array}{l}\text { Methane by } \\
\text { Seewald, } \\
\text { water, } \\
\text { dissolved, } \\
\text { recoverable, } \\
\text { mg/L }\end{array}$ & $\begin{array}{c}\text { Methane, } \\
\text { water, } \\
\text { dissolved, } \\
\text { recoverable, } \\
\text { mg/L }\end{array}$ \\
\hline & & & 01020 & 01145 & 76994 & 68831 & 68831 & 85574 \\
\hline PI 594 & $7 / 18 / 2012$ & 900 & 5 & 0.08 & $\mathrm{U}$ & -- & -- & -- \\
\hline PI 595 & 7/19/2012 & 1300 & 10 & 0.33 & 58 & -- & -- & -- \\
\hline PI 595 & 6/23/2015 & 930 & 11 & 0.08 & -- & -- & $<0.010$ & -- \\
\hline PI 598 & 7/19/2012 & 1000 & $<3$ & $<0.03$ & 7.88 & -- & -- & -- \\
\hline PI 598 & $6 / 22 / 2015$ & 1600 & $<5$ & $<0.05$ & -- & -- & $<0.010$ & -- \\
\hline PI 600 & 7/24/2012 & 1100 & 10 & $<0.03$ & $\mathrm{U}$ & -- & -- & -- \\
\hline PI 600 & 1/9/2013 & 1400 & 10 & $<0.03$ & E0.262 & -- & -- & -- \\
\hline PI 600 & $2 / 12 / 2013$ & 1400 & 11 & $<0.03$ & U & -- & -- & -- \\
\hline PI 600 & $3 / 12 / 2013$ & 1200 & 11 & 0.04 & $\mathrm{U}$ & -- & -- & -- \\
\hline PI 600 & 4/2/2013 & 1500 & 11 & 0.05 & U & -- & -- & -- \\
\hline PI 600 & $5 / 7 / 2013$ & 1300 & 9 & 0.04 & E0.229 & -- & -- & -- \\
\hline PI 600 & 6/4/2013 & 1300 & 8 & 0.05 & $\mathrm{U}$ & -- & -- & -- \\
\hline PI 600 & $6 / 25 / 2013$ & 1400 & 9 & $<0.03$ & -- & -- & -- & -- \\
\hline PI 600 & $6 / 24 / 2015$ & 1400 & 11 & 0.08 & -- & -- & 0.01 & -- \\
\hline PI 601 & 8/2/2012 & 1400 & 22 & 0.12 & 1.22 & -- & -- & -- \\
\hline PI 601 & $6 / 25 / 2015$ & 1000 & 21 & 0.1 & -- & -- & $<0.010$ & -- \\
\hline
\end{tabular}


Table A5-1. Field measurements and results of laboratory analyses for major and minor ions, nutrients, bacteria, trace metals, volatile organic compounds radioactivity, radon-222, and dissolved gases for groundwater samples collected from 79 wells in 2015 and from 18 of the 79 wells sampled at least once previously by USGS during 1982-2013 in Pike County, Pennsylvania. - Continued

[Constituents listed with associated 5-digit U.S. Geological Survey parameter code; 2015 methane analyses by Isotech in bold, with time offset of 5 minutes; mm $\mathrm{Hg}$, millimeters of mercury; ${ }^{\circ} \mathrm{C}$, degrees Celsius; $\mathrm{mg} / \mathrm{L}$, milligrams per liter; lab, laboratory; $\mu \mathrm{S} / \mathrm{cm}$, microsiemens per centimeter; $\mathrm{CaCO}_{3}$, calcium carbonate; $\mu \mathrm{g} / \mathrm{L}$, micrograms per liter; ANC, acid neutralizing capacity; $\mathrm{pCi} / \mathrm{L}$, picocuries per liter; --, no data; <, less than; >, greater than; E, estimated; M, presence verified but not quantified; R, non-detect for radiological analysis; U, analyzed for but not detected; VPDB, PeeDee belemnite; VSMOW, Vienna Standard Mean Ocean Water]

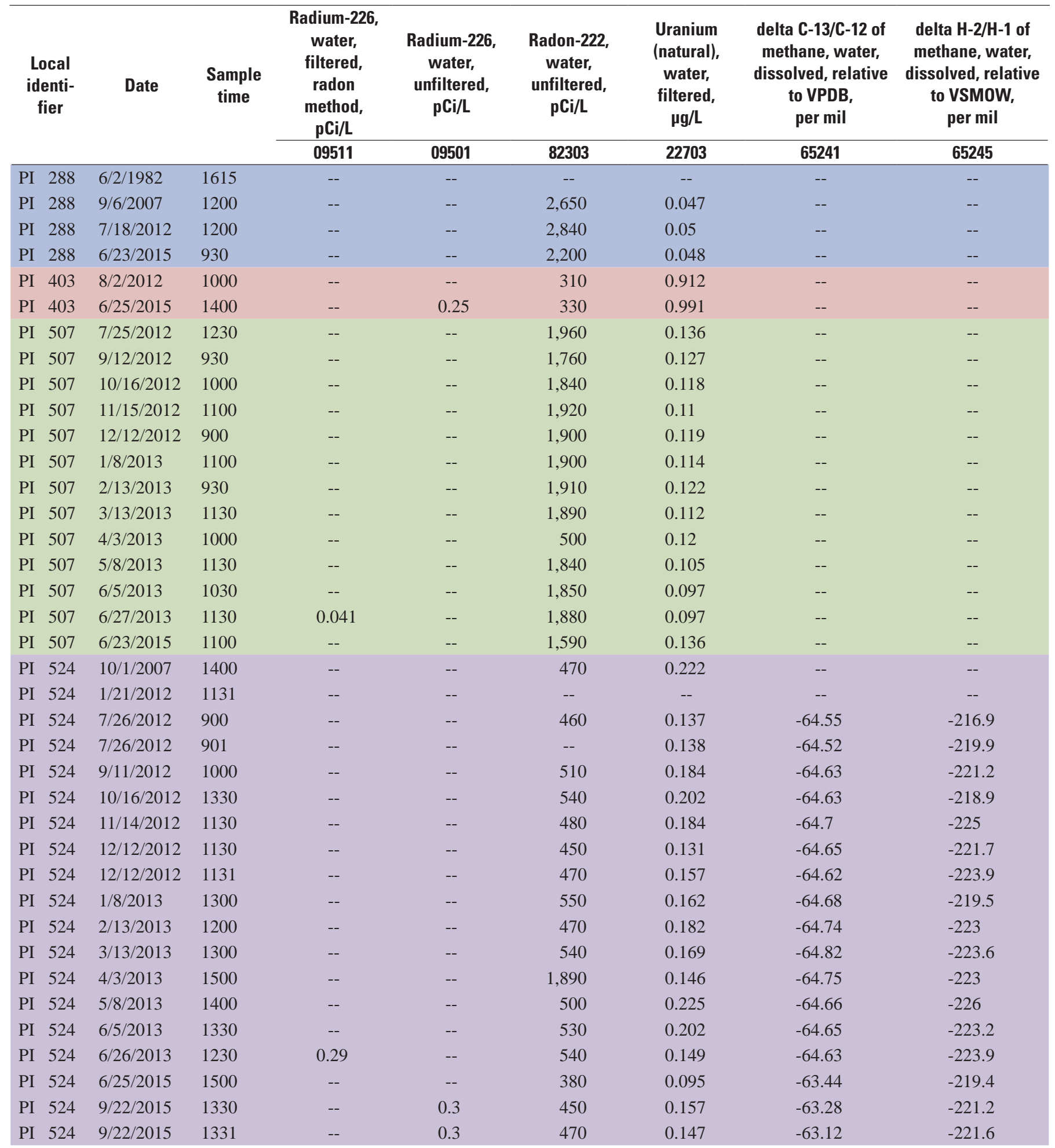


Table A5-1. Field measurements and results of laboratory analyses for major and minor ions, nutrients, bacteria, trace metals, volatile organic compounds radioactivity, radon-222, and dissolved gases for groundwater samples collected from 79 wells in 2015 and from 18 of the 79 wells sampled at least once previously by USGS during 1982-2013 in Pike County, Pennsylvania. - Continued

[Constituents listed with associated 5-digit U.S. Geological Survey parameter code; 2015 methane analyses by Isotech in bold, with time offset of 5 minutes; mm $\mathrm{Hg}$, millimeters of mercury; ${ }^{\circ} \mathrm{C}$, degrees Celsius; $\mathrm{mg} / \mathrm{L}$, milligrams per liter; lab, laboratory; $\mu \mathrm{S} / \mathrm{cm}$, microsiemens per centimeter; $\mathrm{CaCO}_{3}$, calcium carbonate; $\mu \mathrm{g} / \mathrm{L}$, micrograms per liter; ANC, acid neutralizing capacity; $\mathrm{pCi} / \mathrm{L}$, picocuries per liter; --, no data; <, less than; >, greater than; E, estimated; M, presence verified but not quantified; R, non-detect for radiological analysis; U, analyzed for but not detected; VPDB, PeeDee belemnite; VSMOW, Vienna Standard Mean Ocean Water]

\begin{tabular}{|c|c|c|c|c|c|c|c|c|}
\hline \multirow[t]{2}{*}{$\begin{array}{l}\text { Local } \\
\text { identi- } \\
\text { fier }\end{array}$} & \multirow[t]{2}{*}{ Date } & \multirow[t]{2}{*}{$\begin{array}{c}\text { Sample } \\
\text { time }\end{array}$} & $\begin{array}{c}\text { Radium-226, } \\
\text { water, } \\
\text { filtered, } \\
\text { radon } \\
\text { method, }\end{array}$ & $\begin{array}{l}\text { Radium-226, } \\
\text { water, } \\
\text { unfiltered, } \\
\text { pCi/L }\end{array}$ & $\begin{array}{c}\text { Radon-222, } \\
\text { water, } \\
\text { unfiltered, } \\
\text { pCi/L }\end{array}$ & $\begin{array}{c}\text { Uranium } \\
\text { (natural), } \\
\text { water, } \\
\text { filtered, } \\
\mu \mathrm{g} / \mathrm{L}\end{array}$ & $\begin{array}{l}\text { delta C-13/C-12 of } \\
\text { methane, water, } \\
\text { dissolved, relative } \\
\text { to VPDB, } \\
\text { per mil }\end{array}$ & $\begin{array}{c}\text { delta } \mathrm{H}-2 / \mathrm{H}-1 \text { of } \\
\text { methane, water, } \\
\text { dissolved, relative } \\
\text { to VSMOW, } \\
\text { per mil }\end{array}$ \\
\hline & & & 09511 & 09501 & 82303 & 22703 & 65241 & 65245 \\
\hline PI 552 & $8 / 28 / 2007$ & 1600 & -- & -- & 150 & 0.21 & -- & -- \\
\hline PI 552 & 7/24/2012 & 1530 & -- & -- & 121 & 0.102 & -- & -- \\
\hline PI 552 & 6/24/2015 & 1445 & -- & -- & 73 & 0.095 & -- & -- \\
\hline PI 553 & 8/29/2007 & 1000 & -- & -- & 300 & E0.038 & -- & -- \\
\hline PI 553 & 7/25/2012 & 1000 & -- & -- & 242 & 0.034 & -- & -- \\
\hline PI 553 & 6/23/2015 & 1400 & -- & 0.24 & 223 & 0.019 & -- & -- \\
\hline PI 555 & 8/30/2007 & 1000 & -- & -- & 2,430 & 0.332 & -- & -- \\
\hline PI 555 & 7/17/2012 & 1200 & -- & -- & 2,690 & $<0.004$ & -- & -- \\
\hline PI 555 & $6 / 23 / 2015$ & 1100 & -- & 0.16 & 2,510 & 0.386 & -- & -- \\
\hline PI 556 & 8/30/2007 & 1230 & -- & -- & 330 & 0.134 & -- & -- \\
\hline PI 556 & 8/6/2015 & 1030 & -- & -- & 56 & 0.139 & -48.04 & -- \\
\hline PI 558 & 9/5/2007 & 1100 & -- & -- & 1,730 & $<0.040$ & -- & -- \\
\hline PI 558 & $7 / 25 / 2012$ & 1000 & -- & -- & 1,410 & $<0.004$ & -- & -- \\
\hline PI 558 & $7 / 25 / 2012$ & 1001 & -- & -- & 1,480 & -- & -- & -- \\
\hline PI 558 & 6/23/2015 & 1500 & -- & -- & 1,190 & $<0.014$ & -- & -- \\
\hline PI 562 & $10 / 18 / 2007$ & 1100 & -- & -- & 150 & 0.276 & -- & -- \\
\hline PI 562 & 9/23/2015 & 900 & -- & -- & 138 & 0.018 & -- & -- \\
\hline PI 591 & 7/7/2011 & 1200 & -- & -- & 77 & 0.009 & -- & -- \\
\hline PI 591 & 8/5/2015 & 1600 & -- & 0.71 & 94 & 0.015 & -58.97 & -203.2 \\
\hline PI 592 & 8/17/2011 & 1200 & -- & -- & 1,210 & 0.014 & -- & -- \\
\hline PI 592 & 7/26/2012 & 1000 & -- & -- & 1,320 & 0.012 & -64.41 & -201.8 \\
\hline PI 592 & $6 / 25 / 2013$ & 1100 & 0.26 & -- & 1,350 & 0.013 & -64.52 & -204.5 \\
\hline PI 592 & $6 / 24 / 2015$ & 1100 & -- & -- & 1,210 & 0.015 & -63.25 & -198.0 \\
\hline PI 592 & 6/24/2015 & 1101 & -- & -- & 1,240 & $<0.014$ & -63.32 & -199.7 \\
\hline PI 593 & 7/18/2012 & 1500 & -- & -- & 1,240 & 0.59 & -- & -- \\
\hline PI 593 & 9/12/2012 & 1200 & -- & -- & 1,300 & 0.613 & -- & -- \\
\hline PI 593 & $10 / 17 / 2012$ & 1430 & -- & -- & 1,170 & 0.611 & -- & -- \\
\hline PI 593 & $11 / 15 / 2012$ & 1400 & -- & -- & 1,400 & 0.6 & -- & -- \\
\hline PI 593 & $12 / 12 / 2012$ & 700 & -- & -- & 350 & 1.31 & -- & -- \\
\hline PI 593 & 1/9/2013 & 1130 & -- & -- & 880 & 0.906 & -- & -- \\
\hline PI 593 & 2/12/2013 & 1000 & -- & -- & 1,180 & 0.604 & -- & -- \\
\hline PI 593 & 3/12/2013 & 930 & -- & -- & 1,130 & 0.606 & -- & -- \\
\hline PI 593 & 4/4/2013 & 1150 & -- & -- & 1,130 & 0.635 & -- & -- \\
\hline PI 593 & 4/4/2013 & 1405 & -- & -- & 1,130 & 0.627 & -- & -- \\
\hline PI 593 & 5/9/2013 & 1100 & -- & -- & 1,150 & 0.571 & -- & -- \\
\hline PI 593 & 6/4/2013 & 1000 & -- & -- & 1,320 & 0.583 & -- & -- \\
\hline PI 593 & $6 / 25 / 2013$ & 1100 & 0.15 & -- & 1,290 & 0.547 & -- & -- \\
\hline PI 593 & 6/22/2015 & 1300 & -- & -- & 1,100 & 0.558 & -- & -- \\
\hline
\end{tabular}


Table A5-1. Field measurements and results of laboratory analyses for major and minor ions, nutrients, bacteria, trace metals, volatile organic compounds radioactivity, radon-222, and dissolved gases for groundwater samples collected from 79 wells in 2015 and from 18 of the 79 wells sampled at least once previously by USGS during 1982-2013 in Pike County, Pennsylvania.—Continued

[Constituents listed with associated 5-digit U.S. Geological Survey parameter code; 2015 methane analyses by Isotech in bold, with time offset of 5 minutes; mm $\mathrm{Hg}$, millimeters of mercury; ${ }^{\circ} \mathrm{C}$, degrees Celsius; $\mathrm{mg} / \mathrm{L}$, milligrams per liter; lab, laboratory; $\mu \mathrm{S} / \mathrm{cm}$, microsiemens per centimeter; $\mathrm{CaCO}_{3}$, calcium carbonate; $\mu \mathrm{g} / \mathrm{L}$, micrograms per liter; ANC, acid neutralizing capacity; pCi/L, picocuries per liter; --, no data; <, less than; >, greater than; E, estimated; M, presence verified but not quantified; R, non-detect for radiological analysis; U, analyzed for but not detected; VPDB, PeeDee belemnite; VSMOW, Vienna Standard Mean Ocean Water]

\begin{tabular}{|c|c|c|c|c|c|c|c|c|c|}
\hline \multirow{2}{*}{\multicolumn{2}{|c|}{$\begin{array}{l}\text { Local } \\
\text { identi- } \\
\text { fier }\end{array}$}} & \multirow[t]{2}{*}{ Date } & \multirow[t]{2}{*}{$\begin{array}{c}\text { Sample } \\
\text { time }\end{array}$} & \multirow[t]{2}{*}{$\begin{array}{l}\text { Radium-226, } \\
\text { water, } \\
\text { filtered, } \\
\text { radon } \\
\text { method, } \\
\text { pCi/L } \\
09511\end{array}$} & \multirow[t]{2}{*}{$\begin{array}{c}\text { Radium-226, } \\
\text { water, } \\
\text { unfiltered, } \\
\text { pCi/L } \\
09501\end{array}$} & \multirow[t]{2}{*}{$\begin{array}{c}\text { Radon-222, } \\
\text { water, } \\
\text { unfiltered, } \\
\text { pCi/L } \\
82303\end{array}$} & \multirow[t]{2}{*}{$\begin{array}{c}\begin{array}{c}\text { Uranium } \\
\text { (natural), } \\
\text { water, } \\
\text { filtered, } \\
\mu \mathrm{g} / \mathrm{L}\end{array} \\
22703\end{array}$} & \multirow[t]{2}{*}{$\begin{array}{c}\text { delta C-13/C-12 of } \\
\text { methane, water, } \\
\text { dissolved, relative } \\
\text { to VPDB, } \\
\text { per mil }\end{array}$} & \multirow[t]{2}{*}{$\begin{array}{c}\text { delta } \mathrm{H}-2 / \mathrm{H}-1 \text { of } \\
\text { methane, water, } \\
\text { dissolved, relative } \\
\text { to VSMOW, } \\
\text { per mil }\end{array}$} \\
\hline & & & & & & & & & \\
\hline PI & 594 & $7 / 18 / 2012$ & 900 & -- & -- & 4,100 & 0.073 & -- & -- \\
\hline PI & 595 & 7/19/2012 & 1300 & -- & -- & 1,050 & 0.193 & -- & -- \\
\hline PI & 595 & 6/23/2015 & 930 & -- & -- & 1,060 & 0.131 & -- & -- \\
\hline PI & 598 & 7/19/2012 & 1000 & -- & -- & 3,000 & 0.017 & -- & -- \\
\hline PI & 598 & $6 / 22 / 2015$ & 1600 & -- & -- & 2,710 & 0.015 & -- & -- \\
\hline PI & 600 & $7 / 24 / 2012$ & 1100 & -- & -- & 880 & 1.11 & -- & -- \\
\hline PI & 600 & $12 / 13 / 2012$ & 1100 & -- & -- & 930 & 1.15 & -- & -- \\
\hline PI & 600 & $1 / 9 / 2013$ & 1400 & -- & -- & 1,080 & 1.1 & -- & -- \\
\hline PI & 600 & 2/12/2013 & 1400 & -- & -- & 1,090 & 1.12 & -- & -- \\
\hline PI & 600 & $3 / 12 / 2013$ & 1200 & -- & -- & 1,000 & 1.04 & -- & -- \\
\hline PI & 600 & 4/2/2013 & 1500 & -- & -- & 1,030 & 1.1 & -- & -- \\
\hline PI & 600 & 5/7/2013 & 1300 & -- & -- & 920 & 0.926 & -- & -- \\
\hline PI & 600 & 6/4/2013 & 1300 & -- & -- & 1,080 & 0.975 & -- & -- \\
\hline PI & 600 & $6 / 25 / 2013$ & 1400 & 0.08 & -- & 1,080 & 1.01 & -- & -- \\
\hline PI & 600 & 6/24/2015 & 1400 & -- & -- & 1,240 & 1.12 & -- & -- \\
\hline PI & 601 & 8/2/2012 & 1400 & -- & -- & 2,190 & 0.424 & -- & -- \\
\hline
\end{tabular}

For more information about this publication, contact

Director, Pennsylvania Water Science Center

U.S. Geological Survey

215 Limekiln Road

New Cumberland, PA 17070-2424

or visit our website at:

http://pa.water.usgs.gov

Publishing support provided by

West Trenton, Sacramento, and Lafayette Publishing Service Centers 


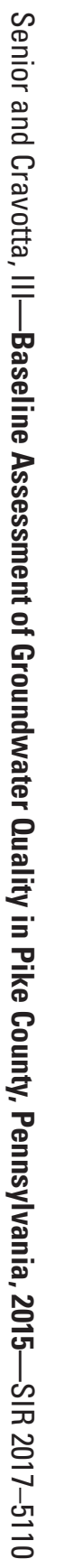

